Universidad Nacional de La Plata

FACULTAD DE HUMANIDADES Y CIENCIAS DE LA EdUCACIÓN SECRETARÍA DE Posgrado

\title{
Insurgentes, misioneras y políticas. Un estudio sobre mujeres y género en la Resistencia peronista (1955-1966)
}

\author{
Anabella Evangelina Gorza
}

Tesis para optar por el grado de Doctora en Historia

Directora Dra. Adriana María Valobra, UNLP

Ensenada, 18 de mayo de 2017 


\section{Resumen}

Esta tesis analiza la participación femenina en la Resistencia peronista durante el período 1955-1966. Parte de las preguntas formuladas por Hélèn Eck (2000) acerca de si puede hablarse de una especificidad femenina de los procesos de resistencia y si la participación de las mujeres en esos procesos se limita a desarrollar tareas de apoyo. A ello se suma el interrogante respecto de si las mujeres en la Resistencia peronista reprodujeron roles de género tradicionales o si los transgredieron. En función de estas preguntas y a la luz del concepto de repertorio de confrontación de Charles Tilly (en Tarrow, 1997), se examinan diferentes modalidades de intervención política femenina -actividades que implicaban el recurso a la violencia política, de reorganización partidaria, prensa política y prácticas rituales de homenaje- y a la vez, la articulación entre la actuación en el espacio público y el mundo doméstico. En relación a cada una de esas modalidades de intervención y a la relación público-privado, examinamos cómo actúan los discursos sociales y las experiencias de socialización previas, sobre el nivel de disrupción en términos de género de las prácticas observadas. Las dimensiones del concepto de género de Joan Scott (1993) vienen a complejizar el análisis, al pretender desentrañar como operan los símbolos, las normas, las instituciones y las subjetividades en dichas prácticas.

Palabras clave: peronismo - mujeres - género - política 


\section{Índice}

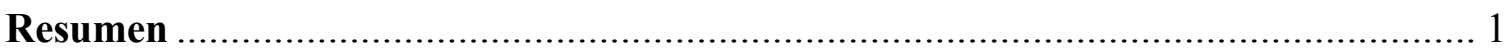

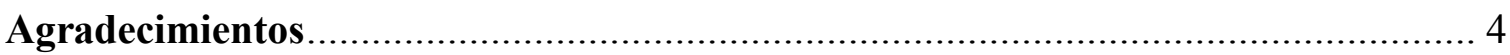

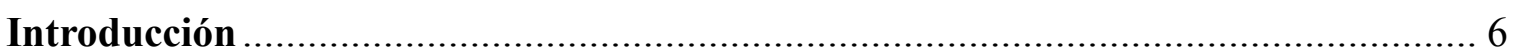

1. Sobre los usos de la expresión Resistencia peronista y sus problemáticas .................... 9

2. Acuerdos y desacuerdos sobre una delimitación temporal de resistencia peronista...... 16

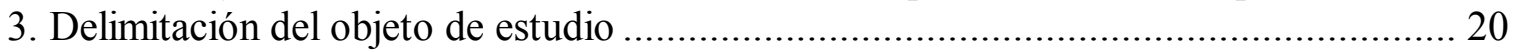

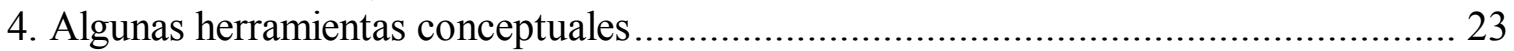

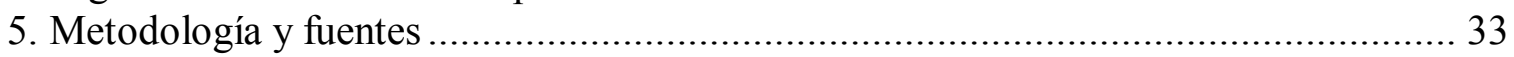

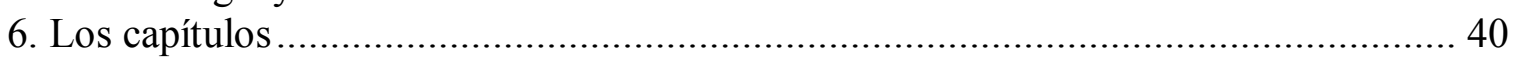

Capítulo I: Dilemas de género: la violencia política en la Resistencia peronista ...... 41

1. El lugar de la violencia en las interpretaciones sobre la Resistencia peronista............. 44

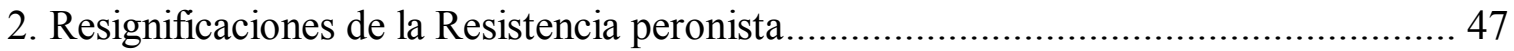

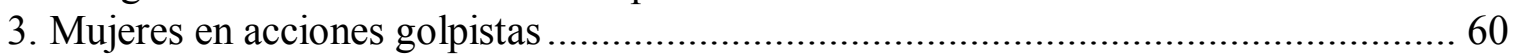

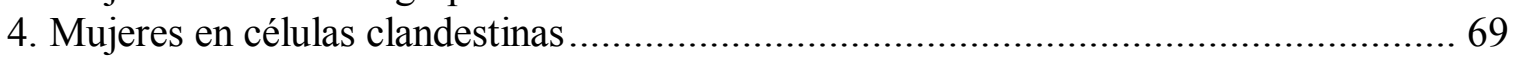

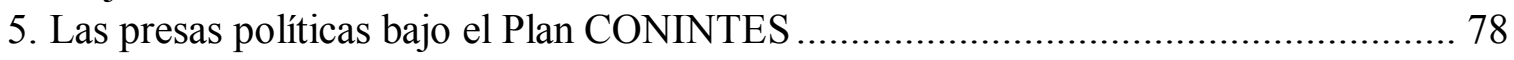

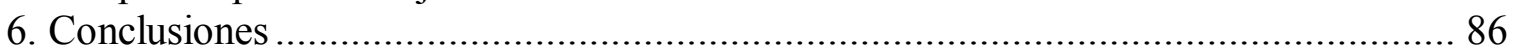

Capítulo II: El partido en el repertorio de confrontación de la Resistencia ............. 91

1. La reestructuración partidaria como parte de la Resistencia ...................................... 94

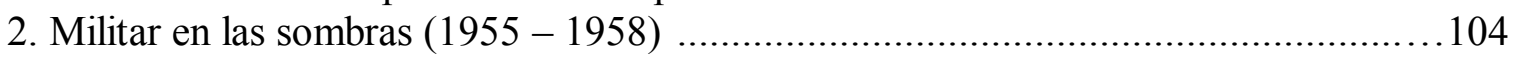

3. El gobierno frondizista y la primera reorganización partidaria $(1958-1962)$................107

4. "Giro a la izquierda" y redes interpartidarias de mujeres .......................................119

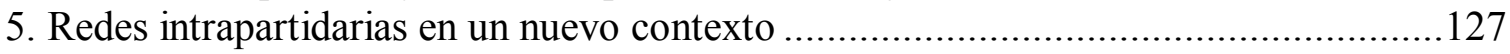

6. Cambios y continuidades en la participación político-partidaria ...............................136

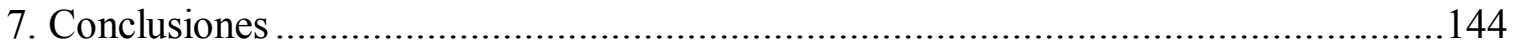

Capítulo III: Mujeres, género y política en la prensa peronista.............................149

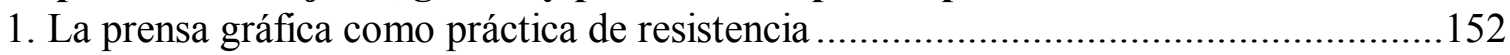

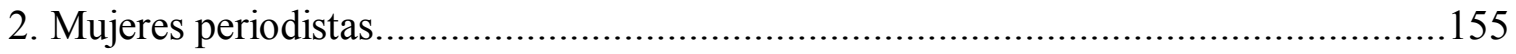

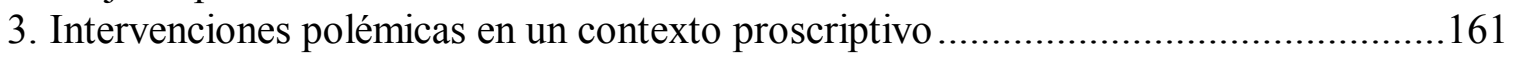

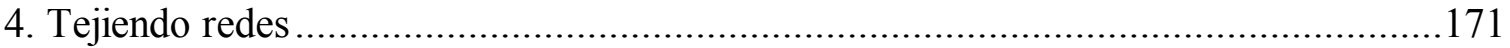

5. Modelizaciones de género en el discurso de la prensa peronista .............................176

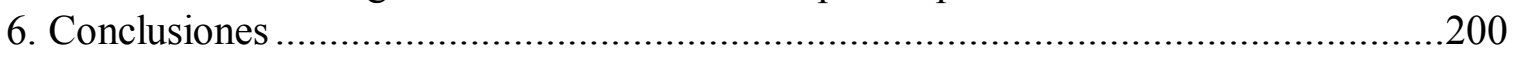

Capítulo IV: Simbolismos, rituales y prácticas políticas ......................................204

1. La Resistencia simbólica y cultural en la historiografia ..........................................207

2. Los homenajes a Eva Perón en el Repertorio de confrontación de la Resistencia .......211

3. Duelo y memoria, disputas simbólicas en espacios públicos......................................220

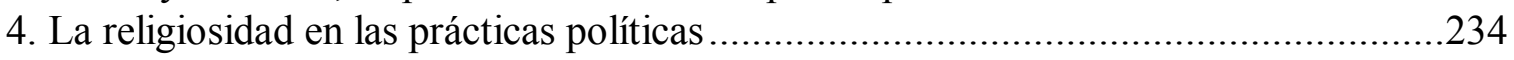

5. Conmemoraciones y participación política femenina.............................................238

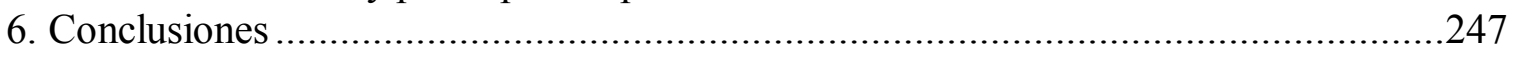

Capítulo V: Militancia y vida cotidiana: entre lo público y lo privado ...................253 


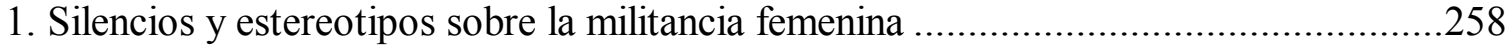

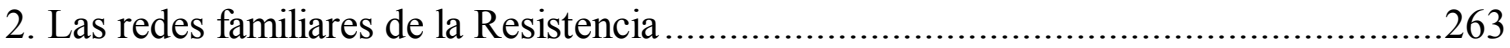

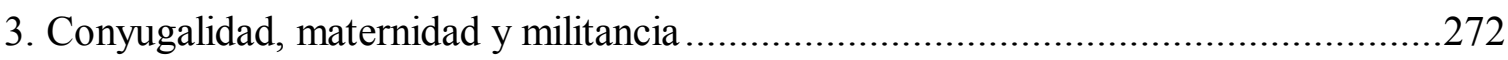

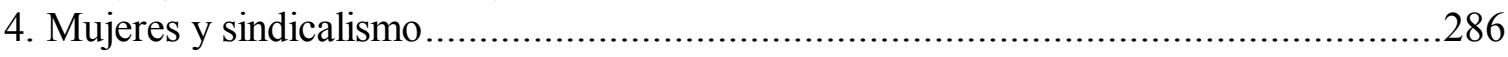

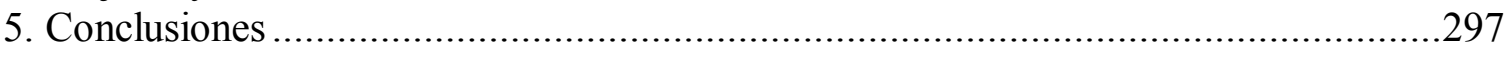

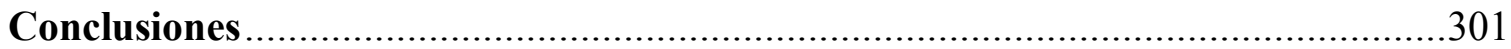

Archivos, hemerotecas y Centros de documentación consultados..........................311

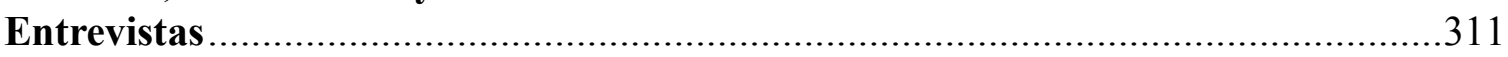

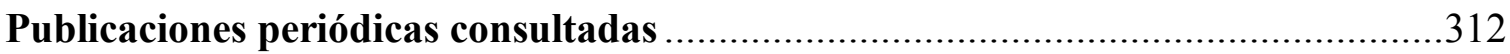

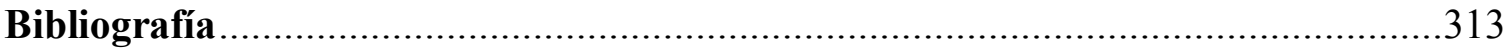




\section{Agradecimientos}

El primer agradecimiento está dedicado a mi directora, Adriana Valobra, quien me brindó la posibilidad de comenzar a transitar el camino de la investigación histórica y generosamente me enseñó las competencias de este hermoso oficio. También le agradezco por el compromiso asumido como directora desde el inicio de esta investigación, por su apoyo, por cada uno de los aportes que enriquecieron esta tesis y por el entusiasmo con el que nos incentiva a trabajar día a día.

Esta investigación fue posible gracias al apoyo material de una beca doctoral de CONICET durante los años 2012-2017 y de una beca de estudio de la Comisión de Investigaciones Científicas de la Provincia de Buenos Aires (CIC) durante el año 2011. También contó con el respaldo institucional del Centro Interdisciplinario de Investigaciones en Género (CInIG) dependiente del Instituto de Investigaciones en Humanidades y Ciencias Sociales (IdIHCS) de la Facultad de Humanidades y Ciencias de la Educación de la Universidad Nacional de La Plata.

Agradezco muy especialmente a todas las personas que me brindaron su testimonio militantes y familiares-, que me abrieron las puertas de sus casas y que confiaron en mí para contarme sus experiencias, muchas de las cuales hoy figuran en las páginas de esta tesis; con quienes pasé, además, momentos muy gratos que quedarán para siempre en mi memoria (Sus nombres podrán encontrarlos a lo largo de los capítulos y al final de la tesis). También a Marta Curone que me permitió hurgar en su archivo personal, que constituye un corpus documental invaluable. A las personas que trabajan en los archivos y bibliotecas que consulté, en especial a la gente de la Comisión por la Memoria de la Provincia de Buenos Aires y del Archivo Dr. Julio Marc de la ciudad de Rosario, que fueron muy generosos conmigo.

Agradezco a Elena Scirica, por sus lecturas y aportes; a Nicolás Damín por sus sugerencias para analizar las prácticas y fuentes que abordo en el capítulo III; y a Carina Capobianco que me regaló sus fuentes cuando recién estaba comenzando esta investigación. También mi reconocimiento va para aquellas personas que contribuyeron con alguna pieza que conforma el corpus documental tan heterogéneo y fragmentario, y tan difícil de conseguir, que sustenta esta investigación -fuentes, contactos, libros, información-: Antonella Trombetta, Carlos Sorá, Elsa Huwiller, Débora D’Antonio, Enrique Pavón 
Pereyra (h), Fabiana Rey y el personal del Archivo Penitenciario de la Provincia de Buenos Aires, Hilda López, Guillermo Clarke, Gonzalo Chávez, Horacio Bustingorry, Ignacio Cloppet, Juan Luis Besoky, Laura Ehrlich, Laura Lenci, María Angélica Corva, Marta Doglione, Mirta Bruno, Nicolás Pizzorno, Oscar Zanella, René Longoni y Roberto Baschetti ; y pido disculpas, porque seguramente esta lista incluye muchos olvidos. Además quiero agradecer a Cecilia Sanabria que colaboró en el armado de la bibliografía y a Sofía Paz, por las desgrabaciones de las entrevistas.

No puedo dejar de mencionar a las compañeras de trabajo que conocí a lo largo de estos años, que me apoyaron con sus palabras de aliento, Eugenia Bordagaray, Gisela Manzoni, Sol Calandria, Paula Salguero y muy especialmente, Nadia Ledesma Prietto, que además de leer y hacer aportes muy enriquecedores a esta tesis, me ofreció su oído, sus consejos y su amistad. También, a Blanca, Irma, Coco, Vane, Soledad, Eliana, Lorena, Cecilia, Isabel y Mariela, familiares y amigas que desde lo cotidiano colaboraron de diferentes maneras para que esta tesis pueda concretarse.

El último párrafo está dedicado a aquellas personas que conforman mi mundo afectivo más cercano. Le agradezco a mi hermana Noe, por estar siempre; a mis padres, Susana y Mario, por confiar en mí y porque sin ellos nada hubiera sido posible; y a las dos personas que compartieron el día a día del armado de esta tesis, y que con su paciencia, sus chistes y su amor hicieron más amenas las jornadas de trabajo: Cata y Mauricio. 


\section{Introducción}

Esta tesis se enfoca en la participación de las mujeres en la Resistencia peronista entre los años 1955-1966 y en las relaciones de género que atravesaron dicho proceso histórico. Aunque la investigación formal comenzó en el año 2011, el interés sobre dicha temática surgió unos años antes, en el marco de la materia Metodología I, donde debíamos formular un proyecto de investigación. La elección del tema respondía, por un lado, a mi gusto por la historia del pasado reciente, de la que había tenido poca o casi ninguna formación en el transcurso de la carrera de grado, ya que hacía pocos años que las temáticas referentes a la misma habían irrumpido en la agenda historiográfica, y por otro, a mi interés por la perspectiva de la historia de las mujeres y de género con la que había tenido el primer contacto hacía muy poco tiempo y que significó un punto disruptivo en mi carrera. Al momento de realizar las primeras exploraciones bibliográficas para el armado de un estado del arte, me encontré con un objeto de estudio más complejo de lo que había imaginado. En primer lugar, existían disputas sobre el significado y alcance de la Resistencia peronista, que afectaban al modo en que se periodizaba, a los actores y al tipo de actividades que implicaba. En segundo lugar, encontré una abundante producción académica sobre la militancia peronista en la década 1970, pero también comprobé que la segunda mitad de la década del cincuenta y la primera de los sesenta no habían recibido la misma atención, y que muchas veces, cuando la recibían, era porque en ese período buscaban el germen de procesos que madurarían en años posteriores. Finalmente, descubrí que esa escasa atención cobraba mayor fuerza respecto de las prácticas y experiencias femeninas, llegando a un silenciamiento casi total. Dicho silenciamiento fue un motivo por demás atrayente para considerar que el tema debía ser abordado. ¿Por qué la participación de las mujeres peronistas de los años cincuenta posteriores al golpe de Estado y tempranos años sesenta no había merecido la misma atención que la militancia de los setenta e incluso que aquella que se había desarrollado durante los primeros gobiernos peronistas? Aunque ese vacío historiográfico ya ha sido señalado por la historiografía adjudicándolo al hecho de que las fuentes para reconstruir la historia de la Resistencia peronista están enunciadas desde el punto de vista masculino debido a la dificultad de hallar testimonios femeninos sobre ese proceso (Centurión, 2007), lo cierto es que hasta el momento no ha sido objeto de una investigación sistemática y ese es el propósito que perseguimos en esta tesis. 
La caída del gobierno peronista en septiembre de 1955 dio comienzo a una nueva etapa en la historia argentina en la que tendría lugar la emergencia de nuevas formas de expresión y participación política. Para el peronismo, que había sido desplazado de las estructuras estatales de poder, implicó el comienzo de la Resistencia. Este fenómeno consistió en diversas acciones que se ensayaron en principio contra las medidas que el gobierno de la Revolución Libertadora encaró en contra de quienes se identificaban con el anterior gobierno, pero también contra los sectores populares en general. Sintéticamente, dichas medidas se tradujeron en la proscripción del Partido Peronista en sus ramas masculina y femenina, la intervención de los sindicatos y su organismo central, la Confederación General de Trabajo -tercera rama-,persecución y encarcelamiento de dirigentes y militantes, confiscación de bienes e inhabilitación para ocupar cargos públicos de los ex funcionarios y dirigentes peronistas, creación de comisiones investigadoras ante las que estos últimos debieron comparecer, destrucción de bienes y edificios relacionados con el gobierno peronista, anulación de algunas de sus políticas, y específicamente, en el plano laboral, introducción de medidas tendientes a incrementar la racionalización del sistema productivo; hecho que atentaba contra los derechos y organización que la clase trabajadora había alcanzado durante el período anterior. A ello debemos agregar la sanción, en marzo de 1956, del decreto 4161 que prohibía el uso de los símbolos peronistas.

El período 1955-1966 es recordado por la inestabilidad política que lo caracterizó. La alternancia de gobiernos militares con democracias débiles y condicionadas; la adopción del papel de árbitro de la política por parte de las Fuerzas Armadas, que intervinieron, ya sea mediante planteos militares o gobernando directamente; la imposibilidad de las clases dominantes por imponer un proyecto hegemónico ante la movilización permanente de los sectores populares que resistieron esos proyectos y la constitución del sindicalismo como una de las fuerzas políticas más gravitantes de la sociedad argentina (Cavarozzi, 1983; Nun, 1973; O'Donnell, 1972; Portantiero, 1973; Smulovitz, 1991). Pese a los intentos del gobierno de la Revolución Libertadora por eliminar al peronismo de la escena política, éste pronto se reveló como un actor insoslayable. Por un lado, la cuestión peronista produjo un resquebrajamiento en la alianza que había posibilitado el triunfo del golpe de Estado de 1955, el cual había contado con la participación de las Fuerzas Armadas, la Iglesia católica, corporaciones burguesas, y un amplio espectro político-partidario que abarcaba a radicales, conservadores, socialistas, demócratas cristianos y nacionalistas. La primera fractura se dio en noviembre de 1955, cuando mediante un golpe interno, Eduardo Lonardi, representante 
de los sectores nacionalistas de las Fuerzas Armadas, fue desplazado de la presidencia por la fórmula Pedro E. Aramburu-Isaac Rojas, que representaba a los sectores liberales de dichas fuerzas y a los más duros en la defensa de las posturas antiperonistas. ${ }^{1}$

La cuestión peronista también suscitaría realineamientos en los partidos tradicionales. A la división del radicalismo en 1957, entre la Unión Cívica Radical Intransigente, crítica del gobierno de Aramburu-Rojas y dispuesta a un acercamiento con el peronismo, y la Unión Cívica Radical del Pueblo, más cercana al gobierno y defensora de un antiperonismo más acentuado (Altamirano, 1998, Spinelli, 2005; Szusterman, 1998), se sumaron los debates que emergieron en el seno de la izquierda tradicional para dar lugar al nacimiento de la "nueva izquierda", producto de las renovadas lecturas que se estaban realizando sobre la cuestión peronista (Altamirano, 2001; Sigal, 2002; Terán, 2013; Tortti, 2009) y las confluencias entre peronistas y sectores del nacionalismo (Besoky, 2013; Cucchetti, 2011; Ehrlich, 2010; Goebel, 2004; Melon Pirro, 1993, 2009). Finalmente, la transformación del propio peronismo, que por primera vez se vio obligado a transitar los caminos de la ilegalidad y de la oposición. Apartado de las estructuras estatales, con su máximo líder exiliado, fue objeto de un proceso centrífugo que acentuó la heterogeneidad que lo había caracterizado desde sus orígenes, al romperse la estructura institucional que la contenía. El exilio de Perón permitió la emergencia de liderazgos locales que debieron legitimar sus decisiones apelando a la palabra del líder ausente. Sin embargo, su distancia del territorio argentino fue un factor que favoreció la maleabilidad de su discurso habilitando interpretaciones diversas e incluso opuestas (Sigal y Verón, 2004). En este contexto, el sindicalismo, cuyas estructuras lograron ser recuperadas tempranamente, se convirtió en el actor de mayor peso político en la interna peronista (Cavarozzi, 1984; Fernández, 1988; James, 2010 [1988]; Schneider, 2005, Torre, 2012) y un actor importante en la escena

\footnotetext{
${ }^{1}$ La heterogeneidad que caracterizó a las fuerzas políticas de la época respecto de cómo concebir el peronismo y cómo actuar frente a él ha sido señalada por María Estela Spinelli (2005), quien menciona diferentes tipos de antiperonismo. Por un lado, reconoce un "antiperonismo tolerante", representado por Lonardi y exponentes del nacionalismo católico, y también por la UCRI y el Partido Comunista. Este antiperonismo repudiaba a Perón, cuyo liderazgo político era visto como demagógico, pero admitía al peronismo como identidad política procurando cooptarlo o asimilarlo al sistema. Por otro lado, refiere a un "antiperonismo radicalizado", que concebía al peronismo como una manifestación local del nazi-fascismo y procuraba erradicarlo completamente de la sociedad, no sólo como partido sino también como ideología. Sus principales exponentes eran los sectores liberales de las Fuerzas Armadas, cuyas figuras visibles eran Rojas y Aramburu. Y finalmente, una tercera variante que denomina como "antiperonismo optimista", representado por la Unión Cívica Radical del Pueblo, que consideraba que el peronismo estaba destinado a desaparecer.
} 
política nacional; aunque no debe menospreciarse la fuerza del neoperonismo, sobre todo en el interior del país. ${ }^{2}$

Hasta el golpe de Estado de 1955, la militancia peronista se había desenvuelto institucionalmente con el favor del gobierno aunque las líneas internas de ese movimiento heterogéneo fueron díscolas en muchas oportunidades y, en algunos casos, como el de Cipriano Reyes, merecieron también persecuciones y encarcelamientos como si fueran los opositores, a quienes no se les ahorraba ni unas ni otros. La ilegalidad que sobrevendría al derrocamiento del peronismo generó incertidumbre en sus filas y expuso a los militantes y simpatizantes peronistas a nuevos tipos de participación. Aunque muchos abandonaron la militancia, otros se volcaron a la Resistencia. Esta abarcó una variedad de formas de intervención política, producto en parte de la incertidumbre que reinaba sobre el futuro del peronismo y sobre la mejor estrategia para retornar al poder, pero también a consecuencia de la heterogeneidad que caracterizaba a dicha fuerza política. Así, la Resistencia peronista abarcó desde manifestaciones aisladas espontáneas hasta intentos de golpes de Estado por la vía militar o la opción por la guerrilla, cuyos primeros intentos se dieron tempranamente en 1959, y en un plano más sostenido, la lucha de los trabajadores en sus espacios de trabajo. Es decir, la Resistencia se expresó a través de diferentes canales y en forma relacionada, en un proceso en el que las luchas de los trabajadores por demandas concretas en el ámbito laboral y por mantener sus organizaciones se combinaron con las reivindicaciones más estrictamente políticas como el retorno de Perón y el levantamiento de la proscripción que pesaba sobre el partido.

\section{Sobre los usos de la expresión "Resistencia peronista" y sus problemáticas}

El debate historiográfico sobre la Resistencia peronista ha girado en torno a tres cuestiones principales estrechamente relacionadas: su definición, periodización y quiénes la protagonizaron. La definición está atravesada por una serie de problemas tales como el peso

\footnotetext{
${ }^{2}$ Se ha llamado neoperonismo a los intentos de dirigentes peronistas locales con trayectoria en dicha fuerza por reorganizar estructuras partidarias al margen del Partido Justicialista, en los años posteriores al golpe de Estado de 1955. Fue un fenómeno que adquirió peso sobre todo en el interior del país. Aunque estos partidos no siempre acataron las directivas de Perón, y por eso, al neoperonismo también se lo llamó "peronismo sin Perón", hubo oportunidades en que siguieron las directivas oficiales y sus estructuras fueron usadas como base para la reorganización partidaria y participación electoral frente a la proscripción e
} 
otorgado en ella al componente sindical y a la presencia de sectores combativos, sindicalistas o no, que se radicalizarían en los años sesenta pero que emergieron en los cincuenta; los canales a través de los cuales se canalizó -sindicatos, comandos, agrupaciones basadas en el lugar de trabajo o en el barrio o con otro tipo de adscripción-; las actividades que implicó, es decir, si éstas se mantuvieron en el reclamo por las condiciones de trabajo o si respondían a ideas u objetivos políticos que trascendían dicho accionar y el papel jugado por la violencia y los aspectos políticos.

La mayoría de las investigaciones reconocen la variedad de actividades que abarcó la Resistencia peronista, pero ponen el acento en un aspecto determinado. El primer trabajo sistemático es el de Daniel James (2010 [1988]), Resistencia e integración, donde se sostiene que la Resistencia comprendió un amplio abanico de intervenciones que iban desde expresiones individuales como la protesta en la vía pública y el sabotaje en las fábricas hasta la actividad clandestina canalizada en los llamados comandos de la resistencia y las sublevaciones militares. Las investigaciones que le sucedieron reconocen esta variedad de modos de participación, aunque algunas han focalizado su análisis en el factor sindical, en el cual también se basa el trabajo de James (Salas, 2006 [1990]; Schneider, 2005), mientas que otras han analizado sus aspectos políticos (Melon Pirro, 2009), violentos o de uso de acciones armadas (Amaral, 2004 [1993]; Seveso, 2010; Raimundo, 1998; Alvarez, 2014, Salas, 2006, Gordillo, 2007) y simbólicos (Salas, 2006 [1990]; Scoufalos, 2007; Seveso, 2010). Entre los autores que destacan los aspectos sindicales, el eje de análisis ha girado en torno a las relaciones entre comandos y sindicatos o más específicamente, comisiones internas de fábrica (James, 2010 [1998]; Salas, 2006 [1990]; Schneider, 2005). No hay una definición exacta sobre los comandos, aunque en general, los definen como nuevas estructuras políticas que se formaron durante el gobierno de la Revolución libertadora y que agrupaban a unas pocas personas para la realización de actividades clandestinas; que podían implicar, o no, el uso de la violencia. Para estos autores, durante el segundo lustro de la década del cincuenta, hubo estrechas vinculaciones entre los comandos y las comisiones internas de fábrica, formadas clandestinamente luego de la intervención de los sindicatos que sobrevino al golpe; colaboración que se rompió a partir de 1959/1960. Por eso, estos autores sitúan el final de la Resistencia peronista en esos años. Salas y Schneider, por su parte, destacan el rol cumplido por las relaciones barriales y familiares de la clase obrera 2006; Tcach, 1995). 
para sostener el proceso de resistencia. Si bien estos tres autores centran su análisis en el movimiento obrero organizado, existen diferencias entre ellos respecto del rol protagónico que éste tuvo en la Resistencia y del carácter ideológico de dicho proceso. James, pese a focalizarse en el análisis de la clase obrera, admite el carácter interclasista de la Resistencia peronista; algo que está ausente en los otros autores, que destacan con énfasis el rol desarrollado por el sector sindical. En el caso de Salas, ello incluye un debate con los discursos de la izquierda peronista producidos en la década del setenta, que borraron el papel cumplido por la dirigencia sindical y -en especial, de aquellos sectores que se burocratizaron durante los sesenta. Por otro lado, James y Salas han enfatizado en la ideología peronista del movimiento obrero, y Schneider, puntualmente, prefiere hablar de Resistencia obrera, ya que el término peronista oculta las acciones de obreros de otras ideologías que también ejercieron resistencia contra el capitalismo, el Estado y los sectores dominantes.

En una perspectiva diferente, debe situarse el trabajo de Samuel Amaral (2004 [1993]) quien identifica la Resistencia peronista con la realización de atentados. En 1958, se habría producido el abandono de una violencia pura, indiscriminada, para dar paso a una violencia más pragmática, vinculada a objetivos políticos y gremiales; y es aquí donde entra a jugar la concepción que Perón tenía sobre el poder, que es central en su argumentación. Los hechos habrían obligado al líder político a abandonar una concepción bélica del poder por otra de carácter político, que incluía la negociación; cambio plasmado en la concreción del pacto con Frondizi. Desde una perspectiva que acentúa el carácter político de la Resistencia, Julio César Melon Pirro (2009) ha cuestionado las miradas bélicas que se han construido en torno a este proceso histórico, afirmando que la Resistencia fue para Perón una opción en un contexto caracterizado por restricciones y que desde un principio fue concebida en términos políticos y no bélicos. Descarta, así, la idea de que hubo un tiempo de la política que habría reemplazado a un tiempo de la Resistencia, entendida ésta en términos de actividades violentas. A su vez, al procurar destacar el carácter político de la Resistencia peronista, ha entablado un debate con aquella bibliografía que pone el acento en la hegemonía del sindicalismo como fuerza impulsora de dicho proceso. A una primera etapa, caracterizada por el sabotaje y con un vínculo estrecho con los lugares de trabajo, le habría seguido una segunda etapa donde se habría impuesto una resistencia netamente política, definida ésta como atentados cometidos en el Gran Buenos Aires, sin vinculación con los sindicatos, que a partir de la creación de la Intersindical en mayo de 1957, habrían 
pasado a adoptar actitudes negociadoras. Para Amaral, las estructuras de la Resistencia durante la primera etapa fueron comandos barriales, y sus actores, obreros, empleados, desocupados y militares. El paso de la primera etapa a la segunda, habría dado lugar al reemplazo de los grupos barriales por grupos sindicales. Melon Pirro, por su parte, pone énfasis en el componente juvenil de los grupos que conformaron la Resistencia peronista. Para el autor, ésta no se organizó preferentemente alrededor de los lugares de trabajo sino que la conformación heterogénea de los grupos demostraría que tuvo un origen extra sindical y que la identidad de sus miembros provendría de un reconocimiento a partir de la residencia común, del barrio y la familia; hecho que explicaría el carácter limitado de las acciones que emprendieron. Sostiene la participación de sectores no pertenecientes a la clase obrera al decir que la identidad peronista alcanzó a otras clases sociales, y que no toda la clase obrera se identificó con el peronismo. En una línea similar, la tesis de Laura Ehrlich (2010) sostiene la necesidad de estudiar a aquellos actores de clase media que participaron de la Resistencia, periodistas e intelectuales, en el período 1955-1962. La autora también ha incorporado el análisis, siempre en relación a la actividad periodística, del accionar de los grupos de Juventud Peronista que comenzaron a activar luego del golpe de Estado y que fueron adquiriendo protagonismo hacia el cambio de década, intentando conformar estructuras más definidas.

Como puede observarse, el debate sobre la definición de Resistencia peronista ha circulado alrededor del papel que cumplió el factor sindical en dicho proceso, puesto que durante los años que siguieron al golpe de Estado de 1955, el sindicalismo se convirtió en el sector de mayor peso en el peronismo y en un protagonista ineludible de la escena política nacional. Por fuera de estos debates, debemos hacer referencia a algunos autores y autoras que han puesto el foco de atención en el carácter cultural de la Resistencia peronista y en sus aspectos simbólicos y discursivos (Salas, 2006 [1990]; Scoufalos, 2007; Seveso, 2010; Sigal y Verón, 2004), preocupándose menos por definir sujetos y periodizaciones; aunque algunos de los autores que participan del debate anterior también se han interesado por analizar ese aspecto. Es el caso de Ernesto Salas (2006 [1990]) para quien la Resistencia peronista adquirió tres formas: la actividad de los comandos, de las comisiones internas de fábrica y una resistencia cultural, entendiendo esta última como una respuesta de los sectores populares a la campaña represiva y al proceso de desperonización encarado por el Estado y las clases dominantes, que sirvió -además - para articular una identidad peronista. De esta manera, Salas busca darle una explicación a una multiplicidad de pequeñas acciones 
que han llegado a nosotros en la forma de lo que el autor denomina microhistorias, y que no necesariamente estaban encuadradas en estructuras formales. Otros autores se centran en la confrontación peronismo-antiperonismo, en las resistencias al decreto 4161 que prohibía el uso de los símbolos y términos peronistas, interpretando esas luchas como batallas culturales en el marco de la construcción de memoria (Seveso, 2010 y Scoufalos, 2007). Finalmente, no podemos dejar de mencionar otros trabajos que, desde disciplinas ajenas a la Historia y a la Sociología, se han acercado al tema para dar respuesta a problemáticas que exceden el análisis de dicho proceso histórico. Son los casos de Silvia Sigal y Eliseo Verón (2004) que, desde una perspectiva del Análisis de los discursos sociales, han procurado dilucidar el entramado discursivo de la Resistencia peronista, y el de Fernando Balbi (2007) que, desde la Antropología Social, se ha acercado a la etapa de la Resistencia para analizar el papel que jugó el ejemplar de la lealtad como eje central del universo de sentidos que articuló las relaciones entre peronistas.

Finalmente, cabe mencionar aquellos trabajos que se han focalizado en la participación de las mujeres como sujetos de la Resistencia peronista o que han hecho alguna referencia tangencial a dicha participación, aunque cabe aclarar que son escasos e incipientes. Ello resulta llamativo si lo comparamos con la abundancia de estudios que han proliferado en los últimos quince años respecto de la militancia femenina durante la etapa de los dos primeros gobiernos peronistas y en el proceso de radicalización política de los años setenta. Es posible que el escaso interés por el período en estudio derive de la dificultad para hallar fuentes que den testimonio del accionar de las mujeres, pero también y en mayor medida, por la gravitación que en la historiografia han desempeñado los dos momentos señalados, el del peronismo clásico y la experiencia setentista. Es claro que en los últimos años ha habido un creciente interés de las Ciencias Sociales por explorar la movilización popular en los años setenta que no ha tenido su correlato en un interés por analizar los años previos a 1966 cuando las manifestaciones de protesta existían, pero no habían alcanzado la magnitud ni el carácter revolucionario que adquirirían en años posteriores. Esta omisión alcanzó con más fuerza a la historia de las mujeres.

El libro de Estela Dos Santos, Las mujeres peronistas (1983), es el primer trabajo que evidencia la multiplicidad de formas de intervención que adoptó esa militancia, aunque el relato es una sumatoria de experiencias, con un tinte anecdótico, donde la participación femenina no aparece problematizada. Luego de este primer intento de visibilización, habrá que esperar más de dos décadas para encontrar un leve interés en la temática. El libro de 
Catalina Scoufalos hace una mención a la intervención de las mujeres, aunque aclara que no es el objetivo principal de su trabajo. Presenta una problematización en torno a este tema, pero las mujeres aparecen mencionadas de manera tangencial, a la vez que carece de investigación empírica al respecto. De la misma época es un artículo de Ana Josefina Centurión (2007), que se centra específicamente en la temática que nos interesa y, además, procura sistematizar ciertas problemáticas que la atraviesan, como el carácter conservador/innovador de los roles desempeñados por las mujeres en la Resistencia peronista; su relación con la participación sindical, señalando la poca representación que tuvieron en ese ámbito y las dificultades para acceder a puestos de conducción, a pesar de su presencia en los conflictos; y cómo, pese a que hay evidencias de intervenciones femeninas en una diversidad de espacios y cumpliendo diferentes roles, dicha participación ha sido interpretada en los relatos sobre la Resistencia como tareas de apoyo. Este trabajo ofrece una propuesta interesante de investigación y de análisis, algunas de cuyas problemáticas retomamos en esta tesis, pero se trata de un trabajo inicial que amerita mayor indagación empírica y complejización conceptual. Por su parte, en un trabajo que se basa en fuentes orales y que articula las problemáticas de la memoria con la influencia del género en las representaciones, Daniel James (2004) lleva a cabo un estudio de la trayectoria de una trabajadora de la industria de la carne de la ciudad de Berisso, pero no se centra específicamente en la Resistencia peronista. Por último, existen algunos trabajos biográficos sobre la trayectoria de Alicia Eguren, la figura femenina más visible y más recordada de los primeros años de la Resistencia (Bellucci, 1991; Deleis, De Tito y Arguindeguy, 2001; Mazzeo, s/f; Seoane, 2014). En general, estos trabajos destacan más su participación en los años sesenta y setenta y es poco lo que aportan sobre su accionar en la Resistencia de los años cincuenta y comienzos de los sesenta. Sin descartar el carácter valioso de estas producciones, que hacen un interesante trabajo de visibilización, cabe decir que se centran en una figura que presenta cierto carácter excepcional que no puede hacerse extensivo a todas las mujeres de la Resistencia, ni siquiera a la mayoría de ellas. Otro trabajo, sobre la biografía de Joe Baxter, hace mención de manera tangencial a las mujeres de la Resistencia (Heguy y Dandan, 2006). Y por último, cabe mencionar algunos trabajos que, aunque no se centran en la Resistencia peronista, se han focalizado en presos y presas políticas de esos años (Seveso, 2009; Castronuovo, 2016). Frente a este panorama, esta tesis procura superar un vacío historiográfico a través de aportes empíricos y problemáticos haciendo de la participación femenina en la Resistencia peronista el eje de su abordaje. 
En la época en estudio circularon varias nociones de resistencia. En las publicaciones peronistas de los años cincuenta, como Línea Dura o Rebeldía, convivían diferentes concepciones de resistencia, más organizada en la primera y menos en la segunda, aunque siempre referidas a acciones de confrontación contra el Estado consideradas ilegales. A su vez, esas acciones podían ser distintas: una resistencia que implicaba el uso de la violencia, una resistencia más cotidiana y menos definida, y también la acción sindical a la que solían dedicarle una gran espacio; de hecho casi todos los periódicos tenían una página dedicada con exclusividad al sector gremial y estaban pendientes de los movimientos en ese sector. Sin lugar a dudas, las directivas de Perón influyeron en el vocabulario con el que se articularon los discursos sobre la resistencia. En la discusión que Melon Pirro mantiene con Amaral, sostiene que Perón -al emitir esas directivas - no estaba pensando en términos bélicos sino que lo que pretendía era movilizar a las bases políticamente, procurando evitar que volvieran a embarcarse en una intentona golpista o en experiencias neoperonistas que hicieran tambalear su liderazgo. En función de ese objetivo, Perón habría utilizado términos como "insurrección” que tenían amplia aceptación entre las bases peronistas (Melon Pirro, 2009).

En una línea similar, el trabajo de Laura Ehrlich (2010) pone de manifiesto el vocabulario utilizado en la época por los propios peronistas para interpretar la experiencia que estaban atravesando. Aunque su tesis se basa en la prensa política y en algunos panfletos cuyos discursos no podemos hacer extensivo a todo el universo peronista, es dable suponer que como medios de comunicación mantuvieron un pacto de lectura con un público potencial que compartía esas visiones, a la vez que como la autora demuestra, se insertaron en un universo discursivo común que excedía el posicionamiento político de cada publicación en la interna peronista. En esos textos había una propensión a entender la resistencia en términos bélicos. La imagen de la Argentina como "país ocupado" y del enemigo, como "invasor" o "ejército de ocupación" eran comunes a estas publicaciones. La figura del invasor se condensaba en el imperialismo británico cuyo brazo armado en el país era el propio gobierno de la Revolución Libertadora y las Fuerzas Armadas, además de tener otros representantes locales como la oligarquía y los partidos políticos tradicionales. Para Ehrlich, la explicación radica en la tradición nacionalista de la que eran portadores muchos de los integrantes de los staff de estas publicaciones, además del tinte nacionalista que había tenido la prédica de la propaganda peronista en el período previo. 
Por otro lado, el antiperonismo también poseía su propio uso del término resistencia. Algunos habían visto en el peronismo la encarnación del fascismo a nivel nacional, por lo que habían nominado su oposición al peronismo como "resistencia", una resistencia que había sido interpretada como una prolongación de la resistencia antifascista que venían desarrollando desde la década del treinta y que se plasmaba en acciones de solidaridad con el bando republicano en la Guerra Civil Española y con los Aliados en la Segunda Guerra Mundial (Moreau de Justo, 1956). Con ello queremos significar que se trató de un término en disputa y que desde sus primeros momentos estuvo atravesado por diferentes connotaciones, a las que se le irían sumando las resignificaciones posteriores, a las que ha hecho referencia Ernesto Salas (2006 [1990]).

Ello nos advierte sobre la complejidad del objeto de estudio y sobre la necesidad de definir de antemano qué noción de resistencia utilizaremos en este trabajo. En principio no se trata de entender la Resistencia peronista como el germen de una resistencia o forma de lucha más evolucionada que se impondría en años posteriores, sino considerarla en el marco de sus características y contradicciones, teniendo en cuenta la emergencia de nuevos fenómenos después del derrocamiento del peronismo pero también la pervivencia de elementos del pasado; el uso de términos, conocimientos, experiencias, modelos de acción, y lecturas de la realidad. Por otro lado, debemos aclarar que las prácticas que observaremos en las páginas siguientes no caben en una definición tradicional de resistencia, es decir, organizada, planificada, con un alto compromiso y conciencia o que necesariamente implicaban el uso de la violencia. Pero tampoco se limitan a la acción sindical o a las acciones en los ámbitos de trabajo. Visibilizar las acciones de las mujeres en la Resistencia peronista nos ha llevado a adoptar un concepto amplio de resistencia y contemplar los diferentes espacios y formas en que se canalizaron esas acciones, que no siempre coinciden con los espacios y formas tradicionales de hacer política. Ahora bien, aunque las acciones que observamos como parte de la Resistencia peronista no necesariamente tuvieron el objetivo estratégico de derrocar a un régimen, sí fueron acciones conscientes y estuvieron motivadas por un interés de reafirmar la identidad peronista de los sujetos.

\section{Acuerdos y desacuerdos sobre una delimitación temporal de Resistencia peronista}


Entre los autores académicos hay coincidencias respecto de que la Resistencia peronista habría finalizado hacia 1959/60. Daniel James (2010 [1988]) señala como indicador la desmovilización obrera que siguió a la aplicación del Plan Conintes a partir de marzo de 1960 y los fracasos de las huelgas obreras de 1959. Estos hechos habrían dado lugar a un proceso de desmovilización de las bases y de burocratización de la cúpula sindical, haciendo que resultara cada vez más difícil reclutar integrantes para los comandos entre la clase obrera. En la década del sesenta, dichas estructuras no desaparecieron, pero pasaron a estar compuestas por jóvenes y estudiantes. Muchos de los sindicalistas que las habían integrado se volvieron activistas clandestinos de tiempo completo sin relación con la actividad sindical diaria o grupos de choque al servicio de los dirigentes sindicales. A la vez, estos últimos comenzaron a mostrar una actitud cada vez más pragmática respecto de su colaboración con las actividades clandestinas (James, 2010 [1988]). En síntesis, para James, la Resistencia culminó cuando se interrumpió la estrecha colaboración entre comandos y sindicatos y cuando aquellos perdieron el componente obrero.

Ernesto Salas (2006 [1990]) sostiene que, además de las derrotas obreras en las huelgas que tuvieron lugar en esos años, el punto final estuvo dado por el levantamiento de Iñíguez, en noviembre de 1960, que fue el último intento de golpe cívico-militar realizado por peronistas y militares. De esta manera, pese a que su trabajo se centra en las acciones del movimiento obrero, su delimitación temporal está señalada por un hecho que remite a cuestiones estratégicas y a la presencia del componente militar como sujeto de la Resistencia. En este sentido, se observa un paralelismo con el trabajo de Marcelo Raimundo quien ha analizado la relación entre militantes peronistas y militares y ha observado la etapa de la Resistencia en los años cincuenta buscando el germen de estrategias de lucha que madurarían y se impondrían a fines de los setenta. Para el autor los comandos estuvieron ligados al proceso de recuperación sindical, que estuvo acompañado de acciones violentas y observa una constante apelación a los militares por parte de los militantes peronistas, dada por el hecho de que aquellos eran quienes poseían las armas y de que se creía que el retorno de Perón sería inminente y que se lograría mediante un golpe de Estado. Hacia 1959/1960, desde algunos sectores del peronismo empezó a cuestionarse la relación con los militares producto de la influencia que generó la revolución cubana, los procesos de liberación nacional en el Tercer Mundo y un acercamiento al marxismo por parte de algunos sectores del peronismo, en especial jóvenes. Entonces empezó a plantearse la posibilidad de crear un ejército popular surgido de las mismas filas de la militancia. Los hechos que el autor marca 
como límite temporal son el primer intento de guerrilla rural, el de los Uturuncos, que tuvo lugar en Tucumán hacia mediados de 1959, que anticipaba las estrategias que se impondrían en el nuevo período, y el levantamiento de Iñíguez, en noviembre de 1960, que cerraba una estrategia que había implicado la colaboración entre civiles y militares (Raimundo, 1998). Otros autores han adoptado las periodizaciones dadas sin ofrecer una problematización al respecto (Amaral, 2004 [1993]; Schneider, 2005); en algunos casos se debe a que han tocado tangencialmente el tema para hablar de otras cuestiones o períodos (Bozza, 2001). Algunos no ofrecen una delimitación temporal precisa (Melon Pirro, 2009; Seveso, 2010, Sigal y Verón, 2004), mientras que otros han señalado diversas fechas de cierre, como 1958 (Centurión, 2007); 1962 (Ehrlich, 2010); 1964 (Scoufalos, 2007); 1966 (Dos Santos, 1993); 1973 (Balbi, 2007). ${ }^{3}$

Al momento de iniciar nuestra investigación tomamos como dada la periodización más clásica ofrecida por la bibliografia académica (1955-1959/60). Sin embargo, a la hora de realizar entrevistas a personas que habían sido partícipes de la Resistencia peronista surgieron distintos momentos para pensar el período que se consideraba Resistencia y muchos concebían una continuidad en los dieciocho años que duró el exilio de Perón, considerando que la Resistencia había durado todo ese período. Por otro lado, al examinar las fuentes escritas, muchas prácticas que considerábamos como expresión de la Resistencia no habían finalizado abruptamente en 1959/60. Los libros de divulgación, por su parte, también brindaban una imagen muy variada sobre el período que asignan a dicho proceso histórico. Ello nos llevó a reconsiderar la periodización de nuestro objeto de estudio. En qué se basan los autores para sostener que la Resistencia peronista habría llegado a su fin en ese momento. James se basa en el fin de la colaboración entre comandos y sindicatos y en el cambio de composición de aquellas estructuras (James, 2010 [1998]). Salas sostiene que hacia fines de la década del '60, en un contexto de desmovilización obrera, ya se hablaba de la Resistencia como algo terminado y que el cambio que se señala en 1960 está vinculado al abandono de la táctica golpista como modo de lucha de la Resistencia. Frente a ello cabe hacer algunas aclaraciones. En principio, otras investigaciones han sostenido que no hubo

\footnotetext{
${ }^{3}$ En el caso de Ehrlich la fecha de cierre está situada en 1962 porque su análisis se basa en la prensa peronista y sus fuentes llegan hasta esa fecha, pero no hay una reflexión acerca de que la Resistencia peronista haya terminado en ese momento; lo mismo Centurión que limita sus observaciones a la etapa del gobierno de la Revolución Libertadora. Scoufalos, sitúa el final hacia 1964, porque es la fecha de derogación del decreto 4161y su investigación se basa en las acciones para burlar ese decreto. Balbi reconoce la multiplicidad de periodizaciones sobre la Resistencia peronista y decide tomar el período más largo, pero sin explicitar su decisión, y el resto de los autores tampoco fundamenta su recorte temporal.
} 
desmovilización obrera luego de la aplicación del Plan Conintes (Schneider, 2005). En segundo lugar, como el propio Salas admite, si los comandos no fueron estructuras extensivas a toda la Resistencia entonces, el hecho de que hayan desaparecido luego de 1960 o que continuaran con otra composición de clase, no implica que no haya habido otras formas de resistencia que sobrevivieron a esa fecha, incluyendo a la resistencia obrera. Finalmente, si los golpes cívico-militares tampoco fueron la manifestación más extendida de la Resistencia peronista, de hecho sólo hubo dos que llegaron a ponerse en marcha, y el segundo de ellos ni siquiera tuvo las repercusiones ni la masividad que había tenido el primero, no resultan un criterio lo suficientemente representativo para señalar el final de dicho proceso. Es cierto que con el cambio de década comenzaron a gestarse nuevos fenómenos que se impondrían a fines de la década del sesenta; aquellos que señala Raimundo y que se vinculan con el acercamiento de algunos militantes peronistas al marxismo y con la adopción de la táctica guerrillera como estrategia de lucha. Sin embargo, ello implicaría definir la Resistencia peronista por la negativa, es decir, por no poseer características que se desarrollarían más acabadamente en años posteriores. Y a la vez, como el mismo autor señala, ese proceso de radicalización no fue extensivo a todo el peronismo, sino a algunos sectores, en especial jóvenes, que además en ese contexto, comienzos de la década del sesenta, todavía se encontraban muy ligados a posturas nacionalistas (Ehrlich, 2010 y Besoky, 2013). Frente a ello, cabe señalar que hubo sectores en el peronismo que participaron de la Resistencia en los años cincuenta, que no adhirieron al marxismo y continuaron resistiendo luego del punto de inflexión que algunos historiadores marcan en 1959/60, porque la proscripción del peronismo no fue levantada luego de esa fecha y, aunque se abrieron canales legales de participación, estos siempre estuvieron restringidos o se vieron interrumpidos.

Desde nuestro punto de vista, la Resistencia peronista se extendió hasta 1973, fecha que coincide con el regreso definitivo de Perón a la Argentina. Sin embargo, tomaremos como período de análisis el lapso temporal comprendido entre 1955-1966, recorte que justificaremos a continuación. Con ello, no pretendemos ser funcionales a los discursos de la izquierda peronista de la década del setenta que buscó en las acciones de resistencia de los años cincuenta el germen de las formas de lucha que se implementarían en aquella década, cuestión que ha sido ampliamente discutida por varios autores (Salas, 2006 [1990]; Melon Pirro, 2009). Sostenemos la idea de que muchas de las prácticas de resistencia implementadas en la década del cincuenta no finalizaron en 1959/60, sino que se 
extendieron más allá de esa fecha, con diferentes duraciones, y que algunas continuaron hasta bien entrados los años sesenta y setenta, conviviendo con las nuevas formas de lucha que se adoptaron en esos años. Las periodizaciones que ofrecen los historiadores están mediadas por sus posturas ideológicas y teóricas, por los fenómenos que pretenden observar y por las fuentes de las que se han valido para llevar adelante sus pesquisas. Estas divergencias, en todo caso, nos demuestran que se trata de un término en disputa. A los efectos de acotar el objeto de estudio, también nos vimos obligados a adoptar una periodización, con lo cual, nos inscribimos en ese espacio de disputa.

\section{Delimitación del objeto de estudio}

El objeto de estudio de esta tesis ha sido delimitado en función del sujeto. Partimos de un interés por visibilizar a las mujeres que tuvieron participación en la Resistencia peronista. Los historiadores se han preocupado por definir la pertenencia de clase y generacional de los sujetos que intervinieron en dicho proceso, pero -hasta el momento- poco se ha dicho sobre las implicancias de género que lo atravesaron ni se ha considerado a sus protagonistas como sujetos sexuados. En general, se han inclinado por el uso del sujeto universal masculino o han hecho referencias circunstanciales a "los hombres y mujeres" que participaron, pero sus análisis se basan en actividades realizadas por varones y en fuentes producidas por ellos o donde sólo se vislumbran sus voces e intervenciones, mientras que el accionar de las mujeres aparece colateralmente, siempre en tercera persona, generalmente bajo la forma de anécdotas y carente de un análisis sistemático. En esta tesis nos proponemos superar ese silencio sobre la participación de las mujeres como sujetos históricos de la Resistencia peronista o su mirada bajo la forma anecdótica. En general, las investigaciones se han basado en las actividades de carácter sindical y en las acciones armadas de la Resistencia. En ambos tipos de manifestaciones, las mujeres se hallan invisibilizadas. En las primeras, si bien estuvieron presentes, se encuentran subrepresentadas en las fuentes, ya que no tuvieron puestos de liderazgo pues, en la decisión de quién los ocupaba, se impusieron lógicas de socialización masculinas. En las segundas, estuvieron subrepresentadas numéricamente y se trata de actividades en las que usualmente se desempeñaron como colaboradoras de tareas impulsadas por varones. Por eso, nuestra observación, aunque contemplará y problematizará este tipo de prácticas, se enfocará en 
otras manifestaciones donde las mujeres tuvieron amplia participación y mostraron autonomía, como la actividad periodística, la reorganización de estructuras políticopartidarias y las manifestaciones públicas con un alto contenido simbólico.

En nuestro análisis se privilegiará el carácter interclasista de la Resistencia peronista sin dejar de considerar el peso del movimiento obrero organizado en dicho proceso; de hecho, algunas de las mujeres cuyas prácticas analizamos, pertenecían a esa clase social, estando algunas sindicalizadas o vinculadas a sujetos que lo estaban. Nuestro interés estará en visibilizarlas en función de su condición de mujeres. Cuando se haga referencia al factor sindical, lo será en la medida en que se vincule con la participación femenina. Por otro lado, observaremos acciones de resistencia con un carácter politizado y que se ejercieron en el marco de la ideología peronista - en el apartado siguiente nos explayaremos sobre lo que entendemos por "resistencia"-. Entonces, contemplando que se trató de un contexto en el que alternaron dictaduras con democracias débiles y condicionadas, que las posibilidades de participación para el peronismo fueron oscilando entre momentos de mayor y menor apertura política y que la proscripción no sería levantada hasta la década del setenta, consideramos como Resistencia peronista a los intentos llevados a cabo por las y los militantes de ese signo político, luego del golpe de Estado de 1955, por lograr que la ideología con la que se identificaban permaneciera en la escena política y por reorganizarse, ya sea creando nuevas formas de organización o reactualizando viejas estructuras.

El período que hemos abordado abarca desde 1955 hasta 1966. Consideramos que la periodización que la bibliografía académica ha atribuido a la Resistencia peronista (19551959/60) es demasiado acotada para el tipo de intervenciones políticas que nos interesaba abordar en nuestra investigación. Por otro lado, creemos que los aspectos que han sido señalados por los investigadores para marcar el final de la Resistencia peronista no son tan significativos para una investigación que se propone visibilizar la agencia femenina. El levantamiento de Iñíguez pone demasiado énfasis en la variante militar de intervención. La interpretación que coloca el cierre de la Resistencia en el fin de la colaboración entre comandos y sindicatos, descuida las actividades de resistencia que tuvieron lugar por fuera de esas estructuras y en la que las mujeres encontraron mayores posibilidades de despliegue. De esta manera, sostenemos que 1966 es una fecha más significativa para delimitar nuestro objeto de estudio. En lo que afecta a la participación y a la organización femenina, un hecho de trascendencia fue que Perón, que hasta ese momento había ignorado la reorganización de las mujeres, se propusiera intervenir en dicho proceso, nombrando una delegada nacional de 
la Rama Femenina y procurando encarar la reorganización desde arriba, lo cual chocó con los intentos, casi siempre infructuosos, que las mujeres habían desarrollado desde 1958 por crear una estructura autónoma diferenciada por género. De manera que esta tesis no sólo se propone indagar la participación de las mujeres en la Resistencia peronista, es decir las acciones que emprendieron para mantener en vigencia al peronismo frente a los gobiernos de turno y al arco opositor, sino también las batallas que dieron en el seno del propio peronismo para hacerse oír, para reorganizarse en estructuras autónomas, para imponer una agenda propia y lograr cuotas de poder. Por eso, esta tesis no sólo pretende iluminar una historia de la participación de las mujeres en la Resistencia peronista sino también una historia de la resistencia de las mujeres en el peronismo.

Por otro lado, existen motivos convencionales que hacen que 1966 sea una fecha más significativa que 1959/60 para señalar un cambio, puesto que en aquella tuvieron lugar hechos de mayor visibilidad y con consecuencias más profundas en la sociedad: en principio, el golpe de Estado que dio lugar a la autodenominada Revolución Argentina señala un punto de inflexión, puesto que al presentarse como un proceso que se proponía una reestructuración de la sociedad con miras a perdurar un tiempo prolongado, irrumpió con medidas radicales como la prohibición de toda la actividad política; de manera que el peronismo pasó a estar en un pie de igualdad con los otros partidos políticos con quienes compartiría, de allí en adelante, la proscripción. A su vez, se inició un nuevo proceso de radicalización que se caracterizaría por el ingreso masivo de jóvenes de clase media a la política; transformación que se venía gestando desde comienzos de la década del sesenta pero que se aceleraría en estos años. En relación con ello, debemos mencionar la consideración de la lucha armada como estrategia para la toma del poder, que comenzó a hacerse cada vez más extensiva. Finalmente, debe adicionarse la consolidación de un sindicalismo cada vez más combativo y el incremento de la movilización popular que se manifestó en episodios de alta conflictividad como fue el Cordobazo en 1969.

Considerando que se trata de la primera investigación sistemática sobre la participación de las mujeres en la Resistencia peronista y que hubo que realizar un exhaustivo trabajo de búsqueda de fuentes, la delimitación geográfica fue delimitada en función de los espacios donde transcurren las manifestaciones de resistencia que se evidencian en dichas fuentes. Esto es, la ciudad de Buenos Aires y Gran Buenos Aires, y las ciudades de La Plata, Berisso, Ensenada y Rosario; con algunas acciones desarrolladas en el interior de la provincia de Buenos Aires como Azul, Mar del Plata y Bahía Blanca. Sin 
embargo, esa delimitación geográfica no es azarosa puesto que coincide con los espacios donde la Resistencia peronista adquirió mayor visibilidad producto del alto grado de movilización política que suele gestarse en los espacios urbanos y con desarrollo industrial.

\section{Algunas herramientas conceptuales}

Como nuestro objeto de estudio está enfocado en la Resistencia peronista, resulta pertinente partir de una especificación acerca de qué entendemos por "resistencia". Pablo Bonavena ha señalado las dificultades para definir rigurosamente dicho concepto debido a la multiplicidad de acciones que usualmente son incluidas bajo esta categorización o que se identifican como tales. La primera articulación conceptual sobre la noción de resistencia la encontramos en Carl Von Clausewitz, cuyo referente empírico inmediato fue la lucha desplegada por el pueblo español frente a la invasión napoleónica a comienzos del siglo XIX (Bonavena, 2015). Esto no implica la ausencia de acciones que podrían englobarse bajo la categoría de resistencia previas a esa época, pero lo que llamaba la atención de Clausewitz era un fenómeno novedoso para la Europa de su tiempo, con características particulares que fueron objeto de sistematización. Nos referimos a la participación informal de la población civil paralela a la de los ejércitos regulares y nacionales que debían actuar en las sombras realizando acciones que dificultaran al invasor la dominación del terreno, como cortar sus comunicaciones y privarlo de sus fuente de abastecimientos, de manera que cuanto mayor fuera el espacio ocupado por el enemigo, más difícil le resultara controlarlo (Clausewitz, 2002). Observamos, entonces que la primera conceptualización de resistencia estuvo ligada a las teorías sobre las estrategias de la guerra. Este tipo de resistencia encontrará otro referente empírico muchos años después, en las resistencias europeas al franquismo, al nazismo y al fascismo en el marco de la Guerra Civil Española y de la Segunda Guerra Mundial y en los procesos de liberación nacional en el Tercer Mundo en el contexto de la posguerra. Esta concepción de resistencia implica la lucha contra un ejército invasor, pero el término también puede aplicarse para referirse a la confrontación en el marco de las fronteras nacionales de diferentes fuerzas sociales de un mismo país, siempre remitiendo a una situación asimétrica entre las fuerzas que participan del conflicto (Bonavena, 2015). 
El caso de Alemania presenta una particularidad que no ha podido ser pasada por alto por los investigadores y es que, en ese contexto, la resistencia no había sido llevada a cabo contra un ejército extranjero. En un país donde el régimen nazi había contado con amplios niveles de aceptación, se planteaba el problema de si había habido resistencia y si el pueblo había participado en ella. Los modelos de inteligibilidad que se habían formulado para las resistencias europeas, en especial la francesa y la italiana, los dos casos emblemáticos de resistencia, no eran aplicables al caso alemán. En función de este problema, el grupo de investigadores nucleados en el proyecto de Baviera se propuso una revisión del concepto. De esta manera, la resistencia que hasta ese momento había hecho referencia a una actividad organizada, que implicaba compromiso y claros objetivos de derrocar a un régimen autoritario, e inclusive asociada al uso de la violencia de manera inherente, se convirtió en un concepto más amplio que incluía diferentes tipos de acciones, con distinto nivel de compromiso y conciencia, alcanzando a aquellos actos que sin proponerse derrocar al régimen nazi, e inclusive con cierto grado de asentimiento, se opusieron a los propósitos de dicho régimen de penetrar todos los espacios de la vida cotidiana. Así, el concepto de resistencia pasó a englobar una multiplicidad de acciones, de distinto nivel, a veces ordenadas en una organización piramidal y valoradas jerárquicamente. Pero además, con el mismo término, se siguió nominando a esas acciones que quedaban incluidas en el primer uso del concepto, dando lugar a la idea de una resistencia propiamente dicha cualitativamente diferente al resto de las acciones (Kershaw, 2004). En el caso que nos compete, se trató de una resistencia desplegada contra gobiernos considerados ilegítimos y/o arbitrarios dentro de las fronteras del propio país. Aunque con características particulares, a la luz del concepto de resistencia civil, la Resistencia peronista puede ser ubicada en el marco de otras resistencias, contemplando el hecho de que se trató de un fenómeno muy extendido a lo largo del siglo XX.

Históricamente, la resistencia se ha manifestado en una multiplicidad de contextos y situaciones. Se ha desplegado contra los gobiernos coloniales, sobre los propios gobiernos dictactoriales y en los movimientos por la reivindicación de derechos y libertades democráticas y ciudadanas (López Martínez, 2012). Probablemente, los antecedentes empíricos de que se valió la Resistencia peronista para articular sus discursos, por su cercanía temporal, hayan sido la resistencia al nazismo y al fascismo en Europa en el marco de la Guerra Civil Española y de la Segunda Guerra Mundial y los procesos de liberación 
nacional en el Tercer Mundo, en el contexto de la posguerra, de cuyo vocabulario se tomaron algunos préstamos pese a que se trató de procesos muy diferentes.

La teoría política ha sistematizado el concepto de "resistencia civil", que desvincula el concepto de resistencia de un contexto de guerra y de las actividades militarizadas. ${ }^{4}$ Desde esta perspectiva, resistencia implica un desafío ejercido por la población contra un gobierno apelando a todos los métodos que tiene a su disposición, en un abanico de formas de lucha que van desde las microresistencias, formas ocultas y disimuladas de resistencia, hasta grandes manifestaciones y huelgas generales. Suelen participar amplios sectores de la población, incluyendo mujeres y niños, e implica la construcción de un poder social que aspira a convertirse en poder político (López Martínez, 2012). Se basa en la idea de que los gobiernos necesitan de la colaboración o, al menos, de la obediencia de gran parte de la sociedad. La resistencia consiste, entonces, en retirar ese apoyo para socavar las fuentes de poder del adversario (Randle, 1998). Sin embargo, sus métodos no se reducen a la no cooperación. Gene Sharp distingue casi doscientos métodos, clasificados en tres grupos, que pueden sintetizarse en actos de no cooperación (por ejemplo: el boicot, el trabajo a desgano, el paro); acciones de intervención (como ocupar lugares prohibidos) y un tercer grupo que remite a acciones con un alto poder simbólico que apuntan a llamar la atención (Sharp, 2011). A su vez, la Resistencia civil contempla comportamientos heterogéneos que abarcan desde actos individuales o en pequeños grupos hasta acciones de masas; acciones esporádicas o persistentes, producto de improvisaciones o de planes organizados, que muchas veces suelen resultar ambiguas en el sentido de que no siempre es fácil discernir su carácter político y sus verdaderas intenciones y significados (Bravo, 2003). Desde la teoría del derecho, el concepto de resistencia remite a la posibilidad de la población de actuar frente a un gobierno considerado arbitrario e ilegítimo. La resistencia parte de la percepción de una injusticia, y por lo tanto, implica a su vez, el reconocimiento de una normalidad, de un estado de justicia que ha sido violado (Ugartemendia Eceizabarrena, 1999).

Salvando las distancias y sin pretender extrapolar al contexto argentino un debate que tiene lugar en relación a otro espacio y período histórico, nos nutriremos de esa

\footnotetext{
${ }^{4}$ Este concepto fue sistematizado por Gene Sharp en la década de 1970, pero encuentra antecedentes en varios pensadores de los siglos XVIII, XIX y XX, entre ellos, Étienne de la Boétie, Henry de Thoreau, León Tolstoy, Dorothy Day y Mohandas Ghandi. En general, se usaron expresiones como "no-resistencia", "resistencia pasiva", "desobediencia", "insumisión" y todas ellas implican el uso de acciones no violentas, opción que, en el caso de Ghandi, se convirtió en un principio filosófico. Para otros autores, la no violencia es simplemente un recurso estratégico, y en esa línea, se insertan los trabajos de Sharp (López Martínez, 2016).
} 
multiplicidad de posibilidades conceptuales que aquellos debates nos permiten para pensar las dimensiones de la Resistencia Peronista en esta tesis. En síntesis, resistencia implica un enfrentamiento ejercido por la población civil con todos los medios que tiene a su alcance contra un Estado al que considera ilegítimo y en una relación de fuerzas desigual. En este sentido, la Resistencia peronista puede ser interpretada bajo este concepto de resistencia con algunas modulaciones al respecto. En principio, la mayoría de los autores que han trabajado con el concepto de resistencia civil sostienen que involucra un rechazo a priori de los métodos violentos de acción. Sin embargo, López Martínez admite que, en la práctica, raramente se da esta situación y que, por lo general, se combinan métodos violentos y no violentos. La Resistencia peronista, en el período abordado, apeló a métodos de acción armada, pero su uso no fue extensivo a todo el movimiento. Siguiendo a Lidia Menapace (citada en López Martínez, 2012), podemos decir que hizo un uso instrumental de dichos métodos y no fundacional, tratándose de un movimiento político y no militar, como ya lo han señalado otros autores (Melon Pirro, 2009).

El concepto de resistencia será revisado a la luz del concepto de "repertorio de confrontación" acuñado por Charles Tilly en el marco de las teorías de la acción colectiva, quien sostiene que dicho repertorio “...es la totalidad de los medios de que dispone un grupo para plantear exigencias de distinto tipo a diferentes individuos o grupos... El repertorio es a la vez un concepto estructural y un concepto cultural. Las 'acciones establecidas' no son sólo lo que hace la gente cuando entra en conflicto con otros; es lo que sabe hacer y lo que los otros esperan que haga" (Tilly citado por Tarrow, 1997, p. 65). Las formas de acción colectiva son históricas. Constituyen repertorios que están asociados a determinados actores, tiempos, lugares y circunstancias. Sin embargo, los repertorios son flexibles; se modifican producto de la negociación, la innovación, el aprendizaje que surge de la propia acción colectiva y de las alteraciones en el contexto institucional (Tilly citado por Tarrow, 1997). El repertorio de acción colectiva se transmite culturalmente. Cada grupo tiene una historia y una memoria de la acción colectiva (Tarrow, 1997). De esta manera, si bien Sharp (2011) sostiene que la resistencia se despliega apelando a los métodos que la gente tiene a su alcance, en la elección de esos métodos intervienen factores culturales y la historia de lucha y de participación de cada grupo. 
Nuestra investigación se posiciona desde una perspectiva de historia de las mujeres y de género, de manera que enfocar la participación femenina en la Resistencia peronista no sólo implica preguntarse por el carácter genérico de la lucha que estas mujeres mantuvieron en el frente externo, contra los gobiernos y opositores al peronismo, sino en el entramado de relaciones del propio peronismo. La problemática política ha sido explorada bajo el prisma del contrato sexual de Carole Pateman (1995), y complementada con otras nociones sobre la sociabilidad política de las mujeres a partir de las teorizaciones de Judith Astelarra (1987) así como las de arquetipo viril propuestas por Amparo Moreno i Sardá (2007) para analizar los estereotipos sociales en la comunicación entendida de modo amplio. Según Pateman (1995), con la teoría del contrato aparece una conceptualización teórica que legitima la relación entre ciudadanía-espacio público-hombre dentro de la sociedad civil, contrapuesta a otra esfera, la privada, como lugar donde se incluye/recluye/excluye a las mujeres. Sin embargo, existe una nueva asociación donde lo civil pasa a ser sólo lo público y lo privado queda como natural y opuesto a lo civil - social. Esta distinción donde cada esfera supone una forma de asociación distintiva y contrastante no tiene las mismas implicancias para hombres y mujeres dado que estas últimas quedan adscriptas al mundo privado mientras que los hombres traspasan ambas esferas y el mandato de la ley del derecho sexual masculino se impone en una y en otra. Al ser excluidas de la esfera social, las mujeres también lo están del contrato social. Este es un pacto entre iguales, que en realidad incluye sólo a los varones y que oculta la existencia de un pacto sexual mediante el cual se establece la relación entre varones y mujeres, que es una relación jerárquica y asimétrica. El contrato sexual es el modo a través del cual los varones tienen garantizado el acceso al cuerpo de las mujeres, es decir, "la ley del derecho político- sexual masculino". Si bien con la modernidad se instaura una relación contractual que deja de lado el papel del status en el estado de naturaleza, ello sólo es aplicable a los varones pues para las mujeres "el sistema de status inherente al género sigue gesticulando y latiendo detrás de la formalidad del contrato" (Segato, 2003, pp. 28 y 29). De este modo, por mecanismos de distinto orden, la violencia original del contrato sexual se perpetúa.

La división de lo público y lo privado, aun teniendo en cuenta la presencia masculina como dominante en ambos espacios, conlleva la construcción de imágenes psicosociales que implican roles que se espera que los sujetos asuman para, por un lado, normativizar el tipo de acciones socialmente esperadas; por otro, para caracterizar a los sujetos que actúan. En relación a ello analizaremos cómo actúa la noción del arquetipo viril, desarrollada por 
Moreno i Sardá. El mismo es "un modelo históricamente atribuido a varones adultos de raza y clase dominantes, fraguado por quienes, para ubicarse y legitimarse en el centro regulador de la vida social -en el centro hegemónico—- se definen a sí mismos positivamente a base de definir negativamente cuantas actitudes y actuaciones humanas no participan de esa voluntad de poder, de esa actividad que cabe considerar anti-humana en la medida en que trata de imponerse sobre otras y otros mujeres y hombres" (Moreno i Sardá, 2007, p. 97). Sin embargo, el mismo actúa en diferentes niveles sociales generando clasificaciones y jerarquizaciones múltiples. Finalmente, nos interesa introducir las nociones de Judith Astelarra (1987) acerca de cómo la división social del trabajo y los procesos de socialización actúan en el mundo de la política determinando las maneras diferenciadas de participación de hombres y mujeres.

En línea con estos planteos conceptuales y articulados con algunos de los problemas antes planteados por las investigaciones históricas, puede ser útil introducir un trabajo sobre la resistencia francesa al nazismo, donde Hélène Eck (2000) se pregunta:

"Se puede distinguir una resistencia <femenina> o, por lo menos, una particularidad femenina de la Resistencia? Es indudable que la Resistencia utilizó como cobertura la feminidad y las presunciones de inocencia, de fragilidad y de ignorancia que distinguen a ésta del sexo fuerte, cobertura cuya eficacia se debe precisamente a que la fuerza de ocupación comparte las mismas representaciones culturales y sociales del comportamiento femenino (...)" (Eck, 2000, p. 278). ${ }^{5}$

Vale decir, podríamos preguntarnos, salvando las distancias entre un caso y otro, si la Resistencia peronista tuvo una forma particular de resistencia "femenina". En ese sentido, continuando con la argumentación de Eck, encontramos un nuevo interrogante:

\footnotetext{
${ }^{5}$ Según la autora, "Los relatos de las resistentes evocan a menudo la utilización de objetos y de gestos femeninos con otros fines: ajustarse una liga o arreglarse el maquillaje en un rincón de un porche permite detenerse unos segundos para inspeccionar los alrededores. Un embarazo real o simulado explica la amplitud de la ropa. El cochecito de un bebé y sus pañales pueden disimular octavillas. En cuanto al capacho, accesorio indispensable en esas épocas de escasez, sirve para todo tipo de transporte. Es allí donde Olga Banciv, única mujer del grupo Manouchian de las FTP-MOI, oculta las armas para los atentados" (Eck, 2000, p. 278).
} 
“¿Hay por ello que concluir que la Resistencia sólo empleó la feminidad como tapadera y sólo consideró a las mujeres como auxiliares, sin duda eficaces y expuestas, pero meramente auxiliares?" (Eck, 2000, p. 278). ${ }^{6}$

Esa particular fragua de las relaciones de poder, centrales en la constitución de lo político, cobra especial significación a la hora de pensar cómo se conforma, en ese marco, un cierto y particular modo de intervención femenino que, a priori, debe sortear una serie de caracterizaciones que la suponen ajena a ese universo, tal y como ha señalado Astelarra (1987). ¿Modificaron las mujeres esas caracterizaciones, conmovieron los marcos de género con su militancia durante la Resistencia? ¿Pudieron quebrar el arquetipo viril histórico y político?

Con estas claves, la estructura de capítulos de esta tesis está organizada en función de la elección de los repertorios de acción colectiva. En cada capítulo se abordará una forma de acción diferente que se considera una dimensión analítica de la noción de Resistencia. Cada uno, además, se ampliará con otras categorías. Esas formas de intervención son entendidas como dimensiones del concepto de resistencia: así, se analizarán los aspectos armados de la Resistencia peronista, sus aspectos organizativos, sus intervenciones sobre el espacio público -entendido este en su carácter físico y discursivo-, y sus aspectos simbólicos y subjetivos. Hemos privilegiado abordar tipos de intervención activa y no los métodos de no colaboración, que ya han sido ampliamente abordados por la bibliografía, aunque no descartaremos alguna mención a ellos.

En cada capítulo se considerarán una serie de ejes de análisis que nos permitirán abordar los objetivos propuestos: el primer eje es el que se enfoca en los repertorios de confrontación elegidos en el período de la Resistencia, retomados, en algunos casos, de experiencias de socialización previa; el segundo eje analizará la influencia de la estructura de oportunidades sobre el desarrollo de las acciones de confrontación; y finalmente, un eje sobre los aspectos subjetivos que rodearon la participación de las mujeres en la Resistencia peronista. Estos ejes de análisis serán articulados con las dimensiones del concepto de género, propuestas por Joan Scott, quien sostiene que “...el género es un elemento

\footnotetext{
${ }^{6}$ La respuesta que da Eck (2000) es que las mujeres realizaron muchas tareas con autonomía y en igualdad con los militantes varones, pero que la misma se perdió a medida que las unidades de la resistencia se
} 
constitutivo de las relaciones sociales basado en las diferencias que se perciben entre los sexos; y es una manera primaria de significar las relaciones de poder..." (Scott, 1993, p. 35.), evidenciando cómo la ideología apela a la naturaleza para legitimar o cuestionar relaciones de poder asimétricas y para justificar las luchas de poder. Para la autora, el género no se construye sólo a través de las relaciones de parentesco y la familia sino también en otros espacios de la sociedad tales como el mercado de trabajo, la educación y la política. Esta historiadora ha ofrecido cuatro dimensiones de análisis que nos resultan atractivas para examinar la Resistencia peronista a la luz de una mirada de género. Ellas son, los simbolismos, los conceptos normativos, las instituciones sociales y la identidad subjetiva, cuya vinculación con los ejes veremos a continuación.

En relación con el primer eje de análisis, el concepto de "repertorio de confrontación" de Charles Tilly, nos permitirá explorar la relación pasado-presente; es decir, cómo las experiencias socializadoras del pasado influyeron en las acciones que las mujeres desplegaron en la Resistencia peronista y en la simbología a la que apelaron para dotar de significado a su participación. Bernard Lahire (2004) ha teorizado acerca de cómo los repertorios de acción se organizan en función de las experiencias socializadoras por las que transitan los actores, tanto individuales como colectivos, procesos en los cuales no sólo se aprenden esquemas de acción sino también su pertinencia contextual. La relación pasado presente es dialéctica porque, por un lado, la interpretación del presente está influida por las experiencias socializadoras pasadas, y a la vez, la situación presente no puede ser ignorada puesto que lo que ha sido aprendido no es idéntico ni necesariamente está en armonía con los requerimientos de la situación actual.

Respecto al uso simbólico, entra a jugar lo que desde las teorías de la acción colectiva se ha llamado el "proceso de enmarcado", que implica una selección de símbolos disponibles culturalmente; símbolos tradicionales que no suelen ser utilizados mecánicamente sino que son escogidos selectivamente y modificados en el curso de la acción y de la interacción en función de las necesidades del presente. Ese proceso de selección, Tarrow lo denomina "alineamiento de marcos", y el mismo actúa en base a "sobreentendidos cognitivos" que contribuyen a dotar de significado a la acción (Tarrow, 1997, pp. 214-216).

fueron militarizando cuando la guerra volvió a su aspecto ordinario. Si bien nuestro contexto no involucra un marco bélico, sus planteos sobre la resistencia nos resultan útiles para pensar el tema. 
Vinculado a la posición de Scott, con la dimensión simbólica apelamos a dilucidar las representaciones a las que apelaron las mujeres para legitimar y significar su participación en la Resistencia peronista y, también, la simbología compartida socialmente que contribuyó a impulsar/inhibir la participación femenina. Esos símbolos encuentran su significado y sus limitaciones en el marco de las normas que imperan en una sociedad en un momento dado, entrando a jugar, de esta manera, la segunda de las dimensiones que Scott (1993) propone para operacionalizar el concepto de género, la normativa. En el caso que nos compete, la delimitación de los símbolos evocados se encuentra estrechamente vinculada con el discurso peronista surgido durante su etapa clásica. De esta manera, pretendemos indagar cómo las acciones que emprendieron las mujeres en la Resistencia peronista y la simbología utilizada para legitimar y significar la acción colectiva guardan relación con las experiencias socializadoras que transitaron en los años previos al derrocamiento y cómo las mismas, al ser desplegadas en un contexto diferente, cambiaron su significado adquiriendo connotaciones confrontativas y subversivas. Frente a esos límites también existieron posibilidades de transgresión en un contexto con características diferentes a las del período de emergencia de esos discursos. Y por otro lado, no podemos dejar de observar cómo operaron las normativas con connotaciones de género que excedía los marcos de la comunidad peronista y que prevalecían en el contexto social de la época.

Este eje se combina con la tercera de las dimensiones que Joan Scott (1993) propone para la operacionalización del concepto de género, la institucional. Como sostiene Scott, una investigación que pretende construir a las mujeres como sujeto de la historia, no puede incorporarlas estudiando sus prácticas de manera aislada, sino que debe considerar al género como categoría analítica y esto implica tener en cuenta cómo a la hora de organizarse socialmente se apela a las diferencias sexuales para justificar dicha organización social y cómo este proceso está atravesado por conflictos y relaciones de poder; lo que convierte a la historia de las mujeres y de género en una historia política. Las problemáticas indagadas a través de este eje nos obligan a considerar el hecho de que, durante la etapa del primer peronismo, las mujeres habían desarrollado una militancia diferenciada genéricamente que funcionó de manera autónoma respecto de las otras ramas que conformaron el peronismo, la política masculina y la sindical, también masculina. Esto nos lleva a preguntarnos acerca de si las acciones que desplegaron las mujeres en la Resistencia peronista y los símbolos de que se valieron para legitimar su actividad estuvieron connotados genéricamente y qué posibilidades hubo de que pudieran generar organizaciones 
basadas en la identidad de género y sostener una agenda propia, teniendo en cuenta que las relaciones de poder internas en el peronismo se inclinaban en favor del sindicalismo, un sector altamente masculinizado, así como de los caudillos políticos del interior del país. ¿Cómo afectaron esos conflictos las relaciones entre mujeres, y a la vez, la posibilidad de generar actividades conjuntas entre varones y mujeres?

El segundo eje de análisis se enfocará en la modificación del repertorio de acción en función de las variaciones del contexto político, alternando entre formas de participación ocultas o clandestinas y formas de superficie, más abiertas y/o legales. Será abordado a partir de la dimensión de análisis que Tarrow define como "estructura de oportunidades", entendida como “...dimensiones del entorno político que ofrecen incentivos para que la gente participe en acciones colectivas al afectar sus expectativas de éxito o fracaso...” (Tarrow, 1997, p.155). La estructura de oportunidades hace referencia a los recursos externos y permite que grupos con escasos recursos internos -recursos monetarios, nivel de organización, poder, nivel de flexibilidad del repertorio de acción- puedan aprovechar dichas oportunidades para lanzarse a la acción colectiva. En general, la estructura de oportunidades remite a un aprovechamiento de las debilidades de quienes detentan el poder (Tarrow, 1997). Sus dimensiones pueden dividirse entre aquellas que hacen referencia a la estructura institucional por un lado, y a las relaciones de poder (Mc Adam, 1999). Entre las segundas, Tarrow (1997) menciona cambios en los alineamientos de los gobiernos, divisiones de las elites y posibilidad de encontrar aliados influyentes. Entre las primeras, hace referencia al acceso a la participación abierta. Aunque la represión no es considerada por Tarrow como una dimensión de la estructura de oportunidades, ya que la concibe como un aspecto estable de la estructura institucional, otros autores la consideran por tratarse de un factor relevante que influye tanto en el nivel como en la naturaleza que adoptará la acción colectiva (Brockett, citado en Mc Adam, 1999). Nuestro objetivo, entonces, al analizar la estructura de oportunidades en que se desarrolló la Resistencia peronista, será indagar cómo el repertorio de acción colectiva de las mujeres fue variando en base a la apertura y cierre de las posibilidades de participación política y cómo se insertaron en los debates de la interna peronista acerca de la adopción de las estrategias a seguir cada vez que cambiaban las oportunidades. 
El tercer y último eje de análisis pretende indagar sobre los procesos de identificación que se generan en las instancias de participación política. En la construcción de una identidad colectiva, las trayectorias individuales se entrelazan con los procesos históricos y lo personal se relaciona con lo colectivo. En los procesos de identificación, las motivaciones emocionales cumplen un rol muy importante a la hora de tomar decisiones que llevan a la acción colectiva, no pudiendo ser reducidas al mero cálculo racional (Revilla Blanco, 1996). Nuestro interés, apelando una vez más a Scott y a la última de las dimensiones que propone, la identidad subjetiva, nos lleva a preguntarnos sobre las connotaciones genéricas que atravesaron el proceso de construcción identitario que se forjó a través de la participación en la Resistencia peronista y cómo la participación en dicho proceso se experimentó individualmente y estuvo atravesada por la relación entre militancia y vida cotidiana.

\section{Metodología y fuentes}

Esta investigación se basa en un enfoque cualitativo que conjuga el análisis de documentos escritos con fuentes orales. El abordaje de una temática que hasta el momento había sido escasamente explorada desde una perspectiva de género y atendiendo a la participación femenina implicó un arduo y minucioso trabajo de búsqueda de fuentes en archivos y hemerotecas. La combinación de una multiplicidad de fuentes, la mayoría de ellas fragmentarias y discontinuas, nos permitió reconstruir un panorama de dicha participación y plantear problemáticas en torno al mismo.

Las primeras fuentes consultadas fueron publicaciones políticas dirigidas por mujeres; nos referimos a Línea Dura (1957-1958), La Argentina (1955) y Soberanía (1956-1958). Más tarde se sumaría Conquista (1963-1964), disponibles en la hemeroteca de la Biblioteca Nacional, el archivo del Museo Histórico Provincial de Rosario Dr. Julio Marc y el archivo personal de Marta Curone. Estas fuentes fueron utilizadas con distintos objetivos. Por un lado, nos permitieron analizar la práctica periodística como una manifestación de la Resistencia peronista en la que algunas mujeres encontraron un espacio de expresión. En segundo lugar, los discursos producidos por esa prensa fueron tomados como objeto de análisis pudiendo así observar la presencia de voces femeninas en el entramado discursivo de la Resistencia peronista a la vez que analizamos las implicancias de género que atravesaron esos discursos. Finalmente, las publicaciones fueron utilizadas en un sentido más tradicional, para ilustrar el contexto político y aspectos biográficos referentes a las 
mujeres que las dirigieron; es decir, las experiencias y prácticas que esas mujeres transitaron como partícipes de la Resistencia.

Respecto de este corpus, hemos considerado algunas cuestiones metodológicas que hacen a su tratamiento como fuentes históricas. En principio, la presencia del periodista como primer dador de sentido de la realidad (Da Orden y Melon Pirro, 2007), algo que también debe tenerse en cuenta para la prensa comercial, sin perder de vista que esta última y la prensa militante parten de pactos de lectura diferentes. Así, mientras que aquella se basa en un pacto de neutralidad y objetividad, aunque sabemos que esas pretensiones son aparentes (Arfuch, 1986), la prensa política se muestra fuertemente personalizada y prevalece en ella el impacto político (Da Orden y Melon Pirro, 2007), a la vez que hace explícitos sus intereses y exalta las críticas al adversario, por estar destinada a un público con quien comparte un colectivo de identificación (Verón, 1987). Se trata de un discurso político explícito y las características de ese discurso se hallan intensamente resaltadas. Por otro lado, los aspectos personalistas, que son evidentes por tratarse de producciones de poca envergadura, fueron tomados positivamente en el análisis porque nos permitieron acceder a aspectos biográficos de las directoras de los periódicos. También, hemos apelado al uso de la prensa comercial y de otras publicaciones políticas, tanto peronistas como de otras fuerzas, mediante las cuales procuramos reconstruir prácticas femeninas en la Resistencia peronista e iluminar el contexto, sin embargo fueron utilizadas como complemento y no se hizo un análisis de las publicaciones en sí mismas; lo que no significa que no hayamos considerado los puntos de vista desde los cuales se posicionan para hablar.

Otro tipo de fuentes al que hemos recurrido son aquellas que integran archivos personales. Hemos examinado el archivo personal de Marta Curone, una militante cuya trayectoria se canalizó a través de estructuras partidarias y cuyo archivo nos permitió acceder a los intentos implementados por mujeres peronistas por crear organizaciones basadas en la identidad de género. ${ }^{7} \mathrm{Al}$ igual que lo que sucede con las fuentes periodísticas, el autor del archivo también aparece como un primer dador de sentido de la realidad. Pero además, estos archivos están impregnados por una intención autobiográfica, que permiten contraponer a una imagen social una imagen íntima (Artières, citado por Castro, 2015). El autor pretende dar una imagen de sí mismo, a la vez que -cuando se trata de militantes-

\footnotetext{
${ }^{7}$ El archivo cuenta con recortes de periódicos, cartas, borradores de discursos y organigramas, el Boletín Conquista, fotografías, invitaciones a Congresos, entre otras cosas. El acceso al mismo fue facilitado por la propia Marta Curone y relevado en su domicilio.
} 
dicha intención biográfica convive con otras que se subsumen a aquella y esos militantes se convierten en historiadores amateurs de sus propias organizaciones de pertenencia (Castro, 2015). Estas intenciones no pueden desestimarse, sobre todo a la hora de investigar los intentos de reorganización partidaria en una fuerza tan heterogénea como el peronismo y en un período de tanta inestabilidad. Siempre que hablamos de reorganización en dicha fuerza política estamos pensando en intentos parciales, encarados desde un sector de la misma, que conviven con otras iniciativas y que no hacen referencia a la totalidad del movimiento. El análisis del archivo personal de Marta Curone ha sido complementado con su libro autobiográfico - publicado on line $\mathrm{e}^{8}$ - y con una entrevista personal. Por último, cabe aclarar que el archivo no fue examinado en su totalidad sino que recurrimos a un recorte temporal que se corresponde con la periodización de esta tesis (1955-1966). Además, se examinó otro archivo personal, el de John William Cooke, disponible en el Centro de Documentación e Investigación de la Cultura de Izquierdas (CeDInC), utilizando de él sólo los documentos que aportaban evidencias respecto de la participación femenina en la Resistencia.

El tercer tipo de fuentes utilizadas son aquellas producidas por los aparatos de represión. Para ello hemos consultado el archivo de la Dirección de Inteligencia de la Policía de la Provincia de Buenos Aires (DIPBA) que funciona en la Comisión por la Memoria de la Provincia de Buenos Aires. A la consulta in situ se sumaron expedientes publicados en CD-ROM por esta misma institución en la compilación Resistencia peronista y plan CONINTES (1956-1975), Colección N¹3 del Área Centro de Documentación y Archivo. Además, examinamos cinco sentencias de los tribunales CONINTES del Archivo Histórico de la Justicia Militar, disponibles en el Archivo Intermedio del Archivo General de la Nación y dos expedientes judiciales del fuero federal disponibles en el Archivo General del Poder Judicial de la Nación correspondientes al año 1956. Es pertinente hacer algunas aclaraciones respecto a las potencialidades y limitaciones de estas fuentes. Los documentos de la DIPBA nos permitieron visibilizar la participación femenina en una gama variada de actividades, como manifestaciones públicas y prácticas simbólicas, intentos de reorganización partidaria $\mathrm{y}$ acciones vinculadas al uso de estrategias armadas. Las fuentes judiciales nos acercaron a este último tipo de prácticas o a acciones que implicaban un desafío directo a las fuerzas del orden.

\footnotetext{
${ }^{8}$ Curone, Marta. Al servicio de la causa. Recuperado de http://movimientoperonista.com/martacurone/alserviciodelacausa.html
} 
A la hora de trabajar con este tipo de documentación debemos tener en cuenta que han sido producidas en contextos represivos y en el marco de relaciones de poder asimétricas (Farge, 1991). Es decir, que el contexto de producción afecta a la información que podemos extraer de las mismas. Las fuentes de la DIPBA nos permiten tener conocimiento de prácticas realizadas por personas que no sabían que estaban siendo observadas mientras aquellas tenían lugar. En cierta medida, nos habilitan a espiar esas prácticas desafiando el tiempo que nos separa de ellas (Farge, 1991). Pero no podemos dejar de considerar la subjetividad de los sujetos que produjeron esos informes y las lógicas burocráticas que impregnaban las prácticas de inteligencia, inventando información para cumplir con la entrega de un informe a un superior (Lorenz en Bacha, 2011), o desestimando el carácter político de algunas acciones, sobre todo en el caso de los comisarios, para evitar sanciones de una autoridad con mayor jerarquía jurisdiccional. También, nos permiten ingresar en la lógica de los agentes de policía y captar sus propias vacilaciones respecto del carácter subversivo de algunas prácticas.

En relación con las fuentes judiciales, nos encontramos con documentos de dos tipos, aquellos que fueron producidos por la justicia ordinaria y los que son producto de la justicia militar. En estos últimos, sólo tuvimos acceso a las sentencias, mientras que entre las primeras pudimos acceder a la voz de los procesados/as ya que se encontraron los expedientes completos que incluyen testimonios y sentencias. Sin embargo, no puede obviarse cómo las relaciones de poder en que se hallaban insertos los sujetos pueden haber influido en sus testimonios. Ello debe alertarnos acerca de la tendencia en los testimonios a negar o minimizar el compromiso político y el involucramiento con las acciones que originaron el procesamiento. También, nos encontramos con las delaciones, que pueden ser verdaderas y redimensionalizar los demás testimonios, a la vez que pueden ser falsas e inculpar a inocentes, sobre todo si consideramos la posibilidad de que hayan sido producidos bajo tortura. Finalmente, debemos explicitar dos elementos a tener en cuenta en el uso de fuentes producidas por los aparatos represivos. Por un lado, la tendencia a exagerar y ver conspiraciones por doquier, planes sistemáticos e infiltración comunista, para justificar la represión (James, 2010 [1998]), y por otro, y tal vez el más importante, las consideraciones éticas que su uso amerita, ya que involucran a personas que fueron víctimas de la represión estatal en un pasado demasiado cercano que aún no ha cerrado las heridas que dejó el terrorismo de Estado, cuyos discursos no fueron emitidos para ser leídos en un futuro o que estaban siendo observados sin saberlo. Por eso, no pretendemos juzgar, a la 
vez que preservaremos la identidad de las personas involucradas en expedientes de este tipo.

Para finalizar debemos hacer referencia al uso que hemos hecho de las fuentes orales y memorias autobiográficas. En la práctica nos encontramos con algunos obstáculos. En principio, la dificultad para identificar a mujeres que hubieran participado de la Resistencia peronista. Una vez identificadas, lograr que quisieran expresarse sobre un período de sus vidas que por diferentes motivos les resultaba conflictivo. Otras veces, la avanzada edad de las personas a entrevistar les dificultó sostener el hilo argumental en sus testimonios. El factor etario no fue un aspecto menor y ello influyó en que la mayoría de nuestros entrevistados sean personas que, al momento de producirse el golpe de Estado en 1955, no superaran los 35 años. Realizamos entrevistas a militantes de ambos géneros porque partimos de una concepción relacional de dicha categoría. También, entrevistamos a familiares, en el caso de militantes cuya trayectoria consideramos relevantes y que se encuentran fallecidos o que, por su avanzada edad, no pudieron brindarnos su testimonio. En dos oportunidades, esos familiares nos facilitaron el acceso a entrevistas realizadas a esos militantes con anterioridad o a escritos dejados por ellos. ${ }^{9}$ Las entrevistas propias fueron complementadas con una entrevista disponible en el archivo oral de la Comisión por la Memoria de la Provincia de Buenos Aires, ${ }^{10}$ y testimonios disponibles en el documental Los Resistentes, de Alejandro Fernández Mouján. ${ }^{11}$

Como todas las fuentes, las orales también exigen recaudos metodológicos. Así como hicimos referencia a los contextos de producción y a los autores como primeros dadores de sentido de la realidad, en las fuentes orales, estos problemas remiten inmediatamente a la distancia temporal que separa el momento en que se generó el testimonio de aquel en que tuvieron lugar los hechos narrados, lo que implica considerar los trabajos de la memoria, y la influencia del investigador y los objetivos de su investigación en la construcción del relato, en tanto el mismo es producto de una autoría conjunta entre entrevistado y entrevistador (Portelli, 2005; Schwarzstein, 2002). Las fuentes orales nos permitieron un acceso privilegiado a las relaciones entre subjetividad e historia ya que en los relatos orales se conjugan varias dimensiones, la experiencia personal con la experiencia colectiva y

\footnotetext{
${ }^{9}$ Enrique Pavón Pereyra (h) nos brindó material audiovisual de su autoría sobre su abuela, Hortensia García Marín (Lala) y Saúl Buzeta (h), nos permitió acceder a los papales de su madre, Inés Dihian.

${ }^{10}$ García Marín, Hortensia. Entrevista realizada por Julieta Sahade. Buenos Aires, 27 de julio de 2010. Archivo Oral. Comisión Provincial por la Memoria.
} 
pública, las memorias personales y las memorias colectivas, a la vez que los hechos históricos son narrados a través de un relato autobiográfico (Portelli, 2005). Si bien las entrevistas fueron utilizadas a lo largo de toda la tesis, su uso principal se encuentra en el capítulo I y en último, donde hacemos referencia a los proceso de subjetivación, puesto que dichas fuentes nos permitieron analizar la construcción de relatos personales y cómo estos reproducen y/o desafian los discursos sociales; hecho que las hace por demás apropiadas para examinar cómo actúa el género en la construcción de esos discursos (James, 1992) y en los propios procesos de subjetivación (Scott, 1993).

Entre las memorias autobiográficas abordadas utilizamos las de Marta Curone, Olga Martín de Hammar y Ana Carmen Macri. ${ }^{12}$ Estas autobiografías de militantes juegan en un doble sentido pues, si bien las colocan en la escena política bajo estudio y evidencian su propia intervención en los hechos históricos, no se construyen a partir de fenómenos introspectivos o confesionales, sino que se expresan en una dimensión polémica reactualizada una y otra vez en el ejercicio de escritura. En general, cuentan también como una forma de autojustificación de las propias intervenciones de manera retrospectiva, aderezando tal vez con observaciones que no tuvieron en aquel momento. Ordenadas bajo una temporalidad muchas veces emocional vinculada al eslabonamiento del recuerdo, quienes escriben memorias asumen, como diría Miraux, que son "testigo de acontecimientos históricos notables, que frecuentó y observó a los grandes de este mundo, los que en mayor o en menor medida influyeron en la vida de una nación, en las decisiones de un Estado, en el espíritu de un pueblo" (Miraux, 2005, p. 17). Estas memorias son insumos importantes para nuestra investigación en tanto no sólo brindan información sino también cosmovisiones del mundo de las personas partícipes de aquellos acontecimientos abordados en esta tesis.

Finalmente, es necesario consignar que utilizamos también un conjunto de correspondencia recuperada en distintos reservorios. El epistolario fue, durante la Resistencia peronista, una de las formas de comunicación que, por antonomasia, quedó asociada a la clandestinidad o semiclandestinidad junto con los mensajes en cintas magnetofónicas que el propio Perón enviaba desde el exilio a la militancia en Argentina. Por ello, hemos utilizado las cartas que Perón intercambió con John William Cooke y dirigentes

\footnotetext{
${ }^{11}$ Fernández Mouján, (2009); Los Resistentes. Relatos de la lucha clandestina entre 1955 y 1965 . Instituto Nacional de Cine y Artes Audiovisuales (INCAA), El Perro en la Luna (Productora). Argentina.

${ }^{12}$ Curone, Marta. "La Secretaría de la Juventud del Consejo Coordinador". Al servicio de la causa, Op. Cit. Hammar, Olga (2009). Tozudamente. Buenos Aires: Intermedia. Macri, Anna (2006). Mi biografía política. Buenos Aires: Instituto Nacional de Investigaciones Históricas Eva Perón.
} 
femeninas como Marta Curone, Elena Fernícola y Juana Larrauri. ${ }^{13}$ Sin embargo, debemos señalar que este medio de comunicación tuvo sus problemas, fundamentalmente, vinculados al contexto proscriptivo. En efecto, algunas de ellas no llegaban porque eran interceptadas por servicios de inteligencia o por simples problemas del correo; otras veces, eran intervenidas por quienes debían portarlas a sus destinatarios $\mathrm{y}$, otras más, podían ser completamente fraguadas. No obstante, en caso de recepción e independientemente de si se ponía o no en duda su contenido y autoría, significaron un aval del líder máximo, directivas sobre la línea a seguir políticamente, etc. Aunque, como veremos, también supusieron interpretaciones diametralmente opuestas entre las ávidas personas que las recibieron y, asimismo, evidenciaron las distorsiones de la distancia en tanto la mirada de Perón estaba mediada por el exilio y una figuración mediada de la Argentina. Difícilmente podríamos considerar esta correspondencia en el orden estricto de escrituras de la intimidad (Caldo y Fernández, 2009) puesto que, precisamente, era la publicidad de estas cartas entre pares de militancia lo que generaba la legitimidad (Sigal y Verón, 2004). Dada la posibilidad de que la carta fuera interceptada, qué decir y cómo requería de un ejercicio de reflexión sobre cada palabra, aunque los tiempos urgentes de la militancia hacían olvidar la necesidad de desdoblamiento del yo que la proscripción requería.

Nuestra propuesta teórico metodológica se nutre, finalmente, del análisis crítico del discurso en tanto permite considerar el discurso como una práctica social, que debe ser situada en el contexto del quien la acciona y quien la recibe y que tiene como fin analizar "las relaciones de dominación, discriminación, poder y control, tal como se manifiestan a través del lenguaje" (Wodak y Meyer, 2003, p. 2). En particular, será de utilidad el análisis del discurso político en el sentido que propone Eliseo Verón (1987), para quien lo que caracteriza al campo discursivo de lo político es el "enfrentamiento" y, por lo tanto, implica la construcción de un "adversario".

En suma, teniendo en cuenta el objeto de estudio, promovemos una postura metodológica heurística (Samaja, 1994). Básicamente, se apelará a observación y crítica y a las técnicas de análisis del discurso. La opción por un abordaje metodológico cualitativo es adecuada para nuestros objetivos, dado que tratamos de comprender el universo de estudio en el mismo marco de referencia de la acción.

${ }^{13}$ Correspondencia Perón-Cooke I (1983). Buenos Aires: Parlamento. Correspondencia Perón-Cooke II (1984). Buenos Aires: Parlamento. Correspondencia de Perón I (1983). Buenos Aires: Corregidor. 


\section{Los capítulos}

La estructura de capítulos, como mencionamos anteriormente, estará organizada en función de diferentes tipos de acción colectiva.

En el capítulo I, analizaremos el recurso a acciones armadas como parte de la Resistencia peronista y el rol cumplido por las mujeres en ese tipo de actividades en vinculación a los discursos sociales sobre la relación entre mujeres y uso de la violencia y las resignificación que sobre ese tipo de manifestaciones se han hecho desde el presente.

Los intentos de las mujeres de organizarse en estructuras político-partidarias y las relaciones intra e intergenéricas que se activaron en relación a ese objetivo serán encaminados en el capítulo II.

El capítulo III estará destinado a abordar la intervención femenina en el espacio discursivo de la Resistencia peronista a través de la prensa gráfica; las connotaciones genéricas de los discursos construidos y los símbolos a los cuales apelaron. A la vez que se considerará la propia práctica periodística como repertorio de acción utilizado por algunas mujeres en la Resistencia peronista.

En el capítulo IV, abordaremos las intervenciones femeninas en el espacio público a través de un tipo de participación con un alto contenido simbólico como fueron las manifestaciones en memoria de Eva Perón en los aniversarios de su nacimiento y muerte.

Finalmente, en el capítulo V, no analizamos un tipo de manifestación de la Resistencia peronista sino que examinaremos los procesos subjetivos que intervinieron en la participación de las mujeres en dicho proceso, sus propias experiencias y la articulación entre militancia y vida cotidiana.

La estructura reposa sobre cómo opera la experiencia del pasado sobre las intervenciones políticas de las mujeres en la Resistencia peronista; cómo dicha herencia influyó en la puesta en práctica de su repertorio de acciones y en la simbología utilizada para legitimar su agencia y, a su vez, sobre cómo la participación femenina está atravesada por la tensión, que recorre todo el período bajo estudio, entre participación institucional y/o de superficie y formas de intervención más solapadas o directamente clandestinas donde los modelos de género cobraron relevancia en los discursos y prácticas así como en la memoria sobre la Resistencia.

Correspondencia de Perón III (1985). Buenos Aires: Corregidor. 


\section{Capítulo I}

\section{Dilemas de género: la violencia política en la Resistencia peronista}

La adopción del concepto de resistencia civil en los debates sobre las resistencias a los regímenes de extrema derecha en Europa en los años '30 y '40 -como señalamos en la introducción de esta tesis - permitió visibilizar la participación de las mujeres en esas experiencias históricas al incorporar al concepto de resistencia actividades estrechamente vinculadas a lo cotidiano y que no implicaban el uso de la violencia, ya que en ellas las mujeres habían tenido una participación muy amplia en términos numéricos; a diferencia de la escasa participación que mostraron en las acciones armadas, que eran las únicas contempladas por las definiciones restringidas de resistencia. Sin embargo, las investigadoras que analizan esas temáticas también admiten la presencia de mujeres en las acciones armadas y en la resistencia encuadrada orgánicamente y defienden el compromiso que asumieron (Bruzzone y Farina en López Martínez, 2012). A diferencia de las resistencias europeas, la Resistencia peronista no transcurrió en un escenario de guerra, por lo que no hubo combatientes en sentido estricto, pese a que no faltaron los discursos que exaltaban esa figura o que interpretaron la situación del país como la de un territorio ocupado (Ehrlich, 2010). Sin embargo, hubo grupos que optaron decididamente por el uso de la violencia como estrategia, que aunque minoritarios y aunque no representaran a la Resistencia en su conjunto, su participación merece ser problematizada y sobre todo en lo que respecta a la presencia femenina, ya que la misma se halla extremadamente silenciada.

En 1955, se inició un período de intensa movilización popular, que dio lugar a una escalada de actos violentos que adquiriría grandes magnitudes en la década del '70 (Gordillo, 2007). Aunque en los cincuenta y comienzos de los sesenta dichas acciones no tuvieron ni la envergadura ni la ubicuidad que tendrían en años posteriores, fueron un fenómeno novedoso para la época. El uso de la violencia, si bien no fue generalizado a toda la Resistencia peronista, ha llamado la atención de los investigadores y de los propios contemporáneos, quedando registradas dichas acciones en las páginas periodísticas y en los documentos de policía y de las Fuerzas Armadas.

Consideramos que la invisibilización de las mujeres como sujetos de la Resistencia peronista se debe en parte a que la mayoría de las prácticas que se han explorado como parte de ese proceso se hallan atravesadas por relaciones de socialización altamente 
masculinizadas, y las que implican el uso de la violencia son un claro ejemplo de ello. Las mismas se hallan atravesadas por un proceso de división sexual del trabajo que asignó roles diferenciados a mujeres y varones, por lo que consideramos que merecen un análisis desde una perspectiva de género. Por ello, nos proponemos analizar esas prácticas en el período 1955-1966, atendiendo a las características que las mismas adquirieron en ese contexto específico y, en particular, las intervenciones de mujeres. Entonces, a lo largo de este capítulo, trataremos de problematizar la participación femenina en la Resistencia peronista durante los años cincuenta y comienzos de los sesenta en acciones que implicaron el uso de la violencia, procurando desentrañar en qué tipo de prácticas se involucraron, qué niveles de compromiso y responsabilidad ocuparon, qué roles desempeñaron, si tuvieron esos roles un carácter disruptivo o más bien conservador en términos de género, si los cuestionaron o los asumieron con naturalidad y, finalmente, cómo resignificaron esas prácticas. En este sentido, abordaremos con más énfasis la dimensión simbólica y biográfica de la operacionalización propuesta por Joan Scott (1993) en sintonía con el eje que aborda los repertorios de confrontación de los que las mujeres se sirvieron para su intervención política.

Las fuentes que hemos utilizado para tal fin son testimonios de militantes procedentes de entrevistas propias y ajenas; expedientes de la justicia ordinaria producidos durante el gobierno de la Revolución Libertadora; sentencias de los tribunales militares creados para efectivizar el Plan CONINTES; expedientes de la DIPBA publicados por la Comisión por la Memoria de la Provincia de Buenos Aires, que contienen informes de inteligencia y recortes periodísticos; prensa política, peronista y comunista y prensa comercial. ${ }^{14}$ Primero, analizaremos la participación femenina en relación a los tradicionales golpes de Estado cívico-militares y luego, en células clandestinas dedicadas a la realización de atentados y sabotajes.

Cabe aclarar que cuando hablamos de violencia, nos estamos refiriendo a la violencia política, aquella que está estrechamente relacionada con el poder, y a su uso por parte de la sociedad. Es decir, la violencia política también incluye acciones de represión y de orden implementadas por el Estado, aunque el carácter político de dichas acciones permanezca

\footnotetext{
${ }^{14}$ Los nombres de las personas que figuran en los expedientes judiciales y policiales no serán dados a conocer a fin de respetar las políticas de protección de datos personales reglamentadas por la Ley n ${ }^{\circ} 25326$ de Protección de datos Personales (Habeas Data). Asimismo, hemos decidido preservar los nombres de aquellas personas que en las entrevistas personales narran sucesos que las vinculan a hechos de violencia,
} 
oculto. Sin embargo, en este capítulo nos interesa explorar el uso popular de la violencia política, vinculada a grupos cuyo propósito fue modificar las relaciones de poder (Moreno Martín, 2009).

En este sentido y en relación a la participación femenina, llamamos la atención, sobre el hecho de que no faltaban ejemplos históricos cercanos de situaciones semejantes, tales como los de la resistencia francesa, antifranquista, italiana o griega. Según consigna la resistente y política italiana Miriam Mafai, "L'ammirazione e la comprensione diminuiscono, quando l'attività della donna sia stata più impegnativa e determinata da una scelta individuale, non giustificata da affetti e solidarietà familiari" [La admiración y comprensión disminuyen, cuando la actividad de la mujer ha sido más exigente y determinada en una elección individual, no justificada por los afectos y la solidaridad familiar] (citada en Yusta Rodrigo, mimeo). Si bien las resistencias europeas frente a los regímenes de derecha tuvieron lugar en otro contexto y adoptaron características muy diferentes respecto de las que adquiriría la Resistencia peronista, lo cierto es que el debate que se ha dado en torno a aquellos procesos nos permite retomar algunas problemáticas respecto de las ideas que circulan en torno a la participación de mujeres en procesos de resistencia. Entonces, subrayamos que la violencia fue parte de un reportorio disponible en el abanico de opciones políticas del momento y que las mujeres que hicieron uso de ella o colaboraron con las tareas para su uso, rompieron estereotipos que las colocaban en actitudes pasivas, antitéticas con el uso de armas, entre otras. Esta perspectiva histórica será complejizada con las reflexiones sobre la violencia que potencian Carole Pateman (1995) y Rita Segato (2003), cuyas obras se concentran en estudiar cómo los pactos patriarcales constituyen una pauta de exclusión violenta de las mujeres del contrato social que se actualiza cotidiana y sutilmente, incluso, cuando las mujeres parecen haber ingresado a ese pacto entre iguales, aunque en realidad, nunca pierden la marca que las distingue como las otras.

A continuación, exploraremos la participación femenina en acciones que conllevaban el uso de la violencia política o su colaboración para la realización de actividades de ese tipo, específicamente en dos modalidades de acción: el tradicional golpe de Estado cívicomilitar y la participación en células clandestinas que se dedicaban al empleo de explosivos. Pero antes, analizaremos las resignificaciones que sobre la Resistencia peronista se han

con la excepción de aquellas cuyos testimonios fueron extraídos de fondos documentales públicos y de material edito. 
construido desde el presente en función del problema de la violencia y las implicancias de género que atraviesan esos relatos.

\section{El lugar de la violencia en las interpretaciones sobre la Resistencia peronista}

La Resistencia peronista ha llamado ampliamente la atención de los investigadores en relación al uso de la violencia como estrategia de lucha. Algunos historiadores se han enfocado en sus aspectos más visibles, aquellos que llenaron las páginas de los diarios; nos referimos a atentados y actos de sabotaje, adjudicando a la Resistencia y a Perón objetivos bélicos (Amaral, 2004 [1993]). Hay autores que interpretaron la realización de esos actos en el marco de estrategias políticas (Melon Pirro, 2009), mientras que otros trataron de desentrañar los aspectos culturales y emocionales de la violencia, por encima de los motivos instrumentales (Seveso, 2010). Existen interpretaciones que se focalizaron en la práctica tradicional del golpe de Estado en contraposición a la novedosa estrategia de la guerrilla (Raimundo, 1998) y en la práctica concreta de esta última (Salas, 2006), a la vez que algunos trabajos hallaron en los años cincuenta y sesenta el origen de una violencia popular que se haría más intensiva y extensiva en la década del '70 (Gordillo, 2007). También se intentó restituir las características que la violencia tuvo en la década del cincuenta advirtiendo sobre las resignificaciones que dicha temática sufrió en los discursos de las organizaciones armadas de los años setenta (Salas, 2006 [1990]). En síntesis, el debate sobre el rol de la violencia en la Resistencia peronista ha girado en torno a su extensión e intensidad, los sujetos que la aplicaron y sus aspectos estratégicos y emocionales. César Seveso (2010), refiere a las connotaciones de género de poemas generados en el contexto de la Resistencia peronista que hacen referencia a prácticas violentas, pero remite a un concepto demasiado amplio de violencia, mientras que lo que pretendemos problematizar en este capítulo, es la relación de las mujeres con prácticas que aluden a un concepto más restringido de violencia, haciendo referencia a aquellas actividades que conllevaban la posibilidad de generar daños materiales o poner en riesgo la vida propia o de otras personas, y que por lo general implicaban el uso de armas o explosivos, con un objetivo político. Por su parte, Laura Ehrlich (2010), ha abordado los modelos de masculinidad en la construcción de la figura del militante combatiente a partir del boletín Trinchera de la Juventud Peronista, pero no problematiza el hecho de que los grupos de esa organización 
también estuvieron conformados por mujeres, algunas de las cuales estuvieron comprometidas en la realización del boletín. Sin embargo, estas interpretaciones, nos resultan sugerentes para pensar esta tesis en tanto, visualizadas en una perspectiva de género, nos abren una puerta para pensar cómo la Resistencia se pensó en masculino, incluso entre los miembros jóvenes, aquellos que integraban la Juventud Peronista (JP), y cómo reprodujo un modelo de masculinidad que naturalizaba la relación de los varones con el uso de la violencia.

Las prácticas vinculadas al uso de la violencia integraron el repertorio de confrontación de la Resistencia peronista. Pero, a diferencia de otras modalidades de acción que conformaron dicho repertorio y que consistieron en una reactualización de prácticas más antiguas, en este caso se trató de un fenómeno bastante novedoso en lo que respecta a la participación femenina. Alejandro Schneider (2005) ha llamado la atención sobre el carácter generacional que adquirió el proceso de transmisión de conocimiento desde viejos militantes anarquistas, comunistas, trotskistas, y ex combatientes republicanos de la Guerra Civil Española, además de dirigentes peronistas y miembros de la Alianza Libertadora Nacionalista, ${ }^{15}$ hacia los militantes jóvenes que integraban los comandos de la Resistencia, las estructuras de base a partir de las cuales se canalizaron las actividades clandestinas, no necesariamente violentas. A su vez, Julio César Melon Pirro (1993) destaca la influencia de militares de tendencia nacionalista cuyas simpatías y vinculación con el peronismo venía de larga data. En las fuentes consultadas, es común encontrar, además, a ex policías y militares retirados realizando este tipo de prácticas. $\mathrm{Y}$ es probable que muchos varones se hayan valido de los conocimientos adquiridos en el servicio militar. Es decir, si a partir del golpe de Estado de 1955 se hizo cada vez más frecuente el uso de la violencia por parte de la población civil y esto se presentó como algo novedoso para la época, consideramos que el carácter disruptivo de este tipo de prácticas tiene que haber sido mayor entre las mujeres. Por un lado, porque si bien es probable que la mayoría de los varones no estuvieran socializados en ellas, aprovecharon los conocimientos de aquellos que si lo estaban. Por

\footnotetext{
${ }^{15}$ La Alianza Libertadora Nacionalista (ALN) fue una organización nacionalista de derecha que tuvo su origen en 1937. En sus comienzos predominaba el componente juvenil aunque también militaban en ella nacionalistas maduros. Incluía integrantes de clase media y alta y también trabajadores. Sus enemigos eran el liberalismo, el capitalismo y el comunismo y sostenía el antisemitismo. Promovía la instauración de un estado corporativo autoritario. Pretendía incorporar a los obreros al nacionalismo a través de un discurso que proclamaba la justicia social. Con la llegada del peronismo quedó reducida a un grupo de choque, desapareciendo las acciones de formación y propaganda, y con un papel marginal en la política argentina. Luego del derrocamiento del peronismo la ALN participó de la Resistencia peronista pero de manera dispersa e inorgánica. Se reorganizó en 1973 con el retorno de Perón a la Argentina (Besoky, 2014).
} 
otro, porque uno de los discursos sociales hegemónicos los legitimaba a hacer uso de la violencia, en tanto ésta interviene como un elemento constitutivo de la masculinidad, que por oposición excluye a las mujeres de su uso (Branz, 2017). La obligación de portar armas y dar la vida por la patria, fue un elemento constitutivo de la identidad masculina que se intentó normativizar desde los discursos decimonónicos ligados a la consolidación del Estado nacional y que tuvieron hondo arraigo incluso hasta las postrimerías del siglo XX. Fue a través de ese deber, lo que se conoce como el tributo de sangre, que se forjó la ciudadanía masculina; un deber del que las mujeres quedaron exceptuadas cuando lograron acceder a los derechos políticos, los cuales estuvieron antecedidos por debates que hacían hincapié en su carácter pacífico y maternal (Valobra, 2010). Entonces, si bien el uso de la violencia presenta un inevitable carácter problemático, tanto para varones como para mujeres, por el riesgo que conlleva y por las implicaciones morales que lo atraviesan, dicha connotación es más visible entre las mujeres por la relación de incompatibilidad entre los roles asociados a lo femenino y el empleo de la violencia que ha prevalecido en los discursos sociales tradicionales.

En la segunda mitad de la década de 1950, el ejercicio de actividades que implicaban el uso de la violencia en la Resistencia peronista consistió preferentemente en la colocación de "caños", bombas de fabricación casera que pasaron a formar parte de su anecdotario, por el carácter rudimentario y poco eficiente de las mismas. Hacia fines de la década del cincuenta se registra el paso hacia el uso de explosivos más sofisticados, y la extensión de prácticas como asaltos y atentados, a la vez que se puso en práctica el primer intento de guerrilla rural, el de los uturuncos, que tuvo lugar en 1959. También se experimentó con la estrategia del golpe de Estado, aunque sólo dos de los múltiples intentos llegaron a ponerse en marcha (James, 2010 [1988]). En esta etapa el uso de la violencia no adquirió la valoración, la expansión y la organización que tendría en los años '70, a la vez que tuvo un carácter primitivo. Pese a ello, consideramos que este aspecto de la Resistencia peronista merece una mirada con perspectiva de género, ya que se trata de una problemática que ha suscitado debates entre los historiadores, pero que aún no ha sido analizada desde dicha perspectiva ni se ha problematizado a partir de la participación femenina.

El vacío historiográfico que se cierne sobre los aspectos violentos de la Resistencia peronista en relación a la participación femenina y desde una perspectiva de género, cobra mayor dimensión si lo comparamos con la abundante bibliografía que aborda esa problemática en la década de 1970, enfocada en la participación femenina en las 
organizaciones armadas, tanto peronistas como marxistas (Diana, 1996; Martínez, 2009; Oberti, 2015; Pascuali, 2008; Seminara y Viano, 2009; Vassallo, 2009). Durante el período que abordamos (1955-1966), la participación de mujeres en actividades con connotaciones violentas no adquirió la magnitud numérica que dicho fenómeno evidenciaría en los años setenta, sino que tuvo un carácter marginal; pero también el uso de la violencia fue menor. Ahora bien, si para la generación de mujeres militantes de los '70, el uso de la violencia se presenta como un factor altamente problemático, dicho carácter cobra una dimensión importante a la hora de analizar la participación de mujeres que se incorporaron a la militancia en los cuarenta y cincuenta, que recientemente habían sido convocadas a participar en la política como ciudadanas, en una sociedad que aún no había experimentado los cambios culturales que se evidenciarían a mediados de la década del sesenta (Cosse, 2010).

Retomar los interrogantes de Hélène Eck (2000) que planteamos en la introducción, nos ayuda a pensar y problematizar la participación de las mujeres en dicho proceso. Entonces, ¿puede decirse que las mujeres que participaron de la Resistencia peronista se limitaron a realizar tareas de apoyo y de simulación? ¿Cómo actuaron los discursos sociales que sostienen la exclusión entre mujeres y violencia sobre las prácticas que desarrollaron las mujeres en dicho proceso? ¿Pudieron las mujeres construir un contradiscurso? Y finalmente, si contemplamos la asociación que tradicionalmente se ha hecho de la Resistencia peronista con el mundo familiar y barrial, ¿podemos deducir a partir de ello que las mujeres se limitaron a participar desde sus espacios cotidianos y desde las tareas que tradicionalmente se les han asignado según su género? ¿O hubo una transgresión a los roles de género tradicionales? En las páginas siguientes trataremos de esbozar algunas respuestas en relación al análisis de dos formas de participación, la práctica del golpe de Estado y la realización de atentados en células clandestinas. Ahora bien, en la medida en que nuestro objeto de estudio se constituye a partir de testimonios, no es posible ignorar el modo en que los militantes construyen sus memorias sobre aquellas acciones y es por ello que, a continuación, introduciremos el modo en que quienes participaron de la Resistencia han concebido esas acciones.

\section{Resignificaciones de la Resistencia peronista}


Ernesto Salas (Salas, 2006 [1990]) ha llamado la atención acerca de los usos y resignificaciones que sufrió la expresión "Resistencia peronista" por los militantes de finales de la década del sesenta y comienzos de los setenta. El autor sostiene que en esos discursos la Resistencia que había tenido lugar en los años cincuenta fue enviada al plano de lo folklórico, creándose una imagen mítica de ella, sin contradicciones, de la cual fue eliminado o subestimado el componente sindical, para resaltar aquellos hechos y momentos de alta combatividad que serían contemplados como antecedentes de la lucha armada que las organizaciones políticas habían adoptado en el momento de producción de esos discursos. Pero la Resistencia peronista también ha sido resignificada desde el presente, y eso es lo que nos interesa analizar en este apartado; en particular el rol que ha cumplido la violencia en esas resignificaciones.

En general, prevalece una mirada mítica sobre la Resistencia que transcurrió en los años inmediatos posteriores al derrocamiento del peronismo, donde el conocimiento que poseemos acerca de ella nos llega en gran medida a través de anécdotas en las que se destaca el carácter heroico pero también inocente de las acciones que se desplegaron, e inclusive se filtra una imagen irracional de las mismas producto de la inexperiencia de quienes estuvieron involucrados. Esto puede apreciarse en libros de divulgación, documentales, discursos de los propios militantes peronistas, tanto de los que formaron parte de ese proceso como de los que no lo hicieron, e inclusive está presente en cierta bibliografia académica. Con ello, no queremos significar que esta tesis se proponga una mirada fría y objetiva de la Resistencia peronista, que además sería imposible de realizar, pero sí señalar que es necesario considerar esas simplificaciones, ya que dejarnos llevar por ellas impediría, como ya lo ha señalado Salas, analizar el período en su complejidad y con todas sus contradicciones.

Así como la violencia se había constituido en un problema en los discursos setentistas respecto de la Resistencia desplegada en los años cincuenta y principio de los sesenta, algo similar sucede en los discursos actuales, pero en un sentido diferente. La militancia de la década del setenta le cuestionó a la primera Resistencia peronista el hecho de que la violencia no hubiera sido extensiva a todo el movimiento y la carencia de objetivos estratégicos y revolucionarios (Salas, 2006 [1990]). Desde nuestro presente, la mirada es bastante diferente, e incluso opuesta. Los discursos actuales llegan a sostener que no hubo violencia en la primera Resistencia peronista o que si la hubo ésta fue escasa, limitada y con 
códigos. Inclusive, estas afirmaciones suelen hacerse para la totalidad del período 19551973, como evidencia el siguiente fragmento:

"La Resistencia Peronista puede vanagloriarse de su éxito: diecisiete años de lucha $[. .$.$] posibilitaron el retorno de Perón, pero puede también ufanarse de no$ haber aprovechado la clandestinidad para llevar a cabo -con excepciones puntuales- represalias sangrientas que hubieran ensombrecido la legitimidad del objetivo perseguido. Si del otro lado era la muerte y la tortura [...] el respeto por la vida de los otros prevaleció por sobre la desesperación [...]”. (Garulli, et. al, 2000, p. 28).

A diferencia de lo que ocurría en los discursos setentistas, desde el presente, la violencia aparece como un elemento deslegitimador de la acción política. Sin embargo, hay discursos que diferencian entre el rol que cumplió la violencia en los primeros años de la Resistencia peronista y en los años setenta. Esos intentos por diferenciar ambos períodos, inclusive están presentes entre aquellos militantes que estuvieron involucrados en actividades que conllevaban un alto compromiso y en el desarrollo de acciones que apelaban al uso de la violencia. En este caso, la misma no es negada, pero suele señalarse la responsabilidad que su uso implicaba y los conflictos morales que generaba. El siguiente testimonio de Juan Carlos Cena extraído del documental Los Resistentes, ilustra claramente esta cuestión, poniendo en evidencia uno de los tópicos que circulan sobre la primera Resistencia peronista, la existencia de códigos: “... Y había códigos. Nunca la Resistencia peronista hizo un atentado o un sabotaje donde había gente. Siempre cuidó al otro, siempre cuidó al ser humano...". ${ }^{16}$ Sin embargo, en su libro El guardapalabras, Cena establece diferencias entre quienes se vinculaban a una violencia con objetivos indiscriminados y quienes consideraban el sabotaje sólo como obstáculo o interrupción de una actividad, oponiéndose a las destrucciones inútiles que atentaban contra el patrimonio nacional, los instrumentos de trabajo o que ponían en peligro la vida de las personas; hechos que además generaban propaganda negativa de la Resistencia peronista (Cena, 1998). Esta idea sobre la existencia de códigos o en todo caso discusiones en el seno de los propios grupos de resistencia sobre el uso responsable y medido de la violencia, también la hemos encontrado en otras entrevistas, propias y ajenas. ${ }^{17}$ Nuestro propósito no es poner en cuestionamiento que esas discusiones existieran. De hecho, hemos encontrado apreciaciones similares en

\footnotetext{
${ }^{16}$ Testimonio de Juan Carlos Cena en Fernández Mouján (2009); Los Resistentes, Op. Cit.
} 
documentos de la época. Así, en el marco del levantamiento de Valle, la policía había incautado directivas para los grupos que iban a participar, en las que se establecían zonas de demarcación que incluían centros de atención de la salud, iglesias y embajadas, donde estaba prohibido realizar atentados y sabotajes, señalando la necesidad de conformar guardias para vigilar que esa normativa se cumpliera. También, se prohibía la realización de desmanes, saqueos, violaciones y atentados en general que pudieran dañar el patrimonio nacional. ${ }^{18}$ Ahora bien, lo que sí nos interesa es señalar la fuerza que esos discursos que tienden a desvincular a la Resistencia peronista del uso de la violencia, tienen en el presente. En el relato siguiente, encontramos cómo cuando se menciona la palabra "resistencia", ésta, automáticamente, va acompañada de una segunda palabra aclaratoria, "pacífica", como si el término "resistencia" remitiera inexorablemente a la violencia:

E: -¿En qué momento se crea la unidad básica que funcionaba en la casa de su hermano?

$[\ldots]$

Nello: -Estas se crearon después [del derrocamiento del peronismo], para la Resistencia, pacífica.

E: -¿Nació como ateneo?

Nello: -Nació como ateneo y después se hizo unidad básica [...]

$[\ldots]$

E: - ¿Y su hermano Francisco había tenido algún tipo de participación política durante el gobierno peronista?

Nello: -No, no, no. En la época de Perón, no. Solamente después del '55. Después de la caída de Perón, del gobierno peronista, ahí sí, ya nos volcamos a la lucha, pero pacífica. Nadie tenía una honda para matar un pajarito [... $]^{19}$

Con ello, no pretendemos sugerir que los entrevistados mientan acerca de su pasado. Sino que semejante énfasis por desvincularse del uso de la violencia, en algunos casos por desligar de la violencia a la Resistencia e incluso a todo el peronismo, nos dan un indicio de que estamos frente a una cuestión problemática; sobre todo, teniendo en cuenta que el cuestionario no incluía preguntas específicas sobre ese tema. Alessandro Portelli (2001 [1999]) ha señalado la existencia de "memorias perturbadoras" e "involuntarias" que se filtran en los relatos sobre el pasado y cómo la negación es el recurso utilizado para

\footnotetext{
${ }^{17}$ Entrevista colectiva; Entrevista de la autora, Rosario, 2012. Testimonio de Jorge Rulli en Entrevista abierta a ex presos CONINTES, Archivo Oral. CPM, La Plata, 30 de mayo de 2008.

${ }^{18}$ Lugo, Nerio y otros. Rebelión e infracción Decreto 4161/56. Exp. 195. Leg. 180. 1956. Archivo Federal. Dirección General de Archivos del Poder Judicial de la Nación.

${ }^{19}$ Fiorenza, Nello; Entrevista de la autora, la Plata, 15 de marzo de 2014.
} 
exorcizarlas. El autor sostiene que el recuerdo del pasado siempre está influido por los valores y preocupaciones del presente; el paso del tiempo actúa sobre los juicios que emitimos acerca de los actos realizados en el pasado. Esto puede responder a cambios en los valores que prevalecen en la sociedad en un determinado momento. A veces, los narradores pueden reconstruir los procesos mentales que hicieron posible que ciertos actos fueran considerados lícitos y/o necesarios en determinadas circunstancias y contextos. Pero otras veces, ello no se logra, y los entrevistados suelen recurrir a fórmulas para exorcizar el surgimiento de esas "memorias perturbadoras".

La Resistencia peronista recurrió al uso de la violencia política, encarada en gran medida por pequeños grupos clandestinos. Además, contó con dos intentos de golpe de Estado que se pusieron en marcha en 1956 y 1960, a lo que debe sumarse el primer intento de guerrilla rural, que tuvo lugar a mediados de 1959. Sin embargo, se trató de acciones de poca envergadura, frustradas, rápidamente reprimidas, a la vez que la violencia no tuvo el carácter gravitante que adquiriría en años posteriores. Ahora bien, ésta se presenta como un tópico problemático, y ello por varias razones. Portelli ha indagado acerca del rol que cumple el tópico de la violencia en las memorias públicas e individuales, para reflexionar, entre otras cuestiones, sobre la lucha partisana en Italia durante la Segunda Guerra Mundial. $\mathrm{Y}$ ha consignado las dificultades de algunos entrevistados para compatibilizar ciertas acciones realizadas en el pasado, con los valores que prevalecen en la sociedad actual y las complicaciones para ubicar históricamente esas acciones; acciones que tuvieron lugar en un contexto de guerra (Portelli, 1999, 2013). La Resistencia peronista no se desarrolló en un contexto de guerra, pero tampoco en un marco democrático. La alternancia de gobiernos civiles y militares, de momentos de completa anulación del funcionamiento de las instituciones republicanas, seguidos de otros caracterizados por una fuerte debilidad institucional y de intromisiones del poder militar en las decisiones gubernamentales, fueron las características que tiñeron el contexto político en el que se desplegó. Se trató de un contexto represivo y proscriptivo, en el que además se implementaron innumerables políticas económicas antipopulares. A ello debe sumarse la legitimidad cada vez más creciente que él uso de la violencia política por parte de los sectores populares estaba adquiriendo en el contexto de la Guerra Fría y de los procesos de descolonización en el Tercer Mundo. Considerar ese contexto haría más comprensible muchas acciones de la Resistencia, porque la violencia es coyuntural; es decir, que está determinada por el 
contexto (Labica, 2008). Sin embargo, no siempre es posible la reconstrucción de ese contexto.

En primer lugar, dicha reconstrucción resulta difícil por las incompatibilidades entre el universo de sentidos del presente, donde hay una mirada condenatoria del uso de la violencia política, en una sociedad que ha atravesado altos niveles de conflictividad social, y donde están muy presentes las secuelas que dejó el terrorismo de Estado; de hecho esas lecturas son muy diferentes de aquellas que se construyeron en la década del setenta para legitimar precisamente la adopción de la lucha armada como método. En el contexto actual, la legítima reivindicación de un sistema democrático que ha estado ausente en la mayor parte del siglo XX y que en el siglo XXI no se halla libre de amenazas ni goza de un funcionamiento pleno, convive con el discurso de la no-violencia, que a veces encubre otros propósitos. Como ha sostenido Georges Labica (2008), retomando una vieja distinción hecha por Karl Marx, en el marco del contexto mundial actual de globalización y políticas ultraliberales, la negación de una violencia "sangrienta", visible, y la colocación de todos los tipos de violencia bajo el mismo parámetro sin establecer distinciones, tiende a ocultar la violencia "muda", invisible pero ampliamente extendida que se vincula con la aplicación de esas medidas.

A la circulación de esos discursos actuales de la no-violencia, debemos sumar el carácter problemático de asumir la propia responsabilidad en acciones de ese tipo ante el temor a posibles sanciones penales y las reservas morales que implica. Incluso entre militantes que adoptaron la lucha armada en la década del setenta existen dificultades para asumir el propio uso de la violencia (Oberti, 2015). La diferencia entre los militantes de los años cincuenta y primeros sesenta y los que se sumaron en los setenta, es que entre estos últimos el problema pasa por reconocer el uso propio de la violencia, mientras que entre los primeros, la negación suele hacerse extensiva a la Resistencia peronista en su totalidad. Es decir, se niega que la Resistencia haya apelado a la violencia como método de lucha.

Hay, además, otro motivo por el cual la violencia resulta perturbadora tanto en los discursos públicos como en los individuales. Y es el hecho de que la Resistencia que siguió inmediatamente al derrocamiento de Perón ha sido construida en los discursos públicos como un paradigma de militancia. Fernando Balbi sostiene que los peronistas, en su socialización política, aprenden ejemplos de lealtad y traición a partir de casos concretos, que están tematizados, estandarizados e integrados al folklore. Estos ejemplares tienen una función cognitiva porque aportan parámetros de comportamiento, con una fuerte carga 
moral, normativa y emotiva. Los relatos de la Resistencia constituyen ejemplares de lealtad que refieren a las relaciones entre Perón y el pueblo o entre Perón y los militantes. Son historias estandarizadas de militancia, relatadas en diferentes organizaciones peronistas, que a diferencia de otros ejemplares que fueron impuestos por la propaganda oficial durante el período 1946-1955, surgieron en gran parte de los mismos protagonistas de dicho proceso. Estos ejemplares transmiten una imagen sobre la Resistencia que se sintetiza en la idea de heroísmo y de entrega, en un momento de adversidad (Balbi, 2007). Entonces, ese tópico de la violencia choca con la construcción de la Resistencia como un paradigma de militancia, que en cierta medida también ha sido construido como reacción a la burocratización y corrupción que ha atravesado a algunos sectores del peronismo, y tal es así que la Resistencia como elemento legitimador y despojada de sus contradicciones y elementos problemáticos es rememorada desde diferente vertientes del peronismo, independientemente del nivel de combatividad o negociación que hayan tenido los sujetos que la reivindican, a lo que hay que agregar que también es evocada por sujetos que no participaron en ella.

Hechas las observaciones anteriores, y procurando responder a los objetivos de esta tesis que pretende desentrañar las implicancias de género que atravesaron a la Resistencia peronista, nos preguntamos cómo dicha categoría, es decir el género, actúa en las memorias sobre ese proceso histórico, en vinculación con el tópico de la violencia.

Al inicio de esta investigación, una de las primeras fuentes consultadas fueron seis entrevistas a mujeres que habían tenido participación en el peronismo durante sus dos primeros gobiernos, disponibles en el archivo oral del Instituto de Investigaciones Históricas Eva Perón. Algo llamativo de esas entrevistas fue que, si bien el cuestionario se enfocaba en ese período, había una pregunta sobre la Resistencia peronista, a la que todas las entrevistadas, excepto una, respondieron que ellas no habían participado y que no habían sido montoneras. Independientemente de si esas mujeres tuvieron o no participación en dicha experiencia, de hecho, muchas personas abandonaron la militancia al producirse el golpe de Estado, esas respuestas nos advierten sobre cómo en los recuerdos personales desde el presente, el fenómeno montonero tiende a eclipsar experiencias previas de resistencia y cómo la asociación de ese fenómeno con la violencia, algo que también es una simplificación, ha llevado a una identificación entre la idea de Resistencia y violencia. De ahí, las necesidades de desvincular a la primera Resistencia peronista de la violencia o de 
redimensionalizar el papel que la violencia cumplió en ella, como lo demuestran los ejemplos expuestos anteriormente.

Consideramos que esta asimilación entre Resistencia y violencia es uno de los factores que hace dificil que muchas mujeres que participaron de la primera Resistencia peronista puedan reconocerse como partícipes de ese proceso. De ahí que la mayoría de las historias sobre el mismo nos hayan llegado a través de relatos masculinos. Ahora bien, entre los militantes varones, pese a rechazar el uso sistemático que las organizaciones de los setenta hicieron de la violencia política, pudo construirse un relato donde ésta aparece matizada. Melon Pirro (2009, p.245 y 246) sostiene que así como hubo una identificación a nivel semántico entre ambas experiencias de militancia, también ha circulado la imagen de un "terrorismo amateur" e "inocente", sostenida por los militantes que tuvieron su participación en la primera experiencia y utilizada para diferenciarse de la militancia setentista, donde la violencia habría sido "menos discriminada" y "menos inocente". Es decir, entre los militantes varones se ha construido un relato alrededor de la tradición del uso del "caño", las bombas de fabricación casera que fueron las que predominaron en los primeros años de la Resistencia peronista. Sin embargo, ese relato no encuentra un paralelismo entre las mujeres. Es como si en ellas el tópico de la violencia ejerciera un efecto más traumático.

El caso Moya constituye un ejemplo de cómo una experiencia violenta emerge de manera diferente en función del género de los emisores del relato. Este hecho remite a una bomba que explotó en la puerta de un bar en el barrio porteño de Congreso, en agosto de 1959. Al parecer, la bomba había estallado por accidente y había generado varios heridos. La llevaba en un portafolios Benito Atilio Moya, un dirigente de la UOM que había sido diputado provincial peronista en Salta, y que estaba acompañado por Lucía Aráoz de Lamadrid, una maestra de 23 años que también era secretaria del sindicato metalúrgico y militaba en la Juventud Peronista, a la vez que encabezaba una unidad básica femenina en Munro, partido de Vicente López. Hay diferentes versiones sobre el hecho, sobre todo en relación con la responsabilidad de Lucía:

"[...] Atilio Moya, que había sido dirigente (creo que de los azucareros), y una chica, que estuvo exiliada después que nosotros en Montevideo. Era maestra, Lucía Arauz [sic] de Lamadrid. Uno la veía y era una dulce maestra de primaria. ¡Y con ese apellido! No sospechaban nunca que actuaba en la Resistencia. Entre 
Moya y ella la pusieron. Ella le hizo de apoyo en una confitería, en Once. Voló todo el edificio [...]." 20

Este relato tiende a naturalizar la participación de Lucía en este hecho y remarca la contradicción entre la apariencia que ella tenía y la que se supone debería tener una mujer dedicada a ese tipo de actividades. De las páginas del boletín Trinchera de la JP, donde esa organización saluda a Lucía Aráoz de Lamadrid mientras estaba cumpliendo su condena, se desprende una imagen de heroísmo sobre su persona:

\begin{abstract}
A LUCIA ARAOZ DE LAMADRID: SALUD!!!
Gracias, por tu silencio

Gracias, por tu sacrificio

Gracias por tu fidelidad a la Causa, por tu temple, tu entereza y tu Fe en la Victoria; por alentarnos desde la fría y lúgubre soledad de tu celda, a continuar la lucha por liberar la Patria.

Por tu valor, por tu conducta, por el auto de fe partidaria con que triunfaste sobre el acoso de los chacales que te torturaron; por ser una JOVEN MUJER DE PUEBLO y haber sabido CUMPLIR... por ser digna de pertenecer a la Juventud Peronista.

GRACIAS COMPAÑERA!!! ${ }^{21}$
\end{abstract}

Lucía Aráoz de Lamadrid sufrió dos años de cárcel, mientras que Moya fue ayudado a escapar por el gremio de la UOM y se refugió en Bolivia. En un relato de Fernando Torres, el abogado del sindicato, comenta que él y Augusto Vandor fueron a despedirlo y sorpresivamente lo encontraron en una fiesta con más de cincuenta personas. Años después, al regresar a la Argentina, Torres relata que Moya todavía disfrutaba contando los relatos de "caños, dinamitas y estruendo", lo que hemos referido en páginas anteriores como un "anecdotario del caño". 22 Olga Martín de Hammar, militante del MRP, recuerda, en su autobiografía que en el contexto del Operativo Retorno en 1964, su pareja, Jorge Hammar, con un grupo de militantes sindicales tenían planeado volar un gasoducto en La Matanza. Como el retorno no se concretó, Hammar se negaba a realizar la operación, pero terminó cediendo ante las presiones de los compañeros. Según Olga, en colocar ese "caño" se jugaban cuestiones de honor y de poder. Ellos querían demostrar que su jurisdicción, La Cava, partido de San Isidro, era capaz de poner más caños que otras jurisdicciones: “...Era

\footnotetext{
${ }^{20}$ Testimonio extraído de Salas (2006)

${ }^{21}$ Trinchera de la Juventud Peronista., Año II, nº9. Buenos Aires, Julio de 1961

${ }^{22}$ Testimonio de Fernando Torres en (Garulli, et al. 2000)
} 
un momento en que se jugaban valores de valentía y además jugaba el sentido de la palabra empeñada: esos eran valores asociados al concepto de virilidad y hombría, que tenían que ver con principios tradicionales del pueblo argentino. $" 23$

Volviendo al caso Moya, Del relato de Mabel Di Leo, quien iba a visitar a Lucía a la cárcel y que se hizo cargo de la unidad básica que ella había dejado vacante, ya que nadie quería hacerlo, se desprende un panorama muy diferente sobre la suerte corrida por esta militante. Lucía habría quedado muy conmovida por los hechos, no volvió a militar y al salir de la cárcel se dedicó sólo a trabajar. Según Di Leo, Lucía no tenía conocimiento del material que Moya llevaba en el maletín, a la vez que también se la había acusado de ser una espía de la policía porque llevaba una credencial de esa fuerza. Frente a ello, la entrevistada aclara que se trataba de una credencial para la obra social, de la cual ella también tenía una, porque los padres de ambas eran policías. ${ }^{24}$ Di Leo comenta que asumió la dirección de la unidad básica que funcionaba en la misma casa de Lucía y, por esa razón, ella comenzó a ser investigada. Para Lucía, que fue quien realmente sufrió las consecuencias del hecho, la experiencia resultó traumática. Para ella no hubo posibilidades de exorcizar los recuerdos, las memorias perturbadoras a las que refiere Portelli, a través del humor o las anécdotas. Por otro lado, su experiencia tampoco encajaba en el modelo ideal de mujer militante que se desprende del artículo de Trinchera.

En nuestra investigación hemos encontrado un solo relato femenino que encaja en ese anecdotario sobre un uso de la violencia inocente y falto de experiencia. En un relato de Lala García Marín, ${ }^{25}$ extraído de una entrevista que le realizara la Comisión por la Memoria de la provincia de Buenos Aires, la militante cuenta que a raíz de encontrarse escondida en un coto de caza en Tandil, producto de sus conversaciones con un vecino, descubrió una fábrica de explosivos. Ella y sus compañeros de militancia, que también estaban prófugos, robaron parte de ese material y lo trasladaron a Buenos Aires, colocándolo debajo de la cama de su padre sin que éste supiera, hasta que por un militar amigo que luego fue a retirar los explosivos, se enteraron que los mismos estallaban por detonación espontánea:

\footnotetext{
${ }^{23}$ Hammar, Olga (2009). Tozudamente. Buenos Aires: Intermedia, p. 76.

${ }^{24}$ Di Leo, Mabel; Entrevista de la autora, Vicente López, 31 de agosto de 2014.

${ }^{25}$ Hortensia García Marín (Lala) fue una militante de la Resistencia peronista que integró el Comando Táctico, habiéndose desempeñado durante los años del gobierno peronista en la Fundación Eva Perón y en el Ministerio de Salud junto a Ramón Carrillo. Combinó la participación en células clandestinas con la actividad partidaria. García Marín, Hortensia. Entrevista realizada por Julieta Sahade. Buenos Aires, 27 de julio de 2010. Archivo Oral. Comisión Provincial por la Memoria.
} 
Lala: Mi papá estaba durmiendo y le pusimos todas las cajas... -“¿Qué son?”, "Cajas que nos han donado, dejá no toqués nada". Era inconciencia total, porque para andar con explosivos uno tiene que tratar de saber qué posibilidad de explosión tiene eso, o lo otro, compenetrarse de lo que está manejando. Nosotros era como manejar papas o batatas.

$[\ldots]$

Julieta: ¿Y su papá se llegó a enterar?

Lala: Sí, papá dijo en calzoncillos largos, dijo: -“¿pero es cierto lo que me han contado? Que han traído y me han puesto... ¿has querido matar a tu padre?" (se ríe). -"No papá, no sabíamos que explotaban solamente espontáneo, era una explosión que hacía el producto". Era un gran patriota él y me aguantó a mí tantos años $[\ldots]$

En este relato se naturaliza el uso de explosivos, experiencia interpretada con una tónica de humor generada por la irresponsabilidad percibida desde el presente, que la entrevistada y sus compañeros de militancia adoptaron en esa oportunidad, no siendo conscientes del peligro que su uso implicaba. Una experiencia similar sobre robo de explosivos en una cantera en La Calera, provincia de Córdoba, es rememorada por una militante que da su testimonio en el documental Los Resistentes, antes referido. Sin embargo, como dijimos anteriormente, este reconocimiento del propio uso de la violencia por parte mujeres, es algo excepcional. En general, las mujeres lo niegan o directamente no se reconocen como parte de ese proceso porque tienden a identificar resistencia con violencia. Pero además, incluso entre mujeres que sí se reconocen como participantes de la Resistencia peronista y que participaron o colaboraron con acciones violentas, suele haber una tendencia a negar la violencia política como elemento constitutivo de la Resistencia. Veamos un ejemplo tomado de una entrevista realizada a mujeres que se vincularon con el levantamiento de Iñíguez en Rosario. Entre estas entrevistadas, la pregunta por la existencia de los comandos de la Resistencia peronista generó un clima de malestar:

E1: -No, nosotros no tuvimos [comandos].

E2: -Los que nos querían combatir, sí.

E3: -Nosotros nunca fuimos de comandos militares [...]

E2: -No, pero los que nos querían combatir, sí.

E3: -Ni tampoco batallones, ni tampoco...

E2: -No, pero los que nos querían combatir, sí. Hacían comandos.

E4: -Los comandos civiles. ${ }^{26}$

\footnotetext{
${ }^{26}$ Entrevista colectiva; Entrevista de la autora, Rosario, 2012.
} 
Cabe aclarar que los comandos no necesariamente desarrollaban acciones que implicaban el uso de la violencia. Sin embargo, se trata de un término que tiene una connotación militar, y esa connotación es la que estuvo presente en el pensamiento de las mujeres entrevistadas y lo que explica la actitud de enojo, ya que inmediatamente a este fragmento seleccionado la entrevista prosigue con una explicación acerca de la existencia de códigos en la Resistencia peronista. Ernesto Salas sostiene que también encontró entre sus entrevistados esta negación a la pertenencia de comandos (Salas, 2006 [1990]). Nuestras entrevistadas no participaron en ninguna estructura que llamaran con ese nombre, puesto que el fenómeno de los comandos no se extendió a toda la Resistencia y ni siquiera a la mayor parte de ella. Su participación en el peronismo pasó por otros espacios y estructuras: el barrio, la familia, la unidad básica barrial, los sindicatos, la CGT local. Pero el fragmento citado es interesante porque revela una oposición enérgica a la violencia y un intento por diferenciarse de los sectores que sí la usaron. En una entrevista posterior a una integrante de este grupo, esta cuestión emerge de manera más evidente:

E: - Para vos ¿Qué fue la Resistencia peronista? ¿Hasta cuándo duró?

E1: -Yo pienso que la Resistencia peronista es lo que hace volver a Perón porque la gente lo pedía continuamente. Está bien que después también tuvimos grupos medio subversivos, en esa época, también nosotros.

E: - ¿Ustedes no los apoyaron a esos grupos?

E4: - No, no apoyábamos. La verdad que nosotros no queríamos que se mate a nadie. Teníamos chicos, jóvenes, que era tanto el fervor peronista que tenían, que ellos querían pelear. Los veían como dioses a esos grupos, pero había que explicarles que dentro de esos grupos no eran todos argentinos, había gente de afuera $[\ldots]$.

$[\ldots]$

E: - Pero en la militancia que ustedes hacían, vos con la unidad básica o con los gremialistas ¿Las actividades que ustedes hacían cambiaron?

E4: -Sí, sí, nosotros lo único que te puedo decir que era distinto es por los grupos subversivos, los cuales anteriormente no habían estado. Anteriormente, éramos realmente compañeros que todos luchábamos por lo mismo. También había otros intereses. Pensá que había gente que quería peronismo sin Perón. ${ }^{27}$

Finalmente, debemos hacer referencia a un testimonio de Mabel Di Leo extraído del documental de Fernández Mouján, Los Resistentes que resulta interesante, porque problematiza el uso de la violencia y reconoce la negación que suele hacerse al respecto. Sin embargo, debe aclararse que se trata de una militante que si bien ingresó a la Resistencia en los años cincuenta tuvo una participación muy activa en los setenta vinculada a la CGT de 
los Argentinos y a la Tendencia Revolucionaria del peronismo. ${ }^{28}$ Hay un testimonio extraído de ese mismo documental que resulta muy interesante, porque si bien también es una excepción en los relatos femeninos, en este caso no hay una naturalización del uso de la violencia sino una problematización:

“[...] Sí, ustedes disculpen compañeras, poníamos bombas. Éramos subversivos. Para los de ahora seríamos terroristas, no sé. Yo me asumo [aplausos] [...] basta de que todos somos nenitos de colegio, buenitos, que nosotros '¡Ah sí, los otros lo hicieron! Nosotros no hicimos nada' [...] El peronismo, disculpen, no empezó en los años setenta. El peronismo empezó en el ' $55[\ldots] . "{ }^{, 29}$

En este relato, la violencia es asumida como un factor inherente a la militancia. A esta militante, la violencia no le resulta problemática en su experiencia personal, pero la desnaturaliza al reconocer que para algunos sí lo fue.

En síntesis, si bien la violencia se presenta como un tópico problemático en los relatos sobre la Resistencia peronista, este aspecto es más acentuado en los relatos femeninos que en los masculinos. Tanto varones como mujeres tienden a minimizar la violencia de la primera Resistencia peronista para diferenciarla de su uso en los años setenta, e incluso negarla. Sin embargo, entre algunos militantes varones pudo crearse un relato sobre el uso del "caño" vinculado a relaciones de camaradería que a través de anécdotas, que apelan al humor producto de la inexperiencia mostrada en ese tipo de acciones o de un acentuado sentimentalismo, les permite reconstruir esas experiencias. Para las mujeres, en cambio, estas parecen haber sido más traumáticas, al punto de que no se ha creado entre ellas un anecdotario en relación a las mismas. Es probable que la mayoría de las mujeres que participaron en la Resistencia peronista en el período estudiado (1955-1966) no hayan realizado acciones violentas directas, aunque muchas acompañaron o ayudaron a quienes las realizaron; sin embargo, no las conciben como tales, es decir no reconocen la presencia real o potencial de la violencia en esas acciones. Por eso, la mayor parte de la información sobre ese tipo de acciones surge de expedientes, es decir, textos que no fueron producidos para

\footnotetext{
${ }^{27}$ E1; Entrevista de la autora, Rosario, 2014.

${ }^{28}$ Mabel Di Leo ingresó a la Resistencia peronista en los años cincuenta como integrante de la Juventud Peronista de Vicente López vinculada a los hermanos Lizaso. A partir de 1959 fue delegada de una unidad básica femenina en San Fernando y en 1966 fue designada por Perón delegada nacional de la Rama Femenina. Junto a su pareja, el mayor Bernardo Alberte, delegado de Perón entre principios de 1967 y de 1968, estuvo vinculada a la CGT de los Argentinos y a la Tendencia Revolucionaria del peronismo.
} 
ser leídos públicamente. Cuando esos testimonios emergen en entrevistas, son matizados con chistes o mostrando irresponsabilidad o ingenuidad, como en el caso de los militantes varones; sin embargo, esos testimonios de mujeres son excepcionales. Ahora bien, establecido este aspecto sobre cómo operan las dimensiones genéricas en la construcción de la memoria sobre las acciones violentas, cabe preguntarnos si es posible reconocer el modo en que las mujeres y los varones intervinieron en aquellas escenas, puntualizando el papel que asumieron las mujeres. A continuación, nos enfocaremos en uno de los aspectos más problemáticos de esa participación violenta como lo fueron los intentos de golpe de Estado desarrollados durante el período por sectores peronistas.

\section{Mujeres en acciones golpistas}

Los golpes cívico-militares se focalizaban en la toma de cuarteles militares, contaban con la participación de militares retirados y de civiles y partían de la premisa de que al ponerse en marcha lograrían el apoyo de oficiales en actividad. Paralelo a este objetivo, una serie de acciones secundarias tendientes a crear el caos social, como la colocación de explosivos en diferentes lugares de la vía pública, el corte de los servicios públicos y las comunicaciones, la interrupción del transporte y la toma de estaciones de radio para transmitir proclamas, eran realizadas con el objetivo de generar el caos social y lograr la movilización de la población. La finalidad de estos golpes era la toma del poder. En ellos, los militares tenían la dirección, mientras que los civiles desarrollaban un papel secundario, ya que aquellos eran quienes poseían las armas y tenían la decisión de entregarlas a los civiles en el momento que consideraran necesario; aunque en general, eran reacios a armarlos y muchos civiles participaban con las armas que lograban conseguir, propias o prestadas, o directamente desarmados (Raimundo, 1998). En la Resistencia peronista hubo dos intentos de golpe cívico-militar que llegaron a ponerse en marcha. El "levantamiento del 9 de junio" o "levantamiento de Valle", tuvo lugar en 1956, y finalizó con los tristemente célebres fusilamientos de varios de sus participantes, civiles y militares, y la detención de cientos de militantes; convirtiéndose en un hecho medular del martirologio de la Resistencia peronista. El segundo intento golpista se concretó el 30 de noviembre de 1960. Se trató del

\footnotetext{
${ }^{29}$ Testimonio de Mabel Di Leo en Fernández Mouján (2009); Los Resistentes, Op. Cit.
} 
"levantamiento de Iñíguez", "levantamiento del COR" o "Revolución del “60". ${ }^{30}$ Es menos conocido que el anterior porque no tuvo su trágico final, pero generó una multiplicidad de allanamientos, detenciones y condenas en el marco del plan CONINTES y es un hecho que ha sido poco estudiado. Además de estos dos intentos golpistas, rápidamente sofocados, hubo incontables conspiraciones en pos de la realización de este tipo de prácticas, pero ninguna llegó a concretarse.

La participación femenina en estos acontecimientos de la Resistencia peronista se halla invisibilizada. La escasa información que hemos encontrado proviene de testimonios orales de mujeres y de expedientes judiciales. De los relatos de dos militantes varones que participaron de la toma del Regimiento 7 en la ciudad de La Plata, se desprende que el hecho central en estos levantamientos, que era la toma de cuarteles militares, era una actividad netamente masculina, donde participaban civiles y militares, pero estos últimos eran quienes tomaban las decisiones. ${ }^{31}$ Sin embargo, con diferentes niveles de compromiso, las mujeres desarrollaron tareas que contribuyeron con esos operativos. En este sentido es interesante retomar las ideas de Anna Bravo (2003) que vienen en consonancia con las preocupaciones que antes mencionamos de Hélène Eck. Bravo elaboró, en un trabajo sobre la resistencia al fascismo y al nazismo en Italia, una tipología de las actividades que suelen desplegar las mujeres cuando se embarcan en movimientos de resistencia: el uso de disfraces, camuflajes y estereotipos consolidados, la apelación al derecho al pudor, prestar sus casas como lugares de reunión, ayudar a los combatientes prófugos, usar sus espacios cotidianos de socialización para agitar políticamente y aplicar códigos que normalmente pertenecen a la esfera personal, como la seducción, el recurso a los sentimientos, la fragilidad y el descaro calculado. Si bien se trata de contextos históricos diferentes, la Resistencia peronista incluyó muchas de esas estrategias de participación, sobre todo en lo que se refiere a las prácticas clandestinas. Por ejemplo, una de nuestras entrevistadas nos cuenta cómo burlaba la requisa policial pasando mensajes a los presos políticos que ocultaba en sus rodetes, porque suponía, acertadamente, que los policías no se atreverían a desarmarle el peinado. ${ }^{32}$

Esto no sólo redimensiona el carácter innovador de la participación femenina en la Resistencia peronista, al ponerla en el marco de otras resistencias, sino también el de la

\footnotetext{
${ }^{30}$ Revolución del COR en referencia a la organización que dirigía Miguel Ángel Iñíguez, el cabecilla del levantamiento, denominada Central de Operaciones de la Resistencia.

${ }^{31}$ E5. Entrevista de la autora, La Plata, 2012 y E6. Entrevista de la autora, La Plata, 2014.
} 
militancia setentista, que muchas veces se valió de prácticas y artilugios que ya tenían una larga trayectoria en las luchas de las mujeres como repertorio de confrontación. De esta manera, los activistas varones en una y otra etapa, necesitaron de ellas para llevar adelante determinadas tareas que reproducían los roles de género tradicionales o porque su condición femenina las volvía menos sospechosas frente a las fuerzas represoras (Cosse, 2014), pero no significa que tuvieran por ello un papel auxiliar sino que era fundamental para aquellas operaciones. Así también, en su testimonio para el documental Los Resistentes de Alejandro Fernández Mouján, Mabel Di Leo informó su participación en el levantamiento de Valle. Di Leo, hija de un ex policía que participó del levantamiento y que en ese entonces tenía quince años, en la noche del 9 de junio de 1956 se encontraba en Aeroparque con un militar esperando por si había algún movimiento. Ella llevaba el arma, y no el militar, porque si los paraba algún representante de las fuerzas del orden era menos probable que revisara a una niña. ${ }^{33}$

Algunas mujeres participaban o eran convocadas a participar desde lo que sabían hacer o desde actividades muy vinculadas a lo doméstico. Por ejemplo, hubo enfermeras que se habían formado como tales durante el gobierno peronista en la Escuela de Enfermería y que su participación en el levantamiento de Valle consistió en organizarse con las personas vinculadas al área de salud para prestar servicios de atención médica a los posibles heridos que pudieran resultar de los enfrentamientos. ${ }^{34}$ Los expedientes judiciales revelan la participación de tres jóvenes de la UES (Unión de Estudiantes Secundarios) -una de ellas hija de un ex diputado peronista y otra, vinculada a una unidad básica durante el gobierno peronista en la que dictaba clases de taquigrafía-, y de una ex delgada censista del Partido Peronista Femenino, que se dedicaban a la venta de juguetes y a la realización de colectas en los locales de venta de alimentos, para juntar fondos y víveres para los presos políticos y sus familias. Este caso es problemático porque la realización de estas acciones se había realizado a pedido de un sujeto vinculado a la ALN que estaba involucrado en las conspiraciones para participar del levantamiento de Valle y que se valió del engaño para comprometer a esas mujeres a la acción. El mismo se dedicaba a contactar a mujeres, la mayoría vinculadas a la UES, a las que seducía e involucraba en tareas políticas, como por ejemplo actuar de enlace y correo para sus actividades subversivas. Pero además, se valía de

\footnotetext{
${ }^{32}$ Entrevista Colectiva. Entrevista de la autora, Rosario, 2012

${ }^{33}$ Testimonio de Mabel Di Leo en Fernández Mouján, (2009); Los Resistentes. Op. Cit.

${ }^{34}$ Testimonio de María Luisa F. en Scoufalos (2007, p.19)
} 
la predisposición de ellas, aprovechando sus ideas políticas y la atracción que sentían hacia él, para encomendarles tareas, como la recién mencionada venta de juguetes y colecta de mercaderías, usando lo recaudado para uso personal. Más allá del verdadero fin a que estuvieron destinadas esas acciones, no podemos desestimar la voluntad que tuvieron las mujeres al realizarlas, donde los motivos sentimentales aparecen estrechamente vinculados con objetivos solidarios y políticos. ${ }^{35}$

Esta relación entre lo cotidiano y lo político también se da en las acciones de cooperación de las mujeres con los presos políticos y sus familias y en la utilización de sus casas para alojar a los activistas que estaban involucrados en las acciones golpistas. Los ejemplos de mujeres que prestaron sus domicilios como lugares de reunión son cuantiosos. Uno de los entrevistados, que participó de la toma del Regimiento 7 en La Plata, sostiene que las reuniones para organizar las acciones se llevaban a cabo en la casa de una partera. ${ }^{36}$ Los expedientes judiciales señalan mujeres cuyas casas eran utilizadas como lugares de reunión, pero además, encontramos implicadas a dos mujeres, madre e hija, en cuya casa se fabricaban explosivos que iban a ser utilizados en el levantamiento del 9 de junio. Si bien, las mujeres no participaron del armado de los explosivos, presenciaban las tareas de fabricación de los mismos y la limpieza de las armas, que además se guardaban en esa casa. ${ }^{37}$ Una de nuestras entrevistadas que estuvo vinculada al levantamiento de Iñíguez en Rosario, nos devuelve un panorama sobre ese tipo de acciones que, no por transcurrir puertas adentro del hogar dejaban de ser peligrosas. El relato refiere a Iñíguez y a un grupo de militares que se alojaron en su casa en los momentos previos a llevar a cabo la toma del Regimiento 11 de Rosario:

E2: -Y bueno, salió de mi casa. Yo no sé cómo no caímos, si no, nos mataban a todos, porque tanto Iñíguez como varios que estaban con él, cuatro no mucho, compraron zapatillas, no de goma, si no de esas zapatillas

E1 y E3: -¿Alpargatas?

E2: -Alpargatas sí. Entonces, sacaron las alpargatas y yo tenía un hueco grande que era para hacer una estufa... Entonces tiraron en el hueco todas las cajas de zapatillas de hombre [ríe] y cuando cae a la mañana; claro, se van ellos, dejan la puerta abierta, así, de mi casa, en una esquina. ¡Era una humareda, que fumaban como locos y no sé cómo no caímos! Bueno, cae el ejército y yo abracé a mis

\footnotetext{
${ }^{35}$ Sturla, Amilcar y otros. Rebelión e infracción Decreto 4161/56. Exp. 32. Leg. 175. 1956. Archivo Federal. Dirección General de Archivos del Poder Judicial de la Nación.

${ }^{36}$ E6. Entrevista de la autora, La Plata, 2014.

${ }^{37}$ Lugo, Nerio y otros. Rebelión e infracción Decreto 4161/56. Exp. 195. Leg. 180. 1956. Archivo Federal. Dirección General de Archivos del Poder Judicial de la Nación.
} 
chicos; mi hijo tenía 10 meses. -"Cállate"- le decía, -"cállate"- y el tipo, al verme con un bebé, se frenó. Y entonces, -"Señora”- dice - ¿Nos permite revisar su casa?" -digo - ¿Mi casa, por qué?”. -Dice -“tenemos órdenes.” "Bueno, pasen". -De milagro mi mamá alcanzó a tirar el revolver de Iñíguez a la casa vecina y le dice a la mujer - "Tape eso con un nylon, tape eso"- y la mujer asustada, -“¡tápelo!” y lo tapó...

$[\ldots]$

E2: -...Entonces, pasó. Y después me dice el tipo..., pero el tipo se avivó; o se avivó por las cajas de zapatillas de tanta cantidad

$[\ldots]$

E2: - ¡Miraron todo eso y no les llamó la atención!

E1: -No, a lo mejor se dieron cuenta que algo

E2: -Por eso, digo que se dieron cuenta. Porque el tipo en el patio de mi casa me abrazó -"Señora cuide a sus chicos, yo sé por qué" - ¿Cómo que no los cuido?", -"Yo sé por qué se lo digo"

E1: -No, debe ser que a lo mejor estaba...

E2: -¡Era peronista. Claro! -“Cuide a sus chicos. Yo sé por qué se lo digo. ¡Ah!

No reciba a nadie que no conozca."- Y se terminaba de ir Iñíguez de mi casa $\left[\right.$ ríe]. ${ }^{38}$

El peligro podía estar dado por la posibilidad de ser detenidas como por el riesgo que implicaba el armado de explosivos y el acopio de material inflamable. En este caso, esta militante se salvó de ser apresada, no sabemos si por su condición de madre o por la posible ideología peronista del militar que fue a allanar su casa. La última frase, "no reciba a nadie que no conozca", parece sugerir que la condición de madre y una supuesta atribución de inocencia derivada de esa condición, fue lo que pesó para que el militar tomara una decisión. A ello hay que sumar la solidaridad de la vecina que escondió el arma. En el caso de las dos mujeres que prestaban su casa para la fabricación de bombas, no se salvaron de la condena que incluyó una estadía en la cárcel de Olmos, en el partido de La Plata. Sin embargo, la detención y el procesamiento se produjo por violación al artículo $1^{\circ}$ del decreto 4161, aquel que prohibía el uso de los símbolos peronistas, ya que de la casa se secuestró material de propaganda peronista, además de directivas de un plan subversivo que una de las mujeres se encargaba de confeccionar y reproducir con una máquina de escribir y un mimeógrafo que también fue hallado en el lugar. Luego se las acusó por conspiración para cometer rebelión, aunque fueron apresadas antes de producirse el levantamiento y al poco tiempo sobreseídas provisionalmente porque si bien el juez consideró que habían estado

\footnotetext{
${ }^{38}$ Entrevista colectiva; Entrevista de la autora, Rosario, 2012.
} 
involucradas en ese hecho no se había podido demostrar que su accionar hubiera tenido el carácter de promotor o que fuera imprescindible para la puesta en marcha del operativo. ${ }^{39}$

Otra modalidad de acción en la que solemos encontrar a las mujeres de la Resistencia peronista, es en la ayuda a los presos políticos y sus familiares. Algo ya vimos en el caso de las mujeres que vendían juguetes y hacían colectas para ayudar en esas circunstancias. Si bien se trató de un engaño, podemos presuponer que quien lo ideó apeló a una actividad que suponía tendría buena aceptación entre las mujeres. Los testimonios de mujeres rosarinas que estuvieron vinculadas al levantamiento de Iñíguez también dan cuenta de cómo se organizaron conjuntamente en los días subsiguientes para llevar la comida a los presos políticos que habían participado de la toma del Regimiento, comida que compartieron con ellos en las fiestas navideñas, y la ayuda que prestaron a los familiares de los detenidos en Salta, que habían sido trasladados a Rosario para ser juzgados por los tribunales de guerra, alojándolos en sus casas. ${ }^{40}$

Finalmente, y aunque de manera menos cuantiosa, hay algunas evidencias de mujeres participando de tareas de conducción, en las organizaciones creadas para el desarrollo de actividades clandestinas; los comandos. En el contexto del levantamiento de Valle, los expedientes judiciales ofrecen la evidencia de mujeres abocadas a la organización de tal tarea. Un sujeto detenido por haber permitido en su casa una reunión política menciona a una mujer de unos 45 años que instaba a los presentes a reunirse en comandos para que los peronistas estuvieran unidos y trabajaran juntos por el retorno al régimen anterior en el cual consideraba que se estaba mejor, ya que el nuevo gobierno estaba vendiendo la Argentina al extranjero. ${ }^{41}$ Ello nos habla de la iniciativa femenina y también del grado de politización de las mujeres involucradas en la Resistencia. Josefina Centurión ofrece varios ejemplos de la actividad de mujeres organizando y dirigiendo comandos, que extrae de las narraciones del libro de Juan Manuel Vigo (1973). ${ }^{42}$ Jorge Vázquez, un militante de la Resistencia peronista

\footnotetext{
${ }^{39}$ El sobreseimiento definitivo se les otorgó durante el gobierno de Frondizi con la ley de amnistía 14436 del 23 de mayo de 1958. Lugo, Nerio y otros. Rebelión e infracción Decreto 4161/56. Exp. 195. Leg. 180. 1956. Archivo Federal. Dirección General de Archivos del Poder Judicial de la Nación.

${ }^{40}$ Entrevista colectiva; Entrevista de la autora, Rosario, 2012 y E1; Entrevista de la autora, Rosario, 2014.

${ }^{41}$ Lugo, Nerio y otros. Rebelión e infracción Decreto 4161/56. Exp. 195. Leg. 180. 1956. Archivo Federal. Dirección General de Archivos del Poder Judicial de la Nación.

42 Juan Manuel Vigo fue un militante del Partido Comunista que luego del derrocamiento del peronismo se unió a la Resistencia peronista y participó de las conspiraciones para el intento de golpe de Estado del 9 de junio de 1956. El libro a que hacemos referencia recoge los manuscritos que escribió en la cárcel de Villa Devoto, en la que estuvo detenido por su vinculación a ese hecho y narra su experiencia en los preparativos para el golpe.
} 
cuyo testimonio tomamos del documental Los Resistentes, recuerda a una mujer, Audelina Domínguez, que dirigía el comando donde él participaba. ${ }^{43}$

Aquí, entonces, retomando la pregunta de Eck sobre si las mujeres actuaron como tapadera en la resistencia francesa, actuando los roles de género, y limitándose a acciones de colaboración, podemos responder para el caso de la Resistencia peronista, que encontramos ejemplos de acciones femeninas que no se reducen a esa idea de tapadera y a acciones meramente auxiliares. Si bien las mujeres quedaron excluidas de la toma de los cuarteles militares en los intentos de golpe de Estado que se pusieron en marcha, paralelo a ese objetivo militar estaba prevista la realización de acciones de sabotaje por comandos o grupos de civiles, algunos de los cuales ya existían previamente, pero otros se conformaron para participar de los levantamientos, y hubo mujeres que participaron de esas estructuras, aunque la documentación al respecto es muy limitada. Es decir, las acciones de las mujeres en la Resistencia peronista no pueden quedar limitadas a meras actividades de apoyo, aunque así se las recuerde en los relatos masculinos sobre dicho proceso. Hubo iniciativas femeninas y si bien fueron en menor número en el desarrollo de prácticas que implicaban el uso de la violencia, a lo largo de esta tesis veremos que en otras actividades no violentas dicha iniciativa fue mayor.

Ahora bien, las mujeres participaron cuantiosamente en actividades de apoyo y en acciones que remiten a la idea de "tapadera" que menciona Eck (2000), pero debemos problematizar cuáles son las implicaciones de esa idea. El término remite a un fingimiento de los roles femeninos tradicionales o que se usara a las mujeres para ocultar actividades subversivas porque el enemigo, basado en una supuesta bondad o ingenuidad o en la presunción de un apoliticismo considerado inherente a la condición femenina, no sospecharía de ellas. Para la autora, esto implica que tanto los resistentes como los enemigos compartían las mismas representaciones sobre los comportamientos femeninos. ¿Pero esto era realmente así? Actuar conforme a los estereotipos tradicionales sobre el comportamiento femenino no es lo mismo que creer en esos estereotipos. La condición de actuación de los roles tradicionales femeninos nos está advirtiendo del hecho de que las mujeres que se comprometieron a actuar de esa manera estaban conscientes de que ellas no encajaban en los mismos y que el compromiso que les exigía su participación política implicaba una cierta transgresión a los modelos de género tradicionales. Si recientemente las

\footnotetext{
${ }^{43}$ Testimonio de Jorge Vázquez en Fernández Mouján (2009); Los Resistentes, Op. Cit.
} 
mujeres habían logrado obtener su carta de ciudadanía y aún generaba muchos recelos en la sociedad el hecho de que votaran,${ }^{44}$ mucho menos comprensible a nivel social era el hecho de que se involucraran en actividades consideradas subversivas y menos aún, si éstas implicaban el uso de la violencia; aunque ellas no participaran directamente del armado y colocación de explosivos o del uso de armas.

Esta función de tapadera, de uso de los atributos femeninos, además suele invisibilizar el riesgo que se esconde detrás de muchas acciones consideradas de apoyo. Veamos un ejemplo extraído de la entrevista antes mencionada sobre el levantamiento de Iñíguez:

E: - ¿Y a usted, además de prestar su casa, le toco hacer algún otro tipo de actividad en la toma del regimiento?

E2: -No, en lo de Iñíguez precisamente no. Tenerlo en mi casa para protegerlo. Después, él salió a la noche siguiente, salió con mi nena. "¡Ay! ¡Que linda, qué linda!"

E3: -¿No dijiste que salió con el perro, que salió a pasear un perro?

E2: -Sí, sí [ríe], pero después a la otra noche, él salió con mi nena, que tendría 4 o 5 años. ‘¡Ay, qué linda la nena, qué linda la nena!' Y salíamos por la calle [ríe] y había salido la foto [de Iñíguez] por todos los diarios y nosotros con la nena como acompañando a una familia que iba..., hasta que pasó un auto...

E1: Sí, se salía así, se salía como si fuese una familia.

E2: Una familia. Y en eso, en una calle, pasó un auto y lo recogió a él, se subió y ahí respiramos, porque yo con mi nena en brazos... "¡Qué linda la nena!", decía $\left[\right.$ ríe]. ${ }^{45}$

Este testimonio es muy revelador del compromiso y del riesgo que muchas veces atravesó la participación femenina en la Resistencia peronista, un factor que tiende a subestimarse por considerar a esa participación como auxiliar. Además redimensiona algunas de las imágenes de la Resistencia que han llegado hasta nuestros días. En el capítulo $\mathrm{V}$, retomaremos estos aspectos con mayor profundidad. Hasta aquí, entonces, podemos considerar que las mujeres en la Resistencia peronista no se limitaron a realizar tareas de apoyo, aunque también las llevaron adelante, sobre todo en el caso de las acciones que

\footnotetext{
${ }^{44}$ Un ejemplo de que el hecho de que las mujeres votaran aún no era tomado con naturalidad por la sociedad en su conjunto en los años posteriores al derrocamiento del peronismo lo encontramos en un artículo periodístico del diario Clarín del año 1961 donde a diez años de que las mujeres votaran por primera vez y a más respecto de la aprobación de la ley de voto femenino, tomaba esa participación a modo de burla. Clarin, "Cuando votan las mujeres...", Buenos Aires, 6 de febrero de 1961.

${ }^{45}$ Entrevista colectiva; Entrevista de la autora, Rosario, 2012 y E1; Entrevista de la autora, Rosario, 2014. E1 en la primera entrevista también hace referencia a un hecho similar en oportunidad de producirse el arribo del dirigente sindical Andrés Framini a Rosario. Para lograr que llegara al local donde daría el discurso, lo escoltaron con la presencia de algún niño, para simular que se trataba del paseo de una familia.
} 
implicaban el uso de la violencia. Sin embargo, ello no significa que no estuvieran politizadas y no tuvieran objetivos claros al participar de esas acciones. Por ejemplo, en el caso del sujeto que engañaba a mujeres para que vendieran juguetes e hicieran colectas de cuyos frutos se beneficiaba, podemos observar que no recurrió a cualquier mujer, sino a militantes de la UES o vinculadas al Partido Peronista Femenino; mujeres que estaban comprometidas con una causa política. Incluso, una de ellas en su testimonio, sostiene que uno de los motivos que la llevó a sentirse atraída por esa persona era por su conocimiento político y porque compartían ideas. Lo que comprometió a muchas de estas mujeres, que no en todos los casos se les pudo comprobar su vinculación con el levantamiento de Valle, fue que tenían en su casa propaganda peronista más elementos para la producción de panfletos, lo que las hacía responsables de violar el decreto $4161 .{ }^{46}$ La resistencia se desarrolló en gran medida a través estructuras cotidianas, pero esas estructuras ya estaban politizadas previamente.

A diferencia del pasado, donde las mujeres habían tenido una militancia autónoma en el Partido Peronista Femenino, luego del golpe de Estado de 1955, la clandestinidad las impulsó a hacer acciones conjuntas con varones. Sin embargo, en estas actividades que estamos analizando hay una clara división del trabajo, porque ellas no participan de la toma de los cuarteles. Esa exclusión aparece muy naturalizada entre las mujeres y no fue cuestionada. Pese a que hubo cierta transgresión de los roles de género tradicionales, la fuerza de los discursos hizo que en este tipo de actividades, los golpes de Estado, no pudieran transgredir los discursos que las excluían del uso de las armas. El hecho de que en estas acciones interviniera una institución conservadora como es el ejército, contribuyó a mantener esa exclusión. A ello debemos agregar que el reclutamiento de civiles se hacía en gran medida a partir de las estructuras sindicales, otra institución basada en relaciones de socialización altamente masculinizadas. En este punto, debemos contemplar que hubo una doble exclusión, porque los varones civiles ocuparon un nivel de decisión menor al de los militares y a ellos los militares les retacearon la entrega de armas. Ello nos coloca frente a las particularidades en relación con la construcción de género de las masculinidades (Branz, 2017) y las marcas que en este contexto asumió una masculinidad, si se quiere, hegemónica respecto de las acciones que se llevaron adelante y que diferenció entre los varones que, por su condición de no militares, tuvieron una posición jerárquica mayor que la de quienes no

\footnotetext{
${ }^{46}$ Sturla, Amilcar y otros. Rebelión e infracción Decreto 4161/56. Exp. 32. Leg. 175. 1956. Archivo Federal. Dirección General de Archivos del Poder Judicial de la Nación.
} 
tenían esa condición. Aun así, muchos se acercaron a participar con las armas que tenían o con las que lograron conseguir, además de que hubo casos donde los militares franquearon esas barreras y optaron por entregar armas a quienes no tuvieron condición militar previa. ${ }^{47}$ Las mujeres quedaron suprimidas desde un principio y esa exclusión se basó en estereotipos de género, es decir, se las excluyó por ser mujeres; una exclusión que tampoco ellas cuestionaron. Ahora veamos cómo se desarrollaron las relaciones de género en células clandestinas dedicadas al uso de explosivos y a la realización de atentados.

\section{Mujeres en células clandestinas}

Entre las estructuras que conformaron la Resistencia peronista se encuentran los comandos. Estos eran grupos que se formaron durante el gobierno de la Revolución libertadora para realizar acciones clandestinas que podían implicar o no el uso de la violencia. Los investigadores han debatido sobre su composición de clase y aunque casi todos sostienen el carácter interclasista de estas agrupaciones, hay diferencias en el protagonismo que le otorgan al factor obrero. Lo cierto es que hacia 1959/1960, todos los autores (Amaral, 2004 [1993]; James, 2010 [1998]; Salas, 2006 [1990]; Schneider, 2005; Raimundo, 1998), señalan el fin de la colaboración entre los comandos y los sindicatos y un incremento del componente juvenil de clase media, con la excepción de Melon Pirro (2009) que sitúa ese cambio hacia 1957. Los comandos no tuvieron una organización centralizada, pese a que no faltaron intentos en pos de ese objetivo (Salas, 2006 [1990]), no fueron extensivos a toda la Resistencia, y también actuaron como estructuras a partir de las cuales se intentó reorganizar políticamente al justicialismo desde la clandestinidad, aunque de manera infructuosa (Schneider, 2005). La composición de los comandos en términos de clase es un tema que ha llamado la atención de los historiadores, pero hasta el momento, es poco lo que se sabe sobre su composición en términos de género. En este apartado, nos interesa reconstruir el accionar de mujeres en células clandestinas o vinculadas a organizaciones de ese tipo, algunas denominadas comandos, que apelaron al uso de la violencia como recurso. Cómo fue la composición de género de esas estructuras, quiénes

\footnotetext{
${ }^{47}$ E6; Entrevista de la autora, La Plata, 2012.
} 
eran las mujeres que participaban, qué actividades hacían, qué niveles de responsabilidad asumieron y a qué riesgos se exponían.

En general, la bibliografía coincide en que la actividad de los comandos durante los primeros años de la Resistencia peronista no tuvo gran envergadura en cuanto al uso de la violencia y que las bombas que predominaron eran de fabricación casera y de poco alcance. Pero hacia fines de la década del cincuenta se habría dado paso a un involucramiento de los comandos en tareas más comprometidas que requerían mayor organización. A partir de 1959, luego de la ruptura del pacto entre el peronismo y Frondizi, hubo una proliferación de huelgas, atentados y una fuerte movilización popular. El accionar de la Resistencia peronista adquirió nuevas características, entre ellas, un incremento del profesionalismo, la realización de acciones de mayor envergadura y un perfeccionamiento en los mecanismos de detonación, a la vez que se había creado un circuito de provisión de insumos para la fabricación de explosivos que iba desde las provincias del interior a Buenos Aires (James, 2010 [1988]). También, se produjeron los primeros intentos de guerrilla rural y de conformación de ejércitos de carácter popular que se proponían superar la dependencia de los sectores militares en los tradicionales golpes de Estado (Raimundo, 1998; Salas, 2006 [1990]). Es en este contexto en que tuvieron lugar las intervenciones de mujeres que detallaremos a continuación.

Las mujeres que aparecen mencionadas en las fuentes, cinco sentencias de los tribunales Conintes, cuatro de las cuales datan de 1960 y una de 1961, y cinco legajos de la DIPBA sobre hechos ocurridos entre 1960 y 1964, formaban parte de células que estaban implicadas con la realización de atentados o tenían vinculación con ellas sin integrarlas permanentemente. Dichas células clandestinas actuaban en diferentes espacios del territorio nacional, especialmente en Capital Federal, el conurbano bonaerense, las ciudades de La Plata, Rosario y las provincias de Mendoza y Salta. Resulta difícil dilucidar el número de miembros que conformaba cada célula. Los documentos CONINTES muestran grupos de individuos juzgados por su participación en un mismo hecho o en hechos relacionados. Además de las personas procesadas, los documentos hacen referencia a personas implicadas que lograron fugarse, resultando dificultoso deducir el grado de vinculación con la célula, el tipo de actuación y el nivel de responsabilidad de estas últimas. Por otro lado, todos los sujetos que figuran en un caso en particular, no necesariamente trabajaban juntos de manera permanente. Hay casos de personas que fueron contactadas para realizar actividades específicas en una operación en particular y de otras, que actuaban vinculadas a una célula - 
ya sea colaborando o desarrollando tareas con cierta autonomía-, pero que no integraban la misma ni tenían conocimiento de la totalidad de las actividades a las que estaba abocada dicha estructura. Respecto de las fuentes de la DIPBA, también resulta difícil obtener una imagen definida de los grupos, por tratarse de informes de inteligencia, reconstrucciones hechas por agentes policiales de las cuales no puede saberse en qué medida se correspondían con la realidad. Por un lado, y como ya lo hemos señalado, tendían a exagerarse las vinculaciones entre las células y a considerarlas como si formaran parte de un gran plan terrorista orquestado por los altos mandos del peronismo o del comunismo, a la vez que es factible que cayeran bajo sospecha personas que posiblemente no estuvieran comprometidas en los hechos que se investigaban, y el caso contrario, sujetos implicados cuyo involucramiento y existencia no llegaran a ser percibidos por los agentes que redactaron los informes. ${ }^{48}$

Tres de los expedientes de los tribunales del Plan CONINTES remiten a sucesos que tuvieron lugar en la provincia de Mendoza. Se trata de atentados que ocurrieron el 25 de mayo de 1960, en los cuales se produjo la voladura de parte de un puente en Tunuyán, explotó una bomba en un hotel en Chacras de Coria, departamento de Luján de Cuyo, que funcionaba como sede de una empresa petrolífera norteamericana, y otra, en la casa del General Cecilio Lavayrú, en la ciudad de Mendoza. No hubo víctimas en ningún caso. En febrero de ese mismo año, el grupo vinculado a estos atentados había robado explosivos de la mina Huemul en Malargüe, parte de los cuales habían sido distribuidos en Mendoza y otro tanto enviados a Buenos Aires. En marzo habían robado una antena de radio ubicada en el refugio de altura de la Laguna Diamante, propiedad de la Universidad Nacional de Cuyo. Y además, habían volado un busto de Urquiza. ${ }^{49}$ En estos hechos tuvo participación una mujer que era la esposa del cabecilla de la banda. Según los expedientes CONINTES, ella habría actuado como correo transportando la correspondencia que su esposo mantenía con reconocidos activistas y dirigentes peronistas, trasladándose por diferentes lugares del país, como San Juan, Buenos Aires, e incluso Montevideo. Había llevado cartas a Mendoza conteniendo directivas para el voto en blanco en las elecciones de 1960, planes para un movimiento subversivo y propaganda peronista. También, había entregado dinero para facilitar la salida del país de activistas implicados en los hechos, intercambio de armas con

\footnotetext{
${ }^{48}$ Para un análisis del archivo de la DIPBA ver (Kahan, 2007)

${ }^{49}$ Estos hechos que tuvieron lugar en la provincia de Mendoza ya han sido analizados por Yamile Álvarez (2014) en un trabajo que procura redimensionalizar el estudio de la Resistencia peronista a nivel geográfico.
} 
otros activistas en base a directivas dadas por su esposo, y había participado del robo a la antena de radio de la Universidad Nacional de Cuyo, y de varios intentos previos. ${ }^{50}$

Otro de los expedientes Conintes narra el caso de una joven de 23 años, miembro de la Juventud Peronista de Mendoza e hija de una ex legisladora peronista, que participó de la redacción de un boletín llamado El Guerrillero y de un panfleto titulado "Ahí van desfilando los uniformes vacíos de la patria”, que estaba previsto ser arrojado el día 25 de mayo durante el desfile militar en Mendoza. Se la había apresado al llegar junto con su hermano al sindicato de la sanidad, ATSA, a buscar los panfletos, que habían sido impresos en ese lugar, y además se la acusaba por haber propuesto, en una reunión de la CGT, tirar monedas al paso de las tropas en el desfile. Si bien no había estado implicada en actividades que conllevaran el uso de la violencia armada, estaba vinculada con el grupo que había hecho los atentados en Mendoza, además de que su propuesta de lanzar monedas en el desfile militar junto con el contenido del panfleto, eran hechos de un alto contenido simbólico y disruptivo, ya que atentaban directamente contra la investidura militar. Los panfletos que ella debía arrojar formaban parte del plan de actos subversivos que estaban planeados para el 25 de mayo. ${ }^{51}$

El tercero de los expedientes remite a un grupo de personas también relacionado con la banda de Mendoza. Estaban acusadas de colaborar en el transporte y resguardo de explosivos. Entre ellas, figuraba una mujer encargada de colocar los explosivos, a pedido de un miembro de la banda, en una casa vecina de la cual poseía las llaves y cuyos dueños estaban ausentes. Al regreso de éstos, los explosivos fueron llevados por ella y otra persona a otras viviendas, incluida la de su hermana, para finalmente ser enterrados. Sin embargo, terminarían siendo encontrados. En un principio, esta mujer había participado con la creencia de que las cajas que transportaban contenían balas, pero luego se le había informado del verdadero contenido, frente a lo cual había propuesto hacer un inventario; una actitud que por un lado demuestra que no se oponía al desarrollo de actividades que implicaban el recurso a la violencia, y por otro, su inexperiencia en las mismas, puesto que al hacer un inventario estaba generando un documento comprometedor. ${ }^{52}$

\footnotetext{
${ }^{50}$ Libro 115. 1960 Bis. Exp. № 21. Folio 125. "Asociación ilícita”. Archivo Histórico de la Justicia Militar (AHJM). Sentencias. Inventario. Consejo Superior de las Fuerzas Armadas. Archivo Intermedio. Archivo General de la Nación (AGN).

${ }^{51}$ Libro 115. 1960 Bis. Exp. N 23. Folio 142. "Conspiración”. (AHJM). Op. Cit.

${ }^{52}$ Libro 117. 1961 Tomo 1. Exp. №3. Folio 14. “Intimidación”. (AHJM). Op. Cit.
} 
Otro de los hechos a que hacen referencia las fuentes CONINTES es la colocación de dos bombas en la casa del General Juan Alberto Lagalaye en Olivos, el 27 de mayo de 1960. Al igual que en el caso anterior, sólo hubo daños materiales. Aquí participaron tres mujeres, dos de ellas vinculadas al sindicato de los telefónicos, FOETRA. Una de esas mujeres actuaba como correo y nexo entre el delegado de Perón en ese momento, Manuel Campos, y uno de los miembros de la banda. Alojó en su domicilio a la persona encargada de poner las bombas luego de realizada la operación y colaboró en la curación de sus heridas. También había contactado a las otras dos mujeres, informándoles las acciones que debían realizar y había concertado reuniones en su casa para facilitar contactos e intercambio de explosivos. Las otras dos mujeres estuvieron abocadas a llevar a los encargados de colocar la bomba hasta la casa de Lagalaye para hacer el reconocimiento del lugar, y luego, para efectuar la operación, utilizando la camioneta de una de ellas. El expediente remite, asimismo, a una cuarta mujer que habría estado implicada en los hechos, junto con su esposo. Pero como estaba prófuga, desconocemos su actividad y vinculación con la banda. Dicha mujer era una reconocida dirigente que participaba paralelamente del proceso de reorganización partidaria de la Rama Femenina del justicialismo. ${ }^{53}$ Finalmente, el último de los expedientes CONINTES remite a un grupo de personas residentes en Tartagal, entre ellas una mujer, que en 1960 trasladaron y alojaron en sus domicilios a tres guerrilleros del área de Tucumán. Entre los guerrilleros había una mujer. ${ }^{54}$

Las fuentes de la DIPBA también hacen referencia a hechos que tuvieron mucha repercusión en la época. Para el aniversario de la Revolución de Mayo en 1960, igual que en Mendoza, estaban planeados atentados en Buenos Aires. La policía detuvo a dos activistas procurando colocar una bomba en el Cabildo de esa ciudad y que, según los documentos, habían participado de atentados previos. En esta oportunidad fue detenida la esposa de uno de ellos, considerado uno de los cabecillas de la banda. La mujer era una obrera textil, de 35 años, a quien se acusaba de haber entregado un paquete a otra de las personas implicadas. ${ }^{55}$ A la vez, se había realizado un allanamiento en Villa Lugano donde, tras la fachada de una fiambrería, se encontraba un depósito de materiales para explosivos, además de otros elementos para realizar atentados y propaganda peronista. En esa

\footnotetext{
${ }^{53}$ Libro 115. 1960 Bis. Exp. No 19. Folio 111. "Estrago". (AHJM). Op. Cit.

${ }^{54}$ Libro 115. 1960 Bis. Exp. No 20. Folio 118. "Encubrimiento". (AHJM). Op. Cit.

55 Legajo ${ }^{\circ}$ 53. Carpeta Bélico. Mesa DS. Fondo documental División Central Archivo y Fichero de la DIPBA en Resistencia peronista y plan CONINTES (1956-1975), Colección $\mathrm{N}^{\circ} 13$ del Área Centro de Documentación y Archivo, Comisión Provincial por la Memoria, La Plata
} 
oportunidad, se detuvo, entre otras personas, a una mujer de 28 años, que también era pareja de uno de los cabecillas de la banda vinculada a los hechos del Cabildo. A esta mujer se la acusaba de participar en el traslado al interior del país de los explosivos que se guardaban en ese depósito. Al parecer, la banda estaba relacionada con los Uturuncos que actuaban en Tucumán. ${ }^{56}$ En junio de 1961, fue detenida otra célula cuya labor giraba en la realización de robos cuyos fondos eran utilizados para ayudar a los familiares de los presos CONINTES y para la fabricación de armas que eran enviadas al depósito antes mencionado. Como parte de la misma, se nombra a una reconocida activista que integraba la Juventud Peronista y que estaba vinculada, junto con otros miembros de la banda, al sindicato de la carne de Avellaneda, en cuyas inmediaciones había sido detenida. ${ }^{57}$

Luego, encontramos datos referentes a un tiroteo generado en una fábrica de baterías para automóviles y depósito de madera en Capital Federal en julio de 1962, que en realidad escondía un arsenal, donde habían muerto dos policías. A raíz de este suceso, se desprendió una investigación que logró descubrir algunas células de activistas vinculadas a ese depósito de explosivos y, al parecer, con algunos de los casos mencionados previamente. En los informes surgen nombres de mujeres, algunas implicadas en casos concretos y otras cuya verdadera actividad no llegamos a dilucidar. Una de esas mujeres era una reconocida dirigente peronista en tiempos de la Resistencia que estaba reclutando activistas para recibir entrenamiento militar en Cuba. A ella se suman dos mujeres que dirigían células en la Facultad de Filosofía y Letras de la Universidad de Buenos Aires. Y también hay referencias a la militante de la JP detenida por robos, antes mencionada. En el local donde se produjo el tiroteo fueron hallados planos de sucursales de casas de crédito de la ciudad de Rosario que habían sido confeccionados por ella, y que ahora se encontraba prófuga luego de haber cumplido una condena en la cárcel de Olmos, en el partido de La Plata, por el caso antes señalado referente al robo de autos. Dicha activista, de 30 años, tenía antecedentes en la provincia de Buenos Aires por robos reiterados, asociación ilícita, falsificación de documentos e infracción al artículo $7^{\circ}$ de la ley 15923, que contemplaba las actividades terroristas. Ella había asistido a una reunión en Montevideo donde se había discutido la técnica de trabajo a ser implementada por las células que actuaban en Argentina, y aunque se le otorgaba libertad a cada célula para decidir su accionar, se había hablado de extender

\footnotetext{
${ }^{56}$ Legajo ${ }^{\circ}$ 58. Carpeta Bélico. Mesa DS. Fondo documental División Central Archivo y Fichero de la DIPBA en Resistencia peronista y plan CONINTES (1956-1975), Op. Cit.
} 
la técnica del robo. Luego de esa reunión había participado en varios robos, obteniendo armas y dinero que luego eran enviados a Uruguay o se empleaban en Argentina para el accionar de células subversivas. Pese a ello, el informe decía que no descuidaba su participación en el plano gremial y político, habiendo participado activamente de las últimas elecciones que habían tenido lugar en el sindicato de la carne. Las fuentes también señalan que militaba junto a su pareja, un reconocido militante de la JP. ${ }^{58}$

El último de los expedientes de la DIPBA refiere a una explosión accidental ocurrida en un departamento de Capital Federal a mediados de 1964, donde funcionaba una banda que tenía en dicho lugar un depósito de explosivos. La explosión causó el derrumbe de parte del edificio y varios muertos y heridos. Algunos de los integrantes de la banda murieron y uno de ellos, una mujer de 24 años, que estaba en pareja con otro de los integrantes, logró escapar, aunque un tiempo después sería apresada en Castelar, donde se había refugiado. Dicha mujer, que en años posteriores adquiriría renombre en el peronismo, residía en la ciudad de La Plata y había actuado entregando armas, usando como nexo a otra mujer de 21 años. De los informes, se desprende una filiación no muy clara entre estas mujeres y el sindicato ATE de La Plata. ${ }^{59}$ La filiación peronista de los sujetos implicados en estos casos se desprende, en parte, porque a algunos de estos grupos le fue secuestrado material de propaganda de esa ideología y por otro lado, porque los nombres de algunas de las personas implicadas son reconocidos como pertenecientes a esa corriente política.

Los expedientes muestran un panorama bastante heterogéneo y confuso, en especial los documentos de la DIPBA, pero consideramos que pueden extraerse algunas características generales. Aproximadamente, los grupos estaban constituidos por números de entre seis y once personas y las mujeres estaban en notoria minoría respecto de los varones, oscilando entre una y tres mujeres por grupo. Las edades de esas mujeres eran muy variadas e iban desde los 21 a los 49 años, pero la mayoría rondaba los treinta años hacia fines de la década del cincuenta. Las fuentes no nos permiten saber si habían tenido trayectoria previa en el peronismo, así como tampoco evidencian sus ocupaciones. Sólo de tres mujeres sabemos que eran estudiantes universitarias y otra, obrera textil. Respecto de la trayectoria política, algunas eran muy jóvenes para tenerla. En uno de los casos, la militante

\footnotetext{
${ }^{57}$ Legajo $n^{\circ}$ 71. Carpeta Bélico. Mesa DS. Fondo documental División Central Archivo y Fichero de la DIPBA en Resistencia peronista y plan CONINTES (1956-1975), Op. Cit.

${ }^{58}$ Legajo ${ }^{\circ} 100$. Carpeta Daños. Mesa DS. Fondo documental División Central Archivo y Fichero de la DIPBA en Resistencia peronista y plan CONINTES (1956-1975), Op. Cit.
} 
provenía de una familia peronista; su madre había sido diputada por ese partido. Dos estaban vinculadas a FOETRA, el gremio telefónico y una al sindicato de la carne en Avellaneda y por fuentes externas sabemos que había tenido militancia en el Partido Comunista en los años previos a 1955. Dos mujeres pertenecían a la JP y de tres de ellas sabemos, por fuentes externas, que participaron del proceso de reorganización de la Rama Femenina, llegando una de ellas a ser diputada provincial en 1965. En total encontramos una mención de 16 mujeres, de las cuales 8 participaban junto a sus parejas; del resto no lo sabemos. Y de sólo de una de ellas constatamos que tenía tres hijos, a la vez que otra de las implicadas también era madre, hecho que también conocemos por fuentes externas.

Las actividades que realizaban estas mujeres eran muy variadas e implicaban diferentes grados de compromiso, a la vez que ocupaban distintas posiciones en la trama de relaciones. Prestaban su domicilio para hacer reuniones en las cuales se generaban contactos y se intercambiaban armas y explosivos; también para esconder prófugos y guardar explosivos. Actuaban como correo y nexo entre militantes; actividad que implicaba no sólo transportar cartas, planes, mensajes, directivas, material propagandístico y dinero, sino también armas y material inflamable. También trasladaban en sus vehículos a los militantes que colocaban los explosivos, ayudándolos a escapar, o dibujaban planos para realizar asaltos. En algunos casos, brindaban apoyo a tareas ingeniadas por otros y, también, ocupaban lugares intermedios, como cuando se desempeñaban generando contactos para sumarlos a determinadas operaciones y transmitiendo directivas. Muchas veces participaban directamente en las operaciones, por ejemplo, en robos de autos o de antenas de radio. Una de las mujeres mencionadas aparece integrando una célula guerrillera y otra reclutando militantes para ser entrenados en esas acciones.

A diferencia del tradicional golpe de Estado que partía de la concepción de que el derrocamiento del gobierno y el retorno de Perón serían inmediatos, estos grupos habían tomado conciencia de que dicha inminencia no era tal y que necesitaban sostener una organización a largo plazo para el logro de sus objetivos (Raimundo, 1998). Si las intentonas golpistas transmiten la idea de una organización acelerada, poco planificada, y de decisiones súbitas por parte de los civiles, en estos casos se aprecia un grado mayor de planificación y un compromiso más sostenido con el desarrollo de actividades que implicaban el uso de la violencia; aunque estamos hablando de células que tenían un nivel de

${ }^{59}$ Legajo ${ }^{\circ}$ 159. Carpeta Bélico. Mesa DS. Fondo documental División Central Archivo y Fichero de la DIPBA en Resistencia peronista y plan CONINTES (1956-1975), Op. Cit. 
organización muy rudimentario si se las compara con las organizaciones guerrilleras de la década de los setenta. Ese compromiso más sostenido en el tiempo se encuentra, por ejemplo, en los viajes a Montevideo para realizar reuniones donde se decidía cuál era la mejor estrategia a emplear por las células clandestinas. A la vez, también había mujeres que eran contactadas para el desarrollo de acciones concretas sin tener un compromiso permanente con las células clandestinas.

Al igual que lo que sucedía con la estrategia del golpe de Estado, aquí también resulta difícil encontrar a las mujeres ocupando lugares de dirigencia, pero sí las hallamos realizando roles de dirigencia intermedia. Por un lado, si bien no detectamos que hubieran colocado bombas, confirmamos que tenían una vinculación muy cercana con los explosivos, ya sea trasladándolos, conviviendo con ellos, o acompañando a los activistas varones al teatro de operaciones. Es decir, aunque había cierta división sexual del trabajo, la exclusión de las mujeres respecto de la vinculación con prácticas violentas es menor que en la estrategia tradicional del golpe de Estado. Por otro lado, las vislumbramos realizando acciones directas que, en algunos casos, implicaban el uso de armas, como ocurría con los robos.

Es poco lo que se sabe sobre otros aspectos de la vida de estas mujeres por fuera de las acciones que registran las fuentes escritas. En algunos casos, había militancia conjunta con la pareja, pero salvo algunas excepciones de activistas muy reconocidas que mostraban mucha autonomía, en casi todos, el varón ocupaba niveles estratégicos mayores. Además, otro aspecto que consideramos importante rescatar es el hecho de que varias de estas mujeres tenían filiaciones políticas por fuera de esas células, vinculadas a algún sindicato o a estructuras políticas como el Partido Justicialista o la Juventud Peronista. Es decir, las acciones armadas sólo ocupaban parte de su militancia, habiendo también un margen para la actividad política y gremial, y salvo la Juventud Peronista, que se había constituido después del golpe de Estado de 1955, en los otros casos, se trata de estructuras tradicionales del peronismo o vinculadas a él. No podemos saber cómo la participación en acciones armadas afectaba su vida cotidiana y la militancia en esos otros espacios, ya que existe una fuerte reticencia de las mujeres que participaron de la Resistencia peronista en sus primeros años a reconocer su participación en acciones que implicaban el uso de la violencia y las mujeres 
concretas que aparecen mencionadas en los expedientes no han podido ser contactadas. ${ }^{60}$ Pese que a diferencia de la práctica del golpe de Estado aquí hubo un mayor acercamiento de las mujeres a las armas, al manejo de explosivos y al teatro de operaciones, se trató de casos aislados y ocultos. No hubo una participación masiva de mujeres en este tipo de actividades como sucedería en la década del setenta, y es probable que no se haya construido un relato alrededor de esas experiencias porque no tuvieron el componente generacional que marcó a la militancia setentista. A la vez, no se registra que haya habido un reconocimiento de estas primeras experiencias femeninas por parte de las generaciones de militantes que le sucedieron, en especial de las que asumieron el compromiso con la lucha armada en los setenta. Probablemente, el carácter aislado de esta participación haya influido en ese silenciamiento, aunque tampoco es de desmerecer el hecho de que algunas de estas mujeres en sus derroteros posteriores estuvieron ligadas a posturas de derecha en el peronismo que eran difíciles de asimilar para los sectores vinculados a la izquierda peronista en los setenta. Tampoco conocemos el discurso en el cual encuadraron sus actividades ni los motivos que marcaron su decisión de asumir este tipo de prácticas. En el apartado siguiente, delinearemos algunos de sus derroteros al caer en manos de la justicia militar.

\section{Las presas políticas bajo el Plan CONINTES}

El estudio de las detenidas políticas durante el período que abordamos en esta tesis (1955-1966) ha sido poco explorado, sobre todo si lo comparamos con el interés que dicha temática ha despertado para los años de la última dictadura militar. ${ }^{61}$ Para el lapso que corre entre 1955 y 1966, puede mencionarse un trabajo de César Seveso (2009), que aunque no particulariza en las mujeres ofrece algunas cifras y testimonios sobre el paso de las mujeres por las cárceles durante esos años, y un reciente artículo de Sabrina Castronuovo (2016) sobre las presas peronistas durante los años de la Revolución Libertadora en la Unidad

\footnotetext{
${ }^{60}$ De algunas se sabe que han fallecido, en otras lo damos por supuesto por la edad que tenían al momento de los hechos, otras fueron desaparecidas por la última dictadura militar y una de ellas, que logramos contactar, se negó a dar su testimonio

${ }^{61}$ En particular, interesa subrayar el estudio pionero de Débora D'Antonio $(2009,2016)$ en el tema. La autora se ocupó de analizar la represión estatal de los setenta en el marco de cárceles legales de presos políticos. El acento no sólo está puesto en las formas de represión sino también en las prácticas de resistencia empleadas por los militantes, negándose a verlos como sujetos pasivos. Ambas acciones, las de represión, como las de resistencia, estuvieron caracterizadas por connotaciones de género que la autora desmenuza en sus investigaciones.
} 
Penitenciaria $\mathrm{n}^{\circ} 8$ de Olmos. Más recientemente, Dora Barrancos ha analizado el impacto de las políticas represivas posteriores a 1955. La autora ha consignado cómo, mientras que durante los gobiernos peronistas no habían faltado medidas anticomunistas y había sido, a su vez, un obstáculo para las intervenciones extranjeras durante la Guerra fría, en el período posterior "las persecuciones al peronismo tuvieron una suerte de asimilación a la represión del comunismo, como si los peligros del peronismo se parangonaran con los que provenían de las izquierdas radicalizadas. Se sostiene que hubo más de cincuenta mil detenidos en todo el país entre 1955-1958, y que al menos diez mil fueron mujeres" (Barrancos, 2017 [en prensa]).

Aunque no es nuestro objetivo profundizar en las políticas carcelarias ni en la aplicación de las medidas represivas, ya que el foco está puesto en las prácticas de la Resistencia peronista, consideramos que analizar el derrotero de algunas mujeres en función de la experiencia carcelaria, ayuda a completar la imagen sobre la participación de las mujeres en ese proceso histórico, puesto que si algo define a nuestro objeto de estudio es precisamente la tensión constante entre posibilidades de participación y represión.

Los hechos arriba mencionados fueron castigados mediante la aplicación del Plan CONINTES, que entró en vigencia el 13 de marzo de 1960 y que fue instrumentado para sofocar el clima insurreccional que se había incrementado a lo largo de 1959. Hasta ese momento, las actividades consideradas terroristas eran investigadas por la policía y juzgadas por la justicia ordinaria. El decreto 2628/60 sometía a las policías provinciales y de la Capital Federal a la autoridad de las Fuerzas Armadas, mientras que el país era dividido en zonas de defensa contra la subversión. Por el decreto 2639/60, se crearon Consejos de Guerra encargados de juzgar a los acusados de actividad subversiva. Estos decretos se mantuvieron en vigencia hasta el 1 de agosto de 1961 (James, 2010 [1988]). El CONINTES tenía su origen en la Ley 13234 de Organización de la Nación en tiempos de Guerra, sancionada en 1948, por la cual se establecía que la población en su conjunto estaba obligada a participar del esfuerzo bélico en caso de que el país entrara en conflicto armado con un enemigo externo y preveía la posibilidad de crear Consejos de Guerra. En 1960 fue adaptada para aplicarla como elemento represivo contra la población local. La otra normativa que constituyó un antecedente de este plan fue el decreto 9880 del 14 de noviembre de 1958, de carácter secreto, que subordinaba las policías provinciales a la autoridad militar (Chiarini y Portugheis, 2014; Damín, 2010; Pontoriero, 2015). Además, desde el 11 de noviembre de 1958 regía el estado de sitio, que había sido implantado a raíz 
del conflicto petrolero suscitado en Mendoza. En principio se estableció por un lapso de 30 días, pero el 11 de diciembre fue promulgada una ley, la 14785, que determinaba su vigencia por tiempo indeterminado (Potash, 1981).

El marco ideológico lo aportó la Doctrina Francesa de la Guerra Revolucionaria que fue incorporada por el Ejército Argentino en 1957 (Pontoriero, 2015). De hecho, la división del territorio en un cuadriculado imitaba la organización territorial que los franceses habían aplicado en Argelia. La justificación ideológica de esta disposición territorial, junto con la creación de Consejos de Guerra, estaba vinculada con el concepto de "enemigo interno". Como se creía que el enemigo se ocultaba y mimetizaba entre la población con la ayuda de esta última, la población nacional se convirtió en enemigo potencial y el territorio nacional en el campo de batalla, a la vez que la obtención de información para conocer la estructura organizativa del enemigo, se convirtió en un problema fundamental (Mazzei, 2000). Si bien la idea de "enemigo interno" que actúa en diferentes planos de la sociedad circuló en Argentina desde comienzos del siglo XX, a partir de 1955, la novedad de esa amenaza se incorporó a los discursos de las Fuerzas Armadas como eje central de las doctrinas y estrategias de defensa en función del conflicto planteado entre oriente y occidente en el marco de la guerra fría. De esta manera, el enemigo interno pasó a estar encarnado en el comunismo y el peronismo (Pontoriero, 2015; Summo y Pontoriero, 2002).

Los expedientes generados por los Consejos de Guerra nos permiten tener un panorama de las penas con las que fueron castigados los miembros de las células clandestinas cuyas acciones hemos descripto en estas páginas, ya que se trata de sentencias. Las fuentes de la DIPBA no ofrecen ese tipo de información por ser informes de inteligencia producidos, por lo general, inmediatamente después de las detenciones o estando prófugas las personas implicadas, a lo que debe agregarse el espionaje desarrollado sobre personas a las que se consideraba sospechosas, pero no detenidas aún.

En el caso de la mujer vinculada a los atentados del 25 de mayo de 1960 en la provincia de Mendoza, que había actuado como correo y robado una antena de radio, le fueron conferidos por el Consejo de Guerra Especial de Mendoza, seis años de cárcel con inhabilitación absoluta, por el delito de transporte de armas, robo en despoblado y encubrimiento. También se la condenó al pago de una indemnización de concepto de reparación de daños materiales producidos por el delito, en forma solidaria con otros cuatro implicados. La sentencia fue recurrida, y el máximo tribunal Conintes, con sede en Buenos Aires, bajó la pena a cuatro años de prisión a la vez que se la absolvió del delito de 
encubrimiento. ${ }^{62}$ A la joven implicada con la elaboración de los panfletos que se arrojarían en el desfile militar del 25 de mayo le fue aplicada una pena de tres años de prisión por el delito de asociación ilícita por parte del mismo Consejo, que luego fue reducida por el Consejo Supremo de las Fuerzas Armadas a un año de prisión. La defensa alegó la indebida aplicación de la ley, ya que el delito que debía caberle era el de conspiración para cometer rebelión y no el de asociación ilícita. ${ }^{63}$ La mujer acusada de colaborar con la banda de Mendoza en el traslado y tenencia de explosivos fue condenada a la pena de dos años y tres meses de prisión por el delito de tenencia y transporte de explosivos, y al pago de una indemnización en concepto de reparación de daños materiales causados por el delito en forma solidaria con otros procesados. Luego el Consejo Supremo de las Fuerzas Armadas bajó su pena a seis meses de prisión y dictaminó que fuera puesta en libertad porque ya había cumplido la pena con el abono de la prisión preventiva; además de eximirla del cargo pecuniario. $^{64}$

El caso de las tres mujeres vinculadas al atentado realizado en la casa del General Lagalaye fue el que generó las penas más severas. La mujer que había forjado los contactos y distribuido directivas, fue condenada a veinte años de prisión por los delitos de estrago en grado de complicidad primaria en concurso real con entrega de explosivos y asociación ilícita en concurso ideal con el delito de encubrimientos reiterados. La pena fue bajada por el Consejo Supremo de las Fuerzas Armadas a 15 años de prisión por estrago, asociación ilícita e intimidación pública. Las otras dos mujeres fueron condenadas a diez años de prisión por el delito de estrago en concurso real con el delito de asociación ilícita. Pese a que la sentencia fue recurrida, se les mantuvo la pena de diez años de prisión, acusándolas del delito de estrago. ${ }^{65}$ Finalmente, en el caso de la mujer que alojó a guerrilleros de Tucumán en su domicilio de Tartagal, el Consejo Superior de las Fuerzas armadas la condenó por el delito de encubrimiento, a seis meses de prisión. ${ }^{66}$

El derrotero de algunas de estas mujeres una vez en prisión puede seguirse a través de las páginas de Nuestra Palabra, publicación del Partido Comunista. Desde este periódico hubo una defensa constante de los presos políticos y se puso énfasis en las mujeres peronistas detenidas por el Plan Conintes, en un momento en que se estaba produciendo un

\footnotetext{
${ }^{62}$ Libro 115. 1960 Bis. Exp. № 21. Folio 125. “Asociación ilícita”. (AHJM). Op. Cit.

${ }^{63}$ Libro 115. 1960 Bis. Exp. N²3. Folio 142. "Conspiración”. (AHJM). Op. Cit.

${ }^{64}$ Libro 117. 1961 Tomo 1. Exp. N 3. Folio 14. "Intimidación”. (AHJM). Op. Cit.

${ }^{65}$ Libro 115. 1960 Bis. Exp. No 19. Folio 111. "Estrago". (AHJM). Op. Cit.

${ }^{66}$ Libro 115. 1960 Bis. Exp. N²0. Folio 118. "Encubrimiento". (AHJM). Op. Cit.
} 
acercamiento entre el peronismo y el comunismo en el marco de lo que se conoció como "el giro a la izquierda del peronismo". ${ }^{67}$ La particularidad que presenta este periódico y que nos permitió apreciar el paso de estas mujeres en prisión es que en sus páginas el reclamo por los presos políticos ocupó un lugar destacado, a la vez que la continuidad y regularidad de su publicación es una característica que no encontramos en la prensa peronista.

El caso de la joven mendocina de la Juventud Peronista que pretendía tirar los panfletos en el desfile del 25 de mayo fue permanentemente denunciado. Sabemos que fue trasladada a la ciudad de Buenos Aires y alojada en el Correccional de Mujeres de Humberto Primo. Su madre, recordemos, una ex diputada provincial peronista de la provincia de Mendoza, denunció que su hija había sido alojada con presas comunes, haciendo llegar su reclamo a los dos bloques de la UCR. Según Nuestra Palabra, la medida había sido adoptada por las monjas del penal argumentando razones de "inmoralidad", ya que hasta el momento del traslado la joven había compartido la celda con una dirigente de la Federación Juvenil Comunista. ${ }^{68}$ Una situación similar ocurría con la mujer mendocina acusada por traslado y tenencia de explosivos, que también se alojaba en el mismo establecimiento. No menos cargado de moralidad era el discurso del periódico, que denunciaba que estas mujeres se hallaban conviviendo con prostitutas y delincuentes. ${ }^{69}$ Respecto de la militante de la Juventud Peronista, se decía que estaba compartiendo la celda con una mujer que había matado a su madre luego de haber sido sorprendida por ésta cometiendo un "acto de inmoralidad" con otra mujer. Y se enfatizaba en la juventud de la detenida, que sólo tenía 21 años. $^{70}$ Además denunciaba el hecho de que habían sido

\footnotetext{
${ }^{67}$ Durante el gobierno de José María Guido y luego de que las Fuerzas Armadas anularan las elecciones del 18 de marzo de 1962 donde la fórmula peronista Andrés Framini-Marcos Anglada había resultado victoriosa en la provincia de Buenos Aires, comienza a producirse un acercamiento y un trabajo conjunto entre peronistas, trotskistas, comunistas y socialistas de vanguardia. Ello se dio en el marco del llamado "giro a la izquierda del peronismo". Ante las políticas proscriptivas del gobierno -el 24 de julio había vuelto a prohibirse la actividad del Partido Justicialista-, y ante el avance del vandorismo, Perón le había otorgado su apoyo al ala más combativa del peronismo representada por Andrés Framini, Sebastián Borro, Jorge Di Pascuale, Juan Jonch. Ello pareció concretarse con el programa de Huerta Grande surgido de un plenario de las 62 Organizaciones, cuyos puntos reclamaban medidas radicales como la participación obrera en el control de la producción, la nacionalización de las industrias básicas y la expropiación de las grandes propiedades rurales. Los partidos de izquierda se entusiasmaron con las posibilidades de estrechar alianzas con el peronismo. Sin embargo, los vandoristas, propensos a negociar con los sectores azules de las Fuerzas Armadas, pronto volverían a dominar en la interna peronista contando con el beneplácito de Perón (Tortti, 2009).

${ }^{68}$ Nuestra Palabra; "Moralidad en la Cárcel de Mujeres", Buenos Aires, 17 de enero de 1961, p. 3.

${ }^{69}$ Nuestra Palabra; "Seis mujeres y un mismo ensañamiento", Buenos Aires, 31 de enero de 1961.

${ }^{70}$ La mujer acusada por traslado de explosivos salió luego de cumplir su pena de seis meses de prisión. Nuestra Palabra; "Tribunales militares obligados a reducir penas", Buenos Aires, 21 de febrero de 1961, p.3.
} 
trasladadas a Buenos Aires alejándolas de sus familiares, hecho que ocurría no sólo con estas mujeres sino también con otras detenidas del plan Conintes; tal es así que las tres mujeres vinculadas al caso Lagalaye que había tenido lugar en Olivos, habían sido trasladadas a la cárcel de Neuquén, mientras que la mujer que participó del robo de la estación de radio en Mendoza, se encontraba en Santa Rosa, provincia de La Pampa. De esta última, el periódico nos hace saber que tenía tres hijos. Para Nuestra Palabra este era el caso más grave, por su calidad de madre. ${ }^{71}$

Hubo acciones de diferentes organizaciones, como COFADE (Comisión de Familiares de Detenidos), la LADH (Liga Argentina por los Derechos del Hombre) y partidos políticos que se movilizaron por mejorar las condiciones de detención de estas mujeres y su liberación. En el mes de septiembre de 1961 las tres mujeres que estaban en Neuquén fueron trasladadas a la cárcel de Capital Federal. ${ }^{72}$ En febrero de 1962 la LADH, la Federación Argentina de Trabajadores de Industrias Químicas y Afines (FATIQA), la CGT y la Federación de Empleados de Comercio lograron facilitar el viaje a Santa Rosa de la madre de uno de los condenados por los atentados de Mendoza y esta llevó a los hijos de la mujer que estaba alojada allí, para que pudiera verlos. ${ }^{73}$ El periódico la define como "una madre argentina condenada por los ilegales tribunales militares". Sabemos que fue puesta en libertad condicional poco antes de que se cumplieran dos años de su encarcelamiento. ${ }^{74}$

En marzo de 1962, Nuestra Palabra denunciaba que los presos a disposición del Poder Ejecutivo Nacional habían recuperado su libertad poco antes de realizarse las elecciones, pero no había ocurrido lo mismo con los detenidos Conintes. ${ }^{75} \mathrm{Y}$ en abril, denunciaba la situación de las tres mujeres que aún permanecían detenidas en el Correccional de Mujeres de Humberto Primo, las vinculadas al caso Lagalaye, ya que las otras habían salido por cumplimiento de su condena, o por libertad condicional, como vimos, en uno de los casos. De esas tres mujeres se decía que primero habían estado en Neuquén, donde habían tenido que soportar condiciones pésimas dadas por el frío, la

De la joven de la Juventud Peronista es probable que haya salido al cumplir la pena de un año a la que había sido condenada, porque el periódico deja de informar sobre su situación.

${ }^{71}$ Nuestra Palabra; "Seis mujeres y un mismo ensañamiento", Buenos Aires, 31 de enero de 1961. Nuestra Palabra; "Declara Imizcoz: 'Hay que arrancar de inmediato una ley de amnistía", Buenos Aires, 16 de mayo de 1961, p. 3. Nuestra Palabra; "Cinco Mujeres”, Buenos Aires, 19 de septiembre de 1961, p. 6.

72 Nuestra Palabra; "Liberados", Buenos Aires, 10 de octubre de 1961.

${ }^{73}$ Nuestra Palabra; "Estado de sitio, proscripciones, presos, fraude", Buenos Aires, 20 de febrero de 1962, p. 3.

${ }^{74}$ Nuestra Palabra; "La señora de Ahumada en libertad condicional", Buenos Aires, 27 de febrero de 1962, p. 5 .

${ }^{75}$ Nuestra Palabra; "Hubo libertades", Buenos Aires, 20 de marzo de 1962, p. 3. 
suciedad y los piojos. Y que ahora, en el Correccional de Mujeres, estaban sometidas a una estricta disciplina establecida por las monjas de la orden del Buen Pastor que implicaba levantarse muy temprano, obligación de oír misa, restricciones para usar el baño, prohibición de hablar tanto en el desayuno como en las celdas, y del acceso a libros y diarios, a la vez que la radio era cortada de inmediato cuando pasaban un tango. El periódico cuestionaba la postura de las monjas que decían que había que cuidar la moralidad de las reclusas pero a la vez les negaban el tratamiento de presas políticas obligándolas a convivir con "reincidentes peligrosos", "homicidas" y "amorales". 76

Mientras tanto, el periódico nos informa de las movilizaciones que se hicieron por la libertad de los presos, particularizando en las mujeres y en las presas Conintes. En mayo de 1962 reclamaba que el movimiento obrero organizado no hubiera desarrollado una acción permanente y organizada en función de la libertad de los presos políticos y gremiales, y que era "imperdonable" que aún no se hubieran levantado voces fuertes e indignadas por la situación de las detenidas Conintes. ${ }^{77}$ A la vez, daba cuenta de las voces de solidaridad de organizaciones de mujeres de otros lugares del mundo con relación a las presas políticas de Argentina, en particular la FDIM (Federación Democrática Internacional de Mujeres) ${ }^{78}$ y varias entidades mexicanas y una japonesa. Por otro lado, la UMA (Unión de Mujeres de la Argentina $)^{79}$ y la Rama Femenina del Partido Justicialista habían acordado una acción conjunta por la libertad de las presas políticas y gremiales, entre ellas las condenadas por el plan CONINTES. ${ }^{80}$ Finalmente, los detenidos CONINTES lograron su libertad con la amnistía del 12 de septiembre de 1963, pocos días antes del traspaso de mando de Guido a Illia.

Las sentencias Conintes y el seguimiento que también pudimos hacer de estas mujeres a través del periódico comunista Nuestra Palabra, nos dan una idea del peligro de represión

\footnotetext{
${ }^{76}$ Nuestra Palabra; "Tres mujeres en la cárcel”, Buenos Aires, 10 de abril de 1962, p. 3.

${ }^{77}$ Nuestra Palabra; "Para liberar a los presos", Buenos Aires, 22 de mayo de 1962, p. 3.

${ }^{78}$ La FDIM fue un organismo creado en 1945 en París, por impulso de la Unión de Mujeres francesa, bajo el auspicio del Partido Comunista Soviético. Fue una coalición de Uniones de Mujeres de distintos países, con orientación comunista y antifascista (Valobra, 2015a)

${ }^{79}$ La UMA fue una organización femenina creada en 1947 por el impulso del Partido Comunista, que intentó convertirse en un movimiento de masas. Surgió con el objetivo de ampliar su base de apoyo observando el potencial que en ese sentido representaban las mujeres y como respuesta a los avances que el peronismo estaba disputando en ese terreno a través del Partido Peronista Femenino. Intentó reeditar la experiencia que la Junta de la Victoria, organización multipartidaria, había desarrollado durante los años de la Segunda Guerra Mundial; aunque estaba más preocupada por las problemáticas locales. Al igual que aquella, la UMA se organizó en filiales barriales. La mayoría de sus integrantes fueron obreras, empleadas y amas de casa. En un principio incluyó integrantes de otras ideologías políticas, pero hacia 1950 cerró sus filas hacia el comunismo (Valobra, 2015b)
} 
al que se exponían. Pese a que no ocupaban altos niveles de decisión, corrían un riesgo de ser penalizadas que inclusive, a veces no era acorde con la tarea que habían realizado, como el caso de la joven condenada a un año de cárcel por haber sido encontrada con panfletos que ni siquiera llegó a arrojar. El ensañamiento en la condena parece haber radicado no en su vinculación con una célula clandestina culpable de cometer atentados, pese a que se la condenó por conspiración para la rebelión y en un principio, por asociación ilícita, sino por el carácter simbólico de la acción que pretendía desarrollar. Los panfletos que se le encontraron cuestionaban el perfil patriótico de las Fuerzas Armadas y la pretendida acción de arrojarle monedas a los militares en el desfile, apuntaba a desacreditarlos públicamente, precisamente en una instancia utilizada tradicionalmente por los uniformados para mostrarse públicamente y reafirmar su rol ante la sociedad. La condena es excesiva si la comparamos con la de la mujer que había transportado explosivos para los miembros de la misma célula, a quien sólo la condenaron a seis meses de cárcel. Es decir, que en este caso el carácter simbólico de una acción pesó más a la hora de decidir la pena que la potencialidad de peligro en términos de daños materiales y de vidas implicado en las acciones. Además de las irregularidades que atravesaron a estos juicios, debemos sumarle las condiciones del encarcelamiento, que no respetaba la condición de presas políticas de estas mujeres obligándolas a compartir el espacio con las presas comunes y a traslados que las alejaban de sus lugares de origen y sus familiares; incluso en el caso de mujeres con hijos. Así como la justicia ordinaria durante el gobierno de la Revolución Libertadora no reparó en la condición de género a la hora de aplicar castigos (Castronuovo, 2016), encontramos la misma situación para el caso de los tribunales del Plan CONINTES. Sin embargo, su condición de mujeres habilitó un discurso moralista tanto entre los defensores de los presos políticos como entre las monjas encargadas de aplicar el castigo. Tal es el caso del periódico comunista Nuestra Palabra, que desde un primer momento hizo hincapié en los presos del Plan CONINTES, por la ilegalidad que atravesó a esas condenas dictadas por Consejos de Guerra, pero que además reparó especialmente en las detenidas mujeres apelando a un discurso que reafirmaba los roles de género tradicionales. A su vez, las monjas de la Orden del Buen Pastor, que por aquellos años estaban a cargo de las cárceles de mujeres, según el mismo periódico, ya que no tenemos acceso a la voz de ellas, articularon un discurso basado en los mismos códigos para negarles a estas mujeres

\footnotetext{
${ }^{80}$ Nuestra Palabra; "Por la libertad de las presas políticas", Buenos Aires, 9 de octubre de 1962, p. 7.
} 
peronistas su condición de presas políticas alojándolas con detenidas comunes. De esta manera, lograban separarlas de las comunistas que también se hallaban detenidas y evitar el intercambio de conocimiento que suele darse en las cárceles entre presos políticos. Sin embargo, fuera de la cárcel, la lucha por la liberación de estas detenidas sí logró unificar las actividades de mujeres comunistas y peronistas a través de acciones conjuntas entre la UMA y la Rama Femenina del PJ, en un momento en que se hablaba del "giro a la izquierda" del peronismo y en que se dieron otras acciones conjuntas entre estas organizaciones femeninas que veremos en capítulos posteriores.

Finalmente, cabe agregar que si bien Nuestra Palabra argumentó su defensa apoyándose en un discurso moralista que reafirmaba los roles de género tradicionales, las razones por las cuales estas mujeres estaban detenidas no necesariamente deben interpretarse como reafirmación de esos roles, como indicamos antes. Con sus prácticas, desafiaron los discursos que excluyen a las mujeres del uso de la violencia; aunque ese desafío no se dio en forma total. Ni tampoco se tradujo en un contradiscurso que cuestionara las exclusiones. A diferencia de la época del gobierno peronista donde las mujeres habían militado en una estructura política diferenciada genéricamente, en la Resistencia tuvieron más posibilidades de militar con activistas varones, pero en estas células clandestinas dedicadas a la realización de atentados estuvieron en minoría y ello les impidió establecer lazos de solidaridad intragenéricos que contribuyeran a la construcción de ese discurso.

\section{Conclusiones}

Desde los primeros momentos, la Resistencia peronista desplegó acciones que implicaban el uso de la violencia política como herramienta de lucha en un contexto represivo. Pese a que la ruptura de la alianza que había hecho posible el triunfo de la Revolución Libertadora, sumado al propio proceso de resistencia ejercido por la sociedad, abrieron paso a momentos de semilegalidad, es decir, a la emergencia de democracias condicionadas, lo cierto es que el peronismo continuó proscripto y en esa estructura de oportunidades algunos consideraron que el mejor camino pasaba por la adopción de acciones armadas. Ese contexto todavía no vería emerger las organizaciones guerrilleras estructuradas y jerarquizadas que tendrían lugar en los años '70. En los cincuenta y primera 
mitad de los sesenta, la violencia política sería ejercida fundamentalmente a partir de dos tipos de acciones que se basaban en organizaciones diferentes. Por un lado, el tradicional golpe de Estado, una herencia del pasado, que implicaba la participación de civiles y militares y por otro, una actividad más novedosa que incluía la realización de sabotajes y atentados urbanos que se canalizaban a través de células clandestinas.

En el caso de los golpes de Estado tradicionales, las intervenciones femeninas, por lo general, se limitaron a actividades de apoyo, a la vez que no hemos encontrado mujeres participando en el campo de operaciones, es decir, en la toma de algún regimiento. Sin embargo, las encontramos en actividades periféricas, que en algunos casos implicaron la vinculación con armas y explosivos y en otros, asistieron y dieron protección a los activistas varones. En esta división sexual del trabajo, consideramos que operaron los discursos tradicionales que excluyen a las mujeres del empleo de la violencia y que a la vez utilizan el valor simbólico de esta última como elemento alrededor del cual se construye la masculinidad. Esos discursos estaban internalizados por las mismas mujeres y su efectividad estaba garantizada por la acentuada socialización masculina que atraviesa a las dos estructuras a través de las cuales solía organizarse el reclutamiento de activistas en ese tipo de prácticas, el ejército y los sindicatos. Si bien había una división del trabajo entre militares y civiles, por la cual los primeros tendían a excluir a los segundos en el uso de armas, dicha exclusión se daba por su condición de no militares, mientras que las mujeres estaban excluidas a priori por su condición de género.

En el caso de las células clandestinas, hubo división sexual del trabajo, pero menos marcadas que en los golpes cívico-militares. Si bien las mujeres no accedieron a lugares de decisión, ocuparon liderazgos intermedios y tuvieron una vinculación más cercana a los explosivos, las armas y el teatro de operaciones. Sin embargo, fueron minoritarias en esas células frente a los activistas varones, algunos de los cuales habían sido militares o policías en el período anterior, a la vez que también hubo sindicalistas, entre otros. Pero el blanco de ataque ya no estaba puesto en un objetivo militar como era la toma de un regimiento, que implicaba enfrentarse a militares profesionales, y donde los ex militares que participaban lo hacían de manera menos corporativa que en el caso anterior. Es decir, se aprovechaba en esas células la experiencia de quienes tenían un conocimiento previo del manejo de armas y explosivos. Pese a que la mayoría de los militantes de la resistencia carecía de experiencia en este aspecto, esta carencia se acentuaba entre las mujeres. Los discursos de exclusión 
femenina sobre el uso de la violencia también habrían operado en estas organizaciones aunque en menor medida que en el caso anterior.

En este sentido son útiles las ideas de Rita Segato quien considera que el fenómeno de la violencia de género "emana de la relación entre dos ejes interconectados. Uno horizontal, formado por términos vinculados por relaciones de alianza o competición, y otro vertical, caracterizado por vínculos de entrega o expropiación. Estos dos ciclos se articulan formando un sistema único cuyo equilibrio es inestable, un sistema de consistencia deficiente" (Segato, 2003, p. 253). La autora articula el eje horizontal con la noción de Carole Pateman de contrato social que supone un vínculo entre varones que construyen relaciones de alianza y de competencia entre ellos, de modo que sus lugares son equivalentes -respecto de las mujeres-, pero no de iguales entre sí, aunque "se organiza ideológicamente en torno de una concepción de contrato entre iguales" (Segato, 2003: 253). En ese sentido, podemos analizar las relaciones en los grupos de militares y civiles que actuaron en las actividades analizadas. A la vez, el eje vertical articula con lo que Pateman considera el contrato sexual, que se "corresponde al mundo premoderno de estamentos y castas" y que "ordena las relaciones entre categorías que, como el género, exhiben marcas de estatus diferenciados, señas clasificatorias que expresan un diferencial de valor en un mundo jerárquico. Estas marcas son construidas y percibidas como indelebles" (Segato, 2003: 253). De este modo, se comprende que se subordina a las mujeres y pone sus cuerpos en disponibilidad para los varones; en este sentido, los lugares son asignados en relación con las representaciones de género binarias que asignan a las mujeres tareas de complementariedad de la acción central y relevante que es la de los varones.

En la Resistencia peronista, al igual que en otras experiencias de resistencia que tuvieron lugar en otros contextos históricos, fue usual que las mujeres desarrollaran actividades que comúnmente han sido consideradas como tareas de apoyo, subestimando el riesgo y el compromiso que las mismas implicaban. Si bien esta participación clandestina a que las obligaba el contexto represivo implicaba una diferencia con la militancia que muchas pudieron haber tenido en el pasado, en circunstancias de legalidad, lo cierto es que se valieron de actividades que se encuentran en el repertorio de confrontación de los procesos de resistencia y que tradicionalmente han estado asociadas a lo femenino, como las de protección a los militantes varones y de actuación de los roles de género tradicionales. Tratando de responder a la pregunta de si las mujeres vinculadas a estas prácticas transgredieron los roles de género socialmente establecidos, consideramos que hay que 
señalar matices. Por un lado, no lo hicieron porque sus prácticas en acciones clandestinas estuvieron signadas por una marcada división sexual del trabajo que ellas, salvo contadas excepciones, no cuestionaron. Sin embargo, dicha actividad les exigía una exposición, un compromiso y un riesgo que era novedoso para ese momento y en relación con la participación que habían tenido tradicionalmente bajo el gobierno peronista en estructuras legales. Por otro lado, la actuación de roles de género tradicionales evidencia que estas mujeres comprendían la diferencia entre el rol ideal, actuado, que era el que las fuerzas del orden esperaban de una mujer y el tipo de mujer que ellas eran realmente, comprometidas con la política y partícipes de actos ilegales, violentos o considerados subversivos. Si bien es durante la década de 1970 que las mujeres se incorporarán de forma masiva a la lucha armada, durante el período estudiado tampoco los militantes varones se volcaron de forma masiva al uso de la violencia política, ya que aún no estaban extendidos los discursos que legitimaban su uso entre los sectores populares. Lo cierto, es que ellos lograron articular un discurso en torno al uso de la violencia, matizado con el recurso del humor, la nostalgia y las ideas de inexperiencia e inocencia; relato que además les permitió diferenciarse del uso sistemático que se haría de la violencia en los años setenta. Sin embargo, entre las mujeres no fue posible ese relato. El carácter aislado que tuvo la participación femenina en acciones violentas a través de prácticas que las excluían de las decisiones y del teatro de operaciones y en células clandestinas donde eran minoría, impidió que pudiera construirse una identidad alrededor de esas prácticas. Ello, no obstante, no nos inhibe de recrear este escenario donde las mujeres peronistas se acercaron al uso de la violencia política como estrategia de intervención. Como vimos, no significó que ellas fueran equiparadas como pares a los varones, pues el contrato sexual siguió latiendo en esas relaciones, sin embargo, los testimonios nos invitan a repensar las configuraciones de género y la falta de herramientas conceptuales que tenemos para pensar este tipo de fenómenos en estos contextos.

Si durante los primeros gobiernos peronistas las mujeres habían militado en estructuras diferenciadas en función del género, ello no fue posible durante los años de la Resistencia peronista en relación a las prácticas que recurrían al uso de la violencia. En ellas, las mujeres perdieron autonomía frente a los militantes varones, más experimentados y con discursos sociales a su disposición que avalaban su participación en dichas prácticas. Pese a que otros autores han hecho mención a la existencia de comandos conformados exclusivamente por mujeres, no hemos encontrado estructuras de ese tipo y con esa composición de género que estuvieran abocadas al uso de la violencia política. Sin embargo, 
la participación de mujeres en acciones violentas y clandestinas no significó el abandono de otras prácticas de superficie. Por lo que es común encontrar a las mujeres participando de células clandestinas a la vez que desarrollaban actividades políticas en sindicatos y estructuras partidarias. En el capítulo siguiente, analizaremos los intentos de reorganización y participación partidaria en un contexto represivo y proscriptivo pero en el que en determinadas circunstancias se abrieron posibilidades, aunque restringidas, de participación legal. 


\section{Capítulo II \\ El partido en el repertorio de confrontación de la Resistencia}

En el capítulo anterior nos explayamos sobre distintos repertorios de confrontación caracterizados por el uso de la violencia que fueron utilizados durante la resistencia y señalamos su impronta de género. En este capítulo nos concentraremos, prioritariamente, en la dimensión institucional de la Resistencia Peronista articulada con la estructura de oportunidades políticas. En este caso, delinearemos las intervenciones femeninas en los espacios político - partidarios del peronismo y las acciones emprendidas por algunas mujeres para recuperar y/o crear organizaciones políticas diferenciadas genéricamente, como había sido en el pasado. Cabe subrayar que la organización partidaria fue uno de los repertorios organizacionales que había cobijado a las mujeres en el período anterior y que, tras la caída del gobierno, desapareció como tal. Conceptualmente, como hemos repasado en la introducción, las investigaciones han desconsiderado los intentos de reorganización partidaria como parte de la Resistencia Peronista. No obstante, al restituirla a esa experiencia, queremos resaltar que se dio en un proceso de semi-clandestinidad, donde algunos hechos se evidenciaron en la superficie por las características públicas que alcanzaron, y otros se mantuvieron ocultos y bajo sigilo. La importancia otorgada a la necesidad de reconstruir la estructura partidaria atravesó toda la experiencia bajo análisis, mostrando, también, las interrelaciones con otras estructuras más tradicionalmente asociadas al fenómeno de la resistencia como son las sindicales.

La composición heterogénea que caracterizó al peronismo en sus orígenes, quedó cristalizada, hacia 1950, en una estructura legal que contemplara, a su vez, el carácter de movimiento que tenía el peronismo. Así, se otorgó representación a sus tres ramas: los sindicatos, que confluían en la Confederación General del Trabajo (CGT); el Partido Peronista, producto de la unión, en sus inicios, de sectores provenientes del laborismo y del radicalismo, al que se sumó un sector independiente; y el Partido Peronista Femenino (PPF), creado en 1949 por impulso de Eva Perón, que habría fusionado la participación de nuevas militantes con otras que venían trabajando activamente en el peronismo y cuya participación se intentó encuadrar (Mackinnon, 2002; Barry, 2009). ${ }^{81}$ Tras el golpe de Estado de 1955,

\footnotetext{
${ }^{81}$ Tampoco deben dejar de mencionarse los intentos realizados en los últimos años del gobierno peronista por encauzar el accionar de los jóvenes en estructuras como la JP (Juventud Peronista), la UES (Unión de Estudiantes Secundarios) y la CGU (Confederación General Universitaria) (Acha, 2011).
} 
este entramado institucional sufrió los embates de las políticas de desperonización emprendidas por el gobierno de la Revolución Libertadora. Pero la suerte corrida por cada una de esas estructuras no fue la misma. La rama sindical logró recomponerse prontamente convirtiéndose en un factor de peso a raíz de las luchas llevadas a cabo por la recuperación de los sindicatos intervenidos; proceso que confluyó en la unificación de los sindicatos peronistas en las 62 Organizaciones, en 1957. Las estructuras partidarias, empero, encontraron más dificultades para desarrollarse en un contexto proscriptivo donde las vías institucionales de participación política estuvieron restringidas o cerradas, y donde los aspectos más importantes de la política no pasaron necesariamente por esos canales. Sin embargo, en los lapsos de apertura del sistema, hubo intentos por reconstruirlas tanto entre la alta dirigencia como entre los sectores de base.

Aunque hubo varios canales a través de los cuales se intentó sortear la inhabilitación partidaria establecida a través de la ley 3855/55 -nos referimos a la conformación de diversos partidos neoperonistas-, nuestra pesquisa se limitará a analizar los intentos de reorganización que tuvieron lugar en el marco de la estructura del Partido Justicialista o en interacción con la misma. Si bien el partido no sería el actor de mayor peso político en el período que se inicia en septiembre de 1955, los peronistas nunca abandonaron los reclamos por el levantamiento de su proscripción ni dejaron de considerar la participación por vía electoral como un modo legítimo de intervención política. Superado un primer momento de proscripción absoluta en la que predominaron las actividades clandestinas y la lucha gremial por la recuperación de los sindicatos intervenidos, hacia 1958, se abrió otra etapa caracterizada por sucesivas convocatorias a elecciones; las que, aunque limitadas, fueron aliciente para incentivar procesos de reorganización partidaria que involucraron a sujetos provenientes de diferentes espacios de participación y que convivieron con las acciones que se desplegaron en otros ámbitos, como el gremial y el de las acciones completamente ilegales y de confrontación abierta. Esos procesos de reorganización partidaria estuvieron atravesados por el problema de la legitimidad para encuadrar a un peronismo disperso que, por primera vez, debía actuar proscripto y como partido de oposición. La conformación de estructuras políticas autónomas que aglutinaran a las mujeres de modo diferenciado, como en épocas del gobierno peronista, se encontró con esas limitaciones, que adquirieron connotaciones de género porque dirimir esa cuestión obligaba a las mujeres con ansias de reorganizarse a dar la batalla no sólo en el frente externo contra los gobiernos de turno, sino también internamente, contra sus propios compañeros varones, políticos y sindicalistas. 
La posibilidad de las mujeres peronistas de reorganizarse políticamente en estructuras partidarias autónomas estuvo estrechamente relacionada con la apertura del sistema político institucional en determinadas coyunturas y los vaivenes en el nivel de represión, proceso que afectó al peronismo en su totalidad. Además, se vinculó a las relaciones de poder internas en el peronismo, ya que entre los factores que se convirtieron en un obstáculo para el logro de ese objetivo se encuentran las otras dos ramas, la sindical y la político-partidaria, ambas de composición netamente masculina; hecho que hizo que esas luchas de poder adquirieran un carácter generizado.

Nuestro trabajo procurará analizar el devenir de la reorganización política femenina, considerando las posibilidades de participación institucional y de reorganización que fueron posibles bajo cada uno de los gobiernos que se sucedieron en el período estudiado (19551966). El foco sobre dichos procesos nos permitirá analizar cómo los peronistas, y las mujeres en particular, aprovecharon la estructura de oportunidades para intentar una participación de tipo legal y de superficie, y a la vez, observar las relaciones intra e intergenéricas que esos procesos conllevaron y cómo, según ha sostenido la historiadora Joan Scott (1993), a la hora de organizarse políticamente se apeló a las diferencias sexuales cómo elemento de legitimación, proceso atravesado por conflictos y relaciones de poder.

El tema que se aborda en este capítulo requirió de una triangulación documental densa debido a la naturaleza del proceso histórico estudiado y a las condiciones en las que se desarrolló. Las fuentes se conforman con un heterogéneo corpus: archivo personal de Marta Curone y su libro autobiográfico, correspondencia entre Juan Domingo Perón y su primer delegado en el exilio, John William Cooke y con otra dirigencia, entre las cuales seleccionamos la que mantuvo con Delia Parodi, Elena Fernícola y Juana Larrauri; el archivo de la DIPBA y la prensa partidaria peronista, Línea Dura, y comunista, Nuestra Palabra.

El intento por reorganizar una estructura partidaria exclusiva de mujeres fue una constante a lo largo de todo el período en estudio. Ahora bien, si el contexto ofrecía oportunidades para innovar, y de hecho muchos actores las aprovecharon, por qué a nivel partidario se decidió mantener una estructura diferenciada por género. ¿Hubo intenciones de experimentar con otras formas de organización? Aun manteniéndose las tres ramas, ¿se ensayaron innovaciones por encima de ellas? ¿Cuáles fueron los conflictos que atravesó el proceso de conformación de una rama femenina? ¿De quiénes surgieron las iniciativas para 
ello? Y finalmente, ¿qué características tuvieron las estructuras que intentaron conformarse y en qué se diferenciaron y/o asimilaron al viejo PPF?

A lo largo de este capítulo haremos un recorrido por la bibliografía que ha restituido a la historiografía del peronismo los estudios sobre el partido y una reflexión sobre las posibilidades de interpretar los intentos de reorganización partidaria bajo el concepto de resistencia. Luego, sintetizaremos las características que adquirió la participación femenina durante los años del gobierno peronista, para desarrollar, a continuación, los intentos de reorganización partidaria en el marco de las diferentes coyunturas políticas que atravesaron al período 1955-1966. Finalizaremos con un análisis de las características de la intervención político-partidaria de las mujeres y su comparación con el período anterior.

\section{La reestructuración partidaria como parte de la resistencia}

Al igual que otras formas de acción colectiva que analizaremos a lo largo del recorrido que propone esta tesis, la participación política a través del Partido hunde sus raíces en la época de los primeros gobiernos peronistas. Pero el estudio de las prácticas partidarias presenta algunos problemas tanto para una como para otra etapa. En general, ha sido un tema soslayado por la historiografia puesto que durante mucho tiempo se impuso la imagen de que se trataba de un partido débil, poco burocratizado y prácticamente inexistente (Luna, 1984; Little, 1973). Para el período 1955-1966, este silencio cobró más fuerza puesto que la gravitación que alcanzó el sindicalismo durante esos años en la interna peronista inhibió aún más cualquier posible interés sobre el devenir del Partido.

El trabajo de Moira Mackinnon (2002) vino a revertir, en cierta medida, esa situación, al objetar la imagen de verticalidad que se había impuesto sobre el Partido Peronista para dar cuenta de la complejidad y heterogeneidad que lo caracterizaron, al menos hasta 1950, y de los procesos de negociación por los que debió atravesar para mantener su unidad. De esta manera, se dio inicio a un intenso proceso de revisión de los estudios sobre el Partido Peronista en su etapa clásica entre los cuales figuran los trabajos de Aelo (2012); Acha y Quiroga (2012); Quiroga (2008, 2012); Rein, Barry, Acha y Quiroga (2009), En los últimos años, algunos autores han señalado la importancia que la estructura partidaria adquirió entre los peronistas, aun durante la proscripción (Melon Pirro, 2010, 2014; Quiroga, 2014; Ladeuix, Melon Pirro, Quiroga, 2014; Marcilese, 2014, 2015a, 2015b). Con anterioridad a 
estos trabajos, Steve Levitsky (2005), desde las ciencias políticas, desplazó el enfoque desde los organismos formales de conducción a las estructuras informales de base. Éstas estarían conformadas por unidades casi autónomas - unidades básicas, bibliotecas, clubes, sociedades de fomento y diversas organizaciones de la sociedad civil-, que no necesariamente interactúan a nivel horizontal ni responden a una estructura burocrática verticalista, pero forman parte del Partido porque en los períodos electorales son movilizadas al igual que las estructuras formales. Por lo tanto, que el Partido Peronista carezca de una estructura burocrática no implica necesariamente su debilidad. Para el período que nos compete, según Levitsky, el peronismo se habría caracterizado por acentuar su carácter movimentista, ${ }^{82}$ a diferencia de otros partidos que en situaciones similares de proscripción y clandestinidad tienden a internalizar sus estructuras y a transitar un estricto proceso de disciplinamiento. Esto no habría ocurrido con el Partido Peronista por tratarse de un "partido de masas informal”, carismático y poco rutinizado. ${ }^{83}$

Si bien al trabajo de Levitsky se le ha adjudicado cierto anacronismo y confundir al Partido con el movimiento peronista, abrió una puerta para el estudio de dicha estructura en el período de la proscripción y señaló la importancia de indagar sobre su funcionamiento en los niveles de base. Ahora bien, los autores que desde la historiografía iniciaron el estudio del Partido Justicialista en el período post '55, aunque adhieren a la idea de que contenía una parte informal, consideran que las estructuras formales también fueron valoradas. Hacen referencia al poder simbólico que poseía el partido en las luchas internas de poder, puesto que el control de una estructura partidaria no sólo los preparaba para hacer frente a una apertura electoral siempre latente sino también porque quien dispusiera de ella y de una sigla que les permitiera sortear las prohibiciones, además de la posesión de un capital de movilización, estaría mejor posicionado en esas disputas (Ladeuix, Melon Pirro, Quiroga, 2014). Otras interpretaciones, como la de Fernando Balbi, descreen que la estructura formal del partido haya sido valorada como un fin en sí mismo, siendo el arte de la "conducción" lo que los peronistas valorarían per se. Ello explicaría que hayan optado alternativamente por

\footnotetext{
${ }^{82}$ Levitsky toma la definición de movimiento de Gerlach y Hine (1970), cuya característica principal es la ausencia de una estructura burocrática y de una autoridad central capaz de coordinar a las diferentes subunidades que lo componen. Duverger (1974) sostiene que, además de carecer de una estructura vertical de disciplina, tampoco existen conexiones horizontales entre las subunidades.

${ }^{83}$ Que el partido sea carismático y poco rutinizado implicaba la ausencia de una estructura burocrática, de una jerarquía de liderazgo y de reglas y procedimientos que le brindaran a la organización un funcionamiento estable e independiente de las decisiones del líder (Levitsky, 2005). Otras interpretaciones, como la de Moira Mackinnon (2002), relativizan el poder de Perón en el partido, analizando el proceso de construcción de ese poder carismático, que recién se habría consolidado hacia 1950.
} 
reforzar la estructura formal del partido, por desactivarla, o por ir por fuera del mismo formando frentes, ya que cada una de esas opciones habría sido la más pertinente a los efectos de garantizar la conducción en momentos determinados (Balbi, 2014). Algunas investigaciones cuestionan el peso atribuido a las fuerzas sindicales en el peronismo durante 1955-1966, sosteniendo que dichas interpretaciones deben matizarse a la luz de investigaciones que no se limiten a Buenos Aires y el Gran Buenos Aires, contemplando los procesos partidarios reorganizativos en el interior del país (Alvarez, 2014 y Marcilese, 2015b). Finalmente, otros señalan características que emparentan la reorganización partidaria del período con las formas que el Partido había adquirido en sus años formativos (Ladeuix, Melon Pirro, Quiroga, 2014), además de que se ha profundizado el análisis en niveles de base, es decir, en los Centros de Acción Justicialista (CAJ), que fue el nuevo nombre que adquirieron las unidades básicas a partir de la normalización de 1959 (Quiroga, 2014).

Pese a esta revisión desarrollada sobre el PJ en los años posteriores al derrocamiento del peronismo, los intentos de reorganización de una estructura femenina han sido omitidos y se da por sentado que no existió tal estructura. José Marcilese se pregunta por el rol que cumplieron las mujeres en dichos procesos, sus trayectorias, el lugar que ocuparon en organismos de conducción y en las listas electorales, y el perfil y carácter genérico de los cargos a los que se postularon, sin embargo, estas problemáticas no constituye el tema central de su investigación (Marcilese, 2014, 2015b). Consideramos que pese a que no se consolidó ninguna estructura femenina durante el período de estudio, los intentos por crearla fueron numerosos y, aunque resultaron infructuosos, merecen un análisis. En todo caso, hay que explicar las causas de ese fracaso.

Gene Sharp (2011) sostiene que los procesos de resistencia suelen desarrollarse a partir de organizaciones no gubernamentales que suministran las bases grupales a partir de las cuales será lanzado el desafío político. Cuando las dictaduras logran destruir o controlar los cuerpos independientes de la sociedad, tienden a crearse nuevos grupos o a recuperarse el control de los cuerpos sociales que han sobrevivido o que se encuentran controlados parcialmente. Uno de los procesos que caracterizó a la Resistencia peronista en los momentos inmediatamente posteriores al golpe, fue precisamente la recuperación de los sindicatos intervenidos (James, 2010 [1988]; Salas, 2006 [1990], Schneider, 2005). Fue a partir de las estructuras sindicales que se lanzó el mayor desafío político contra los sucesivos gobiernos durante el período post peronista. Las organizaciones de base como las 
comisiones internas de fábrica y las relaciones barriales y familiares características de los barrios obreros donde estaban instaladas las fábricas, hicieron que las acciones de la Resistencia desplegadas por los sectores sindicales tuvieran un sustento en relaciones basadas en el lugar de trabajo, en el parentesco y en la vecindad, del que carecieron otras organizaciones que surgieron bajo la órbita del peronismo en esos años; de ahí la continuidad de dichas acciones pese a las medidas represivas impulsadas por los sectores dominantes (Salas, 2006 [1990], Schneider, 2005). Sin embargo, la Resistencia peronista también contó con otros intentos de organización por fuera de las estructuras sindicales, que aunque infructuosos y/o poco duraderos por carecer de relaciones sólidas de sustentación, merecen ser explicados. Es decir, en algunos casos, la Resistencia peronista se canalizó a través de estructuras y redes de relaciones previas como los sindicatos. Otras veces, se crearon nuevos grupos, como los comandos y las organizaciones guerrilleras, incipientes en el período. Unas y otras estructuras sucumbieron en la represión. A veces, se crearon nuevas organizaciones que recuperaban antiguos nombres, como fue el caso de la Juventud Peronista, creada en 1957, que retomaba el nombre de una de las estructuras institucionales surgidas bajo la órbita del gobierno peronista antes de 1955, pero no guardaba relación con ella. El proceso de reorganización partidaria constituye un intento por reactualizar viejas estructuras en un nuevo contexto, el cual era poco propicio para la participación por vía electoral; canal por el cual discurre naturalmente la política partidaria. Eso explica, en parte, que los intentos de reorganización partidaria hayan sido poco exitosos. Sin embargo, el tema merece un análisis, motivado en los procesos intensos de movilización que generó cada instancia reorganizadora.

El motivo que llevó a que muchos peronistas se lanzaran a la reorganización partidaria radica en varios motivos. En principio, consideramos que deben computarse las experiencias socializadoras del pasado. La participación partidaria era una forma de hacer política que estaba en el repertorio de acción de los peronistas. Durante la etapa de los primeros gobiernos peronistas, muchos canalizaron su actividad política a través de esas estructuras, en sus diferentes niveles. ${ }^{84}$ También, hubo quienes, sin haber tenido relación con las mismas,

\footnotetext{
${ }^{84}$ En los niveles de base, muchas unidades básicas habían sido espacios de socialización atravesados por relaciones familiares y vecinales, algunos, transitados desde la niñez. Ello se desprende de testimonios orales. Di Marco, Chiche; Martínez, María; Rivas Natividad y Cánepa, Oscar; Entrevista de la autora, Rosario, 16 de octubre de 2012. Di Marco, Chiche; Entrevista de la autora, Rosario, 11 de noviembre de 2014. En otros casos, la relación con las unidades básicas fue más distante. Di Leo, Mabel. Entrevista de la Autora. Vicente López, 31 de agosto de 2014 y Sotelo, Amanda. Entrevista de la autora. Berisso, 7 de mayo de 2014.
} 
se sumaron a los procesos de reorganización partidaria en el período post '55; probablemente porque la consideraban una vía viable y conocida de acceso al poder. Sin lugar a dudas, influyeron las lecturas sobre la situación política, segundo aspecto a considerar. Al menos en los primeros años después del golpe de Estado, prevaleció entre algunos la esperanza de un retorno inmediato a la situación institucional previa al mismo, asociada con un deseo de retorno al pasado que se basaba en el levantamiento de las proscripciones y en la recuperación de las estructuras institucionales que habían caracterizado al peronismo en su etapa clásica. Los deseos de reactivar esas viejas estructuras convivieron con intentos de crear otras nuevas que implicaban formas menos convencionales de acceso al poder y que se irían imponiendo con el transcurrir de los años. Pero aunque muchos peronistas se lanzaron a la lucha clandestina $-\mathrm{y}$ en algunos casos, armada - el cuestionamiento al sistema tradicional de participación político-partidaria no fue extensivo a todo el movimiento y mucho menos en los primeros tiempos. Por ejemplo, en el contexto de las elecciones constituyentes de 1957, la revista rosarina Soberanía, que propiciaba el voto en blanco, manifestaba la preocupación acerca de las probabilidades de acatamiento de una orden como la de abstención, ya que se pensaba que acarrearía problemas legales a los empleados públicos. ${ }^{85}$ Por otro lado, no hay que perder de vista que hubo actores que se lanzaron paralelamente a una y otra forma de lucha. Además, estaba el problema de que los votos peronistas se orientaran hacia otros partidos, por eso, cada vez que se abría una grieta en el sistema político que permitía participar electoralmente, esa instancia era aprovechada por algunos sectores, aunque luego todo terminara en una anulación de las elecciones o en un nuevo golpe de Estado. Si bien hubo una crítica al sistema liberal de partidos por carecer del contenido social que se atribuía el peronismo para sí, ello no implicaba un cuestionamiento al sistema político institucional como tal ni al sistema de representación, y cuando lo hubo, no fue la tónica mayoritaria del peronismo. ${ }^{86}$

\footnotetext{
${ }^{85}$ Soberanía No 18. "Qué es voto en blanco". Rosario, 27 de mayo de 1957, p. 4.

${ }^{86}$ En el peronismo circuló una noción de repudio a la política y a los políticos, originada en los debates entre laboristas y renovadores. Los primeros, de origen sindical, reprochaban a los segundos -políticos radicales de la línea partidaria pura- pertenecer a la antigua política, a la "politiquería", carente de contenido social. Esta idea fue tomada luego por el discurso peronista oficial para diferenciarse de la política liberal que había primado hasta su llegada (Mackinnon, 2002). Después del golpe de 1955, estas ideas reflotaron. Hubo una crítica a "los políticos", los que provenían del partido -en especial de la rama masculina-, que habrían sido los primeros en traicionar y defeccionar, a diferencia de la rama sindical que se había mantenido en pie. Esa calificación de políticos era atribuida a los dirigentes (James, 2010 [1988], p. 132). Hemos encontrado críticas a "los políticos", es decir, a la dirigencia partidaria, por parte de entrevistados que desarrollaron su militancia en unidades básicas, tanto antes como después del golpe de Estado, y que, empero, se expresan como si esas unidades básicas no fueran políticas o no formaran parte
} 
En general, la historiografia ha interpretado la reorganización partidaria en el peronismo durante el período post '55, como algo diferente e incluso opuesto de la Resistencia, englobando bajo este último concepto sólo a las actividades clandestinas o de abierta confrontación. Melon Pirro (2009), en debate con Samuel Amaral (2004 [1993]), sostiene que la Resistencia fue concebida desde un principio en términos políticos, descartando un tiempo de la resistencia entendido en términos bélicos, que habría sido reemplazado por un tiempo de la política. Es decir, que a una etapa donde predominaron las acciones clandestinas y de choque, siguió otra donde fue posible desplegar, con limitaciones, políticas partidarias; pero en ambos casos se trató de actividades políticas. Ahora bien ¿es posible invertir la afirmación de Melon Pirro y sostener que la política, esto es, la política partidaria, podría ser entendida como parte de la resistencia?

Como han sostenido varios autores, el partido fue una de las tantas herramientas con que contaron los peronistas para expresarse durante el período 1955-1966 (Ladeuix, Melon Pirro y Quiroga, 2014). Sidney Tarrow (1997) sostiene que los procesos electorales que tienen lugar en sistemas abiertos desalientan la movilización. Sin lugar a dudas, este no fue el caso de los procesos de reorganización partidaria durante 1955-1966, ya que no se dieron en un contexto de pleno funcionamiento de las instituciones democráticas sino todo lo contrario. Entonces, un elemento que debemos considerar a la hora de interpretar la reorganización partidaria como una forma de resistencia son los procesos de movilización que esa reorganización implicó. Dichos procesos, que en general tenían lugar en vísperas de elecciones, exigían una intensa movilización de la militancia de base. Hubo organizaciones creadas en los primeros años posteriores al golpe, como ateneos, bibliotecas, sociedades de fomento, que a partir del gobierno de Arturo Frondizi iniciado en 1958, se convirtieron en Centros de Acción Justicialista; centros que, por otra parte, podían crearse en casas de familia y funcionar incluso en un living, una antigua tradición del peronismo. Siguiendo a Levitsky (2005), aunque se ha tendido a identificar al partido con la alta dirigencia, los procesos de reorganización de dicha estructura abarcaron diferentes niveles, y aunque las unidades básicas no siempre respondían a la dirigencia, también eran estructuras políticas, integraban el partido y, como sostiene Quiroga (2014), estaban atravesadas por una intensa vida política. El proceso de afiliación y la campaña implicaban

del partido. Subrayo, así, el carácter discursivo de algunas afirmaciones, puesto que aunque esas unidades básicas no respondieran a la alta dirigencia partidaria, eran entidades políticas y participaban de procesos eleccionarios. 
trabajo, tiempo y dinero que eran aportados por los propios dirigentes y militantes de base, a través de rifas, donaciones, asados, o el aporte de una cuota societaria, a la vez que eran actividades que no estaban libres del peligro de detención o represión, puesto que la proscripción que pesaba sobre el Partido nunca fue completamente levantada durante el período bajo estudio. En general, la actividad partidaria se desarrolló en un contexto repleto de incertidumbre y esto valía para todos los niveles de participación. Debía escogerse la sigla adecuada que fuera capaz de sortear la proscripción, invertir recursos sin tener la garantía plena de aceptación de las listas de candidatos ni obtención de la personería jurídica, y aun con todas esas condiciones, el gobierno podía anular las elecciones o las Fuerzas Armadas efectuar un nuevo golpe de Estado. Ello, sin contar las cambiantes instrucciones que llegaban desde Madrid. Es por eso que, conceptualmente, sostenemos que la participación partidaria, fue una forma de resistencia.

Ahora bien, como se desprende de lo anterior, estas discusiones no han tomado nota de la situación del PPF. ¿No existieron intentos de reorganizarlo durante el período? Para comprender los procesos de reorganización del PPF posteriores a 1955, es necesario señalar algunas cuestiones vinculadas a su surgimiento en el período anterior. El ingreso masivo de las mujeres a las filas del Partido Peronista Femenino estuvo estrechamente vinculado a la sanción de dos leyes: la de derechos políticos y el estatuto de los partidos políticos. La ley 13010, de 1947, permitió el acceso de las mujeres a la ciudadanía política. El peronismo, en particular, tuvo especial ahínco en la organización política de las mujeres y su postulación a cargos representativos de gobierno. Según Carolina Barry (2009), en un primer momento, se discutió si era posible incorporar a las mujeres a la estructura partidaria existente, pero finalmente se decidió que actuaran por separado y que no se denominara "rama", sino "partido", para dar cuenta de esa autonomía, ya que el término "movimiento" remitía a una derivación del Partido Peronista y el término "rama", a una parte accesoria del mismo. ${ }^{87}$ Otra ley importante para la participación política de las mujeres fue la 13645 (septiembre de

\footnotetext{
${ }^{87}$ La creación del PPF coincidió con la adopción de la denominación de movimiento para el peronismo, y se resolvió que éste estaría integrado por tres ramas autónomas, el Partido Peronista, el PPF y la CGT; es decir, las estructuras políticas, una masculina y otra femenina, y la rama sindical. Todas tenían representación en el Consejo Superior, que en el caso del PPF estaba encarnada en la figura de su presidenta, Eva Perón. Mackinnon (2002) señala que ese cambio evidencia un mayor poder de Perón y de hombres de ingreso más reciente al peronismo carentes de otras lealtades políticas, en detrimento de aquellos que provenían del laborismo y del radicalismo, a la vez que marca el fin de las disputas sobre si el Partido Peronista adquiriría una estructura de base sindical o tradicional. La solución fue que los sindicalistas quedaran fuera del Partido pero integraran el movimiento peronista, y tuvieran representación en el Consejo Superior y lugares en las listas partidarias; a la vez que coincide con el reforzamiento de una estructura verticalista.
} 
1949) que modificó el Estatuto de los Partidos Políticos y otorgó un marco legal para el funcionamiento del PPF, al reglamentar la existencia de un partido paralelo dentro de otro partido preexistente. ${ }^{88}$ Según Adriana Valobra (2010), ese Estatuto fue la primera normativa que abordó la organización y participación política de las mujeres pero "no se reparó en que las mujeres, según esta norma, no se insertaban de modo independiente en las lides electorales y se naturalizó su politización sublimada a un partido -masculinopreexistente".

La participación política de las mujeres en el peronismo ha generado debates -a veces larvados - respecto de su carácter rupturista o conservador respecto de los roles tradicionales de género y la participación política propiciada entre las mujeres (Bianchi y Sanchís, 1998; Barry, 2009) y el tono maternalista que algunas consideran que propició (Navarro, 1994; Zink y Di Liscia, 2007; Bianchi y Sanchís, 1998) frente a otros que lo matizan (Valobra, 2010). El fallecimiento de Eva Perón, en julio de 1952, tuvo importantes consecuencias para el desarrollo posterior del PPF. Barry (2009) ha señalado la crisis que sumió al Partido debido a la carencia de mecanismos burocráticos que le permitieran un funcionamiento autónomo, independiente de las directivas emanadas por la Primera Dama; a la vez que resultó imposible reemplazar su liderazgo carismático y Perón asumió la dirección del Partido. Ello llevó a una merma en las tareas de dicha estructura. Además, para algunas autoras, el PPF no había desarrollado ninguna forma de democracia interna; era un partido verticalista, con estructuras débiles, poco burocratizado, en el que las decisiones estaban centralizadas en la figura de Eva Perón (Bianchi y Sanchís, 1998). En enero de 1954, hubo una reforma partidaria en la que el término "partido" fue reemplazado por "rama". Se buscó racionalizar y dinamizar la estructura creando secretarías, un Consejo Consultivo y un Tribunal de Disciplina; pero con resultados infructuosos (Bianchi y Sanchís, 1998). En febrero de ese año, asumió Delia Parodi como Secretaria luego de ser elegida por un grupo de legisladoras seleccionadas por Perón. Según Barry, Parodi asumió esta función de hecho al convertirse en delgada de la Rama Femenina en la Capital Federal, en octubre de 1952. También, se creó un Consejo Superior para darle al partido una organización más sistemática y burocrática, ya que éste no contaba con organismos claros de organización política y de promoción de dirigentes. Sin embargo, todos estos intentos fueron en vano, ya

${ }^{88}$ Conviene señalar la singularidad de un partido exclusivamente integrado por mujeres (Barry, 2009) y recordar que no fue la única organización diferenciada por género: en Argentina estuvo el Partido Feminista Nacional liderado por Julieta Lanteri (1919) y en México, el Partido Feminista Revolucionario (1931). 
que Parodi no logró que su autoridad fuera reconocida como legítima entre las militantes del Partido (Barry, 2009 y 2013).

Como se desprende de lo anterior, el golpe de Estado de 1955 encontró a la Rama Femenina del PJ inmersa en una profunda crisis. A esto, debe agregarse que sus figuras más visibles junto con las mujeres que habían ocupado cargos legislativos, fueron encarceladas y otras se exiliaron o abandonaron la actividad política. Las investigaciones no se han ocupado del seguimiento de este partido después de 1955 y no hay, hasta el momento, discusiones semejantes a las que hemos señalado en relación con las otras estructuras del Partido Peronista con excepción de algunas menciones colaterales. Sin embargo, pese a ello y a la proscripción, en los años subsiguientes no faltaron intentos por reflotar el PPF y creemos que es imprescindible retomar esas experiencias y ampliar la discusión con las obras existentes sobre el tema a fin, también, de pensar cómo esos intentos configuraron la propia Resistencia. A esta tarea se dedican las siguientes páginas.

Nuestro trabajo procurará analizar el devenir de la reorganización política femenina, considerando las posibilidades de participación institucional y de reorganización que fueron posibles bajo cada uno de los gobiernos que se sucedieron en el período estudiado19551966 que configuraron diferentes estructuras de oportunidades políticas en las que el peronismo en general, y las mujeres en particular, desplegaron un repertorio de confrontación así como también, como parte constitutiva de ese mismo proceso, articularon distintas estrategias de organización partidaria.

El período que corre entre septiembre de 1955 y febrero de 1958 son los años de la desperonización más intensa producida durante el gobierno de la Revolución Libertadora. Entonces, el contexto de oportunidades políticas no permite la participación en estructuras partidarias, sin embargo, aparecen las prácticas en la clandestinidad donde se mantuvieron presentes las ramas que antes estructuraban al partido. Será, también, el momento de los primeros contactos de Perón con algunas militantes para organizarse.

El proceso reorganizador comenzó en lo que consideramos la segunda etapa (19581962). Tras las elecciones de 1958 en las que triunfa Frondizi y su llegada a la presidencia, el peronismo se preparaba para actuar nuevamente en política por la vía institucional, con la expectativa de que la proscripción que pesaba sobre las estructuras partidarias sería levantada. Aunque ello no ocurrió, el proceso afiliatorio y reorganizativo tuvo lugar y el peronismo fluctuó entre encontrar estrategias para poder presentarse a elecciones, en particular alianzas con partidos neoperonistas, o pronunciarse por la abstención o el voto en 
blanco. Esta etapa tuvo su fin en marzo de 1962, tras el triunfo de la fórmula FraminiAnglada en las elecciones de la provincia de Buenos Aires, luego anuladas y seguidas del golpe de Estado que derrocó al gobierno frondizista. En ese lapso (1958-1962) podemos señalar un punto de inflexión en enero de 1960 cuando a raíz de la toma del frigorífico nacional Lisandro de la Torre se rompe la alianza entre el peronismo y Frondizi, y el gobierno muestra un perfil más represivo respecto del que había predominado en los primeros meses, aunque las instancias de participación electoral permanecieron abiertas con ciertas restricciones. Durante todo el período, encontraremos intentos de reorganizar el PPF atravesado por los conflictos entre la antigua dirigencia femenina del partido y la que había emergido durante la Revolución Libertadora, no necesariamente más jóvenes.

Bajo gobierno de José María Guido comenzará un nuevo proceso de reestructuración del Partido Justicialista, esta vez en la clandestinidad, que culminará en las elecciones del 7 de julio de 1963, tras las cuales el partido quedará sumido en una profunda crisis. Conocido como el momento del giro a la izquierda del peronismo, mostrará en el frente femenino la interacción con militantes de otros partidos.

A fines de ese año y ya bajo el gobierno de Arturo Illia, se iniciará otro proceso reorganizativo que chocará con el golpe de Estado de la Revolución Argentina, en junio de 1966. Esta etapa estará atravesada por intensos realineamientos políticos que involucran al vandorismo. Además, se observan algunas diferencias respecto de las etapas anteriores porque en ella tienen lugar las primeras elecciones que desde el golpe de Estado de 1955 no fueron anuladas a pesar del triunfo peronista y los candidatos de esa tendencia política pudieron asumir los cargos legislativos para los que fueron votados. Las disputas en el sindicalismo se espejan entre las mujeres y, a su vez, aparecen distintas fórmulas para encaminar su actuación, aunque sin que ninguna hegemonice. El período se cierra con el golpe de Onganía que, en relación con nuestro objetivo de estudio, coincidirá con el objetivo de Perón por darle una estructuración nacional y centralizada a la organización femenina por la que hasta ese momento se había interesado poco, lo que implicó choques con las iniciativas que se habían ido gestando en los años previos.

En este análisis de las relaciones entre el eje de la estructura de oportunidades y la dimensión institucional que se intenta recrear, encontraremos permanentemente lo que Astelarra considera los dos temas centrales en el análisis de la relación entre el sistema de género y la política: por un lado, que "la política está determinada por el sistema de género 
contemporáneo como una actividad masculina" y, por el otro, que "el sistema de género se mantiene y se reproduce por la intervención política" (Astelarra, 1987, p 160).

\section{Militar en las sombras (1955-1958)}

En enero de 1956, Perón se pronunciaba sobre la participación política femenina en las "Directivas Generales para todos los dirigentes peronistas", donde solicitaba a las mujeres que se organizaran, que en cada casa funcionara una unidad básica y que se guiaran por las dirigentes del Partido, a las que pedía que se mantuvieran conectadas con las otras fuerzas del movimiento. ${ }^{89}$ Esta directiva habla del poco conocimiento que tenía Perón de la situación de las estructuras partidarias en los meses posteriores a su derrocamiento. Varias dirigentes del PPF, que se habían desempeñado como legisladoras o que ocupaban la plana mayor del Partido, fueron detenidas en la penitenciaría de Humberto $1^{\circ}$ de la Capital Federal y en la cárcel de Olmos, en el partido de La Plata. Según Estela Dos Santos, la mayoría de ellas recuperaron su libertad para la Navidad de 1955. Josefa Tubio, Otilia Villa Maciel y Susana Correché, fueron liberadas a los seis meses, mientas que Ana Macri y Delia Parodi salieron recién con la amnistía del gobierno frondizista en 1958 (Dos Santos, 1983).

Como señalamos en el apartado anterior, el PPF era una estructura verticalista y poco burocratizada cuyo funcionamiento dependía en gran medida de las decisiones de su presidenta, Eva Perón, y al momento de producirse el golpe de Estado se encontraba con sus actividades muy reducidas debido a la crisis tras la muerte de su líder. Durante los años de su funcionamiento, las delegadas censistas habían sido enviadas a provincias distintas de las que procedían; una estrategia de Evita para evitar que se formaran caudillas, por lo que las dirigentes carecían de arraigo territorial. Estos factores facilitaron la desestructuración del Partido al producirse el golpe de Estado cuando se configuró una estructura de oportunidades caracterizada por un sistema cerrado a la participación política del peronismo y con altos niveles de represión. Ello fue modificándose a lo largo de 1957 en tanto que la alianza que había hecho posible el triunfo del golpe se fue erosionando y algunos de los partidos que lo habían apoyado comenzaron a ver en el peronismo un caudal electoral factible de ser conducido en beneficio propio o un posible aliado.

${ }^{89}$ Correspondencia Perón Cooke II (1984). Buenos Aires: Parlamento. 26 de abril de 1958, pp. 55-56. 
Ante esta situación, y considerando que el PPF había actuado en forma autónoma respecto de las otras ramas del movimiento peronista y que muchas de sus delegadas y subdelegadas no tenían arraigo territorial y no habían formado focos de poder, no es de extrañar que muchas de ellas abandonaran la actividad política tras el derrocamiento del peronismo. El testimonio de una militante cuya labor se había desarrollado en una unidad básica femenina en el barrio porteño de Barracas, evidencia que, tras el golpe de Estado, sus compañeras retornaron a sus provincias de origen y ella, oriunda de Avellaneda, se recluyó en la vida familiar. ${ }^{90}$ Las subdelegadas, empero, se desempeñaban mayoritariamente en sus propias ciudades, pueblos y barrios, tanto en el interior del país como en el conurbano bonaerense, e incluso, las unidades básicas solían funcionar en viviendas particulares; por lo que, si bien esas células partidarias debieron cerrarse, los contactos y algunos liderazgos sobrevivieron al golpe. Amanda Sotelo, militante de Berisso, explica el rol de una vecina, Zoila Padovani, representante de la Rama Femenina en cuya casa había funcionado una unidad básica durante el gobierno peronista, y durante la Revolución Libertadora canalizaba actividades de resistencia en el barrio como pintadas y actos relámpago, nucleando a mujeres adultas y sus hijos -niños y adolescentes-, a la vez que participó de intentos posteriores por reorganizar dicha Rama cuando se dieron las posibilidades para ello. ${ }^{91}$

El ejemplo anterior evidencia que en la Resistencia peronista hubo mujeres cuya trayectoria previa se había encauzado a través de estructuras partidarias, entendiendo que las unidades básicas también integran el Partido. ${ }^{92}$ Ahora bien, independientemente de su adscripción a la estructura partidaria, un hecho que llama la atención de estos primeros años de la Resistencia peronista es la existencia de relaciones femeninas que incluyen la presencia de mujeres de edad madura sobre la cual gravitaban mujeres más jóvenes; aunque se trata de relaciones informales que no llegan a adquirir una estructura formal. En Rosario, por ejemplo, un grupo de mujeres entre 20-25 años al momento de producirse el golpe, cuya militancia se había desarrollado en unidades básicas durante el gobierno peronista, reconocen para los años de la Resistencia la capacidad de adhesión ejercida por algunas mujeres de mayor edad que habían conformado los costureros Eva Perón. ${ }^{93}$ Una joven de

\footnotetext{
${ }^{90}$ Veiga, Cristina. Entrevista de la autora. Avellaneda, 13 de septiembre de 2014.

${ }^{91}$ Sotelo, Amanda. Entrevista de la autora. Berisso, 7 de mayo de 2014.

92 Hubo mujeres que se volcaron a la participación política en los partidos neoperonistas que emergieron luego del derrocamiento del peronismo, como por ejemplo el Partido Laborista o la Unión Popular, pero ello es un tema que excede los objetivos de esta tesis.

${ }^{93}$ Di Marco, Chiche; Martínez, María; Rivas Natividad y Cánepa, Oscar; Entrevista de la autora, Rosario, 16 de octubre de 2012. Di Marco, Chiche; Entrevista de la autora, Rosario, 11 de noviembre de 2014.
} 
16 años de Paraná escribe a Marta Curone, dirigente de la UES antes de 1955 y posteriormente a esa fecha, de la Rama Femenina, y narra la enseñanza que recibió de sus tías, una de ellas delegada entrerriana de una de las tantas comisiones que se formaron para reclamar la devolución del cadáver secuestrado de Evita. Con ellas, que habían estado encarceladas durante el gobierno de la Revolución Libertadora, salía por las noches a pegar carteles de invitación a los homenajes o de adhesión a algún acto. ${ }^{94}$

A esos casos de relaciones informales, se le suman otros que pretendieron una formalidad mayor. Después del golpe de Estado de 1955, la militancia no siempre se desarrolló diferenciada por género. Sin embargo, esta idea de que las mujeres debían tener sus propias estructuras de participación o una representación en su calidad de mujeres, no perdió vigencia entre los peronistas; era parte de cómo entendían esa activación política. Hubo varios intentos por formar estructuras exclusivamente femeninas e, inclusive, se lanzaron consignas destinadas específicamente a un público femenino; por ejemplo, algunos periódicos como Soberanía y Línea Dura tuvieron secciones dedicadas a las mujeres. Si bien este último estaba vinculado a la alta dirigencia partidaria, no era el caso del primero. Además, encontramos estructuras creadas para actuar en la clandestinidad que intentaban reproducir la organización en ramas. Tal el caso del Frente Emancipador de Santa Fe, estructura clandestina que, según Juan Manuel Vigo, constaba de un comité ejecutivo en el que se aspiraba a que la CGT, las dos ramas del partido y la juventud tuvieran representación (Vigo, 1973). También, encontramos a Alicia Eguren, reconocida dirigente de la Resistencia peronista, procurando organizar grupos de mujeres desde la cárcel, a pesar de que su militancia peronista anterior a 1955 no había sido en las filas del PPF. ${ }^{95}$ También, había participado de la campaña por el voto en blanco en las elecciones a constituyentes de 1957, pronunciando mensajes radiales dirigidos específicamente a las mujeres. ${ }^{96}$

\footnotetext{
${ }^{94}$ Carta de Virginia Navarro a Marta Curone. Paraná, 24 de octubre de 1961. Archivo Marta Curone.

${ }^{95}$ Correspondencia Perón-Cooke I (1983). Buenos Aires: Parlamento.11 de abril de 1957, pp. 74-75. Alicia Eguren nació en Buenos Aires en 1924. Estudió Letras. Fue docente y escritora. Estuvo casada con el diplomático Pedro Catella, con quien tuvo un hijo. Integró los grupos de intelectuales nacionalistas de raigambre rosista que apoyaron al peronismo. Editó la revista Sexto Continente, donde se expresaba el nacionalismo. En el contexto del derrocamiento del peronismo se puso en contacto con John William Cooke, que era el interventor del Partido Justicialista de Capital Federal, con quien se casó en 1957. Juntos se incorporaron a la Resistencia. Durante el primer año del gobierno de Frondizi intentaron reorganizar al PJ. A comienzos de la década de 1960 se radicaron en Cuba y se sumaron a las milicias revolucionarias. Alicia reclutó jóvenes argentinos para que recibieran entrenamiento militar en ese país. En los setenta se incorporó a la Tendencia Revolucionaria del Peronismo e integró el staff de la revista Nuevo Hombre. Fue secuestrada en 1977 por un grupo de tareas de la ESMA y arrojada al Río de La Plata en uno de los "vuelos de la muerte" (Mazzeo, s/f; Deleis, De Tito y Arguindeguy, 2001)

${ }^{96}$ Correspondencia Perón-Cooke I (1983). Buenos Aires: Parlamento. s/f, pp. 223-224
} 
En suma, los ejemplos anteriores demuestran que durante el gobierno de la Revolución Libertadora fue común el desarrollo de actividades de resistencia realizados por grupos de mujeres basados en relaciones informales, a veces de vecindad y parentesco, que en algunos casos implicaron a mujeres con trayectoria en unidades básicas $\mathrm{u}$ otras estructuras del peronismo. Además, hubo intentos por formalizar las relaciones entre mujeres para llevar a cabo la resistencia. Entre algunos peronistas prevaleció la idea de que las mujeres debían actuar y organizarse de manera diferenciada respecto de los hombres, aún para actuar en la clandestinidad. Probablemente, esa actitud estuviera acorde con la idea que predominó en los primeros años posteriores al golpe de Estado de 1955, de que el retorno de Perón y la recuperación del poder serían inmediatos y que los grupos que lograrían ese cometido y sus estructuras serían quienes integrarían el nuevo gobierno. Como es sabido, la lucha por el retorno de Perón y por acceder al gobierno fue lo bastante prolongada como para que el proceso de reorganización partidaria fuese complejo y estuviese plagado de conflictos. Cuando ese proceso comenzó a efectivizarse, durante el gobierno de Arturo Frondizi, el problema radicó en resolver quién tenía la legitimidad para encabezarlo, problema que afectó profundamente la reorganización de una estructura partidaria femenina.

\section{El gobierno frondizista y la primera reorganización partidaria (1958-1962)}

El contexto de las elecciones de 1958, en las que fue elegido presidente Arturo Frondizi, marca un punto de inflexión en la trayectoria del peronismo durante la proscripción, porque comienza a plantearse el problema de cómo encuadrar las distintas fuerzas que lo integraban para actuar nuevamente en la política institucional. En principio, implicó un aprovechamiento de las oportunidades políticas que brindó la ruptura de la coalición dominante, que se concretó en el pacto con la UCRI, y una interpretación, por parte de algunos sectores del peronismo, de que se iniciaba un período de legalidad que debía ser aprovechado; hecho que no estuvo libre de conflictos ya que no todos lo interpretaron de la misma manera. Una de las cuestiones que el peronismo negoció con Frondizi a cambio de los votos fue el levantamiento de la proscripción del partido. Aunque se derogó el decreto 4161, la proscripción no fue levantada, por lo que comenzaron a presentarse instancias electorales y canales de participación en un contexto institucional 
muy heterogéneo respecto de lo que estaba permitido. ${ }^{97}$ Desde un primer momento, las mujeres estuvieron subrepresentadas en las estructuras que se crearon para conducir el proceso de reorganización partidaria del peronismo, que desde el golpe de Estado de 1955 había actuado de manera descentralizada. La primera de esas estructuras fue el Comando Táctico y la segunda, la Delegación Nacional, ligadas a la figura de John William Cooke.

El Comando Táctico fue creado en diciembre de 1957. Aglutinaba a la plana mayor del peronismo en la Argentina, proveniente tanto de sectores gremiales como políticos, y estuvo vinculado a la gestión del pacto Perón-Frondizi. Hacia junio de 1958, el Comando, que fue sufriendo sucesivas reincorporaciones, contaba con 123 integrantes, de los cuales, sólo dieciocho eran mujeres. ${ }^{98}$ Para la reorganización a nivel territorial se crearían Comandos Tácticos provinciales y de Capital Federal, y Subcomandos Tácticos locales. En el periódico Línea Dura, cuyos directores integraban el Comando Táctico, y donde se daba a conocer toda esta información, Cooke se encargaba de aclarar que dichas estructuras estarían constituidas por hombres y mujeres que hubieran luchado en la resistencia, en la clandestinidad, además de aquellos que habían participado en organismos de superficie, evidenciando un conflicto entre sujetos provenientes de esos espacios de participación. ${ }^{99}$

En agosto de 1958, el Comando Táctico fue disuelto y remplazado por la Delegación Nacional, integrada por Cooke y quince delegados, en su mayoría sindicalistas. Entre esos delegados había tres mujeres, Ana Macri, Audelina Albóniga y Elena Fernícola. Las tareas de afiliación pasaron a estar a cargo de tres comisiones: comisión gremial (integrada por miembros de las “62" Organizaciones y de la CGT Auténtica), comisión política y de la

\footnotetext{
${ }^{97}$ La ley de amnistía, 14436, promulgada por el Congreso el 22 de mayo de 1958, legalizó el uso de los símbolos peronistas, permitió la propaganda de dicha ideología, a la vez que sus dirigentes políticos y gremiales fueron habilitados para ocupar cargos públicos o sindicales. Pero el Partido Peronista como tal, siguió permaneciendo en un limbo legal (Potash, 1981).

${ }^{98}$ Línea Dura N$^{\circ} 27$. Buenos Aires, 2 de julio de 1958, p. 2. Las mujeres eran: Seferina Rodríguez de Copa (Ex diputada nacional por Salta), Pierina Dealesi (Actriz, amiga personal de Evita, integró la Comisión Directiva del Ateneo Cultural Eva Perón, 1950); Elena Fernícola (ex delegada de territorio nacional en la Cámara de Diputados, elegida en 1951); Hortensia García Marín (ex miembro de la Fundación Eva Perón); María Granata (Periodista y escritora, abordaremos su figura en el capítulo III); Ana Macri (Delegada Censista, Ex diputada por Capital Federal); Celina Rodríguez de Martínez Paiva (Ex delegada censista y legisladora electa en 1951); Susana Valle (Hija del General Valle, fusilado en 1956 por dirigir el levantamiento del 9 de junio, e integrante de uno de los grupos de Juventud Peronista que se constituyeron luego del golpe de Estado de 1955); Edelmira Giúdice (Participó de la campaña "pro sufragio femenino" a través de una serie de artículos titulados "La mujer argentina quiere votar" que se publicaron en Democracia a comienzos de 1947. Ver.: Bianchi y Sanchís, 1998, pp. 46); Audelina Albóniga (Fue docente, dirigió comandos de la Resistencia peronista y estuvo en el Comando Táctico por elección de Alicia Eguren). Del resto, Susana Farías; Matilde Arriet; Angélica Farisano; Ema Gemelli; María Lensi; Dora Julia G. de Morchio; Josefa Q. de Sánchez, no hemos hallado datos.

${ }^{99}$ Linea Dura $\mathrm{N}^{\circ} 25$. Buenos Aires. 18 de junio de 1958, p. 2.
} 
resistencia (integrada por dirigentes, léase varones, del sector político y de la resistencia), y comisión femenina (mujeres, también del Partido y de la resistencia), por partes iguales. ${ }^{100}$ Esta decisión generó conflictos. Según Línea Dura, algunos de los ex integrantes del Comando Táctico manifestaron su disconformidad porque la resistencia no estaba representada en su conjunto en el nuevo organismo. Entre las mujeres, Hortensia García Marín, Ema Gemelli y Susana Farías, impugnaron al grupo femenino de la Delegación; es decir, a Macri, Fernícola y Albóniga. ${ }^{101}$ Grupos de la Resistencia cuestionaron a Ramón Prieto, acusándolo de comunista; a Ana Macri y a Elena Fernícola, por su actuación durante el gobierno de la Revolución Libertadora y por representar a sectores minoritarios del movimiento femenino -ambas eran ex legisladoras y dirigentes del PPF-; y a Audelina Albóniga, porque sostenían que no era representativa de la Resistencia en su totalidad. ${ }^{102}$ Finalmente, Ana Macri también terminaría retirándose de esta estructura por las acusaciones que pesaban contra Prieto. ${ }^{103}$

Ni el Comando Táctico ni la Delegación Nacional lograron encauzar las diferentes fuerzas que estaban actuando en el peronismo desde 1955, a pesar de las consignas de disciplinamiento que se lanzaban desde el periódico Línea Dura, vinculado a las mismas. Tampoco lograron llevar a cabo la afiliación y reestructuración de las ramas partidarias. En octubre de 1958, se creó el Consejo Coordinador y Supervisor del peronismo, que reemplazaría a la Delegación Nacional y evidenciaría el ocaso de Cooke como delegado de Perón, concretado hacia enero de 1959 a raíz de los sucesos en el frigorífico Lisandro de la Torre. A continuación, señalaremos algunas problemáticas suscitadas por el plan de reorganización y encuadramiento propuesto por Cooke.

En principio, emergieron disputas entre aquellos que querían recuperar las estructuras partidarias y quienes deseaban mantenerse en la ilegalidad y continuar con las acciones de confrontación, cuestión que guardaba relación con el debate acerca de si había que votar por Frondizi o propiciar la abstención o el voto en blanco en las elecciones del 23 de febrero de 1958. En segundo lugar, entre quienes deseaban reorganizar el partido estaba el problema de quién tenía la legitimidad para hacerlo, y correlativo a ello, quiénes integrarían los organismos de conducción, cómo se le otorgaría representación a los grupos y dirigentes

\footnotetext{
${ }^{100}$ Línea Dura $\mathrm{N}^{\mathrm{o}} 35$. Buenos Aires. 21 de agosto de 1958, p. 1.

101 Línea Dura No 36. Buenos Aires, 28 de agosto de 1958, p. 1.

102 Correspondencia Perón-Cooke II (1984). Buenos Aires: Parlamento. 1 de septiembre de 1958, pp. 8283
} 
que se habían destacado en las actividades clandestinas de la resistencia, y qué estructuras serían las más adecuadas para encuadrar políticamente al peronismo en un contexto muy diferente al que había transitado con anterioridad a 1955.

Respecto del primer problema, grupos de mujeres participaron de esas pujas políticas. El mismo Cooke menciona a mujeres de Rosario, opuestas a la conformación del Consejo Coordinador, ${ }^{104}$ y los archivos de la DIPBA refieren un grupo femenino en Mar del Plata opuesto a la línea pacífica impartida por las 62 Organizaciones; es decir la línea del pacto. ${ }^{105}$ También, hubo cuestionamientos provenientes de las ex dirigentes del PPF acerca de la conveniencia de reorganizar las estructuras partidarias, como lo demuestra una carta de Perón dirigida a la ex senadora nacional Juana Larrauri en la que aquel que procura convencerla de la necesidad de normalizar las estructuras partidarias, puesto que sin ellas sólo quedaban las de carácter clandestino, que no eran aptas para atravesar la nueva coyuntura que prometía la participación en instancias electorales. ${ }^{106}$

El segundo de los problemas suscitado fue el de la legitimidad para la reorganización partidaria. Silvia Sigal y Eliseo Verón se han explayado sobre la dificultad de los delegados o intermediarios de Perón en el país para hacer valer su autoridad, y el primero en afrontarla fue John William Cooke, tanto frente a los comandos de la Resistencia como también frente a los sectores políticos y sindicales con trayectoria previa en el peronismo. En relación con el encuadramiento político de las mujeres, Cooke se vio enfrentado a las antiguas dirigentes del PPF. En mayo de 1958, el periódico Línea Dura publicaba un reportaje donde éste sostenía que el Comando Superior, es decir, Perón, iba a respetar la existencia de una rama masculina y otra femenina en la estructura organizativa que adquiriera el movimiento peronista, pero que si las mujeres decidían cambiar esa estructura tenían el derecho para hacerlo; un derecho que se habían ganado por luchar a la par de los hombres en la Resistencia. ${ }^{107}$ Esta postura de Cooke no estaba en sus planes iniciales y respondía a las recomendaciones del propio Perón, que en una carta le hacía saber que había recibido quejas de las mujeres del PPF acerca de que se pretendía destruir dicha estructura y le aconsejaba que aclarara que esas pretensiones eran falsas. ${ }^{108}$ Esta carta ha sido citada por

\footnotetext{
103 Macri, Anna (2006). Mi biografía politica. Buenos Aires: Instituto Nacional de Investigaciones Históricas Eva Perón.

${ }^{104}$ Correspondencia Perón-Cooke II (1984). Buenos Aires: Parlamento. 5 de febrero de 1959, pp.141-142

105 DIPBA. Mesa “A”. Factor Político. Carpeta 37. Legajo 83.

${ }^{106}$ Correspondencia de Perón I (1983). Buenos Aires: Parlamento. 14 de septiembre de 1958, pp. 59-70

${ }^{107}$ Línea Dura No20. 12 de mayo de 1958, p. 1

${ }^{108}$ Correspondencia Perón Cooke II (1984). Buenos Aires: Parlamento. 26 de abril de 1958, pp. 54-55.
} 
otras autoras para evidenciar el interés de Perón por preservar la estructura femenina (Centurión, 2007, pp. 251-251 y Dos Santos, 1983, pp. 80-82). Sin embargo, esos trabajos omiten los párrafos en que Perón subestima la importancia de la organización de las mujeres. El interés por preservar las estructuras del Partido Femenino provenía de las mujeres que habían estado vinculadas a ese organismo. Perón estaba más preocupado por evitar el costo político que pudieran acarrear los conflictos derivados de su disolución que por los resultados positivos que le traería su reorganización:

“...Deje usted que ellas se organicen a su manera en igualdad de condiciones con los hombres y la selección natural hará el resto [...]'Nuestro éxito no depende de cómo se organizará el Partido Peronista Femenino, ¿a qué provocar un lío inútil? [...] Si como usted dice, las más capacitadas son las obreras y éstas no incorporarán jamás al Partido Femenino, lo mismo que ocurre con los hombres, ¿qué problema puede representar que se organicen las demás?". ${ }^{109}$

Es posible apreciar que en el argumento esgrimido por Perón "El control masculino del mundo público es una base importante de las relaciones patriarcales modernas, pues los varones regulan las condiciones en las cuales se les permite a las mujeres acceder a él.." (Astelarra, 1987, p. 163). En este marco, se comprende que Cooke diera marcha atrás con su proyecto de intervenir en la reorganización femenina. El periódico Línea Dura recurrió a la palabra de Perón y a la evocación de la figura de Evita para dejar en claro que el Partido Peronista Femenino no sería tocado. ${ }^{110}$

Entre las mujeres que habían integrado el PPF hubo intentos aislados y paralelos por reconstruir estructuras autónomas. Esta es una constante de todo el período. En septiembre de 1958, Perón le comunicaba a Cooke que le había escrito a "la Fernícola" para que se encontrara con él a fin de que pudieran ser eliminadas las diferencias, pero que "si esta muchacha no reacciona de sus errores, usted sabe que la Delegación tiene autoridad para separarla en caso de que cometa alguna irregularidad...". ${ }^{111}$ Elena Fernícola había estado organizando una rifa para reunir fondos que le permitieran enviar delegadas al interior del país a los efectos de reorganizar el Partido Femenino. En un principio, Perón desautorizó esa iniciativa de Fernícola indicándole que se ajustara a las directivas del Comando Táctico,

\footnotetext{
${ }^{109}$ Correspondencia Perón Cooke II (1984). Buenos Aires: Parlamento. 26 de abril de 1958, pp. 55-56.

${ }^{110}$ Línea Dura No27. Buenos Aires. 3 de julio de 1958, 2.

${ }^{111}$ Correspondencia Perón-Cooke I (1983). Buenos Aires: Parlamento. 16 de septiembre de 1958, pp. 92-93
} 
que contaba con fondos para encarar la reorganización. Y le decía que había recibido cartas de otras mujeres en las que se le preguntaba si era verdad que ella o Delia Parodi eran las encargadas de organizar el PPF. ${ }^{112}$ En una carta previa, Perón le pedía que mantuviera contactos con Cooke, vía Brasil o Paraguay, y que le transmitiera a "todas las muchachas" la necesidad de subordinarse al delegado, tratando de superar intereses personales o de grupo. ${ }^{113}$ Sin embargo, en febrero de 1959, con Cooke ya desplazado de la conducción, Perón le aconsejaba a Elena, ante su preocupación por haber perdido comunicación con el Consejo Coordinador, que se mantuviera en contacto con los dirigentes sindicales de las 62 Organizaciones. ${ }^{114}$

A lo largo de la correspondencia que Perón y Cooke mantuvieron, aquel le aconsejaba a su delegado que tomara distancia de las facciones que se iban generando y que operara a nivel general y estratégico. Estas recomendaciones también particularizaban en los problemas que se suscitaban en la organización femenina. Perón le recriminaba a Cooke que estaba recibiendo cartas de disconformidad de distintas mujeres, no sólo contra él sino también contra Alicia Eguren, porque ambos estaban procurando intervenir en la reorganización del partido enviando delegadas a distintos lugares del país. ${ }^{115}$ Perón se oponía a una reorganización encarada de manera centralizada. ${ }^{116}$ Ante estos reproches, Cooke respondía que Alicia sólo se estaba ocupando de conducir actividades de propaganda y agitación clandestinas, introduciendo delegados en las fábricas y comandos para bajar directivas y que no deseaba participar en la reorganización de la rama femenina, y que inclusive había viajado a Río de Janeiro para encontrarse con él y así no estar presente en

\footnotetext{
${ }^{112}$ Correspondencia de Perón I (1983). Buenos Aires: Corregidor. 27 de mayo de 1958, 55-56

${ }^{113}$ De esa carta se desprendía que la dirigente había participado activamente por el voto a Frondizi y había sido responsable de incorporar algunas mujeres al Comando Táctico. Correspondencia de Perón III (1985). Buenos Aires: Corregidor. 20 de marzo de 1958, pp. 136-138

${ }^{114}$ Correspondencia de Perón I (1983). Buenos Aires: Corregidor. 25 de febrero de 1959, 136-138.

${ }^{115}$ Entre esas cartas hallamos una perteneciente a Delia Parodi, donde cuestiona las intenciones de unificar a todas las ramas bajo un comando y le pide que exima a la Rama Femenina de estar subordinada al Comando Táctico. Manifiesta su descontento hacia mujeres que integran esa estructura, que han sido elegidas por Alicia Eguren y que acusan de traidoras a las mujeres provenientes del PPF. También desmiente el hecho de que Eguren no esté interviniendo en la reorganización partidaria. Y le dice que "no permita que le antepongan a las mujeres del partido, las mujeres de la resistencia, ya que ese es también un planteo falso, las auténticas mujeres de la resistencia no están tampoco representadas." La carta es Delia Parodi, pero también fue firmada por otras mujeres: María Rosa C. de Gómez, Hilda Pineda de Molins, Enriqueta Zurita de Maccor (ex delegada de Santiago del Estero), María Nélida Costa de Doce (ex delegada de la Provincia de Buenos Aires), Haydee Merlo (ex delegada de San Juan), María Elena Solari de Bruni (ex subdelegada) y Eva Barrios (ex subdelegada). Carta de Delia Parodi a Perón. Buenos Aires, 7 de julio de 1958. Archivo John William Cooke. CeDInCI.

${ }^{116}$ Correspondencia Perón-Cooke II (1983). Buenos Aires: Corregidor. 18 de junio 1958, pp. 67-68.
} 
Buenos Aires cuando comenzara a conformarse la Comisión Inscriptora Femenina. ${ }^{117}$ Sin embargo, es factible suponer que Eguren tuvo participación en los intentos por reorganizar la rama femenina. Ana Macri sostiene que entre las integrantes de la Delegación Nacional, una era amiga de Eguren: Audelina Albóniga. Marta Curone le reclama a Eguren un lugar en la conducción de la reorganización partidaria y le reprocha haber dejado afuera a mujeres que, pese a haber sostenido el voto en blanco, habían trabajado por el peronismo desde su derrocamiento. ${ }^{118}$ Vale decir, la consideraban responsable de la organización femenina.

El PPF había sido organizado de manera verticalista por Evita, y Cooke pretendió reorganizarlo desde arriba, emulando aquella práctica. Sin embargo, ni él ni Eguren gozaron de la legitimidad para encabezar ese proceso ni tuvieron los recursos del Estado para hacerlo; por la cual sus intentos de convertirse en artífices de las nuevas estructuras que adquiriría el peronismo en la oposición se vieron frustradas. Aunque Alicia no provenía del Partido Femenino, valoraba el mantenimiento de una estructura diferenciada por género. No disponemos de discursos suyos al respecto, pero sus intentos de reorganización revelan esa actitud favorable. A su vez, estas disputas evidencian la tenacidad de algunas mujeres para defender el derecho de ser las encargadas de reorganizar la estructura partidaria femenina, aun en un contexto hostil que les obligaba a generar sus propios medios de financiamiento. La disputa entre las nuevas y viejas dirigentes, en este contexto, se resolvió a favor de estas últimas. Algunos trabajos mencionan el compromiso y la entrega como valores estimados en el peronismo tras el golpe de Estado 1955 (Centurión). Sin embargo, en el proceso de reorganización partidaria prevaleció -en particular entre las mujeres-el prestigio adquirido durante los años del gobierno peronista, producto de haberse desempeñado como censistas y/o legisladoras.

El pacto entre el peronismo y Frondizi se rompió a comienzos de 1959 a raíz de la toma del Frigorífico Lisandro de la Torre, aunque ya había habido un primer altercado en noviembre del año anterior al producirse la huelga petrolera en Mendoza. La máxima estructura política a partir de ese momento fue el Consejo Coordinador y Supervisor del Movimiento Peronista (CCSMP), luego Consejo Coordinador y Supervisor del Partido Justicialista (CCSPJ), creada en septiembre de 1958, en principio para colaborar con la Delegación Nacional del Comando Superior Peronista, pero que luego terminaría

\footnotetext{
${ }^{117}$ Correspondencia Perón-Cooke II (1983). Buenos Aires: Corregidor. 1 de septiembre de 1958, p. 88
} 
reemplazándola. Al comienzo, aglutinó sólo a dirigentes políticos y dirigentes surgidos de la resistencia; a diferencia del Comando Táctico y de la Delegación Nacional, integradas también por sindicalistas. En septiembre de 1959, ingresaron miembros de extracción gremial (Marcilese, 2014). De un total de quince miembros, sólo tres eran mujeres y todas provenían del Partido Peronista Femenino: Delia Parodi, Ceferina Rodríguez de Copa y María Elena Solari de Bruni. Esto evidenciaba que las diferencias que Cooke mantuvo con las mujeres del PPF por la forma y la composición que adquirirían las nuevas estructuras políticas femeninas, se había saldado en favor de estas últimas. Finalmente, la responsabilidad de la Reorganización de las mujeres recayó en Delia Parodi, cuyas credenciales provenían de haber asumido la conducción del Partido Femenino luego de la muerte de Eva Perón, además de la legitimidad que le otorgaban los años trascurridos en la cárcel. Elena Fernícola, quien se había atribuido la organización partidaria, terminaría siendo desplazada del movimiento peronista en octubre de 1959, por "indisciplina"; aunque no conocemos los motivos concretos. ${ }^{119}$

Para llevar a cabo el proceso de reorganización partidaria, el CCSMP promovió la creación de Juntas Provinciales, constituidas por políticos, sindicalistas y dirigentes de la resistencia. Los presidentes de cada una de las Juntas Provinciales integraron la Junta Nacional Promotora del Partido Justicialista (JNPPJ). A la vez que el proceso de reorganización partidaria también preveía la creación de juntas departamentales y Centros de Acción Justicialista, denominación otorgada a las nuevas unidades básicas. (Marcilese, 2015a).

1959 fue un año muy convulsionado. Se sucedieron varios atentados con explosivos y fue detenido el primer foco guerrillero; Uturuncos, en Tucumán. A fines de 1960, se produce un intento de golpe de Estado, el levantamiento de Iñíguez, y en ese contexto el PE también cierra locales del PJ y del PC (James 2010 [1988]). Además, actúan conjuntamente peronismo y comunismo a nivel sindical y partidario, unión alimentada por la opción por el voto en blanco y el contexto represivo (Tortti, 2010). A lo largo de 1959, se presenta la posibilidad para el PJ de participar en procesos electorales provinciales. En un principio, obtuvo la personería jurídica en varios distritos, pero, a medida que se fueron sucediendo dichos procesos, el panorama fue cambiando. En varias provincias, la justicia electoral

${ }^{118}$ Carta de Marta Curone a Alicia Eguren. Buenos Aires. 7 de junio de 1958. Archivo Marta Curone. Al final, Curone encontró un lugar en la estructura partidaria integrando la Comisión Inscriptora Femenina Nacional. Línea Dura $\mathrm{N}^{\circ}$ 41. Buenos Aires, 30 de septiembre de 1958, p. 1. Archivo Marta Curone. 
decidió retirarle la personería al PJ días previos a las elecciones argumentando que la conformación de las listas no cumplía con los requisitos establecidos o directamente, optó por no otorgársela. (Marcilese, 2015a). El peronismo llegó a las elecciones legislativas de marzo de 1960 sosteniendo el voto en blanco, en un contexto en que las oportunidades políticas para la participación por vía institucional se estaban cerrando.

En ese contexto, las fuentes nos devuelven la imagen de mujeres que estaban actuando en la campaña por el voto en blanco. Además de la labor de altas dirigentes como Marta Curone, que integraba el Consejo Coordinador o Lala Marín, ex integrante del Comando Táctico, que participan como oradoras en distintos actos políticos de la provincia de Buenos Aires, ${ }^{120}$ hay algunas evidencias sobre la labor a nivel de base, registrada en panfletos de los Centros de Acción Justicialista que convocaban a las mujeres a concurrir a reuniones y a participar de la campaña. ${ }^{121}$ En las elecciones del 27 de marzo el voto en blanco resultó mayoritario, por encima de la UCRP y de la UCRI. Luego de las elecciones, el gobierno decretó la aplicación del Plan Conintes. Varios dirigentes del Consejo Coordinador y de las juntas provinciales fueron detenidos. Marcilese (2014) señala que, en la provincia de Buenos Aires, la dirección de la Junta Promotora Provincial fue asumida por dos mujeres. Según el autor, recurrir a las mujeres y a dirigentes políticos que hasta entonces ocupaban lugares secundarios fue una forma de sortear la represión sobre el partido que, a partir de ese momento, se volvió ilegal. Las fuentes de la DIPBA ofrecen información sobre mujeres que fueron detenidas por organizar actos en ese contexto. ${ }^{122}$

En este contexto, nuevas problemáticas en lo que respecta a la participación femenina conviven con otras más antiguas. Entre estas últimas figura la representación en los organismos de conducción entre aquellas que habían emergido de actividades clandestinas durante el gobierno de la Revolución Libertadora y las mujeres cuya trayectoria provenía de su participación política en la etapa del gobierno peronista, especialmente el PPF. Entre los nuevos conflictos están los suscitados entre las mujeres que pretendían reorganizar la Rama Femenina y los sectores sindical y político masculinos.

En 1961, se renueva la composición del CCSPJ y el sindicalismo combativo obtiene lugares importantes en esa estructura. También, se concreta una reorganización interna de la

\footnotetext{
${ }^{119}$ DIPBA. Mesa “A”. Factor Político, Carpeta 37, Legajo 137.

${ }^{120}$ Periódico (s/n). Miramar. 7 de marzo de 1960. Archivo Marta Curone.

121 Panfleto del Centro Femenino de Acción Justicialista N ${ }^{\circ} 1$ de Moreno. DIPBA. Mesa "A". Factor Político. Por Localidad. Legajo 6. Moreno-Navarro.

122 DIPBA. Mesa “A”. Factor Político Por Localidad. Legajo 1. Quilmes-Saavedra.
} 
Rama Femenina en ese Consejo, en el que se constituyen doce secretarías integradas por mujeres provenientes del PPF, mujeres que habían participado de actividades clandestinas y de la Juventud Peronista. ${ }^{123}$ Ya, desde principios de 1960, se observan algunos acercamientos de este tipo, entre mujeres que provenían de esos distintos espacios de militancia, con el objetivo de lograr la integración. ${ }^{124}$ Sin embargo, resultó infructuoso lograr la unidad. En principio, hubo problemas con algunas mujeres provenientes de la JP, Beatriz Fortunato y Margarita Malinal. Cómo sus agrupaciones de origen no reconocieron al CCSPJ terminaron retirándose de la Comisión Femenina. ${ }^{125}$

Las disputas entre las nuevas dirigencias que emergieron de la "resistencia" y las mujeres con trayectoria previa no se limitaron a las altas esferas. En el interior del país y a nivel de los Centros de Acción Justicialista, la reorganización del partido también generó conflictos. Por ejemplo, en la localidad bonaerense de Azul se registran disputas al producirse las elecciones internas para renovar la comisión directiva de un CAJ, entre las mujeres que habían tenido actividad en las viejas unidades básicas y una dirigente surgida luego de 1955. Tras triunfar esta última -la prensa sostenía que, deshonestamente, llevando mujeres a votar a cambio de dinero-, las opositoras conformaron una nueva comisión directiva que fue acogida en un CAJ masculino donde funcionaría provisoriamente. La dirigente que había ganado la elección manifestó sus quejas ante la Junta Promotora Provincial argumentado que las mujeres del nuevo CAJ presentaban el problema de la doble afiliación, y que ello creaba una falacia sobre el éxito del proceso afiliatorio, porque crecían los centros pero se mantenía estable el número de afiliados. Un informe policial sobre los hechos, se manifestaba en favor de la vieja dirigente, cuestionando el nivel de capacitación de los sectores a los que aglutinaba la nueva líder. ${ }^{126}$

A comienzos de 1962 y en vísperas de las elecciones a realizarse en marzo de ese año donde se elegiría legisladores en todos los niveles y gobernador en la provincia de Buenos Aires, el peronismo adoptó una postura concurrencista concretando un pacto con la Unión Popular, partido neoperonista liderado por Atilio Bramuglia. Frondizi permitió la

\footnotetext{
${ }^{123}$ Aqui y Ahora. "Se concretó la organización interna de la Rama Femenina del peronismo". Buenos Aires. 20 de septiembre de 1961. Archivo Marta Curone.

${ }^{124}$ Por ejemplo, Marta Curone hace referencia a una reunión realizada en casa de Delia Parodi para lograr la integración entre mujeres que provenían del partido y mujeres de la resistencia. Archivo Marta Curone.

${ }^{125}$ Carta. 27 de septiembre de 1961. Archivo Marta Curone.

${ }^{126}$ En DIPBA. Mesa "A". Factor Político. Carpeta 37. Legajo 195 y Mesa "A". Factor político por localidad. Legajo 2. Ayacucho-Azul. La lógica de creación de los centros de acción justicialista consistía en elegir a las autoridades mediante votación en asamblea por el sistema de lista completa, y un vez logrado este cometido se solicitaba el reconocimiento a la Junta Promotora Provincial (Marcilese, 2014).
} 
participación electoral del peronismo motivado por los triunfos que la UCRI había alcanzado en las elecciones provinciales de Santa Fe, San Luis y Catamarca el año anterior. El armado de las listas se llevó a cabo a través de un Congreso del PJ. Curone señala que las mujeres de la "resistencia" no pudieron ser integradas en las listas partidarias porque no se habían preocupado por formar CAJ ni tampoco eran congresales, por lo que fueron pocas las que pudieron acceder a las postulaciones; pero tampoco esas mujeres se sintieron interesadas por integrar las listas y nadie reclamó por ellas. ${ }^{127}$ Lamentablemente, desconocemos si ese desinterés provenía de un desprecio por la política partidaria, de una desilusión surgida luego de un breve período de participación o falta de experiencia frente a otras dirigentes más avezadas políticamente. Después de este congreso, las disputas entre mujeres con trayectoria previa en el partido y mujeres surgidas de la lucha clandestina, fueron perdiendo vigencia y surgieron otras disputas.

Marcilese sostiene que el armado de las listas en el nivel provincial estuvo plagado de conflictos que se resolvieron en favor del sector sindical. De dieciocho bancas a la legislatura nacional, la mitad fueron asignadas a dirigentes de extracción gremial. Esto atentaba contra la representación por tercios y por lo tanto, afectaba la representación femenina (Marcilese, 2014). ${ }^{128}$ Curone, que participó del Congreso, cuestiona que la elección de las listas se haya hecho en forma conjunta sin respetar la diferenciación por ramas en tanto las mujeres se afiliaban y actuaban separadas de los varones. Sostenía que las candidatas deberían haber sido elegidas sólo por mujeres. ${ }^{129}$

En este contexto, las mujeres abocadas a la reorganización partidaria no sólo tuvieron conflictos con los sectores sindicalistas, sino también con los dirigentes políticos, que en algunos casos atentaron contra la autonomía de las mujeres en la reconstrucción de una rama política autónoma. Un ejemplo puede ser ilustrativo. Curone, integrante del CCSPJ y delegada en Misiones para la organización de la Junta Promotora Provincial, recibió una carta de Delia Parodi habilitándola para actuar como reorganizadora de la Rama Femenina.

\footnotetext{
${ }^{127}$ Curone, Marta. "La Secretaría de la Juventud del Consejo Coordinador". Al servicio de la causa. Recuperado de http://movimientoperonista.com/martacurone/alserviciodelacausa.html.

${ }^{128}$ A nivel seccional la conformación de las listas se hizo por votación en asamblea de representantes de los distritos comunales. Los sindicalistas ocuparon un porcentaje menos representativo que el que ocuparon en las listas a nivel nacional, pero Marcilese nada dice del sector femenino. Los beneficiarios habrían sido dirigentes políticos y funcionarios con trayectoria previa a 1955 (Marcilese, 2014).

129 Curone, Marta. "El 18 de marzo de 1962". Al servicio de la causa. Recuperado de http://movimientoperonista.com/martacurone/alserviciodelacausa.html.
} 
Pero la misiva había sido modificada por el mensajero que agregó párrafos para atribuirse a sí mismo ese poder y expulsó a algunas dirigentes con compromiso y trayectoria. ${ }^{130}$

El proceso de reorganización partidaria que tuvo lugar bajo el gobierno de Arturo Frondizi reveló conflictos entre aquellos militantes que habían surgido en las luchas de la resistencia contra el gobierno de la Revolución Libertadora y los dirigentes con trayectoria previa a 1955, algunos de los cuales habían abandonado la política, mientas que otros habían estado detenidos o exiliados. Además, en este contexto, resurgieron conflictos que habían aquejado al peronismo desde sus orígenes, entre políticos y sindicalistas y entre diferentes sectores del sindicalismo. Las mujeres no estuvieron al margen de estos problemas y en los intentos por reorganizar una estructura partidaria femenina debieron lidiar con ellos. A nivel nacional, quienes se beneficiaron de la reorganización partidaria fueron aquellas mujeres que contaban con trayectoria previa a 1955 en organizaciones políticas, en especial el PPF, en perjuicio de las que habían emergido como dirigentes en las actividades clandestinas durante los años de la Revolución libertadora, incluidas las integrantes de la nueva Juventud Peronista. ${ }^{131}$ Conjuntamente con estos conflictos intragenéricos, hubo disputas intergenéricas dadas por las amenazas lanzadas desde los sectores sindicales y político masculino contra la autonomía de la estructura partidaria femenina y contra la representación equitativa en las estructuras de conducción. Ello implicaba importantes cambios respecto de lo que había sido el funcionamiento del PPF durante el gobierno peronista y bajo la órbita de Evita, donde dicha estructura había mantenido una estricta autonomía respecto de la injerencia de las otras ramas, y donde si bien el tercio electoral no había sido respetado en la conformación de las listas, Evita se había encargado de que las mujeres fueran ubicadas en lugares donde tuvieran posibilidades de ser elegidas (Barry, 2009). Sin embargo, el viejo PPF había carecido de elecciones internas y, por primera vez, después de 1955, las mujeres se enfrentaban a procesos electivos cuyos mecanismos no las beneficiaban. Una unión entre viejas y nuevas dirigentes, tal vez, las habría posicionado mejor para competir con esos dos focos de poder masculino, el político y el sindical; sin embargo, sus identificaciones con los espacios de militancia de los cuales provenían (el Partido, la JP, las estructuras clandestinas de la resistencia), es decir, sus trayectorias políticas, impidieron esa alianza.

\footnotetext{
${ }^{130}$ Carta de Brunilda Robledo a Marta Curone. 18 de abril de 1959. Archivo Marta Curone.
} 


\section{4. "Giro a la izquierda" y redes interpartidarias de mujeres}

Las elecciones del 18 de marzo de 1962 dieron el triunfo al peronismo en varias provincias. En Buenos Aires, venció la fórmula Andrés Framini- Marcos Anglada, luego de que el peronismo amenazara con candidatear a Perón. El gobierno, presionado por los altos mandos militares, decidió anular las elecciones e intervenir las provincias donde había ganado el peronismo. Finalmente, el 29 de marzo se produjo el golpe militar que derrocó a Frondizi. Durante el gobierno de José María Guido, el decreto 217 (julio de 1962), prohibió las actividades de los partidos Peronista, Justicialista y Unión Popular en la provincia de Buenos Aires, y de cualquier organización que "en forma expresa o encubierta sostuviera su misma prédica o usara sus símbolos o emblemas”. El 24 de julio de 1962, volvió a estar en vigencia el decreto 4161 (Scoufalos, 2007).

En este contexto, se reestructuró el Consejo Coordinador y Supervisor del Peronismo: siete representantes de las 62 Organizaciones, siete de la CGT Auténtica, siete de la rama política masculina y siete de la femenina. Como puede observarse, la representación sindical abarcaba el cincuenta por ciento. Delia Parodi integró la Mesa Ejecutiva del Consejo junto a Raúl Matera, Miguel Gazzera y Juan Rachinni, y el resto de las mujeres se distribuyeron en secretarías. Todas las secretarías contaron con alguna presencia femenina a excepción de la gremial. La composición femenina de Consejo incluyó una mujer de la "resistencia", representada en la figura de Leonor Von Wernick, ${ }^{132}$ y de la JP, representada por Marta Curone y por Haydée Pesce. La mayor presencia la tuvieron las representantes del viejo PPF, entre quienes se encontraban, además de Delia Parodi, Nélida de Miguel (ex - diputada nacional 1954-55), Zelmira D’Estéfano y Elena Solari de Bruni. ${ }^{133}$ Con esa fórmula, las mujeres continuaron subrepresentadas en el CCSPJ. En esta renovación se contempló la creación de una comisión que atendería el problema de la reorganización de la juventud y de las mujeres; sin embargo, quienes provenían de los sectores juveniles manifestaron su disgusto ante la discriminación que sufrían en términos

\footnotetext{
${ }^{131}$ Algunas investigaciones sostienen que en las estructuras de nivel provincial se beneficiaron mujeres sin trayectoria previa (Marcilese, 2014), pero es un tema que requiere mayor profundización. Lo cierto es que en las estructuras de nivel nacional, esto es el CCSPJ predominaron las ex integrantes del PPF.

${ }^{132}$ Leonor Von Wernick fue la esposa de Julio Troxler, sobreviviente de la masacre de León Suárez en 1956.

${ }^{133}$ Curone, Marta. "El Consejo Coordinador y Supervisor del Movimiento Nacional Justicialista". $A l$ servicio de la causa. Op. Cit.
} 
etarios y de género. ${ }^{134}$ Se manifestaron quejas sobre las dificultades de las mujeres para hacer valer el tercio en el Consejo Coordinador y en la conformación de las listas partidarias, argumentando que las campañas de afiliación eran sostenidas económicamente por el sector político, pero que los sindicalistas hacían sentir su peso en la distribución de las candidaturas, tanto en cantidad como en calidad. Marta Curone sostiene que hubo reuniones en las que se discutieron esas cuestiones y, aunque las mujeres tuvieron apoyo de algunos políticos y representantes de la CGT Auténtica, no fue suficiente porque la rama política se hallaba dominada por la sindical. ${ }^{135}$

Por fuera del CCSPJ, hubo intentos paralelos de crear organizaciones femeninas. Una vez más encontramos a la díscola Elena Fernícola. Ella había organizado una estructura llamada Partido de la Justicia Social y había entregado a Matera un documento en nombre de una Junta Nacional Justicialista Femenina donde señalaba la emigración de muchas peronistas a otros partidos por falta de representación, y para enmendarlo, proponía realizar una asamblea general para que otros grupos femeninos fueran integrados al PJ y que las dirigentes del Consejo Coordinador fueran elegidas por las bases. Estas mujeres cuestionaban la reorganización verticalista que estaba adoptando el partido. Frente a esta actitud, las integrantes del CCSPJ cuestionaron la legitimidad de la organización creada por Fernícola y basaron la suya apelando al mandato de Perón que, según decían, contando con la representación del pueblo, las había elegido a ellas para el Consejo. ${ }^{136}$

El 18 de junio de 1962, tuvo lugar un plenario de la Rama Femenina en la sede del sindicato de Sanidad, con integrantes de las veinte Juntas Promotoras provinciales. El plenario estuvo presidido por los miembros de la Mesa Ejecutiva del Consejo Coordinador; lo que indica que hubo miembros masculinos, como Raúl Matera y Andrés Framini. Las representantes expusieron acerca de la situación en sus provincias. Lamentablemente, no tenemos acceso al discurso de las oradoras, con excepción del de Marta Curone, que se explayó sobre la subrepresentación femenina en las listas partidarias y problema que creía tendría solución con la capacitación de las mujeres. ${ }^{137}$ Este plenario es una muestra más de las dificultades que tenían las mujeres de la Rama Femenina para mantener su autonomía, no

\footnotetext{
${ }^{134}$ Una carta de Perón, procuraba calmar a las integrantes de la Comisión Femenina de la Juventud del Consejo Coordinador garantizándoles que iban a tener representación en dicho organismo; aunque integrarlo no implicaba que fuesen oídas. Carta de Perón. 20 de febrero de 1962. Archivo Marta Curone.

135135 Curone, Marta. "El Consejo Coordinador y Supervisor del Movimiento Nacional Justicialista". Al servicio de la causa. Op. Cit.

${ }^{136}$ Documento para la Secretaría Femenina de la Mesa Ejecutiva. 1962. Archivo Marta Curone.
} 
sólo por la presencia de varones de la Mesa Ejecutiva del Consejo sino también porque el contexto proscriptivo y la falta de recursos las obligaba a realizar las reuniones en la sede de un sindicato, los cuales contaban no sólo con poder político sino con abundantes recursos materiales, además de la habilitación para actuar en la legalidad. Evidencias de ello también se encuentran a nivel de las bases. ${ }^{138}$ Mientras tanto, la rama femenina continuó su proceso de reorganización intentado expandirse hacia el interior. La prensa menciona viajes de Delia Parodi y de otras integrantes del Consejo Coordinador a las provincias para concretar reuniones con ese objetivo. En esas reuniones, Parodi se vio obligada a explicar la necesidad de mantener ramas separadas por género, remarcando lo infructuosos que habían resultado los intentos de organización conjunta. ${ }^{139}$

En este contexto, el Partido Justicialista ensayó algunas estrategias que se presentaron novedosas respecto de su accionar en la etapa de los primeros gobiernos peronistas, y que consistieron en el estrechamiento de relaciones con otros partidos, en especial el Partido Comunista (PC), con quien el peronismo compartía la condición de proscripto, y que se enmarcó en lo que se dio en llamar "el giro a la izquierda" del peronismo. Este acercamiento a la izquierda se plasmó en la constitución de dos comisiones interpartidarias, una femenina y otra masculina. Durante todo el período y con énfasis tras la caída de Frondizi, el PC propuso la unión entre peronistas y comunistas a nivel sindical y de las bases -proceso que ya se estaba asentando con comandos barriales y fabriles para la acción conjunta - y a nivel partidario (Tortti, 2009). ${ }^{140}$

A mediados de julio de 1962, y a raíz de una convocatoria a las mujeres argentinas para reunirse a fin de luchar por sus derechos como madres, trabajadoras y ciudadanas, se concretaron reuniones entre mujeres de diferentes partidos políticos para la conformación de una Comisión Interpartidaria Femenina. La misma quedó constituida en una asamblea que tuvo lugar el 17 de julio, en el sindicato de molineros, en la cual participaron alrededor

${ }^{137}$ Correo de la Tarde. "En un local gremial efectuose un Plenario del Justicialismo". 19 de junio de 1962. Archivo Marta Curone.

${ }^{138}$ Por ejemplo, en Berisso encontramos a la agrupación 7 de mayo, que se reunía en el local del Sindicato de la Carne de esa ciudad. DIPBA. Mesa "A". Factor Político por Localidad. Legajo 2. Berisso a Bolívar.

139 Justicialista. 18 de diciembre de 1962. Archivo Marta Curone.

${ }^{140}$ Según Hernán Camarero, durante el período, el PC "declamaba la necesidad de una "hegemonía obrera" en el Frente Democrático Nacional, pero para que la burguesía nacional llevase hasta el fin ciertos objetivos, cumpliendo así el papel histórico asignado. En verdad, a la clase obrera y "su partido" lo que se le adjudicaba era el papel de consejeros y aliados críticos. Ello se expresó en el modo como el PC realizó el balance del período justicialista, se ubicó en el ciclo de la Revolución Libertadora, depositó su confianza en el frondizismo hacia 1957-1958, procesó luego la "traición” y el "abandono del programa" por parte de ese 
de 500 mujeres. La integraron las ramas, secretarías y comisiones femeninas del CCSPJ, del Partido Socialista de Vanguardia, del PC, de la Intransigencia Nacional de la UCRP y del Movimiento Popular Argentino. En ella se determinó apoyar la huelga de la CGT programada para el 1 y 2 de agosto, reclamar al Ministerio de Economía la rebaja de los precios de los productos de primera necesidad y exigir la liberación de los presos políticos y gremiales. ${ }^{141}$ Además, se resolvió solicitar una entrevista con la CGT para acordar las medidas a adoptar. ${ }^{142}$ La interpartidaria lanzó una declaración dirigida a las mujeres a fin de repudiar las políticas implementadas por el gobierno, donde se planteaban reclamos preferentemente de temática económico-social, y algunos de carácter político vinculados a las medidas proscriptivas y represivas desatadas por el gobierno contra los partidos y militantes, un hecho que según se sostenía, facilitaba la implementación de políticas económicas nocivas para los sectores populares. No hubo reclamos relativos a demandas específicamente femeninas, con la excepción de un punto que reparaba en las leyes de protección a la mujer trabajadora. En general, los reclamos eran de tipo económico y comprometían a la mujer como madre, en tanto que encargada del consumo hogareño. Las oradoras en la asamblea fueron Julia Constenla, del Partido Socialista de Vanguardia, que versó sobre la necesidad de defensa de los presos políticos y gremiales; María Salud de Ortiz, de la Intransigencia Nacional de la UCRP, que se explayó sobre la necesidad de unidad del pueblo; Susana Domínguez, del PC, que se refirió a las medidas económicas y la carestía de la vida y Gladys Lagándara, del Movimiento Popular Argentino, que disertó sobre la situación de la industria nacional. ${ }^{143}$ Las peronistas criticaron las limitaciones que encontraban las mujeres para desarrollarse en sus partidos de referencia, asimilando dicha exclusión con la que el gobierno efectuaba en relación a los partidos políticos. Se instaba a la participación en los piquetes y comités de huelga en el paro de la CGT que se realizaría 1 y 2 de agosto, un boicot al consumo y tareas de esclarecimiento para explicar causales de dichas acciones. ${ }^{144}$ Mientras esto ocurría en Buenos Aires, también en Córdoba tenía lugar la convocatoria de una asamblea femenina interpartidaria. ${ }^{145}$

gobierno y más tarde pautó los objetivos para los cuales se pensaba una fusión con las masas peronistas (en pleno "giro a la izquierda") y con los socialistas de izquierda en 1962" (Camarero, 2014).

${ }^{141}$ Nuestra Palabra. "Los sectores femeninos de cinco partidos unidos en su acción". Buenos Aires. 31 de julio de 1962, p. 3. Archivo Curone.

${ }_{142}$ Noticias Gráficas. "Justicialismo". 19 de julio de 1962. Archivo Curone.

${ }^{143}$ Nuestra Palabra. Buenos Aires. 17 de julio de 1962.

${ }^{144}$ Curone, Marta. "Unidas para derrotar a la dictadura". Discurso. 17 de julio de 1962. Archivo Marta Curone.

${ }^{145}$ Nuestra Palabra. Buenos Aires. 9 de octubre de 1962. 
El 10 de agosto de 1962, se realizó una movilización de mujeres para entregar al ministro de economía Álvaro Alsogaray un memorial, tal como se había decidido en la asamblea de la Comisión Interpartidaria. Como la policía impidió que la manifestación llegara al Ministerio de Economía, las mujeres se dirigieron al diario Democracia, a fin de que fuera publicado. Lo rubricaron las mismas organizaciones que subscribieron la declaración anterior, y se sumaron otros movimientos, como el Movimiento Social Progresista y el Movimiento de Liberación Nacional. Las integrantes de la delegación que encabezó la marcha fueron Marta Curone, por la rama femenina del CCSPJ, Elisa Rando, del Partido Socialista de Vanguardia, Fanny Edelman e Irene Rodríguez, de la Comisión Femenina del PC, Celia de la Serna de Guevara, madre del Che Guevara y miembro del Movimiento de Liberación Nacional, y Olga Scheimberg, del Movimiento Popular Argentino. El memorial tuvo la adhesión de varios sindicatos, de las 62 Organizaciones, del MUCS y de la UMA, entre otros. ${ }^{146}$ Las reivindicaciones fueron las mismas que las de la declaración, a lo que se sumó la consigna "entrega de la tierra al que la trabaja" y una detallada explicación de los problemas económicos que aquejaban a la sociedad y de las medidas tomadas por el gobierno que favorecían al capital extranjero.

Luego de esa manifestación, continuaron las acciones conjuntas entre mujeres de diferentes partidos políticos surgidas como respuesta a iniciativas lanzadas desde el PC. En la primera quincena de diciembre, la UMA realizó una reunión con delegadas de distintas provincias y, entre las invitadas especiales se contó con mujeres representantes de los partidos que conformaban la Interpartidaria. Los temas que se desarrollaron eran los que venían siendo tratados en las acciones interpartidarias femeninas: carestía de la vida, leyes represivas, solidaridad con Cuba y derechos de las trabajadoras, en relación a lo que se concretaba un reclamo específico para la anulación de los decretos que recientemente habían reimplantado el trabajo nocturno de mujeres y niños. ${ }^{147}$ El tratamiento de esta problemática tuvo su continuidad en una Mesa Redonda por los Derechos de la Mujer, llevada a cabo en diciembre de 1962 en el sindicato de barracas de lanas, de Avellaneda, auspiciada por la Asociación por los Derechos de la Mujer. El problema se había suscitado a raíz de la implementación de un decreto, el 8629, que dejaba sin efecto la prohibición establecida en la ley 11317 de 1924 que versa expresamente sobre trabajo de los niños, aunque ambiguamente incluía a las mujeres (Queirolo, 2010). El mismo tendría aplicación

${ }^{146}$ Nuestra Palabra. Buenos Aires. 21 de agosto de 1962.
${ }^{147}$ Nuestra Palabra. Buenos Aires. 2 de octubre de 1962. 
en el sur del conurbano bonaerense, ya que se había sancionado merced a un incendio en una usina eléctrica de Dock Sud, y ante la presión de la empresa de energía para flexibilizar las relaciones laborales. Intervinieron oradores como Alfredo Palacios, por el Partido Socialista Argentino y el Dr. Barrionuevo, por el peronismo. Además de mujeres representantes de distintos partidos políticos (PJ, PC, PSA de Vanguardia y Movimiento Popular Argentino), participaron algunas obreras. Sólo conocemos los discursos de los representantes peronistas, que apelaron a argumentos que reforzaban los roles de género tradicionales. Marta Curone reclamó la derogación del decreto argumentando que llevaba a la desintegración familiar. ${ }^{148}$ A su vez, Barrionuevo, en su carácter de médico, apeló a argumentos biologicistas, explicando los daños fisiológicos que el trabajo nocturno implicaba para las mujeres; incluyendo trastornos nerviosos causados por el temor de tener que trasladarse en zonas con poca luz y sin vigilancia. ${ }^{149}$

La última instancia importante de estas relaciones interpartidarias propiciadas por la izquierda fue el Congreso de Mujeres de América, realizado en La Habana en enero de 1963. La delegación argentina estuvo constituida por dieciséis mujeres -peronistas, comunistas, en especial de la UMA, e integrantes del PSA de Vanguardia-. Marta Curone aduce que en esa época eran comunes las invitaciones a los congresos y que generalmente los organizaban las comunistas, algo que también la literatura sobre el PC ha confirmado (Valobra, 2015). Curone consideraba que era importante asistir a esos eventos para proyectar al peronismo internacionalmente, pero que había mujeres que no iban debido a la oposición que podía generarse dentro del movimiento, y muchas otras, que si bien participaban, lo hacían a título individual. Ella asistió como representante de las 62 Organizaciones y del Consejo Coordinador, junto a una dirigente vinculada a Raúl Matera, Silvia Moyano del Barco. Si bien las peronistas tuvieron discrepancias, primero con las representantes del PS de Vanguardia y, luego, con el resto de la delegación argentina, en general, valoraron dicha participación de difundir el peronismo en el exterior; aunque

\footnotetext{
${ }^{148}$ Mesa Redonda organizada por la Asociación por los Derechos de la Mujer sobre Trabajo Nocturno de Mujeres y Niños. Doc. De la Mesa Ejecutiva del Consejo Coordinador y Supervisor del Movimiento Justicialista. Archivo Marta Curone.

${ }^{149}$ Esta retórica retomaba los argumentos que se habían dado en los debates a comienzos del siglo XX en relación con la necesidad de protección de la trabajadora en la que coincidieron intelectuales, políticos e integrantes del campo cultural. Todos se alarmaron por los daños físicos y morales que podía generar el trabajo, especialmente nocturno, aunque esas visiones convivieron con otras -las menos- que lo consideraron una oportunidad que el mercado brindaba para superar ciertas situaciones desfavorables económicamente y de autonomía femenina (Queirolo, 2010).
} 
siempre aclararon no adherir al comunismo. ${ }^{150}$ Ya en Argentina, Curone quiso exponer los resultados del Congreso, pero las autoridades del CCSPJ no se lo permitieron, argumentando la peligrosidad del contexto represivo y, pasado un tiempo, apenas pudo hacerlo en una reunión; evidencia de que el giro a la izquierda finalizaba. ${ }^{151}$ Miguel Gazzera, secretario de prensa del Consejo Coordinador, emitió un comunicado justificando el envío de una delegación al Congreso, aclarando que ello no ponía en duda la tercera posición del peronismo. ${ }^{152}$ Sin embargo, algunas mujeres cuestionaron esa participación, lo que le valió a Curone y a Moyano del Barco el calificativo de comunistas; no solamente por su participación en el Congreso sino también en la interpartidaria. ${ }^{153}$

Hacia comienzos de 1963, ya se observa un viraje en el peronismo. El diario la Nación informa que Perón está negociando un frente nacional con la UCRI, a pesar de que mantiene a Roberto García y a Marta Curone en la interpartidaria, donde predomina la izquierda. ${ }^{154}$ En ese contexto, Nuestra Palabra hace referencia a una mujer peronista, Blanca Vázquez, que había concurrido al Congreso Mundial por el Desarme Nuclear celebrado en Moscú en junio de 1962. Había asistido como representante de la UMA. Vázquez daba una opinión muy positiva sobre el régimen soviético. ${ }^{155}$ A principios de diciembre, esta mujer fue negada públicamente por el Consejo Coordinador en una nota publicada por el diario La Razón, donde se decía que no pertenecía a ese organismo. Frente a ello, Vázquez lo desmintió sosteniendo que en 1961 la conducción del Consejo la había nombrado secretaria de organización de la Rama Femenina y comparaba la decisión del Consejo Coordinador del expulsarla del movimiento como una actitud similar a la que habían tenido los "gorilas" de expulsar por decreto a los peronistas de la vida cívica. ${ }^{156}$

\footnotetext{
${ }^{150}$ En ese congreso, las peronistas defendieron el antecedente peronista frente a la originalidad que se le atribuía al proceso cubano y defendieron una vía pacífica, evolutiva, por medios electoralistas, de transformación social, a diferencia de la vía revolucionaria sostenida por Cuba. Curone, Marta. "El Primer Congreso de Mujeres de América. Cuba. 5 al 10 de enero de 1963". Al servicio de la causa (Capítulo sin publicar). Archivo Marta Curone.

${ }^{151}$ Carta de Marta Curone a Raúl Matera. 22 de mayo de 1963. Archivo Marta Curone.

${ }^{152}$ Comunicado de Miguel Gazzera. Buenos Aires. 10 de enero de 1963. Archivo Marta Curone.

${ }^{153}$ Hubo solicitudes para que aquellas mujeres que estaban en el Consejo Coordinador y que se sostenía, trabajaban para el comunismo, fueran expulsadas. Una de esas acusaciones estuvo firmada por una señora de apellido Peralta, que presidía un centro de acción justicialista de la circunscripción $9^{\mathrm{a}}$ de Capital Federal. Otra, fue Emilia C. de Martello. Carta de Marta Curone a Raúl Matera. Buenos Aires, 22 de mayo de 1963 y Careo. "Carta abierta de las bases peronistas a la Señora Marta Curone, firmada por la dirigente Emilia C. de Martello". 16 de octubre de 1963. Archivo Marta Curone.

${ }^{154}$ Curone Marta. Al Servicio de la Casa. (Capítulo inédito). Archivo Marta Curone.

${ }^{155}$ Nuestra Palabra. "Impresiones de la Unión Soviética de una dirigente peronista". Buenos Aires, 8 de noviembre de 1963.

${ }^{156}$ Nuestra Palabra. "Dirigente peronista Blanca Vázquez aclara su situación". Buenos Aires, 1 de enero de 1963, p. 6.
} 
Estas disputas evidencian un cambio en la posición del PJ que ajustó posiciones, negando ese endurecimiento de las posturas.

Esta etapa finaliza con las elecciones de julio de 1963, en que se consagra la candidatura a la presidencia de Arturo Illia por la UCRP, con un porcentaje muy bajo de votos, luego de que el peronismo se pronunciara por la abstención y el voto en blanco, no sin antes haber intentado la conformación de un frente popular con el Partido Conservador y la UCRI. ${ }^{157}$ Durante el gobierno de Arturo Illia, hubo algunas acciones interpartidarias, menos contundentes que las desarrolladas bajo el gobierno de Guido, ${ }^{158}$ y más aisladas; por lo que perdieron la fuerza que habían tenido durante el contexto del "giro a la izquierda".

Durante el breve gobierno de Guido, las mujeres vieron limitada su representación en los órganos de conducción del PJ frente al poderío que había adquirido el sindicalismo sobre la estructura política, sobre todo después de las elecciones del 18 de marzo de 1962. Sin embargo, encontraron nuevos espacios de participación a través de alianzas interpartidarias que las llevaron a tener una presencia más activa en la vía pública y en conflictos de carácter social. Sin embargo, esas relaciones no surgieron de iniciativas autónomas de las mujeres del PJ. En principio, fueron propiciadas por las comunistas y coincidieron con la política que el PJ implementó en ese momento, encuadrada en el giro a la izquierda. Cuando la conducción peronista decidió cambiar de estrategia, en un contexto que permitía una participación electoral y la alianza con partidos de tinte más conservador prometían más

\footnotetext{
${ }^{157}$ Previo a las elecciones de 1963, el peronismo integró un frente nacional que propiciaría la candidatura de Matera a la presidencia, pero el gobierno proscribió su candidatura. Entonces impulsó las candidaturas del conservador Vicente Solano Lima y del radical Carlos Silvestre Begnis, a través de un Frente Nacional y Popular. Matera, por su parte aceptó ser candidato por el Partido Demócrata Cristiano solicitando el apoyo del electorado peronista; lo que le valió la expulsión del Consejo Coordinador. Finalmente, el Poder Ejecutivo impugnó la candidatura de Matera, a la vez que se impugnaron once electores de presidente del Partido Conservador Frente a esta situación, Solano Lima, en acuerdo con las 62 Organizaciones, anunció la abstención del peronismo y el voto en blanco. (Galasso, 2005)

${ }^{158}$ En 1964, en un Congreso Nacional de Mujeres, participa una peronista, aunque sin identificar. Nuestra Palabra. "Congreso Nacional de Mujeres". Buenos Aires, 9 de diciembre de 1964, p. 3. En 1965, ante la invasión a Santo Domingo (SAM_0831), se organiza una Comisión de Madres de Soldados, que sesionó en asamblea frente al local de la Federación Gremial de Trabajadores de la Carne, porque no se les había permitido hacerlo en su interior bajo la amenaza de quitarle la personería gremial al sindicato. Una delegación de mujeres del PJ participó de la asamblea y gestionó que la Comisión pudiera entrevistar a los diputados justicialistas a fin de obtener su apoyo para entregar un petitorio al presidente reclamándole no enviar conscriptos. Por otro lado, en La Matanza, el Consejo Deliberante aprobó una resolución para acompañar a la Comisión de Madres. Nuestra Palabra decía que fue oportuna la nota de los concejales de Unión Popular, en su condición de mujeres, interpretando el sentimiento y decisión de las madres argentinas en defensa de nuestra soberanía y de los pueblos hermanos. También, hubo algunas intervenciones ante situaciones concretas, como la participación de mujeres del Consejo Coordinador del PJ y de la UMA en un barrio del conurbano bonaerense, para solidarizarse con vecinos desalojados. Nuestra Palabra. "Contra la intervención las madres van al Parlamento y a la Casa de Gobierno". Buenos Aires, 2 de junio de 1965, p. 1.
} 
posibilidades de evadir la proscripción, esas solidaridades femeninas se perdieron y las mujeres peronistas se volcaron a fortalecer su organización interna.

\section{Redes intrapartidarias en un nuevo contexto}

Tras las elecciones de julio de 1963, el Partido Justicialista quedó nuevamente desarticulado. Hacia fines de ese año, se iniciará un nuevo proceso reorganizativo. Para ello, Perón designó una Comisión Interventora, también llamada Cuadrunvirato, donde predominaban los sectores duros del sindicalismo, que se encargaría de la reestructuración del partido actuando independientemente del Consejo Coordinador que estaba copado por el vandorismo; aunque este último organismo se mantendría en sus funciones de conducción. El Cuadrunvirato estuvo compuesto por Andrés Framini, Rubén Sosa, Julio Antún e Hilda Pineda de Molins, ex senadora nacional en 1954.

Una orden de Perón, de agosto de 1963, aclaraba que el PJ era uno solo, pero que se mantendría la individualidad entre la rama masculina y femenina, debiendo, en lo que respecta a la composición de los cargos electivos, existir representación proporcional a los respectivos adherentes; es decir, que no se respetaría el tercio. ${ }^{159}$ El tercio consagraba una representación deficitaria para las mujeres porque, aunque nada impedía que la rama gremial pudiera presentar mujeres a cargos electivos, en la práctica, su conducción era completamente masculina; a diferencia de la rama política partidaria, que era masculina por definición. Pero, por otro lado, el tercio garantizaba a las mujeres un porcentaje fijo en la representación, además de un reconocimiento de tipo corporativo y no individual, como era el caso de la representación en función del número de afiliadas. Además, esta forma de elección generaba otros problemas; atentaba contra el funcionamiento autónomo que la rama femenina había tenido en épocas de Eva Perón. Algunas mujeres cuestionaron esta metodología de elección. Marta Curone escribió a Perón considerando que este tipo de elección conjunta y proporcional minaba la autonomía de las mujeres porque la conducción

\footnotetext{
${ }^{159}$ La orden establecía los mecanismos a seguir para la reorganización del Partido, el proceso afiliatorio y las elecciones internas. Como en los procesos anteriores, se continuaría con un modelo de organización verticalista, por el cual la Comisión Interventora Nacional debía formar comisiones interventoras provinciales que designarían delegados seccionales que llevarían a cabo la afiliación y el empadronamiento. Luego, se realizaría una elección interna en la que se elegirían cuerpos directivos provinciales y nacionales, incluidas las nuevas autoridades del Consejo Coordinador. Directivas de Perón, del 20 de agosto de 1963. DIPBA. Mesa “A”. Factor Político. Carpeta 37. Legajo 138.
} 
de la Rama Femenina no había sido elegida sólo por mujeres, como se hacía en el pasado. Consecuencia de ello era el quiebre de dicha rama entre las que apoyaban a Vandor y las que se alineaban con Framini. Además, al quedar atravesada por las disputas sindicales, se había perdido uno de los objetivos de su creación: factor de equilibrio frente a la presión de las otras ramas. ${ }^{160}$

Esas divisiones que atravesaron a la Rama Femenina estuvieron a la orden del día durante el gobierno de Illia. La designación de Hilda Pineda de Molins como integrante del Cuadrunvirato en representación de la rama femenina había sido resistida por Delia Parodi y Nélida de Miguel, vinculadas al vandorismo. A esta división, se sumó un tercer elemento: el Movimiento Revolucionario Peronista (MRP), que nucleaba a los sindicatos duros (FOTIA, navales, calzado, jaboneros y perfumistas) y a grupos de la juventud peronista (los sectores ligados a Gustavo Rearte y a la JP de Salta liderada por Armando Jaime) y militantes cercanos a Héctor Villalón (González Canosa, 2012). Entre fines de 1963 y comienzos de 1965, el tema central que atravesó al peronismo fue el "Operativo Retorno" y cómo debía realizarse. Mientras que el vandorismo proponía la vía pacífica y conciliadora, el MRP sostenía la realización de acciones violentas. Framini, por su parte, mantuvo relaciones con el MRP, aunque, según Daniel James (2010 [1988]), sin comprometerse demasiado, hasta terminar aceptando la vía pacífica, luego de que dicha organización fuera desautorizado por Perón, al ser detenido su impulsor, Héctor Villalón. Este hecho habría llevado al reemplazo del Cuadrunvirato por el Heptunvirato, una estructura que representaba mejor la relación de fuerzas en el peronismo, es decir, el predominio del vandorismo. Entre las mujeres que simpatizaron con el MRP estuvieron Nélida Matteo, Josefina Testa, Marta Curone, Leticia Merlo y Diana Pareja, pertenecientes a la circunscripción $18^{\circ}$ del PJ de Capital Federal. ${ }^{161}$

En este estado de cosas las mujeres llegaron muy debilitadas a las elecciones internas que se concretaron el 28 de junio de 1964. Las mismas estuvieron atravesadas por el conflicto entre fraministas y vandoristas, y consagraron el triunfo de estos últimos.

Luego del fracaso del Operativo Retorno, la justicia electoral retiró la personería jurídica al PJ, por lo que para las elecciones de marzo de 1965 el peronismo se presentó a través de una alianza con la Unión Popular, repitiendo la estrategia de 1962. Respecto de los resultados electorales, Marcilese (2013) aporta los datos referentes a la provincia de

\footnotetext{
${ }^{160}$ Carta de Marta Curone a Perón. Buenos Aires, 1 de marzo de 1964. Archivo Marta Curone.
} 
Buenos Aires, donde la Unión Popular obtuvo 13 diputaciones en la legislatura nacional, de las cuales sólo dos candidatas electas pertenecían al sector femenino, Nélida Riande y Rosaura Isla. En la legislatura provincial ingresó sólo una mujer a la cámara de diputados, Esther Serruya, sobre un total de 21 diputados, y 4 senadoras, sobre un total de 15 miembros. ${ }^{162}$ Este escaso porcentaje de mujeres se debía, según el autor, a que carecían de una estructura. A nivel municipal, de 420 concejalías, sólo 24 fueron ocupadas por ellas. Marcilese sostiene que en los distritos del Gran Buenos Aires fue más probable que se respetara el tercio, pero que en el interior esto no ocurrió y las mujeres fueron relegadas a ocupar lugares en las listas sin posibilidades de ser electas. Por otro lado, las postulaciones femeninas se dieron preferentemente para el cargo de consejeras escolares, un cargo en el que sus postulaciones superaron a las masculinas. $\mathrm{Y}$ hubo distritos que ni siquiera presentaron mujeres, a pesar de que ello estaba en la carta orgánica del PJ. Por un lado, para el autor, estos resultados son un logro, ya que en la elección de 1954 no había habido ninguna candidata a concejalías en la provincia de Buenos Aires, pero por otro lado, destaca el confinamiento de las mujeres a tareas que tradicionalmente eran atribuidas a su género (Marcilese, 2013).

El desarrollo de la labor parlamentaria de las mujeres peronistas que accedieron a bancas legislativas en ese contexto, es un tema que excede los objetivos de esta tesis. Sin embargo, no podemos dejar de pasar por alto las dificultades que tuvieron las mujeres para imponerse en la distribución de candidaturas en las listas partidarias. Ya hicimos referencia a que, en las elecciones de 1951, el tercio no había sido respetado, pero Eva Perón había logrado colocar a todas las candidatas en lugares donde tuvieran posibilidad de ser elegidas. En el nuevo contexto, las mujeres, sin el impulso de Evita y sin una estructura autónoma, se vieron relegadas ante la rama sindical y los sectores políticos, sobre todo en el interior del país. Por otro lado, la representación que lograron en puestos de conducción partidaria, que en algunos casos se acercó al tercio, fue meramente formal. La imposibilidad de construir una estructura y un foco de poder político suele adjudicarse a la incapacidad y falta de interés de las mujeres. Sin embargo, el recorrido que hemos realizado por los sucesivos intentos de reorganización partidaria durante 1955-1966, demuestra que intentos de ese tipo no faltaron, incluso se intentó crear estructuras paralelas a las encaradas desde las altas

161 Conquista. N $\mathrm{N}^{\mathrm{o}}$ 1. Buenos Aires, 20 de diciembre de 1963, p. 2. En esta época no hubo un cuestionamiento explícito a Delia Parodi, cuya autoridad todavía se consideraba legítima y era apelada como árbitro en las peleas internas. Carta de Marta Curone a Delia Parodi. Buenos Aires, 2 de febrero de 1964. 
esferas partidarias. Pero el contexto represivo, la falta de recursos y las internas con los sectores masculinos del peronismo afectaron esos intentos de reorganización autónoma, a lo que se sumó un problema que aquejaba a todo el peronismo: la dependencia de las credenciales otorgadas por Perón para legitimar cualquier intento reorganizativo, del cual las mujeres no quedaron exentas. Retomando a Judith Astelarra, "La complejidad de estas relaciones no permite explicar la desigualdad entre los sexos en las instituciones políticas, sin hacer referencias al sistema de dominación global que ejercen los varones. Se trata de una forma de dominio que utiliza mecanismos específicos que regulan las condiciones de la presencia o ausencia femenina en el mundo público. Como consecuencia, se produce la aceptación o el rechazo de las mujeres en las organizaciones, las instituciones y los cargos políticos" (Astelarra, 1987, p. 161).

El año 1965 estará signado por el fracaso del Operativo Retorno ocurrido en enero de ese año y los intentos de Perón por reorganizar el partido procurando contrarrestar la influencia de Augusto Vandor. Hacia fines de ese año, el conflicto con el vandorismo se hizo explícito y llevó a Perón a crear la Delegación del Comando Superior peronista, el 22 de diciembre, presidida por Isabel Martínez de Perón e integrada por representantes de las diversas ramas, incluidos los sectores juveniles y militares. A comienzos de 1965, se produjo la fractura en las 62 Organizaciones con la creación de las 62 Organizaciones de Pie Junto a Perón, encabezada por el secretario de la CGT, José Alonso, y 18 gremios antivandoristas que se encolumnaron detrás de Isabel. $^{163}$ Luego de las elecciones mendocinas de abril de 1966, que culminaron con las pretensiones electoralistas de Vandor, Delia Parodi y Carlos María Lascano fueron dados de baja en sus funciones partidarias.

En este contexto, la reorganización de las mujeres se vio afectada por la expulsión de Delia Parodi. Entre las críticas que las mujeres peronistas lanzaron a Delia figura la imposibilidad para darle una estructura orgánica a la rama femenina, luego de diez años de conducción; imposibilidad atribuida no tanto a su incapacidad política sino a una elección

${ }^{162}$ Ellas eran María Julia Echagüe, Beatriz Nélida Mesina, Irma Lay y Eufemia Musso (Marcilese, 2013).

${ }^{163163}$ En mayo de 1965 Isabel realizó un viaje a Paraguay donde recibió delegaciones argentinas. En representación de la rama femenina viajó una delegación presidida por Celina Rodríguez de Martínez Paiva Y luego, en octubre, viajó por el interior del país buscando apoyo de los caudillos provinciales para contrarrestar a Vandor. En ese marco, se realizaron cabildos abiertos en apoyo de Isabel. Crónica. "Resisten la Orden de Perón”. Buenos Aires, 1965.DIPBA. Mesa “A”. Factor Político. Carpeta 37. Legajo 137. 
deliberada producto de sus relaciones con el vandorismo. ${ }^{164}$ Es en este contexto, comenzará a gestarse la Federación de Mujeres Peronistas (FMP), que adoptará como criterio de legitimidad el deseo de Eva Perón por mantener la autonomía de la Rama Femenina.

En marzo de 1966, en el Plenario de Tucumán donde los sindicatos antivandoristas se reunieron para constituir las 62 Organizaciones de Pie Junto a Perón, un grupo de mujeres integró una secretaría femenina con el fin de nuclear al resto de las mujeres que asistirían al plenario acompañando a las delegaciones sindicales. Emergió, entonces, una declaración de principios redactada por las delegadas de Entre Ríos, y firmada por todas las delegaciones, donde se mencionaba el deseo de realizar un Congreso Nacional para reorganizar la Rama Femenina. ${ }^{165}$ Desde un primer momento, se esperó que el Congreso fuera convocado por Isabel Perón, pero no pudieron lograrlo como tampoco que Perón les otorgara una carta de acreditación. Algunas de las mujeres que propiciaron esa iniciativa integraban el Congreso Metropolitano del PJ porteño y decidieron convocar a un congreso femenino aunque no tuvieran el aval de los altos dirigentes peronistas. ${ }^{166}$

El Congreso Nacional de Mujeres tuvo lugar el 23 de julio de 1966, casi un mes después de producirse el golpe de Estado encabezado por Juan Carlos Onganía que proscribió la actividad política en su conjunto. Entre marzo y julio, se enviaron cartas al interior del país convocando el envío de delegadas. ${ }^{167}$ Aunque la iniciativa pudo concretarse, las dificultades estuvieron a la orden del día. El problema principal que se les presentaba a las mujeres para poder reunirse era la falta de dinero para costear el viaje y la estadía en Buenos Aires. También, surgieron intervenciones de los caudillos locales que se oponían a esta reorganización, y el hecho de que hubiera dirigentes mujeres de nivel local

\footnotetext{
${ }^{164}$ Según palabras de Marta Curone, Parodi, durante su actuación en la Mesa Ejecutiva del Consejo Coordinador, luego de la renuncia de Matera, fue apuntalada por mujeres, tanto de las estructuras partidarias anteriores a 1955 como de la Resistencia. Piensa que Parodi no quiso enfrentar a la rama gremial por no confiar en la capacidad de la fuerza (femenina) que tenía detrás. Al resignar posiciones, la estructura femenina se partió. Marta Curone. Al Servicio de la Causa (Capítulo sin editar) Archivo Marta Curone.

${ }^{165}$ La declaración manifiesta su alineamiento con Perón, su esposa Isabel y las 62 Organizaciones de Pie Junto a Perón. Entre las delegaciones firmantes figuran seis agrupaciones de Tucumán, siete de la provincia de Buenos Aires, y una de cada una de las siguientes ciudades: Paraná, Rosario, Santa Fe, Santiago del Estero, y las congresales del PJ porteño, Marina Herrera, Angélica Cardozo, Dora Alonso, Diana Pareja, Marta Curone. A ellas se sumaron Beatriz Brun, ex miembro de la Junta Capital del PJ y Adela Santos, de la Juventud Revolucionaria Peronista. Curone, Marta. "La Federación de Mujeres Peronistas". Al servicio de la Causa. Op. Cit.

${ }^{166}$ Carta a César Fáerman de Marta Curone, Dora Alonso, Diana Pareja, Zulema Correa, Angélica Cardoso y Celia Brunetti. Buenos Aires, 2 de febrero de 1966. Archivo Marta Curone.

${ }^{167}$ Hubo representantes de Mercedes (Buenos Aires), Comodoro Rivadavia, Corrientes, Rosario y Formosa. $\mathrm{Y}$ reciben adhesiones de otros lugares, en los que no pudieron enviar representantes. Marta Curone. "La Federación de Mujeres Peronistas". Al servicio de la Causa. Op. Cit.
} 
que respondían a ellos, actuaba contra la posibilidad de que las militantes de la zona participaran o adhirieran al Congreso. ${ }^{168} \mathrm{~A}$ todas estas cuestiones deben agregarse dificultades en las comunicaciones, con cartas que llegaban fuera de término; problemas personales basados principalmente en razones de salud, no sólo propios sino de familiares que, por tradición, recaía la atención en las mujeres. ${ }^{169}$ A pesar de estos inconvenientes, se realizó el Congreso y se constituyó la Federación de Mujeres Peronistas, con una declaración de principios y una estructura de organización.

Una vez conformada la FMP, se planteó cómo trasladar esa estructura a las provincias donde los caudillos locales no dejaban actuar a las mujeres que adherían a la Federación, había dificultades para moverse por falta de medios económicos, la incompatibilidad de la política con las obligaciones familiares, ${ }^{170}$ y además, otro factor concluyente: Perón había designado una nueva conducción en el Comando Táctico, un cuerpo de cinco integrantes de los cuales sólo uno era mujer, Mabel Di Leo, a quien se le había encomendado la reorganización de la Rama Femenina. ${ }^{171}$ Se dificultó a la FMP continuar con la organización ya que, paralelamente, se desarrollaba la que realizaba Di Leo con la colaboración de la ex diputada Ana Macri, conocedora de esas tareas por haber sido delegada censista hasta la conformación del PPF. La situación de la FMP se agravaba aún más ante la falta de un aval de Perón que las legitimara en las provincias, donde reinaba la desconfianza, favorecida por las oscilantes directivas del líder y las cartas apócrifas.

Para conseguir el apoyo en el interior, las dirigentes de la Federación escribían a las mujeres contactadas encargadas de la reorganización en sus distritos, con evidencias sobre las actividades que realizaba y, a la vez, también se las enviaban a Perón, ante quien también tenían que acreditar su accionar. ${ }^{172}$ Sin embargo, desde el interior manifestaban su

${ }^{168}$ Carta de Evangelista C. de la Cárcova e Irma N. de Ibarra, Santiago del Estero, 21 de noviembre de 1966. Carta de Silvia Bernasconi a Marta Curone, La Banda, Santiago del Estero, 17 de septiembre de 1966. Archivo Marta Curone.

${ }^{169}$ Carta de Concepción R. de Santillán. Tucumán, 20 de Julio de 1966. Carta de Arsenia J. Z. de Loto. Termas de Río Hondo, 19 de julio de 1966. Carta d Manuela Toranzo y Felisa F. de Suárez. 18 de junio de 1966. Carta de Matías Figueroa. Santa Rosa, 25 de junio de 1966. Carta de Rubén Clemente, Salta, 20 de junio de 1966. Carta de Silvia Furega, La Niña, 9 de Julio (Buenos Aires), 30 de agosto de 1966. Archivo Marta Curone. Y Curone, Marta. Curone, Marta. "La Federación de Mujeres Peronistas". Al servicio de la Causa. Op. Cit.

${ }^{170}$ Carta de Silvia G. B. M. de Bernasconi. Santiago del Estero, 7 de diciembre de 1966. Carta de Rosa. San Miguel de Tucumán. 14 de diciembre de 1966. Carta de Silvia Furega. La Niña. 9 de Julio (Buenos Aires).

${ }^{171}$ Sobre Mabel Di Leo ya hemos hecho referencia en el Capítulo I.

${ }^{172}$ Algunos ejemplos en Carta de la Mesa Ejecutiva de la FMP a la compañera Cáceres. Buenos Aires, 16 de noviembre de 1966; Carta de la Mesa Ejecutiva de la FMP a la compañera Silvia Bernasconi. Buenos Aires, 16 de noviembre de 1966; Carta de la Comisión Ejecutiva Nacional de la FMP a Perón, Buenos Aires, 29 de noviembre de 1966; Carta de Diana Pareja, Marta Curone, Dolly Pierini y Zulema Gómez a Perón, Buenos 
preocupación porque la falta de credenciales obstaculizaba la adhesión de otras mujeres y alegaban el desánimo y la desconfianza que reinaba allí entre las peronistas. Por ello pedían a las integrantes de la Comisión Ejecutiva de la FMP, residente en Capital Federal, que se acercaran a las provincias para ayudarlas a reorganizar. ${ }^{173}$

Los contactos para extender la Federación al interior del país no necesariamente se hacían con las mujeres de las capitales provinciales ni de las cabeceras de distrito, sino que empezaban con quienes las integrantes de la Comisión Ejecutiva tenían alguna relación previa; algunos de esos contactos provenían de la época del gobierno peronista, subdelegadas censistas o militantes de la UES. En algunos casos, se recurrió a dirigentes varones para contactar a las más activas de sus zonas y las convencieran de unirse a la FMP. Incluso, hubo algunos gremios que se solidarizaron con la Federación para esa tarea, como la FOTIA, en Tucumán, donde un cura era intermediario, Argentino Garbín, las consagró integrantes de una orden religiosa a fin de que actuaran con más facilidad, burlando la proscripción. ${ }^{174}$

Aunque la FMP nació ligada a las 62 Organizaciones de Pie Junto a Perón, esto no impidió diferencias con esa estructura sindical. Por ejemplo, en el contexto de la organización de los actos que se realizarían el 17 de octubre de 1966, las mujeres de la FMP de Santiago del Estero se molestaron porque su voz no era escuchada y sentían que sólo se las había convocado para recibir órdenes. A pesar de su cercanía con las 62 de Pie, el motivo que las reunía era conformar una estructura femenina autónoma, sobre todo respecto de la injerencia sindical, cualquiera fuera su tendencia. ${ }^{175}$ Aun así, en algunas

Aires, 3 de septiembre de 1966; Carta de Marta Curone a Jorge Antonio, Buenos Aires, 28 de agosto de 1966. Archivo Marta Curone.

${ }^{173}$ El problema era que las mujeres de la Comisión Ejecutiva tampoco disponían de medios para viajar; sólo lograron que Susana Valle, con quien tenían buena relación, pero no integraba FMP, hiciera un recorrido por algunas ciudades del interior para lograr adeptas. Otra forma de saldar el problema fue designar a la ex legisladora de Santa Fe, Yamile Nasif, como delegada y reorganizadora en el litoral y norte del país. Durante el breve tiempo que duró la FMP, actuó en solidaridad con Valle, integrante de una Comisión Pro Retorno. Entre esta estructura y la FMP, intercambiaban contactos: Valle invitaba a mujeres de la FMP a integrar la Comisión Pro Retorno y viceversa. Aunque en algunos lugares había resistencia a participar en esa Comisión, la figura de Valle, por ser la hija del general fusilado en junio de 1956, tenía más legitimidad que la de las mujeres que integraban la Mesa Ejecutiva de la FMP. Algunos ejemplos en Carta de Silvia de Bernasconi. La Banda. Santiago del Estero, 21 de agosto y 7 de diciembre de 1966; Carta de Rosa de Roveretti, San Miguel de Tucumán 14 de diciembre de 1966, Carta de la Comisión Ejecutiva Nacional de la FMP a Yamile Nasiff, Buenos Aires, 22 de diciembre de 1966. Archivo Marta Curone.

${ }^{174}$ Carta de Marta Curone, Diana Pareja y Dolly Pierini al Padre Argentino Garbín, Buenos Aires, 17 de octubre de 1966. Archivo Marta Curone.

${ }^{175}$ Carta de Silvia Bernasconi a Marta Curone, La Banda, Santiago del Estero, 20 de octubre de 1966. Archivo Marta Curone. 
oportunidades recibieron ayuda de sindicatos que colaboraron con contactos o donaciones para alguna tarea de carácter social. ${ }^{176}$ Pero, en general, no recibían ayuda económica.

La FMP no actuaba cabalmente como federación. A pesar de que había surgido de un congreso con presencia de delegaciones del interior, había cierta centralización puesto que las integrantes de la Comisión Ejecutiva actuaban en Capital Federal, y, en definitiva, eran las mujeres que la habían impulsado. Esto generó algunas críticas, que las mujeres de la Comisión Ejecutiva explicaban acudiendo a la falta de recursos que impedían un funcionamiento verdaderamente federal. ${ }^{177} \mathrm{El}$ hecho es que la Federación tenía una estructura verticalista, a pesar de que para la reorganización provincial y local estaba previsto que las dirigentes fueran elegidas en sus lugares de origen.

En noviembre de 1966, la conducción Di Leo-Macri les ofreció integrarse a la Rama Femenina que ellas estaban reorganizando, en una Secretaría que se ocuparía de las actividades de superficie, teniendo que informar todo a la conducción. Las dirigentes de la FMP respondieron que la Federación no podría integrarse a dicha secretaría porque actuaban en un estado de semiclandestinidad, mientras que la integración implicaría informar actividades que expondrían a sus integrantes ante las fuerzas represivas. Además, sostenían que estaban evaluando pasar a la clandestinidad completa porque, en cierto modo, el contexto lo exigía y porque esperaban que Perón les encomendara acciones de ese tipo. ${ }^{178}$ Susana Valle, que tenía una postura más flexible frente a la reorganización encarada por Di Leo y Macri, también hizo sus reclamos. Les solicitó que no interfirieran en la labor de Sara Bugallo para la Comisión Pro Retorno en San Martín. Otros grupos de mujeres que actuaban de forma paralela, como el de Haydée Pesce y Flora Pestaña, que concurrieron a la reunión donde se discutieron estos temas, se mantuvieron expectantes. ${ }^{179}$ Estos ejemplos evidencian las iniciativas paralelas que se ensayaban para lograr la reorganización partidaria femenina y que la iniciativa oficialista encarada por Di Leo y Macri tuvo que negociar con esos proyectos previos.

\footnotetext{
${ }^{176}$ Por ejemplo, en un bautismo colectivo realizado en Monte Chingolo recibieron colaboraciones de ATE, Farmacia, Mecánicos, Aceiteros, Hielo, Calzado, Jaboneros, Navales y Perfumistas. Carta de la Mesa Ejecutiva de la FMP a Perón, Buenos Aires, 3 de septiembre de 1966. Archivo Marta Curone.

${ }^{177}$ Carta de Marta Curone a Blanca P. de Marcebo (de Formosa), Buenos Aires, 27 de julio de 1966. Archivo Marta Curone.

${ }^{178}$ Informe de la FMP a Mabel Di Leo, Buenos Aires, 25 de noviembre de 1966. Informe de la Comisión Ampliada de la FMP, Buenos Aires, 18 de diciembre de 1966. Archivo Marta Curone.

${ }^{179}$ Carta a Perón de la Comisión Ejecutiva Nacional de la FMP, Buenos Aires, 29 de noviembre de 1966. Archivo Marta Curone.
} 
Con este estado de cosas, a la FMP le resultó muy difícil continuar porque Di Leo y Macri podían exhibir una credencial que sus promotoras no tenían. A comienzos de 1967, Marta Curone renunció a la FMP, obedeciendo un mensaje de Perón que circulaba en una cinta donde pedía que todos los grupos que integraban el peronismo se deshicieran y se integraran a la Conducción Nacional. Mientras que Marta interpretó que esto incluía a la FMP, Dolly Pierini y Diana Pareja, opinaron lo contrario. Marta se integró a la conducción nacional de la Rama Femenina en carácter individual, luego de renunciar a la FMP, y el FMP terminó integrándose en bloque como parte de la secretaría antes mencionada. ${ }^{180}$

El nombre de Federación que adoptó el último intento analizado, respondía a la idea de una estructura más democrática y más equitativa entre Buenos Aires y las provincias, pero tanto en la práctica como en su diseño institucional prevalecían signos verticalistas; en gran medida por falta de recursos para funcionar como una verdadera federación y obligada por el peso que de por sí ejercía Buenos Aires como capital del país, y en tanto que era en esa ciudad a donde llegaban las primeras noticias provenientes de Madrid. También, la herencia ejercida por prácticas pasadas, pues el PPF había funcionado de esa manera. Sin embargo, la estructura verticalista que había adoptado durante los primeros gobiernos peronistas se mostró obsoleta en este nuevo contexto donde, además de las restricciones que imponía el contexto institucional, se sumaba el hecho de enfrentar una reorganización como partido de oposición, sin recursos y con la ausencia de una figura carismática como había sido Eva Perón, ya percibida desde su muerte en 1952.

Pese a los perjuicios que las disputas gremiales ejercieron sobre la organización y la unidad femeninas, en el caso de la FMP sirvieron para dar impulsar y generar los contactos para creación de la misma; recordemos que surgió ligada a las 62 Organizaciones de Pie Junto a Perón. En esta última etapa, a diferencia de la época del gobierno de Guido, donde las peronistas entablaron redes con las dirigentes de otros partidos -en especial de la izquierda, con quienes compartían la proscripción - volcaron su mirada al interior del país intentando aglutinar a las mujeres dispersas que ya tenían trayectoria previa en el peronismo. Pese a los intentos de las peronistas por organizarse y crear estructuras diferenciadas por género, sus estrategias siempre estuvieron encuadradas en la política general impulsada por el propio Perón o por los organismos de conducción del peronismo $\mathrm{y}$, cuando chocaron con esas medidas, los resultados nos las favorecieron.

${ }^{180}$ Curone, Marta. "La Federación de Mujeres Peronistas". Al Servicio de la Causa. Op. Cit. 


\section{Cambios y continuidades en la participación político-partidaria}

Como hemos señalado en páginas anteriores, los intentos de reactivación de la estructura partidaria entre los peronistas estuvieron vinculados a motivos estratégicos en determinadas coyunturas políticas, a una interpretación del contexto propia de los primeros años de la Resistencia peronista que hacía creer que el retorno de Perón y el acceso al poder estaban próximos y que era posible la vuelta a la situación institucional que había primado antes de 1955. También, porque la socialización política de muchos militantes y dirigentes durante los años del gobierno peronista había transcurrido por las estructuras partidarias en sus diferentes niveles. Luego del golpe de Estado, se reactualizaron viejas prácticas, pero las mismas sufrieron modificaciones motivadas, en gran parte, por las condiciones que imponía el contexto.

A partir de la reorganización partidaria de 1959, las unidades básicas pasaron a llamarse Centros de Acción Justicialista, sin embargo, en la jerga cotidiana continuaron siendo nombradas a la vieja usanza, como se desprende de varias entrevistas. Al cambio de nombre, se sumó cierta flexibilización en las condiciones necesarias para su apertura, como por ejemplo que el acta de afiliados podía realizarse en un cuaderno rayado o que a falta de una máquina de escribir pudiera efectuarse a mano (Marcilese, 2014). También hubo continuidades, como la vinculación de la unidad básica con el territorio, puesto que la afiliación era según domicilio. Ladeuix, Melon Pirro y Quiroga (2014) han mencionado otros elementos de continuidad que exceden el espacio de las unidades básicas y atañen al partido como un todo. Nos referimos a la figura del interventor, el tribunal de disciplina y el "manual de negociación política" - en referencia a formas de resolver los conflictos que pasaban más por la negociación y el consenso que por los mecanismos formales, tales como la realización de elecciones internas-.

El principal elemento de continuidad en lo que atañe a la participación femenina es el tema que hemos venido desarrollando en este capítulo: la conformación de una estructura partidaria autónoma diferenciada en función del género de sus integrantes. Si bien los intentos fueron poco exitosos por los motivos que hemos analizado, lo cierto es que la idea de que las mujeres debían organizarse en una estructura política separada nunca perdió vigencia a pesar de que, luego del golpe de Estado, surgieron instancias de participación clandestina que habían agrupado a militantes de uno y otro género. 
Los intentos de crear ese tipo de estructuras desde los organismos de conducción nacionales preveían una organización de tipo verticalista como la que había predominado en tiempos de Eva Perón. Sin embargo, aquí cabe hacer algunas aclaraciones. En principio, esos intentos fueron infructuosos porque se chocaron con la realidad política que primaba en las provincias; como vimos, interferencias de los caudillos locales sobre la organización femenina, falta de recursos, incompatibilidades entre las tareas domésticas y las exigencias de la actividad política. A veces, las unidades básicas, pese a integrar el partido y a estar reconocidas por los organismos provinciales, no reconocieran a esos organismos y mucho menos a lo nacionales. Nicolás Quiroga (2014) ha desarrollado el concepto de "vida partidaria a ras del suelo" para referirse al desarrollo de actividades partidarias no sólo en estructuras informales como aquellas a las que hace referencia Levitsky, sino también en espacios formales y propiamente partidarios como fue el de las unidades básicas. Sostiene que dicha vida partidaria a ras de suelo fue desarrollada frecuentemente, haciendo caso omiso de los organismos de conducción nacional o provincial. Entre las personas entrevistadas, encontramos ejemplo de militantes de Rosario que tuvieron una intensa actividad en unidades básicas barriales, cuya trayectoria en ese tipo de estructuras se remonta a lo comienzos del gobierno peronista, donde participaron desde su niñez en el marco de relaciones barriales y familiares. En 1959, volvieron a fundar unidades básicas, pero las directivas sobre las actividades a seguir y la información sobre lo acontecido en Buenos Aires o en Madrid les llegaban a través de la CGT local y de los sindicatos. ${ }^{181}$ En segundo lugar, esos intentos verticalistas de reorganización partidaria se vieron frustrados ante la falta de legitimidad de las dirigentes que pretendían conducir esa reorganización. Nadie tenía el carisma de Evita y sin el aval de Perón resultaba difícil convencer a las mujeres que se sumaran a procesos encarados desde Buenos Aires. Todo ello se profundizaba por los problemas en las comunicaciones y la escasez de recursos de un partido que no contaba ya con el apoyo del Estado como en el pasado. Muchas de estas cuestiones que señalamos para la organización femenina también pesaron en la masculina.

Un tópico ligado a la actividad política femenina y la lectura de esa dinámica a ras del suelo en el peronismo y que logró trascender el punto de inflexión que implicó el golpe de Estado de 1955, fue el desarrollo de actividades de carácter social. Para los años posteriores al golpe de Estado de 1955, existe abundante evidencia de que las mujeres peronistas

${ }^{181}$ Di Marco, Chiche; Martínez, María; Rivas Natividad y Cánepa, Oscar; Entrevista de la autora, Rosario, 16 de octubre de 2012. 
continuaron desarrollando tareas de carácter social, tanto en los niveles de conducción como de base. Así, el Consejo Coordinador contaba con una Fundación de Ayuda Social femenina, creada en octubre de 1959 que debía financiarse con el aporte de sus integrantes, que eran 63, a lo que se sumarían donaciones, rifas, venta de bonos, etc. ${ }^{182}$ Observamos a esta comisión en 1962, prestando ayuda asistencial -donativos y dinero para cubrir los gastos de internación- a un niño que había sido herido por la policía en el conflicto suscitado en las inmediaciones del Congreso de la Nación al impedirse que los diputados peronistas electos en marzo de 1962 ocuparan sus bancas. ${ }^{183}$ También, en un desalojo en Villa Lugano, se acercaron a colaborar junto con mujeres de la UMA, en un estrechamiento de relaciones entre en el PC y el PJ. ${ }^{184}$

Asimismo, se registran iniciativas locales y descentralizadas. Por ejemplo, el comando femenino $n^{0} 1$ Evita Inmortal, de Bahía Blanca, en diciembre de 1959, juntaba donaciones para distribuir durante las fiestas -ropa, juguetes y comestibles-, pero no aceptaba dinero en efectivo. ${ }^{185}$ En Rosario, en 1958-1959, encontramos a una agrupación de nombre Cruzada Evita Capitana, cuya dirigente era Manuela Rodríguez, que estaba organizándose para realizar un festival a fin de recaudar fondos para adquirir ropa y juguetes y montar una feria en el barrio Villa Manuelita de esa ciudad, para hacer frente al costo de la vida. ${ }^{186}$ Según Línea Dura, dicha organización pertenecía al Movimiento Peronista Femenino, lo que nos hace pensar que tenía alguna vinculación con los intentos de reorganización partidaria que se estaban realizando en esos años promovidos John William Cooke, con quien el periódico estaba alineado, o que al menos, reconocía esa línea de conducción. ${ }^{187}$ En 1960 , un panfleto del Centro de Acción Justicialista $\mathrm{n}^{\mathrm{0}} 1$ de Moreno, convocaba a las mujeres a participar, a organizarse, a la vez que proponía crear un comisión de ayuda y asistencia social. ${ }^{188} \mathrm{Y}$ en 1965 , en el local del PJ de Ensenada, se reúnen seis mujeres para tratar el tema de la ayuda a familias necesitadas. ${ }^{189}$ De las fuentes orales, también se desprende información de este tipo. Una entrevistada de Rosario relata las actividades en la unidad

\footnotetext{
182 "Reglamento de la Fundación de Ayuda Social”, Octubre de 1959. Archivo Marta Curone.

${ }^{183}$ Descartes. "Una víctima de la 'democracia' imperante fue socorrida por el Consejo Coordinador". 5 de junio de 1962. Archivo Marta Curone.

${ }^{184}$ La Razón. "Por una amenaza llora un barrio". Buenos Aires, octubre de 1962. Archivo Marta Curone.

${ }^{185}$ DIPBA. Mesa “A”. Factor Político por Localidad. Legajo 9. Bahía Blanca.

${ }^{186}$ Informe de Inteligencia. SIDE. Fondo CEN.

${ }^{187}$ Línea Dura, No 40. Buenos Aires, 23 de noviembre de 1958, p.3.

${ }^{188}$ DIPBA. Mesa "A”. Factor Político. Por Localidad. Legajo 6. Moreno-Navarro.

${ }^{189}$ DIPBA. Mesa “A”. Factor Político. Por Localidad. Legajo 5. Ensenada.
} 
básica en la que ella militaba durante el período bajo estudio: atendía un médico, había una biblioteca y se le daba merienda y apoyo escolar a niños y niñas del barrio. ${ }^{190}$

En algunos casos, las agrupaciones femeninas dedicadas a ese tipo de actividades adoptaron nombres con un tinte religioso, como lo demuestra el nombre de "Cruzada". En Bahía Blanca, actuaban las Misioneras Eva Perón. ${ }^{191}$ Y a su vez, se utilizaban denominaciones ligadas a la figura de Eva Perón, o directamente se hacía uso de su nombre. Por ejemplo, la Agrupación femenina 7 de mayo, de Berisso, hacía referencia a la fecha de nacimiento de ex Primera Dama. Esos nombres con connotaciones religiosas parecen recuperar una vieja tradición de la participación política femenina en el peronismo, ya que Evita lanzó la campaña por la ley de voto femenino apelando a ese tipo de denominaciones, como si se tratara de un cruzada religiosa (Barry, 2009).

El desarrollo de actividades sociales también implicó el intento de recrear estructuras que no eran específicamente políticas, como la Fundación Eva Perón. Este emprendimiento, que tuvo lugar en 1958, estuvo ligado al Comando Táctico y tuvo como cabeza a Susana Valle, cuya militancia se desarrollaba en uno de los grupos de Juventud Peronista creado luego del golpe. Desde el periódico Línea Dura se convocaba a que en cada fábrica y barrio funcionara una célula mínima de la Fundación que debía recoger donaciones y contactarse con la secretaría general que se ubicaba provisoriamente en el departamento de Cooke, en la calle Santa Fe de Capital Federal, donde funcionaba el Comando Táctico. Desde el periódico, se convocaba en especial a las enfermeras. La Fundación, que sería reabierta con el nombre de Fundación Popular Evita, había nacido tras producirse inundaciones en la ribera del Río de La Plata. Según Línea Dura, la gente había llevado donaciones espontáneamente a Cooke. El mismo periódico emitía cupones para financiar la institución. ${ }^{192}$ Sin embargo, en la práctica, resultó difícil remontar este proyecto, que fue abandonado prontamente. ${ }^{193}$

\footnotetext{
${ }^{190}$ Di Marco, Chiche. Entrevista de la autora. Rosario, 11 de noviembre de 2014.

191 DIPBA. Mesa Referencia. Legajo 10078. Resistencia peronista y plan CONINTES (1956-1975), Colección $\mathrm{N}^{\circ} 13$ del Área Centro de Documentación y Archivo, Comisión Provincial por la Memoria, La Plata

Informes del 8 de mayo de 1961 y del 26 de julio de 1963. Y Archivo personal de John William Cooke. CeDInCI.

${ }^{192}$ Línea Dura $\mathrm{N}^{\mathrm{o}}$ 33. Buenos Aires, 7 de agosto de 1958, pp. 1 y 3 y Línea Dura $\mathrm{N}^{\circ} 34$. Buenos Aires, 14 de agosto de 1958, p.2.

${ }^{193}$ Ninín, Enrique. Entrevista de la autora. Buenos Aires, 31 de agosto de 2012.
} 
Mientras que Bianchi y Sanchís, al igual que Mariano Plotkin, han hecho hincapié en el carácter social de la actividad desplegada en las unidades básicas, negando su carácter político, Barry ha señalado la condición discursiva de tal concepción al sostener que si bien la tarea social ocupaba un lugar importante entre las actividades desarrolladas en las unidades básicas, además de otorgarle un carácter distintivo a las mismas, el fin último de dichas estructuras era la afiliación y el proselitismo, es decir, tareas eminentemente políticas (Sanchís y Bianchi, 1998; Barry, 2009; Plotkin, 1994). Durante los años de la Resistencia, las mujeres parecen reproducir ese tipo de tareas como si se tratara de actividades inherentes a la condición femenina. No hemos encontrado cuestionamientos referentes a esta conjunción entre actividad política femenina y asistencia social. Eran las formas que las mujeres habían aprendido de hacer política no sólo en el peronismo, sino en muchos otros partidos y organizaciones sociales. Además, se instaló como una costumbre porque ni siquiera fue cuestionado por las mujeres que ingresaron a la política en los años posteriores al golpe de Estado. Por otro lado, no podemos decir que se tratara de una estrategia para atraer mujeres al peronismo, porque durante esta etapa, la afiliación y las convocatorias a participar de las unidades básicas estaban más dirigidas a quienes ya estaban politizadas y se habían dispersado luego del golpe o habían dejado la militancia. En ese sentido, no parece redundante señalar junto con Judith Astelarra, que "La organización social que se deriva de la existencia de la división sexual del trabajo, es el sistema de género que se refiere a los procesos y factores que regulan y organizan a la sociedad de modo que ambos sexos sean, actúen y se consideren diferentes, al mismo tiempo que determina cuáles áreas sociales serán de competencia de uno y cuáles del otro. La política forma parte del sistema de género; sus actividades y sus organizaciones no están al margen de la división sexual del trabajo, que determina las formas de participación diferenciada que tendrán mujeres y varones" (Astelarra, 1987).

Claro que la reactualización de esta actividad en el nuevo contexto implicó algunos cambios. Según Barry, durante los primeros gobiernos peronistas, las unidades básicas femeninas no realizaban actividad social directamente, sino que canalizaban los pedidos que remitían a la Fundación Eva Perón; aunque brindaban servicios, prestados por vecinos o afiliadas, como peluquería, pedicuría, atención médica y de enfermería, guardería, apoyo escolar etc. En el nuevo contexto, el desarrollo de actividades de asistencia social, sobre todo el reparto de ropa, juguetes y comida, necesitó de la colaboración del sindicalismo. Esther Serruya, que había sido delegada censista en tiempos de Eva Perón, sostiene que 
durante los años posteriores al golpe se mantuvo militando en una unidad básica que había creado con su marido, que era dirigente del sindicato del calzado, en su casa del barrio de Haedo, pero que mantuvo actividad de tipo social con sus antiguas compañeras del PPF, obteniendo ayuda de los sectores sindicales. ${ }^{194}$ Es interesante observar cómo opera el discurso oficial sobre la interpretación que esta militante tiene de su propia actividad política, porque la actividad en la unidad básica es entendida como netamente política. La entrevistada reconoce que es allí donde radica su fuente de poder. Mientras que su actividad con las dirigentes del PPF es entendida como social y no como política. Chiche Di Marco rememora que, desde el sindicato del calzado de Rosario, les enviaban cajas con zapatos para que pudieran ser reparados en la unidad básica y luego repartidos. Además, se arreglaba ropa. ${ }^{195}$ En un bautismo colectivo realizado por la FMP en Lanús, también hubo donaciones de sectores sindicales. ${ }^{196}$ Di Leo, responsable de una unidad básica en Munro, comenta que hacían donaciones a hospitales, maternidades, y que ello no era incompatible con el desarrollo de acciones que se consideraban subversivas.

Además, este tipo de tareas de carácter social se amplió en un nuevo contexto atravesado por represión y proscripciones. Por un lado, se sumaron nuevas funciones como la defensa de los presos políticos. Ya en la reestructuración que sufrió el Consejo Coordinador luego de las elecciones de marzo de 1962, se contempló la creación de una subcomisión para ese fin. ${ }^{197}$ En junio de 1965, también se constituyó una Comisión de Solidaridad con los Presos Políticos y Gremiales, perteneciente a la rama femenina. La dirección de la comisión quedó integrada por Delia Parodi y las cuatro legisladoras nacionales ingresantes ese año: Nélida Calviño, Nélida Sarmiento, Teresa Riande y Rosaura Isla, y dos concejalas metropolitanas: María Esther Vargas y Eva Barrios. Participaron delegadas de todas las circunscripciones de Capital Federal para constituir subcomisiones de trabajo. Se establecieron cinco puntos básicos: alimentos, medicinas, ropas, libros y visitas especiales. Además proporcionaron asistencia jurídica y gestionaron traslado de los detenidos a pabellones especiales de presos políticos. También, solicitaron el pase de la cárcel de Devoto a la de Caseros dadas las denuncias por malos tratos en la primera. ${ }^{198} \mathrm{La}$

\footnotetext{
${ }^{194}$ Serruya, Esther. Entrevista de la autora. Castelar, 1 de noviembre de 2012.

${ }^{195}$ Di Marco, Chiche. Entrevista de la autora. Rosario, 11 de noviembre de 2014.

${ }^{196}$ Así. "Un bautismo con Perón y Ponchos". Buenos Aires, 1 de septiembre de 1966.

${ }^{197}$ La Razón. "El Consejo peronista quedó reestructurado y se reunirá mañana". Buenos Aires, 25 de mayo de 1962. Archivo Marta Curone.

${ }^{198}$ Crónica. "Movimiento pro ayuda a los presos políticos peronistas". Buenos Aires, 30 de junio de 1965. DIPBA. Mesa "A". Factor Político. Carpeta 37. Legajo 135.
} 
FMP por su parte, constituyó una comisión de ayuda a los presos políticos y gremiales, que tuvo su actuación inmediata el 17 de octubre de 1966 para asistir a los presos políticos, entre ellos Susana Valle que colaboraba con la Federación; detenidos a raíz de las manifestaciones conmemorativas de esa fecha clave en el calendario peronista. ${ }^{199}$ A ello hay que sumar, a nivel de las bases peronistas, cómo las mujeres se organizaban para llevar alimento a los presos políticos y alojar a sus familiares, tema al que hicimos mención en el capítulo I. $^{200}$

Las unidades básicas siguieron funcionando de modo intermitente, por el contexto de proscripción en el que se desarrollaban y la necesidad de la ayuda prestada por los sindicatos para continuar con el desarrollo de las tareas de carácter social revela los problemas de financiamiento en el nuevo contexto; no solo para el desarrollo de ese tipo de tareas, sino para el funcionamiento cotidiano y para costear las campañas proselitistas, algo que también es extensivo a las unidades básicas masculinas y mixtas. Durante los primeros gobiernos peronistas, Barry sostiene que las delegadas y algunas subdelegadas continuaron cobrando el sueldo que habían percibido por trabajar previamente en un puesto de alguna repartición estatal, a la cual siguieron respondiendo como empleadas. Debían financiar los gastos que requería la implementación de las unidades básicas y el funcionamiento de las actividades partidarias con su salario. Aquellas subdelegadas que no eran empleadas estatales recibían 50 pesos mensuales para gastos de la unidad básica. El partido enviaba el mobiliario para el funcionamiento y podían recibir ayuda de los municipios o autoridades provinciales. Sin embargo, tenían prohibido pedir dinero en donación a los negocios particulares o empresas. Durante los años posteriores al golpe, son las propias militantes y dirigentes quienes deben conseguir ese dinero. Para ello, se implementaron una multiplicidad de actividades: rifas, colectas y festivales o comidas, algunos ejemplos de ello ya enunciados antes. Otro ejemplo lo hallamos en el boletín Conquista, un órgano partidario de un grupo de mujeres de la Rama Femenina, que retrata una cena de camaradería organizada para recaudar fondos, aunque no se había logrado excedente monetario. ${ }^{201}$

La prohibición de recurrir a donaciones de los sectores privados no siempre fue mantenida. En el caso de la Cruzada Evita Capitana a la que hicimos referencia, negaban las

\footnotetext{
${ }^{199}$ Volantes repartidos por la FMP para pedir la libertad de Susana Valle. Archivo Marta Curone.

${ }^{200}$ Di Marco, Chiche; Martínez, María; Rivas, Natividad y Cánepa, Oscar. Entrevista de la autora. Rosario, 16 de octubre de 2012.

${ }^{201}$ Conquista N². "Información General". Buenos Aires, 23 de enero de 1964. Archivo Marta Curone.
} 
donaciones en dinero; pero una tarjeta de invitación a un picnic político organizado por las ramas femenina y masculina de la sección electoral 20 de Rosario, permite captar las adhesiones de particulares. En ellas figuran los propios afiliados, simpatizantes y familias, Juntas Inscriptoras de otras circunscripciones, la Juventud Justicialista de Rosario, a la que se le promocionaba un periódico próximo a salir, una agrupación, Los Leales, que involucraba una cierta cantidad de unidades básicas y sindicatos. También, figuraba la publicidad con la que se había financiado el evento, negocios de barrio, profesionales y personas que desarrollaban algún oficio. ${ }^{202}$ Respecto de las unidades básicas, no tenemos datos precisos sobre los modos de financiamiento. De algunas entrevistas se desprende que los afiliados aportaban una cuota societaria, tanto en las UB masculinas como en las femeninas o mixtas. ${ }^{203}$ En Azul, encontramos un ateneo creado con el objetivo de brindar charlas y conferencias y que funcionaba como lugar de reunión de dirigentes políticos de la zona, que se financiaba con donaciones. ${ }^{204}$

Finalmente, otra de las cuestiones que se discutieron es el perfil social de las mujeres que fueron convocadas por la dirigencia peronista para conformar el partido. Bianchi y Sanchís (1998) sostienen la preeminencia que en dicho discurso adquirieron las amas de casa. Julia Guivant (1985), las obreras y mujeres de sectores subalternos. Marisa Navarro (1994) habla de mujeres obreras y de clase media. Para Barry, la convocatoria fue amplia apelando a las mujeres de todos los sectores sociales, sólo que la recepción fue mejor recibida entre las mujeres de clase baja y media; entre estas últimas, una gran proporción de docentes, a lo que agrega que la condición de ama de casa estaba muy extendida entre las mujeres de la época pero no remite a una condición social (Barry, 2009). Para el período que nos compete consideramos que la extracción social de las mujeres que estuvieron abocadas a la reorganización del partido fue muy variada. Entre las mujeres entrevistadas que ocuparon espacios de dirigencia como Curone y Di Leo, se trató de mujeres de clase media que paralelo a la militancia trabajaban en la administración pública. Entre las militantes de base, encontramos amas de casa de extracción obrera, tanto entre las entrevistadas como entre las que intentaban adherirse a la FMP en el interior del país. Los expedientes policiales nos ofrecen datos de algunas unidades básicas creadas en 1959 y que llegaron a constituirse en materia de interés para la policía al producirse su clausura durante

\footnotetext{
${ }^{202}$ Tarjeta de invitación a un picnic organizado por las ramas femenina y masculina. Sección 20. Empalme Graneros. Rosario. Propiedad de Chiche Di Marco.

${ }^{203}$ Fiorenza, Nello; Entrevista de la autora, la Plata, 15 de marzo de 2014.
} 
con el golpe de Estado de 1966. Un Centro de Acción Justicialista de Avellaneda contaba con una comisión directiva de 18 mujeres de las cuales sólo dos trabajaban fuera de la casa: una era empleada de comercio y la otra, obrera textil. El resto se dedicaba a los quehaceres domésticos, aunque es probable que esta designación invisibilizara alguna actividad rentada dentro del hogar. Cinco de esas mujeres eran solteras, entre ellas, las dos que trabajaban fuera del hogar, y dos viudas. ${ }^{205} \mathrm{El}$ otro CAJ del que poseemos datos estaba radicado en la localidad bonaerense de Daireaux. La comisión directiva estaba conformada por 22 mujeres y tenía un total de 330 afiliadas. Como en el caso anterior, la mayoría eran amas de casa. Sólo dos trabajaban fuera del hogar: una empleada y otra, peluquera. La mayoría eran casadas y sólo 7 eran solteras. ${ }^{206}$ El relato de Chiche Di Marco, también ama de casa, revela el compromiso y el tiempo que le demandaba la unidad básica. Sostiene que se levantaba muy temprano para hacer las tareas domésticas y luego se iba a la unidad básica en la que estaba durante toda la jornada y a la que su esposo asistía recién a la noche, cuando salía de trabajar. Además, se reunían los fines de semana. La entrevistada reconoce que su condición de ama de casa le permitía ese compromiso con la militancia. ${ }^{207}$ Los datos expuestos parecen mostrar el predominio de amas de casa en el desarrollo de estas actividades partidarias. Sin embargo, no son suficientes para establecer generalizaciones. Este es un tema que requiere de mayor indagación empírica y es muy difícil de llevar a cabo sobre un contexto proscriptivo, donde la actividad política fue muy intermitente y descentralizada y donde no se conservan registros oficiales sobre esa actividad.

\section{Conclusiones}

\footnotetext{
${ }^{204}$ DIPBA. Mesa "A". Factor Político por Localidad. Legajo 3. Ayacucho-Azul.

${ }^{205}$ El centro desarrollaba actividades de asistencia social que en la ficha policial se definían como actividades de socorro y ayuda a los necesitados, pero no sostenía cursos ni poseía biblioteca. Figuraba como una organización de carácter social, cultural y político. Algunas mujeres tienen parentesco entre sí. Hay dos cuñadas y una madre y una hija. En cuanto a la edad de las integrantes de la comisión directiva, es muy variada. La presidenta tenía 51 años y la vicepresidenta 20. Las edades extremas eran 20 y 63 años, siendo la distribución muy pareja. DIPBA. Mesa "A". Factor Político por Localidad. Legajo 2. Avellaneda $1^{\mathrm{a}}$ a $5^{\mathrm{a}}$. "Centro de Acción Justicialista".

${ }^{206}$ Las edades son muy parejas, predominando las mujeres de entre 20 y 29 años, que eran 8. Le seguían las que tenían entre 40 y 49 años que eran 6. DIPBA. Mesa "A". Factor Político por Localidad. Legajo 2. Chascomús, Daireaux, Dolores.

${ }^{207}$ Di Marco, Chiche; Entrevista de la autora, Rosario, 11 de noviembre de 2014.
} 
Como han sostenido algunos investigadores sobre la reorganización partidaria en el período post '55, el partido fue una herramienta ponderada por los peronistas como estrategia para la toma del poder (Ladeuix, Melon Pirro y Quiroga, 2014). Entre muchos de ellos prevaleció la convicción de que la participación por la vía electoral era una forma legítima de hacer política y el modo más naturalizado que conocían. Para Gene Sharp (2011), la resistencia suele desarrollarse a partir de los medios que la gente tiene a su alcance, y para algunos, la política partidaria era la forma de participación con la que estaban más familiarizados. Sin embargo, al intentar reeditarla en un contexto de proscripción, se inscribió en la Resistencia en tanto implicó el intento de ocupar lugares prohibidos.

Aquí retomamos el concepto de repertorio de confrontación de C. Tilly (citado por Tarrow, 1997), que en tanto categoría cultural refiere al conjunto de medios de que dispone un grupo para plantear sus exigencias, valiéndose de sus conocimientos y experiencias previas. Sin embargo, la aplicación de un determinado modo de acción depende de las interpretaciones realizadas sobre el contexto en el cual este tiene lugar. No todos los modos de acción son pertinentes en cualquier contexto (Lahire, 2004); de ahí los sucesivos fracasos en intentar un tipo de participación que implicaba la vía electoral en un contexto de frágil institucionalidad como el que prevaleció entre 1955-1966. Siguiendo a Tarrow (1997), la decisión de reactivar la herramienta partidaria en determinados momentos respondió a un aprovechamiento de la estructura de oportunidades; las posibilidades que brindaba el sistema político para participar institucionalmente producto de modificaciones en las relaciones de poder entre las elites dominantes y el resto de la sociedad y de cambios en la relación de fuerzas entre esas mismas elites. Pero este no fue un proceso lineal ni libre de inconvenientes.

Como señalamos al comienzo de este capítulo, nos hemos concentrado en "la política no sólo como un conjunto de actividades e instituciones" sino también como un abanico de "relaciones de poder" donde "el sistema de género también es político porque se mantiene por el uso del poder" (Astelarra, 1987, p. 160-161). En ese proceso, nos interesa reflexionar sobre cómo la diferencia sexual fue relevante, a pesar de que, tradicionalmente, los teóricos políticos y los políticos la consideraran irrelevante. Ello en virtud de que, en palabras de Carole Pateman, "La diferencia sexual es una diferencia política" o, lo que para esta autora se resume también en cómo "la diferencia sexual es la diferencia entre libertad y sujeción" en tanto las mujeres no son parte del contrato originario con el que el 
contractualismo delimitó quiénes podían y quiénes no, ingresar al pacto social sobre el que se construía el edificio de la democracia (Pateman, 1995, p. 15). En efecto, este recorrido por la militancia político partidaria de las mujeres en el peronismo durante 1955-1966 nos permite observar que, pese a que el viejo Partido Peronista Femenino no volvió a tener la estructura y la vitalidad que había tenido en épocas de Evita, hubo intentos de las mujeres por reorganizarse y mantener autonomía. En este sentido, retomando los planteos de Eck acerca de si la participación de las mujeres en la resistencia se limitó a una actuación de los roles de género y a tareas de apoyo, en el capítulo restituimos cómo, independientemente de que funcionaran ciertas representaciones generizadas, no fueron meras auxiliares de un proceso central que otros han ubicado o en el partido masculino o en el sindicato.

Sin duda, como hemos demostrado, en el nuevo contexto, las mujeres encontraron obstáculos para concretarlo. En principio, debieron atravesar las mismas condiciones que se imponían al peronismo en su conjunto, proscripción, represión, limitaciones en la participación, incertidumbre, y el recurrente problema de la legitimidad con que se veía enfrentado cualquier dirigente con intenciones de conducir y organizar, sumado a las cambiantes directivas del líder. Esas limitaciones se hacían sentir de una manera diferenciada en las mujeres, porque la falta de recursos y las dificultades de movilidad las afectaban doblemente, si tenemos en cuenta que en muchos casos tenían obligaciones domésticas que solían dificultar el desarrollo de la militancia y que además no habían llegado a conformar núcleos de poder territoriales durante los años del gobierno peronista; ya que evitar el surgimiento de caudillas había estado entre los objetivos de Eva Perón. Sin duda, hubo mujeres al frente de unidades básicas con influencia barrial; pero no hubo un equivalente al partido masculino donde se formaron liderazgos provinciales.

La participación partidaria de las mujeres en el peronismo es un claro ejemplo de cómo en la política se apela a las diferencias de género a la hora de determinar criterios de organización (Scott, 1993). En el capítulo anterior observamos cómo en la Resistencia peronista se abrieron posibilidades para la participación conjunta de varones y mujeres en las actividades clandestinas. Sin embargo, en las que implicaban el recurso a la violencia política se mantuvo una división del trabajo basada en el género. En el otro extremo del espectro de actividades desarrolladas como parte de la Resistencia, la actividad partidaria, que pese a que en muchos momentos actuó en condiciones de clandestinidad, aspiraba a ser reconocida legalmente, prevaleció una vieja tradición peronista: aquella que sostiene que las mujeres deben organizarse políticamente en una estructura diferenciada. Esta idea estuvo 
presente tanto entre las militante que provenían del viejo PPF como entre las nuevas militantes emergidas en los años de la resistencia a la Revolución Libertadora y que ante las posibilidades de participación partidaria que se abrieron a partir de la llegada de Frondizi a la presidencia se volcaron a esa actividad. Sin embargo, la prevalencia de esta idea sobre una organización separada no llevó a que se reconociera a la organización de las mujeres como fuerza política en los organismos de conducción, hecho cuestionado por las mismas mujeres. Tal como señalara Astelarra, "El control masculino del mundo público es una base importante de las relaciones patriarcales modernas, pues los varones regulan las condiciones en las cuales se les permite a las mujeres acceder a él. Es decir, los obstáculos para la incorporación de las mujeres a las organizaciones, las instituciones y los cargos políticos, también pueden ser una estrategia de mantención del poder masculino" (Astelarra, 1987, p.163).

En la etapa que comienza luego del golpe de Estado de 1955, todos aquellos temores que habían llevado a la primera dama a tomar precauciones para evitar que el PPF viera avasallada su autonomía e impedir que la organización de las mujeres quedara presa de las disputas entre sindicalistas y políticos que aquejaban al peronismo desde sus orígenes, se hicieron presentes desde el primer momento. Pese a los recaudos tomados por Evita para evitar que las mujeres de políticos y funcionarios fueran integradas al partido en cargos de dirigencia e impedir que sus maridos interfirieran en la rama femenina, esto ya no fue posible en el nuevo contexto, donde los caudillos locales hicieron sentir su influencia. A todo esto, se sumó la injerencia de la rama sindical cuyo poderío, tanto en el frente externo como en la interna peronista, dividió a las otras ramas. Aun cuando las mujeres pretendieron crear estructuras con cierta autonomía, siguieron la política adoptada por la alta conducción, ya sea gremial o política, y de hecho, tampoco tenían muchas posibilidades, y probablemente tampoco tuviera sentido, formar una estructura completamente autónoma, porque ello las hubiera dejado fuera del partido y tal vez del peronismo, con menos credenciales aún para movilizar a otras mujeres.

En este sentido, las mujeres no lograron construir lazos de sororidad que lograran mantener sus esfuerzos -intrapartidarios o interpartidarios - o imponerse por sobre los lazos de fraternidad de los varones de su propio partido. Es que, en cierto modo, la lógica partidaria latía detrás de esos vínculos y, en definitiva, la política, en ese contexto, les impedía como "mujeres la identificación positiva de género, el reconocimiento, la agregación en sintonía y la alianza" (Lagarde y de Los Ríos s/f., p. 126). Sin embargo, 
dicho esto, es también relevante reconocer que estos esfuerzos de organización fueron las primeras formas de una sororidad -no en el marco del movimiento feminista al que la atribuye Lagarde, sino en el de una compleja agrupación de mujeres dentro de la lógica de un partido que, como tales, las convertía en iguales: mujeres-. En este sentido, se descubren a pesar del peso de la mirada masculina de la vida política del partido, que había relaciones positivas en esos intentos de unidad con otras mujeres con fines que, muchas veces, no tenían a las mujeres como centro ni procuraban modificar sus opresiones, pero que en ese estar juntas pudieron significar primeras acciones de reconocimiento y apuesta política.

En el próximo capítulo, analizaremos cómo las mujeres intervinieron en el entramado discursivo de la Resistencia peronista haciendo oír su voz a través de una herramienta valorada en tiempos de confrontaciones y proscripciones como fue la prensa gráfica. 


\section{Capítulo III}

\section{Mujeres, género y política en la prensa peronista}

En el capítulo anterior nos centramos en el análisis de la reorganización partidaria analizando la dimensión institucional del concepto de género y las coyunturas específicas en las que se desarrollaron las estrategias de acción de las mujeres. En este capítulo, nos enfocaremos en un ámbito que, en algunos casos, estuvo vinculado a la organización partidaria, y fue capaz de articular políticamente la Resistencia peronista en su conjunto. Nos referiremos, específicamente, a la intervención femenina en el espacio discursivo, vale decir, nos introduce en la dimensión simbólica con la que Scott conceptualiza el universo representacional del género y, a su vez, se articula con uno de los elementos que integran los repertorios de confrontación y con el eje sobre los procesos de identificación que se generan en las instancias de participación política.

En efecto, la Resistencia peronista encontró cauce a través de una multiplicidad de métodos que en gran medida estuvieron vinculados con las trayectorias previas de los sujetos y colectivos que en ella participaron. Una de las primeras respuestas contra el golpe de Estado que derrocó al peronismo consistió en el desarrollo de un discurso político de oposición que se manifestó a través de la prensa. Surgió, entonces, una multiplicidad de periódicos que confrontaron abiertamente contra los gobiernos de turno, a la vez que procuraron burlar la represión y la censura porque, pese a que luego del golpe de Estado se había establecido la libertad de prensa, continuaron ejerciéndose diferentes grados de censura. Aunque no se trató de una prensa partidaria en sentido estricto, puesto que las publicaciones no representaban a un partido en particular, éstas defendieron o impulsaron proyectos políticos. Y pese a que el peronismo no fue la única fuerza que recurrió al desarrollo de estos emprendimientos periodísticos, todos ellos incluyeron a un público lector peronista a la vez sostuvieron proyectos que incluían indefectiblemente al peronismo (Melon Pirro, 2007). Es decir, esta fuerza política se insertó en un campo periodístico en el que intervinieron diversidad de actores pertenecientes a distintas ideologías políticas, desarrollistas, nacionalistas, sectores de izquierda, a la vez que en el propio campo peronista emergieron diversas facciones que se expresaron a través de estos medios.

Nuestro objetivo en este capítulo es analizar la prensa de oposición como una actividad de resistencia por parte de sujetos que en los años posteriores al golpe de Estado 
de 1955 echaron mano de un conocimiento que ya poseían para desarrollar acciones que, en el nuevo contexto, adoptarían un tinte subversivo al desplegarse en un marco confuso respecto de su legalidad. Sharp (2011) establece una distinción entre métodos de resistencia que son conocidos por la gente, vinculados a su cotidianeidad, y métodos que implican salir de esa cotidianeidad y que les exigen a los sujetos que los emplean un mayor esfuerzo o un aprendizaje. El autor sitúa a la prensa entre estos últimos. Sin embargo, pese a que la labor periodística en un contexto represivo exige romper con la cotidianeidad, por las consecuencias que trae aparejado su desarrollo en condiciones en las cuales tiende a ser considerada subversiva, lo cierto es que los sujetos que la desarrollaron en la Resistencia peronista, en su mayoría, ya tenían una vinculación previa con ella y que se remontaba a los años de los primeros gobiernos peronistas. Por ejemplo, Laura Ehrlich (2010) ha rastreado las trayectorias de los individuos dedicados a esta labor, algunas de las cuales se llegan inclusive a las décadas del '30 y del '40. En general, se trató de periodistas, escritores, abogados, y en muchos casos de personas que habían tenido algún tipo de participación en la gestión pública durante los primeros gobiernos peronistas, en especial en áreas de cultura. El conocimiento sobre la labor periodística no era un elemento nada despreciable en los momentos posteriores a la caída del peronismo, si se tienen en cuenta, como sostiene Tarrow (1997) las potencialidades de la prensa como difusora de ideas y como mecanismo de propagación de la acción colectiva a sectores sociales más amplios, estrechando relaciones por encima del grupo más inmediato de identificación; hecho que cobra relevancia en un proceso tan atomizado como fue la Resistencia peronista.

Siguiendo con la perspectiva de este estudio, nuestro interés radica en enfocar la intervención de mujeres que eligieron la actividad periodística como medio de participación en la Resistencia peronista. De esta manera, las publicaciones que analizaremos se presentan con un doble carácter. Como fuentes para estudiar el accionar de las mujeres que las dirigieron y como objeto de estudio en sí mismas, ya que son el producto de esas intervenciones femeninas. Combinadas con fuentes secundarias, nos permitirán establecer el paso de sus directoras por la Resistencia: su trayectoria previa, el entramado de relaciones en el que se insertaron, su postura política, los debates que entablaron. A la vez, desarrollaremos un análisis de los aspectos discursivos que atraviesan a las propias publicaciones: los nudos polémicos en los que se insertaron, las estrategias discursivas para burlar y/o desafiar la censura (Verón, 1987) y fundamentalmente, las implicancias de género que connotaron al lenguaje utilizado -la construcción de ethos discursivos (Amossy, 2001), 
los colectivos de identificación y los diversos destinatarios a los que estuvo dirigido el discurso-, elementos que permiten acercarnos a la dilucidación del pacto de lectura (Arfuch, 1986) que construyó cada publicación en función de los lectores a los cuales iba dirigida. En particular, nos interesa inscribirnos en la línea de Amparo Moreno i Sardá respecto de los medios de comunicación, tanto los masivos como otros que se inscriben en la trama comunicativa de la sociedad, en este caso, la prensa política dirigida por mujeres: entendiendo que éste factor ha sido desconsiderado en la mirada de las investigaciones existentes y que, asimismo, permitirá no sólo revelar el arquetipo viril de la vida pública del período bajo estudio sino también exponer elementos de la trama de género y política desconsiderados (Moreno i Sardá, 2007, p. 229). Vale decir, el objetivo es corrernos de la opacidad del discurso androcéntrico (Moreno i Sardá, 2007, p. 131). Entonces nos preguntamos: ¿Cuál fue el uso de la figura de los líderes peronistas en la construcción de un discurso de resistencia con carácter performativo? ¿Cómo estas publicaciones modificaron su discurso en función de las aperturas-cerramientos del sistema político y de los adversarios con los cuales polemizaron? ¿Qué nos dice el discurso de estas publicaciones sobre el receptor al cuál apelaban y sobre qué elementos se construyó el pacto de lectura? ¿Qué roles de género transmitieron o construyeron? ¿Cómo se entrelazan la clase y el género en esas construcciones?

Para ello, utilizaremos cuatro periódicos cuyo interés, a los efectos de esta tesis, radica en que fueron dirigidos por mujeres Dos de ellos, La Argentina, justa libre y soberana y Soberanía, emprendimientos llevados a cabo por Nora Lagos en Rosario; de diciembre de 1955, el primero, y entre diciembre de 1956 y mayo de 1958 , el segundo. ${ }^{208}$ El tercer emprendimiento editorial analizado fue dirigido por María Granata, Línea Dura, publicado entre noviembre de 1957 y noviembre de $1958 .{ }^{209} \mathrm{Y}$ un cuarto periódico, mucho más modesto que los anteriores, ya que en realidad se trató de un boletín, es Conquista, dirigido por Marta Curone, del cual sólo salieron tres números entre diciembre de 1963 y

\footnotetext{
${ }^{208}$ La Argentina se publicó entre el 8 y el 31 de diciembre de 1955 y en total salieron ocho números, a los que hemos tenido acceso en su totalidad. Soberanía se publicó entre el 17 de diciembre de 1956 y mayo de 1958. El corpus documental es discontinuo. El último número al que hemos accedido es el 41, del 26 de febrero de 1958. Laura Ehrlich (2010) proporciona como fecha de cierre mayo de ese año, pero sin ofrecer una fecha exacta, por lo que no sabemos cuántos números se publicaron en total.

${ }^{209}$ Línea Dura fue publicado entre noviembre de 1957 y noviembre de 1958.El último número al que hemos accedido es el 46, que correspondiente al 11 de noviembre de 1958. No se poseen datos de que el periódico haya seguido publicándose y es muy probable que ese haya sido, si no el último número, al menos uno de los últimos, puesto que coincide con el contexto del conflicto petrolero en Mendoza que marcó el primer momento de crisis entre el peronismo y el gobierno de Frondizi después del pacto, en el cual los realizadores de Línea Dura estuvieron estrechamente involucrados.
} 
febrero de $1964 .^{210}$ Nuestro estudio está centrado en los cuatro periódicos arriba mencionados, porque hemos accedido a un corpus documental, si bien discontinuo, lo suficientemente amplio y explícito como para obtener conclusiones respecto de la participación femenina en la Resistencia peronista y, particularmente, en la prensa.

Luego de un breve recorrido por la bibliografía que ha tomado a la prensa política peronista de los años posteriores a la destitución del peronismo como objeto de investigación y de presentar algunas características generales sobre la misma, detallaremos los aspectos biográficos que es posible reconstruir sobre sus directoras, las características que tuvieron los periódicos analizados, las condiciones de producción de los mismos, para pasar luego a un análisis sobre las estrategias discursivas utilizadas para sortear la censura y las implicancias de género del discurso utilizado.

\section{La prensa gráfica como práctica de resistencia}

En los últimos años algunos trabajos se han ocupado de analizar el desarrollo de la prensa política concibiendo a las publicaciones en tanto que empresas; lo que implica preguntarse por sus condiciones de producción, circulación y financiamiento buscando superar aquellos estudios que, basados en los trabajos de Halperín Donghi (1985) y Duncan (1980) analizaron a la prensa política en su rol de formadora de opinión pública y en los que el foco de atención estuvo puesto en la relación entre prensa y política. De esta manera, no se descarta la posibilidad de utilizar la prensa como fuente historiográfica, pero queda hecha la advertencia sobre el rol de los periodistas en tanto que dadores de sentido de la realidad y realizadores de un trabajo hermenéutico previo al del historiador (Da Orden y Melon Pirro, 2007). En esta línea de análisis, algunas investigaciones que se han centrado específicamente en la prensa peronista de los primeros años posteriores al golpe de Estado de 1955, se han propuesto complejizar los estudios sobre la cultura política de la época que, en general, se han basado en las producciones culturales más sofisticadas y de carácter intelectual, mayoritariamente, las provenientes del ámbito de la Nueva Izquierda (Altamirano, 2001; Bozza, 2001; Raimundo, 2001; Sigal, 2002; Terán, 2013 [1991]; Tortti,

\footnotetext{
${ }^{210}$ De Conquista sólo salieron tres números, entre el 20 de diciembre de 1963 y el 20 de febrero de 1964. El segundo número fue publicado el 23 de enero de 1964, de manera que se trataba de una publicación mensual.
} 
1989, 2013, Tortti, Chama y Celentano, 2014). De esta manera, procuran enfocarse en un tipo de prensa con menores pretensiones de intelectualidad, que intervino en los problemas coyunturales de la política, interpelando directa y enfáticamente al lector y con un alcance mayor por su distribución en kioscos y en formato diario, con el objetivo de tener acceso a las representaciones políticas que circulaban en espacios más amplios que los reducidos círculos intelectuales (Ehrlich, 2010). Y, al mismo tiempo, realizar un trabajo de visibilización de los actores políticos de clase media que participaron de la Resistencia peronista, superando las interpretaciones que se concentraron en la clase obrera como sujeto privilegiado de ese proceso (Ehrlich, 2010; Melon Pirro, 2009).

La multiplicidad de publicaciones fue muy amplia, pero en general, las que han recibido un tratamiento de análisis sistemático han sido aquellas de mayor envergadura, que duraron más tiempo y de las que se conserva mayor cantidad de ejemplares en la actualidad. En conjunto, se ha asociado la prensa como un modo de intervención contemplado en los repertorios de confrontación durante la resistencia peronista.

En general, los trabajos de Ehrlich (2010) y Melon Pirro (2007) abordaron la prensa peronista propiamente dicha y la articulación entre diversos sectores del peronismo y del nacionalismo. Estos autores distinguen un primer momento, inmediato al golpe de Estado de 1955, en el que surgieron una serie de publicaciones, algunas de las cuales consideraron al peronismo como un fenómeno acabado, pero que se identificaron con elementos discursivos de ese signo político, la mayoría de ellas prontamente censuradas. Entre esas publicaciones figuran El Lider y De Frente, que ya se publicaban durante el gobierno peronista, El 45, Palabra Argentina, El Descamisado, Lucha Obrera, La Argentina y El Federalista, entre otras. Luego, señalan un segundo momento, hacia 1957, en que ya era evidente que el peronismo no sólo no desaparecería, sino que se había constituido en un actor ineludible de la escena política y en que diversas tradiciones del nacionalismo y del desarrollismo intentaron cooptar al electorado peronista para un proyecto propio. En este contexto, se distinguieron publicaciones como Palabra Argentina y Azul y Blanco, de tendencia nacionalista; Mayoría, de tendencia nacionalista pero que apoyó el proyecto desarrollista; Qué sucedió en siete días, desarrollista, a lo que deben sumarse publicaciones expresamente peronistas como Rebeldía, Línea Dura y Norte, o de origen trotskista como El Hombre/El Proletario. En este momento, los temas coyunturales que abordaron las publicaciones fueron la convocatoria a elecciones constituyentes en julio de 1957, la asamblea constituyente y las elecciones presidenciales de febrero de 1958. A esos dos 
momentos, Ehrlich agrega un tercero, que se extiende entre 1959 y 1962, cuando ya se había roto el pacto entre el peronismo y Frondizi, marcado por problemáticas tales como la reorganización del PJ, la aplicación del Plan CONINTES, la reactivación de las actividades clandestinas, y las elecciones de 1960 y 1962. Entre las publicaciones de esta época figuran Santo y Seña, De Regreso, 3 Banderas, Recuperación y Trinchera de la Juventud Peronista (Ehrlich, 2010). El segundo período es el que ha recibido un análisis más sistemático por parte de la historiografía. En ese momento, Melon Pirro distingue entre las publicaciones peronistas ortodoxas, que pretendieron convertirse en órganos oficiales del peronismo, como Línea Dura y Norte, y otras como Rebeldía y Palabra Argentina que mantuvieron una línea más independiente en el peronismo, inclusive respecto de Perón (Melon Pirro, 2007).

Otras investigaciones se han centrado en el análisis de periódicos particulares, como el peronista De Frente (Ranalletti, 1998), los nacionalistas Azul y Blanco (Ladeuix y Contreras, 2007; Galván, 2012) y Palabra Argentina (Goebel, 2004). Este último ha sido objeto de atención como medio de difusión del revisionismo histórico, un tema en el que también se ha enfocado Carina Capobianco (2003), que ha basado su análisis en La Argentina y Soberanía, dos de las publicaciones que serán objeto de estudio en este capítulo. Por otro lado, están los trabajos que se centran en las relaciones entre peronismo y desarrollismo, donde encontramos los trabajos de Spinelli (2007) sobre las revista Qué sucedió en siete días y Mayoría, y de César Díaz (2007) sobre la primera de esas publicaciones. $^{211}$

Pese a la abundante bibliografía sobre la prensa política que surgió con posterioridad al derrocamiento del peronismo, la misma aún no ha sido contemplada desde una perspectiva de género. Ehrlich (2010) ha hecho algunas observaciones sobre los modelos de masculinidad que transmitía el boletín Trinchera de la Juventud Peronista, pero aún faltan trabajos sistemáticos en ese sentido. Desde estas páginas nos proponemos, por un lado, analizar los modelos de femineidad que se construyeron a través de los dispositivos de enunciación de las publicaciones analizadas, pero además contemplar la práctica periodística vinculada a la prensa política como un espacio que le permitió a algunas mujeres poder expresarse en el marco de la Resistencia peronista. En conjunto, apuntamos a preguntarnos

${ }^{211}$ Existen una multiplicidad de trabajos que se basan en el análisis de la prensa gráfica en los años que nos competen, pero exceden las preocupaciones de esta tesis. Aquí, nos hemos limitado a mencionar los que 
si las distintas intervenciones de las mujeres en el espacio discursivo de la Resistencia implicaron, además de la obvia identificación política, la construcción de un colectivo de identificación femenino que reconociera los problemas propios de las mujeres e instrumentara estrategias para su resolución. Vale decir, no sólo intentamos visibilizar a las mujeres en la prensa gráfica sino que, además, consideramos que su intervención en la misma pudo haber tenido distintas aristas políticas no sólo vinculadas a la identidad peronista. Ello supone considerar la prensa gráfica como parte de los repertorios de confrontación, claves en ciertos contextos de oportunidades, y también, implica abrir nuevos sentidos sobre cómo la acción política colectiva configura una identidad que también debe considerarse a la hora de evaluar las razones por las que se inscriben las personas en las prácticas de resistencia. De este modo, restituimos también los elementos simbólicos de implicación en la acción de la resistencia que Melucci y otros han señalado como relevantes a la hora de pensar las motivaciones para el involucramiento.

\section{Mujeres periodistas}

Los periódicos que constituían la prensa política opositora que estamos abordando eran pequeños emprendimientos, algunos escritos en su totalidad por su director o directora, aunque solían contar con un grupo reducido de colaboradores. Los trabajos que han abordado esta prensa evidencian su desarrollo en la ciudad de Buenos Aires y en Rosario, aunque se propagaba por varias provincias mediante distribuidores comerciales y, también, a través de los propios integrantes de los equipos de redacción, a lo que debe sumarse la circulación de mano en mano. La periodicidad fue preferentemente semanal, aunque esto se daba más en las intenciones que en la práctica, puesto que lo que primaba era la irregularidad en un contexto signado por la dificultad para conseguir fondos para el financiamiento, y por la represión, que llevaba a la censura y al secuestro de ejemplares. ${ }^{212}$

Además de las publicaciones que analizaremos, La Argentina, Soberanía, Línea Dura y Conquista, hubo otros periódicos que fueron dirigidos por mujeres o que contaron con

abordan periódicos que por sus características, materiales e ideológicas, se encuentran más cercanos a nuestro objeto de estudio.

${ }^{212}$ Para Ehrlich (2010) predominó el tamaño sábana, con una extensión que oscilaba entre las 2 y 8 páginas, con un promedio de 4. Los periódicos tenían una tirada que oscilaba entre 10000 y 40000 ejemplares. 
ellas en sus equipos de redacción o como colaboradoras. Lo que indica que el ejercicio del periodismo como practica de resistencia por las mujeres, si bien fue minoritario en relación a la participación masculina, no fue excepcional. Es el caso de Abanderada (1958) dirigida por Antonia y Jorga Salomón; Voz Femenina (1956 y 1958), dirigida por Ofelia Decivo Braica de Saint Bonnet, y en la redacción participaban, Delia V. de Castellazzi y María Elena Márquez (Carman, 2015) y El 17 (1957-1958), dirigido por Norma Kennedy, quien integraba uno de los grupos de la Juventud Peronista (Carman, 2015). El boletín Trinchera (1960-1962), órgano de la Mesa Ejecutiva de la Juventud Peronista de Capital Federal y Gran Buenos Aires, también contó con mujeres en su equipo de redacción; Beatriz Fortunato y Aída Filipini (Ehrlich, 2010). Además, hubo otros periódicos que contaron con colaboración femenina, como Palabra Prohibida, en donde escribía la ex diputada justicialista Zulema Pracánico; aunque las notas no eran firmadas y sólo figuraba el nombre de su director, Luis Sobrino Aranda. ${ }^{213}$ En este periódico también solían publicarse artículos de Alicia Eguren, aunque ella no formaba parte de su staff. Carmen Hussein, Emi González, Mercedes Marcos y Ana María Lagomarsino colaboraban en la redacción y distribución de El Guerrillero (1957-1958), el periódico que editaba el Comando Nacional Peronista y que estaba a cargo de César Marcos, Raúl Lagomarsino y Héctor Saavedra (Monzón, 2006). Sin embargo, hemos recortado a Línea Dura, Soberanía, La Argentina y Conquista porque nos permiten distinguir distintos perfiles de género.

¿Quiénes eran las tres directoras de los periódicos que analizaremos? Nora Lagos nació en Buenos Aires en 1920. Era bisnieta de Ovidio Lagos, el fundador del diario La Capital de Rosario, del cual su padre, Carlos Lagos, militante del partido demócrata progresista, fue director entre 1916 y 1940. En 1953, Nora alcanzó la dirección del periódico, pese a no gozar de la estima de su familia paterna. ${ }^{214}$ Este cambio implicó una reorientación política del medio gráfico que, hasta ese momento, había sostenido una explícita postura antiperonista. Al ser derrocado el peronismo, los Lagos recuperaron el diario y Nora fue expulsada de la dirección. En diciembre de ese año comenzó la publicación de su primer periódico en la etapa de la Resistencia, La Argentina, justa, libre y soberana, pero para fines de diciembre fue detenida en la cárcel de mujeres de Humberto

\footnotetext{
${ }^{213}$ Sobrino Aranda, Luis. Entrevista de la autora. Rosario, 12 de noviembre de 2014.

${ }^{214}$ Luis Sobrino Aranda sostiene que el "Alemán" Lagos, uno de los miembros de la familia con quien Nora tenía cierta cercanía, impulsó su designación como directora para evitar que fuera expropiado por el gobierno peronista, como había ocurrido con otros medios opositores. Sobrino Aranda. Entrevista de la
} 
Primo en Buenos Aires. En dicha publicación estuvo acompañada por su pareja, Hugo Mac Dougall, quien la secundó como subdirector, como también lo había hecho en el diario $L a$ Capital. Sin embargo, en 1956, decidieron separarse y Mac Dougall se retiró de la vida política. ${ }^{215}$ Hacia fines de ese año, Nora inició la publicación de Soberanía, donde estuvo acompañada por un equipo compuesto por Luis Sobrino Aranda, que también había participado de La Argentina, René Bertelli, Bernardo Iturraspe, Fausto Eduardo López y Juan Puigbó. ${ }^{216}$ Con los dos primeros la unió una relación sentimental. De la relación con Bertelli nació un hijo y juntos compartieron un encarcelamiento en una comisaría en San Justo, en 1957, de donde lograron huir, iniciando una etapa de exilio en Paraguay que incluyó también a las dos hijas de Nora fruto de su relación con Mac Dougall. A fines de 1957 regresaron al país y Nora volvió a hacerse cargo de la dirección del periódico (Baschetti, s/f; Lagos, 2003; Lanfranco, 2005). ${ }^{217}$

El primero de los periódicos de Nora Lagos en la Resistencia peronista, La Argentina, era una publicación de cuatro páginas, de tirada irregular y solía salir más de una vez por semana. Según datos proporcionados por el propio periódico, la tirada era de entre diez mil y veinte mil ejemplares. Se distribuía en Santa Fe y otras provincias como Buenos Aires, Córdoba y Entre Ríos. Soberanía, en cambio, era semanal, con algunos números de tirada

autora. 12 de noviembre de 2014. A su vez, Guillermo Lanfranco (2005) hace referencia a un fallo judicial emitido hacia fines de septiembre de 1953, que habría permitido el reemplazo.

${ }^{215} \mathrm{Al}$ acceder a la dirección del diario La Capital, Nora, junto con su pareja, el guionista cinematográfico Hugo Mac Dougal, se trasladaron de Buenos Aires, ciudad de crianza de Nora, a Rosario. No hemos accedido a información sobre sus actividades anteriores ni sobre si tuvo algún tipo de formación profesional, académica o política. Sobrino Aranda desconoce que haya tenido algún tipo de formación académica, mientras que sus hijas recuerdan que estudió durante algún tiempo alguna carrera, posiblemente Derecho, pero no poseen datos fehacientes al respecto. Sabemos que junto a Mac Dougall frecuentaron los círculos de artistas que dieron su apoyo al peronismo (Lanfranco, 2005). Sobrino Aranda. Entrevista de la autora. 12 de noviembre de 2014. Testimonio de Norah Mascías, Norah; Mascías, Patricia y De Sanctis, Oscar. Entrevista de la autora, 1 de septiembre de 2011.

${ }^{216}$ Algunos de los integrantes del equipo de redacción de Soberanía habían integrado el staff del diario La Capital como los abogados Luis Sobrino Aranda, Bernardo Iturraspe y Fausto Eduardo López (Ehrlich, 2010). Sobrino Aranda. Entrevista de la autora. 12 de noviembre de 2014. No tenemos información acerca de que René Bertelli y Juan Puigbó hayan estado vinculados a ese medio. Puigbó había integrado la ALN, trabajado en el diario La Época, e integrado el Comando Táctico (Baschetti. s/f.). Bertelli fue un fue un militante peronista de origen tucumano que participó en la organización de la Resistencia en Rosario y hacia fines de los años sesenta integró las Fuerzas Armadas Peronistas (Verbitsky. 1985).

${ }^{217}$ Nora falleció por una enfermedad en 1975. En los años setenta militó en una unidad básica, a la vez que apoyó y alentó la militancia de sus hijas; pero su etapa de mayor actividad y compromiso político se remonta a la década del '50. La última vez que estuvo detenida fue en 1961 por su vinculación con la toma del Regimiento 11 de Infantería en la ciudad de Rosario, el 30 de noviembre de 1960. Al parecer, Nora habría actuado como colaboradora en una operación que tenía como integrante a su pareja, René Bertelli, quien dirigió uno de los grupos que actuaron en el operativo. Se encontraron armas en su casa y ése habría sido el motivo de su arresto Norah Mascías, Norah; Mascías, Patricia y De Sanctis, Oscar. Entrevista de la autora, 1 de septiembre de 2011. 
irregular. Al igual que La Argentina, tenía cuatro páginas en blanco y negro, tamaño sábana. El periódico no ofrece datos sobre la cantidad de ejemplares que se imprimían. Sobrino Aranda (1958) estima una cifra de 350.000 ejemplares, un tanto exagerado si se compara con los valores que Laura Ehrlich proporciona para otras publicaciones. ${ }^{218} \mathrm{Se}$ distribuía no sólo en Rosario sino también en el interior de la provincia de Santa Fe, Córdoba, Entre Ríos, Buenos Aires y el Chaco (Capobianco, 2003). Ambos periódicos contaban con críticas políticas, muchas veces en tono irónico y con uso el de caricaturas, característica que compartían con la mayoría de las publicaciones de la época. Algunos artículos aparecían firmados. Había una página sobre cuestiones gremiales, secciones dedicadas a la recopilación de noticias de otros diarios, afines o no, al desarrollo de acontecimientos históricos y a la publicación de cartas de lectores y sus respuestas. En ambos periódicos predominó el contenido político de opinión, pero, a diferencia de Soberanía, La Argentina dedicó cierto espacio a temas de interés general como literatura, deportes y noticias parroquiales (Capobianco, 2003). Soberanía tuvo la particularidad de contar con una sección femenina llamada "La mujer y la patria" desde la que se interpelaba a las mujeres en relación a su participación en la política.

María Granata es una reconocida escritora que formó parte de la intelectualidad que apoyó al peronismo durante sus primeros gobiernos. Nació en Buenos Aires en 1923. Proveniente de una familia de clase media cuyo padre era médico. Integró la comisión administradora del Sindicato Argentino de Escritores (SAE) y trabajó en la Secretaría de Prensa y Difusión junto a Raúl Apold, de manera que paralelamente a su actividad literaria, se abocó al periodismo, trabajando en publicaciones diversas. ${ }^{219}$ El desarrollo de su actividad informativa y literaria la habría acercado a personalidades como el periodista Ramón Prieto y el escritor José María Castiñeira de Dios; ambos integrantes del Comando Táctico en los primeros años de la Resistencia, con quienes compartiría el trabajo de publicar el semanario político Línea Dura. ${ }^{220}$ La propuesta de este emprendimiento le habría

\footnotetext{
${ }^{218}$ Ehrlich (2010) cita un artículo de Rebeldía que registra una tirada de 500.000 ejemplares que se distribuiría entre los diferentes periódicos, por lo que parece muy elevada la cifra de 350.000 sólo para Soberanía, sobre todo si se tiene en cuenta que Rebeldía era de mayor tirada. Además, la autora compara estas cifras con las tiradas de periódicos comerciales de mayor circulación como Tía Vicenta, que habría tenido una tirada de 50.000 ejemplares, mientras que señala una tirada de 350.000 ejemplares para diarios de circulación masiva como La Prensa.

${ }^{219}$ Entre esas publicaciones figuran La Nación, Democracia, Conducta, El Hogar, El Mundo, Selecta, Crítica, Poesía Argentina, La Prensa y la Revista de la Universidad de Buenos Aires (Panella, 2001; Pitchel, 1993; Santiago, 2010).

${ }^{220}$ Ramón Prieto fue un militante y periodista de origen español, participante de la lucha antifascista. Integró la columna de Luis Prestes en Brasil y combatió en el ejército republicano durante la guerra civil
} 
llegado a Granata de la mano de Castiñeira de Dios, con quien había integrado, durante los años del gobierno peronista, la peña Eva Perón -un espacio político cultural de reunión e intercambio. Según Castiñeira, la iniciativa habría partido de dos ex diputadas peronistas, y por la bibliografia Perón-Cooke, sabemos que una de ellas era Elena Fernícola. ${ }^{221}$ En un comienzo iba a llamarse "La Señora", pero por sugerencia de Granata se llamó Línea Dura (Cichero, 1992). Enrique Ninín, ex integrante de la primera Juventud Peronista, quien formó parte del staff de Línea Dura siendo muy joven, recuerda a Ramón Prieto como "cerebro" de Línea Dura, habiéndose recurrido a la figura de Granata por su prestigio y su capacidad para el trabajo periodístico. ${ }^{222}$ Según Granata, los artículos eran escritos por ella en un setenta por ciento, mientras que el resto eran comunicados de los dirigentes gremiales que financiaban el semanario comprando todos los números, que luego distribuían. A su vez, otra mujer vinculada al semanario era Malena Legrand, una cantante de tangos, que cumplía la función de administradora.

Línea Dura estaba constituida por cuatro páginas en blanco y negro, con algunos detalles en color verde, aunque algunos números especiales tuvieron seis páginas. Solía publicar resoluciones del Comando Táctico, directivas de Perón y de John W. Cooke y en general, artículos sobre cuestiones organizativas del peronismo. Comúnmente se publicaban informes sobre los problemas políticos más inmediatos, críticas al gobierno y a los sectores antiperonistas en general, denuncias sobre el destino ominoso que estaban sufriendo las obras del gobierno peronista y sobre la existencia de presos políticos, y críticas a otros sectores del peronismo que no compartían la misma línea. También, se publicaban pasajes del libro de Perón Los Vendepatria. La página tres estaba destinada a la actividad sindical. En ella se expresaba la CGT Auténtica y las "62 organizaciones”; había comunicados de diferentes gremios adheridos a esas organizaciones y reportajes a dirigentes sindicales. El semanario contaba con una sección fija: "La Mujer en la Lucha", que apareció en un principio con el nombre de "A usted, Ama de casa"; espacio desde el cual una interlocutora interpelaba a las mujeres para que comprendieran los problemas que aquejaban al

española. Estuvo vinculado a la gestión del pacto Perón- Frondizi. Luego integró el MID, desprendimiento de la UCRI surgido en 1963, hasta su fallecimiento en 1985 (Longoni, 2012). José María Castiñeira de Dios (1920-2015) fue un escritor y periodista que desempeñó distintos cargos públicos en el área de cultura durante los primeros gobiernos peronistas. Fue director de varias revistas literarias y colaborador y redactor en diversas publicaciones como La Prensa, Democracia, Clarín, entre otras (Santiago, 2010).

${ }^{221}$ Correspondencia Perón-Cooke II (1984). Buenos Aires: Parlamento.

${ }^{222}$ Ninín, Enrique. Entrevista de la autora. Buenos Aires, 31 de agosto de 2012. 
peronismo, y solían aparecer artículos sueltos que relataban la presencia femenina en acciones de resistencia o que convocaban a las mujeres a sumarse a la lucha.

Por último, nos resta situar la trayectoria de Marta Curone, quien estaba a cargo de la edición de Conquista. Marta, a quien hemos hecho referencia en el capítulo anterior por su participación como reorganizadora de la Rama Femenina, al igual que las periodistas anteriores, nació en Buenos Aires en 1935 Provenía de una familia cuyos padres habían estado ligados al gobierno peronista desde los primeros tiempos. Su madre, Elena Spinelli de Curone, había participado de la lucha por la ley que consagró los derechos cívicos femeninos llegando a presidir la rama femenina de un comité de la UCR Junta Renovadora ubicado en el centro de la ciudad de Buenos Aires, pero había quedado fuera de la conducción al crearse el Partido Peronista Femenino. Su padre, Tomás Ramón Curone, fue dirigente metalúrgico y secretario administrativo de una unidad básica. Marta se inició en las filas de la Agrupación Juvenil Justicialista Argentina (AJJA) para pasar a integrar, en 1952, las filas de la UES, llegando a ser secretaria general de la rama femenina de dicha organización, cargo que desempeñó durante todo el año de 1953 siendo ya estudiante de primer año de la carrera de Abogacía. A comienzos de 1954, tuvo su primer contacto con la actividad periodística editando un periódico que se tituló La Gaceta del Norte, de breve duración. Tras la Revolución Libertadora, se integró a la Juventud Peronista que dirigía Alberto De Morra, que era de carácter mixto; una agrupación que había nacido al calor del gobierno peronista en 1951 y que continuó trabajando durante un tiempo muy breve en la clandestinidad, vinculada a la figura de John William Cooke. En esa organización se desempeñó en actividades de prensa y propaganda. En enero de 1956 fue detenida junto con sus padres por salir a la calle a gritar en defensa del peronismo durante los días en que tuvo lugar el golpe de Estado, sufriendo un arresto de quince días en la cárcel de Humberto Primo de Capital Federal. En abril de 1956 volvió a estar detenida, esta vez en la cárcel de Olmos y luego, nuevamente en el penal de Humberto Primo, durante cuatro meses. Fuera de la cárcel, a fines de 1957 comenzó a participar en la organización del Partido Blanco, vinculado a la figura de Alejandro Olmos, al que se incorporó como parte de la Juventud y en el área de prensa y propaganda. Por esos años, también integró el Movimiento Sindical Universitario (MSU) en la facultad de Derecho de la Universidad de Buenos Aires. A comienzos de la década del '60, se incorporó al Consejo Coordinador del Movimiento Peronista componiendo la Comisión Femenina de una Secretaría de la Juventud. Desde entonces, estuvo ligada a la reorganización de la rama femenina del Partido Justicialista. 
Con la destitución de Delia Parodi en 1966, continuó formando parte de los intentos por crear una estructura femenina partidaria que se proponía ocupar el lugar del viejo PPF. A mediados de los '60 mantuvo vinculaciones con el MRP y, a fines de 1965, formó parte de los intentos por crear una Federación de Mujeres Peronistas, de breve duración, que estuvo alineada con las 62 Organizaciones de Pie Junto a Perón. En 1966, se integró a la Rama Femenina del PJ presidida por Mabel Di Leo.

El boletín Conquista contaba con cuatro páginas escritas a máquina. Era un boletín partidario y muy rudimentario. Representaba a las mujeres de la Circunscripción 18 de Capital Federal, que correspondía al barrio de Palermo, donde Curone militaba. Su objetivo era convocar a las mujeres a formar parte de la reorganización partidaria que el peronismo había comenzado en agosto de 1963, luego de la abstención y dispersión de los votos peronistas en las elecciones que consagraron presidente de la Nación a Arturo Illia en julio de ese año. En sus páginas se publicaban llamados a la participación política en el Partido Femenino, pautas para concretar la reorganización del mismo, actividades a las que estaba vinculado el grupo de mujeres de la circunscripción 18 -entre las que se encontraban Josefina Testa, Leticia Merlo, Diana Pareja y Nélida Mateo-, y críticas a otros sectores femeninos del peronismo.

Entonces, las tres directoras de los periódicos que analizaremos -Nora Lagos, María Granata y Marta Curone- presentan distintas trayectorias en sus vínculos con el periodismo en general y el político, en particular. Todas estuvieron vinculadas a la actividad periodística durante los años del gobierno peronista; en los dos primeros casos de manera más sistemática y profesional que en el de Curone. Vale decir, retomando las ideas de Tilly, encontramos una vez más la puesta en práctica de experiencias previas al servicio de una acción que modificar el nuevo contexto político. El conocimiento periodístico, mayor o menor según el caso, no era desdeñable en el marco de la resistencia teniendo en cuenta el papel de la prensa como organizadora de ciertas prácticas y representaciones así como del discurso confrontativo.

\section{Intervenciones polémicas en un contexto proscriptivo}

Producido el golpe de Estado en 1955, el gobierno de la Revolución Libertadora declaró el establecimiento de la libertad de prensa, ya que la falta de pluralidad era una de 
las críticas principales de quienes impulsaron el derrocamiento del gobierno peronista. Sin embargo, en la práctica, se mantuvo una actitud persecutoria sobre una prensa que era favorable a ese gobierno, y que se expresó en detenciones de periodistas y el secuestro y destrucción de ejemplares. En Soberanía, el periódico dirigido por Nora Lagos, se hace referencia al carácter legal del diario y a la estrategia de censura a posteriori que contribuía al desfinanciamiento de los emprendimientos editoriales, al secuestrar los ejemplares una vez que ya estaban en circulación. ${ }^{223}$ Ehrlich (2010) ha llamado la atención sobre el hecho de que estas publicaciones se imprimían en imprentas profesionales, no clandestinas. La Argentina y Soberanía lo hacían en la imprenta de Duchain, única que se animaba a imprimir diarios peronistas; según Sobrino Aranda, con más interés comercial que político. Además, sostiene que estos periódicos eran legales, que se colgaban en los kioscos. ${ }^{224}$ En la portada de Soberanía, Sobrino Aranda figura como propietario, y tanto para el caso de Soberanía como de La Argentina, el número de propiedad intelectual, y las direcciones de redacción, que además eran los domicilios de residencia de Nora Lagos. ${ }^{225}$

Si la prensa de oposición no era ilegal en sí misma, dónde residían las causas que fundamentaban su censura. El decreto 4161 emitido por el Poder Ejecutivo Nacional en marzo de 1956, una disposición legal que prohibía el uso de los símbolos peronistas, inclusive nombrar a sus líderes, se convirtió en un emblema de la represión ejercida por el gobierno sobre los militantes a nivel de lo cotidiano. Sin embargo, dicha disposición, a la vez que se constituyó en un límite que invitaba a ser transgredido, contribuyó a reafirmar la identidad peronista. (Salas, 2006 [1990]; Scoufalos, 2007). La censura de estos periódicos solía hacerse en función de la violación de ese decreto, por eso se ha hablado del carácter de semiclandestinidad de los mismos. ${ }^{226}$ Las estrategias para burlarlo muchas veces se convirtieron en elementos de provocación más que de disimulo.

El contexto de emergencia no es el mismo para todos los periódicos. La Argentina hizo su aparición a mediados de diciembre de 1955, es decir, poco después del golpe de

\footnotetext{
${ }^{223}$ Un artículo denuncia que Bertelli y Sobrino Aranda habían sido detenidos en Buenos Aires por promocionar el periódico, porque en esa ciudad se pensaba que era ilegal, pero luego los habían liberado. Soberanía $\mathrm{N}^{\circ}$ 12. Rosario, 16 de abril de 1957, p. 2. Además, Soberanía № 33. Rosario, 19 de octubre de 1957, p 1. Soberanía No 34. Rosario, 4 de noviembre de 1957, p. 2.

${ }^{224}$ Sobrino Aranda. Entrevista de la autora. 12 de noviembre de 2014

${ }^{225}$ Sobrino Aranda. Entrevista de la autora. 12 de noviembre de 2014. Testimonio de Norah Mascías, Norah; Mascías, Patricia y De Sanctis, Oscar. Entrevista de la autora, 1 de septiembre de 2011.

${ }^{226}$ Liliana Da Orden y Julio César Melon Pirro (2007) hablan de la existencia de diferentes grados de censura. Por su parte, Melon Pirro (2007), hace referencia al decreto 4161, que aunque no versaba sobre la libertad de prensa, inhibió su circulación y limitó las posibilidades de lo que podía publicarse en relación al peronismo.
} 
Estado y ya con Aramburu en la presidencia. Se trató de un marco poco favorable por lo que fue rápidamente censurado junto con otros periódicos de tendencia peronista que habían surgido en ese momento. Es el derrocamiento del peronismo y la propia situación desfavorable lo que les otorga a los realizadores de estos periódicos una causa para lanzarse a la acción colectiva, a la vez que el gobierno y las clases dirigentes se convierten en un blanco común de ataque. En cambio, Soberanía inicia su publicación hacia fines de 1956 durante la convocatoria a elecciones constituyentes, donde se observa cierta apertura política; aunque el periódico y su directora no estuvieron libres de sufrir persecuciones.

Línea Dura hizo su aparición un año después, a fines de 1957, en el marco de una nueva convocatoria electoral, esta vez, para la elección de presidente de la Nación. Entonces, era visible la ruptura de la alianza que había posibilitado el triunfo de la Revolución Libertadora. El triunfo de los votos en blanco en las elecciones de julio había demostrado que el peronismo se mantenía como una fuerza política importante y como identidad que prevalecía en amplias capas de la sociedad. El éxito del votoblanquismo, haya respondido o no a una breve e intensa campaña lanzada por la alta dirigencia peronista, deslegitimaba al gobierno de la Revolución Libertadora.

La emergencia de Conquista, por su parte, responde a un contexto totalmente diferente. Emergió en los primeros meses de la presidencia de Arturo Illia, quien había derogado el decreto 4161 y los decretos que lo habían reactualizado durante el gobierno de José María Guido. Dentro del universo peronista, los sectores gremiales constituían un factor de poder que ni los gobiernos ni las otras fuerzas que componían el peronismo podían obviar a la hora de pensar una agenda política. En este marco, y luego de un proceso electoral en que el sector político del peronismo quedó debilitado, Conquista apareció como un órgano que aspiraba a promover la organización partidaria femenina, y cuyo enemigo no sería el gobierno sino los sectores sindicales que arriesgaba la autonomía de dicho proceso de reorganización y las mujeres que estaban ligadas a esos sectores.

En La Argentina y Soberanía, la figura de su directora está muy presente en el contenido de sus páginas, pese a que contaba con un equipo de colaboradores que incluso se hizo cargo de que la segunda publicación continuara saliendo durante su encarcelamiento y exilio, y de que no todos los artículos eran escritos por ella. A través de las páginas de estos periódicos puede seguirse el derrotero sufrido por Nora Lagos en el clima represivo que caracterizó a la Revolución Libertadora. Así, la primera plana de La Argentina del 31 de diciembre de 1955 contaba con un titular que se preguntaba: “¿Dónde está Nora 
Lagos?". ${ }^{227}$ El editorial aparecía en blanco con una pequeña nota al pie que denunciaba de forma irónica la persecución policial a quien difundiera notas que pudieran atentar contra la seguridad del gobierno. Por ello, como el editorial iba a tratar sobre la situación de los obreros, habían decidido publicarlo en blanco. ${ }^{228}$ Los artículos denunciaban que Lagos había sido secuestrada de su domicilio por fuerzas de la gendarmería sin mediar orden de detención y no podía ubicarse su paradero. Se decía que funcionarios policiales se habían acercado a su domicilio para retirar ropa, a pesar de que su detención era negada en distintas jurisdicciones policiales y del ejército, y se anunciaba una concentración de grupos de obreros que reclamaría ese mismo día una investigación para encontrarla y reclamar su consecuente liberación. $^{229}$ No se sabe con exactitud cuándo fue liberada, pero datos testimoniales afirman que al momento de producirse el levantamiento cívico militar del 9 de junio de 1956 encabezado por el Gral. Valle, ya estaba en libertad. ${ }^{230}$

La publicación de Soberanía comenzó en diciembre de 1956 y para mayo del año siguiente Nora Lagos fue nuevamente detenida por infracción al decreto 4161. La sección "Nuestra bruja predice" del 21 de mayo de 1957, aparece en blanco, sólo con el logo que la identificaba, una bruja, y un recuadro que comunicaba la solidaridad de los compañeros del periódico con su directora encarcelada. Este hecho era concebido como una violación a la libertad de prensa. ${ }^{231}$ Por otro lado, el titular decía: "Pídese proceso a Nora Lagos" y, a continuación, un artículo que denunciaba su detención se titulaba 'No violó el 4161 que se le imputa”. Al parecer, las causas del arresto habían sido la publicación, en el número anterior, de una foto del velatorio de Eva Perón, donde entre el público presente se encontraba el entonces presidente general Pedro Eugenio Aramburu. Las causas aducidas del arresto habrían sido que en la foto se veía a Perón y el ataúd de la Primera Dama, ante lo cual el periódico se excusaba, no sabemos si ingenua o irónicamente, diciendo que la foto no violaba dicho decreto porque el objetivo era mostrar a Aramburu y que en ningún momento se había intentado hacer propaganda del "régimen depuesto". Además, se

\footnotetext{
${ }^{227}$ La Argentina $\mathrm{N}^{\mathrm{o}}$ 8. Rosario, 31 de diciembre de 1955.Según Carina Capobianco (2003), que también hace referencia a ese titular, ese número es el último que se publicó. En el mismo dos artículos hacían referencia a su desaparición: "Autoridades manifiestan desconocer su paradero" y "Se denunció desconocer su posible secuestro".

${ }^{228}$ La Argentina $\mathrm{N}^{\circ} 8$. Rosario, 31 de diciembre de 1955.

${ }^{229}$ La Argentina $\mathrm{N}^{\circ}$ 8. Rosario, 31 de diciembre de 1955.

${ }^{230}$ Testimonio de Norah Mascías, Norah; Mascías, Patricia y De Sanctis, Oscar. Entrevista de la autora, 1 de septiembre de 2011.

Permaneció seis meses en la cárcel, por lo que la liberación se habría concretado en algún momento de junio, ya que había sido detenida en diciembre. Soberanía $\mathrm{N}^{\mathrm{o}} 1$. Rosario, 17 de diciembre de 1956.

${ }^{231}$ Soberanía $\mathrm{N}^{\circ} 17$. Rosario, 21 de mayo de 1957, p. 2.
} 
criticaba el hecho de que otro periódico, Resistencia popular, dirigido por el político radical, Raúl Damonte Taborda, había publicado una foto similar, pero no se habían iniciado acciones en su contra. ${ }^{232}$ A partir de ese momento, Nora permaneció detenida en una comisaría en San Justo, hasta que emprendió el exilio a Paraguay dos meses más tarde.

El 22 de julio de 1957, Soberanía se manifestaba contra el mantenimiento en las cárceles de presos políticos, a pesar de que el 29 de junio de ese año había sido levantado el estado de sitio, ya que el gobierno había convocado a elecciones constituyentes para el 28 de julio. ${ }^{233}$ El artículo denunciaba la invención de causas a los presos políticos, que habrían sido iniciadas con posterioridad a las detenciones. Así, Nora Lagos, que anteriormente había sido acusada de violar el decreto 4161, ahora era demandada en una causa por enriquecimiento ilícito. Se señalaba, especialmente, la detención de periodistas. Según Soberanía, esto era una argucia del gobierno para evitar que dichos periodistas hicieran propaganda por el voto en blanco, puesto que esta alternativa perjudicaba especialmente al gobierno, ya que le quitaba legitimidad a sí mismo, a las elecciones y a la constitución que saliera de la convención constituyente. ${ }^{234}$

Durante la detención y exilio de Lagos, Soberanía siguió publicándose a cargo de Sobrino Aranda, pero a fines de julio se produjo su desvinculación del periódico y comenzó a aparecer como editor Fausto Eduardo López, rol que también había cumplido René Bertelli, que ahora estaba detenido junto con Nora. ${ }^{235}$ A partir del número 34, del 4 de noviembre de 1957, sólo figura el nombre de Lagos en la dirección, que nunca dejó de aparecer, y suponemos que esta fecha coincide con su retorno al país tras la convocatoria a elecciones presidenciales, lo que implicaba un cambio en las reglas del juego político y un relativo relajamiento de la persecución que regía sobre los militantes peronistas.

Línea Dura es menos explícito a la hora de ofrecer información sobre su directora. Pese a que María Granata sostiene haber escrito la mayoría de los artículos, se trató de una iniciativa menos personalista que los emprendimientos editoriales de Lagos. Línea Dura tenía una relación muy estrecha con el Comando Táctico y, por lo tanto, con personalidades de la alta dirigencia peronista vinculados a las estructuras partidarias. Durante los primeros

\footnotetext{
${ }^{232}$ Soberanía $\mathrm{N}^{\circ}$ 17. Rosario, 21 de mayo de 1957, p. 2.

${ }^{233}$ Soberanía $\mathrm{N}^{\circ}$ 22. "Procesan a periodistas para evitar la campaña del voto en blanco". Rosario, 22 de julio de 1957.

${ }^{234}$ Otros ejemplos donde se denuncia o se menciona el encarcelamiento de Nora Lagos son: Soberanía $\mathrm{N}^{\circ}$ 17. 21 de mayo de 1957, p.1. Soberanía $\mathrm{N}^{\circ} 22$, 22 de julio de 1957, p. 2.
} 
diez números salió con el nombre de Nélida Valdez en la dirección. No sabemos si era un nombre inventado o si alguien lo prestó, lo cierto es que era una estrategia para protegerse de la censura. El seudónimo femenino probablemente haya respondido a la idea de que un nombre de mujer eludiría más fácilmente la censura. El número 11, del 10 de marzo de 1958, marca un cambio en dos sentidos. Por un lado, la directora aparece con su nombre verdadero. Por otro, el editorial sostenía: “'Línea Dura' es Desde Este Número el Órgano del Movimiento", y publicaba una directiva de Perón que certificaba este rol del semanario, junto con un informe donde se atacaba a otras publicaciones, sin nombrarlas, que habían quedado disconformes con la orden que indicaba el voto por Frondizi o que habían dudado de su autenticidad y a las que se acusaba de neoperonistas. ${ }^{236}$ Sin duda, este cambio en el nombre de la directora y en la forma de autopresentación del semanario respondía al comienzo de una nueva etapa caracterizada por una merma en la censura o en la creencia de que ello ocurriría, a partir de las elecciones del 23 de febrero de 1958 que le habían dado el triunfo a Frondizi; de hecho, el número 11 es el primer número que se imprime con posterioridad a esas elecciones. Además, los actores políticos que estaban detrás de Línea Dura habían estado estrechamente vinculados a la firma del acuerdo con Frondizi, y el triunfo de este candidato les otorgaba cierta legitimidad, o al menos ellos así lo consideraban, para convertirse en disciplinadores de las corrientes dispersas del peronismo y jerarquizarse respecto de los sectores que se habían opuesto a la orden de Perón, ya que el triunfo del candidato de la UCRI les daba la razón en la postura que sostenían puesto que el mismo había sido posible gracias al voto de las bases peronistas.

En este marco, la figura de María Granata queda desdibujada, pese a su intensa participación como redactora. No hay frases autorreferenciales. En ocasiones, vislumbramos la emergencia de una enunciadora femenina que se inserta en un colectivo de identificación con una posible lectora mujer o con una entidad más amplia como el "pueblo" o las "mujeres del pueblo", pero no hay una identificación entre ese enunciador discursivo y un autor real, en este caso Granata, como lo hay en La Argentina y Soberanía donde el nombre de Nora Lagos, "la directora" o "la dire" aparecen como enunciadores expresándose en primera persona. Sí hay una entrevista a Perón y otra a John William

\footnotetext{
${ }^{235}$ Sobrino Aranda sostiene que su alejamiento de la redacción de Soberanía estuvo vinculado a la finalización de su relación de pareja con Nora Lagos y que a partir de ese momento se abocó a su propia publicación, Palabra Prohibida. Sobrino Aranda. Entrevista de la autora. 12 de noviembre de 2014.

${ }^{236}$ Línea Dura No 11. “'Línea Dura' es Desde Este Número el Órgano del Movimiento”, Buenos Aires, 10 de marzo de 1958, p.1.
} 
Cooke, firmadas por Granata, y fotos del viaje a República Dominicana que muestran a la escritora con Perón y con otros miembros de la delegación; pero constituyen una de las escasas instancias en que hay referencias a su función de directora del periódico. ${ }^{237}$

En el caso de Conquista, tampoco encontramos referencias sobre la trayectoria de su directora, aunque poseemos abundante información a través de su archivo personal a partir del cual hemos basado gran parte del contenido del capítulo II y puede hallarse información al respecto en el mismo. Los números 2 y 3 salieron con la firma de Marta Curone, no así el primero. Se presentaba como un boletín de las mujeres de la circunscripción 18, y había un grupo de otras mujeres que trabajaban con Marta en su misma línea política, pero el boletín estaba completamente a cargo de ella. La característica que tiene este periódico, a diferencia de los anteriores, es que fue hecho en su totalidad por una mujer y estuvo dirigido específicamente a un público femenino, con un objetivo político que afectaba particularmente a las mujeres peronista, como era la reorganización del Partido Femenino. Barry (2010) da cuenta de la existencia de un periódico llamado Conquista, que era el órgano oficial del PPF publicado durante los últimos meses del gobierno peronista. ${ }^{238}$ Probablemente la elección del nombre en del periódico que estamos analizando haya respondido a una estrategia de buscar legitimidad en una publicación previa de carácter oficial, por parte de mujeres que tenían intereses de capitalizar el proceso de rearmado de la Rama Femenina. ${ }^{239}$ El segundo Conquista emergió durante el gobierno de Arturo Illia, y la fugacidad de su aparición estuvo vinculada con las disputas internas del peronismo y la falta de apoyo de Perón, más que con la represión ejercida por el gobierno, como sí sucedió en el caso de los otros periódicos. Por otro lado, se trató de un órgano de difusión interna al partido.

Los cambios en la estructura de oportunidades, en especial en los niveles de represión, acceso a la participación política y disponibilidad de aliados, influyeron de manera decisiva en los nudos polémicos que desarrollaron estas publicaciones. Por un lado, pueden

\footnotetext{
${ }^{237}$ En la portada del número 35, María Granata aparece fotografiada junto a Perón en una entrevista que le hizo al mismo en Ciudad Trujillo. Línea Dura $\mathrm{N}^{\circ}$ 35. Buenos Aires, 21 de agosto de 1958. En el número siguiente, la primera página presenta una fotografía de la directora junto a John W. Cooke e integrantes del Comando Táctico Peronista en el contexto de lectura y discusión de una orden de Perón que decidía disolver dicho Comando ante el cambio de panorama que implicaba el retorno democrático. Línea Dura $\mathrm{N}^{\mathrm{o}} 36$. Buenos Aires, 28 de agosto de 1958.

${ }^{238}$ Su primer número data de mayo de 1955 y su directora era Amelia Monti. (Barry, 2010).

${ }^{239}$ Vimos en el capítulo anterior que en los primeros años de la Resistencia hubo una tendencia a recuperar nominaciones del período anterior. De hecho, hubo un periódico llamado Voz Femenina, referido en páginas anteriores, que también invocaba un nombre de otrora. Según Barry (2010), Voz Femenina apareció muy poco tiempo en 1954 como órgano no oficial del PPF.
} 
observarse diferencias entre una publicación y otra, en función del contexto político en el cual emergieron, a la vez que cada una de ellas sufrió variaciones discursivas con el transcurso del tiempo. La Argentina y Soberanía sostuvieron una línea editorial de franca oposición al gobierno de la Revolución Libertadora y al sistema liberal de partidos políticos, aunque hubo una diferencia de apreciación entre el gobierno de Lonardi y el de Aramburu, que fue muy marcada en el primero de los periódicos. Otro de los blancos de ataque que compartían todos los periódicos peronistas de la época eran, la oligarquía terrateniente, el imperialismo británico y el sistema tradicional de partidos, incluidos los partidos socialista y comunista. Pero había algunas diferencias que estaban determinadas por la forma en que cada periódico se ubicaba en la interna peronista y por los cambios coyunturales en el contexto político.

Al momento de publicación de La Argentina, el enemigo puede sintetizarse en la figura del antiperonismo, pero para el momento de emergencia de Soberanía, comienza a hacerse presente el enemigo interno. En diciembre de 1956, momento de emergencia de éste último periódico, estaba llevándose a cabo el empadronamiento para las elecciones constituyentes que tendrían lugar en julio del año siguiente. En ese contexto, Soberanía desplegó sus críticas contra sectores que como Arturo Jauretche propiciaban un acuerdo del peronismo con la UCRI y los dirigentes peronistas que auspiciaban sus propias candidaturas a través de partidos neoperonistas, como la Unión Popular dirigida por Atilio Bramuglia y el Partido Populista de Vicente Saadi. Desde Soberanía se fomentó el voto en blanco; postura que se mantendría posteriormente para las elecciones presidenciales de febrero de 1958. El último número de Soberanía, del 26 de febrero de ese año, publicado en el marco del triunfo electoral de Arturo Frondizi, continuaba sosteniendo la falsedad de la orden de Perón acerca de votar por el candidato de la UCRI. ${ }^{240}$ Este número estará dedicado a restarle méritos al triunfo frondizista, destacando el aporte peronista. ${ }^{241}$ Además, Soberanía mantuvo una disputa con el Comando Táctico, la estructura promotora del pacto con Frondizi, que según se desprende de las páginas del periódico, acusaba a Nora Lagos de

\footnotetext{
${ }^{240}$ Soberanía $\mathrm{N}^{\mathrm{o}}$ 41. Rosario, 26 de febrero de 1958. "Nuestra Directora exige explicaciones". A diferencia de otros periódicos como Rebeldía que fueron cambiando su opinión respecto de la orden pasando de considerar su falsedad a sostener que Perón había sido forzado a emitirla. Rebeldía. $\mathrm{N}^{\circ} 26$. Buenos Aires, 15 de enero de 1958. Rebeldía. $\mathrm{N}^{\circ}$ 27. Buenos Aires, 22 de enero de 1958. Rebeldía. $\mathrm{N}^{\circ} 31$. Buenos Aires, 15 al 19 de enero de 1958.

${ }^{241}$ Algunos de los titulares son: "Cuidado A. Frondizi", título del editorial, y "No se maree con el triunfo". Soberanía $\mathrm{N}^{\mathrm{0}}$ 41. Rosario, 26 de febrero de 1958
} 
haber recibido dinero del candidato de la UCR del Pueblo, Ricardo Balbín, para fomentar la campaña por el voto en blanco. ${ }^{242}$

Línea Dura respondía a la línea política que le imprimía Ramón Prieto, que era la del pacto con Frondizi. Prieto, Castiñeira de Dios y María Granata eran integrantes del Comando Táctico, una estructura ligada a la figura de John William Cooke, ya analizada en el capítulo II, que fue la encargada de transmitir la orden de votar por el candidato de la UCRI y, cuyas pretensiones luego del triunfo de este último, fue canalizar las fuerzas dispersas del peronismo en el proceso de normalización que se suponía sobrevendría luego del retorno democrático. De esta manera, Línea Dura se posicionó como la voz de la ortodoxia, es decir, de la línea seguida por la conducción del peronismo durante el tiempo que duró el mandato de John William Cooke como delegado de Perón. Así, a la polémica que el semanario mantuvo con los sectores antiperonistas, se sumó la disputa interna por ganar espacios de poder en el propio peronismo que se sintetizaron, por un lado, en críticas a las publicaciones que no confiaron en la autenticidad de la orden de Perón de votar por Frondizi o que, directamente, decidieron no obedecerla; y por otro, en cuestionamientos a los dirigentes políticos que la desconocieron o incluso presentaron sus propias candidaturas y a los sectores que luego del triunfo frondizista se negaron a colaborar, lo que implicaba un abandono de las actividades de oposición desestabilizadoras. Entre los periódicos figuraban Palabra Argentina, Rebeldía y El Hombre. ${ }^{243}$ En cuanto a dirigentes que habían conformado partidos neoperonistas, hay una gran cantidad de artículos denunciando la traición de sus líderes al movimiento. ${ }^{244}$ Entre ellos estaban Alejandro Olmos, director de la mencionada Palabra Argentina e impulsor del Partido Blanco, que se bajó de las elecciones por no obtener el apoyo de Perón; Atilio Bramuglia, ex ministro de relaciones exteriores entre 1946 y 1949, con su partido Unión Popular; y Vicente Saadi, que había sido senador durante el primer gobierno peronista y ahora dirigía el Partido Populista. También, se critica

\footnotetext{
${ }^{242}$ Soberanía No 41. "Nuestra Directora exige explicaciones". Rosario, 26 de febrero de 1958.

${ }^{243}$ Palabra Argentina era dirigida por Alejandro Olmos. Optó por la estrategia neoperonista, a través de la presentación de un partido propio, el Partido Blanco, que a último momento fue retirado de la candidatura por no recibir el apoyo de Perón (Melon Pirro, 2007). Rebeldía, ligada al cura Hernán Benítez, mantuvo una férrea oposición al voto a Frondizi sosteniendo que Perón había sido engañado por los altos dirigentes peronistas, entre ellos Cooke. El Hombre, era tendencia trotskista, pero no hemos accedido a ningún número (Ehrlich, 2010). Línea Dura $\mathrm{N}^{\circ}$ 13. "Titulándose peronista está al servicio de nuestros enemigos". Buenos Aires, 24 de marzo de 1958, p. 2; Línea Dura $\mathrm{N}^{\circ}$ 11. "Coro de Arpías". Buenos Aires, 10 de marzo de 1958, p. 4; Línea Dura N 12. "Los votos en blanco". Buenos Aires, 17 de marzo de 1958, p. 2.

${ }^{244}$ Línea Dura $\mathrm{N}^{\circ}$ 11. "Saldo de Judas". Buenos Aires, 10 de marzo de 1958, p. 2; Línea Dura ํㅜ 12. "Alejandro Olmos desenmascara su antiperonismo". Buenos Aires, 17 de marzo de 1957, p. 4; Línea Dura No 13. "Plan de desesperación gorila". Buenos Aires, 24 de marzo de 1958, p. 1.
} 
a Alejandro Leloir, ex presidente del Consejo Superior del Partido Peronista en los últimos meses del gobierno de Perón. ${ }^{245}$ La condena por el voto en blanco o por la participación en las elecciones con partidos propios estuvo dirigida a los altos sectores del movimiento y no a las bases, a las que el periódico perdonó por considerarlas víctimas del "confusionismo" generado por esos dirigentes. ${ }^{246}$ Un tercer núcleo polémico se entabló con algunos comandos de la Resistencia que no querían abandonar las actividades de tipo insurreccional, lo cual, según el semanario, ponía en peligro el traspaso de poder, y luego, una vez que Frondizi asumió la presidencia, la estabilidad necesaria para evitar una nueva intervención de las Fuerzas Armadas que hiciera más lejano el levantamiento de la proscripción sobre el Partido Peronista, el retorno de Perón y el acceso al gobierno.

Conquista nació como parte del proceso de reorganización de la rama femenina que comenzó en la segunda mitad de 1963, impulsado por un grupo de mujeres del sector femenino del Partido Justicialista. El objetivo de este grupo de mujeres era construir en su circunscripción, la 18, del barrio de Palermo de Capital Federal, un núcleo femenino fuerte para participar de manera organizada en las elecciones internas de 1964 con el objetivo de acceder a cargos de conducción en el PJ. Su emergencia, a fines de 1963 y comienzos de 1964, coincidió con el momento en que el Cuadrunvirato, la Comisión Interventora creada por Perón en agosto de 1963 para hacerse cargo de la normalización del partido y de la rama gremial, donde hubo una presencia significativa de representantes vinculados a Andrés Framini y al MRP (Movimiento Revolucionario Peronista), fue reemplazada por el Heptunvirato, de predominio vandorista. Además, concuerda con el comienzo del planteo de la posibilidad de un retorno de Perón, cuestión que marcaría la agenda de todo el año 1964, en que distintos sectores del peronismo se disputaron la conducción y el modo que debería adoptar dicho retorno. Mientras que los vandoristas promovían la vía pacífica, el MRP se inclinaba por la vía insurreccional. En este contexto, Conquista defendió la independencia de la Rama Femenina respecto de los otros dos sectores del movimiento, la rama política y la sindical, y cuestionó enfáticamente la inclinación de las mujeres del partido por determinados sectores sindicales y la intromisión de estos últimos en la reorganización partidaria femenina. Sus críticas estuvieron dirigidas al grupo de mujeres que

\footnotetext{
${ }^{245} \mathrm{Al}$ igual que Olmos, Saadi retiró su candidatura. Estos dos políticos y Leloir promovieron el voto en blanco, mientras que Bramuglia sí se presentó a elecciones con la Unión Popular.

${ }^{246}$ Todos los dirigentes mencionados fueron expulsados del peronismo en una orden del Comando Táctico, que el semanario se encargó de publicar, entre quienes figuraba también, Elsa Chamorro, una ex legisladora
} 
encabezaba Nélida De Miguel, de inclinación vandorista. Pese a ello, el periódico evidenciaba cierta inclinación por el MRP y por los sectores vinculados a Framini.

A través de sus páginas, estos periódicos nos brindan información sobre sus condiciones de producción y circulación y sobre sus posibilidades de existencia, en general, en un contexto caracterizado por restricciones para la participación política e, incluso, conflictos entre las líneas internas. Sus interpelaciones, asimismo, son moldeadas por ese contexto y, a su vez, buscan modificarlo -con éxito variable. En este sentido, la intervención discursiva resulta una herramienta central para el peronismo en el contexto de oportunidades políticas que, incluso restrictivo, no puede evitarla. Ahora bien, como señalamos, la posibilidad de su intervención discursiva no está sólo vinculada al nivel de permisividad del sistema político ni a la disposición de recursos (factores que pueden explicar el fin de La Argentina), sino que también se conecta con la relación de fuerzas internas en el peronismo, y muchas veces la interrupción de estas publicaciones tiene que ver más con esas fuerzas internas tal como hemos visto en el caso de Línea Dura y Conquista. Asimismo, aunque no en todos los casos se aprecia la incidencia, en el de Conquista actúan, además, elementos vinculados a las relaciones de poder en clave de género en tanto este periódico está intentando organizar a las mujeres con criterios distintos de los que predominan en la cúpula dirigente en ese momento.

\section{Tejiendo redes}

En este apartado, estableceré el entramado que posibilitó la intervención a través de la prensa, en especial, las relaciones sociales que sustentaron la publicación (entendiendo al financiamiento como parte de ella), cómo esta prensa sirvió, también, para difundir una imagen de los actores inscriptos en esas relaciones (en algunos casos más exaltadas por la propia dirección del medio) y cómo construyeron la imagen que intentaron transmitir.

La realización de La Argentina y Soberanía tuvo un carácter localista y apeló a la colaboración de los pobladores de Rosario. Se financiaban, en parte, mediante la venta y, en gran medida, dependían de pequeños donativos que los vecinos acercaban al local de la imprenta, por lo general, gente de extracción social trabajadora, aunque también algunos de 
clase alta, como se reconocía en las propias páginas de Soberanía. ${ }^{247}$ Juan Manuel Vigo (1973) sostiene que en el caso de La Argentina, se intentó que fuera financiada por una estructura clandestina, el Frente Emancipador de Santa Fe, pero ello no pudo concretarse. Según Sobrino Aranda este periódico era financiado por Nora y Hugo Mac Dougall, que conservaban acciones de La Capital. ${ }^{248}$ Había poca publicidad, en general de pequeños negocios de la ciudad, y adhesiones particulares, de obreros de algún sindicato o empresa, de vecinos de alguna calle en particular o de barrios de Rosario e incluso algunas que llaman la atención, como la "Barra del café de la calle San Juan", un grupo de Boys Scout o "varias amas de casa". ${ }^{249}$ Además, se recibían donaciones con alimentos para los redactores y colaboración en forma de trabajo en la propia imprenta, ayudando, fundamentalmente, a doblar los periódicos, distribuirlos o en tareas accesorias como ir al almacén a comprar comida. $^{250}$ Sobrino Aranda recuerda que trabajaban permanentemente cuatro o cinco personas en la elaboración de los periódicos y el resto eran conocidos de Nora, vecinos, gente de Rosario que se acercaba a trabajar a la imprenta Duchain. ${ }^{251}$ Desde los periódicos se convocaba a la gente a que actuaran como corresponsales, enviando noticias y artículos. ${ }^{252}$ Las colaboraciones se agradecían constantemente y ello contribuía a consolidar la imagen de medios populares en permanente relación con "el pueblo", cuyas necesidades apuntaban a reflejar. Esta modalidad encuentra un antecedente en la época en que Nora dirigía La Capital: las oficinas del diario servían como espacio de recepción de personalidades políticas del peronismo que visitaban la ciudad de Rosario y, también, de los vecinos de la ciudad o grupos de personas nucleados en alguna entidad, que se acercaban para llevar sus reclamos a fin de que fueran publicados. ${ }^{253}$

Las publicaciones pretendían posicionarse como medios de difusión obreros, aunque contaban con una columna universitaria y en las cartas de lectores se percibe público de otras extracciones sociales e incluso se canalizaban demandas que excedían a la clase

\footnotetext{
${ }^{247}$ Soberanía $\mathrm{n}^{\circ}$ 3. Rosario, 1 de enero de 1957, p. 4.

${ }^{248}$ Sobrino Aranda, Luis. Entrevista de la autora. Rosario, 12 de noviembre de 2014.

${ }^{249}$ La Argentina. $\mathrm{N}^{\circ}$ 8. Rosario, 31 de diciembre de 1955, p. 4. La Argentina. $\mathrm{N}^{\circ}$ 6. Rosario, 24 de diciembre de 1955, p.1.

${ }^{250}$ Algunos ejemplos pueden observarse en La Argentina $\mathrm{N}^{\circ}$ 2. Rosario, 10 de diciembre de 1955, p. 1. La Argentina. $\mathrm{N}^{\circ}$ 3. Rosario, 13 de diciembre de 1955, p. 2. La Argentina $\mathrm{N}^{\circ} 4$. Rosario, 17 de diciembre de 1955 , p. 1 y Soberanía $\mathrm{N}^{\mathrm{o}} 4$. Rosario, 8 de enero de 1957, p. 3.

${ }^{251}$ Sobrino Aranda, Luis. Entrevista de la autora. Rosario, 12 de noviembre de 2014.

${ }^{252}$ Soberanía. № 8. Rosario, 19 de marzo de 1957, p. 1.

${ }^{253}$ Por ejemplo, una foto retrata una delegación de jubilados que se había acercado a las instalaciones del diario para reclamar que se cumpliera la ley en el pago de sus haberes. La Capital. Rosario, 4 de febrero de 1953.
} 
trabajadora. $^{254}$ Sin embargo, el discurso estaba atravesado permanentemente por una retórica obrerista y gestos en ese sentido. Así, había una sección gremial, que estaba presente en la mayoría de los periódicos de la Resistencia, cuestión vinculada con el peso que el sindicalismo tenía en ese momento en relación a otras fuerzas del peronismo, convocatorias a los gremios para que enviaran sus demandas a efectos de ser publicadas, ${ }^{255}$ y un consultorio jurídico que salió en La Argentina, a cargo de Sobrino Aranda, que contestaba preguntas de los obreros y los atendía gratuitamente un día de la semana.

Soberanía y La Argentina no estaban relacionados con ningún sindicato en particular. Figuraban muchas adhesiones de obreros, en general, grupos de trabajadores de una determinada fábrica. ${ }^{256}$ Desde los periódicos se intentaba transmitir las problemáticas gremiales y se condenó con énfasis la intervención sufrida por la CGT y los sindicatos, considerada una medida favorable a la penetración del comunismo en la clase obrera. No obstante, el sindicalismo no fue apoyado acríticamente. En el marco de las elecciones del 23 de febrero de 1958, desde el editorial de Soberanía se reclamaba a los sindicatos que pusieran el mismo empeño que habían aplicado en pactar con Frondizi en mantener unido al movimiento obrero y en exigirle al presidente el levantamiento de la proscripción que pesaba sobre el partido y la posibilidad del retorno de Perón. De esta manera se desplegaba una diferenciación entre la dirigencia sindical y las bases obreras con las cuales el periódico se identificaba y a quienes interpelaba. ${ }^{257}$ También, les recordaba a los obreros que no bastaba con los reclamos sindicales, que era necesaria la lucha política. ${ }^{258}$

Se evidencia, asimismo, apoyo entre las publicaciones a través de la denuncia de las detenciones de miembros de los staff de diferentes periódicos y censura y secuestro de ejemplares, a la vez que se hacía publicidad cuando un emergía un nuevo medio de prensa (Ehrlich. 2010). Por ejemplo, a fines de 1955, la revista De Frente se solidarizaba con

\footnotetext{
${ }^{254}$ Por ejemplo una carta de la sección "Escribe el pueblo", firmada por "Los cuatrocientos médicos dejados cesantes en el Hospital Centenario". La Argentina. № 5. Rosario, 21 de diciembre de 1955, p. 3.

${ }^{255}$ Soberanía $\mathrm{N}^{\circ}$ 3, Rosario, 1 de enero de 1957, p. 3. Soberanía $\mathrm{N}^{\circ} 8.19$ de marzo de 1957, p. 3.

${ }^{256}$ Por ejemplo "Obreras y Obreros de Estexa", o secciones dentro de una fábrica, tales como "Obreros y Obreras de Alabera Fábregas y Cía. (sección bolsas)", pero no adhesiones de los sindicatos en tanto que entidades. La Argentina. $\mathrm{N}^{\mathrm{o}}$ 6. Rosario, 24 de diciembre de 1955, p. 1. La Argentina $\mathrm{N}^{\mathrm{o}}$ 8. Rosario, 31 de diciembre de 1955, p. 4.

${ }^{257}$ Soberanía $\mathrm{N}^{\mathrm{o}} 41$. Rosario, 28 de febrero de 1958, p. 1.

${ }^{258}$ Esto se observa en una transcripción literal del periódico Lucha Obrera de la sección "La Opinión Nacional": "Desde las fábricas y los lugares de trabajo se libran los últimos combates [...] El delegado de fábrica y la comisión interna son los últimos baluartes [...] Pero esto sólo no basta. No basta la lucha por el sindicato y la CGT [...] Es indispensable que los trabajadores deben [...] luchar también en lo político en defensa de sus intereses sociales y de su país". "La fábrica y el partido baluartes de la victoria" en Lucha Obrera. 15 de diciembre de 1955. Citado en La Argentina N $^{\mathrm{o}}$ 5. Rosario, 21 de diciembre de 1955, p. 2.
} 
Lagos, denunciando su secuestro, que comparaba con el caso Ingallinella que había tenido lugar durante el gobierno peronista. ${ }^{259}$ Esta solidaridad estuvo muy extendida; tanto en $\mathrm{La}$ Argentina como en Soberanía las denuncias sobre la aparición de nuevos periódicos y sobre la persecución policial que sufrían otros medios eran frecuentes. ${ }^{260}$

En la primera de sus detenciones, Nora Lagos fue trasladada a la penitenciaría de Humberto Primo de la Capital Federal, donde trabó relaciones con mujeres del PPF, ya que en esa cárcel se encontraban detenidas las representantes de la plana mayor del peronismo. ${ }^{261}$ En los periódicos que dirigió durante la Resistencia, se registran algunas denuncias relativas a su disolución y al encarcelamiento de sus dirigentes. ${ }^{262}$ Ya desde $L a$ Capital era común que se informara sobre acontecimientos y actividades de la Rama Femenina y que se recibiera en sus oficinas a las autoridades partidarias provinciales para reuniones con dirigentes. ${ }^{263}$ A pesar de esto y que desde las páginas de La Argentina y Soberanía se abogaba por el levantamiento de la proscripción que pesaba sobre el partido, no hubo trabajo colaborativo con las mujeres de dicha estructura ni una imagen autoreferencial en los periódicos basada en una identidad de género. Más bien se difundió una imagen popular, obrerista; cuestión que desarrollaremos más adelante.

En Linea Dura hubo pedidos de colaboración a los lectores, tanto para la distribución de la publicación como para solventar algunos emprendimientos, como por ejemplo, la reactivación de la Fundación Eva Perón. ${ }^{264}$ Pero no para el financiamiento. A la vez que no contaba con publicidad. A diferencia de las publicaciones rosarinas que mantuvieron una apelación a la clase obrera y recibieron colaboración de grupos de trabajadores pero no de sindicatos, Línea Dura, vinculada, procuró establecer contactos con la alta dirigencia sindical. De hecho, Granata, en una entrevista realizada por Marta Cichero (1992) sostiene

\footnotetext{
${ }^{259}$ De Frente $\mathrm{N}^{\circ}$ 95. Buenos Aires, 9 de enero de 1956. Juan Ingallinella fue un médico rosarino, militante del Partido Comunista que al ser detenido por la policía en junio de 1955 resultó muerto por las torturas. Los responsables fueron condenados pero su cuerpo nunca fue hallado.

${ }^{260}$ En Soberanía se observan relaciones de solidaridad con Palabra Argentina, Consigna y su sucesor Nueva Consigna y Lealtad. Y en el caso de La Argentina, con Política y Políticos y El Federalista.

${ }^{261}$ Luis Sobrino Aranda, que actuaba como abogado de Nora, recuerda los encuentros con las mujeres del Partido en los días de visita, en especial con Juana Larrauri, Delia Parodi y Alicia Eguren; aunque esta última no pertenecía a la estructura partidaria. Sobrino Aranda, Luis. Entrevista de la autora. Rosario, 12 de noviembre de 2014.

${ }^{262}$ En el quinto número de Soberanía se intenta visibilizar la situación de las representantes del PPF, que se encontraban detenidas y bajo la vigilancia de las monjas de la Orden del Buen Pastor, destacándose que algunas lo estaban desde hacía ya catorce meses. Soberanía № 5. Rosario, 14 de enero de 1957, p. 2.

${ }^{263}$ Algunos ejemplos en: La Capital. Rosario, 16 de agosto de 1955. La Capital. Rosario, 1 de septiembre de 1955, p. 2. La Capital. Rosario, 1 de septiembre de 1955, p. 3. La Capital. 3 de septiembre de 1955, p. 4. La Capital. 19 de septiembre de 1955, p. 5.
} 
que los sindicalistas de las 62 Organizaciones financiaban el periódico en su totalidad y se encargaban de su distribución. Además de que en sus páginas, como ya hemos señalado, se publicaban comunicados de la CGT Auténtica y de las 62 Organizaciones. ${ }^{265}$

Pese a que el semanario mantuvo un discurso que particularizó en las mujeres como destinatarias en determinadas secciones y artículos y que abogó por el mantenimiento de una rama femenina en el proceso de reorganización partidaria, no se trató de una publicación sostenida exclusivamente por mujeres. Es probable que la gravitación de algunas mujeres, como su directora y de otras vinculadas al Partido, como Elena Fernícola y, además su administradora, que también era una mujer, Malena Legrand, haya incidido para articular un discurso destinado a un público femenino. Sin embargo, no todas las publicaciones de la Resistencia peronista dirigidas por mujeres particularizaron en ese público. Probablemente, la necesidad de Línea Dura de apelar a las mujeres como lectoras haya residido en sus pretensiones de conducir un proceso de reorganización partidaria que implicaba la reactualización de una rama femenina. Un deseo de perpetuar las viejas estructuras políticas del peronismo en el nuevo contexto, incluía un partido constituido sólo por mujeres, cuya importancia era necesario destacar ante los propios militantes y dirigentes varones que leían el semanario.

Conquista es el único de estos emprendimiento sustentado en relaciones de solidaridad femeninas -las de las dirigentes que integraban la circunscripción 18-, y que estuvo dirigido a un público femenino en su totalidad, al que se intentaba convencer de la necesidad de reorganizarse y pelear como fuerza unificada por lugares en las estructuras de poder del PJ. Al mismo tiempo, establecieron discusiones con otros grupos de mujeres. A raíz de una carta de Marta Curone a Perón sabemos que el financiamiento se realizaba con recursos propios y algunas cosas como tinta, esténciles y papel donado por las propias afiliadas. $^{266}$

\footnotetext{
${ }^{264}$ Línea Dura $\mathrm{N}^{\mathrm{o}} 33$. Buenos Aires, 7 de agosto de 1958, p.p. 1 y 3 y Línea Dura $\mathrm{N}^{\mathrm{o}} 34$. Buenos Aires, 14 de agosto de 1958, p.2

${ }^{265}$ Según Enrique Ninín, desde su nacimiento, Línea Dura estuvo vinculada al pacto Perón Frondizi y fue creada para difundirlo, por lo que el financiamiento habría sido obtenido a través de Rogelio Frigerio. Sin embargo, en los primeros números, la opción frondizista es cuestionada o aparece de manera contradictoria y dubitativa. De todos modos, ello no quita que a partir de algún momento pueda haber habido algún financiamiento producto de aquellas negociaciones. Esta versión no contradice otro financiamiento de las 62 Organizaciones, pues esta estructura participó del pacto. Ninín, Enrique. Entrevista de la autora. Buenos Aires, 31 de agosto de 2012.

${ }^{266}$ Carta de Marta Curone a Perón. Buenos Aires, 1 de marzo de 1964. Archivo Marta Curone.
} 
Las relaciones que sustentaron la existencia de estos periódicos influyen certeramente en los discursos que estipularon en sus páginas. Las mujeres en la prensa que hemos abordado fueron artífices necesarias de esas relaciones y, a su vez, su pluma favoreció una intervención que reflejó aquellos vínculos. En el apartado siguiente, veremos cómo esas relaciones y las pretensiones que tuvieron influyen en la construcción del perfil que cada uno de estos periódicos construyó y en la construcción del pacto de lectura.

\section{Modelizaciones de género en el discurso de la prensa peronista}

Las publicaciones abordadas constituyen un espacio privilegiado para analizar discursos construidos por diferentes grupos que conformaron la Resistencia peronista. Nos interesa analizar el pacto de lectura creado por cada una de estas publicaciones respecto de un público femenino. Es decir, cómo se construyen las imágenes discursivas del enunciador y el destinatario, pudiendo este último corresponderse o no con el receptor efectivo del mensaje, y cómo cada medio elaboró estrategias enunciativas estables en función del tipo de destinatario al que estaban dirigidos, procurando responder a sus expectativas y apelando a elementos de un imaginario común (Arfuch, 1986). Ahora bien, en el análisis de ese pacto de lectura procuraremos dilucidar las estrategias específicas para dirigirse a las lectoras y los modelos de género que impregnaron los respectivos discursos.

A continuación analizaremos los periódicos teniendo en cuenta que La Argentina y Soberanía, dirigidos por Nora Lagos, se caracterizaron por posicionarse como prensa popular, inserta en una red de relaciones locales de base y por exaltar la humildad de los orígenes de sus lectores (aunque un claro contraste con el origen de clase de la propia directora. Luego, analizaremos Línea Dura que se define a sí mismo como autoridad sobre el resto atribuyéndose la legitimidad de actuar como organizador de las estructuras políticas del peronismo, resultando ser su voz oficial. Finalmente, Conquista, inaugura un lugar de enunciación más cercano a las posibles lectoras, como si fueran pares, fundiéndose en un colectivo de identificación femenino pujante, diferenciado de otro colectivo, también femenino, pero al que se contrapone dentro del partido.

a. La Argentina y Soberanía, se caracterizaron por una incitación a la militancia activa entre los posibles lectores y el empleo de tópicos recurrentes del imaginario 
peronista, pero resignificados y habiendo sido seleccionados los aspectos más intransigentes del mismo (Capobianco, 2003). Así lo expresan dos cartas publicadas por Soberanía durante la segunda detención de Nora Lagos. En la primera, Nora denunciaba los atropellos que el gobierno de la Revolución Libertadora estaba cometiendo contra "el pueblo", con el cual se sentía identificada y hacía hincapié en su fortaleza y en la del propio pueblo para continuar la lucha y mantener la intransigencia frente a un gobierno considerado "cipayo" por estar al servicio del capital inglés. ${ }^{267}$ Una retórica antiimperialista predomina en el tono de todo el artículo, que a la vez es un pedido a los militantes que estaban libres para que prosiguieran la lucha que ella no podía realizar con toda la eficacia necesaria por estar encerrada. La otra carta continúa con el mismo espíritu que la anterior, pero en tono de despedida, puesto que fue escrita luego de haber escapado de la comisaría donde estaba detenida y a punto de emprender su viaje a Paraguay. En esta carta, lo que se destaca, por encima de todo, como en la anterior, es su fortaleza y su predisposición para la lucha, a pesar de los sacrificios que ello conllevaba. ${ }^{268}$

Dos conclusiones pueden extraerse de esto. Por un lado, las cartas están insertas en un discurso de época que Soberanía, y también La Argentina, compartían con otros periódicos, y que se sintetiza en la interpretación de la coyuntura política del momento en términos de la dicotomía imperialismo/antiimperialismo. Como ha señalado Capobianco (2003), estos periódicos difundieron una versión revisionista de la historia; aunque conservan algunas alusiones positivas a personajes históricos de la tradición liberal. ${ }^{269}$ Por otro lado, nos acercan a las imágenes autorreferenciales utilizadas por Nora Lagos en su discurso; lo que Leonor Arfuch (2002) ha denominado como las "estrategias ficcionales de auto-representación". Los valores que atraviesan estos fragmentos y los artículos en su totalidad, son los de la entrega, la lucha y el sacrificio, y correlativo a esto, la incitación de los lectores a la militancia siguiendo el ejemplo de su directora. Se observa la creación de un ethos discursivo en el que la imagen de la directora cobra un rol central que atraviesa las

\footnotetext{
${ }^{267}$ Soberanía $\mathrm{N}^{\circ}$ 22. "La fuerza, el derecho y las bestias". Rosario, 22 de julio de 1957.

${ }^{268}$ Soberanía $\mathrm{N}^{\circ}$ 30. "A los compañeros". Rosario, 16 de septiembre de 1957, p.1.

269 En un mismo artículo podemos observar reivindicaciones de personalidades tan disímiles como Bartolomé Mitre, Juan Bautista Alberdi, el líder de la unificación italiana Giuseppe Mazzini y el fundador de la editorial Atlántida, Constancio C. Vigil. Y en la misma página, un artículo dedicado a realzar la figura de Tomás Jefferson. La Argentina № 4. Rosario, 17 de diciembre de 1955, p. 2.
} 
páginas de los periódicos en sus diferentes números y en el que su condición femenina no es un atributo secundario sino medular. ${ }^{270}$

Las cartas de lectores nos devuelven fragmentos de las imágenes que ellos construyeron sobre Nora Lagos destacándose el hecho de que la directora del periódico fuera una mujer y haciendo alusiones relativas a su carácter, a su valentía, a su actitud desafiante. Estos atributos eran valorados y resaltados, puesto que prevalecía la idea de que por su condición femenina debería haber actuado de modo contrario. Así, una carta proveniente de un lector de Avellaneda sostenía: "Espero con afán que su periódico siga llegando a manos de los obreros por mucho tiempo y que la 'Libertad de Prensa' no haga desaparecer esta muestra del valor de la mujer Argentina...". ${ }^{271}$ En la sección "Nuestra Bruja Predice" de Soberanía también queda ejemplificada esta cuestión. En dicha sección, diversos personajes representaban a los miembros del equipo de redacción. El personaje principal era una bruja que hacía referencia a una muñeca que Nora había fabricado estando en la cárcel. Por un lado, esto muestra una vez más el uso de imágenes autorreferenciales y la intención de mostrar una relación de continuidad entre la vida cotidiana y privada con la labor periodística y política. Por otro lado, no podemos dejar de pasar por alto el carácter político de la elección de la bruja como emisor principal del discurso en esa sección, por el contenido simbólico que dicha figura encierra; las connotaciones de género que la atraviesan y su carácter subversivo. ${ }^{272}$

Junto a un ethos de la figura de Nora Lagos como directora y como emisora que toma voz en esta prensa, se construye una imagen sobre los propios periódicos. Ambas apuntan a interpelar a un lector militante, como en un artículo titulado "Basta de Comodidades", que invitaba a los lectores a participar activamente en política, ya que no bastaba con leer el

\footnotetext{
${ }^{270}$ Entendemos el ethos como la imagen del locutor proyectada en el discurso con el objetivo de persuadir a la audiencia. Para Chaïm Pérelman, (1989, en Amossy, 2001) la construcción de un ethos implica la movilización de una doxa, es decir, de valores, estereotipos culturales y representaciones que circulan en la sociedad y especialmente entre el grupo al cual va dirigido el discurso. Si bien el orador se hace una representación de su auditorio, para que la persuasión funcione, esa representación debe corresponderse en la mayor medida de lo posible con la audiencia real.

${ }^{271}$ Soberanía $\mathrm{N}^{\circ}$ 7. Rosario, 7 de mayo de 1957, p. 4. Otros ejemplos pueden encontrarse en Soberanía $\mathrm{N}^{\circ}$ 16. Rosario, 14 de mayo de 1957, p. 3. Soberanía $\mathrm{N}^{\circ}$ 19. Rosario, 4 de junio de 1957, p. 4. Soberanía $\mathrm{N}^{\circ}$ 20. Rosario, 11 de junio de 1957, p. 4. Soberanía N³2. Rosario, 9 de septiembre de 1957, p. 4.

${ }^{272}$ Como sostiene Fernanda Gil Lozano (1995), en la temprana Edad Moderna no era accidental que en los casos de brujería que pasaron por la justicia la gran mayoría de los acusados fueran mujeres, en su mayoría viudas o solteras, de edad madura, porque estas mujeres que mostraban ciertos visos de independencia desafiaban el sistema de género socialmente establecido, los roles que la sociedad había asignado a varones y mujeres. De ahí derivan las connotaciones subversivas de la figura de la bruja.
} 
diario. ${ }^{273}$ Por otro lado, la realidad material precaria que afectaba a estos periódicos, tanto por las dificultades que debían atravesar para el financiamiento como para poder circular burlando la censura, era utilizada como elemento argumentativo para resaltar el sacrificio que debían hacer sus responsables para seguir editándolos, así como la pureza y honestidad de los ideales que los motivaban a continuar con semejante esfuerzo: "La 'prensa grande' depende de los capitales. La 'prensa chica' sirve a ideas y mientras los grandes diarios permanecen silenciosos se establece un amplio diálogo entre el público y las humildes hojas periódicas...". 274

La apelación a los lectores se daba en daba en términos concretos e inmediatos. Como ha señalado Ehrlich (2010), los lectores eran convocados como "público" y como "pueblo", y ello implicaba su participación para el sostenimiento de los emprendimientos editoriales, ya sea con aportes económicos, colaborando en la distribución o acercando noticias y artículos para su publicación. Si bien muchos periódicos se financiaban, al menos en parte, con el aporte de los sindicatos o de dirigentes de las ex estructuras partidarias, este no era el caso de los periódicos que Nora Lagos dirigió durante la Resistencia, puesto que dependían en gran medida de la colaboración popular; hecho que era destacado desde sus páginas

“ [...] No importan las amarguras de la vida periodística, ni las dificultades de todo género y calibre por que [sic] tiene que pasar una prensa minúscula, que pretende no repetir lo que todos dicen y se pone a cantar fuera de tono con gran disgusto de los directores de orquesta. Lo que importa es que el pueblo está con nosotros y nos acompaña con su calor que es creación [...]."275

Si bien partía de una realidad adversa, se lo exaltaba contribuyendo a afianzar el ethos discursivo que se pretendía transmitir, el de la militancia sacrificada y desinteresada.

[...] Desde los extremos de la ciudad y de la provincia acuden los humildes trabajadores a ofrecerse. Uno es encuadernador. Otro puede aprender a doblar los diarios. Llegan dibujantes. Llegan los muchachos que quieren vocear el diario, los que lo han hecho conocer en las barriadas que lo necesitaban; los que traen un chimento recogido en sitios insospechados; los que traen artículos, versos, acrósticos, todo garrapateado, según los 'doctos', pero todo de corazón $[\ldots] " .276$

273 Soberanía N $^{\mathrm{o}}$ 5. Rosario, 21 de diciembre de 1955, p. 3.

${ }^{274}$ Soberanía No 5. "La traición de la Prensa grande". Rosario, 21 de diciembre de 1955, p.1.

275 Soberanía No 3. Rosario, 1 de enero de1957, p. 4.

${ }^{276}$ Soberanía $\mathrm{N}^{\mathrm{o}} 3$. Rosario, 1 de enero de 1957, p. 4. 
Otra estrategia discursiva de estos periódicos consistía en apelar a la historia personal de Nora Lagos como elemento legitimador de la existencia de los mismos. Un artículo de La Capital reproduce fragmentos del discurso de Nora en Paraguay, cuando viajó junto a Perón en 1954 a devolver los trofeos obtenidos por Argentina en la guerra de la Triple Alianza, y en él se trasluce la idea de que su misión en el diario era concebida como la devolución del mismo al "pueblo", puesto que así había sido concebido por su bisabuelo Ovidio Lagos, fundador del periódico. Sus descendientes habrían desvirtuado ese objetivo, y gracias al peronismo, Nora sostenía que podía llevarlo a cabo. Este argumento volvemos a encontrarlo en los periódicos que publicó durante la Resistencia. En un artículo de La Argentina un recordatorio al bisabuelo sostenía que, al igual que La Argentina, La Capital también había nacido como un diario humilde. ${ }^{277}$ Así, el enfrentamiento familiar reproducía la dicotomía pueblo/aristocracia, de fuerte arraigo en el discurso peronista de la época. La imagen del peronismo como una nueva etapa de la historia argentina -una era de justicia social que se oponía al período anterior, la década del treinta, marcado por la injusticia y el poder de la oligarquía-, ofrecía una analogía para interpretar el conflicto familiar y viceversa. A su vez, la directora construía un puente con su bisabuelo que le otorgaba legitimidad sobre la dirección del periódico y sobre el giro ideológico que le había conferido. ${ }^{278}$ En las páginas de los periódicos de la Resistencia circuló cierta interpretación del acercamiento de Nora al peronismo como una transgresión de clase, valorada positivamente por algunos contemporáneos. Así, en Soberanía, una nota de Raúl Scalabrini Ortiz ponía el acento en el carácter electivo de la relación de Nora con el peronismo, ya que por provenir de una familia de clase alta podría haber elegido aliarse con el gobierno de la Revolución Libertadora: "Ella podría haber optado por la blandura del silencio y el acercamiento a los ocasionalmente poderosos. Optó por la causa del pueblo que en estos

\footnotetext{
${ }^{277}$ La Argentina $\mathrm{N}^{\circ} 1.8$ de diciembre de 1955, p. 1.

${ }^{278}$ Los Lagos también utilizaron la figura de Ovidio Lagos y referencias a la entidad "pueblo", para legitimar la recuperación del medio gráfico en 1955. El diario La Capital, en un artículo del 30 de diciembre de 1955, ya en manos de la familia Lagos, celebraba la detención de Nora e interpretaba su llegada a la dirección del mismo como producto de un artilugio digitado por los altos mandos del peronismo y denunciaba la pérdida de independencia que había sufrido en sus manos. La Capital. Rosario, 30 de diciembre de 1955. Ya el 23 de septiembre, cuando el diario fue recuperado por la familia Lagos, proceso que se había iniciado el día 21, en el editorial resonaban frases como "La segunda ciudad del país ha recobrado así su diario tradicional [...], que Ovidio Lagos fundó para que sirviera al mejoramiento del pueblo", o "Tal ha sido desde su nacimiento la posición de LA CAPITAL, asi ha entendido cumplir con la consigna del fundador de que 'sus columnas pertenecen al pueblo [destacado en el original] La Capital. Rosario, 23 de septiembre de 1955, p. 2.
} 
momentos se identifica con la causa nacional [...]". ${ }^{279}$ Este artículo contribuía a consolidar la imagen clasista que estos periódicos pretendían transmitir.

La Argentina y Soberanía procuraron llegar a un lector obrero y convertirse en intérpretes de los problemas que lo aquejaban. Sin embargo, las mujeres, aunque de manera acotada, también fueron interpeladas desde sus páginas. En el caso de Soberanía, esto se hizo a través de una sección especial titulada "La Mujer y la Patria". El discurso que estos periódicos desarrollaron en relación a las mujeres estuvo atravesado por concepciones del maternalismo político, es decir, una convocatoria a las mujeres para participar en política y un reconocimiento de su actuación en ella, en tanto madres, esposas, hijas y hermanas (Nari, 2004). Así, se reconocieron ciertas problemáticas femeninas. En un artículo de Soberanía, es denunciada la exclusión histórica sufrida por las mujeres respecto de las esferas de relevancia social como la política, la ciencia y la cultura, y su confinamiento al espacio doméstico. Frente a ello, se reclamaba a los hombres de la política que consideraran un horizonte más amplio para ellas. La argumentación para legitimar dicho reclamo incurría en el maternalismo político: como las mujeres eran educadoras de los hijos, si se ampliaran las posibilidades de su inserción social, la educación sería de mejor calidad y, por tanto, se incrementaría el nivel de progreso social.

"Se le aisló en el hogar con el beneplácito de los antifeministas [...], quienes, empero, no se dieron cuenta que ella tenía en sus manos el arma más formidable, la formación espiritual y moral de los hombres [...] Entendemos que a la mujer moderna es necesario, urgentemente necesario, marcarle otro derrotero, si se quiere que ella como madre, ofrezca a las sociedades mayores y más beneficios $[\ldots]$ "..20

Aunque reconocía las mejoras que en ese sentido se habían realizado en la primera mitad del siglo XX, se creían aún insuficientes. Si bien se responsabilizaba de esta exclusión a las clases dirigentes de extracción social aristocrática, indirectamente el peronismo tampoco quedaba exento de las críticas. Es de destacar que el artículo no caía en una obsecuencia al gobierno peronista que podría haberse limitado a exaltar la ley de voto femenino. Consideraban que la omisión de las problemáticas femeninas atravesaba las ideologías políticas puesto que no sólo los diarios comerciales de gran tirada, acusados por La Argentina y Soberanía de responder a los intereses del gobierno y de los grandes

\footnotetext{
${ }^{279}$ Soberanía $\mathrm{N}^{\circ} 1$. Rosario, 17 de diciembre de 1956, p. 1.

${ }^{280}$ La Argentina $\mathrm{N}^{\circ}$ 6. Rosario, 24 de diciembre de 1955, p. 2.
} 
capitales, evitaban hablar de las mujeres, sino también los pequeños periódicos que estaban en la oposición al gobierno; es decir, los propios periódicos peronistas. ${ }^{281}$

Las publicaciones de Nora Lagos también reconocieron a las mujeres como militantes. Aunque hubo evocaciones de la ley de voto femenino que había permitido su participación en tanto que electoras, en el nuevo contexto, la convocatoria a las mujeres pasaba por la lucha activa. Además, reconocían las implicancias de género que había tenido la decisión del gobierno de Aramburu-Rojas de disolver el Partido Peronista, puesto que había cercenado la capacidad de las mujeres de militar y organizarse masivamente, al atentar contra la rama femenina del partido. ${ }^{282}$ Ahora bien, la problemática femenina estaba atravesada por condicionamientos de clase; las mujeres convocadas eran las trabajadoras, inclusive las amas de casa de condición humilde, "las mujeres del pueblo". ${ }^{283}$ Era un discurso coherente con el perfil obrerista que pretendían transmitir estos periódicos. En ese sentido, se convocaba a los dirigentes políticos, de los que se decía que hablaban mucho del pueblo sin conocerlo, a escuchar a las mujeres humildes que tenían mucho conocimiento que aportar a la política; conocimiento sobre la realidad social que poseían a partir de la experiencia. ${ }^{284}$ Este fue un tópico que, como veremos más adelante, también fue retomado por Línea Dura y que da cuenta de cómo estas publicaciones de la etapa de la Resistencia retomaron elementos del discurso peronista formal de la época anterior para adaptarlo a las confrontaciones políticas que desarrollaron en el nuevo contexto.

Algunas cartas de lectoras reconocen la posibilidad que se les abría desde el periódico para plantear sus problemas: una trabajadora cuya carta se publicó en la sección "Escribe el pueblo" exponía el pesar que estaban atravesando muchas obreras, que si bien ya trabajaban desde la época del gobierno peronista, bajo el nuevo régimen habían tenido que afrontar la responsabilidad de convertirse en jefas de hogares debido a que sus esposos habían perdido sus empleos como consecuencia de su adscripción al peronismo. La misma carta cuestionaba la ausencia de voz que tenían las mujeres para decidir sobre las reformas que estaban introduciéndose en las fábricas tendientes a racionalizar el proceso productivo, la pérdida de derechos de los trabajadores y, concomitante a ello, la intervención de los

\footnotetext{
${ }^{281}$ Soberanía $\mathrm{N}^{\circ}$ 5. Rosario, 14 de enero de 1957, p. 1.

282 Soberanía No 5. Rosario, 14 de enero de 1957, p. 1.

${ }^{283}$ Soberanía $\mathrm{N}^{\circ}$ 5. Rosario, 14 de enero de 1957, p. 1. La Argentina $\mathrm{N}^{\circ}$ 6. Rosario, 24 de diciembre de 1955, p. 2. Soberanía N$^{\circ} 3$. Rosario, 1 de enero de 1957, p. 3.

${ }^{284}$ Soberanía $\mathrm{N}^{\circ}$ 5. Rosario, 14 de enero de 1957, p. 1. Este también fue un tópico reiterativo en Línea Dura.
} 
sindicatos. ${ }^{285}$ Otros ejemplos pueden encontrarse en una carta firmada por "Doscientas obreras de Fábrica Colón y Erlinda Corrales", que aunque no expresaba problemas específicamente femeninos, ofrecía la solidaridad, junto con otras mujeres rosarinas, para defender a la directora del periódico si ello fuera necesario. ${ }^{286}$

A pesar de la intención de otorgarle un espacio a las problemáticas femeninas, dicho objetivo quedó en el camino. Tampoco se lograron las aspiraciones declaradas de Soberanía de convertirse en un medio de expresión de dichas problemáticas. ${ }^{287}$ Este reconocimiento quedó acotado a unos pocos números y el carácter obrerista que pretendían transmitir eclipsó cualquier convocatoria realizada en función de una identidad de género. ${ }^{288}$ Sin embargo, es interesante observar cómo una mujer intenta intervenir en el entramado discursivo de la Resistencia peronista utilizando como elementos de autoridad aspectos de su personalidad que podrían haberle resultado adversos en ese espacio y que sin embargo son utilizados para construir el ethos periodístico. Nos referimos a su condición de mujer, que se valoriza exaltando su valentía, un atributo que en los discursos tradicionales suele considerarse ausente en las mujeres. Y por otro lado, a su condición de clase, la transgresión a sus orígenes aristocráticos, el alineamiento con los sectores populares hecho por elección; elementos que contribuyen a completar ese ethos discursivo.

b. En el caso de Línea Dura, la construcción del pacto de lectura se realiza de una manera diferente y ello se expresa en dos cuestiones específicas. Al igual que en los periódicos de Nora Lagos, hay convocatorias a la militancia activa, de tipo insurreccional, aunque luego del pacto con Frondizi se transforman en convocatorias a una participación de tipo electoral. Sin embargo, no se muestra como un diario humilde sino como un órgano periodístico que se propone difundir las órdenes de los altos mandos del peronismo; es decir, se presenta como la voz oficial del peronismo con atribuciones para llevar adelante el

\footnotetext{
${ }^{285}$ Carta firmada por Matilde Legizamón de la sección "Escribe el Pueblo", Soberanía № 5. Rosario, 14 de enero de 1957, p. 4.

${ }^{286}$ La Argentina $\mathrm{N}^{\circ}$ 8. Rosario, 31 de diciembre de 1955, p. 3.

${ }^{287}$ Soberanía $\mathrm{N}^{\circ}$ 5. 14-01-1957b: 1.

${ }^{288}$ Sólo hemos encontrado cuatro artículos destinados a específicamente a un público femenino, y de ellos, sólo dos recogen problemáticas femeninas: "La Mujer y la Patria" en Soberanía $\mathrm{N}^{\mathrm{0}}$ 5. Rosario, 14 de enero de 1957, p. 1 y "Misión Trascendental de la Mujer Argentina" en La Argentina $\mathrm{N}^{\mathrm{0}}$ 6. Rosario, 24 de diciembre de 1955, p. 2. Los otros dos critican las intenciones de reforma constitucional del gobierno y defienden al peronismo frente a la carta de una mujer publicada en Mundo Argentino que cuestionaba la carencia de democracia en dicho movimiento. Soberanía $\mathrm{N}^{\circ}$ 4. Rosario, 8 de enero de 1957, p. 3. Soberanía $\mathrm{N}^{\circ}$ 3. Rosario, 1 de enero de 1957, p. 3 Sin embargo, al aparecer en una sección femenina, se observa una pretensión de llamar la atención del público femenino frente a estos temas.
} 
proceso de normalización de dicho movimiento. Por otro lado, no aparecen imágenes referenciales a su directora. Son escasas las oportunidades en que encontramos referencias al nombre de María Granata, y en todo caso, éstas remiten a la imagen de una profesional del periodismo más que a la de una luchadora sacrificada.

Algo que caracterizó a Línea Dura es que se hace visible la figura de una enunciadora femenina. Una serie de meta-colectivos singulares, usando el término de Verón (1987), como "el pueblo”, “el antipueblo", "la oligarquía”, se combinan con entidades enumerables más concretas que hacen posible que el género comience a cobrar relevancia como variable en la organización del discurso. Así, "mujeres del pueblo" es la entidad que designa al destinatario positivo del discurso y en el cual, quien enuncia, a veces se incluye, dando marcas de que se asume como parte de ese colectivo, mientras que otras veces se posiciona por fuera de esa entidad, adquiriendo un estatus que le proporciona autoridad. La misma relación se establece con la entidad "pueblo" o con "los hombres y mujeres del pueblo". Este pertenecer y no pertenecer busca una legitimidad fundada en una pertenencia de clase; esa enunciadora mujer que se dirige a las mujeres del pueblo es una más entre ellas, y a la vez, goza de un estatus especial que está dado por la capacidad y posibilidad de expresarse a través de un medio gráfico ligado a sectores de la alta dirigencia peronista y la legitimidad que ello le otorga para aconsejar, criticar y persuadir sobre la mejor línea política a seguir. El paralelismo con el propio juego que Evita propiciaba en sus discursos sobrevuela en los de Línea Dura. ${ }^{289}$

A diferencia de La Argentina y Soberanía donde la imagen de la directora cobra un valor especial y se convierte en un recurso de autoridad, Línea Dura se vio obligada a recurrir a la imagen de los líderes peronistas para que cumplieran dicha función. Sin lugar a dudas, el motivo de apelación a esas figuras estuvo vinculado con su pretensión de convertirse en órgano oficial del movimiento y de reorganizar al peronismo disperso, objetivos para los cuales no hubiera bastado la figura de su directora. Esta estrategia se observa en varias oportunidades. Por ejemplo, en el título del artículo, "Ella ha sido obedecida", se presenta un juego de palabras donde "Ella" posee una doble referencia: explícitamente, refiere a Eva Perón, pero implícitamente, alude a la orden de votar por Frondizi. A su vez, la ex primera dama es colocada como figura de autoridad que legitima la acción de las mujeres de haber obedecido la orden de votar por el candidato de la UCRI,

${ }^{289}$ Ver Valobra (2014) 
frente a aquellos que no lo hicieron. ${ }^{290}$ El recurso a la figura de los líderes del peronismo se vuelve así una estrategia recurrente en la lucha facciosa. Aquí surge la figura del árbitro, constituida por el discurso dogmático. Maingueneau (1980) sostiene que lo que permite la recurrencia a dicha figura es la existencia de un desacuerdo entre los antagonistas que supone un acuerdo sobre un conjunto ideológico común. Pero cada contrincante pretende retener la interpretación válida del discurso dogmático. El conflicto surge de la incompatibilidad de dos universos semánticos en los cuales ninguno reconoce al otro la manera de ser conforme a ese discurso. Según Silvia Sigal y Eliseo Verón (2004), el discurso dogmático de Perón adquirió un papel especial durante la etapa del exilio. Estos autores sostienen que todos los dirigentes del peronismo fueron enunciadores segundos, porque siempre tuvieron que legitimar sus palabras recurriendo a palabras previas de Perón. Durante el exilio, surgió el problema de establecer quién era el verdadero enunciador segundo; estatus que se atribuyeron varios dirigentes que disputaron el espacio discursivo peronista, y Línea Dura actuó como medio para la expresión de algunos de esos dirigentes.

Línea Dura, al igual que los periódicos rosarinos antes analizados, tampoco estuvo dirigida específicamente a un público femenino, pero dedicó espacios destinados a ese fin de manera más decidida. Incluyó una sección fija titulada "La Mujer en la Lucha", que en los primeros números se llamó “A Usted Ama de Casa", e incluyó artículos por fuera de esa sección que apelaron a las lectoras, o que consideraron a la mujer como elemento de legitimación discursiva, en tanto sujeto político. La invocación a las mujeres, en especial a las amas de casa, se hizo en función de las problemáticas coyunturales que atravesaba el peronismo en ese momento, sin preocuparse por expresar demandas que concernieran a una agenda femenina. Más bien, se apelaba a las mujeres con un discurso específico y diferenciado, con el objetivo de persuadirlas de que siguieran la línea política del semanario y de polemizar con diferentes enemigos. En esos usos del concepto de mujer se transmitieron imágenes sobre los roles de género esperados para varones y mujeres.

\footnotetext{
${ }^{290}$ Ya en la campaña por el voto a Frondizi, Línea Dura había publicado un artículo donde se exhortaba a las mujeres a votar por dicho candidato, apelando a la figura de Eva Perón como autoridad legitimante. Línea Dura N 10. "La mujer debe recordar la exhortación de Eva Perón". Buenos Aires, 21 de febrero de 1958 , p. 2. Otro ejemplo lo encontramos en un artículo de julio de 1958. Cooke había propuesto integrar a las mujeres en nuevas estructuras que dieran representación a las destacadas en la resistencia, medida que perjudicaba a las viejas dirigentes del PPF. Para calmar el conflicto, el semanario apeló a un mensaje reciente de Perón que reivindicaba la acción femenina, al que se sumaba otro enviado en 1956, con el mismo sentido, en el que, además, se apelaba a la figura de Evita. Línea Dura $\mathrm{N}^{\circ} 27$. "No ignoro los sacrificios que han realizado las mujeres peronistas"”. Buenos Aires, 3 de julio 1958, p. 2.
} 
En aquellos artículos donde el foco polémico estuvo puesto en el enemigo externo, el gobierno de la Revolución Libertadora y los antiperonistas en general, las "mujeres del pueblo" fueron presentadas como víctimas de los ataques de ese gobierno, y a la vez, como sujetos activos, capaces de luchar por lo que les correspondía. La oposición con el adversario admitía transgredir los roles de género, pero la interpretación de esta actitud como fuera de lo normal, confirmaba una postura tradicional sobre esos comportamientos:

"Con pleno sentido de su responsabilidad, las compañeras de FOETRA lucharon codo a codo sin dejarse impresionar por la acción intimidatoria con que el gobierno pretendió desbaratar su firmeza. Estas luchadoras saben que se está jugando el porvenir de sus hijos, el destino de los hogares humildes. [...]Bien por ellas que no temblaron ante las armas cobardemente empleadas en los locales de la Empresa!...". ${ }^{291}$

Así, las mujeres, en quienes cabría esperar una actitud pasiva, se habían manifestado activa y valientemente. Por su parte, el gobierno y las fuerzas represivas, sujetos masculinos, habían desplegado cobardemente su fuerza sobre ellas. Ahora bien, estos artículos, no sólo están destinados a polemizar con el enemigo, sino que también despliegan una fuerza persuasiva sobre aquellos que necesitan ser convencidos; es decir, las mujeres, a quienes hay que sumar a la causa y los propios varones peronistas, frente a quienes había que demostrar la importancia que la militancia femenina tenía en la lucha contra el adversario. ${ }^{292}$ Veamos otro ejemplo:

"Las mujeres, que en el gremio de los telefónicos son considerable mayoría, han decidido el triunfo de la huelga sostenida en demanda de aumentos que permitan hacer frente al costo de la vida, cuya elevación responde directamente a la entrega de nuestra economía. EL ÉXITO DE LA HUELGA DE FOETRA ES UN TRIUNFO DE LAS MUJERES TRABAJADORAS..." (destacado en el original). ${ }^{293}$

\footnotetext{
${ }^{291}$ Línea Dura $\mathrm{N}^{\circ} 1$. "Cumpliose la huelga pese a los tanques y las tumbas. Triunfo de la Mujer Telefónica en la Huelga frente a la Opresión". Buenos Aires, 4 de noviembre de 1957, p. 3.

${ }^{292}$ María Marta García Negroni (1988) ha dado cuenta de cómo la función polémica, en la cual se basa la relación entre el locutor del discurso y los destinatarios negativos se constituye como subalterna de la función de persuasión y refuerzo de la creencia, que sostiene la relación entre el locutor y los destinatarios positivos del mensaje, aquellos que quedan incluidos en el colectivo de identificación

${ }^{293}$ Linea Dura $\mathrm{N}^{\circ}$ 1. "Cumpliose la huelga pese a los tanques y las tumbas. Triunfo de la Mujer Telefónica en la Huelga frente a la Opresión”. Buenos Aires, 4 de noviembre de 1957, p. 3.
} 
Este artículo deja traslucir una interpelación a los sectores vinculados al sindicalismo, espacio atravesado por prácticas ligadas a valores masculinos que han tendido a ocultar la presencia femenina en algunas ramas de la economía y en las propias prácticas sindicales.

Las elecciones presidenciales del 23 de febrero de 1958, introdujeron otro núcleo problemático que dio lugar a un debate, esta vez, ya no entre el peronismo y sus opositores, sino entre diferentes facciones de aquel. La polémica anterior no desapareció, sino que se mantuvo una doble polémica destinada a distintos adversarios. El Otro estará constituido por aquellos grupos que venían desarrollando una acción de confrontación y choque con el gobierno de la Revolución libertadora, sobre todo a través de los comandos clandestinos. El pacto Perón-Frondizi generó gran malestar entre esos sectores, mientras que Línea Dura fue uno de los órganos difusores del mismo. Luego del triunfo de Frondizi, los comandos se negaban a abandonar su postura intransigente incluida la acción violenta. Esta actitud era contraria, según lo expresado por Línea Dura, a la generación del clima de calma necesario para que se concretara el traspaso de poder, y que el mismo se hiciera sin condicionamientos. En este contexto, la mujer aparece como sujeto capaz de lograr la paz necesaria para garantizar ese traspaso. Veamos un ejemplo en un artículo titulado " $L a$ mujer factor de paz", en el que a través de un discurso a simple vista ingenuo, que resalta las virtudes femeninas vinculadas a lo sentimental y a la bondad, la locutora polemiza con el enemigo interno: “...La mujer, factor de comprensión y sentimiento, será la salvaguardia, de una paz que no debe ser arriesgada. A ella, particularmente, se le encomienda esa otra recuperación, la de la serenidad y espíritu constructivo sobre los escombros de una destrucción que no volverá a repetirse...". ${ }^{294}$ Aquí, la apelación a la mujer como factor de paz, si bien responde a un ideal conservador, también se ajusta a una nueva coyuntura donde, para la tendencia seguida por Línea Dura, la mujer debía reinsertarse en prácticas políticas institucionales retomando el camino que se había iniciado con el acceso a la ciudadanía en 1947. Ya no se las convocaba a la acción violenta que se había requerido en los primeros años de la Resistencia -y que el grupo vinculado a Línea Dura había apoyado - sino a la participación institucional. Veamos otro ejemplo:

"Quienes estaban interesados en que el Movimiento desacatara la orden hacían sus cálculos pensando que la mujer no comprendería la acción táctica, dado que su politización es reciente comparada con la del hombre. Nuestros enemigos veían en la mujer sólo un fervor que en muchos casos podría conducirla a la

\footnotetext{
${ }^{294}$ Linea Dura N$^{\circ}$ 13. “La Mujer, Factor de Paz”, Buenos Aires, 24 de marzo de 1958, p. 2.
} 
indisciplina, pero los cómputos electorales demostraron que la mujer de nuestro Movimiento posee ya una madurez política a la par del hombre, a la vez que un extraordinario sentido de disciplina partidaria... (el destacado es nuestro)". ${ }^{295}$

En el fragmento escogido, se le adjudica al adversario el error de pensar que las mujeres, por su reciente acceso a la ciudadanía política, no acatarían la orden de Perón. Sin embargo, el semanario defendía la madurez política alcanzada por las mujeres en sus pocos años de experiencia, que las colocaba a la altura de los hombres. Esta forma de argumentación encuentra antecedentes en discursos anteriores de María Granata, como el artículo titulado "Valoración de la mujer en el peronismo", publicado en el libro Una Nación Recobrada. Enfoques parciales de la Nueva Argentina, de 1952, donde varios autores exponían sobre un aspecto determinado del peronismo y la escritora se explayaba sobre la temática de la mujer. Por ejemplo, la idea de que la mujer es inherentemente pacífica. Si bien Línea Dura utilizó esa vinculación para convocar a las mujeres a votar por Frondizi, cambiando su estrategia de convocatoria puesto que hasta el momento en que se concretó el pacto las había convocado a la lucha en la resistencia y daba cuenta de su participación en huelgas y manifestaciones, su uso no era meramente estratégico puesto que era una idea que Granata manejaba desde épocas anteriores. En el artículo de 1952, había un subtítulo "La mujer peronista y su contribución a la paz mundial", que hacía referencia a esta cualidad femenina como algo esencial que había permitido su acercamiento al peronismo, puesto que el peronismo también era inherentemente pacífico (Granata, 1952, p. 240-241). Respecto de la idea sobre capacidad de las mujeres para comprender la política pese a su corta experiencia, también se trataba de un elemento preexistente en su argumentación anterior. En el mismo artículo de 1952, se sostenía que pese a su exclusión de la política, la mujer había tenido paciencia, sabiendo observar y aprendiendo a ser prudente (Granata, 1952; 235-236). Sin embargo, esta idea entraba en contradicción con otra que estaba presente en el mismo artículo y que sostenía que el PPF venía a superar una larga inactividad e indiferencia política de la mujer (Granata, 1952, p. 237). De esta manera, se observan relaciones de continuidad no sólo en el recurso a la práctica periodística como modo de participación en los primeros años de la Resistencia peronista, sino también en el lenguaje utilizado, los modos de argumentar y los elementos de legitimación, que ya estaban presentes en productos culturales o periodísticos producidos por estas mujeres en la etapa

${ }^{295}$ Línea Dura $\mathrm{N}^{\circ}$ 11. "Ella ha sido obedecida". Buenos Aires, 10 de marzo de 1958, p. 4. 
anterior. A ello, debe sumarse una reactualización de elementos del discurso peronista formal.

Línea Dura supo articular en sus páginas el género y la clase. Se atribuía a las "mujeres del pueblo" cierta comprensión de la realidad social a partir de las vivencias cotidianas; una capacidad que estaba ausente en las mujeres de clase alta. Si bien esta idea estaba presente en La Argentina y Soberanía, donde era utilizada para desacreditar a los políticos acusándolos de desconocedores de los problemas sociales, se hace más patente en Línea Dura, donde hubo una apelación concreta a las amas de casa: "La mujer integra vitalmente el movimiento de resistencia y toma su puesto de lucha no sólo en la fábrica, en la escuela, en el sitio de su trabajo, sino también en su hogar, trinchera del pueblo donde cada día debe librarse victoriosamente un combate...". ${ }^{296}$ Esta convocatoria se visualiza, sobre todo, en la sección "La Mujer en la Lucha", donde se recurría a una imagen estereotipada de mujer: el ama de casa de una familia de clase trabajadora a quien los problemas de la política y de la economía le eran explicados de manera sencilla y con ejemplos concretos y cotidianos. En un artículo destinado a denunciar al gobierno por lo que costaba económicamente mandar a los hijos a la escuela, la narradora sostenía: "Decir de estas cosas es decir de política también ;Y vaya si lo es! Porque nuestro sentido de la política, el de las mujeres, se basa casi esencialmente en estos pequeños pero sentidos problemas de la felicidad del hogar y el porvenir de los hijos... ". ${ }^{297}$ Esta sección también servía para denunciar acciones cometidas por el gobierno contra los peronistas o la sociedad en general, pero cuya denuncia se hacía desde una postura femenina porque se consideraba que eran problemas que incumbían especialmente a las mujeres o que eran experimentados de forma diferenciada por ellas. Así, ante el plan económico lanzado por el gobierno, considerado un "plan de miseria", el semanario sostenía: "Dicen por ahí que las mujeres no entendemos de alta economía ni de complejos problemas financieros [...] entendemos perfectamente bien el problema del presupuesto diario y mucho mejor que eso puesto que ya lo sentimos con el corazón el hambre de un niño...". ${ }^{298}$

Estas ideas reflejan el uso del discurso peronista formal en un periódico de la Resistencia peronista como fue Línea Dura. Como sostiene Barry (2009), la apelación a las mujeres a participar en política se realizó en dicho discurso, a partir de un conocimiento

\footnotetext{
${ }^{296}$ Línea Dura N N 1. "Consigna”. Buenos Aires, 4 de noviembre de 1957, p. 1.

${ }^{297}$ Línea Dura N 13. "La Mujer en la Lucha”. Buenos Aires, 24 de marzo de 1958, p. 4.

${ }^{298}$ Línea Dura N ${ }^{\circ}$ 15. "La Mujer en la Lucha”. Buenos Aires, 7 de abril de 1958, p. 4.
} 
preexistente, que era su capacidad para organizar la economía doméstica, partiendo de la idea de que las mujeres tenían mayor capacidad que los hombres para resolver problemas cotidianos y que ese pragmatismo lo aplicarían en la política. Estas ideas prevalecieron en el discurso de Eva Perón y fueron incorporadas en el Reglamento General del PPF. Por ejemplo, el adoctrinamiento sobre el Segundo Plan Quinquenal se hizo sobre esa idea. Este nos sólo debía ser explicado en las unidades básicas femeninas a partir de situaciones concretas, sino que además había que comprometer a las mujeres en determinadas tareas que se basaban fundamentalmente en el ahorro.

La apelación a un público femenino no sólo se manifestó a través de un discurso que interpeló a directamente a las mujeres en tanto que lectoras y militantes, sino también a través de un recurso discursivo que consistió en polemizar con mujeres del antiperonismo. Las adversarias eran las esposas de los políticos que propiciaron el golpe de Estado contra Perón y de los funcionarios del nuevo gobierno, las dirigentes políticas e intelectuales que participaban en él o que apoyaron el golpe y las mujeres de la oligarquía; a veces, en este último grupo se las incluía a todas. La argumentación procuraba mostrar a las adversarias como desconocedoras de la realidad y extranjerizantes, frente a las "mujeres del pueblo" conocedoras de la realidad social que vivían y padecían en carne propia. Entonces, un tópico del discurso peronista formal que oponía las causas nacionales y populares a los intereses extranjerizantes de la oligarquía, fue reactualizado en el nuevo contexto, tratando de mostrar su incidencia sobre las mujeres. En este discurso polarizado se vuelcan sentidos y representaciones sobre el significado de lo femenino. Al igual que en los periódicos de Nora Lagos, hubo una crítica a los partidos políticos tradicionales, vinculados a concepciones liberales de la política, por la falta de contenido social de sus agendas y de desconocimiento de la realidad. En el caso de estas mujeres que practicaban la política partidaria, se les cuestionaba la pretensión de querer representar al pueblo cuando eran ajenas a él. Refiriéndose a Alicia Moreau decía:

“... ¿Qué coincidencia hay entre el sentir de esta representante de una politiquería hecha de decadencia, y una auténtica mujer del pueblo, afirmada en la realidad y en el valor de una lucha justa? ¿Qué títulos ganados en el amor al pueblo y en la defensa de la patria avasallada puede ostentar Alicia Moreau de Justo?". 299

${ }^{299}$ Línea Dura $\mathrm{N}^{\circ}$ 2. "La Viuda Consultiva”, Buenos Aires, 11 de noviembre de 1957, p. 2. 
En su disputa con las mujeres de la oligarquía se introduce una idea que se hace extensiva a esta clase social en su totalidad, que es su deshumanización. Esta característica deriva de la conducta insensible de sus integrantes frente al sufrimiento del pueblo. Y esa insensibilidad también las despoja de su condición de mujeres, ya que están transgrediendo una conducta sensible, piadosa y bondadosa que la locutora supone inherente al género femenino, y que sí está presente en las mujeres que integran el colectivo de identificación. Ello podemos observarlo en un artículo sobre los fusilamientos que sucedieron al levantamiento de Valle:

“...Cómplices y culpables. No se oyó de sus bocas ni una sola palabra de clemencia. Inhumanas, terriblemente inhumanas. No merecen ser mujeres. No lo son en sus sentimientos. Almas en estado de carroña...".300

También se despliega una crítica sobre el comportamiento de las adversarias que se sintetiza en una actitud meticulosa y metódica ante situaciones de preocupación o de horror, y ello permite ir construyendo una imagen de estas mujeres como desprovistas de humanidad:

“Aplaudieron la sangre caída sobre el corazón de los argentinos de verdad, con la insensibilidad monstruosa de aquella oligarca que el 9 de junio, entre el desayuno y la misa, abrió las ventanas de su balcón y exclamó gozosa: ‘¡Por fin! ¡Ya han fusilado a dieciocho!'

Llevaba la cuenta de los caídos con prolija exactitud. Hacía su balance. Tenía el increíble temor de que los fusilados fueran pocos [...]. Y ella abrió la ventana y dio su grito de júbilo. Alguien, que pasaba por la calle, reparó en sus palabras llenas de un sombrío ardimiento, reparó en su cara que dejaba en ese momento de ser humana". ${ }^{301}$

La imagen del Otro se condensa en la figura de un personaje ficticio, "aquella oligarca", que contribuye a crear un estereotipo de las mujeres de la clase alta. Éste está caracterizado por el desprecio hacia la gente de su propio país - "los argentinos de verdad", por la crueldad, la frivolidad, el buen pasar económico -sintetizado en la imagen del desayuno y el balcón- y la hipocresía, representada en la imagen de la misa. Estos estereotipos implican una representación simplificada del Otro, prejuiciosa y de tono

\footnotetext{
${ }^{300}$ Línea Dura N$^{\circ}$ 1. "Las Fusiladoras". Buenos Aires, 4 de noviembre de 1957, p. 2.

${ }^{301}$ Línea Dura N 1. "Las Fusiladoras". Buenos Aires, 4 de noviembre de 1957, p. 2.
} 
colectivo; de ahí su carácter dóxico y además, apelan a un saber compartido con el lector para que este último complete automáticamente los rasgos que no se mencionan explícitamente (Amossy, 2000). En este debate se puso en juego una resignificación del concepto de mujer, que en sintonía con el discurso peronista clásico, quedó ligado a su condición popular, siendo, por tanto excluidas de él, las mujeres de clase alta, deshumanizadas, mujeres a las que se les negaba su condición de tales.

Una idea que se filtra en varios artículos de Línea Dura, sobre todo en su lucha contra el enemigo externo, el antiperonista, es la de que hay caracteres y comportamientos que corresponden a lo femenino por naturaleza. De hecho, muchas veces su crítica a esos sectores consistió en mostrar que las mujeres antiperonistas no contaban con esos atributos y que los hombres antiperonistas no se adecuaban al comportamiento asociado a la masculinidad. En el artículo de Granata de 1952, esas ideas se muestran de una manera más explícita y desarrollada. Una de las decisiones más importantes del peronismo, según el artículo, había sido afirmar a la mujer en los caracteres distintivos de su femineidad, caracteres que no eran desvirtuados con su incorporación a la vida política. Criticaba así a las feministas que viciaban la naturaleza femenina imitando al varón (Granata, 1952, 238)

La apelación a las "mujeres del pueblo", que está tan presente en Línea Dura, pero también en los periódicos de Nora Lagos, era un tópico recurrente en el discurso de Evita. Cuál era el alcance de dicha expresión es una cuestión que no ha estado libre de debates. Para autoras como Guivant (1985) y Navarro (1994), claramente la frase encerraba una connotación clasista que hacía referencia a las mujeres trabajadoras, mientras que Bianchi y Sanchís la asocian con la condición de amas de casa de las mujeres convocadas, sosteniendo que las mujeres trabajadoras no tuvieron un lugar en el discurso peronista, ya que hubo una condena expresa del trabajo extradoméstico (Bianchi y Sanchís, 1998). Para Barry, la convocatoria fue general, señalando el amplio alcance que la condición de amas de casa tenía en la época, independientemente de su clase social; y que "mujer del pueblo", sinónimo de "descamisada", no refería una clase social en sí, sino a un sentimiento y una actitud valorativa, y que tampoco la noción de pueblo estaba definida ni se correspondía con un clase social. Las mujeres del pueblo se oponían a las aristócratas o burguesas que no pertenecían al pueblo por tener una vida frívola, vacía y sin objetivos (Barry, 2009; 143 148). Evita, además, excluía a estas mujeres de la categoría mujer (Barry, 2009; 155).

Otros artículos que hacen visibles a las mujeres y que destacan su participación en la Resistencia son aquellos que denuncian su permanencia en las cárceles y el maltrato que 
recibían por parte de otras mujeres que eran sus carceleras, las monjas que estaban a cargo de las penitenciarías femeninas. Así se denuncia que las mujeres que habían estado presas durante los primeros gobiernos peronistas lo habían hecho en comisarías, por poco tiempo y bajo un marco legal y jurídico de garantías que estaba ausente en los casos de las peronistas detenidas durante el gobierno de la Revolución Libertadora. Llama la atención el hecho de que se justificara la detención de mujeres de la oposición durante los gobiernos peronistas, por el hecho de que los motivos del arresto habrían sido “...por escándalo en la vía pública, por faltar a ese decoro que la sociedad exige a toda mujer... ", 302

Línea Dura, a diferencia de Soberanía y La Argentina articuló un discurso donde las figuras de autoridad no consistieron en exaltar la imagen de su directora, sino la de los líderes peronistas; hecho que estaba acorde con sus pretensiones de llevar a cabo el proceso de normalización del peronismo al producirse el arribo de un nuevo gobierno democrático en el que se creería que las proscripciones que pesaban sobre el Partido serían levantadas. En ese proceso, pesó la idea arraigada en la tradición peronista de que las mujeres debían reorganizarse en una estructura política diferenciada de las masculinas. Ello hizo que pusiera énfasis en destinar espacios dedicados a las mujeres. Y a la vez, en demostrar a los otros sectores del peronismo, masculinos, que la participación de las mujeres, ya sea para la lucha insurreccional o para la participación electoral era necesaria. El discurso dirigido a las mujeres particularizó en las amas de casa más que en las obreras, sin embargo no hay una definición sobre los alcances de la expresión "mujeres del pueblo", que fueron definidas por su oposición con las mujeres de la oligarquía; retomando un tópico del discurso peronista formal. Se apeló a un concepto esencialista de mujer, que al igual que el discurso de los periódicos de Nora Lagos, se basó en el maternalismo político. Sin embargo, a pesar de que era un discurso conservador respecto de los roles de género que transmitía, su uso fue muy maleable y habilitó a las mujeres para distintos tipos de prácticas que iban desde la participación electoral hasta la lucha insurreccional.

c. Conquista se presenta como un boletín partidario de la rama femenina, destinado a un público femenino, con un objetivo claro que era la reorganización partidaria de dicha rama. Se adjudicaba una "misión revolucionaria", que en términos concretos implicaba

\footnotetext{
${ }^{302}$ Línea Dura $\mathrm{N}^{\circ}$ 1. "El País de Hoy. Mujeres Presas", Buenos Aires, 4 de noviembre de 1957, p. 2.
} 
revalorizar el lugar de las mujeres en el peronismo y no limitarlo a organizar festejos ni movilizaciones de apoyo a candidatos varones:

"AFIRMAMOS... que el fin de cada peronista no es el de lograr las ventajas que nos pueda arrojar como migajas el absurdo régimen liberal en que vivimos. Sabemos que nuestra misión es muy otra, plena de objetivos revolucionarios que debemos cumplir por sobre los que no comprenden que nuestra tarea debe ir más allá de organizar festejos o movilizar a los compañeros para aportar a tal o cual dirigente circunstancial." 303

Las polémicas que sostuvo giraron en torno a ese tema y, por lo tanto, el adversario político se encontraba dentro del peronismo; no mantuvo disputas con el antiperonismo ni con otros sectores.

Era un boletín hecho por mujeres que durante los años del gobierno peronista habían formado parte de las estructuras juveniles y que, en la nueva coyuntura política, estaban reclamando un lugar en la dirigencia vedado por las mujeres que contaban con una larga trayectoria en la Rama Femenina. Pero para lograr su objetivo necesitaban una estructura política que les otorgara fuerza dentro del PJ, lo que explica sus reiterados llamados a las mujeres para participar y organizarse. Aunque estas mujeres contaban con trayectoria en el peronismo, eran muy jóvenes al momento de producirse el golpe de Estado de la Revolución Libertadora, por lo que carecían de antecedentes en los puestos de conducción partidaria. De manera que para convertirse en reorganizadoras de la rama femenina necesitaban una legitimidad que no les estaba dada por su trayectoria política, o al menos la misma no era suficiente, lo que las llevaba a apelar a otros elementos de legitimación. Al igual que Línea Dura, recurrieron a las figuras de los líderes peronistas, y sobre todo a la imagen de Evita, ya que lo que se proponían reconstruir era la estructura partidaria femenina, de la cual la ex primera dama había sido su creadora e impulsora. Tal es así que un artículo titulado "Partido Femenino. Lo que creó Eva Perón no debe destruirse", estaba destinado a cuestionar a las mujeres que se postulaban a cargos de dirigencia respaldadas por sectores masculinos. ${ }^{304}$ Ello se daba en un marco de reorganización partidaria en el que se discutía si las listas electorales para las internas debían ser mixtas o diferenciadas por género y si las mujeres tendrían representación en las estructuras de conducción en función de la cantidad de afiliadas o si se mantendría la autonomía del partido femenino, como había

${ }^{303}$ Conquista $\mathrm{N}^{\mathrm{o}} 1$. Buenos Aires, 20 de diciembre de 1963. Archivo Marta Curone.

${ }^{304}$ Conquista $\mathrm{N}^{\circ}$ 1. Buenos Aires, 20 de diciembre de 1963. Archivo Marta Curone. 
sido en tiempos del gobierno peronista, con sus propias listas, sus elecciones internas y con representación en los organismos de conducción basada en el tercio. Conquista se posicionaba en esta última opción. "Trabajar de otra manera es actuar contra una conquista de Eva Perón por la cual se dignificó a la mujer". ${ }^{305}$ En otro número sostenían: "El Partido Femenino no fue una creación caprichosa de Eva Perón, puesto que elevó a la mujer a un plano de igualdad con respecto al hombre logrando que fuera considerada en su real valor y ubicada en importantes funciones. Si abandonamos esta posición habremos traicionado el pensamiento de la compañera Evita y dado un paso atrás en el logro de las más caras aspiraciones femeninas". ${ }^{306}$ La figura de Perón también fue utilizada como elemento de legitimación. En una disputa que Conquista mantuvo con un grupo de ex dirigentes partidarias, se recurría a una carta del ex presidente dirigida a Curone, encargada de la confección del Boletín, que avalaba la larga trayectoria de esta militante del peronismo, al que había ingresado desde niña, y por lo tanto, tenía legitimidad para tomar decisiones y defender al movimiento. ${ }^{307}$

Además de apelar al uso de las figuras de los líderes peronistas, otro elemento de legitimación estaba en su nombre, ya que "Conquista" también se había llamado uno de los periódicos de la Rama Femenina que emergió en los últimos meses del gobierno peronista, como ya hemos señalado. Conquista explicitaba valores sobre los que debía asentarse la reorganización del Partido Femenino. Uno de ellos era el trabajo, frente a la realidad de una estructura política femenina que, según decía, hasta el momento se había caracterizado por la inactividad. Y junto al trabajo, un cuestionamiento a quienes sólo les interesaban los cargos políticos en desmedro del bien del conjunto. No es que rechazaran el acceso a los cargos, cuestión que por cierto estaba dentro de sus preocupaciones, sino que cuestionaban que ese fuera el único móvil de la actividad política. Tal es así que proclamaban que cuatro mujeres que integraban la circunscripción 18, a la cual pertenecían las realizadoras del boletín, habían sido designadas para desempeñarse como delegadas de la Comisión Interventora de Capital Federal, y habían solicitado que tres de ellas fueran eximidas de ocupar ese cargo, puesto que consideraban más importante el trabajo de base en la jurisdicción. ${ }^{308}$ En este sentido, el editorial del número dos se titulaba "Perpetuarse en los cargos para beneficio propio es traicionar la causa justicialista". En otro artículo se

\footnotetext{
${ }^{305}$ Conquista $\mathrm{N}^{\mathrm{o}} 1$. Buenos Aires, 20 de diciembre de 1963, p. 1. Archivo Marta Curone.

${ }^{306}$ Conquista $\mathrm{N}^{\mathrm{o}} 3$. Buenos Aires, 20 de febrero de 1964, p. 3. Archivo Marta Curone.

${ }^{307}$ Conquista $\mathrm{N}^{\circ} 3$. Buenos Aires, 20 de febrero de 1963, p. 1. Archivo Marta Curone.
} 
detallaban las características que se suponía debía tener un dirigente. La capacidad estaba en extremo valorada. Pero además, las dirigentes del Partido Femenino, no debían estar atadas a los sectores en pugna, debía haber renovación dirigencial y los dirigentes debían contar con apoyo de las bases y representatividad. ${ }^{309}$

Aun así, y pese a la independencia que pregonaban, las mujeres vinculadas a Conquista tenían ciertas preferencias. En el mismo artículo, se trasluce su alineamiento con los que proponían la vuelta de Perón de manera revolucionaria, lo que evidenciaba una simpatía por el MRP y una crítica al sector vandorista que promovía la vuelta pacífica y negociadora. ${ }^{310}$ En otro artículo, se manifiesta una cierta simpatía por el framinismo, que desde las páginas del mismo boletín es desmentida. Se informaba y se expresaba solidaridad con una cena organizada por sectores del PJ de Capital Federal y el Gran Buenos Aires en homenaje a Framini y al gremio textil que había resultado vencedor en las elecciones del gremio textil. Lo cierto es que el Boletín aclaraba que aunque no eran "furgón de cola de nadie", cuando una organización cumplía con su deber, merecía ser reconocida. ${ }^{311}$

En Conquista, a diferencia de las otras publicaciones que hemos venido analizando, el discurso dirigido específicamente a las mujeres abarcaba al Boletín en su totalidad, a la vez que abordaba una problemática específicamente femenina, que era la de la participación y organización política. En la coyuntura en la que este medio emergió, el problema pasaba por concretar esa organización que había quedado totalmente desarticulada luego del golpe de Estado y en las dificultades para que mantuviera su autonomía respecto de las otras ramas que conformaban el peronismo. A ello se sumaba el desafío de sortear las barreras para llegar a los organismos de conducción del movimiento. Desde el Boletín, se ofrecían estrategias concretas para el logro de dichos objetivos: que las mujeres se mantuvieran organizadas y activas y se capacitaran políticamente. Desde las páginas de Conquista se invitaba a las mujeres a concurrir a cursos de oratoria que las dirigentes de la circunscripción 18 ofrecerían, los cuales incluían clases de formación política. ${ }^{312}$ Pese a que este sector del peronismo femenino no descartaba las tareas de acción social ni las actividades tradicionales asociadas a lo femenino, está claro que consideraba que las mujeres en la política debían tener claros objetivos de acceso a los lugares de poder, un

\footnotetext{
${ }^{308}$ Conquista $\mathrm{N}^{\mathrm{o}}$ 2. Buenos Aires, 23 de enero de 1964, p. 2. Archivo Marta Curone.

${ }^{309}$ Conquista $\mathrm{N}^{\mathrm{o}} 3$. Buenos Aires, 20 de febrero de 1963, p. 2. Archivo Marta Curone.

${ }^{310}$ Conquista $\mathrm{N}^{\mathrm{o}} 3$. Buenos Aires, 20 de febrero de 1963, p. 2. Archivo Marta Curone.

${ }^{311}$ Conquista $\mathrm{N}^{\mathrm{o}} 3$. Buenos Aires, 20 de febrero de 1963, p. 4. Archivo Marta Curone.

${ }^{312}$ Conquista $\mathrm{N}^{\mathrm{o}} 3$. Buenos Aires, 20 de febrero de 1963, p. 2. Archivo Marta Curone.
} 
quiebre con la retórica del "renunciamiento" bajo la cual el gobierno peronista había encuadrado discursivamente la participación política femenina, y para ello la clave pasaba por la formación política y no por cursos de corte y confección. ${ }^{313}$ Además, ya desde el primer número aclaraba que la misión de la mujer debía ser revolucionaria, lo cual implicaba no limitarse a organizar fiestas o a movilizar en apoyo de algún dirigente. Para el segundo de los objetivos, el de la reorganización, el boletín ofrecía pautas concretas, para que la Rama Femenina funcionara orgánicamente con comisiones de trabajo y asambleas: "Organizadas lograremos ser respetadas y podremos desempeñar así un papel clave en las futuras decisiones nacionales". "Sujetas a las reacciones hepáticas del dirigentes de turno quizás no logremos pasar de la sala de espera de los postulantes". ${ }^{314}$

En una carta a dirigida a Perón por Marta Curone, ésta le manifiesta que ella y las demás dirigentes de la Circunscripción 18, lamentaban que Conquista no hubiera salido con anterioridad, porque ello les hubiera permitido capacitar a las mujeres en formación doctrinaria y manifestaba la necesidad de darle organicidad al Partido porque no podía denominarse como tal aquello que se reunía cada seis meses. Esta carta tenía como objetivo convencer a Perón de la importancia del Boletín frente a las críticas del grupo de Nélida de Miguel, a quienes desde sus páginas se había cuestionado por un evento vinculado con un reparto de juguetes al que las mujeres de la circunscripción 18 no habían sido convocadas; aunque de fondo, el conflicto era su alineamiento con el vandorismo y la falta de defensa de la autonomía de la Rama Femenina. Sin embargo, le manifestaba que a pesar de defender el mantenimiento del Boletín, ellas estarían dispuestas a suspenderlo si Perón así lo consideraba; de manera que la autonomía reclamada tenía un límite impuesto por la autoridad del propio Perón. ${ }^{315}$

La injerencia del sector gremial estaba expresada en términos de género. Si bien la rama sindical en el peronismo se definía por la extracción de clase y no de género, como sí ocurría con los dos sectores partidarios, el masculino y el femenino, sus organismos de conducción estaban exclusivamente integrados por varones. Entonces, dicha injerencia era concebida como un avasallamiento frente a la autonomía que se suponía que por tradición las mujeres debían tener en el movimiento peronista: "Si por cualquier causa o motivo el sector gremial tiene problemas por cuestiones de hombres, nada hay mejor que los arregle

\footnotetext{
${ }^{313}$ Sobre el carácter discursivo y uso político del "renunciamiento" de Eva Perón ver capítulo IV.

${ }^{314}$ Conquista $\mathrm{N}^{\mathrm{o}} 3$. Buenos Aires, 20 de febrero de 1963, p. 3. Archivo Marta Curone.

${ }^{315}$ Carta de Marta Curone a Perón. Buenos Aires, 1 de marzo de 1964. Archivo Marta Curone.
} 
en su seno, pues si el día de mañana hubiera una escisión femenina, lejos estaríamos nosotras de ir a pedir apoyo fuera de los organismos naturales porque actuando de esa manera los subestimaríamos incalificablemente [...]". ${ }^{316}$

La defensa de una organización femenina autónoma tenía sus límites. Postulaban una complementariedad de tareas con los hombres estableciendo distinciones entre ellas y las feministas, un pensamiento que no era nuevo en el peronismo. "Ello no significa ser feministas ni querer sectarizar. Muy por el contrario, en una labor de conjunto podemos colaborar con mayor eficacia con las tareas de los hombres sin superposiciones que sólo consiguen parcializar los resultados obtenidos". 317

La articulación entre género y clase es más débil en Conquista que en las otras publicaciones. Su mensaje no estaba dirigido a las mujeres del pueblo, si no a las mujeres peronistas, y en particular, a las de la circunscripción 18, porque el Boletín tenía un objetivo muy concreto que era la reorganización partidaria de esa circunscripción para poder presentar sus boletas en las elecciones internas. Las mujeres vinculadas al boletín tenían en claro que para ganar lugares de poder en la estructura partidaria necesitaban movilizar a las bases y la circunscripción del partido en las que ellas tenían militancia estaba radicada en barrio porteño de Palermo. Un artículo decía "Nosotras no somos clasistas, afirmamos que como rama del movimiento tenemos los mismos derechos y obligaciones que los dos restantes y manifestamos que debe existir una interdependencia de funciones, pero nunca un supeditamento (sic) de nuestros derechos a los intereses de otros!!". ${ }^{318}$ Este párrafo, con su aclaración de que no eran clasistas, no expresa una postura antimarxista. Lo que afirmaba, era la defensa de la autonomía del sector femenino de los otros sectores del peronismo y en especial del sector gremial, que estaba fagocitando a las otras dos ramas. El mismo artículo sostenía que no creían necesario tener que repetir que existían tres ramas del movimiento y que la desaparición de una de ellas destruía el equilibrio interno; un problema que el peronismo arrastraba desde sus orígenes.

De hecho, las problemáticas que plantea Conquista también las observamos en una publicación hecha por mujeres en los primeros años del gobierno peronista. Se trata de $L a$ Mujer de la Esperanza. Esta era una publicación de la Agrupación Femenina de Ayuda

\footnotetext{
316 Conquista $\mathrm{N}^{\mathrm{o}}$ 2. "No nos prestemos a la división!!! No apoyemos a hombres sino a conductas". Buenos Aires, 20 de febrero de 1964, p. 4. Archivo Marta Curone.

${ }^{317}$ Conquista $\mathrm{N}^{\circ}$ 3. Buenos Aires, 20 de febrero de 1964, p. 3. Archivo Marta Curone.

${ }^{318}$ Conquista $\mathrm{N}^{\circ}$ 2. Buenos Aires, 23 de enero de 1964, p. 2. Archivo Marta Curone.
} 
Social María Eva Duarte de Perón (AFAS), de la ciudad de Rosario. ${ }^{319}$ Esta agrupación estaba alineada con el gobierno peronista y con Evita en la promoción de la campaña por la ley de derechos políticos femeninos, pero abogaba por mantener su autonomía y defenderla de la injerencia masculina que algunos políticos peronistas pretendían efectuar. No se trataba de una publicación oficial, y desde sus páginas se convocaba a las mujeres a organizarse y convocaba a la afiliación para mantener una lucha sostenida. ${ }^{320}$ Esta publicación cuestionaba a los políticos que procuraban hacerse con el control de las organizaciones femeninas, impidiendo el acceso de las mujeres a puestos de dirección, y denunciaba las estrategias implementadas por esos políticos. Una de ellas consistía en presentar a las organizaciones femeninas como desprovistas de un criterio propio para gobernarse. La otra, consistía en generar disturbios internos para dividirlas, creando confusionismo. El periódico reconocía la necesidad de unificación de las agrupaciones femeninas que estaban luchando por la ley de voto femenino, pero sosteniendo la idea de que esa unificación debía hacerse por iniciativa de las propias mujeres y no promovida por dirigentes políticos. ${ }^{321} \mathrm{Y}$ criticaba a las mujeres que ponían en manos masculinas la solución de los problemas femeninos, otorgándoles a los políticos el lugar de dirigentes, formadores o dueños de agrupaciones femeninas. ${ }^{322}$

Al igual que Línea Dura, Conquista se vio obligado a recurrir a los líderes peronistas como figuras de autoridad para legitimar su pretensión de intervenir en un proceso de reorganización partidaria. A diferencia de todos los periódicos aquí analizados, estuvo dirigido específicamente a un público femenino, las mujeres a quienes se pretendía reorganizar. A diferencia de Línea Dura que apeló a conceptos esencialistas de mujer para legitimar su postura política, pese a que también hubo una visibilización de la actividad desarrollada por las mujeres y de su importancia en el movimiento peronista, en Conquista se expusieron explícitamente cuestiones vinculadas a problemáticas femeninas como las dificultades para ser reconocidas como sujetos políticos en su propio movimiento, el peronismo, y poder ocupar espacios de poder en las estructuras partidarias. De esta manera, Conquista abogaba por el mantenimiento de elementos que habían caracterizado a la participación política de las mujeres en el peronismo: el mantenimiento de la autonomía

\footnotetext{
${ }^{319}$ Su Directora era Elvira P. de Cerini, jefa de una de las circunscripciones en que se organizaba AFAS y su jefa de redacción, Lourdes del Rey de Michelino, vicepresidenta de AFAS.

${ }^{320}$ La Mujer de la Esperanza $\mathrm{N}^{\circ}$ 3. Rosario, Mayo de 1947.

${ }^{321}$ La Mujer de la Esperanza $\mathrm{N}^{\circ}$ 3. Rosario, Mayo de 1947.

${ }^{322}$ La Mujer de la Esperanza $\mathrm{N}^{\circ}$ 3. Rosario, Julio de 1947.
} 
respecto de las otras ramas -masculinas- y su reconocimiento en los organismos de conducción. Respecto de las modelizaciones de género que transmitía su discurso, podemos decir que propiciaba posturas rupturistas en relación de lo que había sido la participación política de las mujeres en el período anterior, puesto que si bien no renegaba de las actividades tradicionales que se habían promovido desde la dirigencia del viejo PPF, ligadas a las tareas domésticas, impulsaba la necesidad de las mujeres de capacitarse para lograr la igualdad política con los hombres, y esa capacitación pasaba concretamente por la formación política. Sin embargo, esas transgresiones tuvieron un límite, porque la actividad política femenina se interpretó como una complementariedad de las actividades masculinas, y la defensa de la autonomía encontró un límite en el propio Perón cuya autoridad no podían desconocer, a riesgo de quedar afuera del movimiento.

\section{Conclusiones}

En el capítulo primero nos preguntábamos si la participación de las mujeres en la Resistencia peronista se había limitado a actuar los roles de género, a cumplir funciones de simulación y a desarrollar tareas de apoyo, retomando una pregunta que Hélène Eck (2000) se hizo sobre los procesos de resistencia a los regímenes de extrema derecha en Europa. El desarrollo de la prensa gráfica como estrategia de protesta es una muestra más de la heterogeneidad que caracterizó a las acciones que desarrollaron las mujeres en la Resistencia peronista. En el primer capítulo observamos a las mujeres en el uso de la violencia política en un marco de relaciones de género desiguales incuestionadas. En el capítulo dos, las delineamos intentando organizarse para una participación legal, también en relaciones desiguales, pero cuestionándolas y luchando por recuperar los espacios ganados durante los gobiernos peronistas. Mientras que en este capítulo, las encontramos haciendo uso de la palabra escrita para intervenir en el espacio discursivo de la Resistencia peronista, un espacio que también estuvo muy masculinizado. La prensa gráfica es una instancia interesante para observar que las mujeres no se limitaron a realizar tareas de apoyo, ni de disimulo, ni tampoco a métodos de no colaboración, sino que irrumpieron con acciones de resistencia activa: intervinieron en el espacio público y discutieron sobre política y sobre las estrategias que creían convenientes al peronismo. En dos de los casos analizados, comprobamos que estaban interesadas por la organización para participar en las instancias 
electorales que, intermitente y con limitaciones ofrecía el sistema político; y en otros casos, su interés era incentivarlas a la lucha confrontativa o ambas, según la coyuntura política por la que transitaran.

Aquí hay que tener en cuenta cómo actúa la clase en el recurso al empleo de métodos conocidos, ya que estamos hablando de mujeres de clase media, con cierto nivel de instrucción y familiarizadas con la labor periodística desde los primeros gobiernos peronistas. No se trata de mujeres que tuvieron que recurrir a métodos que desconocían y que significaban un quiebre para ellas o un proceso de aprendizaje, sino que ya venían haciendo uso de ellos; e incluso, en el caso de Granata y Lagos, habían logrado alcanzar un reconocimiento público. La ruptura pasaba por el hecho de que, en el pasado, la actividad periodística se había desarrollado en marcos legales y en y con apoyo del oficialismo, mientras que en el momento posterior se desplegaba como una actividad contestataria y en un contexto proscriptivo, por lo que había adquirido un carácter subversivo con los riesgos que ello implicaba. Por eso, el hecho de que apelaran a actividades que ya conocían no significa que la relación entre militancia y vida cotidiana fuera armónica, porque con el desarrollo de esta prensa se exponían a la persecución política; algo que se observa sobre todo en el caso de Nora Lagos, donde su papel periodístico le valió encarcelamientos y un período de exilio. En Línea Dura también hubo persecución aunque con resultados menos drásticos y en el caso de Conquista en menor medida, porque fue un medio que no tuvo la circulación de los otros y que se desarrolló, además, en otro marco, aunque su realizadora ya había sufrido varios meses de cárcel en los años de la Revolución Libertadora. La de la prensa es una de las pocas instancias de la Resistencia peronista en que observamos a las mujeres desarrollando actividades en las que tuvieron que estampar su firma; lo que les permite cobrar visibilidad, pero también exponerse a los riesgos de la represión.

Respecto de los modelos de femineidad que estos periódicos transmitieron, hubo matices entre ellos. En general se aferraron a modelos tradicionales de mujer, basados en visiones esencialistas, pero con objetivos y estrategias disímiles, que habilitaban a las mujeres para actividades que eran disruptivas desde el punto de vista de los roles de género socialmente aceptados, como la lucha confrontativa con los gobiernos de turno e inclusive la participación por vía electoral, ya que se trataba de un contexto donde éste era un derecho recientemente adquirido por las mujeres que no había cristalizado aún en la totalidad de los discursos sociales. Y a la vez, todos cuestionaron la exclusión sufrida por las mujeres en términos políticos y/o sociales y reclamaron mejoras en las posibilidades de 
participación, ya sea a nivel social como en las propias estructuras partidarias del peronismo. En los periódicos de Nora Lagos y en Línea Dura, sin embargo, esos reclamos por la participación femenina se vieron opacados por la importancia dada a problemas coyunturales y a los que afectaban particularmente al peronismo, como la proscripción y el exilio obligado de Perón. Conquista, en cambio, fue creado para polemizar con un adversario interno que afectaba directamente contra la reorganización femenina, por eso los nudos problemáticos se articularon alrededor de esa temática, centro de su argumentación. Por ello, Conquista se distingue por ser un medio que reclamaba un lugar en los cargos partidarios para las mujeres en función de reconocer su capacidad de trabajo y no en función de la legitimidad que otorgaba haber pertenecido al viejo PPF.

En suma, podemos sostener que las trayectorias de las mujeres que dirigieron estos periódicos fueron atravesadas por la experiencia de la clandestinidad; sin embargo, desplegaron diversas estrategias para organizar la Resistencia y, en particular, la creación de diferentes emprendimientos periodísticos las colocó en posiciones que, en aquel contexto, en su mayoría, dominaban varones. Por ello, es interesante consignar sus actividades porque, a través de ellas podemos evidenciar, cómo las mujeres, en un medio poco favorable, asumieron lugares visibles en la organización de la resistencia, aspecto invisibilizado por los estudios clásicos que subsumieron la actuación femenina en el supuesto universal masculino -el arquetipo viril al que se refiere Moreno i Sardá- y no rescataron la estrategia genérica de reconocimiento e interpelación a las que apelaron estas mujeres. Vale decir, a lo largo del capítulo hemos presentado esta prensa como inscripta en un doble fin político: el de la resistencia y el de la toma de la palabra por parte de las mujeres. Ello, no obstante, no significa que consideremos a las mujeres que cumplieron estos roles como un grupo homogéneo que propendió a su propia reivindicación. Más bien, el análisis del discurso político de las diversas publicaciones, nos permite situar a estas mujeres como sujetos políticos activos que intervinieron en la reelaboración y discusión de la doctrina- ideología peronista en momentos conflictivos. Además, en algunos casos, pero no en todos, señalaron su condición de género, tales como Conquista, donde desarrollaron críticas sobre el lugar en el que las ubicaban sus compañeros, deslizándose así del arquetipo viril que caracterizó la prensa política, y, a través de la prensa y su vida cotidiana, denunciaron la desigualdad en la participación política. ${ }^{323}$

${ }^{323}$ Esto diferencia esta prensa de otras donde intervinieron mujeres El 17 -dirigido por Norma Kennedy-,
Trinchera - que en su staff contaba con Aída Filipini y Beatriz Fortunato- y Palabra Prohibida -dirigido 
Finalmente, también tomaron la palabra para diferenciarse de otras mujeres que en el mundo político consideraron traidoras a los ideales populares por no ser peronistas, por distinguirlas como las otras, las no peronistas. No dudaron, al hacerlo, en fustigar a algunas de las líderes feministas más reconocidas de aquellos años como Alicia Moreau de Justo, que se convirtió en una representante oprobiosa del colectivo feminista para estas periodistas políticas. En este sentido, se desmarcan de la idea que prevalece en las posiciones clásicas y androcéntricas, que considera a las mujeres como idénticas e intercambiables en la serie de género femenino, tal como ha señalado Celia Amorós (Amorós, 1987). Restituyen, a través de la politización, su definición como individualidad y su derecho a tomar un lugar en el contrato político en tanto mujeres y peronistas.

por Luis Sobrino Aranda, con participación de la ex legisladora Zulema Pracánico. Todas utilizaron el universal masculino que invisibiliza a las mujeres y no manifestaron interés por sus temáticas. Otras publicaciones que se posicionaron como escritas por mujeres y para mujeres fueron Abanderada y Voz Femenina (Carman, 2015). 


\section{Capítulo IV}

\section{Simbolismos, rituales y prácticas políticas}

En el capítulo anterior, analizamos la intervención polémica de las mujeres en el espacio discursivo de la Resistencia Peronista a través de la prensa. En este capítulo, nos concentraremos en prácticas profundamente impregnadas de elementos simbólicos de alta significación que constituyeron, a su vez, formas originales resignificadas del pasado y ubicadas en el repertorio de confrontación de la Resistencia. Nos referimos a las manifestaciones en memoria del natalicio y fallecimiento de Eva Perón, desplegadas durante los días 7 de mayo y 26 de julio respectivamente. En el cruce, entonces, entre la dimensión representacional propuesta por Joan Scott y el eje de los repertorios de confrontación cambiante en cada contexto de oportunidades, nos instalamos en lo que Sharp (2011) refiere como intervenciones sobre el espacio público que constituyen retos simbólicos que permiten llamar la atención del conjunto de la población.

Sidney Tarrow (1997) denomina como proceso de enmarcado la elección selectiva de símbolos culturales que realizan los grupos a fin de otorgar un marco de inteligibilidad y legitimidad a su causa. Ese proceso implica una negociación de significados que surge de la interacción y se basa en sobreentendidos cognitivos; en general, consiste en ubicar la acción colectiva en un marco de injusticia seleccionando un enemigo. En el caso que nos compete, ese marco de injusticia está claramente delimitado por el derrocamiento del peronismo, la proscripción, el proceso de desperonización y, más particularmente, la desaparición del cadáver de Evita. El desarrollo de las prácticas que analizaremos implicaron un "alineamiento de marcos", ya que se tomaron símbolos del pasado pero modificados para adaptarlos a la situación presente; en este caso, la que se había instaurado a partir del golpe de Estado de 1955 caracterizada por la proscripción del peronismo. Dichas prácticas poseen un carácter simbólico porque, además del lugar que ocupa en ellas la figura de Eva Perón, cargada en sí misma de esas connotaciones, implicaron una disputa por el significado político de diferentes lugares del espacio público.

En efecto, la Resistencia peronista se manifestó en un plano cultural que se materializó en la disputa por los objetos y espacios que revestían importancia simbólica para el peronismo (James 2010 [1988]; Salas, 2006 [1990]; Scoufalos, 2007; Seveso, 2010). El calendario peronista contiene una serie de fechas con una carga emotiva importante que 
durante el período en estudio (1955-1966) incentivaron intensos procesos de movilización popular. Entre esas fechas observamos que aquellas vinculadas a la figura de Eva Perón adquirieron un carácter ritualizado y provocaron una cuantiosa participación femenina. No es que las mujeres no participaran convocadas por otras efemérides del peronismo ni que en esas fechas motivadas por el recuerdo de Evita lo hicieran sin presencia masculina. Pero en ese tipo de prácticas, los documentos nos devuelven el panorama de una participación intensa y numerosa, a diferencia de otras intervenciones donde estuvieron en notable minoría respecto de los militantes varones o en las que si bien participaron masivamente, las fuentes no las registran o no particularizan en ellas por no haber ocupado los lugares protagónicos. La explicación, tal vez, radique, en el nexo que las unía con la ex primera dama. De hecho, Evita había sido capaz de formular un discurso dirigido específicamente a las mujeres, de sostener un reclamo políticos que las afectaba directa y especialmente, como la ley de voto femenino, y había cumplido un rol medular como organizadora y presidenta de la organización política que las había encuadrado de manera diferenciada respecto de las estructuras que nucleaban a los militantes varones, el Partido Peronista Femenino; además de gestionar otras instituciones no específicamente políticas que contaron con una intensa presencia femenina como la Fundación Eva Perón. Ese nexo llevó a las mujeres a alcanzar cierto protagonismo en los actos y manifestaciones destinados a mantener viva su memoria, y esto se mantuvo aún después de la caída del peronismo. Por otro lado, durante el período de estudio (1955-1966) dichas prácticas presentaban ambigüedad respecto de su carácter político y subversivo, no sólo para los encargados de controlar y reprimir sino también para las mujeres que las realizaban. De todas las prácticas analizadas, estas son las que más se vinculan a la cotidianeidad de las personas que las practicaban y que se hunden en sentimientos que a veces exceden los fines políticos o bien, si esos fines están, no son interpretados como tales. ${ }^{324}$

A lo largo del capítulo, analizaremos el despliegue de estas prácticas conmemorativas en relación a varios factores. Por un lado, las variaciones en el contexto político, en un

\footnotetext{
${ }^{324}$ Con esta última afirmación lo que intentamos decir es que probablemente muchas mujeres que se volcaban a la realización de actividades desplegadas en memoria de Eva Perón no lo hicieran con un fin político o no lo concibieran como una actividad política, a pesar de que sabían de su prohibición. También, es posible que muchas fueran simpatizantes peronistas, no militantes, y no se atrevieran o no estuvieran interesadas en realizar otro tipo de actividad que requiriera mayor dedicación, compromiso y riesgo. De hecho, una entrevistada de la ciudad de Berisso que perdió una pierna en un accidente de tranvía cuando iba a una misa en memoria de Eva Perón en La Plata, participaba de estos actos por provenir de una familia peronista, pero ella no militaba regularmente. Lucero, María. Entrevista de la autora. Berisso, 14 de mayo de 2014.
} 
espacio de diez años en que hubo mayores o menores posibilidades de expresar estos actos de manera más o menos abierta o velada. Dichas variaciones, serán acompañadas de un análisis espacial. El espacio urbano sobre el cual se desplegaron cobra fundamental importancia en el significado del mensaje que se intentaba transmitir a través de ellas, en tanto actos de enunciación (Lienhard, 2000), y sobre su carácter político y/o subversivo y, por lo tanto, sobre su factibilidad de ser objetos de represión. Además, la cuestión espacial está estrechamente vinculada con los anclajes materiales y territoriales de la memoria, puesto que interpretamos estas acciones de resistencia como intentos tempranos de conformación de una memoria sobre el peronismo. Una memoria en proceso de construcción (Jelin y Langland, 2003; Halbwachs, 2004; Nora, 2008), en estrecha vinculación con las problemáticas que aquejaban al peronismo en los años posteriores a su derrocamiento y con proyecciones políticas a futuro.

Tampoco podemos dejar de considerar la religiosidad que atravesó a estas prácticas. En este sentido, como ha señalado Blasco Herranz (2005) para España, la feminización del catolicismo a fines del siglo XIX, en un proceso de secularización, constituyó un fenómeno político "en el marco de la política de masas, de la configuración de las mujeres como sujetos políticos y del impulso hacia la recristianización” y supuso, asimismo, un impulso de movilización pública y política del colectivo femenino. Así fue abordado por la historiografía, señalando su carácter conservador. En este capítulo, por el contrario, rescatamos una apropiación política por parte de las mujeres de aquel universo religioso. En ese sentido, hacemos propias las palabras de Mari-Sol García Somoza e Irrazabal (2014), para quien: "Evitando el conformismo de una mirada unívoca que piensa a la religión como el espacio de subordinación de las mujeres y de reproducción de desigualdad de géneros, aunque sin negar el lugar que históricamente ocuparon las tradiciones y jerarquías religiosas como herramientas de dominación y categorización- nos inclinamos a favor de la pluralidad de miradas y contextos. Apostamos a la idea de que la investigación con perspectiva de género y una crítica reflexiva nos otorga la posibilidad de miradas ricas en complejidades y matices”. Ese posicionamiento nos lleva a considerar las posibilidades estratégicas que esa característica ofrecía en tiempos de proscripción y, a su vez, sobre el sentimiento genuino que la figura de Evita despertaba sobre militantes y adherentes peronistas en relación con la fe católica que muchos profesaban.

Este tipo de prácticas con connotaciones religiosas abrieron posibilidades para la participación política femenina en la Resistencia peronista en un momento cambiante e 
inestable. Aquí, juegan un papel fundamental las relaciones de continuidad y ruptura en relación al pasado inmediato; esto es, la época del gobierno peronista donde tanto mujeres como varones se socializaron en esas prácticas. El cambio de contexto político produjo una mudanza en el significado de las mismas. Nacidas como prácticas de memoria, en algunos casos por iniciativa de las bases peronistas y en otros, impulsadas por los sectores dirigentes; se convirtieron también en prácticas de resistencia. Así, el recordar a la ex primera dama, se cargó de nuevos contenidos cuya connotación política era un reto a la autoridad y a los planes de los gobiernos de turno que sucedieron al peronismo. Entonces, cabe preguntarnos sobre el lugar de las mujeres en la construcción y transmisión de memoria en el peronismo y su vínculo con la agenda política del momento.

Finalmente, nos interesa reflexionar sobre los límites y potencialidades que la imagen de Eva Perón generó como aliciente para la participación política femenina. Una vez más, al igual que en el pasado, la figura de Evita continuó legitimando e impulsando la participación política de las mujeres. La pregunta de la que partimos es cómo actuó esa figura en tanto símbolo para impulsar y/o limitar esa participación y cuáles fueron las connotaciones de género que adquirió.

A lo largo del capítulo, repasaremos los aportes de algunos autores que se han centrado en los aspectos simbólicos y ritualistas de la Resistencia peronista, para luego analizar los homenajes desplegados en memoria de Eva Perón durante el decenio 1955-1966 señalando cambios y continuidades respecto de las características que esas prácticas adoptaron bajo el segundo gobierno peronista (Gorza, 2016). Posteriormente, las analizaremos durante el período bajo estudio recuperando sus variaciones en la coyuntura política y en los espacios en los cuales tuvieron lugar. A ello, le seguirá una problematización sobre las características religiosas que las atravesaron, para finalmente centrarnos en las potencialidades simbólicas de la figura de Eva Perón como inspiradora de las actividades que desplegaron las mujeres como parte de la Resistencia peronista.

\section{La resistencia simbólica y cultural en la historiografía}

Las manifestaciones de duelo por Eva Perón constituyen una práctica que ha sido objeto de indagación para la época del segundo gobierno peronista. Según Lila Caimari (1995), que esas manifestaciones hayan estado asociadas a elementos religiosos se vincula al 
hecho de que Evita, desde un primer momento, apeló al uso de elementos del catolicismo en la construcción de su imagen pública. Luego, su muerte hizo que entre la población se multiplicaran las imágenes religiosas en torno a su persona. Si bien la propaganda oficial lo explotó en su favor, se habría tratado de un hecho espontáneo vinculado al lugar que en la cultura argentina ocupa la religión católica en los ritos fúnebres. Por su parte, Lucía Santos Lepera (2012), centrada en la provincia de Tucumán, analiza el desarrollo de esas manifestaciones a través de prácticas rituales que se desplegaban a través del espacio urbano, el rol de la Iglesia Católica en tratar de canalizar esas expresiones de religiosidad popular hacia formas más ortodoxas y la colaboración cumplida por los curas párrocos en su concreción. Por otro lado, la dimensión simbólica y religiosa de la figura de Eva Perón, ha despertado una multiplicidad de trabajos desde distintas disciplinas (Amar Sánchez, 2002; Grinberg Pla, 2005; Guy, 2004; Navarro, 2011; Rosano; 2006), a la vez que otros trabajos se han centrado en las relaciones que Evita mantuvo con la Iglesia católica (Zanatta, 2011).

Sin enfocarse específicamente en los homenajes a Eva Perón, otros autores han destacado la importancia del ritual en las prácticas del peronismo durante sus dos primeros gobiernos. Mariano Plotkin (1994), señala el rol cumplido por los rituales y la simbología en la construcción, por parte de la propaganda oficial, de un imaginario peronista que ayudó a consolidar el poder carismático de Perón, señalando para los primeros tiempos el uso de elementos del catolicismo que luego fueron dejados de lado, en la medida en que el peronismo fue monopolizando el espacio simbólico público. Plotkin ha señalado el valor simbólico de algunos lugares del espacio público urbano, hecho que también ha llamado la atención de otros investigadores que han enfatizado en las disputas por ese espacio en relación al acontecimiento del 17 de octubre de 1945, desatacando las iniciativas populares (James, 1987; 2010 [1988]; Neiburg, 1992). Nicolás Quiroga (2014), por otro lado, procura una redefinición del ritual restándole el carácter unilateral y de imposición para la obtención del consenso pasivo y del carisma que tradicionalmente se le ha atribuido, y en lugar de ello, lo concibe dentro de su definición de vida política a ras del suelo, interpretándolo en términos de prácticas cuya finalidad era flexibilizar los procedimientos partidarios en contextos locales, adaptarlos a la realidad y procesar las tensiones que se producían a nivel local.

Aunque las manifestaciones de duelo por Eva Perón tuvieron su origen con la muerte de la primera dama en julio de 1952, e incluso un año antes al darse a conocer su 
enfermedad, fueron reactualizadas en los años posteriores a 1955, permitiéndonos vislumbrar algunas continuidades respecto del período previo. Sin embargo, aún no han recibido un análisis sistemático para el período que se inicia con el golpe de Estado producido ese año, en el cual comenzaron a estar atravesadas por las acciones de la Resistencia peronista; con la excepción de las exploraciones realizadas por Laura Ehrlich $(2010 ; 2015 ; 2016)$ donde destaca la importancia que las misas, realizadas con motivo de alguna fecha de relevancia para el peronismo o en homenaje de los caídos en los fusilamientos del 9 de junio de 1956, tuvieron como instancia de reunión y de reconocimiento para simpatizantes peronistas que estaban buscando espacios y estructuras dónde militar, sobre todo entre los grupos de juventudes peronistas que se estaban conformando en esos años, y de referencias tangenciales en los trabajos sobre el Partido Justicialista de José Marcilese (2014) donde el autor sostiene que la dinámica del partido se intensificaba en oportunidad de conmemorar alguna fecha significativa del calendario peronista para luego regresar a un estado de actividad restringida, a la vez que observa cómo en algunos momentos las misas se constituyeron en una alternativa para sortear las restricciones que pesaban sobre la actividad partidaria.

Nuestro objetivo será entender esas prácticas de conmemoración a la figura de Eva Perón como acciones de la Resistencia peronista. Por ello, cabe mencionar a otros autores que si bien no se han centrado específicamente en los homenajes efectuados en la memoria de Evita, han abordado la Resistencia contemplando aspectos discursivos, simbólicos y culturales. Quien abrió la puerta para pensar la dimensión cultural de la Resistencia peronista es Daniel James (2010 [1988]), señalando la influencia del discurso peronista formal en la conformación de una cultura obrera y su carácter "herético", que habría motivado a los trabajadores a resistir los embates del Estado y de la patronal en los años que se sucedieron a la destitución del peronismo, a la vez que habría impedido que la crítica a la explotación capitalista pudiera ser articulada en un discurso ideológico y clasista, sintetizándose en la disputa peronismo-antiperonismo y expresándose más bien, en términos de un relato cargado de connotaciones morales en el que elementos del discurso peronista formal fueron resignificados.

Desde un enfoque específicamente discursivo, Silvia Sigal y Eliseo Verón (2004) analizaron el dispositivo de enunciación puesto en práctica durante los años que duró el exilio de Perón (1955-1973) caracterizado por unas condiciones de circulación restringida, para concluir que las decisiones del gobierno de la Revolución Libertadora que recayeron 
sobre la simbología peronista tuvieron el efecto contrario al de su objetivo, al sacralizar la palabra del líder ausente; lo que le habría otorgado a éste un gran poder político. Ernesto Salas (2006 [1990]), señala los significados culturales de las prácticas que se ensayaron como respuesta a la promulgación del decreto 4161 que prohibía la utilización de los símbolos peronistas con un claro objetivo de actuar sobre la memoria colectiva procurando borrar al peronismo de todos los espacios de las sociedad. Los militantes y simpatizantes de dicho signo político, motivados a transgredirlo por las prohibiciones que instauraba, terminaron reforzando su identidad política y frustrando los planes hegemónicos de los sectores dirigentes. De esta manera, se opone a aquellos trabajos que enfatizan en demasía los aspectos discursivos en detrimento de la materialidad que habría impregnado a dichos actos, a la vez que destaca el carácter clasista de la confrontación peronismo-antiperonismo.

Catalina Scoufalos (2007), a través de fuentes orales, indaga acerca de cómo operó la memoria en los primeros años de la Resistencia peronista, otorgando también especial importancia a las batallas simbólicas que tuvieron lugar a raíz del establecimiento del decreto 4161. Esas batallas habrían tenido como eje incidir en el sentido que se le otorgaría a la representación del pasado reciente, esto es, la etapa del gobierno peronista, a la vez que las actividades de la Resistencia se habrían centrado en preservar la identidad peronista y la memoria colectiva, que serían transmitidas a las nuevas generaciones. César Seveso (2010), en un trabajo que toma como objeto de análisis las producciones literarias de la Resistencia peronista, en particular la poesía, apunta a considerar las bases no materiales y no ideológicas que guían la acción colectiva, y para ello, examina las emociones. Estudia las dimensiones culturales de la violencia que atravesaron el conflicto peronismoantiperonismo, y sostiene que la socialización de ciertas emociones como la vergüenza y la humillación, a la vez que la socialización del duelo, permitieron la emergencia de un discurso contrahegemónico. Finalmente, Ana Josefina Centurión (2007) ha introducido la perspectiva de género para analizar la experiencia de las mujeres que participaron en la Resistencia peronista y los valores que fueron tomados como articuladores de la acción. Puntualmente, analiza la gravitación que jugó la figura de Eva Perón y el uso selectivo de ciertos atributos de su imagen como movilizadores de la acción.

Estos tres trabajos, aunque incipientes, esbozan algunas líneas de análisis que resultan interesantes para nuestro tema de investigación en el presente artículo. Los de Seveso y Scoufalos, marcan en primer lugar, el interés por indagar cómo actuó la memoria durante la etapa de la Resistencia respecto de un pasado reciente que era el del gobierno peronista. En 
segundo lugar, advierten sobre los anclajes materiales y territoriales de la memoria, las disputas por el espacio público y la existencia de una cultura material constituida por bustos, monumentos, banderas y emblemas que se convirtieron en objetos de batalla entre peronistas y antiperonistas. Nuestro objetivo en estas páginas, además de observar cómo se construye la memoria sobre el espacio, será analizar el rol que cumplieron las mujeres en dicho proceso y cómo influyó en ello la herencia del pasado y el proceso de socialización política que habían atravesado en los años previos (Lahire, 2004). Nuestro aporte será analizar cómo los rituales, particularmente los dedicados a evocar a Eva Perón, se constituyeron en prácticas de socialización que permitieron a las mujeres volcarse al espacio público.

\section{Los homenajes a Eva Perón en el repertorio de confrontación de la Resistencia}

Los homenajes a Evita constituyen un ejemplo de reactualización de prácticas existentes en la tradición peronista que pasaron a formar parte del repertorio de confrontación después de 1955. Así, mientras en el pasado primaba el refuerzo de un colectivo de identificación donde la figura de Evita mantenía la unidad, en este marco, la confrontación cobró otra relevancia. Esa confrontación existía en las prácticas originarias como modo de disputar a los opositores reforzando la posición de poder que el peronismo tenía al estar en el gobierno; sin embargo, en el momento posterior, esa confrontación sirvió para nuclear a los peronistas reforzando sus sentimientos de pertenencia $\mathrm{y}$, asimismo, fue una forma de socavar el lugar de poder de los gobierno que los proscribían. Para precisar este derrotero, analizaremos a continuación el despliegue de esas prácticas, primero durante el segundo gobierno peronistas; y luego, durante el período bajo estudio.

Los homenajes en torno a la figura de Eva Perón surgieron poco antes de su muerte, al hacerse de conocimiento público su enfermedad y al poco tiempo del renunciamiento a su candidatura a la vicepresidencia de la Nación, que se hizo por cadena nacional en agosto de 1951, poco después de un acto masivo conocido como "Cabildo Abierto del Justicialismo", en el que la dirigencia de la CGT solicitó públicamente su candidatura. En ese acto, según Caimari (1995), no faltaron las connotaciones religiosas. Las fechas del 17 y 18 de Octubre de ese año, le estuvieron especialmente dedicadas, reemplazando el nombre de "San Perón" de esta última, por el de "Santa Evita" (Plotkin, 1994). Entidades y espacios públicos 
recibieron su nombre, incluyendo ciudades y una provincia, la de La Pampa. Se decidió por ley la construcción de monumentos consagrados a su persona, a la vez que al año siguiente, por decisión del Congreso, fue declarada "Jefa Espiritual de la Nación” y se lanzó el libro La razón de mi vida, que recreaba su biografía. Paralelas a estas decisiones gubernamentales, hubo manifestaciones de carácter espontáneo, como la proliferación de misas y peregrinaciones en su nombre. Finalmente, los actos funerarios a que dio lugar su muerte en julio de 1952, fueron majestuosos. Su cuerpo fue expuesto durante dos semanas en el edificio de la CGT para que sus seguidores pudieran despedirse (Caimari, 1995).

En julio de 1953, fue conmemorado el primer aniversario de su fallecimiento. ${ }^{325}$ Desde un comienzo, las misas y los "homenajes cívicos" se desarrollaban preferentemente al caer la tarde y tenían su punto culminante a las 20:25, horario del deceso, para terminar poco después. Se realizaban durante toda la semana y finalizaban el 26 de julio. Si bien los actos cívicos tenían lugar en los espacios públicos fuera de las iglesias, estaban impregnados de una serie de prácticas propiamente religiosas como la colocación de ofrendas, los rezos y la emisión de música sacra. En la ciudad de Buenos Aires, la misa principal, a la que acudían las autoridades gubernamentales, gremiales y partidarias, se realizaba en la basílica de San Francisco, ya que Evita había estado vinculada a esa Orden religiosa, a la que se había incorporado en 1947 como Hermana Terciaria, y el acto cívico oficial consistía en un itinerario desplegado por las calles de Buenos Aires. Alrededor de las ocho de la noche, en la intersección de Moreno y 9 de Julio, lugar donde en agosto de 1951 había tenido lugar el "Cabildo Abierto", se realizaba la concentración, frente a un gran retrato sostenido con columnas que recordaban el "renunciamiento" a su candidatura. Entonces, a las 20.25, luego del sonido de clarines, se hacía un minuto de silencio, se rezaba una oración y las personas agrupadas en el lugar procedían a encender antorchas que previamente habían sido repartidas por la CGT. Mientras tanto, en el edificio del Ministerio de Obras Públicas, a una cuadra del lugar, se encendían las luces de las ventanas, formando la palabra EVA, a lo que se sumaba un juego de luces con reflectores y luego, la marcha de antorchas hacia el edificio de la CGT, en la calle Azopardo al 800, donde se hallaban los restos de la primera dama, y cuyo frente era abarrotado de coronas florales enviadas por distintas dependencias y

\footnotetext{
${ }^{325}$ En mayo de ese año había tenido lugar el primer aniversario de su nacimiento posterior a su muerte. El acto principal se había realizado en la Escuela de Enfermería de la Fundación Eva Perón en la ciudad de Buenos Aires y había estado seguido por la colocación de ofrendas florales en un altar levantado en el edificio de la CGT, lugar donde descansaban sus restos, y frente al cual desfilaron distintas delegaciones, a
} 
organizaciones. ${ }^{326}$ Después de pasar por dicho edificio, se realizaba la desconcentración, aunque muchos se detenían frente a la Fundación Eva Perón sobre Paseo Colón, donde funciona actualmente la Facultad de Ingeniería, para marchar posteriormente hacia las calles céntricas con las antorchas encendidas. ${ }^{327}$ En términos muy sintéticos, esto era lo que sucedía en la ciudad de Buenos Aires, donde además del acto oficial, se repetían multiplicidad de homenajes en distintos lugares efectuados por diferentes entidades. ${ }^{328}$

Mientras tanto, en las ciudades y pueblos del interior del país, la concentración se realizaba en las plazas principales donde por medio de altoparlantes se transmitía lo que ocurría en el acto central de Buenos Aires, a la vez que se repetía el proceso de enviar ofrendas florales a las sedes locales de la CGT, la marcha de antorchas, la realización de misas, el depósito de coronas en los bustos y monumentos públicos y la erección de bustos y colocación de placas; en muchos casos costeados por los propios vecinos. ${ }^{329}$

Las expresiones de duelo por la muerte de Eva Perón pueden ser entendidas como prácticas de memoria; una memoria que encontraba su expresión material a través de placas, bustos y monumentos, pero que también se desplegaba en un espacio, inclusive en un itinerario, como lo demuestra el recorrido que se realizaba por determinadas calles de la ciudad de Buenos Aires. Esas marcas y prácticas de la memoria se trasladaban a otros espacios, a menor escala, en otras ciudades y pueblos del interior del país, así como a otros espacios periféricos de la Capital Federal. ${ }^{330}$

En 1954, los homenajes volvieron a repetirse con pocas variaciones, por lo que no merece que nos detengamos en su descripción. Mayo de 1955 es la última fecha donde las conmemoraciones se desarrollaron con normalidad. Hacia julio de ese año, ya desatado el conflicto con la Iglesia, producido el bombardeo del 16 de junio sobre la Plaza de Mayo por los aviones de la Marina y a pocos meses de producirse el golpe de Estado que derrocaría al peronismo, es de destacar la ausencia en los diarios de menciones sobre la realización de

la vez que se montaron guardias de honor. La Nación. "Homenajes a la Señora Eva Perón”. Buenos Aires, 8 de mayo de 1953, p. 2

${ }^{326}$ Luego de la concentración en Moreno y 9 de Julio, la procesión continuaba por la calle Belgrano hasta Paseo Colón y de ahí hasta Chile, realizando una cuadra por dicha calle, para tomar finalmente por Azopardo.

${ }^{327}$ La Nación. "Densa multitud participó en la procesión cívica". Buenos Aires, 27 de julio de 1953, p. 1.

${ }^{328}$ La Nación. Buenos Aires, 26 de julio de 1953, pp. 1 y 2; La Nación. Buenos Aires, 27 de julio de 1953, pp. 1 y 2; La Nación. Buenos Aires, 26 de julio de 1954, p. 1; La Nación. Buenos Aires, 27 de julio de 1954 , pp. 1 у 2.

${ }^{329}$ La Nación. "La adhesión en el interior de la República”. Buenos Aires, 27 de julio de 1953, p. 1.

${ }^{330}$ Para un análisis teórico sobre las marcas materiales y territoriales de la memoria y sobre su factibilidad de ser recreadas en otros espacios ver Jelin \& Langland (2003). 
misas, al menos a nivel oficial. ${ }^{331}$ En cuanto al acto principal, si bien no dejó de ser masivo y majestuoso, disminuyó el nivel de ostentación respecto de los años previos. Las fuentes periodísticas transmiten cierta cautela por parte de las autoridades de gobierno por evitar actitudes provocativas que pudieran desatar enfrentamientos con grupos opositores. El momento culminante de la ceremonia ya no se realizó sobre la Avenida 9 de Julio, sino frente a la CGT, cuyo edificio se mantuvo cerrado; la manifestación se desplegó con un trayecto menor, por Azopardo desde Belgrano a Carlos Calvo; se prohibió la portación de antorchas y de carteles o distintivos partidarios y se prestó especial cuidado a que la desconcentración se realizara en orden. ${ }^{332}$ En La Plata y otras ciudades del interior del país, el acto central que solía tener lugar en las plazas principales, se replegó a los locales de la CGT. $^{333}$

Como pudimos observar, para los años del gobierno peronista, los actos de homenaje en memoria de Eva Perón, estuvieron impregnados de elementos religiosos, a la vez que se caracterizaron por la repetición de ciertas prácticas y su despliegue en el espacio urbano, en un proceso en el que se combinaron iniciativas espontáneas con respuestas a las decisiones emanadas desde el gobierno central. Desatado el conflicto con la Iglesia y en un clima de malestar y de abierta oposición al peronismo, durante el año 1955, estos actos decayeron en magnitud y magnificencia, lo que evidencia el atravesamiento por las coyunturas de disputa política.

A partir del golpe de Estado, el gobierno de la Revolución Libertadora intentó borrar al peronismo de la escena política lo cual implicó una prohibición sobre los usos de símbolos y emblemas que lo identificaban. Es así que el inicio ese gobierno estuvo acompañado de un proceso de iconoclasia. Como sostiene Gilbert Gardes (citado en Candau, 2006), estos procesos suelen venir aparejados a los momentos de crisis política puesto que, en dichas circunstancias, la nueva memoria dominante o que aspira a convertirse en tal, no tolera la memoria encarnada en los monumentos. Estela Spinelli (2005) señala que una de las primeras medidas tomadas por el nuevo gobierno fue cambiar los nombres de calles, ciudades, plazas y demás espacios y edificios públicos que hacían alusión a los líderes peronistas o a referencias partidarias, seguidos por la prohibición de

\footnotetext{
${ }^{331}$ No hemos indagado sobre su realización en los barrios alejados del centro de Buenos Aires o en lugares del interior del país.

${ }^{332}$ La Nación. Buenos Aires, 26 de julio de 1955, pp. 1 y 2; La Nación "Hízose frente a la CGT el acto principal". Buenos Aires, 27 de julio de 1955, pp. 1 y 2.

${ }^{333}$ La Nación. Buenos Aires, 27 de julio de 1955, p. 2; El Día, La Plata, 27 de julio de 1955, p. 2.
} 
cantar la marcha "Los muchachos peronistas" y por la quema pública de los libros de lectura de ese signo político. A pesar de que el gobierno de Eduardo Lonardi se había propuesto la pacificación, objetivo que incluso figuraba en la proclama de la Marina de Guerra donde se afirmaba, entre otras cosas, la prohibición de destrozar bienes privados o públicos, estatuas y símbolos, el mismo no fue coherente con el proceso de desperonización iniciado por los sectores del antiperonismo más recalcitrante, que tenían representantes en el gabinete e incluso en la vicepresidencia encarnada por Isaac Rojas. Estos sectores antiperonistas encontrarían cauce a sus aspiraciones en el segundo gobierno de la Revolución Libertadora; el de Pedro E. Aramburu e Isaac Rojas, iniciado en noviembre de 1955.

Durante el gobierno de Aramburu-Rojas, la desperonización fue una consigna clave que encontró expresión en políticas concretas. Entre otras medidas, podemos mencionar la promulgación, el 5 de marzo de 1956, del decreto 4161, previamente mencionado. Otras acciones fueron, la liquidación de la Fundación Eva Perón, la demolición del palacio Unzué, que había servido de residencia presidencial, y el robo del cadáver de Eva Perón del edificio de la CGT por parte de un comando del Ejército (Spinelli, 2005). También, deben sumarse los actos de destrucción de bustos y monumentos y su exhibición pública, llevada a cabo por grupos de personas que apoyaron el golpe y por los comandos civiles que habían comenzado a actuar como fuerzas desestabilizadoras desde los meses anteriores al derrocamiento (Baschetti, 2013).

Frente a esta situación, la respuesta de los militantes y adherentes peronistas no se haría esperar. Los intentos por homenajear a Eva Perón en los aniversarios de su nacimiento y muerte pasaron a integrar el repertorio de acciones de la Resistencia peronista para afrontar el proceso de desperonización encarado desde el Estado y mantener viva la memoria, ya no sólo de su líder femenina sino del peronismo en general, que estaba proscripto, imposibilitado de hacer uso de su simbología, con su máximo líder exiliado y con los dirigentes de primera línea presos e inhabilitados para ocupar cargos.

La costumbre de homenajear a Eva Perón en los aniversarios de su natalicio y fallecimiento, desde un primer momento, adquirió una doble forma que se caracterizó por la realización de misas y de homenajes cívicos que estuvieron atravesados por rituales religiosos; algunos de carácter oficial y otros de origen popular y espontáneo (Caimari, 1995; Santos Lepera, 2012). Proponemos entender estas prácticas ritualistas como parte del repertorio de acción colectiva de la Resistencia peronista. Como sostiene Tilly (citado por Tarrow, 1997), los sujetos internalizan el repertorio de acción colectiva en la propia 
práctica y gracias a las luchas precedentes. Sin embargo, la familiaridad que los militantes y simpatizantes peronistas habían desarrollado con estos rituales no provenía de una trayectoria de luchas, sino que habían sido socializados en ellos durante la época del gobierno peronista, momento en que los mismas gozaban de legitimidad. Al producirse la destitución del peronismo, terminarían constituyéndose en prácticas de acción colectiva contenciosas, ya que pasaron a ser ilegales. Al mismo tiempo, hubo por parte de los sujetos que hicieron uso de ellas, una resignificación realizada en relación a las necesidades de ese presente, puesto que su función ya no se limitaba a homenajear a Eva Perón sino que además servían para plantear demandas a los gobiernos de turno y para reafirmar la identidad peronista.

En general, las manifestaciones de duelo por Eva Perón durante los años de la Resistencia peronista se basaron en la colocación de ofrendas florales en lugares donde previamente había estado emplazado algún elemento que recordara la presencia de la ex primera dama, ya sea un busto, una placa o un monumento, o en edificios públicos en torno a los cuales se habían desarrollado las ceremonias oficiales e incluso en la repetición de algún trayecto que había formado parte de esas ceremonias. El concepto de lieux de mémoire desarrollado por Pierre Nora, definido como aquellos lugares en donde la memoria "se cristaliza y se refugia", puede resultar esclarecedor para comprender estas prácticas de los primeros tiempos de la Resistencia peronista. Estos lugares tienen el propósito de detener el tiempo para fijar un estado de cosas, y sin embargo, van mutando su significado con el devenir histórico. Con el desarrollo de este concepto, Nora ha pretendido otorgarle una explicación a la emergencia excesiva de los lugares de memoria en la sociedad moderna, una sociedad que ha roto sus lazos con el pasado y que necesita de apoyos externos para recuperarlos (Nora, 2008). Ahora bien, para el tema que nos compete, el de la Resistencia peronista, los monumentos, rituales y marcas territoriales de la memoria, más que devolvernos una imagen cristalizada y acabada de ésta, nos proyectan a un escenario dinámico, de disputas, donde los diferentes actores sociales pujan por imponer su propia interpretación del pasado; pero de un pasado demasiado reciente, aun no concluido, que todavía ejercía su peso sobre las acciones y discusiones políticas del momento. Evidencias de esas disputas se registran desde los primeros días posteriores al golpe. De hecho, una de las imágenes anecdóticas sobre la Resistencia peronista que ha quedado cristalizada y que se repite en los testimonios orales es la de grupos de mujeres de barrio, algunas integrantes de 
unidades básicas o enfermeras, que protegieron los bustos de ataques opositores y que los escondieron para impedir que fueran destruidos (Centurión, 2007; Dos Santos, 1983). ${ }^{334}$

En la ciudad de Buenos Aires observamos un patrón de comportamiento que se repetía año tras año. Los problemas se suscitaban en horas de la noche, sobre todo, a partir de las veinte horas, en que tenían lugar las concentraciones para recordar el momento exacto del fallecimiento. En general, las acciones se volcaban a resucitar antiguas prácticas, como las marchas de antorchas y la realización de procesiones recreando el itinerario oficial que se realizaba en épocas del gobierno peronista, además de devolverle su anterior significado a los lugares, edificios y monumentos que en esos años habían sido consagrados desde el Estado para mantener la memoria de la primera dama. Por eso, los centros del conflicto eran las zonas aledañas a la CGT; la policía trataba de impedir por todos los medios la llegada de los manifestantes a dicho edificio. Se sumaban la Facultad de Ingeniería de la Universidad de Buenos Aires, ex sede de la Fundación Eva Perón; el monumento al Trabajo, ubicado frente a la Facultad; y el Consejo Deliberante, donde había funcionado el Ministerio de Trabajo y Previsión; además de las zonas céntricas de la ciudad. ${ }^{335}$ El edificio de la Facultad de Ingeniería se había transformado en un objeto en disputa entre peronistas y antiperonistas, tal es así que en julio de 1958, durante la presidencia de Arturo Frondizi, los estudiantes universitarios intentaron atrincherarse para defenderlo contra un posible avance de los manifestantes peronistas, acción que fue evitada por el rector de la Universidad de Buenos Aires, Rizieri Frondizi. ${ }^{336}$ El edificio del ex Ministerio de Trabajo y Previsión había sido declarado monumento histórico durante el gobierno peronista mediante la ley 14.129. Depositar flores en su frente fue una estrategia de los manifestantes que se veían imposibilitados de llegar hasta el edificio de la CGT, porque la policía se los impedía. En diciembre de 1955, el periódico rosarino La Argentina, cuestionaba la derogación de esa ley por decreto del Poder Ejecutivo. ${ }^{337}$

\footnotetext{
${ }^{334}$ Referencias a este tipo de hechos emergen en algunos de los relatos de las entrevistas realizadas a militantes de la Resistencia: Mura, Elsa. Entrevista de la autora. El Palomar, 27 de mayo de 2014; Omar Dalponte. Entrevista de la autora. Lanús, 7 de julio de 2014.

${ }^{335}$ La Nación. "Un homenaje póstumo motivó incidentes". Buenos Aires, 27 de julio de 1957, p. 11; La Nación. "En varias zonas de la ciudad hubo agitación", 27 de julio de 1958, p. 11; La Nación. "Provocaron disturbios ayer grupos aislados". Buenos Aires, 27 de julio 1959, p. 11; La Razón. "Se adoptarán medidas policiales para evitar desórdenes en la fecha de hoy". Buenos Aires, 26 de julio de 1960, p. 12 y La Razón. "Hubo anoche ligeros incidentes en el centro y en Constitución: 10 detenidos". Buenos Aires, 27 de julio de 1960, p. 10.

${ }^{336}$. La Nación. "En varias zonas de la ciudad hubo agitación". Buenos Aires, 27 de julio de 1958, p. 11.

${ }^{337}$ La Argentina. "Tres leyes han sido derogadas". Rosario, 8 de diciembre de 1955.
} 
Los grandes despliegues policiales en los lugares recién señalados, como medida preventiva, evidencian que las manifestaciones se realizaban con regularidad y que las fuerzas represivas no sólo preveían que ello sucedería, sino que también sabían cuáles eran los lugares en que tendrían lugar, ya que estos no eran elegidos al azar, sino que eran sitios que previamente, durante el gobierno peronista, habían sido escogidos como lugares transmisores de memoria. En el nuevo contexto habían adquirido nuevos significados, porque su elección ya no sólo tenía como objetivo transmitir una memoria sobre Eva Perón, sino también sobre el peronismo en general que se resistía a desaparecer. Como sostienen Elizabeth Jelin y Victoria Langland (2003), los lugares de memoria no siempre surgen de nuevas construcciones, a veces se otorga un nuevo sentido a un lugar preexistente con significados previos. Por supuesto que, a diferencia de la época peronista en que todo estaba organizado y calculado, después del 55 primaban el desorden, la espontaneidad y la improvisación. Por ejemplo, las antorchas ya no eran repartidas por la CGT, sino que se hacían con papel, e inclusive, los diarios registran que en 1958, desde los balcones, los vecinos tiraron papeles de diario a los manifestantes para ese fin. ${ }^{338}$ Mariano Plotkin (1994) ha observado para la celebración del 17 de Octubre que en el acto original de 1945, los participantes también improvisaron antorchas con periódicos, y en1946, se lanzaron papeles desde los balcones que rodeaban a la Plaza de Mayo, para recrear la escena del año anterior. Luego, a partir de 1948, y como una manifestación de lo que el autor considera una regulación del ritual por parte del gobierno y una pérdida de espontaneidad, los papeles eran distribuidos por los organizadores del acto, para reproducir escenas que en años previos se habían generado de manera espontánea por iniciativa de los manifestantes. De alguna manera, la etapa de la Resistencia venía a recrear prácticas que habían tenido su origen no sólo en la liturgia oficial sino también de manera espontánea muchos años antes de la muerte de la ex primera dama y en relación a otras celebraciones importantes del peronismo.

Si bien la improvisación y espontaneidad rodearon a algunas de las prácticas implementadas para recordar a Eva Perón durante los años de la Resistencia, es de notar que estas no se producían en el vacío, porque los participantes en esas manifestaciones procuraban actualizar prácticas que se inscribían en un pasado compartido. En general, los asistentes a las marchas trataban de repetir el mismo trayecto que solía desplegarse cuando

\footnotetext{
${ }^{338}$ La Nación. "En varias zonas de la ciudad hubo agitación”. Buenos Aires, 27 de julio de 1958, p. 11.
} 
el peronismo aún estaba en el gobierno y de realizar homenajes frente a los edificios que habían integrado el ritual oficial. Como sostiene Maurice Halbwachs, “[...] la mayoría de los grupos [...] dibuja en cierto modo su forma sobre el suelo y encuentran sus recuerdos colectivos en el marco espacial así definido" (Halbwachs, 2004, p. 160). Los grupos se resisten a la modificación de su entorno material porque hay una tradición que se encarna en él y ante un cambio de las condiciones de ese entorno buscan restablecer el antiguo equilibrio (Halbwachs, 2004).

Cuando observamos la realización de estos actos de homenaje en los años que siguieron al golpe de Estado de 1955, nos encontramos con un intento de los militantes y simpatizantes peronistas por repetir las mismas prácticas que habían desarrollado durante el gobierno peronista como parte del ritual, y de hacerlo en los mismos lugares. Ejemplo de ello son los edificios públicos que hemos mencionado para la ciudad de Buenos Aires, el Cristo Redentor en Rosario, el Monumento a la Madre en Mar del Plata o el Policlínico de Lanús, entre otros. Elizabeth Jelin y Victoria Langland (2003), interesadas por destacar el papel de la agencia de los sujetos en el proceso por el cual un espacio físico se transforma en un "lugar", al cual se le otorgan sentidos, han hecho hincapié en las luchas políticas que atraviesan ese proceso. Esos lugares, que son significativos para una comunidad y alrededor de los cuales se concentra el ritual, reciben el reconocimiento legítimo del Estado, pero este reconocimiento es el resultado de luchas de poder. La descripción que hemos desarrollado sobre el despliegue de los actos en memoria de Eva Perón nos presenta una imagen por demás conflictiva, donde construir una memoria sobre el período del gobierno peronista, más que buscar la aprobación del Estado, entró en competencia con los mismos sectores gobernantes que tenían proyectos propios respecto del peronismo y con el antiperonismo en general encarnado en diferentes sectores de la sociedad.

En términos generales podemos decir que la tendencia que prevalece es la pervivencia de prácticas del período anterior que pujaban por mantenerse, no sin conflicto, en el nuevo contexto, y sufriendo alteraciones en su significado. Algunos autores conciben a las prácticas de memoria como actos de enunciación o de comunicación. En este sentido, Martín Lienhard enumera los diferentes destinatarios que puede tener un acto de memoria popular, entendiendo como tal a la memoria de los grupos subalternos, y cómo la presencia o ausencia de estos destinatarios influye en el mensaje que se intenta transmitir. Así, la presencia de observadores externos, en este caso externos al peronismo, y sobre todo la presencia del enemigo, el antiperonismo, actúan como factores para modificar prácticas que 
en un pasado, los años del gobierno peronista, habían tenido otro significado. Ello no quiere decir que en aquellos años no tuvieran un significado político, sobre todo si tenemos en cuenta el uso que de ellas se hizo por parte del gobierno y la dirigencia política. Pero también debemos considerar que entre muchos militantes y simpatizantes sólo estuvo el simple objetivo de homenajear y llorar a Evita. Lo que está claro es que en tiempos de la Resistencia una serie de prácticas que tuvieron como fin el reforzamiento de la legitimidad de un régimen o simples manifestaciones de duelo, transmutaron en un significado subversivo con objetivos de autoafirmación y de socavamiento de la legitimidad de los gobiernos que siguieron al peronismo. Ello no significa que deba descartarse la posibilidad de que también en esta época muchos persiguieran simplemente homenajear a Evita, sin embargo esa finalidad no eximía a estas prácticas de ser objetos susceptibles de represión

\section{Duelo y memoria, disputas simbólicas en espacios públicos}

A diferencia de otras prácticas analizadas en esta tesis donde captamos los conflictos que atravesaron internamente al peronismo, en este tipo de prácticas de memoria organizadas en torno a la figura de Eva Perón resulta más difícil establecer esas disputas, siendo más visible la confrontación peronismo - antiperonismo. Ahora bien, aunque el mensaje transmitido debía ser entendido por el enemigo porque implicaba una autoafirmación de la propia identidad peronista, su potencialidad radicaba en las ambigüedades que generaba acerca de su carácter subversivo, y por lo tanto, en las dudas que provocaba sobre los agentes del orden respecto de la factibilidad de ser reprimidos. Estas prácticas, a veces, adoptan las características de lo que James Scott (2003) ha caracterizado como un discurso oculto surgido entre los sectores subalternos que sale a escena de manera velada introduciendo un mensajes con connotaciones políticas y subversivas dentro de los marcos de la ley, aprovechando las inconsistencias, las ambigüedades y los silencios que la misma permite. Se trataría de un mensaje que debe ser claro para aquellos que pertenecen al propio colectivo de identificación, en este caso los peronistas, y que se logra apelando a la utilización de códigos compartidos, pero que a la vez debe ser inteligible para el enemigo, porque de lo contrario pasaría desapercibido y perdería su carácter confrontativo. Las prácticas abiertamente confrontativas, sobre todo las que apelan al uso de la violencia política, tienen la desventaja de reducir la incertidumbre 
sobre el enemigo y generar pretextos para reprimir (Tarrow, 1997). Los homenajes a Eva Perón dieron lugar a prácticas cuyo carácter desafiante y confrontativo, muchas veces, permaneció ambiguo y oculto. Sin embargo, más de una vez, los límites entre los que las fuerzas del orden estaban dispuestas a aceptar y lo que no, fue transgredido. Cabe aclarar que la dimensión espacial se convirtió en un factor determinante de la factibilidad de represión y un recurso aprovechado por los actores, puesto que las respuestas de las fuerzas de seguridad consideraron el espacio como un criterio que determinó el carácter subversivo o no de estas prácticas. Debemos aclarar que en el marco del contexto político de la época no generaba la misma repercusión homenajear a Eva Perón en las iglesias o cementerios que en los espacios urbanos al aire libre.

A continuación, analizaremos el despliegue de los rituales en los espacios públicos a través del tiempo, diferenciando los realizados en plazas, edificios, monumentos y calles, entre otros, de alto poder de congregación simbólica; y los espacios atravesados por connotaciones religiosas como iglesias y cementerios.

a. Desde épocas tan tempranas como julio de 1956, se observan algunas acciones que eran interpretadas por la prensa y por la policía como transgresiones al decreto 4161 . Ejemplo de ello lo constituye un conflicto desatado en el cementerio de la Chacarita donde un grupo de aproximadamente cincuenta personas había sido detenido por la policía al intentar colocar ofrendas florales en la tumba del Dr. Tomás Perón, el abuelo del ex presidente. Aunque, como decía La Nación, “...los concurrentes deseaban efectuar un homenaje a otra persona...", que por lo establecido en dicho decreto, no podía nombrarse, y aclaraba que algunos de los asistentes estaban rezando. ${ }^{339}$ Ernesto Goldar hace una referencia a cómo durante el gobierno peronista, en el peristilo del cementerio de la Chacarita, solían depositarse ofrendas florales frente a un busto de Evita ubicado allí, pero luego de que fuera destruido durante el gobierno de la Revolución Libertadora, las flores continuaron apareciendo en el piso, en el mismo lugar donde antes había estado emplazado el busto (Goldar, citado en Rosano, 2006). Con los años, estas prácticas se irían haciendo cada vez más públicas y, hacia 1959, los diarios comienzan a dar testimonio de ellas de manera más asidua; momento que coincide con el inicio de los intentos de reorganización del Partido Justicialista, y donde ya, con cierto relajamiento en las restricciones, a los actos

\footnotetext{
${ }^{339}$ La Nación. "Acción policial en la Chacarita". Buenos Aires, 27 de julio de 1956, p. 7.
} 
de este tipo asistían altos dirigentes gremiales y políticos. ${ }^{340}$ Los informes de policía ofrecen evidencias de estas prácticas en otros cementerios, como los de La Plata, Bahía Blanca, Las Flores y Chivilcoy. ${ }^{341}$

Las huellas obtenidas a través de documentación periodística sobre la existencia de manifestaciones en homenaje a Eva Perón durante los primeros momentos posteriores al golpe de Estado en el que tuvieron lugar las políticas de desperonización más ofensivas, resultan más bien escasas. Al parecer, los homenajes se realizaban de manera más solapada respecto de la forma que adquirirían en épocas posteriores. Del relato de un grupo de militantes de Rosario, se desprenden evidencias sobre la costumbre que se hizo común en esa ciudad de llevar coronas florales con forma de corazón al monumento del Cristo Redentor que se encuentra ubicado frente al cementerio del Salvador. Esta costumbre habría nacido poco después de la muerte de Evita. Durante los años de la Revolución Libertadora, esta práctica se mantuvo aunque con modificaciones. Como les estaba prohibido reunirse, los manifestantes pasaban de a uno tirando una flor, usualmente durante la noche anterior al día del aniversario. Ya con el ascenso de Frondizi, retornarían las reuniones masivas frente al monumento y la colocación de coronas; práctica que hasta el día de hoy se mantiene vigente. ${ }^{342}$ También fue usual la erección de altares en los hogares de las familias peronistas, una práctica que se prolongaba desde 1952. Al parecer, ésta tuvo continuidad, ya que en julio de 1960, el comisario de la localidad bonaerense de Azul remitía a la D.I.P.B.A. un artículo del diario El Tiempo de esa ciudad, donde se denunciaba la prohibición para homenajear públicamente a Evita, advirtiendo que ello no impediría las

\footnotetext{
${ }^{340}$ El Día. "Realizáronse actos en memoria de Eva Perón”. La Plata, 27 de julio de 1959; La Razón. "Un aniversario se ha recordado con misas y distintas reuniones". Buenos Aires, 27 de julio de 1961, p. 4.

${ }^{341}$ El Día. La Plata, 26 de julio de 1961. DIPBA. Mesa Referencia. Legajo 10078. Resistencia peronista y plan CONINTES (1956-1975), Colección N 13 del Área Centro de Documentación y Archivo, Comisión Provincial por la Memoria, La Plata (Las Flores, 26 de julio de 1960; Bahía Blanca, 27 de julio de 1960, 8 de mayo de 1961; 7 de mayo de 1963 y 26 de julio de 1963; La Plata, 26 de julio de 1962; Chivilcoy, 30 de julio de 1962)

${ }^{342}$ Di Marco, Chiche; Martínez, María; Rivas Natividad y Cánepa, Oscar. Entrevista de la autora, Rosario, 16 de octubre de 2012. Hacia julio de 1957, la prensa registran conflicto en distintos lugares de la ciudad de Rosario, entre ellos, el Cristo Redentor. Ver: La Nación. Buenos Aires, 27 de julio de 1957; y La Nación. Buenos Aires, 28 de julio de 1957, p. 11. Pero además del Cristo, otro lugar propicio para la emergencia de conflictos era el edificio del diario La Capital, de conocida filiación antiperonista. La Nación. "Hubo agitación en las calles". Buenos Aires, 8 de mayo de 1958, p. 2.
} 
expresiones de duelo que se realizarían a lo largo de todo el país en los altares domésticos. $^{343}$

Hacia julio de 1957, se perciben algunos cambios respecto de las posibilidades para el peronismo de manifestarse públicamente. Ya era evidente la ruptura del consenso entre las diferentes fuerzas políticas que había hecho posible el triunfo de la Revolución Libertadora y las discrepancias sobre cómo encarar el fenómeno peronista estaban a la orden del día. El 29 de junio fue levantado el estado de sitio y el 28 de julio se realizaron votaciones para elegir representantes a la Convención Constituyente que sancionaría una nueva Constitución para reemplazar a la de 1949. En este contexto, la prensa comienza a reflejar la realización pública de actos, pero también la pervivencia de conflictos. El triunfo de Arturo Frondizi, en las elecciones del 23 de febrero de 1958, fue recibido con expectativa por algunos sectores del peronismo, y si bien marcó un punto de inflexión respecto de las posibilidades de participación y organización para dicha fuerza política, comparado con lo que habían sido los años de la Revolución Libertadora, las prohibiciones para las expresiones públicas continuaron, en un clima caracterizado por ambigüedades y contradicciones respecto de lo que estaba o no permitido; no sólo para los manifestantes que querían rendir homenajes a Eva Perón sino también para los propios agentes policiales encargados de reprimir.

En mayo de 1958, Línea Dura, el periódico de filiación peronista analizado en el capítulo anterior, celebraba el hecho de que habían podido realizarse reuniones a puertas abiertas, con motivo de la organización de las ceremonias para conmemorar el natalicio de Eva Perón, lo mismo que la concreción de esos actos, como evidencia del nuevo clima democrático que se estaba abriendo a partir del ascenso de Frondizi. ${ }^{344}$ En contraste con el optimismo de Línea Dura, que había sostenido la campaña del voto por el candidato de la UCRI, la prensa comercial devuelve otro panorama. Nuevamente, el cementerio de la Chacarita se había convertido en un espacio de disputa cuando unas doscientas personas, según la crónica periodística, reunidas en la bóveda de la familia Duarte, reclamaban la entrega del cadáver de Eva Perón. Otros disturbios se habían producido en el edificio de la CGT, a la vez que había habido manifestaciones en varios puntos de la ciudad, dispersados con gases lacrimógenos. Aun así, la prensa no menciona que haya habido detenciones, a la

\footnotetext{
${ }^{343}$ Informes S.I.P.B.A. 26 de julio de 1960 en DIPBA. Mesa Referencia. Legajo 10078. Resistencia peronista y plan CONINTES (1956-1975), Colección N ${ }^{\circ} 13$ del Área Centro de Documentación y Archivo, Comisión Provincial por la Memoria, La Plata.

${ }^{344}$ Línea Dura No 20. “Actos peronistas en todo el país”. Buenos Aires, 12 de mayo de 1958, p. 2.
} 
vez que se registra la realización de actos en otros lugares del país, donde desarrollaron sin conflictos; con la excepción de San Miguel de Tucumán y Mendoza. ${ }^{345}$

Si bien la proscripción que pesaba sobre el Partido Peronista, no fue levantada durante el gobierno de Frondizi, la ley de amnistía 14436, del 22 de mayo de 1958, legalizó el uso de los símbolos peronistas y la propaganda y habilitó a sus dirigentes políticos y gremiales para ocupar cargos. En esta situación, podría pensarse que la realización de homenajes estaba permitida; sin embargo, las posibilidades de su concreción eran imprecisas. En parte, la decisión sobre lo que estaba permitido o no, descansaba en las autoridades policiales. De hecho, en julio de 1958, la Policía Federal prohibió los actos públicos durante la semana en que tendría lugar el aniversario. Pero un comunicado del Ministerio del Interior hacía saber que esa disposición no era de orden nacional y dejaba librado a los gobiernos provinciales la posibilidad de actuar como lo creyeran conveniente. En esa oportunidad, la represión que se ejerció en lugares como la ciudad de Buenos Aires, contrasta con los homenajes que se realizaron en otros sitios del país y que se desarrollaron de manera pacífica. ${ }^{346}$

Además de los conflictos que tenían lugar en las calles céntricas de Buenos Aires, solían generarse disturbios en los lugares de paso que conectan la capital con el sur del conurbano, y aquí también la situación era heterogénea. En ese año de 1958, la policía bonaerense impidió que alrededor de mil quinientas personas que entonaban la marcha peronista atravesaran el puente Uriburu que une Lanús con Buenos Aires, para sumarse a los actos céntricos. Pero en las plazas principales de las localidades del Sur del Gran Buenos Aires, como Avellaneda, Lanús y Lomas de Zamora, los actos se realizaron con normalidad. ${ }^{347}$ Entre 1959 y 1961, el panorama continuó siendo heterogéneo. En 1959, los conflictos continuaron registrándose en las calles de Buenos Aires. En el resto del país, los actos se realizaron con relativa calma. En 1960 hubo disturbios en localidades del conurbano bonaerense y de la provincia donde la policía había intentado evitar la colocación de ofrendas florales en lugares donde previamente había estado emplazado algún busto, como el caso del Policlínico de Lanús, ex Hospital Evita, o monumentos que habían sido

\footnotetext{
${ }^{345}$ La Nación. "Hubo agitación en las calles". Buenos Aires, 8 de mayo de 1958, p. 13.

${ }^{346}$ La Nación "En varias zonas de la ciudad hubo agitación". Buenos Aires, 27 de julio de 1958, p. 11. Línea Dura $\mathrm{N}^{\circ}$ 33. "En el interior los homenajes a Eva Perón alcanzaron gran magnitud". Buenos Aires, 7 de agosto de 1958, p. 4.

${ }^{347}$ La Nación. "En varias zonas de la ciudad hubo agitación”. Buenos Aires, 27 de julio de 1958, p. 11.
} 
tradicionalmente lugares de duelo, como el Monumento a la Madre en Mar del Plata. ${ }^{348}$ Todo ello en un marco caracterizado por el establecimiento del estado de sitio por tiempo indeterminado en noviembre de 1958, y la vigencia del Plan Conintes desde marzo de 1960, que sería derogado recién en agosto de 1961.

Como puede observarse, el panorama sobre lo que estaba permitido o no, era complejo y además de variar temporalmente, lo hacía espacialmente a nivel geográfico y jurisdiccional. Para los propios agentes policiales no estaba claro cómo debía actuarse en cada caso. Además del decreto 4161 podían aplicarse otras normativas, como lo demuestra un caso suscitado en Pergamino el 26 de julio de 1960, donde una persona había sido detenida por colocar una palma con una leyenda que refería a Eva Perón, y a quien se acusaba de violar el artículo 39 inciso C del decreto 24333/56. Este decreto le otorgaba al jefe de Policía las atribuciones de un Juez de Faltas. El artículo violado penaba con un arresto de diez a treinta días la distribución de folletos y escritos en general que pudieran perturbar la tranquilidad colectiva. ${ }^{349}$

En julio de 1962, durante el gobierno de facto de José María Guido, una circular instruía a los comisarios locales sobre la aplicabilidad del decreto 217/62 que prohibía las actividades de los partidos Peronista, Justicialista y Unión Popular en el territorio de la provincia de Buenos Aires, y de cualquier organización que "en forma expresa o encubierta sostuviera su misma prédica o usara sus símbolos o emblemas". Dicha circular diferenciaba las ceremonias que tenían lugar dentro de las iglesias de las manifestaciones que se desarrollaban por fuera de ellas. Estas últimas se consideraban actividad partidaria y política y les cabía la aplicación de dicho decreto. ${ }^{350}$ A esto hay que agregar que el 24 de julio de 1962, dos días antes de que se cumplieran los diez años del aniversario de la muerte de Eva Perón, había vuelto a ponerse en vigencia el decreto 4161 .

\footnotetext{
${ }^{348}$ La Nación. "Provocaron ayer disturbios grupos aislados" y "Tres atentados de terroristas". Buenos Aires, 27 de julio de 1959, p. 11. También se registran conflictos para ese año en Punta Alta, Lomas de Zamora, Necochea y Pergamino. Informes S.I.P.B.A, del 27 de julio de 1960 y 28 de julio de 1960. DIPBA. Mesa Referencia. Legajo 10078. Resistencia peronista y plan CONINTES (1956-1975), Colección №13 del Área Centro de Documentación y Archivo, Comisión Provincial por la Memoria, La Plata.

${ }^{349}$ Informe S.I.P.B.A. 30 de julio de 1960. DIPBA. Mesa Referencia. Legajo 10078. Resistencia peronista y plan CONINTES (1956-1975), Colección N 13 del Área Centro de Documentación y Archivo, Comisión Provincial por la Memoria, La Plata.

${ }^{350}$ Informe S.I.P.B.A. 3 de julio de 1962. DIPBA. Mesa Referencia. Legajo 10078. Resistencia peronista y plan CONINTES (1956-1975), Colección N ${ }^{\circ} 13$ del Área Centro de Documentación y Archivo, Comisión Provincial por la Memoria, La Plata.
} 
Las mismas fuentes de la D.I.P.B.A. evidencian que, ese año, los actos se realizaron de todos modos, denunciando que los comisarios de Zárate, Necochea y Mar del Plata no habían acatado la orden al permitir que los mismos tuvieran lugar. Según las fuentes, en la mayoría de los lugares donde las manifestaciones se llevaron a cabo, la policía intervino para desarmar las concentraciones logrando su cometido pacíficamente. ${ }^{351}$ Sin embargo, debe hacerse una salvedad sobre el sesgo de estas fuentes, ya que muchos de estos documentos eran remitidos por los comisarios locales a sus superiores a nivel provincial, por lo que es dable pensar que quisieran proporcionar una imagen de armonía respecto de lo que pasaba en sus respectivas jurisdicciones, como así también que dejaran hacer porque ellos compartían la misma filiación política que los sujetos a ser reprimidos, como se desprende de algunos testimonios. ${ }^{352}$ Estos testimonios, además, nos muestran la importancia del espacio, ya que el lugar donde se desplegaban las prácticas de conmemoración era fundamental para determinar si se trataba de prácticas políticas o no, y por lo tanto si era pertinente la intervención policial. Un ejemplo claro lo demuestra la consulta de un inspector de la policía a sus superiores, en mayo de 1963, sobre cómo actuar frente a la convocatoria a una misa y a la colocación de una ofrenda floral en el cementerio por parte del Centro de Acción Social Misioneras Eva Perón, en la ciudad de Bahía Blanca. Se le respondía que la misa era de incumbencia de la Iglesia y que, fuera del templo, los actos no estaban permitidos, a menos que se colocaran ofrendas en el cementerio, de manera individual, y no por parte de delegaciones; a la vez que estaba prohibido el uso de la palabra. ${ }^{353}$

Con el gobierno de Arturo Illia, que tuvo inicio en octubre de 1963, se abre un paréntesis respecto de las condiciones para la realización de este tipo de manifestaciones. En este sentido, Mónica Gordillo (2007) observa para ese momento un punto de inflexión en la realización de actos, incluido el 17 de octubre y otras conmemoraciones de la liturgia peronista, al permitirse celebrarlos de manera pública. La autora señala varias transformaciones, entre ellas, la necesidad de un gobierno débil de abrir canales de participación, ya que no contaba con la mayoría de los votos y que debía enfrentarse a un

\footnotetext{
${ }^{351}$ Informe S.I.P.B.A. 27 de julio de 1962. DIPBA. Mesa Referencia. Legajo 10078. Resistencia peronista y plan CONINTES (1956-1975), Colección N 13 del Área Centro de Documentación y Archivo, Comisión Provincial por la Memoria, La Plata.

${ }_{352}$ Di Marco, Chiche; Martínez, María; Rivas Natividad y Cánepa, Oscar; Entrevista de la autora, Rosario, 16 de octubre de 2012.
} 
movimiento obrero organizado que se había convertido en el sector más poderoso entre las fuerzas peronistas. Sin embargo, conviene establecer algunos matices respecto de las apreciaciones de Gordillo en relación a las posibilidades que se abrieron con el gobierno de Illia, pese a que se trataba de un gobierno democrático.

En julio de 1963, el diario La Razón destacaba el accionar del sector femenino del PJ en los actos para homenajear a Evita, que -además de las prácticas usuales - incluyeron una marcha a la residencia presidencial que por ese entonces estaba en Palermo llevando ofrendas florales, lo que habla de cierto grado de permisividad. Pero en otros lugares habían intervenido las fuerzas policiales; por ejemplo en el barrio de Saavedra donde los manifestantes fueron obligados a desconcentrarse en el momento en que empezaban a entonar las estrofas de Evita Capitana. ${ }^{354}$ En julio de 1964, se registraron incidentes cuando los asistentes a una misa en la catedral de La Plata intentaron realizar una marcha de antorchas que fue dispersada por la policía, con resistencia por parte de los manifestantes. ${ }^{355}$ En noviembre de 1964 fue derogado el decreto 4161; sin embargo, los diarios no registran para el año siguiente actos multitudinarios en lugares centrales, por lo que podemos pensar que si se realizaban, lo hacían con discreción o no generaban disturbios que los hicieran atractivos para los medios periodísticos. Es más común hallar manifestaciones en lugares periféricos desde el punto de vista jurisdiccional, pero que a la vez se trata de zonas de concentración obrera y de extensa filiación peronista. En Avellaneda, hubo un acto en la sede central del PJ local, para rememorar el nacimiento de Eva Perón, el 7 de mayo, donde asistieron unas 500 personas y contó con la presencia de un cura que ofició una misa en un altar cívico, mientras que en Villa Domínico, partido de Avellaneda, la JP realizó una misa en una iglesia sin problemas, aunque al finalizar, pretendieron erigir un busto en el parque Sarmiento, que terminó siendo frustrado por la intervención policial. ${ }^{356}$ En julio de 1966, a poco de producirse el golpe de Estado de la Revolución Argentina, los actos continuaron realizándose, al parecer, de manera más discreta. No tenemos noticias de que haya habido algún tipo de actividad conmemorativa en el centro de Buenos Aires o La Plata. En lugares, más periféricos como Avellaneda y Mataderos, hubo marchas posteriores a la misa, que

${ }^{353}$ Informe S.I.P.B.A. 6 de mayo de 1963. . DIPBA. Mesa Referencia. Legajo 10078. Resistencia peronista y plan CONINTES (1956-1975), Colección N ${ }^{\circ} 13$ del Área Centro de Documentación y Archivo, Comisión Provincial por la Memoria, La Plata.

${ }^{354}$ La Razón. "Se rezaron misas por la extinta esposa del mandatario depuesto". Buenos Aires, 27 de julio de 1963 , p. 9

${ }^{355}$ El Día. "Hubo incidentes después de la misa a la señora de Perón". La Plata, 27 de julio de 1964; La Nación. "Al finalizar un acto prodújose una incidencia". Buenos Aires, 27 de julio de 1964. 
fueron permitidas, y se caracterizaron por su brevedad y por realizarse en silencio y de manera ordenada. ${ }^{357}$

Sintetizando, a partir del gobierno de Frondizi, se abrieron nuevas posibilidades de participación para el peronismo, pero ello no implicó un levantamiento pleno de las proscripciones; y lo mismo puede decirse del gobierno del Illia. A lo largo de todo el período analizado (1955-1966), hubo momentos de apertura y retroceso, con variaciones entre diferentes espacios geográficos y jurisdiccionales, incluso en una misma ciudad o pueblo, ya que para las autoridades encargadas de controlar y reprimir, homenajear a Evita en las iglesias y cementerios no tenía el mismo significado que hacerlo en la vía pública. Por otro lado, esas mismas autoridades tuvieron dificultades a la hora de aplicar la normativa regulatoria en un marco legal repleto de ambigüedades, en el que tampoco estaba claro a quién le tocaba intervenir. Toda esta confusión generó intersticios que permitieron a los militantes burlar la censura en muchas oportunidades. Ahora bien, aunque estas prácticas cobraron visibilidad respecto de la forma velada que habían debido adoptar durante los años más intensos de la desperonización, los de la Revolución Libertadora, nunca recobraron la legalidad plena y continuaron generando conflictos hasta el final del período en estudio.

A continuación, nos enfocaremos en qué sucedía dentro de las iglesias, donde las posibilidades de control y represión diferían respecto de su aplicación en la vía pública.

b. Las Iglesias, así como los cementerios, pasaron a tener un papel de "trincheras políticas" en tanto se convirtieron en parte de espacios de realización de prácticas de confrontación de la resistencia peronista. Durante el gobierno de la Revolución Libertadora las misas continuaron siendo una práctica para conmemorar los aniversarios vinculados a la figura de Eva Perón, sin embargo, tenían lugar de forma velada, por lo que, para la historiografía, una de las pocas maneras de acceder a ellas es a través de las fuentes orales. Amanda Sotelo, una militante de Berisso, recuerda que iban a las iglesias donde sabían que los dejarían entrar, llevando una vela o una flor; y aunque los sacerdotes no mencionaban el nombre de Evita durante la misa comprendían que los allí presentes estaban para rememorar el aniversario de su nacimiento o muerte.

\footnotetext{
${ }^{356}$ La Nación. "Homenaje”. Buenos Aires, 8 de mayo de 1965, p.8.

${ }^{357}$ La Nación. "En sufragio de Eva Perón rezaron misas". Buenos Aires, 27 de julio de 1966.
} 
Amanda: - [...] Cuando no podíamos, era hacer esto: actos relámpago de, digamos, nombrarla, cantarle y qué se yo... En vez de cantar la marcha peronista, cantar Evita Capitana, que es más o menos igual; estas cuestiones. $\mathrm{O}$ ir a las iglesias por ahí, a las iglesias que más o menos... Por ejemplo, acá en el barrio obrero, que sabíamos que nos iban a dejar entrar y llevar una velita y acordarnos ¿no? Por ahí una foto de ella en cada casa y colocarle una flor y una velita, o ir al Monumento de la Madre en Ensenada, íbamos los días 17 de octubre o el día del cumpleaños de Evita y bueno, llevar una palma o flores [...] Entrevistadora: - ¿Y en la Iglesia cómo era cuando hacían una misa, ya estaba establecido que esa era la misa para Eva?

Amanda: - Claro, sabíamos sin decirlo.

Entrevistadora: - ¿El cura lo decía?

Amanda: - No, no decía nada. El hacía la misa, pero bueno, veía que nosotros estábamos con la velita ahí o la flor y todos los que estábamos e íbamos sabíamos que era por Evita. ${ }^{358}$

En Berisso, encontraron un buen espacio en la parroquia de San José Obrero, cuyo cura es mencionado también por otras entrevistadas que sostienen que, aunque no se declaraba abiertamente peronista, apoyaba todos los actos que se hacían en el barrio obrero de esa ciudad. ${ }^{359}$ Según la historiadora Mirta Lobato, la Iglesia Católica, a través de los curas, mantenía relaciones con el Sindicato Autónomo de la Industria de la Carne de Berisso desde la creación de esa entidad en los años cuarenta, hecho que interpreta como “un síntoma del fenómeno de 'peronización' del campo cristiano y de la presencia más sistemática de los curas en los conflictos sociales"; aunque de manera más moderada y sin adquirir la impronta radical que caracterizaría al Movimiento de Sacerdotes para el Tercer Mundo en años posteriores (Lobato, 2001). El relato de Chiche Di Marco, una militante de Rosario, también reconoce la colaboración de algunos sacerdotes, al sostener que ella con otros peronistas asistían siempre a las misas que se efectuaban en la parroquia de San Antonio, donde tenían buena acogida por parte del cura que, aunque tampoco mencionaba a Evita, sabía que los asistentes a la misa deseaban homenajearla. ${ }^{360}$

La primera referencia en las fuentes periodísticas a una misa realizada explícitamente en memoria de Eva Perón data de julio de 1957. Tuvo lugar en la iglesia de San Ponciano, en el centro de la ciudad de La Plata, y ha quedado registrada en la prensa porque durante y

\footnotetext{
${ }^{358}$ Sotelo, Amanda. Entrevista de la autora. Berisso, 7 de mayo de 2014.

${ }^{359}$ Sotelo, Amanda. Entrevista de la autora. Berisso, 7 de mayo de 2014.; Dora Roldán. Entrevista de la autora. Berisso, 3 de mayo de 2014; María Lucero. Entrevista de la autora, Berisso, 14 de mayo de 2014. Los testimonios hacen referencia al padre Pascual Ruperto, estrechamente vinculación al movimiento obrero de Berisso. Ver. Lobato (2001, p. 303).

${ }^{360}$ Di Marco, Chiche. Entrevista de la autora. Rosario, 11 de noviembre de 2014.
} 
luego de su realización se produjeron disturbios. ${ }^{361}$ A través de una carta reproducida en el diario platense El Día, el canónigo de la iglesia brindaba explicaciones de por qué había sido aceptada la realización de la misa, argumentando que ningún sacerdote podía negar una misa de sufragio, aquella que se celebra en nombre de los difuntos, y que desde 1952 se venían encargando y aceptando misas en todos los templos del país. Además, agregaba que se habían tomado precauciones advirtiendo la suspensión de la misa en caso de que tuvieran lugar acciones irrespetuosas dentro del templo y desmentía el hecho de que la iglesia hubiese aceptado dinero en retribución, más allá del estipendio ordinario que requería una misa rezada y que en este caso había sido utilizado para pagar los servicios de un cura extranjero y ajeno al clero parroquial. ${ }^{362}$ El conflicto se había suscitado fuera del templo, mientras tenía lugar la ceremonia, entre los peronistas que estaban en su interior y en el jardín de la iglesia, que por aquellos años estaba vallado con rejas, con los antiperonistas que estaban fuera del vallado. Había intervenido la policía, no sólo para calmar el enfrentamiento sino también para disipar los intentos de realizar procesiones al finalizar la misa. ${ }^{363}$ Este ejemplo demuestra la estricta prohibición que regía en ese momento, época del gobierno de la Revolución Libertadora, de realizar manifestaciones en la vía pública; a pesar de que el gobierno ya estaba en retroceso. Y a la vez, evidencia las ambivalencias que suscitaba homenajear a Eva Perón en las iglesias; algo que al parecer se había venido realizando desde años anteriores pero no de manera explícita. Por otro lado, la necesidad de la iglesia de convocar a un sacerdote extranjero expone las dificultades para encontrar a un cura cuyas convicciones políticas no le impidieran realizar la misa, que no temiera involucrarse en cuestiones políticas que podrían traerle inconvenientes con el gobierno o con sectores de la iglesia decididamente antiperonistas, o que la propia iglesia no quisiera exponerse poniendo un sacerdote propio.

Al parecer, la posibilidad de efectuar misas en memoria de Eva Perón dependía de la voluntad de los curas y de las propias iglesias, ya que las autoridades civiles encontraban dificultades para regular sobre jurisdicción eclesiástica. Entre 1960 y 1962, los documentos de la D.I.P.B.A. muestran multitud de informes de comisarios locales de las ciudades y pueblos de la provincia de Buenos Aires y de la ciudad de La Plata presentando las

\footnotetext{
${ }^{361}$ La Nación. Buenos Aires, 27 de julio de 1957.

${ }^{362}$ El Día. "Sobre la realización de una misa en San Ponciano". La Plata, 27 de julio de 1957, p. 2.

${ }^{363}$ El Día. "Sobre la realización de una misa en San Ponciano". La Plata, 27 de julio de 1957, p. 2; La Nación. "Un homenaje póstumo motivó incidentes". Buenos Aires, 27 de julio de 1957.
} 
solicitudes de misas, que solían hacerse con varios días de anticipación. ${ }^{364}$ Aun así, los espacios de las iglesias no estuvieron libres de conflictos. En mayo de 1958, en la iglesia de San Ignacio, una iglesia tradicional ubicada en el centro de Buenos Aires a pocas cuadras de la casa de gobierno y de la Plaza de Mayo, se generó una gran concentración de personas; pero las puertas de la iglesia no se abrieron. Sin embargo, los asistentes permanecieron reunidos en la puerta del edificio, arrodillados y rezando a coro un Ave María. Por su parte, el cura negó que estuviera prevista una misa para ese día. ${ }^{365}$ En mayo de 1959, en la iglesia del Corazón de María ubicada frente a Plaza Constitución unas mil personas asistieron a una misa. Las informalidades que atravesaron la celebración parecían preocupar al diario $L a$ Nación, que reparaba en que las mujeres no llevaban las mantillas que solían usarse en esas ocasiones mientras que los hombres hablaban de cuestiones ajenas a la ceremonia. Al término de la misa, la iglesia se había visto invadida por gritos y discusiones, ya que los asistentes reclamaban que Evita no había sido nombrada en voz alta en el momento en que se recordaba a los difuntos. ${ }^{366}$ Se habían coreado vivas a los líderes peronistas y se había rezado un responso en medio de las discusiones, mientras que un retrato de la ex primera dama había sido colocado debajo de la estatua de San Roque con una vela encendida que se usaba para el culto al santo. Como afuera de la iglesia había agentes policiales, muchas personas permanecieron en su interior para evitar ser arrestadas. ${ }^{367}$ En julio de 1960, al producirse la congregación de simpatizantes peronistas frente al templo, directamente se les prohibiría el acceso. ${ }^{368}$

En algunos casos, la relación entre los simpatizantes y militantes peronistas y sacerdotes fue más armónica. En una misa efectuada en la parroquia Nuestra Señora de los Dolores, de la catedral de La Plata, el presbítero que la ofició, previo a su realización

\footnotetext{
364 DIPBA. Mesa Referencia. Legajo 10078. Resistencia peronista y plan CONINTES (1956-1975), Colección $N^{\circ} 13$ del Área Centro de Documentación y Archivo, Comisión Provincial por la Memoria, La Plata.

${ }^{365}$ La Nación. "Hubo agitación en las calles". Buenos Aires, 8 de mayo de 1958, p. 2

${ }^{366}$ Era común que los asistentes a una misa manifestaran sus quejas porque Evita no era nombrada o porque la misa se acortaba o era realizada de "mala gana". En uno de estos casos el cura se justificó argumentando que el nombre de Eva había sido pronunciado en latín. La Nación. "Sobre una misa en Santo Domingo". Buenos Aires, 9 de julio de 1960, p. 3; Informes S.I.P.B.A, 26 de julio de 1960 y 7 de mayo de 1960. DIPBA. Mesa Referencia. Legajo 10078. Resistencia peronista y plan CONINTES (19561975), Colección $\mathrm{N}^{\circ} 13$ del Área Centro de Documentación y Archivo, Comisión Provincial por la Memoria, La Plata.

${ }^{367}$ La Nación. "Hubo desorden durante una misa". Buenos Aires, 8 de mayo de 1959, p. 8.

${ }^{368}$ La Razón. "Hubo anoche ligeros incidentes en el centro y en Constitución: 10 detenidos". Buenos Aires, 27 de julio de 1960, p. 10.
} 
pronunció palabras referidas a la obra social de Eva Perón. ${ }^{369}$ El caso más llamativo lo observamos en mayo de 1961, en la iglesia San Vicente de Paul en el barrio de Mataderos, en una misa convocada por la Junta Nacional Justicialista Femenina, a la que asistieron reconocidos dirigentes y entre ellos ex legisladoras peronistas. Frente al altar, un grupo de mujeres se ubicó portando una bandera argentina y un retrato de Evita. Muchos se acercaron para besar el retrato, a la vez que se distribuyeron estampas con el rostro de "la desaparecida esposa del dictador prófugo”, como sostenía el diario El Día. ${ }^{370}$

A las autoridades civiles y militares se les hacía difícil regular lo que sucedía dentro de las iglesias, pero ello no implicaba que la realización de misas no les resultara un asunto problemático. El inconveniente radicaba en que las misas ofrecían la posibilidad de que los atrios de las iglesias se constituyeran en puntos de encuentro de las manifestaciones que se realizaban hasta las plazas principales de las ciudades y pueblos donde se colocaban ofrendas florales en los lugares en que previamente había estado erigido algún busto, monolito o placa. Este tipo de actividades solía generar conflictos entre los asistentes y la policía, porque por fuera de las iglesias, las manifestaciones en honor a Evita se consideraban actividad partidaria.

La Resistencia peronista se caracterizó por el empleo de una diversidad de prácticas. Algunas de ellas pueden encuadrarse en lo que los autores de la acción colectiva definen como el repertorio moderno, con carácter modular, referente al empleo de formas de acción colectiva flexibles, conocidas por la gente producto de un proceso de socialización realizado en la práctica, y factibles de ser combinables. Las dos formas principales de acción colectiva del repertorio moderno son la huelga y la manifestación (Tilly; Tarrow, 1997). La Resistencia peronista contó con ambas. Sin embargo, la estructura de oportunidades obligó a combinarlas con formas más discretas. Las prácticas desarrolladas en este capítulo oscilaron en presentarse, por momentos, de manera abierta, combinándose con la manifestación, y en otros, de manera solapada. En algunos casos, también fueron acompañadas por huelgas, como en el caso de Berisso, donde solían parar los frigoríficos de la ciudad. ${ }^{371}$ Pero, lo que llama la atención de dichos rituales es que prácticas del repertorio

\footnotetext{
${ }^{369}$ El Día. "Realizáronse actos en memoria de Eva Perón". La Plata, 27 de julio de 1959, p. 6.

370 El Día. "Han evocado a la Sra. Eva Duarte de Perón". La Plata, 27 de julio de 1959. Entre las dirigentes que habían participado figuran Elena Fernícola, ex diputada por Misiones, María Luisa Montesano de Melicchio, ex diputada provincial en la legislatura bonaerense, Otilia Villa Maciel de Cano, ex diputada nacional por Tucumán, Urbelina Tejada, ex diputada nacional por la provincia de San Juan, y María Luisa Bring.

${ }^{371}$ La Nación. "Un homenaje póstumo motivó incidentes". Buenos Aires, 27 de julio de 1957.
} 
moderno, en especial la manifestación, se combinaron con formas de acción colectiva que pueden ser interpretadas como parte del repertorio premoderno; en este caso, por su asociación con la temática de la muerte. Como sostendría Tarrow (1997), ese tono premoderno se expresaría, por ejemplo, en las ceremonias vinculadas a la muerte como forma institucionalizada de acción colectiva: el funeral. Sin embargo, esa idea de premoderno no se aplica a los casos bajo estudio puesto que lo que prima en esa conmemoración funeraria es la ocasión de desafiar los sistemas represivos de un estadonación puesto al servicio de reprimir el derecho de reunión, como ocurrió en varios momentos del período abordado.

Sintetizando, podemos decir que la estructura de oportunidades políticas que presenta el período 1955-1966 estuvo caracterizada por la alternancia de momentos altamente represivos con otros donde se abrieron posibilidades de participación política legal; pero siempre con restricciones y ambigüedades. Ello dio lugar a la emergencia, en términos de James Scott (2003) de un "discurso oculto fuera de escena", que en relación a los actos conmemorativos por Eva Perón tuvieron su expresión en prácticas tales como los altares domésticos que se levantaron en las viviendas familiares, retomando una práctica que se desarrollaba desde su muerte. Paralelo a ello, el discurso oculto hizo su emergencia en la escena pública a veces de manera solapada y otras, de manera más visible y disruptiva. Hubo instancias de mayor permisividad política que permitieron el despliegue del discurso oculto de manera explícita en escena; pero fueron limitados y el grado de apertura varió de un lugar a otro, de manera que la represión se hizo presente en muchas oportunidades. Ahora bien, la factibilidad de reprimir no siempre estuvo clara para las autoridades. En parte, porque en la vía publica también se apeló al uso de elementos religiosos y, además, porque la realización de prácticas vinculadas a la muerte ofrecía ciertos resguardos para evitar la represión. Las autoridades, por su parte, ante la inevitabilidad del despliegue de estas formas de acción colectiva intentaron desarrollar estrategias de control, como por ejemplo el hecho de que en determinados momentos hubiera que pedir permiso para la concreción de dichas acciones; una forma de otorgarles un carácter legítimo e institucional. De todos modos, a pesar de que hubo cambios con el transcurso del tiempo, según se tratara de gobiernos institucionales o de facto y de diferentes coyunturas en el marco de un mismo gobierno, las prácticas de este tipo nunca llegaron a estar totalmente institucionalizadas; a las autoridades les fue imposible domesticarlas, y continuaron dando 
lugar a conflictos. Tampoco se observa un patrón ascendente de permisividad, sino más bien de avances y retrocesos.

\section{La religiosidad en las prácticas políticas}

Así como señalamos una diferenciación entre espacios jurisdiccionales y geográficos respecto de las posibilidades de participación, también se observan diferencias de actitud entre las propias iglesias sobre ese tema, como pudimos observar en el apartado anterior, donde se distingue la actitud adoptada por las iglesias de barrio respecto de las iglesias céntricas, y entre aquellas con un perfil más popular y las que tenían características más tradicionales. Por otro lado, no podemos dejar de tener en cuenta la solidaridad de algunos sacerdotes, la mayoría curas párrocos, que actuaron como posibles aliados para los militantes y simpatizantes peronistas. En algunos casos, el comportamiento de los curas fue ambiguo y dubitativo, como en el ejemplo de la iglesia del barrio de Constitución donde un año se permitió la realización de la misa, pero ante las formas poco ortodoxas que adquirió su desarrollo y ante los conflictos que se desataron, la iglesia decidió no abrir sus puertas al año siguiente.

En julio de 1962 se registra un pedido de autorización a la policía para la realización de un acto en un parque de Avellaneda en el que un sacerdote de la Iglesia católica pronunciaría un responso; intentado revivir de esta manera una práctica del período peronista en el que habían sido comunes las misas de campaña, que tenían lugar fuera de las iglesias (Plotkin, 1994; Santos Lepera, 2012). Para justificar el pedido, se aclaraba que no se pronunciarían discursos y se remitían al artículo 14 de la Constitución Nacional, que, entre otras cosas, establece la libertad de culto. El permiso fue concedido; sin embargo, cuando el acto tuvo lugar, los participantes fueron obligados a retirarse. ${ }^{372}$ Lucía Santos Lepera (2012) sostiene que luego de la muerte de Eva Perón la realización de misas de campaña en plazas y sedes partidarias y sindicales dio lugar a una "puja por las zonas de duelo". Pero a pesar de que los curas pretendieron limitarlas procurando que las misas sólo se realizaran en el espacio de los templos donde era más fácil controlar las formas que

\footnotetext{
${ }^{372}$ Informes S.I.P.B.A. del 17 de julio de 1962, 23 de julio de 1962 y 26 de julio de 1962. DIPBA. Mesa Referencia. Legajo 10078. Resistencia peronista y plan CONINTES (1956-1975), Colección №13 del Área Centro de Documentación y Archivo, Comisión Provincial por la Memoria, La Plata.
} 
adquiría el ritual, se mostraron flexibles y terminaron aceptándolas. En los años posteriores al golpe de Estado de 1955, al menos desde el ascenso de Frondizi, estas prácticas parecen haber revivido, como lo muestra también el testimonio oral antes mencionado sobre la realización de misas en el Cristo Redentor de la ciudad de Rosario. ${ }^{373}$ En estos casos, la ambigüedad sobre el carácter político y/o subversivo de estas prácticas ya no estaba dado por el resguardo que ofrecían los espacios de las iglesias sobre los cuales las autoridades encontraban límites para reprimir, sino por el carácter religioso de la práctica en sí, la realización de una misa, que por más que se realizara en la vía pública no dejaba de ser un ritual de la liturgia católica; una manifestación en el marco de un credo que compartían tanto peronistas como antiperonistas.

En la etapa de la Resistencia, como también lo había sido durante la época del gobierno peronista, los actos para rememorar a Eva Perón adquirieron la forma de lo religioso, no sólo porque parte de esas celebraciones estuvieron constituidas por misas, sino porque los actos realizados por fuera de las iglesias, en las calles, plazas y necrópolis, estuvieron impregnados de prácticas propias de la liturgia católica. Interpretaciones como la de Mariano Plotkin (1994) sostienen que, en los primeros años, el peronismo habría hecho uso de elementos del catolicismo con el objetivo de cooptar a las masas, para finalmente reemplazarlos por la doctrina peronista al producirse su conversión en una religión política centrada en el culto a Perón y a Evita, que habría monopolizado el espacio público entrando en competencia con la religión católica. Frente a ello, otras interpretaciones, como las de Lila Caimari (1995), observan en las prácticas en torno a la muerte de Eva Perón, un producto de la fuerte religiosidad popular de raíz católica presente en la sociedad argentina, desechando la posibilidad de un posible culto a Evita que habría competido con el catolicismo y defendiendo la probabilidad de que la gente rezara por Evita y no a santa Evita. $^{374}$

Para Caimari (1995) el problema que dichas manifestaciones de duelo provocaron en la jerarquía católica habría radicado más en la forma que en el contenido y en la preocupación de la Iglesia por perder el monopolio de la movilización religiosa masiva, ya que la muerte de Eva Perón había generado una ola de religiosidad popular con diferentes

\footnotetext{
${ }^{373}$ Di Marco, Chiche. Entrevista de la autora. Rosario, 11 de noviembre de 2014.

${ }^{374}$ Según Caimari (1995), las interpretaciones acerca de un posible culto a santa Evita provendrían de un pedido al Vaticano para su canonización; una iniciativa aislada que estuvo a cargo de un sindicato poco representativo como el de los canillitas.
} 
niveles de espontaneidad, que no necesariamente se ajustaba a la ortodoxia católica y que en general prescindió de la jerarquía. A su vez, Santos Lepera (2012) enfatiza el rescate de instancias de cooperación entre la Iglesia y el Estado. No observa un desplazamiento de la Iglesia católica del espacio público sino más bien la recurrencia del peronismo a requerir las funciones de los curas párrocos, cuya presencia habría sido fundamental para el desarrollo de estas prácticas; no sólo para oficiar misas y encabezar peregrinaciones, sino también porque a través de ellos se elevaban los pedidos de autorización a los obispados para realizar las misas.

Luego del derrocamiento del peronismo los activistas y adherentes peronistas continuaron haciendo uso, no sólo de rituales propios del catolicismo sino también de sus espacios, las iglesias. La actitud de los curas en relación a ello a veces fue de cooperación y otras de rechazo. Esto nos demuestra que el posicionamiento de la Iglesia católica frente al peronismo durante esa etapa no fue homogéneo. Al menos a nivel de los curas párrocos, los más involucrados en las comunidades locales, hubo actitudes de colaboración con el peronismo que trascendieron la ruptura de dicha fuerza política con la cúpula de la Iglesia, prolongando viejas relaciones que databan del período anterior ${ }^{375}$.

Para la etapa abordada en este trabajo, 1955-1966, las fechas relacionadas a la figura de Eva Perón pudieron haber suscitado la emergencia de otro tipo de prácticas, desvinculadas de lo religioso, sobre todo teniendo en cuenta el importante papel que la Iglesia y amplios sectores del laicado católico habían cumplido en el golpe de Estado que derrocó al peronismo. Sin embargo, se mantuvo un sustrato de cultura popular que continuó homenajeando a Evita con rituales propios del catolicismo. Ahora bien, nuevos sentidos se agregaron a dichas prácticas ya que pasaron a constituir acciones de resistencia que servían no sólo para rememorar a Eva Perón sino también para hacer visible al peronismo proscripto que se resistía a desaparecer. En estas prácticas, los límites entre lo religioso y lo propiamente político eran difusos y, por su carácter ambiguo, ofrecían grietas por donde burlar las restricciones. Sin embargo, no podemos afirmar que la recurrencia a esos elementos del catolicismo se haya limitado a un objetivo meramente estratégico, poniendo en cuestionamiento el sentir religioso que la figura de Evita despertaba en muchos

\footnotetext{
${ }^{375}$ Varios autores se han explayado sobre las relaciones entre el peronismo y la iglesia católica (Bosca, 1997; Caimari, 1995; Zanatta, 1996), a la vez que se ha enfatizado en la necesidad de hablar de "catolicismos" para evitar esencializar y contemplar la diversidad de formas en que esa fe es entendida (Mallimaci, 2011). Por otra parte, es menester deslindar a la "Iglesia católica", en términos
} 
de sus seguidores. Por un lado la apelación a recursos religiosos les otorgaba cierta protección para defenderse o directamente evitar una posible represión; envolvía con un ropaje religioso una práctica política y permitía, en términos de James Scott, que el discurso oculto de los peronistas pudiera ser expresado en escena aunque ello se diera en cierta medida de forma disfrazada. Pero tampoco podemos pensar, como el mismo Scott sostiene, que los sujetos hicieran uso de esos recursos como un objetivo puramente estratégico, producto de una manipulación premeditada y cínica, a pesar de que el mismo autor enfatiza en demasía la capacidad táctica y estratégica del discurso de los sectores subalternos. En todo caso, estas prácticas nos hablan de los elementos ritualizados que en ocasiones suelen atravesar a la política y del papel que juegan en ella los sentimientos y emociones como factores que otorgan sentido a la acción. Además, debemos reconocer el hecho de que muchos peronistas que habían sido socializados en el catolicismo compartían la adhesión a una religión que también era la de sus opositores.

Retomando las apreciaciones de Lila Caimari acerca de las preocupaciones que la Iglesia tenía por el uso de las formas en los despliegues de religiosidad popular durante los años del gobierno peronista, es factible que algo similar ocurriera durante los años de la Resistencia, como bien lo manifiesta la crónica del diario La Nación al horrorizarse por las acciones desplegadas dentro de las iglesias que tendían a generar caos y desorden y que descuidaban las formas y las jerarquías del espacio eclesiástico. Entonces, podemos pensar que recurrir a los elementos de la liturgia católica también era una forma de desafiar el poder de una Iglesia declaradamente antiperonista, que había participado activamente del derrocamiento; un desafío que tenía lugar en su propio espacio, en su propia jurisdicción, y que al mismo tiempo aprovechaba además la disponibilidad de aliados en la propia institución eclesiástica, los curas párrocos que colaboraban con el peronismo.

Por otro lado, debemos recordar que estas prácticas no se iniciaron durante los años de la Resistencia sino que se venían desplegando desde la muerte de Eva Perón, en 1952, momento en que habían surgido, en algunos casos como iniciativas particulares y espontáneas y, en otros, por iniciativa estatal y de diferentes organizaciones. Lo que nos interesa en este punto es matizar algunas de las afirmaciones de Plotkin respecto de la imposición unilateral del ritual político y su carácter coercitivo. El hecho de que los rituales continuaran desarrollándose tras el derrocamiento del peronismo, a pesar de la proscripción

institucionales, de los catolicismos y las religiosidades experimentadas por quienes comparten ese credo religioso (Cucchetti, 2003). 
que pesaba sobre ellos y del peligro de represión que implicaban, evidencia que estos rituales habían sido internalizados por muchos peronistas, para quienes no se trataba de prácticas meramente vacías y repetitivas sino que estaban cargados de un contenido emocional. Puede que muchos los utilizaran con un fin puramente estratégico pero por qué dudar de las emociones que podía suscitar la figura de Evita y el propio ritual religioso, cuando los sujetos disponían de otras formas de manifestarse presentes en el repertorio de acción colectiva.

\section{Conmemoraciones y participación política femenina}

En 1959, los actos conmemorativos comenzaron a estar atravesados por el proceso de reorganización partidaria que estaba teniendo lugar en las filas del peronismo; de manera que el Consejo Coordinador del Partido Justicialista y los centros de acción justicialista masculinos y femeninos, ex unidades básicas, comenzaron a actuar como organizadores, sumándose a otros grupos peronistas y procurando centralizar los homenajes. ${ }^{376}$ Ya en 1958, algunos actos aparecen organizados por el Comando Táctico, estructura que por entonces procuraba centralizar, aunque sin éxito, a las fuerzas dispersas del peronismo. ${ }^{377}$ Las convocatorias a misas y actos eran publicadas por los diarios y allí se registra quiénes eran los organizadores; además de la rama femenina del Partido Justicialista en distintas localidades o ambas ramas del Partido en forma conjunta, también actuaban sindicatos, partidos neoperonistas y grupos de la Juventud Peronista; inclusive encontramos un anuncio en los diarios firmado por los presos Conintes. Las convocatorias también se hacían mediante la distribución de panfletos. ${ }^{378}$ Además, actuaron grupos de vecinos y comisiones formadas específicamente para ese fin. Hacia principios de los años sesenta, comenzaron a formarse comisiones que tenían la doble función de organizar los actos de homenaje y reclamar por la devolución del cuerpo de Evita; muchas veces presididas por mujeres. El cadáver había sido secuestrado del edificio de la CGT, convirtiéndose, como ha sostenido

\footnotetext{
${ }^{376}$ El Día. "Habrá una marcha del silencio el 26 en nuestra ciudad". La Plata, 23 de julio de 1959; El Día. "Realizáronse actos en memoria de Eva Perón". La Plata, 27 de julio de 1959.

${ }^{377}$ El Día. "Recordárase hoy a la Señora Eva Perón". La Plata, 26 de julio de 1958; El Día. La Plata, 27 de julio de 1958, p. 5.

378 DIPBA. Mesa Referencia. Legajo 10078. Resistencia peronista y plan CONINTES (1956-1975), Colección $\mathrm{N}^{\circ} 13$ del Área Centro de Documentación y Archivo, Comisión Provincial por la Memoria, La Plata.
} 
Amar Sánchez, en un objeto en disputa (Amar Sánchez, citado en Rosano, 2006). ${ }^{379}$ En un acto realizado en la CGT en julio de 1961, Lala Marín, una militante de la Resistencia que había formado parte del Comando Táctico, y ex integrante de la Fundación Eva Perón, a quien hicimos referencia en el capítulo I, sostenía en su discurso la esperanza de que el cuerpo de Evita fuera devuelto como parte del inventario de la central obrera, en momentos en que dicha entidad aún estaba intervenida y en que se estaban llevando a cabo acciones para su normalización. ${ }^{380} \mathrm{Sin}$ embargo, como ha demostrado la historia, la recuperación no sería tan simple.

Estas prácticas convocaban a un amplio espectro del universo peronista, a la vez que adquirían un nuevo significado que se sumaba a los anteriores; es decir, además de homenajear a Eva Perón y aspirar a mantener la memoria del peronismo proscripto frente a los opositores, se habían convertido en instancias que le permitían a los diferentes grupos del movimiento cobrar visibilidad en las internas y servir como canales de encuadramiento de las heterogéneas fuerzas que lo conformaban. Los actos de conmemoración entonces, se hacían por iniciativa de diversas agrupaciones y organizaciones peronistas, algunas creadas específicamente para ese fin, como las comisiones organizadoras, mientras que en otros casos respondían a iniciativas más informales, generalmente de grupos de vecinos. Sin embargo, pese a la amplia convocatoria que implicaba a personas con diferente pertenencia en el peronismo e independientemente de su género, una particularidad que presenta este tipo de prácticas es la visibilidad que las mujeres cobraron en ellas y la capacidad de iniciativa que demostraron. Esta participación femenina se realizó a través de manifestaciones espontáneas como la defensa y ocultamiento de los bustos frente a los ataques de los opositores en los primeros días posteriores al golpe de Estado; en los conflictos callejeros que se suscitaban cuando los manifestantes pretendían rendir un homenaje en algún lugar público que había formado parte del ritual durante los tiempos del gobierno peronista, de hecho los diarios particularizaban en la presencia femenina; emitiendo discursos en los actos que tenían lugar en la vía pública, generalmente, como representantes del Partido Justicialista, de la Juventud Peronista o de algún partido

\footnotetext{
${ }^{379}$ El cadáver de Eva Perón fue secuestrado en un operativo clandestino dirigido por el teniente coronel Carlos Eugenio Moori Koening el 23 de noviembre de 1955. Fue devuelto a Perón, en estado de deterioro, recién el 3 de septiembre de 1971, como producto de negociaciones políticas con el entonces presidente de facto Agustín Lanusse. La devolución estuvo a cargo del coronel Héctor Cabanillas, el mismo que en años anteriores había gestionado su entierro en un cementerio italiano bajo el nombre de María Maggi de Magistris. Ver (Galasso, 2005; Rosano, 2006).
} 
neoperonista; y presidiendo algunas de las comisiones encargadas de la organización. Es común encontrar en las fuentes la referencia a comisiones mixtas, pero que solían estar presididas por mujeres, y otras exclusivas del género femenino. ${ }^{381}$ También, era usual que distintas mujeres fueran mencionadas en los documentos organizando actos o pidiendo misas a título individual. En Trenque Lauquen, por ejemplo, en un informe de inteligencia, se cita a un comisario que se explaya sobre las características de una mujer que ha solicitado autorización para realizar una misa, diciendo que "Dicha persona merece buen concepto dentro del ámbito social de Trenque Lauquen”, una apreciación de carácter moral que es frecuente hallar en los informes policiales que hacen referencia a mujeres. ${ }^{382}$ A la vez, las fotografías de los diarios platenses revelan esa presencia. ${ }^{383}$ Oscar, un militante rosarino, recuerda el rol que cumplieron algunas mujeres en la iniciativa, ya referida, de llevar una corona con forma de corazón al Cristo Redentor de esa ciudad:

Naty: "Hubo épocas en que la gente llevaba una flor. Pasaban al lado del Cristo, tiraban la flor, pasaba otro y tiraba la flor, porque no nos dejaban."

Entrevistadora: “¿No iban todos Juntos?"

Naty: "No, no podíamos, no podíamos."

Oscar: "El Cristo Redentor era un ámbito muy emblemático para el peronismo de Rosario. Todos los aniversarios de la muerte y nacimiento de Evita, hace más de cincuenta años, se hace el corazón $[. .$.

$[\ldots]$

Oscar: Y siempre, más allá de toda represión, más allá de todo, siempre el corazón estuvo."

María: "Aunque sea a las doce de la noche del día antes."

Oscar: "Es un símbolo de la permanente identidad de la Resistencia peronista. Entonces la gente pasaba por ahí y veía el corazón, y era la señal de que la cosa continuaba. Por eso tenía ese valor fundamental. Y la madre de ella, la tía Tallarico y la abuela Tello, fueron las dos mujeres que fundamentalmente llevaron adelante esa idea. Y después fue asumida por un montón de compañeras que siempre la mantuvieron". ${ }^{384}$

\footnotetext{
${ }^{380}$ La Razón. "Un aniversario se ha recordado con misas y distintas reuniones". Buenos Aires, 27 de julio de 1961, p.4.

${ }^{381}$ Informes S.I.P.B.A. La Plata, 26 de julio de 1962; El Día. "En memoria de la señora Eva Perón”. La Plata, 13 de julio de 1962; El Argentino. "Se oficiará el 26 en memoria de Eva Perón una misa". La Plata, 13 de julio de 1962. DIPBA. Mesa Referencia. Legajo 10078. Resistencia peronista y plan CONINTES (1956-1975), Colección N 13 del Área Centro de Documentación y Archivo, Comisión Provincial por la Memoria, La Plata.

382 Informes S.I.P.B.A. Trenque Lauquen, 26 de julio de 1962; Tres Arroyos, 14 de julio de 1962, en DIPBA. Mesa Referencia. Legajo 10078. Resistencia peronista y plan CONINTES (1956-1975), Colección No13 del Área Centro de Documentación y Archivo, Comisión Provincial por la Memoria, La Plata.

${ }^{383}$ El Día. "Cumpliéronse actos en memoria de Eva Perón”. La Plata, 27 de julio de 1961, p. 6; El Día. “Misa por Eva Duarte de Perón”. La Plata, 27 de julio de 1958, p. 5.

384 Di Marco, Chiche; Martínez, María; Rivas Natividad y Cánepa, Oscar. Entrevista de la autora, Rosario, 16 de octubre de 2012.
} 
Mientras que Amanda, otra militante, como hemos señalado en otro capítulo, también reconoce el papel gravitante de algunas mujeres del barrio obrero de Berisso en la realización de actos relámpago para homenajear a Evita. En ambos casos, los testimonios refieren a mujeres de edad madura que habían formado parte de la rama femenina del Partido Peronista y que actuaban en sus barrios como aglutinadoras de las acciones de la Resistencia atrayendo a militantes más jóvenes. ${ }^{385}$ Por otro lado, a estas mujeres y a las más anónimas que aparecen en las páginas periodísticas debemos sumar la intervención de las ex legisladoras y altas dirigentes del Partido Peronista Femenino así como de dirigentes locales de dicha estructura en la organización de actos y pedidos de misas.

En los primeros momentos posteriores al golpe de Estado de la Revolución Libertadora, Perón había designado a algunas mujeres para que se ocuparan de la tarea de reclamar por los restos de su esposa. Una de ellas fue Elsa Chamorro Alamán, una abogada que había sido delegada censista del PPF por la provincia de Córdoba y, en 1954, había integrado el Consejo Superior de dicha estructura, formado ese año, como Secretaria de inspecciones (Barry, 2009). Al caer el peronismo, según su testimonio, había intentado establecer una comunicación con Eduardo Lonardi para solicitar que los restos de Evita fueran devueltos a fin de ser sepultados, no obteniendo ninguna respuesta; aunque sí la había obtenido de Perón, que la había nombrado “depositaria del cadáver". ${ }^{386}$ Perón entendía que dicho reclamo era una tarea que le competía especialmente a las mujeres del Partido, y así lo expresaba en una carta de septiembre de 1958 dirigida a Juana Larrauri, en la que manifestaba sus quejas porque en el marco político en que se estaba intentando reorganizar el Partido, luego del pacto con Frondizi y el ascenso de éste a la presidencia, las dirigentes de dicha estructura estaban peleándose por los cargos en lugar de abocarse a organizar tareas violentas para la recuperación del cuerpo de Evita. ${ }^{387}$ Perón se basaba en el rol que las mujeres de dicha estructura habían tenido durante los años de su segundo gobierno en la organización de homenajes. De hecho, en 1954 había sido constituida una “Comisión Pro Monumento a Eva Perón”, presidida por Juana Larrauri, que además de gestionar la construcción del "Monumento al descamisado" donde se depositarían

\footnotetext{
${ }^{385}$ Amanda Sotelo. Entrevista de la autora. Berisso, 7 de mayo de 2014

386 "Reportaje a la Dra. Elsa Chamorro sobre Evita (1971)". En Maidana, R., Archivo Di Film, Archivo Fílmico de Cine y Televisión, Buenos Aires, 1 de junio de 1971, Código C-00248. Recuperado de https://www.youtube.com/watch?v=5zgwdWsPLZg
} 
definitivamente los restos de la primera dama, que por entonces estaban en la CGT, era la encargada de organizar los actos en su memoria. ${ }^{388}$ También es de destacar que las legisladoras peronistas habían cumplido un papel importante en dar impulso, desde el Parlamento, a una serie de acciones destinadas a homenajear a Evita. Este hecho ha sido analizado por Adriana Valobra, quien destaca el uso de la "función memorial" como estrategia de poder por parte de mujeres que debieron legitimar su lugar y su accionar en un espacio político donde eran recién llegadas, estaban en minoría de género y en el cual primaban lógicas de socialización masculinas (Valobra, 2010).

Pese a las críticas de Perón, lo cierto es que la rama femenina del Partido Peronista, tanto en Buenos Aires como en ciudades y pueblos del interior y a nivel de las bases y de la dirigencia, a partir de 1959, demostró tener iniciativa en estas acciones. ${ }^{389}$ Un panfleto del 26 de julio de 1960, firmado por catorce Centros de Acción Justicialista de Avellaneda, nueve femeninos y cinco masculinos, convocaba a un acto en el parque Sarmiento de Lanús, y finalizaba con la frase ¡COMPAÑERAS/OS NO FALTE! ¡ES UNA CITA DE HONOR! (destacado en el original). ${ }^{390} \mathrm{Si}$ bien también participaban los centros masculinos, lo cierto es que los femeninos eran mayoría y que en la convocatoria se particularizaba en las mujeres, siendo que podrían haber recurrido al universal masculino como sucede en la mayoría de los panfletos de la época.

En Bahía Blanca encontramos la actuación de una agrupación que si bien fue creada como una fundación dedicada a la ayuda social, estuvo estrechamente vinculada a la realización de estos homenajes. Nos referimos al Centro de Acción Social Misioneras de Eva Perón. Esta organización fue creada por las integrantes de la Agrupación Peronista Femenina Evita Inmortal. Esta agrupación había comenzado a desarrollar ayuda social el 26 de julio de 1958, es decir en ocasión de realizarse un homenaje a Evita. Como la actividad social continuó luego de esa fecha, hacia septiembre decidieron crear una entidad que

\footnotetext{
${ }^{387}$ Correspondencia I (1983). Carta de Juan D. Perón a Juana Larrauri. Ciudad Trujillo, 14 de septiembre de 1958. Buenos Aires, Corregidor, pp. 68-69.

${ }^{388}$ La Nación. "La Comisión del Monumento dio amplio informe". Buenos Aires, 26 de julio de 1953, p. 1.

${ }^{389}$ Algunos casos pueden hallarse en El Plata. "Se realizan varios actos en memoria de Eva Perón". La Plata, 26 de julio de 1962; Democracia. "Más actos anuncian en memoria de Eva Perón". Buenos Aires, 21 de julio de 1962; El Día. "En memoria de la Sra. Eva Perón". La Plata, 13 de julio de 1962, DIPBA. Mesa Referencia. Legajo 10078. Resistencia peronista y plan CONINTES (1956-1975), Colección №13 del Área Centro de Documentación y Archivo, Comisión Provincial por la Memoria, La Plata.

390 DIPBA. Mesa Referencia. Legajo 10078. Resistencia peronista y plan CONINTES (1956-1975), Colección $\mathrm{N}^{\circ} 13$ del Área Centro de Documentación y Archivo, Comisión Provincial por la Memoria, La Plata.
} 
estuviera dedicada específicamente a ese fin. Misioneras de Eva Perón surgió entonces como un Centro de Acción Social inspirado en la Fundación Eva Perón que había actuado durante los años del gobierno peronista y su objetivo era, además de realizar ayuda social, bregar por la recuperación de esa institución e integrarse a ella como filial una vez que el objetivo fuera logrado. ${ }^{391}$ Pese a que no había discriminación de género para ser socio de la organización, la comisión directiva estaba constituida en su totalidad por mujeres. A la vez, una de las funciones de la comisión era estrechar vínculos de solidaridad con los sindicatos; precisamente porque eran las estructuras que contaban con recursos que podían canalizarse a través de donaciones. Sin embargo, preveían otros métodos de financiamiento, como la cuota societaria y la organización de rifas y festivales. Pese a que era una organización de ayuda social, sus objetivos eran muy amplios y superaban las acciones caritativas. De hecho, su primera finalidad rezaba: "Propender al desarrollo integral de la personalidad, inculcando el sentido profundamente moral de la cooperación y el trabajo activo". 392 En términos concretos, ello implicaba el desarrollo de actividades educacionales, culturales, de asistencia médicas y de promoción del trabajo cooperativo; se proponían luchar contra el analfabetismo, promoviendo la educación integral, incluyendo la educación física, creando internados, escuelas y bibliotecas, desarrollando conferencias, reuniones de discusión doctrinaria, publicaciones y también atención médica, mediante la creación de consultorios y farmacias. A ello se sumaba, entre otras cosas, la provisión de servicios tales como, asistencia jurídica, gestión de becas, creación de una bolsa de trabajo, provisión de elementos de trabajo, etc. Objetivos demasiado ambiciosos para ser desarrollados en un momento en que si bien había pasado el momento proscriptivo más duro todavía pesaban restricciones sobre la participación del peronismo y en que no contaban con los recursos económicos del Estado, pero que revelan dos cosas, por un lado las esperanzas puestas en el gobierno de Frondizi sobre el retorno a la normalidad institucional y el levantamiento completo de las restricciones entre lo que se encontraba la recuperación de la Fundación Eva Perón, y por otro lado el deseo de volver al estado de cosas previo al golpe de Estado.

No disponemos de información respecto del devenir de esta organización, ni si llegó a cumplir aunque sea mínimamente alguno de los objetivos propuestos; aunque por el carácter

\footnotetext{
${ }^{391}$ Esta organización había pedido ser reconocida por la estructura que en ese entonces procuraba reorganizar al peronismo a nivel nacional, la Delegación Nacional del Consejo Superior, de ahí que su estatuto y su acta de constitución, los documentos de donde obtuvimos la información, formen parte del archivo personal de John W. Cooke que se encuentra en del Cedinci.

${ }^{392}$ Estatuto de la Fundación Misioneras de Eva Perón. En Archivo John William Cooke. CeDInCI.
} 
desmedido que presentaba en relación a la coyuntura política es probable que muy poco de ello se haya logrado. Sin embargo, unos años más tarde -1961 y 1963- y como hemos hecho referencia en páginas anteriores, volvemos a encontrarla realizando un homenaje a Evita en el cementerio de Bahía Blanca, habiendo absorbido la función de la institución que le había dado origen, la agrupación Evita Inmortal. ${ }^{393}$ Esto por un lado es una muestra de su continuidad en el tiempo, lo cual es llamativo porque las organizaciones que se formaron en los primeros años de la Resistencia peronista tendieron a ser muy fugaces. Por otro lado, si bien la encontramos realizando un acto de homenaje, es probable que aún continuaran con la actividad social, como se desprende de su denominación. Y es interesante observar la relación intrínseca entre estas actividades que estaban destinadas a homenajear a Evita, acciones atravesadas por elementos religiosos, y el desarrollo de actividades de tipo social. De hecho, el mismo nombre, "misioneras", remite a ese doble carácter, religioso y de ayuda a los necesitados, y que recrea los nombres de algunas de las primeras organizaciones que fueron creadas por auspicio de Eva Perón para movilizar a las mujeres en la campaña por el voto femenino (Barry, 2009). ${ }^{394}$

La misma imbricación entre lo religioso y la acción social la encontramos entre las mujeres que habían constituido la Federación de Mujeres Peronistas en 1966, que tratáramos en el capítulo II, en relación a la realización de una ceremonia de bautismos colectivos que tuvo lugar en Monte Chingolo, partido de Lanús. Si bien no se trató de un homenaje a Evita por el aniversario de su nacimiento o muerte, sí se hizo una misa en su memoria para recordar el día del "renunciamiento". ${ }^{395}$ A la vez, el acto había contado con una merienda que se había ofrecido a los niños del barrio, donaciones de alimentos y ropa. En este acto se observa la colaboración de los curas párrocos; de hecho, la misa había estado a cargo del cura Rafael Argentino Garbín, que según decía la revista Así, había pertenecido a la Iglesia Católica Apostólica Románica, pero ahora era "sacerdote obrero" e integraba la "Iglesia Católica Apostólica Argentina", que seguía los lineamientos de la religión católica pero no respondía al Vaticano; siendo una iglesia que se autodefinía como

\footnotetext{
${ }^{393}$ Informes S.I.P.B.A. 8 de mayo de 1961 y 26 de julio de 1963. DIPBA. Mesa Referencia. Legajo 10078. Resistencia peronista y plan CONINTES (1956-1975), Colección N 13 del Área Centro de Documentación y Archivo, Comisión Provincial por la Memoria, La Plata.

${ }^{394}$ Barry (2009) da cuenta de cómo elementos del discurso religioso fueron utilizado por Eva Perón para construir la relación con las delegadas y subdelegadas censistas del PPF, utilizando términos como "apóstoles de la doctrina peronista" o "misioneras" para referirse a ellas.

${ }^{395}$ Carta de Diana Pareja, Marta Curone, Dolly Pierini y Zulema Gómez a Perón. Buenos Aires, 3 de septiembre de 1966. Archivo Marta Curone.
} 
nacional. ${ }^{396} \mathrm{Al}$ mismo tiempo, estuvo presente la colaboración de los sindicatos. Perón había figurado como padrino de los niños bautizados y en su representación había mandado a un dirigente sindical del Sindicato de Obreros Navales, al mismo tiempo que ese sindicato había colaborado con donaciones. Pero también otras mujeres de la Rama Femenina habían cooperado de la misma manera. El principal objetivo de este acto era hacer visible a la Federación de Mujeres Peronistas, reclutar mujeres a sus filas y suponemos que lograr penetración territorial. Garbín era la persona que las mujeres de la Federación tenían para hacer contactos en esa provincia. Para poder desplazarse con mayor seguridad por el interior del país las había nombrado integrantes de una orden religiosa, las "Hermanas Laicas Misioneras de Cristo Obrero". 397 Otras mujeres de Santiago del Estero que integraban la Federación, también quisieron hacer lo mismo, pero no consiguieron el aval de Perón. Se hacían llamar "Misioneras de Eva Perón". 398

Susana Bianchi y Norma Sanchís (1998) sostienen que el acceso de las mujeres a la política durante los años de los primeros gobiernos peronistas quedó despojado de contenidos estrictamente políticos, ya que las mujeres no avanzaron sobre el campo del poder, es decir, sobre la posibilidad de tomar decisiones, por su inexperiencia en la materia. Y también, que esas limitaciones quedaron enmarcadas en un discurso que hacía hincapié en el carácter inherentemente altruista de las mujeres y en su falta de ambiciones personales. Esta idea fue reforzada con la figura del "renunciamiento", explotada por la propaganda oficial para significar que Evita había renunciado a la candidatura a la vicepresidencia de la nación por su desinterés en ocupar cargos políticos, cuando en realidad ese discurso ocultaba que lo hacía frente a la oposición de las jerarquías militar y eclesiástica, no llegando siquiera a contar con el apoyo del propio Perón (Valobra, 2010). Pese a la fuerza de esos discursos, lo cierto es que en la práctica encontraron sus limitaciones. El compromiso expresado por algunas militantes en mantener los homenajes a través de los años, realizando los mismos rituales en los mismos lugares, y también la costumbre de las propias dirigentes del Partido, que a pesar de las críticas de Perón, siguieron celebrando misas en nombre de su líder femenina y organizándose para reclamar por sus restos, ofrecen muestras de la influencia que sobre ellas continuaba ejerciendo la figura de Eva Perón aún después de su muerte y del

\footnotetext{
${ }^{396}$ Así. "Un bautismo con Perón y Ponchos". 1 de septiembre de 1966. Archivo Marta Curone.

${ }^{397}$ Carta a Perón de la Comisión Ejecutiva Nacional de la Federación de Mujeres Peronistas. Buenos Aires, 29 de noviembre de 1966. Archivo Marta Curone.
} 
derrocamiento del peronismo. De alguna manera, las mujeres interpretaron que homenajear a Evita era una tarea que les correspondía inherentemente y la explicación, tal vez, radique además de en la influencia de los discursos oficiales, en la impronta personal que Evita le había conferido a las estructuras institucionales que habían encuadrado la participación política o asistencial de las mujeres durante el primer peronismo. Ahora bien, esto no era incompatible con el ejercicio de la política en sí misma, como por ejemplo, las disputas por cargos en las estructuras partidarias. En todo caso demuestra, por un lado, una apropiación, por parte de las mujeres, de las imágenes que sobre la militancia femenina se habían pretendido transmitir desde las altas esferas del gobierno durante el período anterior, pero por otro, los límites en esa apropiación. No todas las imágenes relativas a la figura de Evita fueron tomadas literalmente como modelo para la acción. Es decir, no es que el "renunciamiento" no fuera recordado ni valorado; pero ello no significaba que las mujeres quisieran apropiarse de esa imagen para seguirla al pie de la letra. Ello lo observamos, por ejemplo, en la responsabilidad que Perón le atribuía a las mujeres, y sobre todo a las dirigentes del PPF, en el reclamo por los restos de "su fundadora", citando sus propias palabras y en sus críticas respecto de que se estaban peleando por los cargos en lugar de hacer acciones para recuperar el cadáver; como se visualiza en la carta dirigida a Juana Larrauri citada antes.

Por otro lado, es interesante observar cómo el interés por homenajear a Evita impulsó a las mujeres a desarrollar su capacidad organizativa. Las interpretaciones sobre la primera Resistencia peronista construidas en los años setenta por los grupos radicalizados del peronismo, la concibieron como inorgánica y espontánea, problemas que esos grupos se proponían superar; por lo tanto, también la consideraron un proceso incompleto. Ernesto Salas (2006 [1990]) ha discutido esta idea sosteniendo que dichas apreciaciones no son aplicables a la resistencia en su totalidad, ya que esos discursos tendieron a considerar que entre Perón y las bases peronistas no había nada, omitiendo la gravitación que en dicho movimiento tuvo el sindicalismo que proveyó de objetivos estratégicos a su actividad: la recuperación de los sindicatos y la reorganización del movimiento obrero. Por lo tanto, no sería acertado decir que la primera Resistencia fue inorgánica y espontánea en su totalidad. Ahora bien, los intentos de organización no se limitaron a los sindicatos. En el caso de las

\footnotetext{
${ }^{398}$ Carta de Silvia Bernasconi a Marta Curone. La Banda, Santiago del Estero, 7 de diciembre de 1966. Carta de Silvia Bernasconi y Evangelista de Cáceres a Marta Curone. La Banda, Santiago del Estero, octubre de 1966. Archivo Marta Curone.
} 
prácticas que estamos analizando en este capítulo, aunque a veces surgieron de manera informal, es decir que podía haber, por ejemplo, un grupo de vecinos detrás de ellas sin que hubiera una organización formal, lo cierto es que no tuvieron un origen espontáneo. Puede ser que la reacción de proteger los bustos de los embates del gobierno en los años de la Revolución Libertadora lo tuvieran, pero no los homenajes que se repetían año tras año y que intentaban reproducir rutinas y trayectos. Ello, más bien, nos habla de la existencia de un repertorio de acción colectiva aprendido que los sujetos aspiraban a reactualizar cada vez que lo ponían en práctica, aunque no sin innovaciones. Tampoco consideramos que haya carecido de organicidad y de objetivos estratégicos. Siguiendo a James Scott (2003), ciertas características que rodearon los actos de la resistencia peronista vinculados con homenajes a la figura de Eva Perón, por ejemplo el anonimato, la falta de organización formal y la fugacidad de algunos de ellos, como los actos relámpago, pueden ser interpretados como ventajas tácticas acordes al contexto, más que síntomas de incompletud. Es decir, como modos efectivos de protesta en el marco de una estructura de oportunidades restrictiva y producto de una comprensión por parte de los actores del propio arte de lo posible; un conocimiento de aquellas tácticas que sabían de antemano que podían resultar efectivas y que se adaptaban a los recursos internos con los que contaban - organizaciones débiles, escasez de poder y de recursos económicos. Ahora bien, también es cierto que pasados los años más restrictivos del gobierno de la Revolución Libertadora, las organizaciones para rendirle homenaje a Eva Perón se multiplicaron y otras, ya existentes, crearon comisiones para ese fin. Tenían objetivos estratégicos, sólo que no eran los objetivos de la militancia setentista. Esos objetivos, generalmente, se vinculaban con el deseo de volver a una situación pasada, aquella que había reinado en años del gobierno peronista. También, a veces, esos homenajes tenían objetivos concretos: visibilizar algún sector en la interna peronista, encuadrar fuerzas dispersas, recuperar el cadáver de Eva Perón, desarrollar actividades con contenido social y un pronto retorno a la legalidad.

\section{Conclusiones}

Uno de los elementos que caracteriza a los movimientos de resistencia es precisamente la ambigüedad que suele atravesar a sus intervenciones. Claro que esto no es aplicable a la totalidad de la Resistencia peronista, pero sí, a gran parte de ella. Si hay un 
tipo de actividad que cumple con esas características es precisamente la que consistía en homenajear a Eva Perón en los aniversarios de su nacimiento y muerte, donde diferentes capas de significado se fueron superponiendo al significado primigenio. Este había consistido en expresar el duelo ante la ausencia de la primera dama; la ambigüedad durante los años posteriores al golpe de Estado de 1955 derivó del uso de las formas religiosas que adquirió. Sin embargo, ya desde un primer momento, dicha actividad estuvo atravesada por connotaciones políticas, porque el simple acto de llorar su muerte implicaba una politización. Luego, emergieron los significados otorgados por la propaganda peronista oficial y a ello se sumaron las nuevas significaciones que se les atribuyeron a partir de la destitución del peronismo: construcción de una memoria sobre el peronismo proscripto, instancias de visibilidad para diferentes sectores del peronismo, reclamo del cuerpo de Evita, disputa por el significado político de los lugares del espacio público y de los espacios y rituales de la liturgia católica.

En efecto, el hecho de que estas prácticas de resistencia estuvieran impregnadas de elementos del catolicismo, remite al uso de esos elementos por la propia Evita para construir su figura pública en los primeros años de su carrera política y a los usos de su muerte por la propaganda peronista oficial, pero también al lugar que ocupa lo religioso en las ceremonias vinculadas a la muerte, de hondo arraigo en la cultura argentina (Caimari, 1995). Podríamos hablar, entonces, de una memoria popular, entendida en los términos en que lo expresa Martin Lienhard (2000), como memoria colectiva de los grupos subalternos, cuyos elementos constitutivos provienen de núcleos propiamente populares que derivan de la experiencia, pero también, de núcleos de la cultura de elite y de masas, de cuyos discursos se apropia. El autor se refiere a las dificultades en las sociedades contemporáneas de encontrar núcleos de cultura auténticamente populares, siendo cada vez más evidente la influencia sobre esos núcleos de discursos provenientes de la cultura de elite y de masas, aunque articulados bajo la lógica que los sectores populares pretenden otorgarles. Ello nos permite observar cómo, en algunas oportunidades, la Resistencia fue desplegada a partir de elementos culturales compartidos por peronistas y antiperonistas; hecho que coadyuvó a conferirles un manto de ambigüedad a estas prácticas, que influyó sobre la posibilidad de que fueran percibidas o no como subversivas. Sin embargo, su despliegue no se hizo con un mero fin estratégico. Al recurrir a elementos religiosos, los peronistas se enfrentaron al antiperonismo haciendo uso de un vocabulario común, aunque con eventuales significaciones diferentes. En un caso, enarbolado como medio para la glorificación del 
movimiento perseguido, aprovechando los aliados que tenían en el propio campo católico y la propia heterogeneidad de ese campo, mientras que en el otro, como escudo desde el cual se había apoyado el derrocamiento del mismo. En todo caso, ello nos permite observar cómo lo religioso se convirtió en sí mismo en un espacio de disputa. En efecto, según sintetiza David Lehman en relación a los aportes de varios autores respecto de la religión y su carácter popular, "todas las religiones populares son generadas dentro de una dialéctica con la religión y la cultura oficiales (...) La única forma en que podemos acomodar la religión popular como una expresión auténtica, tanto de conciencia popular como de disensión político-cultural, es reconociendo que es una construcción, pero que la construcción cultural en sí misma es una forma de perseguir el cambio social, ya que la cultura en sí es un campo de lucha por el poder” (Lehman, 2004, p. 229). Estas ideas, para el caso argentino, han sido reforzadas por Fortunato Mallimacci (2010), quien considera que el catolicismo forma parte de la vida política y cultural y, a su vez, se ha presentado como garante y sostén de la nacionalidad argentina, lo cual abrió posibilidad para relacionarse con actores que deseaban ser expresión de esa argentinidad. A su vez, la imbricación de lo político con lo religioso constituye una muestra de la importancia que las emociones y los sentimientos juegan como motivadores de la acción política, que no siempre puede analizarse bajo la óptica de paradigmas estrictamente racionales.

Finalmente, observar este tipo de prácticas nos ha permitido acceder a un panorama del rol que las mujeres desempeñaron en la Resistencia peronista y de cómo la socialización que habían tenido en el peronismo en la etapa previa ejerció su influencia en el nuevo contexto al asumir los homenajes por la memoria de su líder femenina como una obligación que les incumbía de manera especial. El peronismo, en su etapa clásica, se había caracterizado por ofrecerles a las mujeres espacios propios de participación, diferenciados de los espacios de militancia masculina; a pesar de que hubo interacción entre ellos. Esos espacios quedaron estrechamente asociados a la figura de Eva Perón. Durante los años de la proscripción, fue más difícil mantener su existencia. En general, las mujeres se acoplaron a las acciones desarrolladas por los militantes varones que, con todo, consideraron las que ellas realizaban como tareas de "apoyo", aun cuando fueran un engranaje fundamental para la consecución de la acción. Incluso cuando asumieron tareas de alto compromiso de organización o conducción, no fueron objeto de reconocimiento en los relatos sobre la Resistencia peronista ni tampoco ellas lograron construir un discurso de reconocimiento común basado en esas experiencias. Como sostiene Hélène Eck, "las mujeres, aún más 
alejadas que los hombres de las esferas del poder y de las instituciones políticas, no han hecho prevalecer la experiencia adquirida. El aspecto doméstico de los actos consumados oculta o hace olvidar el riesgo que se ha afrontado" (Eck, 2000, p. 277). En nuestro caso, lo hemos comprobado al ampliar el foco de atención y contemplar prácticas que a primera vista podrían ser interpretadas como simples rituales religiosos sin contenido político, pero que en realidad lo tenían porque en un marco de prohibiciones y proscripciones habían adquirido matices subversivos. En el despliegue de esas prácticas encontramos a las mujeres como sujetos políticos activos, y una vez más, como en el pasado, la figura de Evita actuando como legitimadora e inspiradora de esas acciones. Ello puede resultar útil para observar, por un lado, las continuidades con el pasado, al reactualizar en un nuevo contexto el vínculo gestado entre las militantes y su líder y la capacidad de su figura para habilitarlas a su participación en la arena política. Y por otro lado, para pensar los espacios en que tiene lugar la militancia femenina y las formas que adquiere, que no siempre se corresponde con los espacios y formas más tradicionales en los que se manifiesta la actividad política.

La respuesta a la pregunta inicial acerca de si, durante el período en estudio, el hecho de que la figura de Eva Perón siguiera constituyendo un aliciente para la acción femenina, llevó a las mujeres a transgredir los roles de género o a reproducir roles conservadores, sin lugar a dudas está cargada de matices, siendo imposible ofrecer una respuesta cerrada. Por un lado, la figura de Evita puso un límite a las posibles transgresiones en términos de género puesto que las prácticas que incentivaba se mantuvieron ligadas a atributos conservadores, por su vinculación con espacios y formas religiosas. Ahora bien, ¿debemos concluir que por esa connotación religiosa las mujeres estaban reproduciendo roles de género tradicionales? La tenacidad por revivir esas prácticas en un contexto adverso hizo que las mujeres se volcaran al espacio público, que se enfrentaran a las fuerzas policiales y que, inclusive, desafiaran a las autoridades religiosas en su propio espacio, en tanto sus propuestas de misas y homenajes en cementerios tenían mucho de eclecticismo y poco de ortodoxia. Tampoco se sometieron acríticamente a los discursos que previamente habían provenido del peronismo en el gobierno y ahora del propio Perón en el exilio, como el que sostenía la figura del renunciamiento. Es cierto que las transgresiones de género no se expresaron a través de un discurso articulado, sino que lo hicieron mediante acciones que implicaban una intervención sobre el espacio público cuestionando los discursos que asociaban tradicionalmente a la mujer al espacio doméstico en un contexto donde el derecho de las mujeres a participar políticamente si bien estaba establecido por ley, aún no había cuajado 
completamente en una sociedad en la que aún circulaban discursos de exclusión en ese sentido. En todo caso, los aspectos religiosos de esas prácticas fueron empleados positivamente para reclamar el derecho a intervenir en esos lugares del espacio público.

A diferencia de las prácticas analizadas en el capítulo I, recordemos, las que apelaban al uso de la violencia política, atravesadas por discursos sociales que excluían a las mujeres, aquí tenemos el caso inverso. Las encontramos participando de la Resistencia peronista a través de prácticas que se suponían asociadas a su género. Por un lado, porque la relación que Eva Perón había construido con las mujeres para impulsarlas a la política había apelado al uso de elementos religiosos. Por otro, porque los homenajes en torno a su memoria fueron concebidos por el discurso peronista oficial como una responsabilidad que concebía especialmente a las mujeres; pero una responsabilidad que las mujeres hicieron propia y que en muchos casos había emergido de manera espontánea entre ellas mismas. Y además, por la asociación, mucho más antigua, entre mujeres y catolicismo. Retomando la pregunta de Hélèn Eck con la que dimos comienzo a esta tesis, acerca de si las mujeres se limitaron a realizar tareas de apoyo y de simulación, pero también si puede hablarse de una especificidad femenina de la resistencia, en el caso que nos compete podemos considerar lo siguiente. Está claro que aquí las mujeres no desarrollaron tareas de apoyo, sino que tuvieron iniciativa propia. Las observamos organizándose y participando de manera autónoma $\mathrm{y}$, otras veces, junto a militantes varones, pero encabezando las actividades. Tampoco se trató de tareas de simulación. Si bien lo religioso adquirió ciertas connotaciones estratégicas por las ambigüedades que generaba sobre el carácter subversivo de las intervenciones, ambigüedad que no dejó de ser explotada, ello no quiere decir que las formas católicas de las que hicieron uso fueran meros disfraces y que la muerte de Evita no les despertara un sentir asociado a la religiosidad. Y respecto de si puede hablarse de una especificidad femenina de la resistencia, sin lugar a dudas este es un ejemplo que demuestra que en respecto de algunas prácticas las mujeres fueron más propensas a participar, ya que se trataba de modos de intervención con los que tenían familiaridad producto de una socialización previa; de hecho, como sostiene Sharp (2011), la resistencia muchas veces se hace a partir de los medios con los que la gente conoce y de los que dispone en su cotidianeidad. Ahora bien, ello no limita el carácter confrontativo de estas prácticas ni el riesgo y compromiso que asumieron las mujeres al llevarlas a cabo, ni la politización previa que su desarrollo implicaba. La clave radica en que no se trataba de misas ni procesiones comunes sino organizadas en torno a una figura, como era la de Eva Perón, con un valor 
simbólico desestabilizante, que además había adquirido un carácter subversivo. Las mujeres que desplegaban estas acciones estaban transgrediendo una serie de restricciones sobre la participación política, como la prohibición del derecho de reunión o de emitir discursos políticos en la vía pública, entre otras, que como vimos fueron variables a lo largo del tiempo; las formas ortodoxas de la liturgia católica, de las que además se apropiaron para darle un significado político; y, fundamentalmente, la prohibición de nombrar públicamente al peronismo. 


\section{Capítulo V}

\section{Militancia y vida cotidiana: entre lo público y lo privado}

A lo largo de los diferentes capítulos que integran esta tesis procuramos demostrar que la participación femenina en la Resistencia peronista no se limitó a desarrollar tareas auxiliares de actividades que tuvieron como protagonistas a los militantes varones ni a una actuación de los roles de género tradicionales para pasar desapercibidas ante las fuerzas de control. Pese a que esas actividades existieron, las mujeres se integraron a la Resistencia a través de una variedad de prácticas desplegadas en diversos espacios, alcanzando diferentes niveles de compromiso y mostrando distintos grados de iniciativa. También, observamos que los procesos de socialización que estas mujeres habían desarrollado en tiempos de los primeros gobiernos peronistas influyeron en el modo en que se incorporaron a la Resistencia y que la capacidad de iniciativa y de autonomía estuvo influenciada en gran medida por esa experiencia previa. Por otro lado, los discursos sociales que atraviesan a las diferentes prácticas de resistencia, habilitando o inhibiendo la participación femenina, también ejercieron su peso en el mismo sentido. En este capítulo, nos proponemos cuestionar algunos estereotipos sobre la participación de las mujeres en la Resistencia peronista, que están relacionados con aquel que le atribuye funciones auxiliares, y para ello, al igual que en los capítulos anteriores, recurrimos a algunas problematizaciones formuladas por las autoras que han abordado las resistencias europeas a los regímenes de derecha en el marco de la Guerra Civil Española y de la Segunda Guerra Mundial. En varias ocasiones esa participación se ha interpretado en términos de un maternalismo político, es decir, que las mujeres se sumaron a la resistencia en función de una prolongación de sus roles domésticos y maternales y de un altruismo inherente a su condición femenina pero no porque estuvieran politizadas (Bravo y Bruzzone en López Martínez, 2012). ${ }^{399}$ Este es un debate que cobra sentido en un contexto donde la participación en acciones de resistencia no siempre estuvo movida por intereses políticos y, muchas veces, se limitó a intentos de supervivencia; incluso hubo casos donde se llegó a la politización a través del proceso de lucha. Sin

\footnotetext{
${ }^{399}$ La relación entre maternalismo y participación política no es tan lineal y es problematizada por varias autoras. En el debate sobre las resistencias europeas aparece estrechamente vinculado a la cuestión de si las mujeres participaron movilizadas por ideales políticos o por un altruismo inherente a su condición de mujeres y, asimismo, se problematiza la participación en las milicias donde las mujeres, en un primer
} 
embargo, este no es el caso de la Resistencia peronista, que supone una politización previa de las mujeres que participaron. Ahora bien, el mismo debate se desarrolló para problematizar el ingreso de las mujeres a la política a partir de la ley de voto femenino sancionada en 1947 y en relación al ingreso a la militancia en las estructuras del Partido Peronista Femenino durante el primer gobierno peronista. Este debate no ha cobrado la misma fuerza para la etapa de la Resistencia, porque tampoco hasta el momento ha habido investigaciones sistemáticas sobre la participación femenina en dicho proceso, aunque no han faltado interpretaciones en ese sentido (Scoufalos, 2007). A la vez, han circulado relatos que para calificar dicha participación han acudido a otra figura que, al igual que la de madre, remite al mundo familiar; nos referimos al apelativo de "tía". Ana Josefina Centurión (2007) ha llamado la atención sobre las connotaciones de género que lo atraviesan; el término instala la idea de que las mujeres se limitaron a desarrollar tareas de apoyo y que remite a un sujeto asexuado, sin nada que perder, que brinda protección a unos sobrinos sin cuestionar sus razones. Frente a ello, brinda ejemplos sobre mujeres que demostraron iniciativa propia y señala que el apelativo de tías tendió a invisibilizar la heterogeneidad que caracterizó a esa militancia. Los diferentes capítulos de esta tesis también procuraron dar cuenta de esa heterogeneidad profundizando en cada una de esas diferentes modalidades de intervención. El objetivo aquí es demostrar el carácter estereotipado y simplificador del apelativo de tías, a partir de la trayectoria individual de algunas mujeres que participaron en la Resistencia peronista, a través del uso de fuentes orales, que nos permiten introducir la dimensión de las subjetividades involucradas en la participación política y analizar cómo en esa participación se articulan lo público y lo privado.

Además del estereotipo de tía de los relatos sobre la Resistencia peronista, nos interesa problematizar otra imagen que ha circulado en esos relatos; aquella según la cual la resistencia se hizo desde las cocinas de los hogares de las familias obreras. ${ }^{400}$ Sin lugar a dudas, y como se deduce de los testimonios y documentos, los hogares sirvieron como lugares de reunión donde se planificaron acciones, se fabricaron explosivos y se escondieron prófugos y armas. La Resistencia de los años cincuenta y comienzos de los sesenta ha sido pensada en relación a lo cotidiano. Y esto no sólo desde los testimonios de militantes y

momento, hicieron uso de las armas y batallaron en el frente (Bravo, 2003; Bravo y Bruzzone en López Martínez, 2012; Nash, 2000; Yusta Rodrigo, mimeo).

${ }^{400}$ Esta idea sobre el lugar de las cocinas de la Resistencia peronista como espacios de socialización se popularizó a partir de un discurso de César Marcos, dirigente del Comando Nacional (Baschetti, s/f). No 
libros de divulgación sino que desde la bibliografía académica se ha desarrollado un análisis sobre las estructuras familiares y barriales que sostuvieron las luchas obreras (Salas, 2006 [1990]; Schneider, 2005). No es nuestro objetivo negar esas relaciones, que de hecho sustentaron gran parte de la Resistencia, sino problematizar este hecho. La pregunta que nos hacemos es, teniendo en cuenta la gravitación de esas relaciones y espacios familiares y barriales, y de las cocinas como lugares de socialización -un espacio asociado tradicionalmente a la feminidad- cómo es que las mujeres tienen tan poco protagonismo en los relatos sobre la Resistencia, construidos tanto desde los ámbitos académicos como políticos. ¿Qué implicaba militar en familia y desde lo cotidiano? ¿Significa que la militancia comprendió un proceso armónico que no conllevaba rupturas con el mundo privado de los militantes? Por otro lado, si las cocinas fueron tan importantes en la Resistencia peronista, cómo es posible que las mujeres tengan un lugar tan marginal en los relatos sobre dicho proceso histórico. ¿El hecho de que los espacios domésticos y cotidianos, como las cocinas y los barrios, ocupen un lugar tan importante en los relatos sobre la Resistencia peronista, es acaso un factor que ha contribuido a interpretar la participación femenina en dicho proceso como reproductora de roles de género tradicionales? Consideramos que la visibilización de los aspectos domésticos que atraviesan la vida de las militantes complejiza el análisis de la participación política; una participación que en los capítulos anteriores ha sido abordada sólo en función de la intervención de las mujeres sobre el espacio público. Perspectivas de este tipo han sido ampliamente desarrolladas para analizar la participación política femenina en las década del sesenta y setenta (entre otras, Andújar [et. al.], 2009; Cosse, 2010; Cosse, Felitti y Manzano, 2010; Felliti, 2012; D’Antonio, 2009, Grammático, 2011; Guglielmucci, 2006; Martínez, 2009; Oberti, 2015, Peller, 2013) pero aún no ha tenido un desarrollo sistemático en relación a la participación femenina en la Resistencia peronista. En base a la incorporación de esta nueva dimensión, volvemos a preguntarnos si las mujeres que participaron en la Resistencia peronista se limitaron a reproducir roles de género tradicionales o si sus intervenciones fueron disruptivas en términos de género.

Consideramos que el silencio historiográfico sobre la participación femenina en la Resistencia peronista se vincula con el tipo de modalidades de acción que han focalizado los estudios que se abocan al tema; por una lado, las intervenciones de carácter violento y por otro, o de manera relacionada con las anteriores, las luchas obreras en el marco de

estamos sugiriendo que sea equivocada, sino que debe problematizarse, sobre todo teniendo en cuenta el lugar simbólico que ocupa ese espacio doméstico en la normalización de los roles de género. 
organizaciones sindicales. Sobre las primeras ya hemos hecho referencia en el capítulo I, donde señalamos que las mujeres se incorporaron en calidad de subordinación y de manera cuantitativamente menor respecto de los activistas varones, debido a la falta de experiencias de socialización en esas prácticas y a la influencia de discursos sociales que las excluían del uso de las armas y de la violencia; elementos alrededor de los cuales se construye la masculinidad. Los espacios y relaciones sindicales también han sido construidos en base a modelos de masculinidad. La gravitación que ese sector adquirió en el peronismo durante los años que siguieron a su destitución, es una de las causas que ha contribuido a silenciar la presencia femenina en las narraciones sobre la Resistencia. En este capítulo, procuraremos analizar las imágenes de masculinidad que sobre los sindicalistas emerge en los relatos orales, muchas veces asociadas a vínculos de parentesco, visibilizar intervenciones femeninas en espacios obreros y sindicales, y las interpretaciones que las mujeres construyeron sobre esa participación en función de que se insertaban en un espacio atravesado por lógicas de socialización masculinas.

Joan Scott (2009) plantea la idea de un concepto amplio de política que exceda las concepciones tradicionales que la han limitado al estudio del Estado y de las relaciones gubernamentales. Sostiene que la Historia ha eliminado instancias importantes de la experiencia, frente a lo cual, propone acabar con las dicotomías como Estado y familia, público y privado, trabajo y sexualidad, y preguntarse sobre las relaciones entre esos ámbitos que tradicionalmente han sido abordados por separado. Norbert Lechner (1990), por su parte, argumenta acerca de lo artificioso de considerar la vida cotidiana como un ámbito cerrado y autónomo y plantea la necesidad de reflexionar sobre la articulación entre los diferentes ámbitos en que se desarrolla la vida de un individuo y de cómo una actividad que en principio parecería estar acotada a uno de esos ámbitos adquiere diferentes significados para el individuo en tanto que participante de otras esferas sociales. De esta manera, nos interesa indagar cómo la actividad política de las mujeres cuyas trayectorias analizaremos en este capítulo estuvo atravesada por motivaciones personales, por las problemáticas que afectaron su vida privada y por las relaciones que entablaron en los ámbitos cotidianos y a la vez, cómo la actividad política definió para ellas una forma de relación con el mundo familiar y cotidiano. Tibor Scitovsky sostiene que los individuos tienen necesidades de entrar en relaciones de solidaridad porque ello no sólo fortalece la identidad colectiva sino que también produce un reforzamiento de la propia identidad individual al inscribirse las personas en un círculo de reconocimiento, de manera tal que, en 
ese proceso en que los individuos deciden lanzarse a la militancia, las motivaciones personales ocupan un lugar primordial (Scitovsky citado en Revilla Blanco, 1996). Ahora bien, la construcción de la identidad adquiere un carácter generizado. Ello nos introduce en la cuarta dimensión que Joan Scott (1993) propone para dimensionalizar el concepto de género, la identidad subjetiva, y cómo esta se construye en relación a la actividad política.

Las fuentes de las que nos nutrimos para hacer este análisis son entrevistas realizadas a militantes de la época. Se trata de mujeres que tenían entre 15 y 30 años al momento de producirse el golpe de Estado de 1955, con dos excepciones, la de Esther Serruya y Lala Marín, que tenían 35 años. Son mujeres que desarrollaron su militancia en diferentes espacios de participación. Chiche Di Marco (19), Naty Rivas (25 aprox.) y María Martínez (25), militaron en unidades básicas barriales en la ciudad de Rosario, a la vez que tuvieron una estrecha relación con sectores del sindicalismo local. Elsa Mura (20) e Inés Dihian $(25)^{401}$ fueron mujeres que hicieron su experiencia política a través de la actividad sindical, en el gremio metalúrgico y Empleados de Comercio, respectivamente. Amanda Sotelo (15), militó en Berisso y Ensenada. Su militancia estuvo muy marcada por las relaciones familiares y barriales. Hortensia García Marín (Lala), participó en el Comando Táctico y estuvo en células clandestinas. Mabel Di Leo (14) fue delegada nacional de la Rama Femenina en 1966 y estuvo ligada a la Tendencia Revolucionaria del peronismo y a la CGT de los Argentinos, pero en el período que nos interesa, su militancia se desarrolló a través de relaciones barriales en Vicente López, en la JP de ese distrito y en una unidad básica barrial de la Rama Femenina del PJ. Sobre Marta Curone hemos hecho referencia en los capítulos II y III donde pudimos observar que, muy tempranamente, se involucró en los intentos de reorganizar la Rama Femenina, participando de la altas estructuras partidarias como el Consejo Coordinador o intentando reorganizaciones por fuera de esa estructura, como fue la Federación de Mujeres Peronistas, en 1965. Sin embargo, previamente participó en varias estructuras juveniles como la UES, durante el segundo gobierno peronista, y tras el golpe de Estado, en la Juventud Peronista ligada a los hermanos Traversi y De Morra, en la CGU, y en los intentos de conformar un Partido Blanco en 1958. Esther Serruya fue una alta dirigente del PPF desde sus comienzos, que se desempeñó como delegada censista, pero que mantuvo una militancia paralela en una unidad básica en el

${ }^{401}$ Inés falleció en 2012. Su testimonio está mediado por el de su hijo, Saúl Buzeta (h), que nos leyó un manuscrito dejado por Inés, de una entrevista que alguien le hiciera, pero no pudo aportarnos más datos al 
barrio de Haedo en el cual vivía. También haremos mención a algunas voces masculinas y femeninas extraídas de entrevistas propias y de testimonios presentes en entrevistas y publicaciones ajenas. ${ }^{402}$

Aunque la muestra es limitada en términos cuantitativos, en razón de que, por distintos motivos que hemos señalado en la introducción y en el capítulo I de esta tesis, no es sencillo identificar a mujeres que hayan participado de la Resistencia peronista en el período abordado y que se reconozcan partícipes de dicho proceso, resulta interesante en términos cualitativos en tanto que da cuenta de una variedad de experiencias, de relaciones sociales y puntos de vista, de manera que en la selección han primado los criterios de significatividad (Guber, 2009)

En el primer apartado, nos referiremos a la invisibilización de la participación femenina en los relatos sobre la Resistencia. En el segundo, procuraremos dilucidar las relaciones que sustentaron la militancia de estas mujeres, los espacios donde se canalizó esa actividad y la vinculación con sus familias de origen en relación a las posibilidades de participación política. Luego, realizaremos un análisis sobre la relación entre esa participación y el mundo doméstico en el que se insertaron formando familias propias. Finalmente, introducirnos las problemáticas que afectaron la participación femenina en relación al predominio de los sectores sindicales en la Resistencia peronista.

\section{Silencios y estereotipos sobre la militancia femenina}

La invisibilización femenina en los relatos sobre la Resistencia peronista es una cuestión con la que también nos topamos en nuestras propias entrevistas. Ante la pregunta a los entrevistados sobre si recordaban la presencia de mujeres en los espacios y estructuras donde militaban, algunos respondieron que no había mujeres y cuando hicieron esfuerzos por recordar, esas mujeres aparecieron vinculadas al nombre de sus esposos. ${ }^{403}$ En otros casos reconocieron la participación femenina, pero no pudieron dar detalles, ya sea porque

respecto acerca del origen del manuscrito. La entrevista fue realizada vía skype, ya que Saúl vive en Costa Rica, donde se radicó con su madre durante la última dictadura militar.

${ }^{402}$ Nello Fiorenza, Omar Dalponte, Francisco Marino, Manuel Gallardo, Carlos Geymonat, Enrique Ninín, Ángel Gherman, Luis Sobrino Aranda, Roberto Miguélez.

${ }^{403}$ Marino, Francisco. Entrevista de la autora. La Plata, 3 de abril de 2014. Fiorenza, Nello. Entrevista de la autora. La Plata, 15 de marzo de 2014. 
no las recodaban o porque ellos en sus experiencias personales no militaron junto a mujeres, ${ }^{404}$ mientras que en otros casos, esa participación fue reducida a tareas de colaboración. ${ }^{405}$ Uno de los testimonios resulta interesante, ya que hace un reconocimiento desde el presente y a partir de nuestras inquietudes a la hora de realizar la entrevista- sobre el machismo que primaba en la época y el que pervive en la actualidad, que impide recordar la participación femenina:

Enrique: "Mirá, en el Comando [Táctico] hay mujeres. Están, hay una lista, Gemelli, Fernícola, Parodi. Pero claro, vos pensá que éramos más machistas que ahora... bastante... Es decir, las mujeres eran como... medio... más excepcional."

$[\ldots]$

E: “Ellas cómo fueron a parar ahí, al Comando Táctico?”

$[\ldots]$

E: "Algunas eran diputadas. ¿Porque eran figuras visibles?"

Enrique: "Claro, sí, eran figuras visibles. Y otras porque se ganaron los laureles, Norma Kennedy, que no estaba en el Comando, pero también. Eran gente que así como yo, estaban militando en la revista [Línea Dura], hacían grupos y trabajaban, imprimían panfletos, estuvieron en acciones...."

$[\ldots]$

E: “María Granata tampoco?"

Enrique: 'No, es otra cosa; respetable, respetada. Pero tampoco se metía; como era muy machista ¿viste? Yo, a María siempre la vi como compañera de Prieto, ¿viste?"

E: "Claro, y de las otras..."

Enrique: 'No, no. La Parodi era un poco más, tenía más presencia, más historia, más militancia. ¡Pero mirá qué curioso! ¿Te das cuenta? No las recuerdo, porque yo tengo la visión, por ahí, bueno, equivocada por el tiempo, pero me vienen, lo que me viene es (sic) [son] los tipos, las mujeres me vienen como lo que te digo $[\ldots]]^{\prime 4}{ }^{406}$

Estos testimonios nos llevan a preguntarnos acerca de si el borramiento de las mujeres en los relatos sobre la Resistencia peronista se debe a que realmente fueron minoría en relación a los militantes varones o a que lisa y llanamente fueron borradas por las visiones androcéntricas del arquetipo viril, señaladas por Moreno i Sardá (2007) que impera en la construcción de esos relatos, como bien reconoce el militante citado. Esta cuestión no ha pasado desapercibida para algunas mujeres. Elina Nizán recuerda su participación en la

\footnotetext{
${ }^{404}$ Geymonat, Carlos. Entrevista de la autora. Berisso. 18 de febrero de 2014.

${ }^{405}$ Gallardo, Manuel. Entrevista de la autora. Quilmes, 24 de julio de 2015. Fiorenza, Nello. Entrevista de la autora. La Plata, 15 de marzo de 2014. Dalponte. Entrevista de la autora. Lanús, 7 de julio de 2014.
} 
Resistencia con una mayoría de hombres y sólo cuatro o cinco mujeres, causa que ella encuentra en el hecho de que muchas estaban detenidas, tenían miedo de involucrarse, eran celosas o no eran peronistas. ${ }^{407}$ Como hemos señalado en los capítulos anteriores, la mayor o menor participación de mujeres estuvo vinculada con los espacios en los cuáles se desarrolló la militancia, en un proceso en el que intervinieron las experiencias socializadoras previas y los discursos que habilitaban determinados modos de participación. Elsa Mura, a través de su relato, nos brinda una imagen de la participación femenina en uno de los espacios desde los cuales se desarrolló la Resistencia peronista, el mundo fabril; espacio que en determinados rubros estuvo muy transitado por mujeres. Para Mura, que adhirió al feminismo en la década del ' 80 y cuyo relato se halla atravesado por la perspectiva de género, los motivos del silenciamiento de la participación femenina en los relatos sobre la Resistencia no sólo residen en la influencia de los discursos machistas que circulan en el presente y que atraviesa a esos relatos sino también en las desigualdades de género que permearon las experiencias que esos relatos transmiten; como se desprende también del testimonio de Enrique Ninín previamente citado. Mura señala la imposibilidad de las mujeres por acceder a lugares de dirigencia y las relaciones de discriminación en términos de género que se desarrollaban en los espacios sindicales y otros espacios de militancia: “... Nos desdibujó la historia o el machismo desdibuja a las mujeres en esa época. Las mujeres eran el brazo de la militancia y éramos las que hacíamos las cosas tapadas, digamos, lo que no tenía tal vez una trascendencia política...". 408 Esta militante también cuestiona la ausencia femenina en los relatos sobre hechos específicos, como el levantamiento de Valle o la toma del frigorífico Lisandro de La Torre, donde ella, las obreras de su fábrica y gran cantidad de otras mujeres participaron, y la imposibilidad de encontrar en esa época cuadros políticos femeninos. Considera que sí los hubo en los años '70, aunque no se los reconozca, pero que antes del Cordobazo fueron pocas las mujeres que pudieron llegar a ese nivel de militancia, porque tuvieron impedimentos para hacerlo por el propio machismo que imperaba en las relaciones de militancia; con la excepción de Alicia Eguren, que por el protagonismo que alcanzó resulta difícil ignorarla: “...a la Eguren no se la puede tapar, ¿con qué vas a tapar el sol? No la pueden tapar a la Eguren y; sin embargo, lo hacen”. 409

\footnotetext{
${ }^{406}$ Ninín, Enrique. Entrevista de la autora. Buenos Aires, 31 de agosto de 2012.

407 Testimonio de Elina Nizán de Kubinsky en Gamba, Susana y Vasallo, Marta (1983). "Las mujeres en el peronismo". Revista Unidos Mujer Nº1, mayo.

${ }^{408}$ Mura, Elsa. Entrevista de la autora. El Palomar, 27 de mayo de 2014

${ }^{409}$ Mura, Elsa. Entrevista de la autora. El Palomar, 27 de mayo de 2014
} 
Este proceso de invisibilización de la participación femenina en la Resistencia peronista no sólo se ejerce a partir de la omisión de esa participación sino también a través de la construcción de estereotipos que tienden a simplificarla, reduciéndola al desarrollo de tareas auxiliares de las acciones planeadas por los militantes varones. Como señalamos al comienzo, Josefina Centurión ha expuesto las implicancias de género y del carácter simplificador del apelativo de tías con que usualmente se suele hacer referencia a las mujeres que participaron de la Resistencia peronista. Aquí, a partir del análisis de fuentes orales, nos preguntarnos sobre el alcance que dicho apelativo adquirió en el contexto en que las acciones de la Resistencia tuvieron lugar. Sólo en una de las entrevistas realizadas hubo menciones al mismo y de ella se desprende que el término no tenía una aplicación tan amplia; es decir, no alcanzaba a todas las mujeres de la Resistencia. Esto contrasta con los relatos masculinos que circulan en los libros y material de divulgación en los que cuando se hace referencia a alguna mujer, enseguida tiende a ubicársela bajo esa denominación. En la entrevista de mujeres recién mencionada, éstas hacen uso de la palabra y no se veían a sí mismas como tales ni eran llamadas así por sus compañeros de militancia, porque ese apelativo, en aquella época sólo era aplicable a algunas mujeres:

E: ¿Y su mamá también militaba?

E3: Sí, ella, ¡sí! A mí mamá la llamaban la Tía, en todo el movimiento. No solamente acá, en toda la Argentina y hasta afuera.

E: ¿Por qué la llamaban así?

E3: Y no sé por qué le llamaron la tía

E4: Le decíamos la Tía Tallarico. Porque como era más grande... tenemos a la viejita Tello, la abuela Tello...

E3: Ah! porque hicieron ellas el costurero Eva Perón, por eso estaban las dos, las dos más viejas, trabajando denodadamente para el corazón, para el costurero. Para el costurero Eva Perón. ${ }^{410}$

De este testimonio se evidencia que se nominaba como tías a mujeres que tenían una edad avanzada. Nuestras entrevistadas, que rondaban los 25 y 30 años al momento de producirse los hechos que estamos analizando, no calificaban en esa categoría. Pero además, las tías tenían cierto reconocimiento entre la militancia y esa visibilidad se debía a su compromiso y a una participación insistente y continua, como se aprecia en el relato siguiente:

${ }^{410}$ Entrevista colectiva; Entrevista de la autora, Rosario, 16 de octubre de 2012. 
Naty: A mi mamá una vez la llevaron porque nosotros en mi casa recibíamos a todos los escapados de todo el país. Y ya, esa casa estaba conocida. Y fueron a agarrar a uno de Buenos Aires que estaba ahí. Y va mi mamá con un abogado. Y va un empleado, al jefe de la policía: "Señor, tenemos aquí a la Tía". “¿Cómo?”. Dice: "Sí, la tenemos aquí, qué hacemos”. Y fue él a verla. Y la abrazó a mi mamá (risas). Y la abrazó: “¿Es la Tía, usted es la Tía?” “Pensar que en todas las corridas estaba siempre delante mío y yo buscaba quién era la Tía!"”

En el testimonio de una militante de Berisso, aunque no refiere al nombre de tías, también se hace mención a la participación de mujeres de edad madura con trayectoria en el peronismo que actuaban en los barrios como aglutinadoras de otras mujeres y de militantes más jóvenes; una actitud que la entrevistada designa con el nombre más actual de "puntera". ${ }^{411}$ Entonces, lo que podemos decir es que los usos actuales del término "tía" tienden a homogeneizar una participación cuyas características fueron heterogéneas, a la vez que se pierde la especificidad que ese término tuvo en el contexto analizado.

El otro estereotipo que nos propusimos problematizar es el que otorga un lugar importante a las cocinas en los relatos sobre la Resistencia:

"Allí siempre había una cocina amiga donde tomar unos mates y un sitio seguro donde poder aguantar si era necesario. ¡Las cocinas que hemos conocido! [...] No sé hacer poemas, pero sugiero ese pequeño homenaje que todavía no se ha rendido a las cocinas humildes, de nuestras barriadas, que fueron verdaderos fortines del Movimiento Peronista. Allí se realizaban las reuniones con los compañeros barriales, se distribuía la propaganda, se establecían enlaces, se programaban las pintadas, se planeaba la acción. Allí nos reuníamos, donde todos son iguales y se confunden, donde nadie llama la atención, como en una gran familia". ${ }^{412}$

Nuestro objetivo no es negar el rol que ese espacio doméstico cumplió como lugar de reuniones, planificaciones y desarrollo de materiales para la Resistencia, desde la confección de panfletos hasta la fabricación de caños, sino problematizarlo en relación a la militancia femenina. ¿El lugar que las cocinas jugaron en la Resistencia peronista, debe llevarnos a pensar que las mujeres que participaron en ella tendieron a reproducir roles tradicionales de género? ¿Significa que la militancia se desarrolló en un proceso de continuidad y armonía entre las obligaciones que les imponía ese espacio, asociadas a modelos de género

\footnotetext{
${ }^{411}$ Amanda Sotelo; Entrevista de la autora, Berisso, 7 de mayo de 2014.

${ }^{412}$ Testimonio de César Marcos en Baschetti, Roberto. Militantes del peronismo uno por uno. Recuperado de http://www.robertobaschetti.com/biografia/m/52.html
} 
tradicionales, y las exigencias de la militancia? El carácter barrial de la Resistencia ha llevado a algunas autoras a sostener que el mismo fue un motivo para que las mujeres tuvieran una amplia intervención en dicho proceso, pudiendo participar en política desde sus lugares tradicionales, como eran el hogar, el barrio, el mercado (Scoufalos, 2007). Ya vimos que la militancia femenina no se limitaba a esos espacios, pero aún en los casos que estuvieron sustentados en relaciones barriales y familiares, ¿podemos sostener que no hubo contradicciones entre las exigencias de la actividad política y las del espacio doméstico? ¿Las mujeres se lanzaron a la participación en la Resistencia como una prolongación de sus roles conyugales y maternales? ¿O haciendo honor al lugar de tías, se limitaron a ayudar a los militantes varones porque ello no les generaba contradicciones con su vida privada? A lo largo de los diferentes apartados procuraremos ofrecer algunas respuestas a estos interrogantes, a partir de las experiencias individuales de mujeres que desde diferentes espacios y modalidades fueron partícipes de la Resistencia peronista.

\section{Las redes familiares de la Resistencia}

Los relatos orales contienen información muy rica en cuanto a la articulación entre la las dimensiones pública y privada de la experiencia y entre esta última y los hechos procesos históricos, y no sólo por el contenido de lo que narran, sino también por la forma en que los relatos son estructurados. Ello se observa, incluso, en las formas de periodizar. Alessandro Portelli (1994; 2001 [1999]) distingue dos formas principales de hacerlo. Por un lado, reconoce una periodización horizontal, en la que el relato es descompuesto en bloques temporales homogéneos, por lo general vinculados a un hecho significativo, respecto al cual los acontecimientos se disponen antes o después. Y por otro lado, una periodización vertical, que no revela tanto el carácter diacrónico del tiempo como su carácter sincrónico, y está vinculada a tres modalidades del relato. Así, distingue, una modalidad "ético-política" o "institucional", en la que las referencias espaciales y temporales del relato pertenecen a la esfera pública y a los grupos dirigentes. A veces, esta modalidad resulta predominante ya que el narrador puede derivar autoridad de su contacto con figuras destacadas de la política. Una segunda modalidad, "colectiva", que remite a la actividad del grupo circundante como un todo, pero de carácter pública. $\mathrm{Y}$ finalmente, una modalidad personal, que utiliza referencias del mundo privado, familiar. Estas modalidades, que suelen estar combinadas en 
un mismo relato, dan cuenta de las estratificaciones de la experiencia. La primera de esas modalidades, la periodización horizontal, nos permite observar cómo las etapas en la vida de una persona se entrelazan con el contexto político; mientras que la segunda, la modalidad vertical, nos ayuda a comprender la red de relaciones en la que estuvo inserta la militancia. El objetivo de este apartado será delinear los perfiles de las mujeres entrevistadas y evidenciar la variedad de experiencias de las que se nutrió la Resistencia peronista, a fin de reflexionar sobre el rol que cumplieron las familias de origen en el desarrollo de su militancia.

En el caso de Chiche Di Marco, Naty Rivas y María Martínez, las entidades políticas que emergen de sus relatos como espacios en los que desarrollaron su militancia, son las unidades básicas barriales y la CGT de Rosario; estructuras que remiten al componente colectivo. Cada una de ellas militó en una unidad básica diferente, porque vivían en distintos barrios, pero se encontraban en las movilizaciones. Esa modalidad colectiva aparece estrechamente vinculada con la modalidad personal. A la cabeza de las unidades básicas en que cada una de ellas había iniciado su militancia durante el gobierno peronista siendo niñas o adolescentes, solía haber un pariente o un amigo de la familia. A ellas, la política y el peronismo no se les presentó como una "revelación", como una opción de vida, sino que fueron experimentados desde la infancia, junto a la familia, en la cotidianeidad de la unidad básica. Sin embargo, reconocen en el golpe de Estado de 1955 un quiebre, un momento en que la militancia se volvió "consciente", más comprometida: "Ahí empezamos la verdadera militancia". ${ }^{413}$ Es el momento en el cual se sumaron a la Resistencia, un proceso que marcó sus vidas y que es estructurante de su identidad. Aquí opera la periodización horizontal, porque el derrocamiento de Perón se convirtió en un punto de inflexión que significó la separación entre una militancia que ellas consideran desarrollada de manera natural y una militancia que implicaba un mayor grado de compromiso y la toma de decisiones que afectaban la vida personal.

Estos testimonios, además, evidencian una forma de hacer política en la que la familia entera compartía espacios de participación. Así como ellas lo hicieron en el pasado, como niñas, acompañando la actividad política de los adultos de su círculo familiar, luego, durante los años de la Resistencia, repitieron la experiencia con sus propios hijos. No se observa una ruptura generacional. Si bien reconocen la gravitación que ejercían los sindicalistas -

${ }^{413}$ Di Marco, Chiche; Martínez, María; Rivas Natividad y Cánepa, Oscar. Entrevista de la autora, Rosario, 16 de octubre de 2012. 
gravitación que también se da en un plano personal, ya que estuvieron relacionadas con ellos a través de relaciones de parentesco- también manifiestan un reconocimiento de la capacidad de liderazgo ejercida por algunas mujeres de mayor edad, como la madre de una de ellas, que estaba muy comprometida con las acciones de la Resistencia.

En el relato de Amanda Sotelo, una militante del barrio obrero de Berisso, también se observa un predominio de la modalidad personal. Las relaciones de socialización que definen la militancia son la familia y el barrio. Hay un personaje decisivo en la inclinación de Amanda por la política y el peronismo, su madre. Ella reconoce que, en su casa, quienes militaban eran mujeres, mientras que los miembros masculinos de la familia -el padre y su hermano - si bien apoyaban al peronismo, no tenían una militancia activa, ya sea por apatía o por falta de tiempo. Las actividades que desarrolló durante la Resistencia tienen como impulsoras a su madre y a la mujer que había dirigido la unidad básica del barrio. Esa mujer habría seguido teniendo gravitación entre los vecinos luego del derrocamiento del peronismo; pues les hacía llegar los mensajes de Perón. Su relato transmite cómo las acciones que realizaba con estas mujeres podían ser interpretadas por las fuerzas encargadas de reprimir como comportamientos que no eran los propios del género femenino:

"Después conocíamos a una señora que era media puntera acá en el barrio, doña Sonia [sic] Padovani, que se juntaba con mi mamá. Y bueno, íbamos a la zona nacional; la zona nacional le llaman a la Nueva York, que está más custodiada por los marinos y eso. [...] Y llevábamos, por ejemplo, panfletos, ¿no? Y eran dos señoras que paseaban con sus hijos, que éramos nosotros, de catorce, quince, dieciséis años. Éramos las dos señoras y cinco o seis muchachas y muchachos. Y llevábamos unos panfletos donde decía 'luche y vuelve'. Y lo pegábamos en los árboles. Hasta que algún marinero se daba cuenta y nos sacaba: 'váyase, váyase a su casa'; les decían, a las madres, ¿no? ‘¡Váyanse a lavar la ropa, a cocinar, déjense de embromar, acá!". ${ }^{414}$

Además de las relaciones familiares y barriales, encarnadas en el vínculo con su madre, su vecina y otros jóvenes del barrio, para el desarrollo de acciones en la Resistencia, Amanda también menciona a su familia extendida; sus tías y primos de Ensenada con

\footnotetext{
${ }^{414}$ Sotelo, Amanda. Entrevista de la autora. Berisso, 7 de mayo de 2014. El "Luche y Vuelve" fue una consigna lanzada por la izquierda peronista en la etapa previa a las elecciones presidenciales de 1973 y al regreso definitivo de Perón a la Argentina. Es probable que la entrevistada esté confundiéndose con la consigna "Perón Vuelve", que estuvo vigente desde los primeros años de la Resistencia peronista; etapa que coincide con la edad que ella dice tener en el momento en el cual transcurre la anécdota, catorce, quince o dieciséis años.
} 
quienes compartía espacios de socialización que se remontaban a la época en que sus padres habían emigrado de la provincia de Corrientes, en busca de trabajo, para luego radicarse en esa zona. Allí, se vincularon con familiares y otros correntinos que vivían en el lugar, a través de bailes y reuniones, y también descubrieron al peronismo que estaba naciendo en esos momentos. El componente colectivo en el relato de Amanda está constituido por sus propios parientes, vecinos y amigos, de ambos distritos que por entonces todavía eran barrios platenses, siempre atravesado por anécdotas personales. Amanda recuerda cómo las comidas familiares servían como una excusa que les permitían reunirse para hablar de política.

El relato de esta militante presenta una periodización horizontal que contiene tres bloques temporales separados por dos puntos de inflexión. El primero está representado por el golpe de Estado de 1955. Amanda tenía quince años en ese entonces y ahí comenzó su accionar en la Resistencia peronista. El segundo punto de inflexión se produjo en 1964, cuando hizo su ingreso al primer trabajo formal como enfermera en un hospital; oficio para el cual había estudiado y que coincidió con su ingreso al sindicato de salud. Durante 19551964, no reconoce relaciones con ninguna estructura gremial. El sindicalismo es concebido como una etapa superadora de la que se había desarrollado con anterioridad a 1964, vinculada a una madurez personal y también a un desarrollo más complejo del sindicato de salud con el que ella estuvo relacionada. La etapa previa a ese año es interpretada a la luz de esta última, como un período de cierta ingenuidad y de poca relevancia de las acciones que se llevaban a cabo; una imagen que coincide con las que se han construido en los relatos públicos sobre la Resistencia peronista:

“[...] Después de juntarnos y hacer, les llamábamos actos relámpagos, para resistir. Acá pasaban dos líneas de tranvía. Entonces nos juntábamos, como que íbamos a viajar, y después, allá en el fondo, que no había nadie, la calle cuarenta, esta es la treinta y cuatro, le bajábamos, le sacábamos el riel al tranvía para que no ande; esas tonterías. La comisaría estaba a dos cuadras. Entonces, por lo general, eran italianos: ‘ $¡ E h$, ma, qué me está'ciendo! ¡Andá a cantarle a Perón a otro lado!' Bueno, hacíamos esas pavadas, porque era ingenuo, dentro de todo." 415

Así como el quiebre que se produce en el relato, situado en 1964, marca el inicio de una actividad política y de una actividad laboral más regulares y comprometidas, signos de

${ }^{415}$ Sotelo, Amanda. Entrevista de la autora. Berisso, 7 de mayo de 2014. 
mayor madurez personal, el punto de inflexión anterior, ubicado en 1955, marca el despertar a la adolescencia. Aunque del relato de Amanda se desprende una continuidad y un acompañamiento de las actividades que desarrollaban los mayores, durante esta etapa también hay un intento por diferenciarse de esos mayores de los que reconoce que nunca se separaron definitivamente. Con sus primos y amigos de Berisso y Ensenada intentaron formar una "juventud peronista", que comenzó a desarrollar algunas tareas diferenciadas de las de los adultos, aunque no tuvieron organicidad ni continuidad en el tiempo:

Amanda: Y después estaba en ese momento, también, el Comando Táctico; que estaba dirigido y organizado por William Cooke, que era uno de los intelectuales del peronismo, ¿no? Ellos sí estaban más organizados, y nosotros queríamos saber qué eran los caños. 'No, ustedes son chicos, ustedes no se metan, qué esto que el otro'.

E: ¿Quiénes les decían eso?

Amanda: Los padres nuestros, los compañeros...

$[\ldots]$

Amanda: Ellos [los integrantes del Comando Táctico] se conectaban distinto, no sé cómo se conectaban pero estaban más organizados que nosotros, las familias. ${ }^{416}$

Este fragmento del relato de Amanda refleja dos cuestiones. Por un lado, las diferencias generacionales que comenzaban a gestarse entre los jóvenes de su edad y los mayores. Y por otro lado, la centralidad de la familia como marco a través del cual se canalizaba la militancia. El Comando Táctico es la única estructura que Amanda reconoce por fuera de Berisso y Ensenada con influencia en su actividad política; el único referente de la modalidad político-institucional. Sin embargo, las relaciones con el Comando son secundarias respecto de la familia y el barrio.

En síntesis, lo que nos muestran estos dos relatos es un tipo de militancia muy ligado a las relaciones familiares y barriales y una continuidad generacional. El ingreso a la militancia se hizo de manera espontánea en el marco de esas relaciones durante la etapa de los primeros gobiernos peronistas. Pese al quiebre que significó 1955 en cuanto a la forma y posibilidades de militar, a la adopción de un compromiso más consciente con la política, por los riesgos que ello implicaba, y a los tímidos intentos de los jóvenes por diferenciarse de los adultos, hecho que se vislumbra en el segundo relato, lo cierto es que no hubo una

\footnotetext{
${ }^{416}$ Sotelo, Amanda. Entrevista de la autora. Berisso, 7 de mayo de 2014.
} 
ruptura generacional y que el ingreso a la militancia no fue una decisión disruptiva en sus vidas personales.

El caso de Marta Curone también revela un acceso a los espacios políticos a través de las relaciones familiares. Proviene de una familia de clase media porteña. Su padre era dirigente metalúrgico y su madre había militado en un centro cívico de la UCR Junta Renovadora en la ciudad de Buenos Aires, al que Marta concurría siendo niña. Sin embargo, sus espacios de socialización política son muy diferentes a los que emergen de los relatos anteriores, porque aquí no hay relaciones barriales y hay un acceso a niveles de dirigencia. De hecho, cuando Marta estaba cursando el último año del secundario ingresó en la UES y al poco tiempo se convertiría en secretaria de la rama femenina de esa organización. La periodización vertical está dada por elementos del componente colectivo e institucional y por fuera de la relación con sus padres, hay pocas referencias a su vida personal. El golpe de Estado de 1955 marcó un punto de inflexión en su relato, dado fundamentalmente por los encarcelamientos que sufrió. Las cárceles se convirtieron en un espacio donde estrechó relaciones con las altas dirigentes del PPF que también habían sido detenidas luego del golpe y con otras mujeres de la Resistencia.

La militancia durante el segundo gobierno peronista le había permitido articular su proyecto personal con el político, porque la participación política en ese contexto se había dado a través de una estructura estrechamente ligada al mundo estudiantil como era la UES. A diferencia de ello, su compromiso político que trascendió al golpe de Estado, hizo que terminara abandonando sus estudios universitarios; que completó muchos años después, luego del retorno a la democracia. En una carta a Perón manifiesta las dificultades de las mujeres para poder organizarse bajo la situación que primaba durante los años de la proscripción. Mientras que durante los años del peronismo, la participación política les había dado a las mujeres la oportunidad de estudiar, en el nuevo contexto se les dificultaba por la situación económica que les obligaba a trabajar:

"La generación de los treinta años se ha dedicado en su mayor parte a estudiar o a sus ocupaciones individuales. Son muy pocas las que como yo olvidan su vida privada para dedicarse a las tareas del movimiento. El peronismo abrió a la mujer enormes posibilidades. Salió entonces de su hogar para aportar sus conocimientos al engrandecimiento del país. En la actualidad no tiene tiempo porque el sistema liberal de vida que soporta es injusto y materialista, por lo que piensa en subsistir [... $]^{, 417}$

${ }^{417}$ Carta de Marta Curone a Perón. Buenos Aires, 25 de julio de 1964. Archivo Marta Curone. 
Es decir, el golpe de Estado de 1955 era interpretado como un punto disruptivo en su trayectoria que le había obligado a llevar un tipo de militancia que atentaba contra los proyectos personales de promoción política y profesional.

A diferencia de los relatos anteriores, Curone estuvo estrechamente vinculada a estructuras de dirigencia durante los años de la Resistencia, como el Consejo Coordinador y Supervisor del peronismo, pero, al igual que en esos testimonios, tampoco hubo una ruptura generacional. Si bien hay un reconocimiento de pertenencia a una generación diferente a la de la dirigencia del PPF, su militancia es interpretada como una continuación de la militancia de sus padres. De hecho, sostiene que ellos dejaron de participar en política para darle lugar a ella. ${ }^{418}$

Para otras mujeres, el ingreso a la política sí marcó una decisión importante en sus vidas, pero ese momento no se produjo durante la etapa de la Resistencia sino que ya se había dado durante los años del gobierno peronista. En estos casos, el 17 de Octubre fue una revelación; un hecho que marcó sus vidas. Pero además hubo un momento concreto en que asumieron el desafío político. En el caso de Esther Serruya, por ejemplo, que llegó a ser delegada censista, ese momento estuvo dado por la convocatoria de Eva Perón para constituir el Partido Peronista Femenino, al cual se sumó impulsada por su novio -que era sindicalista- y con el apoyo de su madre. La disconformidad con la carrera que había estudiado también la impulsó a sumarse al partido. ${ }^{419}$ Paralelamente a su actividad en PPF, fundó una unidad básica en su casa en un barrio del conurbano bonaerense y los vecinos del barrio constituyeron las redes de relaciones que mantuvo luego del golpe de Estado, pese a que continuó vinculada a las mujeres del PPF y que fue diputada provincial en 1965. Es decir, tanto antes como después del golpe de Estado de 1955, su militancia se insertó en diferentes niveles. En el caso de Inés Dihian, delegada del sindicato de Empleados de Comercio en Capital Federal, ese quiebre en su vida estuvo dado por el momento en que decidió aceptar el pedido de sus compañeras de trabajo, de tendencia socialista, para ser delegada; pese a que ella siempre se mantuvo en el peronismo. Esa decisión implicaba abandonar su deseo de ser azafata o de dedicarse al periodismo y, en el momento en que fue

\footnotetext{
${ }^{418}$ Curone, Marta. Entrevista de la autora. Buenos Aires, 18 de julio de 2014.

${ }^{419}$ Serruya, Esther. Entrevista de la autora. Castelar, 1 de noviembre de 2012.
} 
tomada, tuvo conciencia de estaba eligiendo una opción de vida. ${ }^{420}$ En ambos casos, estas mujeres no provenían de familias peronistas ni politizadas, pero la decisión de ingresar a la política en uno u otro espacio fue apoyada por sus madres. Los padres de ambas habían fallecido para ese momento. En el caso de Lala Marín, fue al revés. Su madre había fallecido siendo ella niña y su padre, que era peronista, apoyó su participación política. ${ }^{421}$

Claro que hubo casos de mujeres que ingresaron a la militancia en los años posteriores al golpe de Estado, pero esa participación también estuvo estrechamente vinculada con las relaciones familiares, barriales o laborales, y parecen haberse dado de manera espontánea y no como producto de una decisión rupturista, como en los dos casos anteriores. Elsa Mura llegó a Buenos Aires desde San Luis a comienzos de la década del cincuenta y siendo adolescente comenzó a trabajar en la industria metalúrgica. Su compromiso con la militancia se fue dando en las sucesivas huelgas y a través de las relaciones con sus compañeras de trabajo que eran peronistas, con la excepción de una, que era radical. Pese a que militó en estructuras del peronismo nunca se cerró en esa filiación política identificándose con los sectores populares en general y permaneciendo abierta a la posibilidad de estrechar relaciones con personas y organizaciones de izquierda. Sus referencias políticas están constituidas, especialmente, por sus compañeras de trabajo; es decir, que el componente colectivo está muy acentuado en su relato y lo mismo puede decirse del componente personal. Hay referencias a entidades del componente institucional, pero la relación que establece con ellas es de un vínculo laxo, de no encuadramiento, como en los casos del Sindicato de Farmacia, la Juventud Peronista y la FEDE (Federación Juvenil Comunista), y en algunos casos, de abierto conflicto, como la alta dirigencia sindical. ${ }^{422}$

El acontecimiento que aparece como un punto de inflexión en su relato es la toma del Frigorífico Lisandro de La Torre. Ese hecho, se manifiesta como un momento que equivale a un cambio cualitativo en la forma de organizarse y de participar de las mujeres y de capitalización de las experiencias previas; a la vez que las impulsa a hacer acciones más arriesgadas. Aunque su militancia se desarrolló a escondidas de su madre y sus hermanas, que no estaban politizadas, encontró un buen apoyo en su padre, de ideología peronista,

\footnotetext{
${ }^{420}$ Buzeta, Saúl (h). Entrevista de la autora. Vía skype. 11 de marzo de 2014.

${ }^{421}$ Es poco lo que sabemos sobre esta militante porque los testimonios sobre su participación fueron extraídos de una entrevista ajena, disponible en la Comisión por la Memoria de la Provincia de Buenos Aires. Algunos datos fueron completados con una entrevista a su nieto, Enrique Pavón Pereyra (h). Sabemos que García Marín integró el Comando Táctico, que se desarrolló en células clandestinas y político partidarias que en los años previos a la Resistencia había trabajado en el Ministerio de Salud y en la Fundación Eva Perón.
} 
pero que había transitado previamente por las filas del anarquismo. Él jugó un papel importante como transmisor de conocimiento a partir de sus experiencias políticas previas, sobre todo en lo referente a seguridad y defensa personal.

Mabel Di Leo también comenzó su militancia luego del golpe de Estado de 1955. Si bien su familia no tenía participación política, sí tenía conciencia política. Su padre era policía y había renunciado luego de producirse el golpe de Estado, y su madre era ama de casa pero había tenido una formación metodista. En su casa se hablaba de política. Su padre participó del levantamiento de Valle, donde Mabel tuvo una participación que hemos referido en el primer capítulo, y que contó con la aprobación de sus padres apoyaron. Si bien con los años pasaría a integrar niveles de dirigencia, en los primeros tiempos posteriores al golpe al derrocamiento del peronismo su militancia se desarrolló en su barrio con otros jóvenes con quienes conformaron la juventud peronista de Vicente López y en una unidad básica barrial de la Rama Femenina. ${ }^{423}$

Como se desprende de los testimonios, las experiencias de militancia son muy diversas. Se insertan en diferentes espacios y redes de relaciones. Algo que caracteriza a varios de ellos es que, pese a que muchas mujeres se desarrollaron en ámbitos de dirigencia, mantuvieron militancias paralelas en los niveles de base. Y por otro lado, no hay manifestaciones de haber experimentado la militancia como una ruptura generacional. Los padres, o bien eran peronistas o sin serlo, estaban politizados, y apoyaron el involucramiento de sus hijas en la política. En otros casos no estaban politizados, pero aun así las acompañaron e incluso llegaron a encuadrarse detrás de su militancia. En dos relatos, el de Elsa Mura y el de Mabel Di Leo, surge la idea de que su padres, varones, les hicieron tomar conciencia de las desigualdades a las que estaban expuestas por ser mujeres, y sobre la necesidad de luchar por sus derechos. En otros casos, ellas se incorporaron a la política siguiendo la actividad de sus padres, en interpretándola en una relación continuidad. Hubo casos donde hubo cierto tipo de transgresión, como en el de Elsa Mura, donde su actividad política es interpretada como una reacción frente al apoliticismo de su madre, pero a la vez, como una continuidad con la militancia de su padre. Es decir, no es que estas militantes no se percibieran a sí mismas como integrantes de un sector etario diferenciado, la juventud, sino que el ingreso a la militancia no es recordado como una transgresión a la generación anterior, como sí lo fue para muchas militantes de clase media que se

${ }^{422}$ Mura, Elsa. Entrevista de la autora. El Palomar, 27 de mayo de 2014

${ }^{423}$ Di Leo, Mabel. Entrevista de la Autora. Vicente López, 31 de agosto de 2014 
incorporaron a la política en la década del '70, donde esa transgresión se dio en términos ideológicos, por la adscripción al peronismo de muchas de ellas, siendo que provenían de familias antiperonistas, sino en términos de repudio a al modelo de domesticidad que encarnaban esas familias y al rol de ama de casa representado por sus madres (Cosse, 2010). Ese modelo de la domesticidad refería a una relación de complementariedad de los cónyuges, jerárquica, en la que la mujer adoptaba el rol de reproductora y cuidadora, quedando relegada al espacio doméstico, mientras que el varón debía adoptar la función de proveedor, a la vez que a él le estaba reservado el espacio público; un modelo disciplinador que había sido reforzado en la década del '30, que se impuso, sobre todo, entre las familias de clase media como medida de respetabilidad, y que a mediados del siglo XX continuaba con mucha vigencia (Cosse, 2010). Ahora bien, cabe preguntarnos, el hecho de que varias de las mujeres entrevistadas hayan desplegado su militancia a partir de una socialización que partió de sus familias de origen o que hayan contado con el apoyo de sus padres, ¿significó que hayan reproducido los roles tradicionales asociados al modelo de la domesticidad? ¿Cómo fue la articulación entre sus experiencias como militantes y las exigencias que provenían del mundo doméstico? ¿Podemos sostener que su participación en la Resistencia se produjo como una prolongación de sus roles domésticos? En el apartado siguiente intentaremos ofrecer algunas respuestas a estos interrogantes contemplando cómo fue su militancia en relación a las relaciones familiares en las que se insertaron como esposas y madres.

\section{Conyugalidad, maternidad y militancia}

El problema de las obligaciones familiares o de las incompatibilidades entre el proyecto personal y el político, hacen su emergencia tanto en los relatos femeninos como en los masculinos. Sin embargo, se presentan de una manera diferente. La persecución política y las malas condiciones económicas que podía traer aparejada la militancia es un tópico que suele estar presente en los relatos masculinos. De hecho, algunos militantes, luego de haberse comprometidos con la Resistencia e incluso sufrir experiencias de exilio, decidieron abandonar la militancia para dedicarse a su proyecto personal; sobre todo aquellos cuya participación política no había estado vinculada a los lugares de trabajo, como sucede con la 
militancia sindical. ${ }^{424}$ En otros casos, pese a los sacrificios que la militancia implicaba, asumieron un alto compromiso y el mismo conllevó una ruptura abrupta con la vida cotidiana desarrollada hasta el momento, como se desprende del relato de Juan Carlos Cena, un militante sindical que participó de organizaciones clandestinas de la resistencia vinculadas a las estructuras del ferrocarril:

"Mi viejo estaba total y absolutamente indignado y es cuando me habla y me dijo [...] la Resistencia te precisa [...] y después de un tiempo paso a la estructura del ferrocarril que estaba totalmente tabicada y ahí empieza la enseñanza de la militancia en la Resistencia. La primera vez que fui clandestino. Tengo que cambiar mis maneras de comportamiento. Tengo que cambiar mi manera de ser, tengo que ser menos bocón, tengo que andar bien vestido $\mathrm{y}$ cambiar los amigos, no tengo que ir más al sindicato. Yo era mensajero y tenía que andar bien vestido, cambiar de pista de baile también, porque yo era cuartetero y tenía que ir a los lugares, bailar en Atenas o bailar en Rieles Argentinos donde se bailaba más de salón, menos apretadito". ${ }^{425}$

Este relato es una muestra de las implicancias que el compromiso político podía significar para un joven en relación a sus posibilidades de esparcimiento, a la vez que refuerza la idea sostenida en el apartado anterior de una militancia que fue promovida por las familias de origen de aquellos militantes que se iniciaron en la Resistencia siendo muy jóvenes. Pero veamos el siguiente ejemplo de una de las mujeres entrevistadas, Amanda, que también era muy joven en los inicios de la Resistencia:

“[...] Eran tiempos que te exigían bastante ¿no? Porque si había una reunión, qué sé yo, a las veinte de la noche y vos te levantabas a las cuatro de la mañana (porque trabajaba de mañana): de acá, de Berisso, me iba a Gonnet, al hospital de Gonnet a trabajar... y bueno, costaba, pero lo hacía ¿viste? Cuando eras joven y estabas convencida de que eso era para algo bueno [...] A veces no te daban los tiempos pero bueno, tratás de buscarlos. Por lo general, porque todos más o menos estábamos en la misma situación, se usaban los domingos, la reunión, para escuchar la voz de Perón o algún papel donde se dijera algo [...] Peor eran las mujeres que estaba casadas, que tenían hijos y todo; pero bueno, ellos venían, venían todos, el que mamaba, el chiquitito que apenas caminaba, todos venían a la reunión." 426

\footnotetext{
${ }^{424}$ Ninín, Enrique. Entrevista de la autora. Buenos Aires, 31 de agosto de 2012; Gherman, Ángel. Entrevista de la autora. La Plata, 2 de septiembre de 2012; Sobrino Aranda, Luis. Entrevista de la autora. Rosario, 12 de noviembre de 2014.

${ }^{425}$ Testimonio de Juan Carlos Cena en Fernández Mouján, Alejandro (2009). Los Resistentes. Op. Cit.

${ }^{426}$ Sotelo, Amanda. Entrevista de la autora. Berisso, 7 de mayo de 2014.
} 
Estos testimonios nos demuestran que la participación política implicaba sacrificios de distinta índole para las y los militantes. Sin embargo, en los relatos femeninos emerge un tópico que es insoslayable, nos referimos a la cuestión de la maternidad. Esta militante, pese a que no tenía hijos en el momento a que hacen referencia las experiencias narradas, no pasa por alto los problemas que la maternidad y la conyugalidad podían generar para las mujeres que estaban abocadas a la militancia, aunque esta se desarrollara en el marco de relaciones barriales y familiares. Raramente estos tópicos emergen en los relatos masculinos. En las entrevistas que realizamos a militantes varones, la crianza de los hijos y las relaciones de pareja, son cuestiones que no están presentes como una preocupación, o que ni siquiera aparecen; las experiencias de la Resistencia son narradas como si transcurrieran de manera independiente de la vida doméstica. Por ejemplo, en el relato de Francisco Marino, un dirigente sindical de ATE, ante las preguntas por su participación en determinados hechos respondió con referencias a las acciones de personas destacadas, eliminando todo vestigio de la vida personal. ${ }^{427}$ Pero en los relatos femeninos siempre emergen referencias relativas a ese ámbito; aún entre mujeres que tuvieron altos niveles de compromiso y que estuvieron relacionadas con los niveles de dirigencia. Por ejemplo, en el relato de Esther Serruya, cada episodio narrado está marcado por la impronta de su participación y por referencias a personas del ámbito familiar o barrial, e inclusive, por los inconvenientes de la vida cotidiana que influían en su actividad política y viceversa. De esta manera, emergen las referencias a su viudez y a la solidaridad de las mujeres del barrio, que le ayudaron confeccionándole la ropa para poder presentarse a la reunión en que fue propuesta como candidata a diputada o que le ayudaban cuidando a sus hijos cuando ella se ausentaba por razones políticas. Incluso cuando hace referencias a un hecho tan conocido como el Plenario de Avellaneda en el que Vandor manifestó la independencia de Perón, y luego del cual fue perseguida por los sectores vandoristas por haberse animado a contradecirlos, aparecen las menciones a sus hijos, que habían quedado solos en la casa:

“[...] Y fueron a buscarme. Mis hijos habían quedado solitos en la casa; yo tenía tres criaturas. Aparecen los que estaban de Haedo [vecinos de Haedo que estaban en la reunión]; habían ido ahí. [...] A la noche aparecen los de Haedo a mi casa, entonces atiende mi hijo mayor; mi hijo mayor tenía 12 años. Y le dice [...] '¿Y ustedes están solitos acá?' 'Sí, estamos solitos acá, pero nosotros somos tres hombres'; tenía un carácter fuerte mi hijo, y sale el segundo y dice:

\footnotetext{
${ }^{427}$ Esto es muy evidente en la entrevista realizada a Francisco Marino (2014), dirigente sindical de ATE de La Plata, y a Carlos Geymonat (2014), dirigente político del Partido Justicialista en la localidad de Berisso.
} 
'Sí, acá estamos nosotros; cualquiera que venga le damos un palazo'. Y los tipos se reían, entonces dice: 'Cualquier cosa que precisás, tomá, acá tenés mi teléfono, me llamás y nosotros venimos a cuidarlos a ustedes' [...] Esto me lo cuentan los tipos después, ¿no? [...]". ${ }^{428}$

La cuestión de la maternidad es un tópico recurrente en los relatos femeninos. A las mujeres se les presentaba el problema de cómo compatibilizar la militancia con el cuidado de los hijos; un tema que está ausente de los relatos masculinos y que en los femeninos suele emerger hasta de manera espontánea, sin que haya preguntas que remitan a ese tema. Estos problemas también aparecen en la correspondencia. En el capítulo II hicimos referencia a los intentos de constitución de una estructura partidaria que se autodenominó Federación de Mujeres Peronistas, que pretendió constituirse en la base de una reorganización de la Rama Femenina. Las cartas que enviaban las mujeres del interior del país a las mujeres que conformaban la mesa directiva de la organización, radicadas en Buenos Aires, revelan las dificultades para compatibilizar la maternidad con la actividad política. Pero además, en las cartas, se vislumbran otros inconvenientes, como el tiempo que les demandaba ocuparse de los familiares enfermos, otra obligación doméstica que suele recaer en las mujeres. Este es un tópico repetitivo en varias cartas:

[...] yo estoy de acuerdo con todo lo que sea justicialismo y que se haga hasta lo imposible por traer al líder de los argentinos [...] ahora bien, yo quiero estar en contacto con ustedes pero sin dedicarme exclusivamente a ello porque tengo a mi padre delicado y mi salud no está como para descuidarla, pero yo, todo lo que pueda colaborar con ustedes, ya saben que yo soy Peronista ante Dios y la Patria por un Pueblo grande, libre y soberano." 429

Otros casos, revelan que se sobreponían a las complicaciones que les ocasionaba la maternidad, pero evidenciando que no era lo mismo militar con hijos que sin ellos:

"Si hay posibilidades en intensiones sinceras de continuar la lucha sin aflojadas, indicame qué debo hacer. Yo voy a cumplir y sé cómo moverme y dónde moverme. [...] Volveré a luchar como en mis mejores tiempos, no obstante mi maternidad. Y te aseguro que vamos a hacer algo efectivo". ${ }^{430}$

\footnotetext{
${ }^{428}$ Serruya, Esther. Entrevista de la autora. Castelar, 1 de noviembre de 2012.

${ }^{429}$ Carta de Delia G. de Furga a Marta Curone. La Niña. 9 de Julio. 30 de agosto de 1966.

${ }^{430}$ Carta de Susana F. de Floreak a Marta Curone. Río Gallegos, 18 de octubre de 1964. Archivo Marta Curone. El contexto de producción de esta carta es el del operativo retorno. Estas mujeres apoyaban la línea insurreccional para lograr el retorno de Perón, en contra del vandorismo, que propiciaba la línea pacífica.
} 
Hubo casos de mujeres que contaron con la ayuda de otras mujeres para la crianza de los hijos. Aunque los tiempos de la familia debieron supeditarse a los tiempos de la militancia, el hecho de que en el relato emerjan esas referencias relativas al mundo privado, nos habla de un reconocimiento por parte de la testimoniante de que había una norma que estaba siendo quebrantada:

"[...] Tuve también mis críticas, con referencia a que descuidaba algunas cosas; o mi trabajo o... bien, la formación de los chicos. Ellos consideraban que los chicos ya tenían que estar en secundaria y no estaban; y todas esas cosas que realmente fueron. Pero todo no se podía hacer. Después estudiaron y fueron lo que fueron. No al tiempo que el tambor de mis hermanas, mis hermanos querían, ¿no?’431

Otros testimonios revelan casos donde la toma de conciencia sobre las dificultades que para la militancia podía implicar la maternidad, e inclusive los deseos de estudiar, se resolvieron con la decisión de no tener hijos. ${ }^{432}$ En otros relatos, las mujeres participaron junto con sus hijos, ya sea de las actividades diarias que les demandaba la política, como de acciones puntuales. En las entrevistas no pasó desapercibido el sacrificio que ello podía implicar para los niños, al exponerlos a una vida con otros ritmos, ${ }^{433}$ a la vez que se desprenden imágenes de los riesgos que podía acarrear el involucramiento de los hijos en las acciones de la Resistencia y de cómo para algunas mujeres participar en determinadas actividades implicó tomar decisiones en relación a esos hijos:

"[...] Pensando de que yo iba a una asamblea y de que iba y volvía. Cuando se habla de la toma de fábrica, se terminó toda la discusión y se resolvió que íbamos a hacer una toma en la fábrica. Yo dije: "miren, yo tengo que salir, tengo que ir a ver mi nena, tengo que tomar una decisión, ¿la traigo? ¿qué hago con la nena?". Mi marido estaba trabajando en Córdoba y a él ya lo habían despedido un montón de meses [...]

[...] y yo ocupé la fábrica 27 días con mi bebé, que en ese momento tenía 9 meses, y ocuparla en épocas de dictadura militar o de gobiernos así, medios blandengue, era meterse como en la boca del lobo porque no sabías cómo iban a ser las reacciones y en qué momento nos iban a sacar volando por la ventana. Y más sobre todo, que trabajan en una fábrica donde había solo una entrada y una

\footnotetext{
431 García Marín, Hortensia. Entrevista realizada por Julieta Sahade. Buenos Aires, 27 de julio de 2010. Archivo Oral. Comisión Provincial por la Memoria.

432 Di Leo, Mabel. Entrevista de la Autora. Vicente López, 31 de agosto de 2014

${ }^{433}$ Di Marco, Chiche; Entrevista de la autora, Rosario, 11 de noviembre de 2014.
} 
sola salida. Si te bloquean esa salida, ¿por dónde salís? Como ratón quedamos encerradas allá dentro. Y esos eran los peligros que se tenían cuando se tomaba una fábrica, porque para poder tomar una fábrica, mínimamente, tiene que tener uno un conocimiento de defensa personal; de decir, bueno, por dónde me escapo en caso de que te tiroteen la fábrica." ${ }^{434}$

Este testimonio nos lleva a reflexionar una vez más sobre el lugar que ocupan las mujeres en los relatos sobre la Resistencia peronista. Las mujeres siempre son referidas desarrollando tareas de apoyo, pero qué sucedía cuando eran las mujeres las que protagonizaban los hechos. A todas las decisiones y recaudos que debían contemplarse a la hora de adoptar una decisión como podía ser la toma de una fábrica, se les sumaba el problema de qué hacer con sus hijos y si involucrarlos o no en acciones que estaban demasiado expuestas a ser reprimidas. Ya en el primer capítulo observamos una situación similar a través de un relato que refiere a la participación de una niña en las acciones de simulación desplegadas para ayudar a escapar a un prófugo. En síntesis, lo que estos ejemplos demuestran es que, pese a que las acciones de muchas mujeres en la Resistencia estuvieron desarrolladas en los espacios cotidianos, se sustentaron en relaciones familiares o barriales o simularon situaciones cotidianas para pasar desapercibidas ante las fuerzas represivas, lo cierto es que muchas de ellas implicaron exponerse a situaciones de riesgo o conllevaron contradicciones entre las obligaciones del mundo doméstico y las exigidas por la militancia; que quedan invisibilizadas bajo el apelativo de tías con el que se designa la participación de esas mujeres, a la vez que desmienten la idea de que dicha participación se haya dado como una prolongación de sus roles domésticos.

Sólo uno de nuestros entrevistados varones narró las dificultades de compatibilizar la militancia con las obligaciones laborales y el cuidado de los niños, ya que quien trabajaba fuera del hogar era su esposa, que se dedicaba a la docencia; mientras que él desempeñaba su oficio de sastre desde su casa. Sin embargo, quedarse en la casa respondía a las características de su trabajo y no a una situación impuesta por la militancia. ${ }^{435}$ En Pareja, sexualidad y familia en los años sesenta, Isabella Cosse (2010) reproduce una viñeta de la revista Satiricón de 1974, que muestra una situación familiar en la que el hombre está limpiando la casa y cuidando a su hijo, mientras la mujer vuelve de una reunión política. Para el período que estamos analizando, difícilmente encontremos una situación como la

\footnotetext{
${ }^{434}$ Mura, Elsa. Entrevista de la autora. El Palomar, 27 de mayo de 2014.

${ }^{435}$ Fiorenza, Nello. Entrevista de la autora. La Plata, 15 de marzo de 2014.
} 
que narra la historieta presentada por Cosse. En nuestras entrevistas, encontramos situaciones donde sólo uno de los cónyuges militaba, pero éste siempre era el varón; mientras que en los casos inversos, tendían a resolverse con una separación. En el relato de Lala Marín se evidencia cómo su compromiso político tuvo más pesó a la hora de decidir si abandonaba la militancia o si se adaptaba a los requerimientos de su esposo, que no era peronista, y que le cuestionaba su participación política y sus largas ausencias de la casa. ${ }^{436}$ En este caso primó el compromiso político, decisión que llevó a la ruptura de la pareja:

Lala: Teníamos un círculo de mujeres, pero cada cual tenía su pareja, su amor su marido. Y yo para ellas fui un poco rebelde.

E: ¿Por?

No se metían a decir "vivo este amor y dejo este otro". Yo, al peronismo no lo dejaba por ningún amor. Y mi marido era contra y, un día le dije: -"Mirá, o te vas y no me hablás de Perón más mal o te voy a denunciar como que sos un gran conspirador". -Agarró, empacó y se fue [...]

E: ¿Cómo hizo para vivir con un contra?

Lala: [...] porque él no me aguantaba a mí con mi peronismo. Yo me iba a la Plaza de Mayo. Había una reunión, yo me iba. No se puede aguantar a una mujer así. Como los hijos míos me los cuidaba mi hermana, mis hermanas, mi padre. Yo me iba, pero mis hijos estaban asegurados. Era también por eso que yo tenía la posibilidad de estar en una lucha permanente. Porque otras madres que tienen que estar haciéndoles la comida y todo eso. Si bien yo los atendía a mis hijos, yo tenía las madres sustitutas que eran hermanas mías. ${ }^{437}$

Este testimonio nos muestra que la relación entre la vida familiar y política se expresaba con altos niveles de tensión; sobre todo cuando el compromiso político era demasiado intenso pero no funcionaba como un proyecto común de la pareja. En general, el modelo que prevalece en los relatos es el de parejas que militaban de forma conjunta pero en las cuales el varón adquiría mayor protagonismo y compromiso. Cuando emergen situaciones que reflejan lo contrario, es decir, que la mujer adquiere mayor protagonismo y el hombre asume los roles que se suponen propios del género femenino, las mismas son relatadas como anécdotas que destacan su carácter excepcional:

\footnotetext{
${ }^{436}$ Relatos del período anterior también muestran ese peso de lo político como en el caso de Beba Gil. Gil, Clementina (2004). Memorias. Clementina F. Gil (Beba). Instituto Nacional de Investigaciones Históricas Eva Perón, Buenos Aires.

${ }^{437}$ García Marín, Hortensia. Entrevista realizada por Julieta Sahade. Buenos Aires, 27 de julio de 2010. Archivo Oral. Comisión Provincial por la Memoria.
} 
María: "La Naty con la panza así en la CGT"

Chiche: "Naty, sí. Naty, el marido sentado en la escalera, pobre santo, y un hijito de cada lado dormido, y ella peleando..."

María: "por Perón, por la vuelta de Perón."

Chiche: "¡Sí! Peleando, a ver. Pero yo, viste, la tengo..."

Naty: "Es verdad, yo peleaba adentro y mi marido con los chicos"

Chiche: "con los dos chicos dormidos, ¿viste?"438

Este relato evidencia que las mujeres, pese a que no rompieron completamente con los roles que se esperaba de ellas, son conscientes de que la militancia muchas veces las ponía en situaciones que las llevaban a transgredir esos roles. Además, nos revela una vez más, la imposibilidad de poder escindir su compromiso político de sus obligaciones domésticas, dando cuenta de que la participación política no era una extensión de los roles que debían cumplir en el espacio domésticos, sino que podía entrar en contradicción con los mismos. Difícilmente en los relatos masculinos encontremos una imagen semejante, porque no tenía nada de excepcional que las mujeres se ocuparan de los niños mientras ellos se dedicaban a la política. Algunos testimonios de varones presentes en publicaciones hacen referencia a las esposas, pero el lugar en el que las colocan es el de colaboradoras y sostenedoras de una actividad política llevada a cabo por ellos; por ejemplo, haciéndose cargo del hogar cuando sus esposos eran detenidos o estaban prófugos:

“[...] En las épocas jodidas, cuando tenía que rajarme, mi mujer se quedaba con los pibes y bancaba la casa. Además, las mujeres vivían la incertidumbre de los allanamientos, de no saber dónde estaba el compañero y, además, tenían que arreglárselas como pudieran, pedirle a uno y a otro, ir a los sindicatos, sin lo cual muchos compañeros no hubiesen podido llevar adelante su lucha [...]"439

En otros casos, ni siquiera están presentes esas referencias y los relatos sobre la militancia se suceden como si estuvieran totalmente escindidos del mundo familiar. Ahora bien, el lugar que el último testimoniante citado otorga a su pareja y a las esposas de los militantes de la Resistencia en general, es un lugar subordinado. Pero qué sucedía cuando eran las mujeres las protagonistas, las que estaban detenidas o prófugas o las que tenían que ser escondidas y protegidas. La trayectoria de Nora Lagos, una de las mujeres cuya

\footnotetext{
${ }^{438}$ Di Marco, Chiche; Martínez, María; Rivas Natividad y Cánepa, Oscar. Entrevista de la autora, Rosario, 16 de octubre de 2012 .

${ }^{439}$ Testimonio de Roberto Miguélez en Garulli [et. al.] (2000)
} 
actividad analizamos en el capítulo III al hacer referencia a la prensa de la Resistencia peronista, nos devuelve una imagen de cómo el involucramiento en la militancia podía llevar a situaciones de persecución política que arrastraban a la familia y que llevaban a las mujeres a desempeñar roles de género que transgredían las modelizaciones normativas. Recordemos, esta militante estuvo detenida en dos oportunidades por el desarrollo de su labor como periodista, debido a que desde las páginas de sus periódicos, La Argentina y Soberanía se atacaba al gobierno de la Revolución Libertadora. Primero, estuvo presa en el Correccional de Mujeres de Humberto Primo en Buenos Aires, en 1955 y luego, en 1957, en una comisaría en San Justo de la que se fugó rumbo a Paraguay, en un exilio que compartió junto con su pareja, René Bertelli, y sus hijas, fruto de la relación anterior con el guionista cinematográfico Hugo Mac Dougall. Uno de los relatos que nos ha llegado sobre su participación en la Resistencia peronista es un capítulo del libro Argentinos de raza, del escritor Ovidio Lagos, sobrino segundo de Nora. Dos ideas centrales recorren el capítulo. La falta de racionalidad de la decisión de Nora de adherir al peronismo, lo que es interpretado como una traición a su clase social, sobre todo por su compromiso en una etapa desfavorable para este movimiento como fue la de la Resistencia, y la idea de una transgresión a un modelo de mujer como madre y esposa:

Y es aquí cuando toma una decisión poco comprensible, que hace difícil calificar su rol de madre. Decide que la huida al Paraguay — donde buscarían asilo político - debía hacerla con sus dos hijas. Si se hubiera tratado de una guerra, habría sido aceptable. Pero someter a dos niñas que aún no habían cumplido los diez años a semejante epopeya hace difícil precisar el límite entre una madre que, malgré elle même [a pesar de ella misma], se niega a separarse de sus hijas y una progenitora desvariada. ${ }^{440}$

Ovidio Lagos narra episodios del período de la Resistencia que incluyen los momentos de prisión, la fuga y el exilio de Nora Lagos, en un tono de desaprobación que interpreta dichas acciones como transgresiones a un mandato maternal. También, menciona las diferentes parejas que Nora tuvo en distintas etapas de su vida y las presenta como la transgresión al rol de mujer en tanto que esposa. Por su parte, las hijas de Nora cuentan las dificultades que implicó vivir una vida de militancia, recordando, por ejemplo, que debían comer arroz y fideos todos los días o que tuvieron problemas para que las tomaran en una

${ }^{440}$ Lagos, Ovidio (2003). "China Moon. Nora Lagos”. En Argentinos de Raza. Buenos Aires, Emecé, p. 187. 
escuela, por el rechazo que generaba en las autoridades religiosas del colegio el compromiso político de su madre. Sin embargo, ellas valoran su decisión de llevarlas con ellas al exilio como un aspecto positivo de su personalidad: "nosotras íbamos a todos lados, la verdad, que no nos abandonó nunca". ${ }^{441}$ A la vez que nos invitan a reflexionar sobre la existencia de diferentes perspectivas para evaluar o definir la maternidad: “...no lo analices con los parámetros con que se analiza cualquier vida" o "ahí hay que marcar lo que es la vida del militante". Ello nos lleva a pensar en la articulación entre las dimensiones pública y privada y en la relación entre militancia y vida cotidiana. Norbert Lechner (1990) propone desnaturalizar la idea de lo cotidiano, reflexionar sobre su carácter histórico y sobre la movilidad de los límites entre lo cotidiano y lo no cotidiano, a la vez que se pregunta sobre los criterios de normalidad que son definidos a partir de la cotidianeidad. Si contemplamos la historia de Nora Lagos, cabría preguntarse si lo que aparece como anormal a los ojos del escritor Ovidio Lagos, en realidad no forma parte de las vicisitudes y contingencias que suelen atravesar la vida de cualquier militante en un período de interdicciones políticas. Ahora bien, esto también nos advierte sobre las implicancias de género que atraviesan la militancia y las interpretaciones sobre la misma. Difícilmente encontremos juicios sobre las cualidades paternales y conyugales de los militantes varones o que a dichos militantes se les pregunte sobre cómo compatibilizaban su actividad política con su vida privada. En los relatos femeninos siempre emergen estas referencias al mundo familiar, y las mismas suelen surgir incluso de manera espontánea, sin ser generadas como respuestas a preguntas que indaguen esos temas. En los relatos masculinos, estos problemas no aparecen o si lo hacen, suele estar la referencia a una mujer capaz de hacerse cargo del mundo familiar y de sostener los costos que trae aparejada la militancia de su cónyuge.

Volviendo al ejemplo de Nora Lagos, podemos decir que su participación en la Resistencia la llevó a desplegar acciones que implicaban un modo de ejercer la maternidad que no era el que se esperaba para las mujeres de la época; una maternidad desarrollada puertas adentro del hogar. Ahora bien, tampoco se adaptaba al modelo de esposa socialmente aceptado. Otros relatos transmiten experiencias de participación conjunta de la pareja donde se reproducen modelos de conyugalidad más tradicionales. Sin embargo, los mismos no están libres de fisuras. Veamos el siguiente ejemplo:

${ }^{441}$ Mascías, Norah; Mascías, Patricia; De Sánctis, Oscar. Entrevista de la autora. Rosario, 1 de septiembre de 2011. 
Entonces él me dice a mí: -"Paloma”- porque él me decía Paloma a mí, "Mañana no salgas a baldear" - dice -"Esperá y tomamos mate juntos, te tengo que contar una cosa". -"Claro" -dije yo. [...] Me dice: - "¡Mirá vos lo que el negro Britos le dijo a un compañero, que tiene que ir a la [Policía] Federal a decir que él no es peronista!” -“¡Ay!” -le hago yo -“¿Pero cómo?”-“Sí, el tipo no sabe qué hacer" -dice. -"Yo le dije que no vaya". -"¡Pero claro!" -le digo "¡Cómo si es peronista va a ir a hacer una declaración que él no tiene nada que ver!” -Y dice -“¿Vos qué harías si fueses la mujer?”. Le digo -“¡No, yo me voy a limpiar casas; pero llega a decir eso y lo mato!” -“Ah bueno, ¡Venga Paloma, deme un beso! Ese soy yo", 442

Esta anécdota revela una relación familiar acorde con el modelo de la domesticidad al que hicimos referencia en el apartado anterior; el varón proveedor y la mujer procreadora y cuidadora de los hijos (Nari, 2004, Cosse, 2010). Muestra también la idea de excepcionalidad que solía rodear al trabajo femenino en los discursos sociales de la época, una idea que desde hacía varios años venía siendo cuestionada por el ingreso masivo de las mujeres al mundo laboral, pero que todavía a mediados del siglo XX continuaba ejerciendo su influencia. Graciela Queirolo (2010) ha llamado la atención sobre esta cuestión para la primera mitad del siglo XX, en que el trabajo de las mujeres estaba justificado sólo ante situaciones de necesidad generadas por viudez, soltería, separación, orfandad o ingresos insuficientes del marido. ${ }^{443}$ Ahora bien, dónde radicaba la condición de excepcionalidad en el ejemplo citado. Precisamente, en razones políticas. La posibilidad de que esta mujer trabajara fuera del hogar fue contemplada ante la pérdida de trabajo por parte de su esposo por motivos políticos; hecho que no se concretó, porque él consiguió un nuevo empleo prontamente. El proyecto político que ambos compartían podía justificar el trabajo de la mujer fuera del hogar y además, que esa mujer estuviera largas horas fuera de su casa abocada a las tareas de la militancia. De esta manera, la política introducía fisuras en el modelo de la domesticidad legitimando el acceso de las mujeres al espacio público. Un ejemplo similar lo encontramos en el relato de Esther Serruya. Aquí, la situación es más llamativa aún, porque se trata de una pareja en la que los dos tenían un título universitario

${ }^{442}$ Di Marco, Chiche. Entrevista de la autora. Rosario, 11 de noviembre de 2014.

${ }^{443}$ Queirolo (2010) menciona también las concepciones de transitoriedad y de complementariedad que reforzaron el principio de excepcionalidad. Con la primera, se refiere al hecho de que las mujeres podían realizar actividades asalariadas por un tiempo limitado, hasta que pasara ese momento de excepción que había generado la necesidad de salir a trabajar. Y con la segunda remite a la idea de que el salario femenino era concebido como un suplemento del presupuesto familiar aportado por el varón; una noción que contribuyó a justificar los salarios inferiores de las mujeres en el mundo laboral. 
en Química y se habían conocido siendo estudiantes y trabajadores de la industria del calzado. Sin embargo, luego de recibirse, sólo él se dedicó a trabajar en la industria química continuando como dirigente sindical, mientras que una vez casados se opuso a que ella trabajara. Por otro lado, cabe desatacar que Esther encontró en la política un lugar donde se sentía mucho más a gusto que en el ejercicio de su carrera. Su actividad política, que fue una labor de tiempo completo, no sólo no fue cuestionada en el ámbito de la pareja sino, que fue impulsada por su esposo. Ella recuerda que él fue quien la incentivó para animarse a hablar en público por primera vez y quien la alentó a aceptar la convocatoria de Eva Perón para integrarse a las filas del Partido Peronista Femenino. ${ }^{444}$

Ahora bien, la militancia compartida no llevó a una distribución de las tareas domésticas en el ámbito hogareño. Pese a que muchas veces la militancia se desarrolló en familia, no estuvo exenta de crear una sobrecarga para las obligaciones que las mujeres ya tenían en sus hogares; por lo menos para aquellas mujeres que consideraron que su participación política no las eximía de esas obligaciones y que quisieron cumplir con las exigencias que se les presentaban en los diferentes ámbitos en los que se desarrollaba su vida:

E: $[\ldots]$ ¿Cómo hacían para poder militar y para poder subsistir?

María: las dos cosas

E: ¿Cómo se hacía?

Chiche: Levantándose súper temprano. Yo siempre digo, la militancia es un ejemplo, y me digo ¿para qué?

María: Yo cosía para afuera

Chiche: Si no, no sirve. Si yo me iba a militar, dejaba mi casa sucia, mi hija abandonada, mi esposo sucio, no es buena la militancia. La militancia con el ejemplo. Ser honesto, tener tu casa en condiciones, tener tu hija, pobrecita, que yo la llevaba, nos quedábamos en la básica hasta las dos de la mañana y a las seis de la mañana levantarse para ir a la escuela, viste. ${ }^{445}$

Chiche: Yo me levantaba, me limpiaba toda la casa y recién me iba. ${ }^{446}$

En otros casos, la realización de las tareas domésticas era más equitativa. El testimonio de Olga Hammar, obtenido de su autobiografia, ${ }^{447}$ es muy ilustrativo respecto de esas

\footnotetext{
${ }^{444}$ Serruya, Esther. Entrevista de la autora. Castelar, 1 de noviembre de 2012.

${ }^{445}$ Di Marco, Chiche; Martínez, María; Rivas Natividad y Cánepa, Oscar. Entrevista de la autora, Rosario, 16 de octubre de 2012.

${ }^{446}$ Di Marco, Chiche. Entrevista de la autora. Rosario, 11 de noviembre de 2014.

${ }^{447}$ Hammar, Olga (2009). Tozudamente. Buenos Aires, Intermedia.
} 
relaciones. Pese a tener la misma edad de muchas de las mujeres cuyas experiencias estamos analizando, no se reconoce como parte de la misma generación, ya que su ingreso a la política se produjo un poco más tarde, a comienzos de la década del 1960 vinculada a sectores de la intelectualidad y del peronismo revolucionario. Sin embargo, aporta información sobre las relaciones conyugales de las parejas militantes de la época. Señala que con su pareja, Jorge Hammar, compartían las tareas domésticas y la crianza de su hijo. Sin embargo, esa equidad en las tareas domésticas era una excepción y era cuestionada por otros militantes. También, sostiene que el proyecto político que sostenían ella y su pareja estaba tan incorporado a la vida cotidiana que hizo que el nacimiento de su hijo no los llevara a la separación, como solía ocurrir con otras parejas de militantes. Pero a la vez, menciona varios episodios en donde la militancia les creaba problemas con la vida cotidiana y viceversa, sobre todo cuando relata el viaje a China de su pareja durante un año en el cual estuvieron casi incomunicados mientras que ella se hizo cargo de construir una vivienda y de sostener el hogar, cuestión que le provocaba un gran malestar.

Las experiencias de vida que hemos analizado son muy variadas y reflejan comportamientos disímiles en cuanto a la manera en que las mujeres resolvieron las tensiones entre las exigencias que les demandaba el mundo de la política y las obligaciones domésticas que estaban asociadas a su género. La política no fue fácil de complementar con el mandato de la maternidad. Las mujeres resolvieron esa incompatibilidad adoptando modos de maternidad poco ortodoxos que consistieron en que la misma se ejerciera en el espacio público y que implicaron un involucramiento de los niños en la militancia, con los riesgos que ello podía traer aparejado; o directamente delegaron esa responsabilidad en familiares o decidieron no asumir ese mandato negándose a tener hijos. Las entrevistas y otras fuentes también dan cuenta de la pérdida de embarazos provocados por el ritmo de vida acelerado y arriesgado que atravesaba a la militancia.

Respecto de las relaciones de pareja, observamos casos de mujeres que quebraron los roles tradicionales al otorgarle primacía a su compromiso político por sobre las obligaciones conyugales, cuando el proyecto político no era compartido con el marido. Pero hubo otras situaciones donde la militancia se desarrolló de manera conjunta. Por lo general, se trató casos donde el varón tenía un reconocimiento público mayor que el de la mujer. En estos casos, los integrantes varones de la pareja incentivaron la participación política de las mujeres y el compromiso político se convirtió en la clave para acceder al espacio público. Sin embargo, esas posturas favorables hacia la militancia no se tradujeron en actitudes 
similares ante la posibilidad de que las mujeres trabajaran. Con ello, no queremos decir que entre las mujeres de la Resistencia predominaran las amas de casa, pues de hecho muchas se lanzaron a la militancia a partir de sus lugares de trabajo; aunque por el carácter clandestino que adoptó la militancia resulta difícil hacer estimaciones sobre el perfil social predominante entre estas mujeres. Sí nos interesa resaltar esta actitud paradójica que acepta por parte de los varones un tipo de participación en la vida pública asociado a la política pero no al trabajo; un resabio del modelo de la domesticidad que se veía amenazado en la condición de proveedor que según el modelo debía adoptar el hombre. No es casual que los casos donde observamos este tipo de actitudes estuvieran constituidos por familias donde el hombre era sindicalista. Silvana Palermo (2009), en un trabajo sobre las relaciones de género que atraviesan al mundo sindical, explica cómo el modelo de la domesticidad también se extendió a los sectores obreros y cómo la construcción de relaciones de solidaridad en esos espacios estuvo sustentada en valores como la respetabilidad y honorabilidad masculinas asociadas a los deberes de proveedores en el hogar. La imposibilidad de cumplir con esas obligaciones en los períodos de crisis fue experimentada como una deshonra y una amenaza a su identidad sexual, que articularon en las resistencias a sus superiores. ${ }^{448}$ En el apartado siguiente retomaremos esta cuestión.

Las exigencias que la política le demandaba a las mujeres no llevaron a una distribución más equitativa de las tareas domésticas. Cuando esto último sucedió fue contemplado como una excepción. Sin embargo, no faltaron casos de mujeres que con su actividad política transgredieron los lugares de subordinación que les asignaban las normativas de género, desarrollando actitudes con mayor protagonismo que las de sus parejas. Estos casos no encajan en el lugar subordinado en que los relatos masculinos sitúan a las mujeres y cuando emergen en los relatos de las propias mujeres, lo hacen bajo un formato humorístico que revela el hecho de que ellas son conscientes de que al desplegar esas actitudes estaban rompiendo con los roles que se consideraban normales para su género.

Sin lugar a dudas, la condición de madres y esposas de muchas de esas mujeres, definió una forma de militar, ya que en las decisiones que debieron tomar en su militancia estaban incluidos esos condicionamientos del mundo doméstico. Y también la vida familiar

\footnotetext{
${ }^{448}$ Si bien el trabajo de Palermo hace referencia particularmente al sindicato ferroviario en las primeras décadas del siglo XX, consideramos que las actitudes que se observan en los testimonios analizados pueden ser interpretadas bajo esa interpretación.
} 
que llevaron se vio afectada por su compromiso político. De esta manera, sus relatos son muy diferentes a los de los militantes varones donde la política parece transcurrir despegada de ese mundo doméstico, como si se tratara de una esfera independiente. Y en todo caso, si la política les creaba contradicciones era respecto de su rol como proveedores y sostenedores económicos del hogar pero no como padres que debían hacerse cargo del cuidado directo de los hijos y sopesar si se involucraban o no en una acción en función de esa responsabilidad.

En el apartado siguiente, analizaremos en qué medida el hecho de que la Resistencia haya sido encarada en gran parte por sujetos provenientes del sindicalismo, un espacio de predominio casi exclusivamente masculino, contribuyó a que las mujeres no fueran objeto de atención por los relatos tanto académicos como políticos sobre la dicho proceso histórico y cómo hicieron ellas para moverse en un espacio caracterizado por relaciones de género que las excluían.

\section{Mujeres y sindicalismo}

Así como hemos procurado desnaturalizar algunos estereotipos que atraviesan las imágenes sobre la participación de las mujeres en la Resistencia peronista, consideramos que también es necesario reflexionar sobre el tratamiento que la historia académica le ha dado a dicho proceso. Joan Scott (2009) ha argumentado acerca de la propia responsabilidad de la disciplina histórica en la construcción de estereotipos de género. Esta historia ha versado sobre un sujeto masculino, universal y abstracto. La incorporación de las mujeres a la historia ha tendido a reforzar la universalidad de dicho sujeto, por contraste con la particularidad femenina, ya que las mujeres no han encajado en esa representación. Frente a ello, Scott propone contemplar la particularidad de los propios sujetos masculinos y de todos los sujetos históricos. La mayoría de los relatos académicos sobre la Resistencia peronista han oscilado entre, por un lado, el uso del universal masculino, haciendo extensiva a las mujeres las actividades desarrolladas por los militantes varones sin indagar cuáles fueron las acciones que realmente llevaron a cabo, y por otro, la especificación de que se centran en sujetos masculinos, haciendo referencia a las mujeres en casos particulares y de manera accesoria. Suelen tomarse como dadas las imágenes que tradicionalmente se han atribuido a las mujeres en ese proceso sin mediar detrás una investigación empírica. 
Durante los años que siguieron al derrocamiento del peronismo, el sindicalismo se convirtió en el actor con mayor peso en la interna peronista. Marcó su agenda política y gran parte de la Resistencia estuvo constituida por sujetos provenientes de sus filas. Las mujeres de origen obrero y ligadas a las estructuras sindicales también tuvieron su participación en dicho proceso. Sin embargo, la intervención femenina en el sindicalismo durante el período abordado es un tema que hasta el momento ha sido poco trabajado por la historiografía. Destacan algunos trabajos que no se centran específicamente en el período analizado, aunque lo comprenden (Lobato, 2001, 2007, James, 2004) o que analizan esas participaciones en otros períodos históricos (D’Antonio, 2000), mientras que otros se centran en el estudio de las masculinidades asociadas a esos ámbitos (Palermo, 2009; Silva, 2004; Baron, 2006; French y James, 1997), pero no se registran investigaciones sobre la articulación de la militancia femenina en los espacios sindicales en relación a la Resistencia peronista. Las causas posiblemente radiquen en la dificultad de hallar registros de esa participación en las fuentes, debido a que representaron una abrumadora minoría respecto de la afiliación en relación a los hombres y a que les estuvo vedado el acceso a lugares de dirigencia sindical. Santiago Senén González (2012) ofrece algunas cifras sobre la participación femenina en el Congreso Normalizador de la CGT que tuvo lugar en agosto de 1957; un hecho emblemático de la Resistencia ya que de él saldría la Intersindical, símbolo de la unión obrera frente a las intervenciones desplegadas por el gobierno de la Revolución Libertadora, de la que luego se desprenderían las 62 Organizaciones. Sobre un total de 700 delegados varones, sólo hubo 20 mujeres. FONIVA, el gremio del vestido fue la más numerosa y contó con 13 delegadas, Empleados de Comercio con 2 y lo mismo, Municipales. El sindicato del Vidrio, Edificios de Rentas y Particulares y FOETRA (Telefónicos), sólo presentaron una delegada cada uno. El hecho de que el sector sindical haya tenido tanta gravitación en la Resistencia peronista y que sea un espacio tan masculinizado, no sólo por la preponderancia masculina en términos numéricos sino también por las relaciones que lo atraviesan, sin lugar a dudas ha sido un factor que ha contribuido a ese silenciamiento de la participación femenina en los relatos, sobre la Resistencia; tanto los generados en el seno de la militancia como en la academia.

En general, los sujetos que pueblan las páginas de los libros sobre la Resistencia peronista son masculinos. Como hemos señalado en la introducción de esta tesis, se ha desarrollado un debate sobre el carácter clasista de dichos sujetos, pero no sobre su condición de género. Aquí hay que señalar que ni la bibliografía que aborda la Resistencia a 
partir de sujetos vinculados a los espacios sindicales, ni los trabajos que se enfocan en otros actores, se han interesado por las intervenciones femeninas. Sin embargo, cabe mencionar que Alejandro Schneider (2005), en su libro Los Compañeros, no pasa por alto la particularidad de los sujetos masculinos que analiza. Desarrolla un análisis pormenorizado de los espacios cotidianos de la clase obrera que sirvieron como sustento de las acciones de resistencia y señala un límite en la solidaridad de esa clase en términos de género, ya que vislumbra que se trataba de una solidaridad masculina respecto de la cual las mujeres sufrían cierto nivel de exclusión, porque si participaban en los espacios de socialización obrera lo hacían siempre en un lugar secundario en tanto que esposas y como acompañantes de sus maridos trabajadores. Por ejemplo, las actividades de esparcimiento que practicaban los obreros durante su tiempo libre, como las celebraciones propias de cada gremio, despedidas de soltero y comidas de fin de año, no incluían a las mujeres y, si lo hacían, éstas participaban en menor medida que los varones, como acompañantes y sólo si asistían otras mujeres, o si los almuerzos y cenas eran de carácter familiar y se realizaban en casa de algún obrero. El término "compañero", que da título a su libro, no era extensivo al género femenino. Si bien los obreros solían referirse a sus esposas como "mi compañera", este término no tenía el mismo significado que cuando se aplicaba en relación a otro obrero, porque "compañero", aunque podía hacerse extensivo al sindicato o a la clase trabajadora en su totalidad, en general hacía referencia a aquella persona, de género masculino, que trabajaba al lado de uno. La "compañera", en cambio, era la esposa, y se decía de ella que era "una buena compañera" cuando "...llevaba adelante el hogar y apoyaba al marido cuando este tenía dificultades en el trabajo" (Schneider, 2005, p. 373-375). Si bien el autor sostiene que en sus entrevistas realizadas a obreros, varios hicieron referencia a la participación de las mujeres en los conflictos, también señala la diferencia que solía establecerse entre las esposas de los obreros y otras mujeres: "Si bien existe en el obrero una cultura bastante machista [...], había una consideración favorable hacia su cónyuge como compañera; por ende, en las fábricas se diferenciaba entre las esposas de los compañeros y otras mujeres. Las primeras eran tratadas con respeto, hasta el punto de no utilizar un lenguaje soez en su presencia" (Schneider, 2005, p. 375). En definitiva, si bien el autor reconoce la particularidad de los sujetos que investiga en términos de género, la imagen que nos devuelve es la de un universo masculino donde predominan relaciones de solidaridad también masculinas. En este apartado procuraremos avanzar sobre algunas representaciones construidas sobre la militancia sindical durante el período analizado y las 
formas de inserción de las mujeres en esos espacios, a través de relatos orales y algunos documentos.

La interpretación del sindicalismo como un espacio predominantemente masculino emerge en muchos relatos. En los capítulos segundo y tercero analizamos la incidencia que sobre los intentos de reorganización partidaria femeninos tuvo el hecho de que durante el período en estudio dicho sector haya sido el más poderoso en la interna peronista. Por un lado, hubo críticas a ese sector que atentó contra el mantenimiento de la autonomía de la Rama Femenina y contra el acceso de las mujeres a los niveles de conducción partidaria. Por otro, dimos cuenta de algunas relaciones de solidaridad entre ambas ramas, ya que los locales sindicales sirvieron como espacios de reunión o como fuentes de recursos que se canalizaban a través de donaciones, en un contexto en que las estructuras sindicales contaban con importantes fondos económicos, a diferencia de las partidarias, y con la habilitación de sus locales para funcionar de manera legal. En las críticas lanzadas por algunas mujeres a esa injerencia por parte de la rama sindical sobre la rama partidaria femenina, emergía la idea de un avasallamiento masculino sobre un área que no les correspondía por su condición de género. Si bien las estructuras partidarias del peronismo estaban definidas en función del género, no ocurría lo mismo con la rama sindical. Sin embargo, se daba por sentado que era una rama inherentemente masculina; de hecho no había mujeres en la conducción y como hemos señalado más arriba, la afiliación y el acceso a los cargos representativos era muy desigual en términos de género. En este apartado, nos interesa señalar cómo esa masculinidad que definía al sindicalismo se hizo sentir en las relaciones cotidianas.

La figura del sindicalista ocupa un lugar simbólico importante en los relatos de algunas mujeres y aparece ligada a una figura masculina con la que se vinculan a través de relaciones de parentesco. En el caso Chiche, Naty y María, la CGT de Rosario es mencionada en sus relatos como una de las entidades políticas de referencia, con un nivel más abarcativo que las unidades básicas barriales donde cada una de ellas desplegaba su militancia cotidiana. Era el lugar que les permitía estrechar relaciones con otros peronistas por fuera de la unidad básica y donde podían tener noticias de las decisiones tomadas en relación al peronismo en otros lugares, como Buenos Aires, o donde recibían los mensajes llegados desde Madrid. El sindicalismo es definido como un espacio masculino; las entrevistadas hacen referencia a la buena relación que mantuvieron con "los muchachos sindicalistas", una relación que ya había comenzado durante la época de los primeros 
gobiernos peronistas pero que se hizo más fuerte durante la Resistencia, cuando las unidades básicas en las cuales militaban se cerraron o comenzaron a funcionar de manera intermitente. Esa relación con el sindicalismo queda ejemplificada a través de anécdotas que remiten al plano personal y familiar:

María: "[...] nosotros hemos trabajado mucho con los muchachos sindicalistas." $[\ldots]$

Chiche: "Claro, yo me conozco también con Rodolfo, con mi marido [...] Él por la parte gremial"

E: "Sí"

Chiche: "Yo, en el barrio, en las pintadas [...]"

Naty: "Y en los revuelos se conocieron"

(Risas)

$[\ldots]$

Chiche: "Mirá, yo más me pongo de novia con él, el 7 de mayo que voy al Cristo a llevar las flores para Evita. Por ahí andan las fotos. Y bueno, ya me pongo de novia. Por eso, nosotras siempre hemos estado al lado de la parte gremial. Porque pensábamos que la parte gremial defendía al obrero, al pobre, al que necesita. Es completamente distinto a la parte política. Ese es mi pensamiento."

Naty: "Y nosotras casi todas actuábamos igual. ¡Sí! Y con los políticos poco.”

Chiche: "Claro"

Naty: "Pero con los gremiales, sí."

Chiche: "Bien decía Evita: 'Un gremialista para el país. Doscientos políticos o mil políticos juntos, no lo pueden parar, pero un gremio te para el país",449

Este relato refleja el repudio a "los políticos", esto es, a la dirigencia partidaria, que primó durante los años de la Resistencia peronista, por considerar que esos políticos habían claudicado luego del golpe de Estado, a diferencia de los sindicalistas que se habían mantenido en actitudes combativas. En el capítulo II hicimos referencia a cómo dicha diferencia entre sindicalistas y políticos remite a una vieja controversia que data de los orígenes del peronismo, a las diputas entre radicales renovadores y laboristas, y sobre el carácter discursivo de la misma, puesto que muchas de las personas que criticaban a los políticos también hacían actividad partidaria, en sus unidades básicas, aunque no respondieran a la dirigencia nacional o provincial del $\mathrm{PJ}$; y este es el caso de las testimoniantes, puesto que ellas militaron en unidades básicas barriales. En su relato, la rama política masculina, entiéndase los altos dirigentes del partido, representan la 
contracara de los sindicalistas, que se constituyen en un ejemplo de militancia. Pero lo que nos interesa destacar aquí es la emergencia, en este relato, de la figura del sindicalista como fuente de autoridad. Esta imagen casi siempre es masculina: un novio, un marido, un padre, pero además es quien parece tener una idea clara sobre la política. Una situación similar encontramos en el relato de Esther Serruya. En el PPF, la figura de referencia para Esther es Evita, pero quien la indujo a responder a la convocatoria de la primera dama para conformar las estructuras de dicha organización fue su pareja, que además fue gravitante en toda su actividad política, y sobre todo en la tarea que juntos desarrollaron en la unidad básica que fundaron en su domicilio particular cuando se casaron. Por otro lado, reconoce que los sindicalistas fueron quienes le ayudaron, facilitándole recursos, cuando con las mujeres de la Rama Femenina siguieron haciendo obra social durante los años de la proscripción.

Estos relatos nos devuelven un panorama de la participación de mujeres que se insertaron en la política en un contexto donde el sindicalismo era la fuerza preponderante. Aunque sus trayectorias de militancia exceden los lugares tradicionales en que las ubican los relatos sobre la Resistencia, como realizadoras de tareas de apoyo y protección, se observa cierta jerarquía en la trama de relaciones en la que se insertaron para desarrollar esas acciones de resistencia. Son mujeres que lograron salir de los espacios domésticos para volcarse al mundo de la política, pero ese espacio de la política estaba atravesado por relaciones sociales jerárquicas en las que los sindicalistas ocuparon lugares privilegiados; y esos sindicalistas eran varones. Su conocimiento de la política y la red de relaciones más amplia a la que tenían acceso, los colocó en ese lugar. Ahora bien, qué sucedía cuando eran las propias mujeres las que se involucraban en el mundo sindical.

El testimonio de Elsa Mura, la militante sindical antes mencionada, nos devuelve un panorama sobre ese tipo de militancia:

... No ocupábamos los palcos, digamos ¿no? Era toda esa tarea minuciosa que se hacía de darle seguridad al que venía de afuera y al que estaba acá, por ejemplo; participar en las huelgas y en las asambleas que jamás nos daban la palabra para que habláramos las mujeres. Las mujeres éramos, si se quiere, a lo mejor, alguna notita erótica como una gran novedad; nos ignoraban olímpicamente los varones. Meterse en el sindicalismo en esa época significaba ser una machona y después ya era la cosa más atrevida "anda a saber detrás de que tipo anda esta"; nunca era por razones

449 Di Marco, Chiche; Martínez, María; Rivas Natividad y Cánepa, Oscar. Entrevista de la autora, Rosario, 16 de octubre de 2012. 
políticas o sindicales. O sea, como que las mujeres no pensábamos, no decidíamos por nosotras mismas y eran ellos y lo siguen siendo de alguna manera ¿no? ${ }^{450}$

Mura es consciente de las relaciones de género desiguales que atravesaban los espacios sindicales, aunque reconoce que las mismas se extendían también a otros ámbitos de militancia. Aunque sostiene que los sindicalistas no las dejaban "ni asomarse", reconoce la existencia de relaciones horizontales entre las mujeres de la fábrica donde trabajaba, lo que les permitió organizarse sindicalmente. Por una lado, relata las relaciones de solidaridad forjadas entre las mujeres de la fábrica para albergar a los militantes que estaban siendo perseguidos y el conocimiento que cada una de ellas tenía de su barrio y de las casas que podían servir como albergues; un tipo de participación que encaja en el rol de las mujeres desarrollando tareas de apoyo. Sin embargo, de su relato se desprenden imágenes que exceden ese rol y que nos muestran a las mujeres desplegando su capacidad de iniciativa y de organización. Aunque reconoce que esa capacidad de organización no estuvo desde un primer momento, sino que fue el resultado de un proceso de aprendizaje que tuvo varias etapas. Su relato, construido desde un presente en el que la testimoniante se identifica con el feminismo, se articula en relación a esas relaciones de solidaridad femenina, la vez que la confrontación es desplegada contra enemigos que están encarnados en figuras masculinas: las fuerzas policiales, los patrones y la burocracia sindical. En ese proceso de aprendizaje al que hace referencia, el primer antecedente es atribuido a una huelga de brazos caídos que tuvo lugar en 1956. Fue una huelga interna de la fábrica. Aún no estaban organizadas ni afiliadas, y el conflicto se desencadenó a partir de la provocación del patrón.

[...] yo te digo lo que fue la huelga de brazos caídos interna, que no era del sindicato, que era nuestra. Fue porque el dueño de la fábrica -eso fue en el '56el dueño de la fábrica entra y dice, se pasea con las manos para atrás [...] y decía "les voy a sacar todos los -cómo es que se llamaban estos - los plus, y les voy a hacer tomar el tiempo por la pérdida de producción" y nadie contestaba nada. - ¿YY ahora que Perón se fue, de qué se van a agarrar?”-dijo, y ahí, si no lo hubiese dicho tal vez nos la hubiéramos aguantado, pero fue una provocación. Él consideró que nadie iba a hacer nada, nadie contestó ni una palabra. El yanqui se fue, cada una siguió trabajando y yo, en un momento dado me fui al baño, saqué el lápiz de labio y puse en el vidrio, un vidrio enorme en todo el largo del baño, "minga al yanqui” y te juró, ardió la fábrica conmigo ahí adentro. A cada rato venía alguien y me decía -"Anda al baño que te llaman..." -a cada rato iba al baño. Y llegó el capataz y me dice: "“Qué le pasa, tiene diarrea?" -"Si" -"Tiene que ir al médico más tarde" -"Bueno" y me iba a la

${ }^{450}$ Mura, Elsa. Entrevista de la autora. El Palomar, 27 de mayo de 2014. 
reunión, de acá para allá. Hasta que el médico llegara, nosotras salíamos a las 17 y él venía a las 15 [...] teníamos todo el tiempo, todo el día para organizarnos. Y organizamos brazo caído y quite de colaboración $[\ldots]^{451}$

Pese a que el motivo de la huelga implicaba una demanda muy común entre la clase obrera, tendiente a limitar las intenciones de imponer incrementos en el nivel de productividad por parte de la patronal, lo cierto es que se produjo en un marco de relaciones personales, donde había una relación cara a cara con el patrón que estaba encarnado en una figura masculina. Frente ello, Elsa destaca que fue una experiencia sólo de mujeres; que el sindicato no se acercó a apoyarlas y que tampoco el patrón se acercó a negociar. Las negociaciones se hicieron por medio de un compañero que trabajaba en el laboratorio.

El año 1959 señala un punto de inflexión con la toma del Frigorífico Lisandro de La Torre en la que ella y sus compañeras de trabajo tuvieron participación. Cuáles fueron las implicancias de este hecho. Según Elsa, una toma de conciencia en varios planos. Por un lado, un aprendizaje técnico, porque sostiene que las mujeres se foguearon en el uso de la gomera; un instrumento que les permitía poder enfrentarse a la policía montada; y de hecho, la primera vez que estuvo detenida fue por voltear del caballo a un policía. Por otro lado, la participación en la toma del frigorífico las llevó a tomar conciencia de que no podían quedarse con la práctica del acto relámpago, que tenían que pasar a acciones más contundentes y organizadas y que tenían que aglutinarse con otros sectores en lugar de trabajar de manera aislada. En su caso, estrechó relaciones con sectores del peronismo combativo como la Juventud Peronista y el Sindicato de Farmacia. Ese mismo año, tuvo lugar la gran huelga metalúrgica, donde es la primera vez que ellas participaron como mujeres de la fábrica, se organizaron y eligieron delegadas. Y, en 1962, llevaron a cabo la toma de la fábrica. La entrevistada sostiene que tomar una fábrica implicaba un nivel de organización muy importante, y no hubieran podido llevarla a cabo sin el aprendizaje que les otorgó la experiencia acumulada:

[...] en ese mismo '59 viene una gigantesca huelga metalúrgica y ahí sí, nosotras nos habíamos fogueado, las mujeres, con la gomera en el Lisandro de la Torre. En la huelga del 59 fue la organización, fue la primera organización como mujeres de la fábrica que hacemos, porque teníamos necesidades de tener comida, tener, como poder decirte, seguridad, organización, determinar si

${ }^{451}$ Mura, Elsa. Entrevista de la autora. El Palomar, 27 de mayo de 2014. 
hacíamos una asamblea aquí, qué íbamos a hacer. Si se presentaba algún caso teníamos que tener mínimamente una decisión ya tomada y elegir delegados, todos, ¿no? Se eligen cinco mujeres delegadas dentro de las que me cuento y a mí me toca en esa huelga seguridad, entonces era con otra muchacha, nos turnábamos, si una iba a bañarse o a comer a su casa se tenía que quedar una sí o sí de seguridad, y seguridad era la que recorría a ver si venía la policía; si venía la policía con la montada, era un silbato, y si venía con los perros eran dos. Todo era así, y organizarnos para la defensa porque la policía montada nos atropellaba $[\ldots]^{452}$

A diferencia de los relatos anteriores que pertenecían a mujeres que no eran sindicalistas y que se vincularon con el mundo sindical a partir de relaciones de parentesco con militantes sindicales, aquí tenemos la experiencia de una mujer que intervino directamente en el mundo sindical. De su relato se desprende cómo para poder desenvolverse en ese ámbito tuvieron que desarrollar un proceso de aprendizaje. El otro tópico que emerge de su relato es refiere a la discriminación que sufrían las mujeres en los espacios sindicales, por ejemplo ante la imposibilidad de poder tomar la palabra en las asambleas. Recuerda que viajaban a diferentes lugares del país, con muchas ideas para proponer, y que volvían decepcionadas sin haber podido intervenir en las discusiones porque los varones, frente a los que estaban en marcada minoría, no las dejaban hablar. La burocracia sindical se imponía también con todas su fuerzas. De hecho, la toma de fábrica a la que hace referencia, se resolvió con una negociación de la cúpula de la UOM con la patronal que culminó en el despido de las trabajadoras, que a su vez era el motivo por el cual habían decidido hacer la toma, e influyó en un cambio de rubro por parte de Elsa hacia el gremio del vestido, ya que la dirigencia metalúrgica le impedía trabajar en las empresas que estaban bajo su órbita.

Experiencias similares se desprenden del relato de Inés Dihian, una militante del sindicato de Empleados de Comercio que llegaría a ser subsecretaria en la década de 1970, cuando una lista peronista logró ganarle las elecciones al dirigente socialista Armando March que estaba en el sindicato desde la intervención en 1955. Inés también describe el proceso de aprendizaje por el que debió atravesar siendo delegada, puesto al que llegó durante la etapa de los primeros gobiernos peronistas; aunque en su caso, ese aprendizaje, además de la práctica estuvo acompañado de un intenso estudio sobre leyes laborales que realizaba en la biblioteca de la CGT. También, expresa las dificultades que tenían las mujeres para desarrollarse en un mundo tan masculinizado como era el sindical, y ganarse el

${ }^{452}$ Mura, Elsa. Entrevista de la autora. El Palomar, 27 de mayo de 2014. 
respeto no sólo de los hombres que ya contaban con cuotas de poder, sino de las propias mujeres a las que representaba como delegada. Las mujeres debían sobre exigirse si querían ganar reconocimiento. El testimonio de su hijo en base a unos apuntes dejados por Inés, es muy revelador al respecto:

[...] Ella tenía que trabajar más que los hombres, tenía que demostrar que era mejor que los hombres, tenía que estudiar más que los hombres, militar más que los hombres, caminar más que los hombres, para demostrar que estaba a la altura de los hombres. Hoy, vos, decís eso, decís 'no, que barbaridad, cómo se te ocurre'. Pero mamá se dio cuenta que si ella no hacía eso en su militancia no solamente no se ganaba su espacio sino que no sostenía su carácter de delegada $[\ldots]^{453}$

Es patente en estos relatos que el mundo sindical era un espacio masculinizado y que, si las mujeres querían desenvolverse en él, debían aprender sus códigos. Sin embargo, por debajo de las relaciones jerárquicas y burocráticas que lo caracterizaban, las mujeres pudieron estrechar alianzas y relaciones de solidaridad que les permitieron enfrentar a la patronal, a la propia burocracia sindical y a las fuerzas represivas, y desplegar acciones autónomas o intervenciones donde fueron ellas quienes tuvieron la iniciativa, sobre todo en los rubros industriales que estaban constituidos en su mayoría por mujeres. Las fuentes policiales también exponen estas intervenciones, sobre todo en gremios con una alta presencia femenina como el telefónico y el de la industria del textil.

En algunos casos, encontramos actuando a una mayoría de mujeres con minoría de varones. Por ejemplo, en un establecimiento textil de San Nicolás, en diciembre de 1962, las fuentes refieren un paro real, al que se plegaron 80 obreros, de los cuales, el $65 \%$ eran mujeres. ${ }^{454}$ En diciembre de 1963 , en otra fábrica textil de Vicente López se registra un paro de 51 mujeres y 9 hombres. ${ }^{455}$ Otras veces, eran sólo mujeres las que actuaban. Por ejemplo, en una fábrica textil de Lavallol, partido de Lomas de Zamora, en mayo de 1963, todas las trabajadoras de la sección confecciones iniciaron el trabajo "a reglamento". Frente a ello la patronal despidió a cinco obreras a las que consideraba promotoras. ${ }^{456}$ El relato de Elsa Mura viene a complementar la imagen ofrecida por las fuentes policiales. En la fábrica donde ella se desempeñaba, había unos pocos varones que trabajaban en secciones

\footnotetext{
${ }^{453}$ Buzeta, Saúl (h). Entrevista de la autora. Vía skype. 11 de marzo de 2014.

${ }^{454}$ DIPBA. Mesa "B". Factor Gremial. Carpeta Huelgas y Conflictos. Legajo 22.

${ }^{455}$ DIPBA. Mesa "B". Factor Gremial. Carpeta Huelgas y Conflictos. Legajo 22.

${ }^{456}$ DIPBA. Mesa "B”. Factor Gremial. Carpeta Huelgas y Conflictos. Legajo 22.
} 
específicas como expedición, administración y laboratorio, pero en las actividades de producción eran todas mujeres. Y sostiene que las "bullangueras y huelgueras" eran ellas, que los compañeros varones no se oponían a sus manifestaciones de resistencia en la fábrica, pero tampoco se sumaban; pese a que cuando ellas conseguían alguna reivindicación, ellos también se beneficiaban. ${ }^{457}$

Las fuentes policiales, además, nos devuelven un panorama muy conflictivo que involucraba a mujeres. Muchas de esas situaciones estaban vinculadas a las peleas que se generaban por la presencia de rompehuelgas, y que han quedado registradas en los documentos porque solían terminar con intervenciones policiales. ${ }^{458}$ Del relato de Chiche Di Marco también se desprenden referencias a ese tipo de intervenciones femeninas. Esta militante establece una diferencia entre la actividad de su hermana, sindicalista del gremio textil, y la suya. A pesar de que las dos militaban en la unidad básica, porque era común que participara toda la familia, sostiene que ella estaba todo el día en ese espacio, mientras que su hermana pasaba menos tiempo allí, pero mostraba más audacia en el tipo de actividades que desarrollaba como parte de la Resistencia. Con esto quería decir que su hermana se involucraba en actividades que podían desembocar en la agresión física, como recorrer las fábricas en los días de huelga para sacar a las mujeres que no se plegaban, lo que en una oportunidad le valió enfrentamientos físico con la dueña de una fábrica textil, y en otra se salvó de los tiros que le propició la dueña de una zapatería. Chiche, en cambio, se incorporaba a las tareas propuestas por los sectores sindicales pero de otra manera; por ejemplo, participando de las reuniones cuando se discutían cuestiones de política que no concernían directamente a los problemas laborales, pero sí al peronismo, y cuando había paros con movilización. ${ }^{459}$

La participación femenina en la Resistencia peronista a través de los espacios sindicales es un tema que reclama una mayor indagación empírica y un análisis con perspectiva de género. Sin embargo, el recorrido que hemos hecho hasta aquí nos permite esbozar algunas características sobre la intervención de las mujeres en dichos espacios. En principio, nos devuelve un panorama complejo sobre esa participación que no se condice con los estereotipos construidos para la militancia femenina asociados a tareas de apoyo, ni

\footnotetext{
${ }^{457}$ Mura, Elsa. Entrevista de la autora. El Palomar, 27 de mayo de 2014.

${ }^{458}$ DIPBA. Mesa "B". Factor Gremial. Carpeta Agitadores y Perturbadores. Legajo 6. Bahía Blanca y Legajo 2. Lanús; Mesa "B". Factor Gremial. Carpeta Huelgas y Conflictos. Legajo 22.

${ }^{459}$ Di Marco, Chiche; Martínez, María; Rivas Natividad y Cánepa, Oscar. Entrevista de la autora, Rosario, 16 de octubre de 2012 .
} 
a una prolongación de los roles maternales al espacio de la política. Inclusive, las mujeres muchas veces aparecen involucradas en actitudes que no eran las esperadas para su género y que implicaban acciones vinculadas al uso de la violencia física. Más bien se desprende la idea de un espacio caracterizado por relaciones de género altamente masculinizadas donde las mujeres debieron pelear por obtener reconocimiento y para poder desplegar iniciativas propias. El ingreso a ese mundo, que les era ajeno, implicó que tuvieran que atravesar un proceso de aprendizaje de las prácticas sindicales, que se contrapone con la figura de autoridad y poseedora de conocimientos que ocupa la imagen del sindicalista en los relatos de mujeres que no integraron esos espacios pero que se relacionaron con sujetos provenientes del mismo a partir de relaciones de parentesco. En esos relatos, la imagen del sindicalista se halla naturalizada como una figura masculina. Finalmente, observamos el desarrollo de acciones que no sólo estaban basados en relaciones de clase sino también en relaciones de género, donde el adversario al cual se enfrentaban estaba encarnado en una figura masculina, ya fuera el patrón, el dirigente sindical o el policía encargado de reprimir. Anteriormente hicimos referencia al trabajo de Silvana Palermo (2009), sobre las relaciones de género que habitan los espacios sindicales, acerca de cómo la amenaza sobre el deber de los hombres en tanto que sostenedores económicos de sus hogares sirvió como incentivo para la solidaridad obrera y para lanzar acciones de resistencia frente a los patrones. El relato de Elsa Mura nos devuelve una imagen según la cual, por debajo de los niveles de dirigencia, existía la posibilidad de que las mujeres pudieran estrechar lazos de solidaridad, y a la vez desplegar acciones de resistencia contra figuras de autoridad que estaban encarnadas por sujetos masculinos; de manera que la identidad de género también estaban actuando en esos desafíos. Sin embargo, en este caso, a diferencia de sus pares masculinos que con sus relaciones de camaradería reforzaban el modelo de la domesticidad, las mujeres cuestionaron el lugar que les estaba asignado en ese modelo; aunque ese cuestionamiento se dio a través de la práctica y no de un discurso articulado.

\section{Conclusiones}

$\mathrm{Al}$ discutir con los historiadores políticos tradicionales, reacios a incorporar el género como categoría de análisis y que recurren al tema de la guerra, la diplomacia y la alta política como pretexto para argumentar la inutilidad de dicha categoría, Scott esboza una frase que 
resume las implicancias de género que atraviesan las definiciones acotadas de lo político: “[...] El concepto de la política ha sido construido genéricamente porque una de las razones que la hace importante y poderosa es que las mujeres están excluidas de ella [...]” (Scott, 1993, p. 42). Sin embargo, como ha sostenido Carole Pateman (1995), dicha división de la sociedad en una esfera pública y una privada y la reclusión de las mujeres en esta última, es en sí misma una construcción política que tiende a legitimar las desigualdades de género. Estas divisiones operan en la construcción de los relatos históricos y han contribuido a borrar a las mujeres de esos relatos puesto que sus intervenciones han sido numéricamente inferiores a las de los varones en los espacios donde transcurre tradicionalmente la política. Pero en el caso de la Resistencia peronista, la ausencia de mujeres llama notablemente la atención puesto que -si bien se sostiene que la misma fue planteada desde los espacios cotidianos y sustentada en relaciones barriales y familiares, espacios y redes de relaciones a los que las mujeres han sido confinadas por los discursos sociales - ello no se ha traducido en una visibilización de su participación política.

El hacer visible la historia de las mujeres en la Resistencia peronista y al adoptar una perspectiva de género, no sólo nos lleva a problematizar los límites entre lo público y lo privado, las interrelaciones entre vida política y vida cotidiana, y el carácter construido de las esferas en que se divide la totalidad social, sino también los límites del concepto de política que ha caracterizado a los enfoques de la historiografía tradicional. Al indagar cómo la política se filtra en los espacios que afectan al mundo cotidiano de los militantes y, a la inversa, cómo la participación política está determinada por los condicionamientos del mundo privado, observamos las formas diferenciadas en que varones y mujeres ejercen experimentaron el ejercicio de la política. Así, pudimos observar cómo la militancia femenina es inescindible de las obligaciones que les impone el ámbito doméstico, y cómo en función de esas exigencias se desplegaron intervenciones que las llevaron a ejercer la maternidad en el espacio público, desafiando los mandatos maternales que exigían que ésta fuera ejercida puertas adentros del hogar. También, contemplamos que el hecho de que la Resistencia fuera desarrollada en el marco de relaciones familiares y barriales, no significó que la militancia se haya dado de manera armónica con las exigencias del mundo doméstico, sino que las mujeres fueron conscientes de las incompatibilidades que podían generarse entre esas exigencias y las del mundo de la política. Tal es así que, aunque hubo muchas que se lanzaron con sus hijos a la militancia, también hubo otras que decidieron no ser madres o delegar esa responsabilidad en otros. También, hubo separaciones cuando el proyecto de 
militancia no era compartido por la pareja, faltando con ello al mandato de esposa. Donde la participación de las mujeres no parece haber entrado en contradicción con el mundo familiar es en relación a las familias de origen de las mujeres que se incorporaron a la Resistencia siendo jóvenes. Si bien se percibieron a sí mismas como integrantes de otra generación, no concibieron su militancia como un desafío a la autoridad de los padres sino como una continuación de la militancia de ellos.

Al comienzo nos preguntamos si el hecho de que la Resistencia peronista haya estado sustentada en gran parte sobre relaciones familiares llevó a las mujeres a reproducir los roles de género tradicionales establecidos por el modelo de la domesticidad o si en realidad lo cuestionaron. Esta problemática ha sido ampliamente abordada en relación a la militancia que se desplegó en la década de los setenta. Algunas autoras sostienen que si bien la pauta del matrimonio heterosexual no fue cuestionada, sí hubo desafíos al modelo de la domesticidad, entre ellos porque las mujeres, sobre todo de clase media, cuestionaron los modelos de mujer ama de casa a la vez que articularon proyectos que las impulsaban al espacio doméstico vinculados a la posibilidad de trabajar y estudiar (Cosse, 2009). La etapa de la Resistencia peronista que se desplegó en la segunda mitad de la década del cincuenta y primera de los sesenta ha quedado estrechamente asociada a estereotipos e imágenes que remiten a ese modelo de la domesticidad. A los que ya hemos mencionado, como el uso del término tía para referir a las mujeres, pueden sumarse otros. Por ejemplo, en la autobiografia de Olga Hammar cuando se menciona a las mujeres de la Resistencia peronista que habían tenido participación en la década del cincuenta, se apela al uso de una fórmula que remite a la imagen de señoras mayores, muy asociada al rol de amas de casa: "las señoras de rodete". ${ }^{460}$ También, entre las organizaciones políticas de los años setenta emergieron ese tipo de imágenes. Por ejemplo, Karin Grammático hace referencia a la figura de las "madres de la Resistencia", en los discursos de la organización Montoneros, en referencia a aquellas mujeres que habían parido a los jóvenes revolucionarios del peronismo de la época. A su vez, la autora llama la atención sobre el carácter construido de esa imagen, puesto que muchos de los integrantes de dicha organización provenían de familias antiperonistas. La diversidad de experiencias que los relatos orales transmiten, echan por tierra con esos estereotipos, al demostrar que las mujeres no se incorporaron a la militancia como una prolongación de sus roles maternales y conyugales, a la vez que en esas

${ }^{460}$ Hammar, Olga (2009). Tozudamente. Buenos Aires, Intermedia, p. 96. 
proyecciones al espacio público no se limitaron a apoyar tareas pensadas por otros sino que se ponían en juego proyectos propios. Con ello no queremos decir que el modelo de la domesticidad no tuviera vigencia, después de todo, el mismo continuó operando hasta bien entrada la década del setenta. De hecho, pese a que las mujeres que se incorporaron a las organizaciones político-armadas de esos años, experimentaron el ingreso a la militancia como una ruptura generacional, como ha señalado Alejandra Oberti (2015), no lograron romper con el mandato maternal porque en el proyecto de las propias organizaciones estaba incorporada la idea de que tenían que parir y criar hijos para la revolución, a la vez que compatibilizar las exigencias de la maternidad y la militancia. Por otro lado, la división de tareas en el hogar continuó beneficiando al varón, ya que cuando las responsabilidades políticas de ambos cónyuges de superponían, se priorizaban las del varón. Durante el período abordado, el modelo de la domesticidad continuó actuando, pero la militancia implicó un desafío más que una reproducción al mismo; aunque ese desafío no pudiera ser articulado en forma de un discurso consciente. Además, si contemplamos el hecho de estas mujeres se lanzaron a la política en un tiempo en el que aún no habían tenido lugar las transformaciones que se registran para mediados de la década del sesenta que tendieron a cambiar la situación de las mujeres, y que eran mujeres que recientemente habían accedido a sus derechos de ciudadanía, eran las que habían votado por primera vez en 1951, o tal vez en 1954, o sus hijas, lo cierto es que tuvieron que pasar rápidamente de una militancia que las había convocado en tanto que ciudadanas para participar en estructuras legales, a otra, en donde se imponían los riesgos y vicisitudes de la ilegalidad y la clandestinidad, y donde los conocimientos que habían desarrollado en la política en los años previos no siempre resultaban pertinentes en el nuevo contexto. 


\section{Conclusiones}

Esta tesis ha estado articulada alrededor de algunos interrogantes propuestos por Hélèn Eck (2000) para pensar la intervención femenina en los procesos de resistencia a los regímenes de extrema derecha en Europa, en las décadas del '30 y '40 del siglo XX. Salvando las distancias y procurando no caer en anacronismos, consideramos que las preguntas formuladas por la autora ante una coyuntura específica, pueden ser capitalizadas conceptualmente para ponerlas a prueba en otros contextos históricos. En efecto, sus preguntas resultan interesantes para problematizar la participación femenina en la Resistencia peronista entre los años 1955 y 1966. Así, si bien nuestro objeto de estudio posee características muy diferentes al analizado por Eck, lo cierto es que comparte ciertos elementos básicos que desde la teoría política han sido considerados como constitutivos de los procesos de resistencia. Entre ellos, podemos mencionar la participación de amplios sectores de la población civil, el enfrentamiento de este sector con una fuerza más poderosa, que puede ser un ejército invasor o un gobierno nativo al que se considera ilegítimo, una relación asimétrica de fuerzas, la apelación por parte de la población civil a todos los métodos que tiene a su disposición y la heterogeneidad de los modos de intervención, que van desde micro-resistencias, formas ocultas y disimuladas hasta desafíos abiertos, que pueden ser masivos o incluso violentos, a la vez que implica la combinación de métodos de no colaboración con métodos activos de intervención. Finalmente, podemos decir que involucra la construcción de un poder social que aspira a convertirse en poder político (López Martínez, 2012 y Sharp, 2011).

Las preguntas que Eck se formula se basan en si la participación femenina en los procesos de resistencia se limitan a desarrollar tareas auxiliares y a "actuar" los roles de género tradicionales, $\mathrm{y}$, también, se interroga sobre si puede hablarse de una especificidad femenina de la resistencia. Luego de un intenso trabajo empírico y analítico que ha implicado el cruce de fuentes muy diversas, escritas y orales, consideramos que podemos ofrecer algunas respuestas en lo que concierne a esa participación en la Resistencia peronista. En principio, podemos decir que, pese a que las mujeres muchas veces desarrollaron tareas que parecían acordes a los modelos de género y que socialmente se visualizaban como "apoyo", la heterogeneidad de experiencias que caracterizó a esa participación no se redujo a ello y ello ha quedado reflejado en cada capítulo. Los mismos 
fueron estructurados en función de evidenciar una modalidad distinta de intervención, apelando al concepto de repertorio de confrontación acuñado por Charles Tilly (citado por Tarrow, 1997); un concepto estructural y cultural que evidencia los procesos selectivos que hacen los actores a la hora de elegir las formas mediante las cuales lanzarán el desafío político, eligiendo en base a un abanico de oportunidades que está definido en función de la historia de cada grupo. De esta manera, analizamos la participación femenina en acciones que implicaban el uso de la violencia política, ya sea a través de golpes de Estado como de la realización de atentados y sabotajes canalizados a través de células clandestinas -una actividad novedosa, no sólo para las mujeres sino para la mayoría de los varones que participaban de ellas-. También, las observamos apelando a su experiencia previa, recurriendo a modos de intervención con los que se habían familiarizado durante los años del gobierno peronista, sólo que ahora implicaban nuevos desafíos porque su desarrollo en un contexto diferente los había convertido en actividades clandestinas o semiclandestinas; nos referimos a los intentos de reorganización partidaria, al desarrollo de la actividad periodística a través de la prensa gráfica y al despliegue de homenajes en memoria de Eva Perón en los aniversarios de su nacimiento y muerte.

A través de los términos que conforman la primera parte del título que da nombre a esta tesis, "Insurgentes, misioneras y políticas", se intentó dar cuenta de esa heterogeneidad en las modalidades de participación femenina. Según la Real Academia Española, "insurgencia" implica un levantamiento contra la autoridad. Si bien todas las actividades que hemos analizado podrían ser calificadas de insurgentes, porque todas implicaban un desafío político, algunas se adecúan mejor a ese término; nos referimos a las actividades de confrontación abierta que implicaban el uso de la violencia. En el caso de las actividades de reorganización partidaria, pese a que el contexto fue cambiante y muchas veces se desarrollaron en condiciones de clandestinidad, el fin perseguido era el reconocimiento del propio partido para actuar en la legalidad. Aun así, el desafío estaba planteado, si pensamos en que a lo largo de todo el período no cesaron las medidas proscriptivas y represivas. En cuanto al desarrollo de la prensa política, en principio, lanzó un desafío a la autoridad a partir del nombramiento de lo que estaba prohibido. Los discursos a los que apelaron fueron de abierta confrontación. Sin embargo, ese vocabulario se fue modulando en la medida en se observaban variaciones en el contexto político, y la estructura de oportunidades les ofrecía a los peronistas formas alternativas de participación. Entonces variaron entre 
sostener estrategias de participación de abierta confrontación y el sostenimiento de actividades que reclamaban un reconocimiento legal.

La realización de homenajes a Eva Perón implicó una estrategia diferente. El segundo término -"misioneras"- hace referencia especialmente a esta modalidad de intervención, ya que es uno de los nombres que algunas organizaciones encargadas de realizar ese tipo de actos eligieron para autonominarse; en parte, por la connotación religiosa que atravesó a esas prácticas, y a su vez, porque remitía a las primeras organizaciones creadas por Eva Perón para lanzar la campaña por el voto femenino, campaña que había sido anunciada como una cruzada (Barry, 2009). En este caso, también se trató de prácticas que implicaban un desafío político, ya que nombraban lo innombrable en el espacio público, a través de intervenciones cargadas de un simbolismo muy marcado. Sin embargo, muchas veces, el contenido político y subversivo pasó desapercibido gracias a las connotaciones religiosas que las atravesaban. Pero no era raro que dieran lugar a episodios de confrontación entre los manifestantes y las fuerzas policiales, cuando estas últimas se percataban de que las acciones que tenían lugar bajo su mirada no eran simples misas y recordatorios fúnebres.

Y con el término "políticas" hacemos referencia a todas las prácticas de la Resistencia peronista, porque todas tuvieron un carácter politizado e implicaban una politización previa por parte de las mujeres que se lanzaron a la acción, aunque muchas de esas acciones estuvieran estrechamente vinculadas con la vida cotidiana. Sin embargo, en ese contexto, "políticas" adquiere otras connotaciones. Las palabras política, políticas y políticos tuvieron un carácter despectivo en el peronismo de la época. Por un lado, remitían a la dirigencia partidaria, a la que se consideraba traidora por la actitud desplegada luego del golpe de 1955, en oposición al sector sindical, que se había mantenido en pie de lucha; aunque algunos, también, habían defeccionado. Por otro lado, remitía al desarrollo de la política previo a la llegada del peronismo, a la "politiquería" encarnada en los partidos tradicionales cuyo discurso carecía del contenido social que sí poseía el peronismo. Entre las mujeres que encabezaron en el PPF, la política hacía referencia a este último significado, razón por la que ellas no podían concebir su actividad como tal (Barry, 2009; Bianchi y Sanchís, 1998). Sin embargo, ellas también eran tildadas de políticas por su adscripción a la estructura partidaria. Y entre militantes que desarrollaron su participación en unidades básicas de base, la política hacía referencia al partido, no pudiendo asimilar el hecho de que su actividad en la unidad básica también era una intervención de tipo partidaria, aunque no respondiera a las estructuras supralocales del PJ. En fin, se trató de un término problemático, pero no 
podemos dejar de considerar que cualquiera fuera la actividad que realizaran, en el espacio en que lo hicieran y en el nivel en que tuvieran lugar, la participación de las mujeres en la Resistencia peronista fue una actividad política. Y además de este sentido más amplio, es aplicable -en un sentido más restringido- a las mujeres que se volcaron a la actividad partidaria. Finalmente, cabe aclarar, que los diferentes modos de intervención no fueron excluyentes y que las mujeres podían participar en diferentes espacios y con distintas modalidades en forma simultánea o de manera consecutiva.

Volviendo a la pregunta de Eck sobre si puede hablarse de una especificidad femenina para los procesos de resistencia, en el caso que nos compete diremos que en cierta medida sí, ya que en el momento en que tuvo lugar la Resistencia peronista circularon discursos que habilitaban ciertos roles de género y que excluían a las mujeres de determinadas actividades. Es decir, las mujeres no se insertaron de la misma manera en todas las prácticas que desplegaron. Ya vimos que no fue lo mismo la inserción en prácticas que implicaban el recurso a la violencia, donde las mujeres se incorporaron de manera subordinada, por los discursos que las excluían y que a la vez definían masculinidades hegemónicas basadas en el uso de las armas, que en aquellas que estaban atravesadas por discursos que las asociaban a la condición femenina; por ejemplo, las que se hacían desde la cotidianeidad, como la ayuda a los presos políticos y sus familiares, o las que consistían en homenajear a Eva Perón donde la participación femenina se veía favorecida por los discursos instalados desde fines del siglo XIX que asociaban a las mujeres con el catolicismo (Herranz, 2005). En este tipo de actividades, las mujeres demostraron tener mucha iniciativa y participaron masivamente.

Cabe mencionar que además de los discursos sociales que habilitaban ciertas prácticas, también actuaron los procesos de socialización previos (Lahire, 2004). Las mujeres intentaron reactualizar prácticas con las que se habían familiarizado durante los años del gobierno peronista. Homenajear a Eva Perón en los aniversarios de su nacimiento y muerte era una práctica que venían realizando desde 1952, y desde un primer momento se había instalado como una actividad femenina debido a la impronta personal que Evita le había conferido a las organizaciones que agrupaban a las mujeres, políticas o no, que se crearon bajo el mandato de Perón. Por otro lado, muchas de estas mujeres que se lanzaron a la Resistencia, habían sido socializadas en las estructuras del Partido Peronista Femenino, una organización basada en una identidad de género. Intentar reactivar esa estructura durante los años que siguieron al derrocamiento del peronismo fue una constante que se desarrolló tanto en niveles de base como de dirigencia y que implicó intentos paralelos. La 
idea de una organización política diferenciada para las mujeres estaba instalada en la tradición peronista de una manera tal que, luego del golpe de Estado, involucró inclusive a mujeres que no habían participado de esa estructura en años previos. Respecto de la participación en la prensa, por requerir conocimientos especiales, no fue una actividad tan extendida y, por lo menos en los casos analizados, se trató de mujeres con conocimientos previos sobre la labor periodística y con determinado nivel social que les había permitido acceder a esos conocimientos.

Ahora bien, el hecho de plantear que hubo una especificidad femenina en la Resistencia peronista ¿debe llevarnos a concluir que las mujeres se limitaron a reproducir roles de género tradicionales? En principio, la actuación de esos roles de género para pasar desapercibidas frente a las personas que encarnaban la autoridad, nos indica que las mujeres tenían plena conciencia de cuáles eran los roles socialmente aceptados y que ellas, por su participación en actividades que estaban prohibidas, no encajaban en los mismos. Esto no era incompatible con el hecho de que en determinadas instancias se adaptaran a esos estereotipos, pero no siempre ni de manera ineludible.

En segundo lugar, la exclusión de las mujeres de determinadas actividades no fue completa. Es decir, los discursos las excluían pero ellas desafiaron esos discursos. En el caso de las acciones que conllevaban el uso de la violencia política, observamos que en algunas instancias, como la del golpe de Estado, algunos varones también fueron excluidos, pero por su condición de civiles. Las mujeres lo fueron por motivos basados en la diferencia de género. Aun así, observamos que en otro tipo de intervenciones que implicaban el uso de la violencia y donde no intervenían los militares de manera corporativa, provenientes de una institución tan jerárquica y masculinizada, las mujeres adquirieron mayor protagonismo y alcanzaron niveles más altos de decisión, aunque también de manera subordinada. Sin embargo, no fueron capaces de crear un contradiscurso que cuestionara los hegemónicos. Las intervenciones femeninas en este campo fueron más bien aisladas, a diferencia de la generación de mujeres que en la década del setenta se incorporaron masivamente a la lucha armada. Posiblemente, esa participación aislada y subordinada haya contribuido a inhibir la emergencia de un posible contradiscurso. Ahora bien, para analizar si las prácticas que desarrollaron estas mujeres tuvieron un carácter disruptivo en términos de género, debemos situarlas en su contexto político. De esta manera, no podemos dejar de pasar por alto que en la década del cincuenta y primera de los sesenta el acceso de las mujeres a la ciudadanía política era muy reciente y los derechos alcanzados aún no habían cristalizado en la 
sociedad como un hecho indiscutible. Entonces, si todavía se cuestionaba su participación por la vía legal, la participación por la vía armada era un hecho más transgresor aún.

En tercer lugar, debemos decir que aun cuando actuaron a través de acciones con las que estaban familiarizadas o en las que tenían mayor margen de despliegue por la existencia de discursos sociales que las avalaban, como fueron la reorganización partidaria en una estructura femenina y los homenajes a Eva Perón; también hubo actitudes disruptivas en diferentes sentidos. En el primer caso, el de la reorganización partidaria, estaban avaladas por la tradición peronista en la que estaba arraigada la idea de que las mujeres debían reorganizarse de una manera diferenciada y la figura de Eva Perón actuaba como elemento legitimador, ya que el Partido Femenino había sido una creación suya. Sin embargo, en los años que prosiguieron al golpe de Estado de 1955, las mujeres debieron luchar en varios frentes por mantener esa estructura. En el externo, contra el antiperonismo y los gobiernos de turno, que proscribieron la actividad del peronismo. $\mathrm{Y}$ si bien compartieron esta condición con las otras ramas del movimiento, a las mujeres les afectó de manera especial, porque carecían de fuentes propias de poder y de recursos. De hecho, las estrategias que utilizaron para financiar los intentos de reorganización fueron muy rudimentarias: rifas, festivales y colectas. En algunas oportunidades, debieron recurrir a los sindicatos, pero ello atentaba contra su autonomía. Por otro lado, se vieron obligadas a mantener la batalla en el frente interno, contra las otras ramas del partido, sindical y política, que muchas veces atentaron contra la reorganización femenina y el mantenimiento de la autonomía y contra las imposiciones del propio Perón. Mientras que, entre las estructuras masculinas del peronismo, ya sea sindical o política, se formaron núcleos de poder que les permitieron disputar espacios de representación y de decisión en el peronismo, ello no fue posible entre las mujeres. Ellas no lograron crear esos focos de poder y en ello influyeron las características que el Partido Femenino había adoptado en tiempos de Eva Perón, donde la existencia de una estructura verticalista que giraba alrededor de la primera dama había impedido su emergencia. De manera que, en los años posteriores al golpe de Estado de 1955, no hubo dirigentes femeninas con el suficiente poder y capacidad de movilización como para organizar una estructura partidaria a partir de ellas. Es decir, la organización diferenciada, pese a tratarse de una tradición peronista, no estaba garantizada en el propio peronismo. Y a ello debemos sumar, los discursos de época que restringían la participación política femenina. Las mujeres eran recién llegadas a la política y ellas tuvieron conciencia de ello y así lo expresaron en los discursos que emitieron, tanto en actos políticos como en 
los que se articularon a través de la prensa. La novedad que trae el período es que tanto las mujeres como los varones peronistas se vieron imposibilitados de participar por la vía partidaria. En este contexto la identidad peronista pesó más que cualquier posible identidad basada en la condición femenina a la hora de intentar procesos de reorganización. Hubo cuestionamientos por parte de las propias mujeres a la injerencia masculina, pero no lograron crear lazos lo suficientemente fuertes para resistir las imposiciones masculinas, y mucho menos las del propio Perón, ya que ello hubiera significado quedar fuera del peronismo.

Parte de esos cuestionamientos se desarrollaron a partir de la prensa. La intervención de las mujeres fue decisiva para articular un discurso que particularizaba en las mujeres. Sin embargo, una vez más, la identidad peronista pesó más que cualquier otra identificación sustentada en el género. Es decir, emergió un discurso basado en las mujeres, pero ello no significó que se plantearan demandas de una agenda femenina que fueran más allá de los límites impuestos a las mujeres en la participación política. En el caso de uno de los periódicos analizados, esas demandas existieron en relación a la exclusión de las mujeres de los espacios considerados importantes en la sociedad, en especial la cultura, la política y la ciencia, a la vez que se cuestionó la ausencia de estas temáticas en otras publicaciones, incluso peronistas. Pero se expresó en términos de un maternalismo político y quedó eclipsado ante la identidad popular que planteaba el periódico, más arraigada en la identidad de clase que de género. Otro de los periódicos, planteó explícitamente las problemáticas femeninas en torno a la exclusión de las mujeres de la participación política y del acceso a los espacios de toma de decisiones, para lo cual ofreció soluciones al respecto basadas en la organización, capacitación y formación política, aunque tuvo poca vida, precisamente por la injerencia de las disputas políticas que atravesaban al peronismo, a la vez que no contó con el apoyo de Perón en un contexto en que un aval suyo constituía un elemento de legitimación de cualquier pretensión de movilización de las bases peronistas (Sigal y Verón, 2004). Y un tercero, que no planteó problemáticas femeninas pero que usó a las mujeres como elemento simbólico y recurso discursivo, apelando a argumentos esencialistas, para legitimar una línea política, o que particularizó en las mujeres antiperonistas en las polémicas que entabló, visibilizando además, la importancia de la participación femenina en la política; a la vez que también contempló a las mujeres como lectoras. Pese a estas variaciones en los posicionamientos, no podemos pasar por alto que la intervención femenina en la prensa fue un hecho disruptivo, si tenemos en cuenta que se trata de un 
universo preferentemente masculino y que incluso su vocabulario oculta la existencia de esa particularidad bajo la apariencia de un lenguaje universal, que en realidad es masculino (Moreno i Sardá, 2007). Las directoras de los periódicos, con su intervención, pusieron al descubierto la artificiosidad de esa universalidad, al particularizar en las mujeres, aunque ello no siempre se haya traducido en la articulación de una agenda femenina.

Respecto de los homenajes a Eva Perón, podemos decir que en este caso las mujeres intervinieron a partir de prácticas que les eran familiares y atravesadas por discursos que habilitaban la participación femenina en relación a las mismas. Sin embargo, pese a que esas prácticas estaban amparadas por discursos que asociaban a las mujeres a cumplir roles y a desempeñarse en espacios tradicionales, ellas no se limitaron a reproducir los lineamientos de esos discursos sino que se apropiaron de los mismos para legitimar su intervención sobre el espacio público. Actuaron en lugares tradicionales, como las iglesias y cementerios, pero en prácticas litúrgicas poco ortodoxas que desafiaban la autoridad de la Iglesia en sus propios espacios. Y además, esas prácticas tuvieron connotaciones subversivas, porque implicaron un enfrentamiento con las autoridades policiales y una afirmación sobre el espacio público de su identidad peronista en un momento en que ser peronista implicaba exponerse a ser objeto de represión. No fueron actos de mera simulación, porque no podemos poner en duda el sentimiento religioso que Evita les despertaba, pero tampoco fueron simples misas, por las connotaciones subversivas que tenía la figura de Eva Perón en ese momento. Fueron actos de afirmación política en un espacio que usualmente no es contemplado como político y que en todo caso nos habla de cómo la participación política femenina suele adquirir formas y desplegarse en lugares que no siempre se corresponden con los lugares tradicionales por los que transcurre usualmente la política.

Finalmente, debemos considerar que la imagen que tradicionalmente ha circulado sobre la Resistencia peronista, tanto en los relatos de militantes como en la bibliografía académica es la de la cotidianeidad a partir de la cual fue desarrollada. Es decir, una resistencia desplegada a partir de los espacios cotidianos, domésticos, barriales y laborales. Sin embargo, y pese a los discursos sociales de la época que asociaban a las mujeres a esos espacios, ello no se ha traducido en una visibilización de la participación femenina en la Resistencia peronista; por un lado, por la propia desigualdad que caracterizó a las relaciones de género que atravesaron las prácticas de la Resistencia y por otro, por los discursos de género excluyentes que continúan impregnando a los relatos construidos desde el presente. Sin embargo, cuando incluimos la dimensión de la vida cotidiana para analizar la 
participación de las mujeres, nos encontramos con experiencias que están profundamente atravesadas por problemáticas definidas en función del género. En principio, en los relatos orales de mujeres, la participación política se muestra inescindible de la vida cotidiana y esta se hace presente a partir de las obligaciones del ámbito doméstico que dificultan la labor política, en especial la maternidad y la conyugalidad; elementos prácticamente ausentes de los relatos masculinos, donde la política es contemplada como una esfera independiente de la doméstica y donde, si aparece la vida privada, no es en relación a las obligaciones paternales y conyugales, que por otro lado, les plantean a los varones otras exigencias que no son las atribuidas a las mujeres. De esta manera, observamos que para las mujeres la participación en la Resistencia peronista implicó exigencias que muchas veces fueron incompatibles con el cumplimiento de las obligaciones asociadas a su género impuestas por los discursos sociales. A veces, transgredieron esos roles, ya sea dando primacía a la actividad política o tratando de compatibilizar ambas tareas, arrastrando a sus hijos a la militancia y desarrollando prácticas de maternidad que no se ajustaban a las socialmente aceptadas. Otras veces, sobreexigiéndose para cumplir con las obligaciones inherentes a uno y otro ámbito. Por otro lado, el aspecto doméstico de muchos de los actos desplegados, de hecho, no estamos negando que hubiera acciones de este tipo, hizo que muchas mujeres olvidaran los riesgos que corrieron. Y ello contribuyó también a la construcción de relatos donde sus intervenciones son consideradas como auxiliares o directamente ignoradas.

Retomando las dimensiones del concepto de género de Joan Scott (1993), podemos decir que la imagen de Eva Perón actuó como un símbolo que impulsó a muchas mujeres a actuar políticamente. Si bien, esa actuación se desplegó en lugares tradicionales asociados a la liturgia católica, las mujeres se apropiaron de esos lugares y de los discursos que las asociaban a lo religioso para desarrollar acciones políticas consideradas subversivas. La dimensión normativa actuó a partir de la multiplicidad de discursos sociales, incluidos los producidos por el discurso peronista formal, que habilitaron a las mujeres a actuar en determinados ámbitos y las excluyeron en otros. En el caso de los primeros, fueron utilizados por las propias mujeres como argumentos a partir de los cuales legitimaron su derecho a la participación. En el caso de los segundos, procuraron transgredir esa exclusión, aunque la misma no haya sido completa o no haya podido ser articulada en un contradiscurso. Respecto de la dimensión institucional, cabe decir que pese a desarrollarse en un contexto de proscripción poco propicio para la participación de tipo electoral, no faltaron intentos por reconstruir una estructura partidaria, y la forma que había adquirido 
esa organización institucional en años del gobierno peronista tuvo una importante influencia sobre el período abordado, es decir se procuró continuar con una estructura basada en la identidad de género. Finalmente, la dimensión subjetiva del género, nos devuelve una imagen de la Resistencia peronista con todas sus complejidades donde se observan los desafíos en términos de género que la militancia implicó para las mujeres en un proceso en que la actividad política es inescindible de las exigencias del mundo doméstico.

En síntesis, bajo el gobierno peronista las mujeres habían alcanzado derechos plenos de participación política, en términos normativos. Luego del derrocamiento del peronismo, volvieron a sufrir procesos de exclusión, pero esta vez, no en calidad de mujeres, sino por su condición de peronistas. La clandestinidad las lanzó al espacio público en tareas compartidas con los militantes varones con quienes las igualaba la condición de proscripción que pesaba sobre unas y otros, pero esa participación conjunta se desarrolló en posiciones subordinadas para las mujeres, sobre todo en aquellas actividades que con las que no se habían socializado previamente y que desafiaban más enérgicamente los discursos sociales tradicionales. Las mujeres no cuestionaron esa subordinación, y en todo caso, donde más lo hicieron fue en aquellas instancias asociadas a la participación partidaria que buscaban el reconocimiento legal, precisamente el ámbito donde más se había avanzado durante la etapa del gobierno anterior. Retomando a Carole Pateman (1995), podemos decir que las mujeres no pudieron romper con los estereotipos que implicaba el contrato sexual, porque si bien se desgarró el contrato social, por su ingreso a la política y al espacio público, se trató de un ingreso diferenciado; es decir, el contrato sexual continuó latiendo detrás del contrato social. 


\section{Archivos, hemerotecas y centros de documentación consultados}

Archivo de la DIPBA (Dirección de Inteligencia de la Policía de la Provincia de Buenos Aires. Comisión por la Memoria de la Provincia de Buenos Aires

Archivo Intermedio del Archivo General de la Nación

Archivo Oral de la Comisión Provincial de la Memoria de la Provincia de Buenos Aires

Archivo Oral del Instituto Nacional de Investigaciones Históricas Eva Perón

Archivo Personal de Marta Curone

Centro de Documentación e Investigación de la Cultura de Izquierdas (CeDInCI)

Dirección Federal de Archivos del Poder Judicial de la Nación

Hemeroteca de la Biblioteca Argentina Dr. Juan Alvarez. Rosario

Hemeroteca del Congreso Nacional de la Nación

Hemeroteca de la Legislatura de la Provincia de Buenos Aires

Hemeroteca de la Biblioteca Nacional Mariano Moreno

Hemeroteca del Museo Histórico Provincial de Rosario "Dr. Julio Marc"

Fondo Centro de Estudios Nacionales. Arturo Frondizi. Biblioteca Nacional Mariano Moreno

\section{Entrevistas personales}

Buzeta, Manuel (h) (hijo de Inés Dihian)

Cánepa, Oscar

Curone, Marta

De Sánctis, Oscar (yerno de Nora Lagos)

Di Leo, Mabel

Di Marco, Chiche

Dalponte, Omar

Fiorenza, Nello

Gallardo, Manuel

Geymonat, Carlos

Gherman, Ángel

Granata, María

Lucero, María

Marino, Francisco 
Martínez, María

Mascías, Norah (hija de Nora Lagos)

Mascías Patricia (hija de Nora Lagos)

Mura, Elsa

Ninín, Enrique

Pavón Pereyra (h) (nieto de Hortensia García Marín)

Rivas, Natividad

Roldán, Dora

Sotelo, Amanda

Sobrino Aranda, Luis

\section{Entrevistas de la Comisión por la Memoria de la Provincia de Buenos} Aires

García Marín, Hortensia (Lala)

Rulli, Jorge

\section{Prensa consultada}

Clarín

Democracia

El Día

La Capital (de Rosario)

La Prensa

La Razón

Conquista

La Argentina

Línea Dura

Nuestra Palabra

Rebeldía

Trinchera de la Juventud Peronista

Soberanía 


\section{Bibliografía}

Acha, Omar (2011). Los muchachos peronistas: Orígenes olvidados de la Juventud Peronista (1945-1955). Buenos Aires: Planeta, 2011

Acha, Omar y Quiroga, Nicolás (2012). El Hecho maldito. Conversaciones para otro historia del peronismo. Rosario.

Aelo, Oscar (2012). El Peronismo en la provincia de Buenos Aires, 1946-1955. Buenos Aires: Eduntref

Altamirano, Carlos (1998). Arturo Frondizi: O el hombre de ideas como político. Buenos Aires [AR]: FCE.

\section{Editorial.}

(2001). Peronismo y cultura de izquierda. Buenos Aires: Temas Grupo

Álvarez, Yamile (2006). "El neoperonismo en Mendoza". Estudios contemporáneos $\mathrm{n}^{\mathrm{o}} 1$. Universidad Nacional de Cuyo. Facultad de Filosofía y Letras. Instituto Multidisciplinario de Estudios Sociales Contemporáneos. Recuperado de:

http://bdigital.uncu.edu.ar/objetos_digitales/4956/esc1-alvarez.pdf

(2014). "La Resistencia peronista en Mendoza (1955-1960). Una aproximación a su estudio a través del relato de sus protagonistas. Revista de Historia Americana y Argentina, Vol. 49, n 2. Mendoza: Universidad Nacional de Cuyo.

Amaral, Samuel (2004) [1993]. "El avión negro: retórica y práctica de la violencia". En Samuel Amaral y Mariano Ben Plotkin (Comp.). Perón del exilio al poder. Buenos Aires: EDUNTREF.

Amar Sánchez, Ana María (2002). "Evita: Cuerpo político/imagen pública". En Evita: Mitos y representaciones. Comp. Marysa Navarro. Buenos Aires: Fondo de Cultura Económica.

Amorós, Celia (1987). "Espacio de los iguales, espacio de las idénticas. Nota sobre poder y principio de individuación”. Arbor, CXXVIII.

Amossy, Ruth (2000). "Lo plausible y lo evidente: doxa, interdiscurso, tópicos", en L'argumentation dans le discours. Discours politique, littérature d'idées, fiction. París, Nathan. (traducción de Soledad Montero, mimeo).

Andújar, Andrea [et. al.] (2009). De minifaldas, militancias y revoluciones. Exploraciones sobre los '70 en la Argentina. Buenos Aires: Luxemburg.

Arfuch, Leonor (1986). "Titulares de prensa: tematización y estrategias enunciativas". Revista Topiques, Buenos Aires.

Arfuch, Leonor (2002). "El espacio biográfico. Mapa del territorio". El espacio biográfico. Dilemas de la subjetividad contemporánea. Buenos Aires: FCE. 
Arias, María F. y García Heras, Raúl (2004). "Carisma disperso y rebelión: los partidos neoperonistas". En Samuel Amaral y Mariano Ben Plotkin (Comp.). Perón del exilio al poder. Buenos Aires: EDUNTREF.

Arrosagaray, Enrique (2016). La resistencia y el General Valle. Buenos Aires: Punto de Encuentro.

Artières, Philippe (1998). "Arquivar a própia vida". Estudos Históricos, n. 21, Río de Janeiro. Citado en Castro, María Virginia (2015). "Silencios y énfasis en los archivos personales, saber de los archivos. Archivo, Cultura y patrimonio. Actas de las I Jornadas de reflexión sobre la construcción del archivo. Centro de documentación e Investigación de la cultura de la izquierda (CeDInCI) y Biblioteca central de la Universidad de San Martín. Buenos Aires.

Astelarra, Judith (1987). La cultura política de las mujeres. En Norbert Lechner (Comp.) Cultura política y democratización. CLACSO/ FLACSO/ICI. Recuperado de http://flacsochile.org/biblioteca/pub/publicos/1987/libro/000115.pdf

Balbi, Fernando (2007). De leales, desleales y traidores: valor moral y concepción de la política en el peronismo. Buenos Aires: Antropofagia.

Balbi, Fernando Alberto (2014). ““...quiero andar con mucha libertad' Consideraciones en torno de los lugares de las organizaciones partidarias y de la conducción en la praxis política de los peronistas". En Melon Pirro, Julio César y Quiroga, Nicolás (Comps.). El peronismo y sus partidos. Tradiciones y prácticas políticas entre 1946 y 1976. Rosario: Prohistoria.

Barrancos, Dora (2017). "Mujeres en vilo: Género y Guerra fría en América Latina". En Eugenia Rodríguez Sáenz (editora). Ciudadanas de la Guerra Fría en América Central (1945-1970): Perspectivas transnacionales. Costa Rica: Editorial de la Universidad Estatal a Distancia. (En prensa).

Barry, Carolina (2009). Evita Capitana. Buenos Aires: EDUNTREF.

Barry, Carolina (2013). "Delia Degliuomini de Parodi. El desafío de reemplazar lo irremplazable. En Panella, Claudio y Rein, Raanan. La segunda línea. Liderazgo peronista 1945-1955. Buenos Aires: Pueblo Heredero-Eduntref.

Barry, Carolina (2010). "Conquista: la mujer es noticia". En Claudio Panella y Guillermo Korn (compiladores). Ideas y debates para la nueva argentina. Revistas culturales y políticas del peronismo (1946-1955), Volumen I. La Plata: Universidad Nacional de La Plata, 2010.

Baschetti, Roberto (2013). La violencia oligárquica antiperonista entre 1951 y 1964: su consecuencia directa. Buenos Aires: Corregidor.

Baschetti, Roberto (s/f). "César Marcos. Militantes del peronismo revolucionario uno por uno." Recuperado de: http://www.robertobaschetti.com/biografia/l/13.html 
Bellucci, Mabel (1991). "Alicia Eguren, la voz contestataria del peronismo". Todo es Historia, $\mathrm{n}^{\mathrm{o}} 288$, julio.

Besoky, Juan Luis (2013). "La derecha peronista en perspectiva". Nuevo Mundo Mundos Nuevos. Cuestiones del tiempo presente. Recuperado de:

https://nuevomundo.revues.org/65374

(2014). "Algunas cuestiones para pensar la violencia paraestatal 19661976". VII Jornadas de Trabajo de Historia Reciente. La Plata: Universidad Nacional de La Plata.

Bianchi, Susana y Sanchís, Norma (1998). El partido peronista femenino. Buenos Aires: CEAL.

Blasco Herranz (2005). "Género y religión: de la feminización de la religión a la movilización católica femenina. Una revisión crítica”. Historia Social, No. 53 (2005).

Bonavena, Pablo (2015). "Guerra del pueblo y resistencia durante la segunda guerra mundial: consideraciones para una construcción conceptual”. XI Jornadas de sociología de la UBA. Buenos Aires, 13 a 17 de julio de 2015.

Bosca, Ricardo (1997). La Iglesia nacional peronista. Factor religioso y poder político. Buenos Aires: Sudamericana.

Bozza, Juan (2001). "El peronismo revolucionario, itinerario y vertientes de la radicalización, 1959-1969. Sociohistórica. Nº9-10, La Plata: UNLP.

Branz, Juan (2017). "Masculinidades y Ciencias Sociales: una relación (todavía) distante". Descentrada, Revista interdisciplinaria de feminismos y género, $\mathrm{n}^{\mathrm{o}} 1$. Centro Interdisciplinario de Investigaciones en Género (CInIG) IdIHCS - CONICET. Facultad de Humanidades y Ciencias de la Educación. Universidad Nacional de La Plata.

Bravo, Anna (2003). "Mujeres y segunda guerra mundial: estrategias cotidianas, resistencia civil y problemas de interpretación". En Mary Nash y Tavera Susana (Ed.). Las mujeres y las guerras. El papel de las mujeres en las guerras de la Edad Antigua a la Contemporánea. Barcelona: Icaria Editorial.

Bravo, Anna y Bruzzone, Anna María (1995). In guerra senza armi. Storie di donne 19401945. Roma-Bari, Laterza. Citado en López Martínez, Mario (2012). Ni paz ni guerra sino todo lo contrario. Ensayos sobre defensa y resistencia civil. Granada: Educatori.

Brocket (1991) citado en McAdam, Doug (1999). "Orígenes terminológicos, problemas actuales y futuras líneas de investigación”. En Dough Mc Adam, John Mc Carthy y Zald N. Mayer (Ed.). Movimientos sociales: perspectivas comparadas. Oportunidades politicas estructuras de movilización y marcos interpretativos culturales. Madrid, España: ISTMO. (trad. Sandra Chaparro).

Bruzzone, Anna María y Farina, Renata (1976). La Resistenza taciuta. Milano. La Pietra. Citado en López Martínez, Mario (2012). Ni paz ni guerra sino todo lo contrario. Ensayos 
sobre defensa y resistencia civil, Granada: Educatori.

Bucciarelli, Mario Arias (2014). "La peculiar institucionalización del peronismo en Neuquén. El Movimiento Popular Neuquino, 1961/1973”. En Melon Pirro, Julio César (2014). El peronismo y sus partidos. Tradiciones y prácticas políticas entre 1946 y 1976. Rosario: Prohistoria Ediciones.

Caimari, Lila (1995). Perón y la Iglesia Católica. Religión, Estado y Sociedad en Argentina (1943-1955). Buenos Aires: Ariel/Espasa Calpe.

Caldo, Paula y Fernández, Sandra (2009). "Por los senderos del epistolario: las huellas de la sociabilidad". Antíteses, vol. 2, n. 4, jul.-dez. Recuperado de http://www.uel.br/revistas/uel/index.php/antiteses

Camarero, Hernán (2014). "Tras las huellas de una ilusión: el Partido Comunista argentino y sus planteos del Frente Democrático Nacional (1955-1963)". ARCHIVOS de historia del movimiento obrero y la izquierda, año III, $\mathrm{n}^{\circ}$ 5: 31-50, p. 48.

Capobianco, Carina (2003). "Reconstrucción de un discurso peronista durante los años de la Revolución Libertadora. Lectura interpretativa de publicaciones rosarinas." Rosario: Mimeo.

Carman, Fernando (2015). El Poder la Palabra Escrita. Revistas y Periódicos Argentinos 1955 - 1976. Buenos Aires: Ediciones Biblioteca Nacional

Castro, María Virginia (2015). "Silencios y énfasis en los archivos personales, saber de los archivos. Archivo, Cultura y patrimonio. Actas de las I Jornadas de reflexión sobre la construcción del archivo. Centro de documentación e Investigación de la cultura de la izquierda (CeDinCi) y Biblioteca central de la Universidad de San Martín. Buenos Aires.

Castronuovo, Sabrina (2016). "El rol de la Revolución Libertadora en el encarcelamiento de la militancia femenina peronista (1955-1958)". Revista de historia del derecho, $\mathrm{n}^{\circ} 51$.

Cavarozzi, Marcelo (1983). Autoritarismo y Democracia (1955-1983). Buenos Aires: CEAL.

(1984). Sindicatos y política en la Argentina. Buenos Aires: CEAL.

Cena, Juan Carlos (1998). El guardapalabras: memorias de un ferroviario. Buenos Aires: La Rosa blindada.

Centurión, Ana Josefina (2007). "Las mujeres en la resistencia peronista. Sentidos y representaciones". En María Cecilia Bravo, Fernanda Gil Lozano y Valeria Pita (Comp.). Historia de luchas, resistencias y representaciones. Mujeres en la Argentina, siglos XIX y $X X$. San Miguel de Tucumán: EDUNT.

Cichero, Marta (1992). Cartas peligrosas. La apasionada discusión entre Juan Domingo Perón y el padre Hernán Benítez sobre la violencia politica. Buenos Aires: Planeta. 
Chiarini, Sebastián y Portugheis, Rosa Elsa (2014). Plan Conintes. Represión política y sindical. Ministerio de Justicia y Derechos Humanos de la Nación. Secretaría de Derechos Humanos, Archivo Nacional de la Memoria. Recuperado de http://www.jus.gob.ar/media/2824358/publicacion_libro plan_conintes.pdf

Clausewitz, Karl (2002). De la guerra. Recuperado de http://lahaine.org/amauta/b2img/Clausewitz\%20Karl\%20von\%20-\%20De\%20la\%20guerra.pdf

Cosse, Isabella (2010). Pareja, sexualidad y familia en los años sesenta. Una revolución sexual discreta en Buenos Aires. Buenos Aires: Siglo XXI Editores.

(2014). Militancia, sexualidad y erotismo en la izquierda armada en la Argentina de los años setenta. En Barrancos, Dora, Guy, Donna y Valobra, Adriana. Moralidades y comportamientos sexuales. Argentina 1880-2011. Buenos Aires: Biblos

(2009). "Los nuevos prototipos femeninos en los 60 y 70: de la mujer doméstica a la joven 'liberada'.” En Andrea, Andújar; Débora, D’Antonio; Fernanda Gil Lozano; Karin Grammático y María Laura Rosa (Comp.). De minifaldas, militancias y revoluciones. Exploraciones sobre los 70 en la Argentina, Buenos Aires: Ediciones Luxemburg.

Cosse, Isabella; Felitti, Karina y Manzano, Valeria (2010). Los '60 de otra manera: Vida cotidiana, género y sexualidades en la Argentina. Buenos Aires: Prometeo.

Cucchetti, Humberto (2013). “¿Derechas peronistas? Organizaciones militantes entre nacionalismo, cruzada anti-montoneros y profesionalización política", Nuevo Mundo Mundos Nuevos. Cuestiones del tiempo presente. Recuperado de http://nuevomundo.revues.org/65363

Cucchetti, Humberto (2003). "Diversidad religiosa y política: la construcción peronista de la ciudadanía religiosa (1945- 1955)" En III Jornadas de Ciencias Sociales y Religión, CEIL PIETTE, Buenos Aires.

Damín, Nicolás (2010). Plan CONINTES y Resistencia Peronista, 1955-1973. Buenos Aires: Instituto Nacional Juan Domingo Perón.

Dandan, Alejandra y Heguy, Silvina (2006). Joe Baxter. Del nazismo a la extrema izquierda. La historia secreta de un guerrillero. Buenos Aires: Norma.

D’Antonio, Débora (2016). La prisión en los años setenta: Historia, género y política, Buenos Aires: Biblos.

(2009). “'Rejas, gritos, cadenas, ruidos, ollas'. La agencia política en las cárceles del Estado terrorista en Argentina, 1974-1983”. En Andrea, Andújar; Débora, D’Antonio; Fernanda Gil Lozano; Karin Grammático y María Laura Rosa (Comp.). De minifaldas, militancias y revoluciones. Exploraciones sobre los 70 en la Argentina, Buenos Aires: Ediciones Luxemburg. 
(2000). "Representaciones de género en la huelga de la construcción. Buenos Aires, 1935-1936. En Gil Lozano, Fernanda; Pita, Valeria y Marcela Ini (Comp.) Historia de las mujeres en la Argentina. Buenos Aires, Taurus.

Da Orden, María Liliana y Melon Pirro, Julio César (2007). "Prensa y peronismo: el problema y el tratamiento de las fuentes". En María Liliana Da Orden y Julio César Melon Pirro, Julio César (Comps.). Prensa y peronismo. Discursos, prácticas, empresas, 19431958.Rosario: Prohistoria Ediciones.

Deleis, Mónica, De Titto, Ricardo y Arguindeguy, Diego (2001) Mujeres de la política argentina. Buenos Aires: Aguilar.

Diana, Marta (1996). Mujeres guerrilleras: la militancia de los setenta en el testimonio de sus protagonistas femeninas. Buenos Aires: Planeta

Díaz, César (2007). Combatiendo la "ignorancia aprendida”. La prédica jauretchiana en revista Qué. 1955-1958. La Plata: EDULP.

Dos Santos, Estela (1983). Las mujeres peronistas. Buenos Aires: Centro Editor de América Latina.

Duncan, Tim (1980). “La Prensa política: 'Sud América' 1884-1891”. En Ferrari, Gustavo y Gallo, Ezequiel (Comp.). La Argentina del 80 al Centenario. Buenos Aires: Sudamericana.

Duverger, Maurice (1974) Los Partidos Políticos. México: FCE, 1974. Levitsky, Steve (2005) La transformación del justicialismo: del partido sindical al partido clientelista, 1983-1999. Buenos Aires, Siglo XXI.

Little, Walter (1973). "Party and State in Peronist Argentina, 1945-1955." The Hispanic American Historical Review.

Eck, Hélène (2000). "Mujeres del desastre. ¿Ciudadanas por el desastre? Las francesas bajo el régimen de Vichy (1940-1944)" En Georges Duby y Michelle Perrot. Historia de las mujeres en occidente. Volumen V. El siglo XX. Madrid: Grupo Santillana de Ediciones.

Ehrlich, Laura. (2010). Rebeldes, intransigentes y duros en el activismo peronista, 1955 1962. (Tesis de Maestría). Universidad Nacional de General Sarmiento. Instituto de Desarrollo Económico y Social. Recuperado de http://www.riehr.com.ar/detalleTesis.php

Farge, Arlette (1991) La atracción del archivo. Edicions Alfons el managen, Institución Valenciana D'estudis investigagio.

Ferla, Salvador (2007). Mártires y verdugos: el levantamiento de Valle y los 27 fusilamientos. Buenos Aires: Continente.

Fernández, Arturo (1988). Las prácticas sociopolíticas del sindicalismo (1955-1985). Buenos Aires: CEAL. 
Fraga, Rosendo (1992). El ejército y Frondizi, 1958/1962. Buenos Aires: Emecé.

Galasso, Norberto (2005). Perón: exilio, resistencia, retorno y muerte: 1955-1974. Buenos Aires: Colihue.

Galván, María Valeria (2012). Publicaciones periódicas nacionalistas de derecha: las tres etapas de Azul y Blanco (Azul y Blanco 1956-1960, Segunda República 1961-1963, Azul y Blanco-Segunda Época 1966-1969). Tesis presentada para la obtención del grado de Doctora en Historia. La Plata. FaHCE. Memoria Académica.

García Negroni, María Marta (1988). "La destinación en el discurso político: una categoría múltiple”. Lenguaje en Contexto, I, 1/2: 85-111.

García Somoza, Mari Sol e Irrazabal, Gabriela. "Géneros, sexualidades y religiones: relaciones, intersecciones y confrontaciones. Soc. relig. [online]. vol.24, n.42 Disponible en: $<$ http://www.scielo.org.ar/scielo.php?script=sci_arttext\&pid=S1853-

$70812014000200006 \& \operatorname{lng}=\mathrm{es} \& n \mathrm{~nm}=\mathrm{iso}>$. ISSN 1853-7081

Gardes, Gilbert citado por Candau, Joël (2006). Antropología de la memoria, Buenos Aires: Nueva Visión.

Garulli, Liliana; Carvallo, Liliana; Charlier, Noemí y Cafiero, Mercedes (2000) Nomeolvides. Memoria de la resistencia peronista (1955-1972). Buenos Aires: Biblos.

Gerlach, Luther \& Hine, Virginia (1970) People, Power Change: Moments of social transformation. Indianapolis: Bobs Merril En Levitsky, Steve (2005) La transformación del justicialismo: del partido sindical al partido clientelista, 1983-1999. Buenos Aires, Siglo XXI.

Gil Lozano, Fernanda (1995). "Una problemática de género a comienzos de la modernidad: las brujas". Mora n 1, Buenos Aires: IIEGE, 101-111.

Goebel, Michael (2004). "La prensa peronista como medio de difusión del revisionismo histórico durante la Revolución Libertadora". Revista Prohistoria, nº. Rosario.

Goldar, Ernesto (1992) citado Rosano, Susana. (2006). Rostros y máscaras de Eva Perón. Imaginario populista y representación, Rosario: Beatriz Viterbo.

González Canosa (2012). Mora. Las Fuerzas Armadas Revolucionarias: Orígenes y desarrollo de una particular conjunción entre marxismo, peronismo y lucha armada. Tesis de Doctorado. La Plata. FaHCE-UNLP.

Gordillo, Mónica (2007). Protesta, rebelión y movilización: de la Resistencia a la lucha armada, 1955-1973. En Daniel James (Dir.). Violencia, proscripción y autoritarismo: 1955-1976. Buenos Aires: Sudamericana. 
Gorza, Anabella (2016); "Los homenajes a Eva Perón como prácticas de memoria en tiempos de la Resistencia peronista (1955-1963)", en Anuario del Instituto de Historia Argentina, FaHCE-UNLP, vol. 16, $n^{\circ} 1$. Recuperado de http://www.anuarioiha.fahce.unlp.edu.ar/article/view/IHAv16n1a07/7263

Grammático, Karin (2011); Mujeres Montoneras. Una Historia de la Agrupación Evita 1973- 1974, Buenos Aires, Luxemburg.

Granata, María (1952). "Valoración de la mujer en el peronismo". En Una nación recobrada. Enfoques parciales de la Nueva Argentina. Buenos Aires: Presidencia de la Nación. Subsecretaría de informaciones.

Grimberg Pla, Valeria (2005). "De las relaciones non sanctas entre el discurso político y el discurso religioso: el caso de Eva Perón.” Istmo. Revista virtual de estudios literarios y culturales centroamericanos $\mathrm{N}^{\mathrm{o}} 10$.

Disponible en http://istmo.denison.edu/n10/articulos/relaciones.html

Guivant, Julia (1985). "La visible Eva Perón y el invisible rol político femenino: 19461952". Cuadernos de Ciencias Sociales, Vol. 5, $\mathrm{n}^{\mathrm{o}}$ 1, Universidad Federal de Santa Catarina.

Halbwachs, Maurice (2004). Los marcos sociales de la memoria. Barcelona: Anthropos Editorial.

Halperín Donghi, Tulio (1985). José Hernández y Sus Mundos. Buenos Aires: Sudamericana.

James, Daniel (1992). "Historias contadas en los márgenes. La vida de doña María: historia oral y problemática de género". Revista Entrepasados, Año II Número 3.

(2010) [1998]. Resistencia e integración: El peronismo y la clase trabajadora argentina, 1946-1976. Buenos Aires: Siglo XXI Editores.

Buenos Aires; Manantial.

James, Daniel (1987). "17 y 18 de octubre de 1945: el peronismo, la protesta de masas y la clase obrera argentina.” En Desarrollo Económico No 107.

Jelin, Elizabeth \& Langland, Victoria (2003). "Las marcas territoriales como nexo entre pasado y presente". En E. Jelin \& V. Langland (Comp.). Monumentos, memoriales y marcas territoriales. Buenos Aires: Siglo XXI Editores.

Kahan, Emmanuel (2007). “¿Qué represión, qué memoria? El 'archivo de la represión’ de la DIPBA: problemas y perspectivas". Revista Question, n ${ }^{\circ} 16$, Facultad de Periodismo y Ciencias de la Comunicación de la Universidad Nacional de La Plata.

Kershaw, Ian (2004). La dictadura nazi: problemas y perspectivas de interpretación. Buenos Aires: Siglo XXI. 
Labica, Georges (2008). "Para una teoría de la violencia". Polis, no 19. Recuperado de http://polis.revues.org/3866

Ladeiux, Juan; Melon Pirro, Julio César y Quiroga, Nicolás (2014). "El Partido Peronista: problemas organizativos, prácticas políticas y liderazgo en tres momentos de normalización partidaria. Revista Escuela de Historia. Vol. 1.

Ladeuix, Juan I. y Contreras, Gustavo N. (2007). "Entre los generales y las masas. Un derrotero nacionalista durante la Libertadora, Azul y Blanco (1956-1958). En Da Orden, María Liliana y Melon Pirro, Julio Cesar (Comps.). Prensa y peronismo. Discursos, prácticas, empresas, 1943-1958. Rosario: Prohistoria Ediciones.

Lahire, Bernard (2004). El hombre plural. Los resortes de la acción. Barcelona: Ediciones Bellaterra.

Lienhard, M (2000). "La memoria popular y sus transformaciones." En M. Lienhard (Coord.). La memoria popular y sus transformaciones/ A memória popular e as suas transformações - América Latina y/e países lusoafricanos. Madrid-Frankfurt: Iberoamericana-Vervuert.

Lagarde y de los Ríos, Marcela (s.f.) "Pacto entre mujeres. Sororidad". Aportes para el debate. Recuperado de

www.asociacionag.org.ar/pdfaportes/25/09.pdf

Lechner, Norbert. "Estudiar la vida cotidiana". En Los patios interiores de la democracia. Subjetividad y política. Santiago de Chile: FCE, 1990.

Levitsky, Steve (2005) La transformación del justicialismo: del partido sindical al partido clientelista, 1983-1999. Buenos Aires, Siglo XXI.

David Lehmann (2004) "La religión en las ciencias sociales contemporáneas en América Latina" Revista Mexicana de Sociología, Vol. 66, Número especial (traducción de Mariana Gumá Montalvo)

Lobato, Mirta Zaida (2001) La vida en las fábricas. Buenos Aires: PrometeoEntrepasados.

Longoni, René (2012). "Ramón Prieto 1902 - 1985 (Primera Parte)." Ponencia en Tercer Congreso de Estudios sobre el peronismo (1943-2012), Jujuy, Red de Estudios sobre el peronismo, Facultad de Humanidades y Ciencias Sociales, Universidad Nacional de Jujuy, 18,19 y 20 de octubre.

López Martínez, Mario (2012). Ni paz, ni guerra, sino todo lo contrario. Ensayos sobre defensa y resistencia civil. Granada: Educatori.

(2016). "La resistencia civil examinada: de Thoreau a Chemoweth". Polis, Revista Latinoamericana, vol. $14 \mathrm{n}^{\mathrm{o}}$ 43. Santiago de Chile: Universidad de Los Lagos. Recuperado de 
http://www.redalyc.org/articulo.oa?id=30545999003

Lorenz, Federico en Bacha, Hernán. (2011). "Desafíos historiográficos en la historia del pasado reciente: Entrevista con Federico Lorenz". Quinto sol, 15(2), 1-22. Recuperado de http://www.scielo.org.ar/scielo.php?script $=$ sci arttext\&pid $=\mathrm{S} 1851$ 28792011000200004\&lng=es\&tlng=es.

Luna, Félix (1984) Perón y su tiempo: La Argentina era una fiesta, 1946-1949. Buenos Aires: Sudamericana.

Mackinnon, María Moira (2002). Los años formativos del Parido Peronista (1946-1950). Buenos Aires: Editorial De la Campana.

Mallimaci, Fortunato (2011). "De la Argentina católica a la Argentina diversa. De los catolicismos a la diversidad religiosa". En Olga Odgers Ortiz (Coordinadora): Pluralización religiosa de América Latina, Tijuana: El Colegio de la Frontera Norte. México: CIESAS.

Mallimaci, Fortunato (2010), "Entre lo "que es" y lo que "queremos que sea": secularización y laicidad en la Argentina Soc. relig. vol.20 no.32-33 Ciudad Autónoma de Buenos Aires. Disponible en:

http://www.scielo.org.ar/scielo.php?script=sci arttext\&pid=S185370812010000100003\&ln $\mathrm{g}=\mathrm{es} \& \mathrm{nrm}=\mathrm{iso}$

Marcilese, José (2015a). "La formación del Partido Justicialista. El peronismo, entre la proscripción y la reorganización (1958-1959)”. Santa Rosa: Quinto Sol, vol. 19 p. 1 - 24.

(2015b). "El peronismo y las elecciones bonaerenses de 1965. De la proscripción a la legislatura". Universidad Nacional del Sur. Centro de estudios regionales "Félix Weinberg". CONICET.

(2014). "De la proscripción a la participación, el peronismo bonaerense entre el Partido Justicialista y la Unión Popular (1959-1962)". Revista Sociohistórica. Universidad Nacional de La Plata, Facultad de Humanidades y Ciencias de la Educación. Centro de Investigaciones Sociohistóricas.

(2013). "Proscriptos, enfrentados y reorganizados. La dinámica partidaria del peronismo bonaerense entre 1962 y 1965". XIV Jornadas Interescuelas/Departamentos de Historia. Departamento de Historia de la Facultad de Filosofia y Letras. Mendoza: Universidad Nacional de Cuyo.

Maingueneau, Dominique (1980). Introducción a los métodos de análisis del discurso. Buenos Aires: Hachette.

Martínez, Paola (2009). Género, política y revolución en los años setenta. Las mujeres del PRT-ERP. Buenos Aires: Imago Mundi.

Mazzeo, Miguel (s/f). Notas para una biografía de Alicia Eguren. Recuperado de http://www.lahaine.org/b2-img12/EgurenLaHaine.pdf

Mazzei, Daniel (2000). “Tiempo de revancha: la desperonización del ejército durante la 
Revolución Libertadora". Taller, nº12. Buenos Aires.

Melon Pirro, Julio César (1993). "La resistencia peronista. Alcances y significados". Anuario del IEHS, nº. Tandil: Universidad Nacional del Centro.

(2007). "Informe sobre la prensa clandestina. Los peronistas entre 1955 y 1960". En Da Orden, María Liliana y Melon Pirro, Julio César (Comps.). Prensa y peronismo. Discursos, prácticas, empresas, 1943-1958. Rosario: Prohistoria Ediciones.

(2009) El peronismo después del peronismo: resistencia, sindicalismo y política luego del 55, Buenos Aires, Siglo XXI.

(2010). "Un partido en situación de espera. Los alineamientos políticos del peronismo en el segundo momento de la proscripción, 1963-1964". En Actas de las X Jornadas de Historia Política.

Melon Pirro, Julio César y Quiroga, Nicolás (Comps.) (2014). El peronismo y sus partidos. Tradiciones y prácticas políticas entre 1946 y 1976. Rosario: Prohistoria.

Menapace, Lidia (1995) Alcuni ricordi e riflessioni. En Giorgio Ganinni la resistenza nonarmela. Roma: Sinnos. Citado en Mario López Martínez (2012). Ni paz, ni guerra, sino todo lo contrario. Ensayos sobre defensa y resistencia civil. Granada: Educatori.

McAdam, Doug (1999). “Orígenes terminológicos, problemas actuales y futuras líneas de investigación”. En Dough Mc Adam, John Mc Carthy y Zald N. Mayer (Ed.). Movimientos sociales: perspectivas comparadas. Oportunidades políticas estructuras de movilización y marcos interpretativos culturales. Madrid, España: ISTMO. (trad. Sandra Chaparro).

Miraux, Jean Philippe (2005). La autobiografia. Las escrituras del yo. Buenos Aires: Ediciones Nueva Visión.

Moreau de Justo, Alicia (1956). "Prólogo". En Guillermo Bonaparte. Un país sin justicia: un episodio de la resistencia. Universidad de Míchigan: Ediciones Populares Argentinas.

Moreno i Sardá, Amparo (2007). De qué hablamos cuando hablamos del hombre. Treinta años de crítica y alternativas al pensamiento androcéntrico. Barcelona: Icaria.

Moreno Martín, Florentino. (2009). "Violencia colectiva, violencia política, violencia social. Aproximaciones conceptuales". Trabajo presentado en XXIV Congreso de la Asociación Española de Neuropsiquiatría, Cádiz, Asociación Española de Neuropsiquiatría, 3-6 de junio.

http://documentacion.aen.es/pdf/libros-aen/coleccion-estudios/violencia-y-saludmental/parte1-algunos-conceptos-sobre-la-violencia/019-aproximaciones-conceptuales.pdf

Monzón, Florencio (h) (2006). Llegó Carta de Perón: Rapsodia de la Resistencia 19551959. Buenos Aires: Corregidor.

Nardoni, Liliana (1994-1995). "Solos en la Madrugada". Vasto Mundo, segunda época nº 7, Rosario: Amalevi. 
Nari, Marcela (2004). Políticas de maternidad y maternalismo político. Buenos Aires, 1890-1940. Buenos Aires: Editorial Biblos.

Nash, Mary (2000). Rojas. Las mujeres republicanas en la guerra civil. Madrid: Taurus.

Navarro, Marysa (1994). Evita. Buenos Aires: Grupo Editorial Planeta.

Neiburg, Federico (1992). "O 17 de outubro na Argentina: espaco e formacao social do carisma".Revista Brasileira de Ciências Sociais № 20

Nora, Pierre (2008). "Entre memoria e historia. La problemática de los lugares". En $P$. Nora. Pierre Nora en Les lieux de mémoire. Montevideo: Trilce. (Traducción de Entre mémoire et histoire. Les lieux de mémoire, por L. Masello, 1984, Paris: Gallimard).

Nun, José (1973). "El control obrero y el problema de la organización". Pasado y Presente, Córdoba, $n^{\circ}$ 2-3 (nueva serie).

Oberti, Alejandra (2015). Las revolucionarias. Militancia, vida cotidiana y afectividad en los setenta. Buenos Aires: Edhasa.

O’Donnell, Guillermo (1972). "Modernización y golpes militares. Teoría, comparación y el caso argentino". Desarrollo Económico, vol. 12, n 47. Buenos Aires.

Palermo, Silvana (2009). "Masculinidad, conflictos y solidaridades en el mundo del trabajo ferroviario en Argentina (1912-1917)". Revista Mundos do Trabalho, vol. 1, n. 2, juliodiciembre.

Pascuali, Laura (2008). "Mandatos y voluntades: aspectos de la militancia de mujeres en la guerrilla. Temas de mujeres, Año 4, no 4.

Pateman, Carole (1995). El Contrato Sexual, México, Anthopos/UAM

Panella, Claudio (2001). La Prensa y el peronismo. Crítica, conflicto y expropiación, La Plata, UNLP, Facultad de Periodismo y Comunicación Social, 2001.

Pitchel, Vera (1993) Evita íntima. Los sueños, las alegrías, el sufrimiento de la mujer más poderosa del mundo. Buenos Aires: Planeta.

Pontoriero, Esteban (2015). "Estado de excepción y contrainsurgencia. El Plan CONINTES y la militarización de la seguridad interna en la Argentina (1958-1962)". Contenciosa, n ${ }^{\circ}$ 4(3). Primer semestre

Portantiero, Juan Carlos (1973). Clases dominantes y crisis política de la Argentina actual. Pasado y presente. En Brown, Oscar. El capitalismo argentino en crisis. Buenos Aires: Siglo: XXI.

Portelli, Alessandro (1999). "La battaglia di Poggio Bustone: violenza, memoria e immaginazione in un episodio della guerra partigiana". En N. Gallerano (Ed.). La Resistenza fra storia e memoria. Milano: Franco Angeli. 
(1999/2001). “L'assassinio di Luigi Trastulli. La memoria e l'evento, Provincia di Terni”. En C. Bermani (Ed.). Introduzione alla storia orale. Roma:Odradek.

(2013). "Sobre los usos de la memoria: memoria-monumento, memoria involuntaria, memoria perturbadora. Sociohistórica, $\mathrm{n}^{\mathrm{o}} 32$. Recuperado de: http://www.sociohistorica.fahce.unlp.edu.ar/article/view/SH2013n32a05

(2005). "El uso de la entrevista en la historia oral". En Historia, memoria y pasado reciente. Anuario $\mathrm{N}^{\circ} 20$. Escuela de Historia, Universidad Nacional de Rosario.

Potash, Roberto (1981). El ejército y la política en la Argentina 1945-1962. Buenos Aires: Sudamericana.

Plotkin, Mariano (1994). Mañana es San Perón. Propaganda, rituales políticos y educación en el régimen peronista (1946-1955). Buenos Aires: Ariel/Espasa Calpe.

Queirolo, Graciela (2010). "Las mujeres y los niños en el mercado de trabajo urbano (Buenos Aires, 1890-1940)" en Héctor E. Recalde (Compilador). Señoras, universitarias y mujeres (1910-2010). La Cuestión Femenina entre el Centenario y el Bicentenario de la Revolución de Mayo. Buenos Aires: Grupo Editor Universitario.

Quiroga, Nicolás (2014). "Una crasa mitología. Carisma y vida partidaria en el peronismo proscripto”. Melon Pirro, Julio César y Quiroga, Nicolás (Comps.) (2014). El peronismo y sus partidos. Tradiciones y prácticas políticas entre 1946 y 1976. Rosario: Prohistoria.

Quiroga, Nicolás (2012). El partido político en los estudios sobre el primer peronismo. Vida partidaria y prácticas políticas durante el primer peronismo. ANUARIO IEHS. Tandil

Quiroga, Nicolás (2008) Las unidades básicas durante el primer peronismo. Cuatro notas sobre el Partido Peronista a nivel local. Buenos Aires: Mundo Nuevo.

Raimundo, Marcelo (1998). "La política armada del peronismo: 1955-1966". Cuadernos del CISH, N4, UNLP, La Plata.

(2001). "Compañero y los orígenes del Peronismo Revolucionario" Revista Sociohistórica. Universidad Nacional de La Plata. Facultad de Humanidades y Ciencias de la Educación. Centro de Investigaciones Socio Históricas

Randle, Michael. (1998) Resistencia civil: la ciudadanía ante las arbitrariedades de los gobiernos. Estado y sociedad No48. Barcelona: Paidós.

Revilla Blanco, Marisa (1996). "El concepto de movimiento social: acción, identidad y sentido". Ultima década, No 005, Centro de Investigación y Difusión Poblacional de Achupallas. Viña del Mar. Recuperado de:

http://www.ses.unam.mx/docencia/2014II/Revilla_ElConceptoDeMovimientoSocial.pdf 
Rein, Raanan (2006). Juan Atilio Bramuglia: bajo la sombra del líder. Buenos Aires: Lumiere ediciones.

Rein, Raanan; Barry, Carolina; Acha, Omar y Quiroga, Nicolás (2009). Los estudios sobre el primer peronismo. La Plata: Instituto Cultural de la Provincia de Buenos Aires.

Rosano, Susana (2006). Rostros y máscaras de Eva Perón. Imaginario populista y representación. Rosario: Beatriz Viterbo.

Salas, Ernesto (2006 [1990]). La resistencia peronista: La toma del frigorífico Lisandro de La Torre. Buenos Aires: Retórica Ediciones: Altamira.

Salas, Ernesto. (2006) Uturuncos. El origen de la guerrilla peronista. Buenos Aires: Biblos.

Samaja, Juan (1994). Epistemología y metodología. Elementos para una teoría de la investigación científica. Buenos Aires: Eudeba.

Santiago, María Eugenia (2010). "Poesía y política: producciones poéticas del peronismo ¿proyecciones de imaginario peronista?”, Ponencia en Segundo Congreso de Estudios sobre el Peronismo 1943 - 1976, Buenos Aires, Universidad Nacional de Tres de Febrero. Recuperado de http://redesperonismo.com.ar/archivos/CD2/Acha.pdf.

Santos Lepera, Lucía (2012). "Las manifestaciones colectivas de duelo frente a la muerte de Eva Perón”. Boletín Americanista, Año LXII, 1, nº 64, Barcelona.

Schneider, Alejando (2005). Los compañeros. Trabajadores, izquierda y peronismo, 1955 1973. Buenos Aires: Imago Mundi.

Segato, Rita (2003). Las estructuras elementales de la violencia: Ensayos sobre género entre la antropología, el psicoanálisis y los derechos humanos, UNQ, Bernal.

Seminara, Luciana y Viano, Cristina (2009). Las dos Verónicas y los múltiples senderos de la militancia: de las organizaciones revolucionarias de los años 70 al feminismo. En Andrea, Andújar; Débora, D’Antonio; Fernanda Gil Lozano; Karin Grammático y María Laura Rosa (Comp.). De minifaldas, militancias y revoluciones. Exploraciones sobre los 70 en la Argentina, Buenos Aires: Ediciones Luxemburg.

Seveso, César (2009). "Escuelas de militancia. La experiencia de los presos políticos en Argentina, 1995-1972. Contracorriente, vol. 6, $\mathrm{n}^{\mathrm{o}}$ 3. Spring. Recuperado de https://www.ncsu.edu/acontracorriente/spring_09/docs/Seveso.pdf

(2010). "Political Emotions and the Origins of the Peronist Resistance". En Matthew Karush \& Oscar Chamosa (Eds.). New Cultural History of Peronism: Power and Identity in Mid- Twntieth-Century Argentina. Durham, NC, USA: University Press.

Schwarzstein, Dora (2002). "Fuentes orales en los archivos: desafíos y problemas". Historia, Antropología y Fuentes Orales, No. 27, Apariencia y Compromiso.

Scott, James (2003). Los dominados y el arte de la resistencia. México: Ediciones Era. 
Scott, Joan (1993). "El género: una categoría útil para el análisis histórico". En María Cecilia Cangiano y Lindsay Dubois (Comp.). De mujer a Género, teoría, interpretación, y práctica feminista en las ciencias sociales. Buenos Aires: CEAL. -- (2009). Género e historia. México: FCE.

Scoufalos, Catalina (2007). 1955, memoria y resistencia. Buenos Aires: Biblos.

Seoane, María (2014). Bravas. Alicia Eguren de Cooke y Susana Pirí Lugones. Dos mujeres para una pasión argentina. Buenos Aires: Sudamericana.

Sharp, (2011). De la dictadura a la democracia. Un sistema conceptual para la liberación. Boston: The Albert Einstein Institution.

Sigal, Silvia (2002). Intelectuales y poder en Argentina. La década del sesenta. Buenos Aires: Punto Sur.

Sigal, Silvia y Verón, Eliseo (2004). Perón o muerte. Los fundamentos discursivos del fenómeno peronista. Buenos Aires: Eudeba.

Smulovitz, Catalina (1991). "En búsqueda de la fórmula perdida. Desarrollo económico, $\mathrm{n}^{\mathrm{o}}$ 121. Buenos Aires: IDES.

Sobrino Aranda, Luis (1958). Después que cayó Perón. Juicio histórico a los asesinos. Buenos Aires: Trafac.

Spinelli, Estela (2005) Los vencedores vencidos. El antiperonismo y la "revolución libertadora". Buenos Aires: Biblos.

Spinelli, María Estela (2007). "Las revistas Qué sucedió en 7 días y Mayoría. El enfrentamiento en el antiperonismo durante los primeros años del "frondizismo". En Melon Pirro, Julio César (Comp.), Prensa y peronismo. Discursos, prácticas, empresas, 19431958. Rosario: Prohistoria Ediciones.

Summo, Marcelo y Pontotiero, Esteban (2002). "Pensar la 'guerra revolucionaria': doctrina antisubversiva francesa y legislación de defensa en la Argentina (1958-1962)". Cuadernos de Marte, Año 2, $\mathrm{n}^{\mathrm{o}} 3$.

Szusterman, Celia (1998). Frondizi, la política del desconcierto. Buenos Aires: Emecé.

Tarrow, Sidney. (1997). El poder en movimiento. Los movimientos sociales, la acción colectiva y la política. Madrid: Alianza.

Tilly, Charles (2001) Collective action, Encyclopedia of European Social History vol. 3. New York: Peter N. Stearms. Citado por Tarrow, Sidney. (1997). El poder en movimiento. Los movimientos sociales, la acción colectiva y la política. Madrid: Alianza.

Tcach, César (1995). "Neoperonismo y resistencia obrera en la Córdoba libertadora, 1955- 
1958”. Desarrollo Económico, vol. 36, nº 137, abril- julio

Terán, Oscar (2013) Nuestros años sesenta: la formación de la nueva izquierda intelectual en la Argentina, 1956-1966. Buenos Aires: Siglo XXI.

Torre, Juan Carlos (2012). Ensayos sobre el movimiento obrero y peronismo. Buenos Aires: Siglo XXI.

Tortti, María Cristina (2009). El "viejo" partido socialista y los orígenes de la nueva izquierda (1955-1965). Buenos Aires: Prometeo libros.

(2010). "Soluciones: una experiencia de acercamiento entre el peronismo y la izquierda durante la campaña por el voto en blanco en 1960. Segundo Congreso de Estudios sobre el Peronismo (1943-1976). Buenos Aires: Universidad Nacional de Tres de Febrero.

(2013). Che: una revista de la "nueva izquierda" (1960-1961). Colección Antologías y documentos. Vol. 3. Buenos Aires: CeDInCI.

Ugartemendia, Eceizabarrena (enero-marzo 1999). Revista de estudios políticos (Nueva Época). $\mathrm{N}^{\mathrm{o}} 103$.

Valobra, Adriana María (2010). Del hogar a las urnas. Recorridos de la ciudadanía política femenina: Argentina, 1946-1955. Rosario: Prohistoria Ediciones.

(2015). “'Mujeres-sombra' y 'Barbudas' Género y política en el Primer Congreso Latinoamericano de Mujeres, Chile- 1959”. Anuario del Instituto de Historia Argentina, $\mathrm{n}^{\circ}$ 14. Universidad Nacional de La Plata. Facultad de Humanidades y Ciencias de la Educación. Centro de Historia Argentina y Americana.

(2015). "Formación de cuadros y frentes populares: relaciones de clase y género en el Partido Comunista de Argentina, 1935-1951". Izquierdas, Año: 2015

Vasallo, Marta (2009). "Militancia y transgresión". En Andrea, Andújar; Débora, D’Antonio; Fernanda Gil Lozano; Karin Grammático y María Laura Rosa (Comp.). De minifaldas, militancias y revoluciones. Exploraciones sobre los 70 en la Argentina, Buenos Aires: Ediciones Luxemburg.

Verbitsky, Horacio (1985). Ezeiza. Buenos Aires: Editorial Contrapunto.

Verón, Eliseo (1987). ; "La palabra adversativa. Observaciones sobre la enunciación política”. En AA. VV. El discurso Político. Lenguajes y acontecimientos. Buenos Aires. Hachette.

Vigo, Juan Manuel (1973). Crónicas de la resistencia. ¡La vida por Perón! Buenos Aires: Peña Lillo Editor.

Walsh, Rodolfo (2007). Operación Masacre. Buenos Aires: De la Flor. 
Wodak, Ruth y Meyer, Michael (Comp.) (2003). Métodos de análisis crítico del discurso. Barcelona: Gedisa.

Yusta Rodrigo, Mercedes (2016). "Por una historia de género de la guerrilla antifranquista" (mimeo)

Zanatta, Loris (2011). Eva Perón. Una biografía política. Buenos Aires: Sudamericana.

Zanatta, Loris (1996). Del Estado liberal a la nación católica. Iglesia y Ejército en los orígenes del peronismo. Buenos Aires: UNQ.

Zink, Mirta y Di Liscia, María Herminia (2007). "Gestar una ciudadanía política. La incorporación de las mujeres al Estado peronista, apoyos y resistencias (1945-1955)”. En Bravo, María Celia; Gil Lozano, Fernanda y Pita Valeria (Comp.), Historia de luchas, resistencias y representaciones. Mujeres en la Argentina, siglos XIX y XX. San Miguel de Tucumán: EDUNT, Editorial de la Universidad Nacional de Tucumán. 